\title{
TOMÁS OLCESE
}

\section{Formação histórica da real property law inglesa: tenures, estates, equity \& trusts \\ (Dissertação de Mestrado)}

Orientador:

Prof. Associado Bernardo Bissoto Queiroz de Moraes

Universidade de São Paulo

Faculdade de Direito

São Paulo

2012 
1. ASPECTOS PRELIMINARES E METODOLÓGICOS ...............................................5

2. OS COMPONENTES FEUDAIS NA FORMAÇÃO DA REAL PROPERTY LAW .... 12

2.1. OS WRITS E AS FORMS OF ACTION ............................................................................16

2.2. A ESTRUTURA DOS DIREITOS REAIS NA INGLATERRA: TENURES.................................. 25

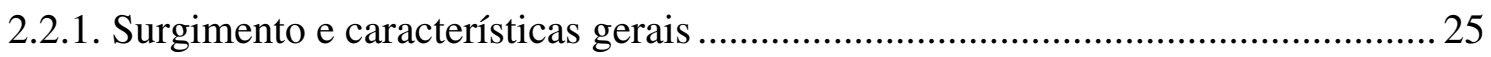

2.2.2. A articulação das terras em função do regime de concessão feudal ....................... 35

2.2.3. O elemento material da concessão feudal: seisin ................................................. 42

2.2.4. As categorias baseadas na seisin e sua extensão temporal: estates of freehold .... 55

2.2.4.1. A concessão hereditária perpétua: o estate in fee simple ................................. 58

2.2.4.2. A concessão hereditária condicional inalienável: o estate in fee tail ............... 63

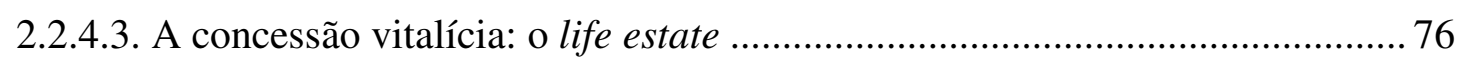

2.3. HERANÇAS DO SISTEMA DAS TENURES NA REAL PROPERTY LAW INGLESA.................... 82

2.3.1. A concessão sem seisin: unfree tenure ......................................................... 83

2.3.2. Statutum Quia Emptores Terrarum 1290 ........................................................ 91

3. A FORMAÇÃO HISTÓRICA DA EQUITY E DOS TRUSTS...................................... 102

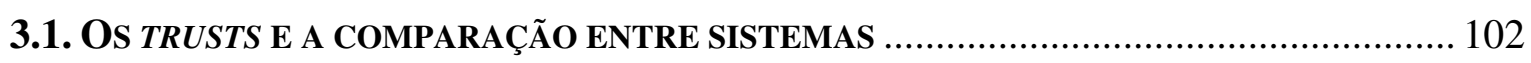

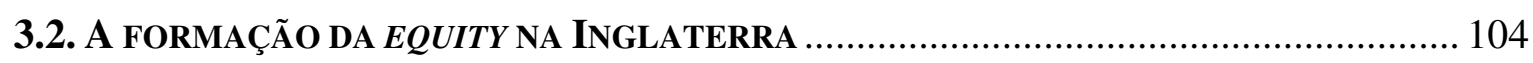

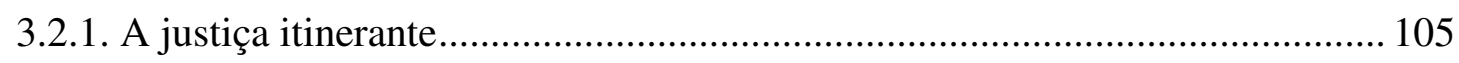

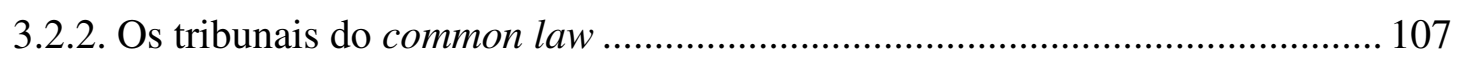

3.2.3. A Court of Chancery e a atividade jurisdicional do Chancellor ...................... 109

3.2.4. Princípios diretores da equity: maxims of equity ............................................. 117

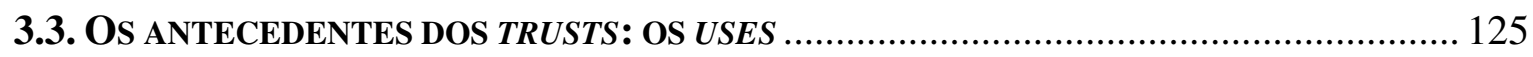

3.4. A TRANSFORMAÇÃO DOS USES EM TRUSTS: STATUTE OF USES 1536 ……………..... 131

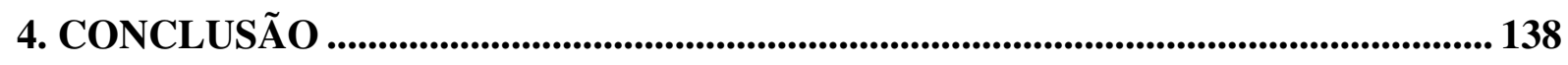

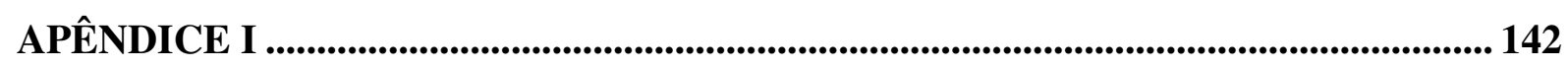

APÊNDICE II.................................................................................................. 143

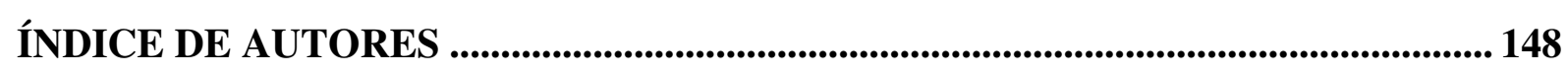

ÍNDICE DE FONTES..................................................................... Erro! Indicador não definido.

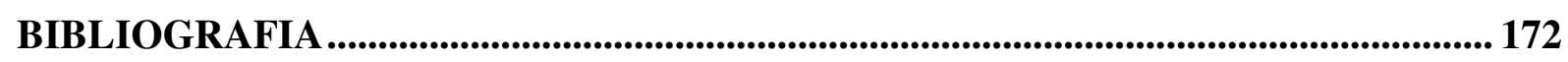




\section{Principais abreviaturas}

AJLH

All ER

All ER Rep

All ER Rep Ext

App Cas

BGB

Bl Comm

BNB

Bracton

C.

CC

$\mathrm{Ch}$

Ch App

Ch D

CLR

Co Litt

Co Rep

Cod. Dipl.

Cro Eliz

D.

DCFR

East

ED

EHR

Eq Rep

ER

Fleta
= American Journal of Legal History

$=$ All England Law Reports - England \& Wales

$=$ All England Law Reports Reprint - England \& Wales

= All England Law Reports Reprint - Australian Extension Volumes Australia

$=$ Law Reports - Appeal Cases - England \& Wales

= Bürgerliches Gesetzbuch

= Commentaries on the Laws of England

= Bracton's Note Book

= De legibus et consuetudinibus Angliae

= Codex Iustinianus - P. KRÜGER, in Corpus iuris civilis II, $11^{\mathrm{a}}$ ed., Berlin, Weidmann, 1954

= Código Civil

$=$ Law Reports - Chancery Division $\left(3^{\text {rd }}\right.$ series $)-$ England \& Wales

$=$ Law Reports - Chancery Appeal Cases - England \& Wales

$=$ Law Reports - Chancery Division $\left(2^{\text {nd }}\right.$ series $)-$ England \& Wales

= Commonwealth Law Reports - Austrália

= A Commentary Upon Littleton

= Coke's King's Bench Reports - England \& Wales

= Codex Diplomaticus Aevi Saxonici

$=$ Croke's King's Bench Reports - England \& Wales

= Digesta - T. MOMMSEN e P. KRÜGER, in Corpus iuris civilis I, $16^{\mathrm{a}}$ ed., Belin, Weidmann, 1954

$=$ Draft Common Frame of Reference

= East's Term Reports - King's Bench - England \& Wales

= Enciclopedia del diritto (Milano)

= The English Historical Review (Oxford)

$=$ Common Law \& Equity Reports - England \& Wales

$=$ English Reports - England \& Wales

= Fleta seu Commentarius Juris Anglicani 
Flor. Epit.

Fortescue

Gai.

Glanvill

Hare

Hist. Rames.

Inst.

Lib. Feod.

Lib. Papiens.

Litt

LR Eq

LR QB

$\mathrm{MGH}$

NDI

OED

OJLS

OLD

Pauli sent.

QB

QB D

Stat.

Swans

TR

UKPC

Vern

Ves

ZRG
= Epitome Rerum Romanorum

= De laudibus legum Angliae

= Gai institutiones $-\mathrm{J}$. BAVIERA, in FIRA II

= Tractatus de legibus et consuetudinibus regni Angliae

= Hare's Chancery Reports - England \& Wales

= Historia Ramesiensis

= Institutiones Iustiniani - P. KRÜGER, in Corpus Iuris Civilis I, 16 ${ }^{\mathrm{a}} \mathrm{ed}$., Berlin, Weidmann, 1954

= Liber Feodorum - Testa de Nevill

= Liber Papiensis seu Liber Legum Langobardorum

= Littleton's Tenures

= Law Reports - Equity Cases - England \& Wales

$=$ Law Reports - Queen's Bench $\left(1^{\text {st }}\right.$ series $)-$ England \& Wales

= Monumenta Germaniae Histórica

= Nuovo digesto italiano (Torino)

= Oxford English Dictionary

= Oxford Journal of Legal Studies

= Oxford Latin Dictionary

= Pauli sententiae

= Law Reports - Queen's Bench (3rd series) - England \& Wales

= Law Reports - Queen's Bench Division - England \& Wales

$=$ Statute

= Swanston's Chancery Reports - England \& Wales

$=$ Tijdschrift voor rechtsgeschiedenis - Revue d'histoire du droit - The

Legal History Review (Harlem)

= United Kingdom Privy Council - Commonwealth

= Vernon's Chancery Reports - England \& Wales

= Vesey Chancery Reports - England \& Wales

= Zeitschrift der Savigny-Stiftung für Rechtsgeschichte (Weimar) 


\section{ASPECTOS PRELIMINARES E METODOLÓGICOS*}

Antes de iniciar a leitura da pesquisa propriamente dita, convém destacar alguns aspectos acerca do tema escolhido. Em primeiro lugar, convém destacar que o aspecto substancial da pesquisa corresponde à análise dos componentes estruturais e terminológicos dos direitos reais no direito inglês, tema já discutido pela literatura comparatística, contudo pouco aprofundado no que diz respeito ao estudo das fontes inglesas sobre o tema ${ }^{1}$.

* Em relação aos aspectos formais da metodologia adotada, seguimos as orientações indicadas em E. C. SilveIRA MARCHI, Guia de Metodologia Jurídica (Teses, Monografias e Artigos), Lecce, Grifo, 2001, pp. 179235 e 291-315, com as ressalvas feitas, em razão do tema escolhido, na nota 7 infra.

Assim, as citações bibliográficas seguem o padrão internacional franco-italiano adotado pela literatura científica jurídica, particularmente pelos romanistas. A citação dos nomes científicos de juristas brasileiros, ibéricos e latino-americanos, no entanto, merece um tratamento diferenciado, dadas as suas peculiaridades. A grande importância dada ao prenome das pessoas na literatura pátria, bem como a inclusão do apelido materno ao lado do patronímico na península ibérica, torna difícil a padronização das citações numa obra científica, forçando o pesquisador a optar entre a maior clareza para o leitor nacional e a uniformização e coerência na técnica de citação.

Para contornar essa dificuldade, os autores nacionais, ibéricos e sul-americanos serão citados, nas notas de rodapé, do modo como são conhecidos na literatura dos seus respectivos países, de modo a facilitar sua identificação pelo leitor. Na bibliografia final, no entanto, serão citados de acordo com os padrões internacionais de citação, de modo a atender à necessidade de padronização científica.

No que diz respeito à citação de fontes jurídicas inglesas, tanto jurisprudenciais (case law) quanto legais (statutes), adotamos o padrão estabelecido em S. MEREDITH e D. NOLAN (ed.), Oxford Standard for the Citation of Legal Authorities, $4^{\text {a }}$ ed., Oxford, Oxford University, 2010, pp. 3-50, disponível em formato eletrônico in http://www.law.ox.ac.uk/publications/oscola.php [16-02-2011].

${ }^{1}$ As principais obras ou artigos de direito comparado que tratam do tema com alguma profundidade são (em ordem cronológica de publicação): K. E. GÜTERBOCK, Henricus de Bracton und sein Verhältniss zum römischen Rechte: Ein beitrag zur geschichte des römischen rechts in mittelalter, Berlin, Springer, 1862, trad. ing. de B. Coxe, Bracton and His Relation to Roman Law: A Contribution to the History of the Roman Law in the Middle Ages, Philadelphia, Lippincott, 1866, pp. 13-175; P. LEPAUlLE, Civil Law Substitutes for Trusts, in Yale Law Journal 36 (1926-1927), pp. 1126-1147; P. LEPAULLE, Traite theorique et pratique des trusts en droit interne en droit international, Paris, Rousseau, 1932, pp. 1-442; M. RHEINSTEIN, Some Fundamental Differences in Real Property Ideas of the "Civil Law" and the Common Law Systems, in University of Chicago Law Review, 3 (1935-1936), pp. 624-635; W. W. BuCKLAND e A. D. MCNAIR, Roman Law and Common Law - A Comparison in Outline, Cambridge, Cambridge University, 1936, pp. 1-341; R. DAVID, Les grands systèmes du droit contemporains, $3^{\text {a }}$ ed., Paris, Dalloz, 1969, pp. 1-648; K. ZWEIGERT e H. KÖTZ, Einführung in die Rechtsvergleichung auf dem Gebiete des Privatrechts, 1971, trad. ing. de T. Weir, Introduction to Comparative Law, $3^{\text {a }}$ ed., Oxford, Clarendon Press, 1998, pp. 1-708; R. HelmHOlZ e R. ZIMMERMANN (org.), Itinera Fiduciae: Trust and Treuhand in Historical Perspective, Berlin, Duncker \& Humblot, 1998, pp. 27-542; A. Watson, Roman Law \& Comparative Law, Athens, University of Georgia, 1991, pp. 3-272; M. C. MALAGUTI, Il trust, in F. GAlgano (org.), Atlante di diritto privato comparato, $3^{\mathrm{a}}$ ed., Bologna, Zanichelli, 1999, pp. 179193; G. CRISCUOLI, Introduzione allo studio del diritto inglese - le fonti, $3^{\mathrm{a}}$ ed., Milano, Giuffrè, 2000, pp. 1519; C. H. VAN RHEE, Trusts, Trust-like Concepts and Ius Commune, in European Review of Private Law 3 (2000), pp. 453-462; L. MocCIA, Il modello inglese di “proprietà", in G. AlPA et al., Diritto privato comparato - istituti e problemi, Roma, Laterza, 2004, pp. 35-145; J. GoRdLEY, Foundations of Private Law, Oxford, Oxford University, 2006, pp. 1-481; S. VAN ERP, Comparative Property Law, in M. REIMANN e R. ZIMMERMANN (coord.), The Oxford Handbook of Comparative Law, Oxford, Oxford University, 2006, pp. 10431070; M. J. WAAL, Comparative Succession Law, in M. REIMANN e R. ZIMMERMANN (coord.), The Oxford Handbook of Comparative Law, Oxford, Oxford University, 2006, pp. 1071-1098.

No direito inglês, nossas principais referências em relação à configuração da real property law, além das obras de natureza histórica, são H. W. CHALlis, Law of Real Property, $3^{\mathrm{a}}$ ed., London, Butterworth, 1911, pp. 1422; M. LupoI, Trusts, Milano, Giuffrè, 1997, trad. ing. de S. Dix, Trusts: A Comparative Study, Cambridge, Cambridge University, 2000, pp. 1-386; R. MEgarRy e W. WADE, The Law of Real Property, $7^{\mathrm{a}}$ ed., London, 
Nosso foco, portanto, não é o estudo dos direitos reais nos sistemas de matriz civilística, muito embora procuremos, na medida do possível, cotejar os institutos do direito inglês com características e figuras do direito privado de base romanística.

Nosso principal objetivo, portanto, é estudar os principais elementos que deram origem à real property law inglesa e determinaram sua particular formação histórica, de modo a contribuir para o delineamento de uma eventual aproximação entre os sistemas do common law e os de base romanística, mediante um estudo que aponte para a "diversa tessitura o grammatica" que os caracteriza ${ }^{2}$. Os quatro elementos formativos escolhidos para realizar essa tarefa são o sistema das tenures, a doutrina dos estates e o surgimento da equity e dos trusts $^{3}$.

Por sua vez, o objeto da nossa análise restringe-se, geograficamente, ao desenvolvimento da real property law na Inglaterra, ou seja, limita-se ao âmbito do ordenamento tradicionalmente submetido à jurisdição dos tribunais reais ingleses ${ }^{4}$. Portanto, o objetivo de eventuais referências incidentais a normas ou institutos de outros ordenamentos pertencentes ao sistema do common law é apenas facilitar a exposição do direito inglês 5 .

Já a delimitação temporal da pesquisa é mais difusa, dado o assincronismo dos períodos formativos de cada instituto. Assim, a estruturação do sistema das tenures ocorre, principalmente, entre os séculos XI e XIII; a sistematização dos estates se consolida a partir do século $\mathrm{XV}^{6}$; a equity e os trusts, por sua vez, começam a ganhar suas feições

Sweet \& Maxwell, 2008, pp. 1-1528; C. BAR e E. CLIVE, Principles, Definitions and Model Rules of European Private Law, vol. V, München, Sellier, 2009, pp. 4205-5387; K. GRAY e S. F. GRAY, Elements of Land Law, ${ }^{\mathrm{a}}$ ed., Oxford, Oxford University, 2009, pp. 2-1400; G. MofFat, Trusts Law, $5^{\text {a }}$ ed., Cambridge, Cambridge University, 2009, pp. 1-1080; P. H. PETTIT, Equity and the Law of Trusts, $11^{\mathrm{a}}$ ed., Oxford, Oxford University, 2009 , pp. 1-713.

${ }_{2}^{2}$ Cf. L. MocCIA, Il modello inglese cit. (nota 1 supra), p. 38.

${ }^{3} \mathrm{~A}$ escolha desses elementos deve-se, principalmente, à sua indisputável influência na formação do sistema da real property law inglesa e à riqueza de oportundidades que fornecem para marcar os principais contrastes entre os sistemas do common law e os de base romanística, que é o primeiro passo para identificar as eventuais convergências, cf. S. VAN ERP, Comparative Property Law cit. (nota 1 supra), p. 1048. Outros componentes, tais como leaseholds (locações de longo prazo), easements (servidões), profits (percepção de utilidades), mortgages (hipotecas), adverse possession (usucapião) etc., somente serão mencionados incidentalmente conforme surja a necessidade.

${ }^{4}$ Nesse sentido, não fazem parte do nosso objeto de estudo, embora possam ser eventualmente mencionados, os demais ordenamentos pertencentes ao sistema do common law, sobre os quais uma breve exposição pode ser vista em S. VogenaUER, s.v. Common Law, in J. BASEDOw, K. HoPT e R. ZIMMERMANN, The Max Planck Encyclopedia of European Private Law, vol. I, Oxford, Oxford University, 2012, pp. 265-266. No âmbito territorial das ilhas britânicas, ficam excluídos o ordenamento jurídico da Escócia, classificado como um sistema misto, e as Ilhas do Canal (Channel Islands), cujo ordenamento se manteve vinculado ao antigo direito costumeiro normando, cf. K. ZWEIGERT e H. KÖTZ, Einführung cit. (nota 1 supra), pp. 201-202.

${ }^{5}$ Assim, por exemplo, a referência à case law australiana na questão relativa ao título radical da Coroa inglesa, cf. nota 97 infra.

${ }^{6}$ Especialmente a partir da publicação da obra de Thomas Littleton, cf. nota 192 infra. 
caracterizadoras a partir do século XVI. Dada essa variedade de momentos determinantes na história de cada instituto, não é possível restringir um estudo desta natureza a um período específico. A pesquisa, nesse aspecto, pauta-se mais pela preocupação com unidades de sentido do que com a delimitação categórica de etapas históricas.

Em relação ao material bibliográfico consultado para a pesquisa, adotamos como fontes primárias ${ }^{7}$ tanto textos legislativos (statutes $^{8}$ ) quanto jurisprudenciais (case law $^{9}$ ),

\footnotetext{
${ }^{7}$ Para distinguir as fontes primárias das secundárias, adotamos o critério indicado em E. C. SILVEIRA MARCHI, Guia de Metodologia Jurídica cit. (nota * supra), pp. 137-140, com a exceção dos chamados books of authority, que elencamos entre as fontes primárias em função da sua inclusão, no ordenamento jurídico inglês, entre as fontes dessa natureza. Acerca das fontes inglesas e sua classificação, cf. G. CRISCUOLI, Introduzione cit. (nota 1 supra), pp. 43-59.

${ }^{8}$ Os textos legislativos ingleses foram recolhidos, ao longo dos séculos, em várias coletâneas particulares,
} cf. D. M. WALKER, The Oxford Companion to Law, Oxford, Clarendon, 1980, pp. 1185-1186 (no verbete "statutes, editions of"). A partir do século XIX, passaram a ser publicadas regularmente as primeiras edições oficiais dos statutes ingleses, que hoje se encontram disponíveis para consulta em meio eletrônico. Uma das principais dessas coletâneas oficiais é Statutes of the Realm, vols. I-IX, London, Record Commission, 18101822, que abrange o período de 1235 a 1713. Daí foi extraída a maior parte dos textos legislativos citados neste trabalho. A legislação não inclusa nessa coletânea foi extraída das seguintes coleções (os períodos abrangidos pela respectiva coletânea encontram-se entre colchetes): O. RUFFHEAD, The Statutes at Large, vols. I-XIV [1215-1800], London, Basket, Eyre \& Strahan, 1763-1800; D. PICKERING, The Statutes at Large, vols. I-XLVI [1215-1806], Cambridge, Bentham, Archdeacon et al., 1762-1807; W. STUBBS, Select Charters and Other Illustrations of English Constitutional History, $9^{\mathrm{a}}$ ed., Oxford, Clarendon, 1921, pp. 1-506; J. M. LELY e W. D. I. FoulKES (org.), The Judicature Acts 1873 and 1875, $2^{\mathrm{a}}$ ed., London, Sweet, 1877, pp. 1-560; L. SHELFORD (org.), The Real Property Statutes Passed in the Reigns of King William IV and Queen Victoria, London, Sweet et al., 1863, pp. 1-770; B. THORPE e R. PRICE (org.), Ancient Laws and Institutes of England, s.1., Public Records Commission, 1840, pp. 1-548; A Collection of the Public General Statutes Passed in the Second and Third Year of the Reign of Her Majesty Queen Victoria, London, Richards \& Co., 1839, pp. 1-715; The Statutes of the United Kingdom of Great Britain and Ireland - 2 \& 3 William IV, London, His Majesty's Printers, 1832, pp. 1834; A Collection of the Public General Statutes Passed in the Third and Fourth Year of the Reign of His Majesty King William the Fourth, London, Richards, 1833, pp. 1-1134; J. STEPHEN (org.), The Common Law Procedure Act 1860, London, Butterworths, 1860, pp. 1-74; W. F. FINLASON, The Common Law Procedure Acts of 1852, 1854 and 1860, London, Stevens \& Sons, 1860, pp. 1-373. Os textos legislativos ainda em vigor no Reino Unido encontram-se disponíveis no endereço eletrônico http://www.legislation.gov.uk/ [10-09-2012]. Acerca da publicação e citação das fontes legislativas inglesas, cf. G. CRISCUOLI, Introduzione cit. (nota 1 supra), pp. 459-464.

${ }^{9}$ Os principais repertórios da case law inglesa encontram-se hoje disponíveis em meio eletrônico, cf. http://www.lexisnexis.com/ [10-09-2012]. Além do uso desse recurso, consultamos as seguintes coleções e volumes de decisões judiciais (os períodos abrangidos pelos reports encontram-se entre colchetes): C. BEAVAN, Reports of Cases in Chancery, vols. I-XXXVI [1838-1866], London, Saunders \& Benning, 1840-1869; E. COKE, The Reports of Sir Edward Coke, vols. I-VI, [1572-1616], London, Butterworth, 1826; G. CROKE, Reports of Sir George Croke Knight Formerly One of the Justices of the Courts of King's Bench and Common Pleas of Such Select Cases as Were Adjudged in the Said Courts During the Reign of Queen Elizabeth, vols. I-II [1582-1603], London, Brooke \& Whieldon, 1790; E. EAST, Reports of Cases Argued and Determined in the Court of King's Bench, vols. I-XVI [1800-1812], London, Butterworth, 1801-1814; E. PLOWDEN, Commentaries or Reports of Edmund Plowden, vol. único [1548-1579], London, Brooke, 1816; A. W. SCOTT, Select Cases and Other Authorities on the Law of Trusts, Langdell Hall, Cambridge, 1919, pp. 1-836; T. HARE, Reports of Cases Argued in the High Court of Chancery, vols. I-XI [1841-1853], London, Maxwell, 1843-1858; I. S. LEADAM, Select Cases in the Court of Requests - 1497-1569, in The Publications of the Selden Society, vol. XII, London, Selden Society, 1898, pp. 1-209; C. T. SwAnston, Reports of Cases Argued and Determined in the High Court of Chancery, vols. I-III [1818-1819], London, Butterworth, 1821-1827; W. H. BENNET, The Equity Reports, vols. IIII [1853-1855], London, Benning \& Co., 1853-1855; T. VERnON, Cases Argued and Adjudged in the High Court of Chancery, vols. I-II [1681-1720], London, Butterworth, 1828; F. VESEY, Reports of Cases Argued and Determined in the High Court of Chancery, vols. I-XX [1789-1817], London, Brooke, 1827-1833; J. H. BAKER e 
doutrinários (books of authority ${ }^{10}$ ) e até documentais ${ }^{11}$. As principais fontes secundárias consultadas correspondem aos estudos elaborados pelos historiadores do direito inglês, principalmente a partir do século $\mathrm{XIX}^{12}$, bem como a dicionários e enciclopédias especializadas $^{13}$.

Também convém fazer algumas observações gerais a respeito da terminologia adotada ao longo do trabalho.

O termo common law, tal como aparece em muitos manuais de direito comparado e história do direito ${ }^{14}$, na verdade comporta vários sentidos. Ele pode referir-se tanto ao

S. F. C. Milsom, Sources of English History: Private Law to 1750, $2^{\mathrm{a}}$ ed., Oxford, Oxford University, 2010, pp. $1-715$.

${ }^{10}$ Procuramos, ao longo deste trabalho, compulsar as edições de cada authority consagradas pela melhor doutrina inglesa, bem como as traduções mais avalizadas das obras em latim ou law French. Assim, citamos, ao longo da pesquisa, os textos reproduzidos nas seguintes edições dos books of authority: R. GLANVILLA, Tractatus de legibus et consuetudinibus regni Angliae (c. 1187-1189), London, White \& Brooke, 1780, pp. 1237; J. BEAMES, A Translation of Glanville, Washington, John Byrne \& Co., 1900, pp. 1-291; F. W. MarTLAND, Bracton's Note Book, vols. I-III, London, Clay \& Sons, 1887; G. E. WoodBINE, Bracton De legibus et consuetudinibus Angliae (c. 1268), vols. I-IV, New Haven, Yale, 1915-1942; S. E. THORNE, On the Laws and Customs of England, vols. I-IV, Cambridge, Harvard University, 1968-1977; Fleta seu Commentarius Juris Anglicani (c. 1290), $2^{\mathrm{a}}$ ed., London, 1685, pp. 1-553; J. FORTESCUE, De laudibus legum Angliae (1470), trad. ao ing. de A. Amos, De laudibus legum Angliae - The Translation into English, Cambridge, Smith, 1825, pp. 2274; T. LitTLETON, Tenores Novelli, London, Lettou \& Machlinia, 1482, trad. ing. de E. Coke, London, reed. e rev. por T. E. TomLINS, Lyttleton - His Treatise of Tenures - In French and English, London, Sweet, 1841, pp. 1-693; T. LitTLETON, Tenores Novelli, London, Lettou \& Machlinia, 1482, trad. ing. de E. Coke, London, reed. e rev. por E. WAMBAUGH, Littleton's Tenures - In English, Washington, John Byrne \& Co., 1903, pp. 1-338; E. COKE, The First Part of the Institutes of the Laws of England or A Commentary Upon Littleton, 1628, vols. I-II, anot. e coment. por F. Hargrave e C. ButLer, $19^{a}$ ed., Philadelphia, Small, 1853, s. n.; W. Blackstone, Commentaries on the Laws of England, vols. I-IV, Oxford, Clarendon, 1768-1770.

${ }^{11}$ É o caso, por exemplo, das referências ao Domesday Book e ao Liber Feodorum (cf. notas 90 e 91 infra), dentre outras.

${ }^{12}$ As principais obras, citadas neste trabalho, dedicadas à história do direito inglês, são (em ordem cronológica de publicação): G. SPENCE, The Equitable Jurisdiction of the Court of Chancery, vols. I-II, London, Stevens \& Norton, 1846-1849; J. ReEves, History of the English Law, vols. I-V, Philadelphia, Murphy, 1880; F. Pollock e F. W. MaITLAND, The History of English Law Before the Time of Edward I, vols. I-II, 2a ed., Cambridge, Cambridge University, 1898-1899; F. W. MAITLAND, Equity - Also the Forms of Action at Common Law, Cambridge, Cambridge University, 1910, pp. 1-375; W. S. HoldsworTH, A History of English Law, vols. I-III, $3^{\text {a }}$ ed., London, Methuen \& Co., 1922-1923; T. F. T. PluCKNETT, A Concise History of the Common Law, $5^{\mathrm{a}}$ ed., London, Butterworth, 1956, pp. 3-746; S. F. C. MiLsOM, Historical Foundations of the Common Law, $2^{\mathrm{a}}$ ed., Oxford, Oxford University, 1981, pp. 1-428; J. H. BAKER, An Introduction to English Legal History, $4^{\mathrm{a}}$ ed., Oxford, Oxford University, 2002, pp. 1-536.

${ }^{13} \mathrm{O}$ recurso a esse tipo de literatura é freqüente ao longo do trabalho, dada a necessidade de desvendar o particular vocabulário jurídico inglês. As principais obras consultadas são (em ordem cronológica de publicação): C. F. DU CANGE, Glossarium mediae et infimae latinitatis (1678), Niort, Favre, vols. I-X, 18831887; H. SPELMANNUS, Glossarium archiaologicum continens latino-barbara, peregrina, obsoleta \& novatae significationis vocabula, $3^{\mathrm{a}}$ ed., Thomas Braddyll, London, 1687, pp. 1-576; A. M. BURRILL, A New Law Dictionary, vols. I-II, New York, John Voorhies, 1850-1851, pp. 1-1078; A. BERGER, Encyclopedic Dictionary of Roman Law, in Transactions of the American Philosophical Society, 43 (1953), pp. 333-809; D. M. WALKER, The Oxford Companion cit. (nota 8 supra), pp. 1-1315; P. G. W. GLARE (coord.), Oxford Latin Dictionary, London, Oxford University, 1982 [reimpr. 2007], pp. 1-2126; J. A. SIMPSON e E. S. C. WEINER (coord.), Oxford English Dictionary, vols. I-XX, Oxford, Clarendon, 1989; B. A. GARNER (coord.), Black's Law Dictionary, $9^{a}$ ed., Saint Paul, West, 2010, pp. 1-1389.

${ }^{14}$ Apenas como exemplo, citamos duas obras traduzidas à língua portuguesa que contribuiram para aumentar, no Brasil, o interesse pelo common law, cf. R. DAVID, Les grands systèmes du droit contemporains, 
sistema de direito surgido e desenvolvido na Inglaterra a partir do século $\mathrm{XI}^{15}$, quanto ao direito desenvolvido e aplicado exclusivamente pelos tribunais reais da Inglaterra. Pode-se dizer que, conceitualmente, a relação entre essas duas acepções seja de generalidade e especificidade.

No que diz respeito à origem histórica da locução common law, cabe ressaltar que os juristas ingleses se apropriaram do termo ius commune ${ }^{16}$, que já era utilizado no século XIII pelos canonistas na Inglaterra em referência ao direito da Igreja católica ${ }^{17}$, para indicar o conjunto de normas costumeiras gerais válidas em todo o território inglês, distintas da legislação (statutes), do costume local (local custom) e das prerrogativas reais (royal

trad. port. de H. A. Carvalho, Os Grandes Sistemas de Direito Contemporâneo, $4^{\mathrm{a}}$ ed., São Paulo, Martins Fontes, 2002, pp. 351-508; J. GILISSEN, Introduction historique au Droit, 1976, trad. port. de A. M. Espanha e M. M. Malheiros, Introdução Histórica ao Direito, $4^{\mathrm{a}}$ ed., Lisboa, Fundação Calouste Gulbenkian, 2003, pp. 207-220.

${ }^{15}$ Esse sentido corresponde genericamente ao significado do termo "direito inglês" [=English law], cf. D. M. WALKER, The Oxford Companion cit. (nota 8 supra), pp. 403-419 (no verbete "English law").

${ }^{16}$ Conforme explica F. W. MaITLAND, Canon Law in England, in EHR 43 (1896), p. 448, o termo common law nasceu na Inglaterra do século XIII para fazer referência específica ao direito jurisprudencial desenvolvido e aplicado nos tribunais reais de Westminster (cf. capítulo 3.2.2 infra). Assim, o termo indica um âmbito que não se confunde com o sentido dado à locução "direito comum" no Continente, que pode incluir os costumes locais. $\mathrm{O}$ autor nota, por exemplo, que para a doutrina alemã, a diferença da inglesa, o termo gemeines Recht (direito comum) engloba tanto as leis comuns alemãs (Gemeindeutsche Gesetze) quanto os costumes comuns alemães (Gemeindeutsche Gewohnheiten), ambos fontes do direito comum alemão (Quellen des gemeinen deutschen Privatrecht), cf. O. F. GIERKE, vol. I, Deutsches Privatrecht, Leipzig, Duncker \& Humblot, 1895, p. 54.

A distinção entre o significado do termo ius commune (entendido como "common law" na segunda acepção) no Continente e na Inglaterra também é notada em C. F. DU CANGE, Glossarium cit. (nota 13 supra), t. 4, col. 467c (no verbete "jus commune"): “'Jus Commune' appellant nostri jus illud, quo in Gallia utuntur civitates, consuetudines municipales, cui opponitur Jus scriptum, seu 'Lex Romana' (...) Ita etiam Angli 'Jus civile Anglorum' vocant".

${ }^{17}$ Assim, por exemplo, vê-se a expressão em J. WYCLIF, The Grete Sentence of Curs Expounded, 1383 in T. ARNOLD, Selected English Works of John Wyclif, vol. III, Oxford, Clarendon, 1871, pp. 289: "perfore seide Seynt Gregory and pe comyn lawe of pe Chirche, pat honour or prelacie schulde not be zoven to him pat seken and coveiten it, but to siche men as fleen honouris and dignyte (...)”.

No continente, a expressão ius commune refere-se ao corpo de direito considerado comum a todo o mundo cristão medieval. Desenvolvido principalmente entre os séculos XII e XIV, é também designado pelo termo utrumque ius ("um e outro direito") e era composto pelas normas pertencentes ao ius civile e ao ius canonicum. Junto com o ius proprium, ou seja, as normas desenvolvidas e aplicadas localmente, o ius commune perfaz o núcleo da cultura jurídica no continente europeu medieval, cf. M. BELLOMO, L'Europa del diritto commune, 1988, trad. ing. de Cochrane, Lydia G., The Common Legal Past of Europe, Washington, Catholic University, 1995, p. 74.

Cabe ressaltar que a historiografia jurídica ainda discute o grau de penetração do ius commune na práxis jurídica medieval e, consequentemente, sua influência na formação do direito contemporâneo. Assim, alguns sustentam que a influência do ius commune no pensamento jurídico medieval foi meramente marginal e desvinculada do direito efetivamente aplicado. É o caso de G. TARELLO, Storia della cultura giuridica moderna, vol. I, Bologna, Mulino, 1976, pp. 29-30, nt. 11, para quem "per 'diritto commune' si intende un diritto residuale che si applica a tutti salve le deroghe costituite da qualsivoglia legge particolare, come le leggi locali, le leggi applicate a particolari tipi do persona (nobili, mercanti, clero, servi, ebrei, cattolici, protestanti), o anche a particolari tipi di Beni (terre del sovrano, terre nobili), e a particolare tipi di rapporti (vendite commerciali, trasporti marittimi)...'Diritto commune' è concetto relativo, che se contrappone a 'particolare...". $\mathrm{Na}$ Alemanha, a mesma posição prevalece e encontra expressão inclusive na divisão da famosa revista $Z R G$ em três departamentos (Abteilungen): o departamento germânico (Germanistische Abteilung), o departamento romanístico (Romanistische Abteilung) e o departamento canonístico (Kanonistische Abteilung), cf. M. BELlomo, L'Europa del diritto commune cit. (nesta nota), pp. 78-79, nt. 1. 
prerrogatives $)^{18}$. Daí que hoje se possa dizer que os significados dos termos ius commune e common law não se confundem ${ }^{19}$.

Assim, em sentido amplo, common law significa o direito inglês como um todo, incluídos o direito eclesiástico e os direitos marítimo e mercantil aplicados na Inglaterra, em contraposição aos direitos de base romanística. Já em sentido estrito, common law refere-se ao direito desenvolvido e aplicado a partir do século XII pelos tribunais reais, distinto dos costumes locais, do direito eclesiástico, dos sistemas romanísticos de direito e das normas desenvolvidas pelos tribunais da equity ${ }^{20}$.

Por opção metodológica e com o objetivo de facilitar a leitura deste trabalho, será utilizada a expressão common law, sem qualquer qualificação, para fazer referência unicamente ao direito desenvolvido e aplicado pelos tribunais reais a partir do século XII. Quando se tratar do ordenamento jurídico inglês como um todo, utilizar-se-ão os termos "sistema do common law" ou "direito inglês",

Por sua vez, o vocábulo equity, no linguajar jurídico inglês, tem várias acepções $^{22}$. Em sentido mais amplo, seu significado é similar ao sentido da palavra

${ }^{18}$ Cf. F. W. Maitland, Canon Law in England cit. (nota 16 supra), p. 448.

${ }^{19}$ Cf. R. C. CAEnegem, The Birth of the English Common Law, Cambridge, Cambridge University, 1997, p. 88. Nos países de língua portuguesa, no entanto, o uso de uma terminologia ambígua pode gerar confusão entre os termos ius commune e common law. É o caso, conforme apontado por E. C. SILVEIRA MARCHI na banca de qualificação deste candidato celebrada em 19-10-2011, da clássica obra O. W. HoLMES, The Common Law, Boston, Little Brown, 1881, trad. port. de J. L. Melo, O Direito Comum - Origens do Direito Anglo-Americano, Rio de Janeiro, Cruzeiro, 1967, pp. 11-329, em que a expressão "common law", como o próprio título em português indica, foi traduzida literalmente por "direito comum", locução que, em língua portuguesa, é mais adequada para designar o direito intermédio continental europeu, cf. A. M. HESPANHA, Cultura Jurídica Européia: Síntese de um Milênio, Florianópolis, Boiteux, 2005, pp. 121-123. As traduções mais modernas evitam traduzir o termo common law, distinguindo assim entre o direito de matriz inglesa, de um lado, e o direito comum continental europeu, de outro, cf. as obras citadas na nota 14 supra.

20 Acerca das diversas acepções da expressão common law na língua inglesa, cf. D. M. WALKER, The Oxford Companion cit. (nota 13 supra), p. 253 (no verbete "common law"), com os seguintes principais significados possíveis: (i) o ordenamento jurídico da Igreja, distinto dos costumes locais, também denominado ius commune; (ii) o conjunto de normas pertencentes ao sistema judiciário real centralizado; (iii) o direito inglês como um todo; (iv) no contexto do direito comparado, o sistema de direito que abarca os ordenamentos inspirados no direito inglês, em oposição ao sistema de direito romano-germânico; (v) o direito aplicado pelos três tribunais reais sediados em Westminster, em oposição à equity. De modo geral, cf. J. A. SIMPSON e E. S. C. WEINER (coord.), OED 3 (1989), p. 570 (no verbete "common law").

${ }^{21}$ Cabe lembrar que a maior parte dos autores ingleses utilizam o termo anglo-saxon law para referir-se ao direito vigente na Inglaterra antes da conquista de 1066, cf. nota 101 infra. Apesar de não tratarmos desse assunto, no nosso trabalho preferiremos os termos "sistema do common law" e "direito inglês" para manter o nosso vocabulário compatível com o da doutrina jurídica e historiográfica inglesa.

22 Para uma exposição dos vários sentidos do termo, cf. B. A. GARNER (coord.), Black's cit. (nota 13 supra), pp. $486-487$ (no verbete "equity”). O vocábulo tem uma acepção geral, que é a qualidade daquilo que é justo, correto, equitativo ou imparcial, e um sentido específico para as ciências jurídicas. Nessa última acepção, o termo equity pode significar: (i) o recurso aos princípios gerais de justiça derivados da naturalis aequitas romana, como forma de complementar e corrigir o direito vigente; (ii) na Inglaterra, Irlanda e os Estados Unidos, o sistema de direito que coexistiu com o common law e o statute law, prevalecendo sobre estes em caso de conflito; (iii) um direito reconhecido por um tribunal da equity; (iv) a qualidade daquilo relacionado ou 
"equidade" em português e denota a honestidade e a retidão empregadas nas relações humanas, ou seja, a qualidade daquilo que é feito ex aequo et bono ${ }^{23}$. Utiliza-se também, em sentido um pouco mais restrito, para fazer referência ao conjunto de princípios de justiça com base nos quais o juiz decide os litígios, criando normas novas em detrimento do direito estabelecido $^{24}$.

Em sentido estrito, no entanto, utiliza-se em oposição ao direito antigamente aplicado nos tribunais reais ${ }^{25}$ assentados em Westminster ${ }^{26}$ e que posteriormente veio a ser denominado common $\operatorname{law}^{27}$. Trata-se, na verdade, de um corpo normativo que, até 1875 , era o conjunto de normas aplicadas apenas e exclusivamente pelos tribunais ingleses denominados Courts of Equity. Porém, dado que esses tribunais foram extintos entre 1873 e $1875^{28}$, é mais correto dizer que a equity é "o conjunto de normas aplicadas pelos tribunais ingleses que, não fosse pela promulgação dos Judicature Acts de 1875, seriam aplicadas apenas e exclusivamente pelos tribunais denominados tribunais da equity" ${ }^{29}$. É esse sentido mais restrito que serve de parâmetro para a nossa exposição ${ }^{30}$.

pertencente à jurisdição da equity, i.e. equity-bar, equity court, equity-judge, equity-lawyer; (v) o direito de obter uma decisão judicial baseada num juízo equitativo; (vi) o valor de um bem ou um direito após a subtração de quaisquer ônus, e (vii) um direito real sobre um determinado patrimônio, em especial na área do comércio.

${ }^{23}$ Cf. J. STORY, Commentaries on Equity Jurisprudence, $3^{\mathrm{a}}$ ed., London, Sweet \& Maxwell, 1920, p. 1. É interessante notar que, para esse autor, a noção mais ampla de equity corresponde à idéia de justiça que aparece nas fontes romanas, especificamente em Ulp. 2 regul., D. 1, 1, 10 pr.: "Iustitia est constans et perpetua voluntas ius suum cuique tribuendi"; Ulp. 2 regul., D. 1, 1, 10, 1: "Iuris praecepta sunt haec: honeste vivere, alterum non laedere, suum cuique tribuere"; Paul. 14 ad Sab., D. 1, 1, 11: "Ius pluribus modis dicitur: uno modo, cum id quod semper aequum ac bonum est ius dicitur, ut est ius naturale. Altero modo, quod omnibus aut pluribus in quaque civitate utile est, ut est ius civile. Nec minus ius recte appellatur in civitate nostra ius honorarium (...)" (Diz-se "direito" em vários sentidos. Um sentido <é adotado> quando se denomina "direito" aquilo que sempre é bom e equitativo, tal como o ius naturale. Outro sentido <é adotado para designar> aquilo que é conveniente para todos ou a maioria em cada cidade, tal como o ius civile. E não menos corretamente denomina-se "direito", na nossa cidade, o ius honorarium (...)). O mesmo autor também associa a noção mais ampla de equity ao pensamento de H. GROTIUs, De aequitate, indulgentia et facilitate, 1625, anot. por Barbeyrac, Jean Amsterdam, 1720, I, § 4: "Latinis autem aequi prudentia vertitur, quae fefe ita ad aequitatem habet, ut juri/prudentia ut juftitiam", bem como a Bracton f. 3: "Item ius quandoque supponitur pro iure naturali, quod semper bonum et aquum est. Quandoque pro iure civili tantum. Quandoque pro iure pretorio tantum. Quandoque pro eo tantum quod competit ex sententia" (Da mesma forma, ius às vezes é utilizado para <designar $>$ o direito natural, o qual é sempre bom e equitativo; às vezes para <designar > apenas o direito civil; às vezes para <designar > o direito pretoriano; às vezes para < designar $>$ apenas aquilo que diz respeito a uma sentença).

${ }^{24}$ É nesse sentido que vários autores ingleses utilizam o termo equity, tal como W. S. HOLDSWORTH, A History of English Law cit., vol. I (nota 12 supra), pp. 446-449 (ao tratar da competência dos diversos tribunais ingleses para modificar o direito preestabelecido) e J. H. BAKER, An Introduction cit. (nota 12 supra), p. 106 (ao descrever a natureza do direito aplicado pelo Chancellor a partir da era dos monarcas da dinastia Tudor).

${ }^{25}$ Cf. capítulo 3.2.2 infra.

${ }^{26}$ Para um percurso histórico de Westminster Hall e dos tribunais que ali funcionaram, cf. J. H. BAKER, The Common Law Tradition, London, Hambledon, 2000, pp. 247-262.

${ }^{27}$ Cf. W. S. HoldSwORTH, A History of English Law cit., vol. I (nota 12 supra), pp. 4-5.

${ }^{28}$ Cf. Stat. 36 \& 37 Vic. (1873), c. 66 e Stat. 38 \& 39 Vic. (1875), c. 77.

${ }^{29}$ Cf. F. W. Maitland, Equity cit. (nota 12 supra), p. 1. O autor reconhece que essa não seja uma definição muito científica; porém, na sua visão, a única outra forma de definir a equity seria enumerar cada uma das regras que compõem o conjunto, o que não representaria qualquer vantagem do ponto de vista dogmático, na 


\section{OS COMPONENTES FEUDAIS NA FORMAÇÃO DA REAL PROPERTY LAW}

Não é fácil para um jurista educado e treinado no pensamento jurídico da tradição civilista compreender, prima facie, a terminologia e a estrutura da real property law inglesa ${ }^{31}$. Em larga medida essa dificuldade deve-se ao fato de que o arcabouço conceitual sobre o qual hoje descansa a propriedade nos sistemas de base romanística é bem distinto do que era no século XI, época em que o common law dava os seus primeiros passos ${ }^{32}$. A compreensão da real property law inglesa exige, nesse sentido, algum conhecimento histórico ${ }^{33}$ acerca da estrutura dos direitos reais sobre a terra $\left(\operatorname{land}^{34}\right)$ na Inglaterra medieval ${ }^{35}$.

Assim, para entender aquilo que no direito inglês se entende por ownership ${ }^{36}$, é necessário perceber a distinção entre o moderno direito de propriedade de origem civilística e o conceito de domínio de raízes feudais, tal como se apresentava na cultura medieval ${ }^{37}$.

medida em que a única característica que permite agrupar essas normas num mesmo conjunto é o fato de que todas eram aplicadas, até a data citada, pelos tribunais da equity.

${ }^{30}$ Cf. capítulo 3.2 infra.

${ }^{31}$ Essa dificuldade atribue-se, em larga medida, ao apego dos juristas, advogados e juízes ingleses a uma tradição cujas bases foram lançadas no contexto da conquista normanda de 1066, cf. K. ZWEIGERT e H. KÖTZ, Einführung cit. (nota 1 supra), p. 181. Sobre a conquista normanda, cf. nota 101 infra.

${ }^{32}$ Referimo-nos, especificamente, à cultura jurídica continental anterior às grandes codificações. Acerca da estrutura e características gerais dos direitos reais no continente europeu durante a Idade Média, cf. A. THIER, s.v. Feudal Law, in J. BASEDOw, K. Hopt e R. Zimmermann, The Max Planck Encyclopedia of European Private Law, vol. I, Oxford, Oxford University, 2012, pp. 686-690; G. ASTUTI, s.v. Feudo, in ED 17 (1968), pp. 292-313.

${ }^{33}$ A utilidade dos estudos históricos no âmbito dos estudos voltados para a compreensão do common law é ressaltada e exemplificada com um breve estudo acerca da evolução da responsabilidade objetiva por fato de terceiro (vicarious libaility) em R. ZIMMERMANN, Roman Law, Contemporary Law, European Law - The Civilian Tradition Today, Oxford, Oxford University, 2004, pp. 111-126.

${ }^{34}$ Cf. K. GRAY e S. F. GRAY, Elements of Land Law cit. (nota 1 supra), pp. 12-13. Hoje, o termo "land", no direito inglês, tem um significado amplo que abrange o solo e seus acessórios (corporeal hereditaments) e quaisquer direitos dele decorrente (incorporeal hereditaments), cf. Stat. 15 \& 16 Geo. V (1925), c. 20 , s. 205 (1) (ix): "'Land' includes land of any tenure, and mines and minerals, whether or not held apart from the surface, buildings or part of buildings (whether the division is horizontal, vertical or made in any other way), and other corporeal hereditaments; also a manor, an advowson, and a rent and other incorporeal hereditaments, and an easement, right, privilege, or benefit in, over, or derived from land (...)". Cf. também B1 Comm 2, 2, 16-18 [=W. Blackstone, Commentaries cit., vol. II (nota 10 supra), pp. 16-18]. No contexto da nossa exposição, o uso dos termos "terreno", "terra", "bem imóvel" e outros correlatos deve ser interpretado de acordo com o mesmo critério amplo adotado no direito inglês.

${ }^{35}$ Cf. M. C. MAlagUTI, Il trust cit. (nota 1 supra), pp. 183 e 186. A mesma orientação já aparece em B1 Comm 2, 4, 44 [=W. Blackstone, Commentaries cit., vol. II (nota 10 supra), p. 44]: "It is impoffible to understand, with any degree of accuracy, either the civil conftitution of this kingdom, or the laws which regulate its landed property, without some general acquaintance with the nature and doctrine of feuds, or the feodal law (...)".

${ }^{36}$ É interessante notar que a definição genérica do termo ownership no direito inglês, que engloba tanto a propriedade dos bens corpóreos quanto incorpóreos (direitos), não é dissimilar ao civilístico, já que "a person having ownership has the fullest group of rights which a person can legally have in relation to things of that kind, including at least some of the rights to occupy, possess, use, abuse, use up, let out, lend, transfer in security, sell, exchange, gift, bequeath, and destroy", cf. D. M. WALKER, The Oxford Companion cit. (nota 8 supra), p. 910 (no verbete "ownership"). Já se depreende do conceito, no entanto, a preocupação em nominar e especificar as faculdades do owner, que por isso é titular, pelo menos em tese, de um direito mais condicionado (e potencialmente restrito) que o do proprietário da tradição civilística. 


\section{A noção civilística contemporânea de propriedade se baseia numa idéia de}

dominium como apropriação total e exclusiva da coisa pelo titular do direito, sobre a qual descansa um paradigma único e absoluto de propriedade sobre a coisa em sentido material ${ }^{38}$. É essa a noção que ficou plasmada, com algumas variações, nas principais codificações ${ }^{39}$ de direito privado moderno ${ }^{40}$.

${ }^{37}$ Cf. T. F. T. Plucknett, A Concise History cit. (nota 12 supra), p. 506.

${ }^{38}$ Cf. P. Bonfante, Istituzioni di diritto romano, $10^{\mathrm{a}}$ ed., Torino, Giappichelli, 1946, pp. 249-250. Acerca do conceito de propriedade de base romanística, cabe recordar a definição formulada por esse autor, segundo a qual a propriedade é a "signoria più generale sulla cosa, sia in atto, sia per lo meno in potenza". De acordo com ela, o conteúdo da propriedade é propositadamente mais genérico, na medida em que ele não pode ser determinado positivamente, mas apenas de forma negativa, em função das limitações legais ao seu exercício. Ao mesmo tempo, esse conceito leva em consideração a possibilidade de o proprietário alienar uma ou mais das suas faculdades, ou seja, de transferir a outrem a faculdade de usar, gozar, dispor ou até reivindicar a coisa, tornando seu direito mais ou menos amplo, porém conservando-o na sua integralidade, fenômeno denominado "elasticidade da propriedade". Essa concepção absoluta do dominium, conforme explica F. PRINGSHEIM, The Unique Character of Classical Roman Law, in The Journal of Roman Studies 34 (1944), pp. 62-63, é uma das características que distinguem o direito romano clássico de todos os demais direitos antigos.

${ }^{39}$ Cabe mencionar que, de acordo com M. Bellomo, L'Europa del diritto commune cit. (nota 17 supra), pp. 32-33, o aumento do interesse nas últimas décadas nos estudos comparatísticos voltados para a análise do common law está relacionado, entre outros motivos, ao fenômeno de decodificação provocado pela profusão de leis extravagantes que, ao longo dos anos, têm suprimido a aplicação de seções inteiras dos códigos civis em sistemas romanísticos e levado a uma crescente fragmentação do modelo codificado. De acordo com essa visão, o sistema do common law proporciona um interessante objeto de estudo, na medida em que o direito inglês retém algumas das características da cultura jurídica continental anterior à era das grandes codificações.

${ }^{40}$ Do ponto de vista comparatístico, é interessante notar os mais recentes esforços para unificar o conceito de propriedade, pelo menos no que diz respeito aos sistemas de direito de base romanística. Nesse sentido, destaca-se o Draft Common Frame of Reference (DCFR), desenvolvido pelo Study Group on a European Civil Code, obra que consiste num esboço codificado dos princípios, definições e regras-modelo de direito privado europeu. Cada artigo vem acompanhado de extensas notas explicando o dispositivo e as particularidades do instituto em cada sistema.

O artigo VIII.-1:202 do DCFR define o direito de propriedade (ownership) da seguinte forma: "'Ownership' is the most comprehensive right a person, the 'owner', can have over property, including the exclusive right, so far as consistent with applicable laws or rights granted by the owner, to use, enjoy, modify, destroy, dispose of and recover the property". No comentário ao artigo citado, ressalta-se que, apesar das diferenças existentes entre os vários sistemas de direito civil, esse conceito engloba uma série de elementos comuns a todos eles. Assim, o direito de propriedade se carcateriza pela sua imediaticidade (referente à relação direta entre a coisa e o proprietário, o que significa que esse direito não depende de qualquer relação deste com outra pessoa), absoluticidade (a vedação à interferência nessa relação por parte de terceiros), elasticidade (a capacidade de recuperar sua extensão originária toda vez que eventuais limitações decorrentes de iura in re aliena deixarem de existir) e historicidade comum (retomada da noção romana de dominium unitária e absoluta, como resultado do fim do sistema feudal baseado no desmembramento entre o dominium directum e o dominium utilis e adoção dos conceitos de propriedade disseminados principalmente pelo CC francês e o BGB alemão), cf. C. BAR e E. Clive, Principles cit., vol V (nota 1 supra), pp. 4250-4256.

Comparando alguns dos principais expoentes da codificação civilística é possível verificar que, de fato, as definições baseiam-se na mesma idéia: artigo 544 do CC francês: "La propriété est le droit de jouir et disposer des choses de la manière la plus absolue, pourvu qu'on n'en fasse pas un usage prohibé par les lois ou par les règlements"; § 903 BGB: "Der Eigentümer einer Sache kann, soweit nicht das Gesetz oder Rechte Dritter entgegenstehen, mit der Sache nach Belieben verfahren und andere von jeder Einwirkung ausschließen. Der Eigentümer eines Tieres hat bei der Ausübung seiner Befugnisse die besonderen Vorschriften zum Schutz der Tiere zu beachten" (O proprietário de uma coisa pode, salvo quando a lei ou o direito de terceiros o impeça, proceder conforme lhe aprouver em relação à coisa e excluir qualquer influência de outrem. O proprietário de um animal deve, ao exercer seus poderes, levar em consideração as regras especiais para a proteção dos animais); artigo 832 do CC italiano: "Il proprietario ha diritto di godere e disporre delle cose in modo pieno ed esclusivo, entro i limiti e con l'osservanza degli obblighi stabiliti dall'ordinamento giuridico"; artigo 348 do CC espanhol: "La propiedad es el derecho de gozar y disponer de una cosa, sin más limitaciones que las 
Já a noção de direitos reais como resultado de uma relação feudal ${ }^{41}$, na qual se baseia a real property law inglesa, muito embora possa encontrar algumas raízes em instituições romanas, desenvolveu-se num contexto medieval ${ }^{42}$ em que era comum a existência de múltiples relações jurídicas sobre a mesma coisa por parte de vários sujeitos, tendo como conseqüência a relativização da distinção entre o dominium e os iura in re aliena.

establecidas en las leyes. El propietario tiene acción contra el tenedor y el poseedor de la cosa para reivindicarla". No mesmo sentido, o artigo 1.228 do atual CC brasileiro: "O proprietário tem a faculdade de usar, gozar e dispor da coisa, e o direito de reavê-la do poder de quem quer que injustamente a possua ou a detenha".

${ }^{41}$ De fato, a própria denominação das principais categorias de diretos reais sobre bens imóveis são prova dessa influência. Assim, a palavra fee, utilizada até os dias de hoje para qualificar um estate, foi incorporada à língua inglesa a partir do francês medieval fief, cuja raíz latina é, ao que parece, foedum, cf. J. A. SIMPSON e E. S. C. WEINER (coord.), OED 5 (1989), pp. 796-798 (nos verbetes "fee" e "fee "), se bem que ainda há discussões a respeito da origem etimológica da palavra (cf. nota 124 infra). Embora originariamente pudesse significar tanto a extensão mínima necessária de um lote de terra para suprir o sustento de um cavaleiro, quanto a concessão de terras feita por um senhor feudal ao seu vassalo em troca de determinados serviços, com o passar do tempo passou a designar vários tipos de direito real sobre bens imóveis, cf. D. M. WALKER, The Oxford Companion cit. (nota 8 supra), p. 463 (no verbete "fee").

Quanto à palavra foedum, embora não haja consenso quanto à sua origem, cf. G. Long (coord.), Penny Cyclopaedia 9 (1837), pp. 243-244, o verbete correspondente em C. F. DU CANGE, Glossarium cit. (nota 13 supra), t. 3, col. 463c (no verbete "foedum") remete a beneficium, que, na sua primeira acepção, é definido da seguinte forma: "Scriptoribus mediae aetatis, dicitur praedium fiscale, quod a Rege vel Príncipe, vel ab alio quolibet ad vitam viro nobili utendum conceditur. Ita autem apellatum est, quod is ex mera dantis Beneficio ac liberalitate illud possideat", cf. C. F. DU CANGE, Glossarium cit. (nota 13 supra), t. 1, col. 629b (no verbete "beneficium" "). A definição fornece uma noção do funcionamento do sistema feudal, que foi a base sobre a qual se estruturou a real property law inglesa, constituindo, até hoje, uma das chaves terminológicas dos direitos reais de matriz inglesa.

42 Acerca das origens do sistema feudal, uma breve explicação sobre a sua (possível) origem pode ser lida em Bl Comm 2, 4, 44-45 [=W. Blackstone, Commentaries cit., vol. II (nota 10 supra), p. 44-45]. O autor considera que os primeiros indícios de feudalismo chegaram à península itálica com os povos bárbaros, particularmente os Cimbri e Teutones (o autor não menciona os Tigurinos), que teriam pedido terrae stipendiariae aos romanos no século I a.C. em troca de serviços de natureza militar, com base no fragmento Flor. Epit. 1, 38, 1-2: "Cimbri, Teutoni atque Tigurini ab extremis Galliae profugi, cum terras eorum inundasset Oceanus, novas sedes toto orbe quaerebant, exclusisque et Gallia et Hispania cum in Italiam demigrarent, misere legatos in castra Silani, inde ad senatum, petentes ut Martius populus aliquid sibi terrae daret quasi stipendium, ceterum ut vellet manibus atque armis suis uteretur" (Tendo os Cimbros, Teutones e os Tigurinos escapado do extremo da Gália, dado que o Oceano tinha inundado suas terras, procuravam pelo mundo todo novas localidades < para se estabelecer>, e excluídas tanto a Gália quanto a Espanha, dado que tinham imigrado para dentro da Itália, enviaram embaixadores ao acampamento de Silano, e de lá para o Senado, pedindo que o povo Guerreiro lhes desse algo de terra a título de soldo, quanto ao demais que utilizasse como quisessem suas mãos e armas).

A intuição de Blackstone parece acertada, pelo menos no que diz respeito à existência desse costume entre os povos bárbaros. O mais provável, contudo, é que as instituições mais típicas do feudalismo (suserania, vassalagem, homenagem etc.) tenham resultado de uma espécie de amalgamação das instituições romanas com os costumes bárbaros, principalmente germânicos, mesmo que não seja possível circunscrever sua origem a um grupo étnico específico, cf. M. BLOCH, La société féodal (1939), Paris, Pierre Palpant, 2005 [=L'évolution de l'Humanité, vols. XXXIV-XXXIVbis, Paris, Albin Michel, 1982], p. 146. Na opinião de G. SPENCE, The Equitable Jurisdiction cit., vol. I (nota 12 supra), p. 31, nt. y, no entanto, a concessão de terras, que se caracterizava pela manutenção da titularidade do dominium directum no Estado romano ao lado da atribuição do dominium utile ao concessionário, era comum muito antes do momento descrito e o fragmento em si não representa o marco inicial do fenômeno. As concessões de terras pertencentes ao Estado romano, de fato, se inserem no processo de "privatização" do ager publicus promovido através da divisio et adsignatio, que evoluiu de uma locação por prazo determinado (normalmente quinquenal) na época republicana para um verdadeiro direito real tutelado por uma actio in rem no principado, cf. M. TALAMANCA, Istituzioni di diritto romano, Milano, Giuffrè, 1990, pp. 394-397. 
Consequentemente, a titularidade formal do que se poderia denominar um direito de "propriedade" adquiriu importância secundária diante da efetividade dos direitos de gozo e fruição (enjoyment) sobre a coisa e a aparência de titularidade deles decorrente ${ }^{43}$.

${ }^{43}$ Cf. L. MoccIA, Il modello inglese cit. (nota 1 supra), pp. 37-38. Nesse sentido, o problema do confronto entre o modelo romanístico e o modelo inglês de propriedade envolve questões terminológicas, na medida em que não há correspondência direta entre os elementos que compõem cada modelo.

O modelo romanístico, construído a partir da experiência jurídica romana, posteriormente refinada pela civilística continental e finalmente plasmada nos códigos nacionais que surgiram a partir do séculofo XIX, concebe a propriedade como um direito absoluto e exclusivo de um sujeito sobre uma coisa móvel ou imóvel, como atesta a definição de P. BONFANTE citada acima (cf. nota 38 supra). O direito de propriedade é tradicionalmente considerado o direito real mais amplo, em torno do qual orbitam os demais direitos denominados reais. Assim, a propriedade é concebida como uma categoria que se opõe, do ponto de vista interno, à categoria dos direitos reais limitados, denominados direitos reais sobre coisa alheia, e do ponto de vista externo, à categoria dos direitos pessoais ou de crédito.

Por outro lado, o termo property tem uma conotação patrimonialista que o torna ambíguo aos olhos do jurista de base romanista. Em sentido subjetivo, diz respeito a diversos direitos reais sobre coisa alheia; já em sentido objetivo, refere-se ao complexo de bens materiais e imateriais, inclusive os direitos pessoais, que compõem o patrimônio de uma pessoa. Assim, o vocábulo property tem significado plurívoco, e pode referir-se a uma coisa fisicamente considerada (tangible thing), a um direito sobre uma coisa (rights ou interests) ou a um direito subjetivo, tal como um direito de crédito, cf. D. M. WALKER, The Oxford Companion cit. (nota 8 supra), pp. 1007-1008 (no verbete "property"). Em virtude da polissemia do termo property, é tecnicamente mais correto utilizar a palavra ownership para referir-se à propriedade no sentido romanístico. O modelo da property inglesa deve ser apreendido não a partir de uma dimensão terminológica ou lingüística, mas por meio do seu instrumentário conceitual e do tratamento sistemático da matéria (law of property ou property law), ou seja, da compreensão das regras, categorias e classificações que a disciplinam.

As categorias de coisas e direitos, por exemplo, não se articulam no plano do direito material, mas no âmbito do direito processual, ou seja, em função do tipo de ação que tutela a relação em questão. A property, dessa forma, divide-se em duas categorias: a real property ou realty, tutelada por real actions, e a personal property ou personalty, que é aquela tutelada por personal actions. A primeira categoria deriva, no contexto das concessões feudais (tenures), das situações de caráter possessório, relativas ao gozo (enjoyment) de um terreno (lands e tenements), as quais eram tuteladas mediante um writ of right ou um writ of entry, cujo objetivo era obter a reintegração na posse da coisa em questão. Tais writs eram qualificados como real actions não tanto porque visavam a reaver a coisa de qualquer sujeito, como pelo fato de que permitiam a recuperação efetiva da coisa, fosse de qualquer pessoa, fosse de um terceiro específico.

A segunda categoria, por sua vez, formou-se paulatinamente, constituindo uma espécie de classificação residual e subsidiária à primeira, na qual passaram a figurar os bens insuscetíveis de inclusão na primeira categoria, principalmente os goods ou chattels, tutelados por personal actions que não visavam especificamente à restituição da coisa e, portanto, facultavam ao réu o pagamento do valor correspondente, como ocorria com as ações de detinue e de trover, pelas quais se buscava a condenação do réu ao pagamento de uma soma em dinheiro.

Mesmo com o desaparecimento do feudalismo, a abolição das real actions e da maior parte das regras que distinguiam a realty da personalty, bem como o reconhecimento, por parte da doutrina inglesa, de que a única distinção verdadeiramente relevante é a que se faz entre os bens móveis e imóveis, a terminologia ancorada na tradição jurídica inglesa ainda gera resultados sui generis, em função das implicações das suas categorias, especialmente no âmbito do direito comercial.

De qualquer forma, o que fica claro é que o particular desenvolvimento do direito inglês, à margem da tradição romanística que marcou a formação do direito privado continental, impediu a formação de uma terminologia compatível com as categorias da tradição civilística, caracterizando um caso de resistência - no sentido dado a esse termo por P. KosCHAKER, Europa und das römische Recht, $3^{\mathrm{a}}$ ed., München, Beck, 1958, pp. 124-141 e 352 - à influência do direito romano, pelo menos no que diz respeito ao conteúdo dos direitos denominados reais.

A respeito da comparação das categorias relativas aos direitos reais e a property law, cf. L. MoCCIA, Il modello inglese cit. (nota 1 supra), pp. 37-41 e W. W. BUCKLAND e A. D. MCNAIR, Roman Law and Common Law cit. (nota 1 supra), pp. 56-97. Para uma análise mais detalhada do direito de propriedade nos sistemas de base romanística ao longo dos principais períodos da sua evolução histórica, cf. L. CAPOGROSSI COLOGNESI, s.v. Proprietà (dir. rom.), in ED 37 (1988), pp. 160-226; P. GROSSI, s.v. Proprietà (dir. interm.), in ED 37 (1988), pp. 226-254; P. RESCIGNO, s.v. Proprietà (dir. priv.), in ED 37 (1988), pp. 254-297. 
Nesse sentido, os textos jurídicos ingleses muitas vezes aludem a determinados direitos sobre o mesmo bem (principalmente sobre bens imóveis) que, desde uma perspectiva civilística, seriam colidentes. Daí que, a despeito do fato de que a definição genérica de ownership encontrada em algumas obras possa ser superficialmente similar à continental ${ }^{44}$, convenha raciocinar mais em termos da relação entre um sujeito e um ius (ou, modernamente, um estate $)^{45}$ do que em termos da relação de controle direto e absoluto entre um sujeito e um bem $^{46}$.

Diante desse quadro marcado pelas diferenças entre os dois sistemas, poder-se-ia pensar que as diferenças entre a real property law e os direitos reais de base romanística são irreconciliáveis, e que esse campo do conhecimento jurídico é de natureza eminentemente $\operatorname{local}^{47}$. Não menos provável seria que o civilista descartasse qualquer possibilidade de compreender a real property law em virtude dessa mesma, pelo menos aparente, incompatibilidade. No entanto, apesar das diferenças, um estudo acerca dos elementos que estruturaram historicamente os direitos reais de matriz inglesa pode contribuir para uma eventual harmonização.

\subsection{Os writs e as forms of action}

Em larga medida, um dos principais argumentos sustentados pela doutrina ${ }^{48}$ para explicar as diferenças entre os direitos de base romanística e o direito inglês, bem como a

${ }^{44}$ Um bom expoente desse modo de exposição é Bl Comm 2, 1, 2 [=W. BlaCKSTONE, Commentaries cit., vol. II (nota 10 supra), p. 2]: "There is nothing which fo generally ftrikes the imagination, and engages the affections of mankind, as the right of property, or that fole and defpotic dominion which one man claims and exercifes over the external things of the world, in total exclufion of the right of any other individual of the univerfe".

Nesse sentido, é interessante comparar a descrição acima com aqula apresentada em C. BAR e E. CLIVE, Principles cit., vol V (nota 1 supra), p. 4258, segundo a qual a ownership é um feixe de direitos sobre uma coisa que abarca, principalmente, "the perpetual right to possess and enjoy the thing; the perpetual right to the fruits and profits generated by it; and the right to alienate, bequeath or destroy it". Essa última definição é uma tentativa de harmonizar o direito privado europeu como um todo, e talvez por isso tenda a enumerar em maior detalhe as faculdades do proprietário no próprio conceito do instituto. Conforme se verá, a forte relação conceitual entre ownership e possession, bem como o particular desmembramento dos direitos reais, especialmente no que diz respeito aos bens imóveis, é uma das características marcantes da real property law inglesa.

${ }^{45}$ Cf. Lowe (Inspector of Taxes) v J W Ashmore Ltd [1971] Ch 545: “(...) the subject-matter of ownership is not the land itself but the estates or interests artificially created in that land".

${ }^{46}$ Cf. M. LUPOI, s.v. Trusts - Profili generali e diritto straniero, in Enciclopedia Giuridica Treccani 34 (1995), p. 3 .

${ }^{47}$ Cf. S. VAN ERP, Comparative Property Law cit. (nota 1 supra), p. 1044. O autor atribui a escassa produção de trabalhos comparatísiticos entre a property law e os direitos reais em sistemas de direito civil à dificuldade para conciliar as diferenças entre as respectivas tradições.

${ }^{48}$ Cf. J. GoRDLEY, Foundations of Private Law cit. (nota 1 supra), pp. 42-44. O autor ressalta que as principais diferenças entre os sistemas romanísticos e o sistema inglês não são de natureza principiológica, mas 
complexidade deste ${ }^{49}$, adota como ponto de partida o intrincado sistema dos writs $^{50}$, que deu origem às forms of action (formas de ação) ${ }^{51}$, com a sua divisão tripartita das ações ${ }^{52}$, pela

meramente instrumental, na medida em que todos se baseiam em premissas éticas muito semelhantes, mesmo que o resultado da atividade doutrinária ou jurisdicional possa ser divergente.

${ }^{49}$ Cf. A. WATSON, Roman Law \& Comparative Law cit. (nota 1 supra), p. 265.

${ }^{50}$ O substantivo writ, cujo significado geral é "algo escrito", não é de origem latina. O vocábulo provém do verbo wrītan no anglo-saxão antigo, anterior ao século XII, que significa "riscar", "desenhar" ou "inscrever", e tem formas análogas em várias línguas nórdicas antigas, cf. J. A. SIMPSON e E. S. C. WEINER (coord.), OED 20 (1989), p. 637 (no verbete "writ"). O equivalente em latim medieval é breve, cf. C. F. DU CANGE, Glossarium cit. (nota 13 supra), t. 1, col. 746a (no verbete "breve"): "Cowello dicitur Citatio, vel decretum causam breviter continens, ob quam quis in jus vocatur, aut aliquid aliud facere jubetur. Ita autem appellatur".

${ }^{51} \mathrm{Na}$ Inglaterra, deu-se a denominação forms of actions à técnica processual baseada no uso de writs nos tribunais reais. Adaptados pelos reis normados com base nas práticas administrativas anglo-saxãs e incorporados ao sistema do common law no final do século XII, originariamente os writs eram documentos escritos de uso amplo que determinavam, proibiam ou notificavam algo. O termo técnico breve originale surge em 1203 para denominar uma ordem escrita emitida pelo Chancellor que determinava o início de um procedimento judicial perante uma comissão real, cf. R. C. CAENEGEM, The Birth of the English Common Law cit. (nota 19 supra), pp. 29-30. Os writs dividem-se em duas grandes categorias: de um lado, os breves originales, que eram emitidos pela Court of Chancery e especificavam a natureza e o objeto do litígio, os nomes das partes e outros elementos do processo; de outro, os breves judiciales, que eram emitidos pelos tribunais do common law e se referiam a questões incidentais do processo, cf. F. W. MAITLAND, Register of Original Writs, in H. A. L. FISHER, The Collected Papers of Frederic William Maitland, vol. II, Cambridge, Cambridge University, 1911, pp. 123-124. A distinção entre breves originales e breves judiciales foi importante para diferenciar o assize [=assisa], instalado pelo primeiro tipo de writ, do júri [=jurata], convocado pela segunda espécie, cf. F. W. MAITLAND, Equity cit. (nota 12 supra), p. 329. A combinação da assisa e da jurata lançou as bases do júri moderno, cf. W. FORSYTH, History of Trial by Jury, London, Parker and Son, 1852, pp. 139-149.

A importância das forms of action para a formação do common law não pode ser minimizada, pois foi por meio desses instrumentos que se consolidou a máxima estabelecida em Bracton f. 413b: “(...) Et quorum quadam sunt personalia, quadam realia, quadam mixta, secundum quod sunt actiones diversa et varia, quia tot erunt formula brevium quot sunt genera actionum, quia non potest quis sine brevi agere, cum non teneatur alius sine brevi respondere nisi gratis voluerit, et ex hoc ei non iniuriatur, cum volenti et scienti non fiat iniuria (...)" ((...) E dessas <ações> algumas são pessoais, algumas reais, algumas mistas, motivo pelo qual as ações são diversas e variadas, pois haverá tantas formulas de writs quanto existem gêneros de ações, porque não pode alguém demandar sem um writ, na medida em que o outro não é obrigado a responder sem um writ, a menos que tenha querido <fazê-lo $>$ gratuitamente, e neste caso não lhe é feita uma injustiça, dado que não se faz injustiça a quem quer e tem ciência (...)). Daí a máxima da doutrina inglesa "remedies precede rights", que bem resume as condições sob as quais o sistema do common law se desenvolveu, ao ponto, inclusive, de forjar as categorias e conceitos jurídicos do sistema do common law, à margem dos sistemas de base romanista, cf. R. DAVID, Les grands systèmes cit. (nota 1 supra), pp. 325-326.

Acerca das forms of action, de modo geral cf. D. M. WALKER, The Oxford Companion cit. (nota 8 supra), pp. 20-21 (no verbete “actio, forms of'); sobre os writs, cf. D. M. WALKER, The Oxford Companion cit. (nota 8 supra), pp. 1050-1051 (no verbete "register of writs"); R. C. CAENEGEM, The Birth of the English Common Law cit. (nota 19 supra), pp. 29-61.

52 A classificação das ações em três tipos espécies, bem como a distinção entre ações in personam de natureza penal e civil, ocorre em Bracton f. 101b: "Et sciendum quod omnium actionum sive placitorum, ut inde utatur aquivoce, hac est prima divisio, quod quadam sunt in rem, quadam in personam et quadam mixtce. Item earum qua sunt in personam alia criminalia alia civilia, secundum quod descendunt ex maleficiis vel contractibus" (E deve-se saber que esta é a divisão primeira de todas as ações ou demandas, para utilizar indistintamente <cada termo>: que certas <ações> são in rem, certas in personam e certas <outras> mistas. Da mesma forma, dentre aquelas in personam algumas são penais e algumas civis, segundo provenham de uma infração ou de um contrato). Glanvill também classifica as ações, porém distingue apenas entre ações penais e civis, e não entre actiones in rem e in personam. Assim, Glanvill 1, 1 [=R. GLANVILLA, Tractatus de legibus cit. (nota 10 supra), p. 1]: "Placitorum, aliud eft criminale, aliud civile" (Dentre as demandas, algumas são penais, outras <são> civis). Porém, já se encontra uma distinção entre as ações civis julgadas nos tribunais locais e aquelas processados perante a curia regis, conforme Glanvill 1, 3 [=R. GLANVILLA, Tractatus de legibus cit. (nota 10 supra), p. 2]: "Placitum civile, aliud in Curia domini Regis tantum placitatur et terminatur, aliud ad Vicecomites provinciarum pertinet" (Uma <espécie de> demanda civil é ajuizada apenas no tribunal do senhor rei; outra <espécie> diz respeito ao sheriff das províncias). 
qual as actiones in rem tem por objeto as res imobilis e as actiones in personam as res mobilis $^{53}$.

O estudo dos writs e do sistema das forms of actions foi de fundamental importância para a formação dos juristas ingleses ${ }^{54}$ nos primeiros séculos do common law ${ }^{55} \mathrm{e}$ condicionou o pensamento jurídico inglês ao estabelecer como referência, mesmo no âmbito

Cabe observar que a classificação de Bracton nem sempre foi muito observada no direito inglês, mas que ela se baseia nas fontes romanas, especialmente em Inst. 4, 6, 1: "Omnium actionum, quibus inter aliquos apud iudices arbitrosve de qua re quaeritur, summa divisio in duo genera deducitur: aut enim in rem sunt aut in personam (...)" (A principal divisão de todas as ações, pelas quais entre as partes diante dos juizes ou árbitros discute-se acerca de alguma coisa, se reduz a duas espécies: ou são in rem ou in personam). Apesar de Bracton classificar as ações em três tipos, as duas categorias verdadeiramente relevantes, pelo menos para o estudos dos direitos reais no direito inglês, são as das actiones in rem e in personam.

${ }^{53}$ A divisão entre actiones in rem e actiones in personam passou a corresponder, desde cedo, à divisão das coisas entre bens móveis e imóveis, cabendo ações in personam no primeiro caso e in rem no segundo, a raiz do fragmento Bracton f. 102b: "Dictum est supra si res sit immobilis qua petitur, nunc tamen sit res mobilis quae petatur, sicut leo, bos, vel asinus, vestimentum, vel aliud quod consistat in pondere vel mensura. Videtur prima facie quod actio sive placitum esse debeat tam in rem quam in personam, eo quod certa res petitur, et quia possidens tenetur restituere rem petitam. Sed re vera erit in personam tantum, quia ille a quo res petitur non tenetur pracise ad rem restituendam, sed sub disiunctione, vel ad rem vel ad pretium" (O que foi dito acima <aplica-se> caso a coisa exigida seja imóvel; agora, contudo, <caso> a coisa exigida seja móvel, tal como um leão, um boi ou um asno, um vestido ou outra coisa que se caracterize pelo <seu $>$ peso ou <sua $>$ medida, parece, a primeira vista, que a ação ou demanda deva ser tanto in rem quanto in personam, na medida em que se exige uma coisa certa, e porque o possuidor é obrigado a restituir a coisa exigida. Porém, na verdade será somente in personam, porque aquele de quem a coisa é exigida não é obrigado à restituição da coisa precisamente, mas sob $<$ regime de> disjunção, <sendo obrigado à restituição > da coisa ou do preço).

O fragmento acima foi parafraseado, de modo a explicitar ainda mais a regra, em Fleta 60, 21 [=Fleta seu Commentarius cit. (nota 10 supra), pp. 129-130]: “Cum autem res fit mobilis quae peti debet, ficut bos, leo, afinus, veftimentum, vel aliud quod confiftat in pondere vel mensura, videtur prima facie quod action five placitum effe debet tam in rem quam in perfonam, eo quod certa res petitur, \& quia poffidens tenetur reftituere rem petitam; fed revera erit in perfonam tantum, quia ille, a quo res petitur, non tenetur rem pracise reftituere fed fub disjunctione, vel ad rem vel ad precium, \& folvendo tantum precium liberatur, five res appareat five non".

Daí conclui K. E. GÜTERBOCK, Henricus de Bracton cit. (nota 1 supra), p. 150, nt. c, que o direito inglês sempre rejeitou a possibilidade de uma coisa móvel ser objeto de uma actio in rem (muito embora o tradutor $\mathrm{B}$. Coxe faça uma ressalva, na mesma nota, em relação à action of detinue, de natureza real, porém cujo objeto é uma coisa móvel).

${ }^{54}$ Neste ponto em particular, empregamos o termo "juristas" livremente para nos referir aos operadores do direito no contexto dos tribunais, e não a doutrinadores, pois durante o período formativo do common law é notória a falta de juristas eruditos, cf. A. WATSON, Roman Law \& Comparative Law cit. (nota 1 supra), pp. 258259.

55 Cf. S. F. C. MILSOM, Historical Foundations cit. (nota 12 supra), pp. 37-38 e J. H. BAKER, An Introduction cit. (nota 12 supra), pp. 175-178. Passou a ser comum, a partir do século XIII, que os advogados e demais frequentadores dos tribunais reais mantivessem coletâneas de writs e pleadings (a partir do século XVI) como repositórios de conhecimento jurídico.

Assim, os modelos a serem seguidos para cada tipo de ação foram recolhidos, ao longo de mais de três séculos, em diversos Registers of Writs (Registra Brevium), nenhum deles de caráter oficial - embora se levante a hipótese de que haja existido um Master Register na Chancery, cf. R. C. CAENEGEM, The Birth of the English Common Law cit. (nota 19 supra), p. 30 - e muitos deles divergentes entre si, particularmente no que diz respeito à organização dos diversos writs, cf. F. W. MAITLAND, Register of Original Writs cit. (nota 51 supra), pp. 119-120. Em 1531, William Rastell publicou em Londres pela primeira vez uma versão impressa do Register of Judicial Writs intitulada Regnum Omnium Brevium Iudicialium, marcando assim o fim da sua evolução. A quarta e última edição dos brevia é de 1687 e foi impressa também em Londres pelos adquirentes de Richard e Edward Atkins sob o título Registrum Brevium Tam Originalium Quam Judicialium. A. FITZHERBERT também confeccionou uma das principais coleções de writs, a qual foi traduzida à língua inglesa, cf. A. FITZHERBERT, The New Natura Brevium, 8 ed., London, Savoy, 1755, pp. 1-606. 
da casuística ${ }^{56}$, não uma doutrina baseada em princípios e normas abstratas, mas o funcionamento dos tribunais.

\author{
Não é um exagero dizer, portanto, que entre os séculos XIII e XIX as \\ formalidades do processo dominaram o pensamento juirídico inglês ${ }^{57}$, nem supreende que um \\ fenômeno que inicialmente se revestia de caráter marcadamente contratual, isto é, as relações \\ feudais de suserania e vassalagem nas quais se basearam, num primeiro momento, os direitos
}

\footnotetext{
${ }^{56}$ Ao confrontar a análise casuística típica dos sistemas romanísticos com os do sistema anglo-americano, F. HoRAK, Dogmática e Casuística no Direito Romano e nos Direitos Modernos (sem título em alemão), trad. port. de E. C. Silveira Marchi, in Revista de Direito Civil, Imobiliário, Agrário e Empresarial 28 (1984), pp. 8290 distingue entre o judge made law anglo-americano, regulado pelo princípio do stare decisis, e o juristenrecht ou direito jurisprudencial da casuísitica romana, desprovido de força vinculante no âmbito judicial.

Para o autor, o case law típico do sistema anglo-americano é casuístico, porém a casuística do direito romano jurisprudencial não constitui um case law. A marca distintiva entre um e outro sistema seria o grau de "purificação" do caso das particularidades concretas irrelevantes para a construção da dogmática. Assim, enquanto o case law carece de fattispecie fixas e baseia sua ratio decidendi em confrontos entre descrições pormenorizadas de casos anteriores com um novo caso concreto, a casuística de base romana busca subordinar um conceito mais restrito a outro mais amplo mediante um processo de subsunção, o qual toma como ponto de partida uma descrição dos fatos já reduzida aos elementos caracterizantes da sua substância jurídica. Ao mesmo tempo, a ratio decidendi anglo-americana não seria nunca fixada definitivamente, mas apenas ad hoc, pois seria possível a qualquer juiz analizar novamente a riqueza de detalhes concretos presentes na descrição dos fatos de casos anteriores e chegar a um resultado diferente. Por outro lado, os casos descritos pelos juristas romanos nas fontes, os quais são frequentemente hipóteses fictícias, estão reduzidos ao essencial para a resolução do problema, de modo a construir fattispecie abstratas.

É a partir dessas fattispecie técnicas que os juristas romanos formaram regulae de caráter abstrato e geral, as quais tornaram-se vinculantes uma vez que as decisões dos juristas passaram a ter força de lei. Desse modo lançaram-se as bases para a dogmática jurídica, entendida como um "corpus de preceitos geralmente vinculantes de diverso grau de abstração, expressos em linguagem técnica”. O ápice da dogmática jurídica e da Konstruktionjurisprudenz (jurisprudência construtiva) foi alcançado no século XIX com a Begriffsjurisprudenz. (jurisprudência dos conceitos) de Savigny, e apesar dos seus excessos, muitos dos quais foram criticados por Jhering, constituem hoje a base do pensamento jurídico dos sistemas de base romanística.

Cabe mencionar que, no que se refere ao método casuístico, L. VACCA, Contributo allo studio del metodo casistico nel diritto romano, Milano, Giuffrè, 1976, pp. 133-137 e 140-144, ressalta que tanto o sistema de direito romano quanto o de direito inglês, nos seus respectivos períodos formativos, repousam numa comunhão de pressupostos que se revela não tanto nos resultados finais da atividade jurisprudencial, quanto na presença de uma classe de juristas (os juízes no direito inglês e os jurisconsultos no direito romano) que detêm o monopólio relativo à concretização da ratio de um ordenamento originário de modo a formular regulae para o caso concreto. Assim, em ambos os ordenamentos, a função da casuística teria sido a de fornecer a matéria prima a partir da qual a interpretação desses juristas, com sua eventual força vinculante (consistente no stare decisis inglês e o ius respondendi ex auctoritate principis romano) pôde construir o sistema jurídico.

As duas opiniões esboçadas acima não são antagônicas. De fato, elas são complementares se adotarmos como ponto de partida o fato que os autores analizam a casuística sob dois aspectos. Assim, enquanto F. HoRAK, ao analizar a estrutura típica dos casos que fornecem a matéria prima da casuística, busca comparar o objeto sobre o qual recai a tarefa interpretativa dos juristas de cada sistema, L. VACCA concentra o seu estudo acerca da casuística no resultado das interpretações desses juristas ao longo do tempo. Pode-se dizer, portanto, que enquanto a primeira análise e estrutural, a segunda é histórica.

${ }^{57}$ Cf. J. H. BAKER, An Introduction cit. (nota 12 supra), p. 53. Em larga medida o predomínio do processo ocorreu porque as garantias dos súditos reais eram efetivadas por meio do due process of law. Um dos principais instrumentos dessas garantias foi a Magna Carta 1215 e suas subsequentes reedições, a partir da qual formou-se, ao longo dos séculos, o corpo de direito constitucional inglês. Cf. W. STUBBS, The Constitutional History of England, vol. I, Oxford, Clarendon, 1880, pp. 595-610, para quem o direito constitucional inglês é, em essência, um comentário à Magna Carta 1215.
} 
sobre a terra ${ }^{58}$, se convertisse num complexo de direitos reais a partir da evolução de writs como o writ of right $[=\text { breve de recto }]^{59}$.

Deve-se a esse sistema de ações, baseado em premissas particulares ao direito inglês dos séculos XI a XIII, a tendência ao predomínio das normas de natureza processual, em detrimento das normas de direito material no sistema do common law inglês ${ }^{60}$.

De fato, um dos principais fatores que moldaram o common law e lhe imprimiram algumas das suas principais características foi a impossibilidade de ajuizar uma demanda se não houvesse um writ específico ${ }^{61}$ que tutelasse o interesse do autor e permitisse

${ }^{58}$ Cf. capítulo 2.2.3 infra acerca do tema.

${ }^{59}$ Cf. J. H. BAKER, An Introduction cit. (nota 12 supra), 2002, p. 232. De acordo com o autor, o intuito do writ of right era justamente permitir ao tenant recuperar a posse do imóvel objeto da concessão feudal, ao invés de sujeitar o senhor à entrega de outro terreno em substituição ou ao pagamento de uma indenização pecuniária.

Isso fica claro ao analisar a formulação básica do breve de recto em Bracton f. 328a: "Rex K salutem. Praecipimus tibi quod sine dilatione plenum rectum teneas $A$ de uno messuagio cum pertinentiis in Trumpingtone quod clamat tenere de te per liberum servitium [unius denarii per annum] pro omni servitio, et quod X ei deforciat. Et nisi feceris, vicecomes de Cantabrigia faciat, ne amplius inde clamorem audiamus pro defectu recti" (O rei a K, saudações. Comandamos-te que sem dilação tuteles o pleno direito de A acerca de uma casa com seus acessórios em Trumpington que alega ter de ti pelo serviço livre de um denário por ano por todo o serviço, e da qual X o esbulha. E a menos que tu o faças, que o sheriff de Cambridge o faça, para que não mais ouçamos, em função da falta de <tutela do > direito, reclamações acerca disso).

A expressão plenum rectum tenere é padrão no breve de recto e pode ser traduzido por "tutelar o pleno direito" [= "do full right"], cf. A. M. BuRRILL, A New Law Dictionary cit., vol. II (nota 13 supra), p. 805 (no verbete "plenum rectum"). O vocábulo messuagio, nas fontes inglesas, refere-se a uma casa, seu quintal e demais construções e dependências adjacentes, cf. H. SpElmANnus, Glossarium cit. (nota 13 supra), pp. 408-409 (no verbete "messuagium"): "Honeftius eft habitaculum cum aliquid fundi adjacentis in ejufdem ufum deputati". O verbo deforciare significa retirar a alguém algo com violência, cf. C. F. DU CANGE, Glossarium cit. (nota 13 supra), t. 3, col. 115a (no verbete "difforciare"): "Deforciare, Per vim et contra jus auferre, detinere". O vocábulo pertinentiae tem o sentido de "coisas acessórias", e deu origem à palavra inglesa appurtenances, cf. A. M. BURRILl, A New Law Dictionary cit., vol. I (nota 13 supra), p. 84 (no verbete “appurtenances").

${ }^{60}$ Cf. H. S. MAINE, Dissertations on Early Law and Custom, $8^{\text {a }}$ ed., London, John Murray, 1891, pp. 389390. Cabe ressaltar que à época em que o autor escreve essa característica já estava em fase de progressiva superação, especialmente pela promulgação dos Judicature Acts 1873 e 1875 [=Stat. 36 \& 37 Vic. (1873), c. 66 e Stat. 38 \& 39 Vic. (1875), c. 77].

${ }^{61}$ As formas dos writs são várias, dependendo da sua formulação básica. As mais variadas causas de pedir muitas vezes agrupavam-se sob a mesma categoria de writs, o que prova o predomínio do processo até para classificar o direito substantivo. Uma breve exposição de algumas dessas categorias pode lança alguma luz acerca desse fenômeno.

A principal distinção, quanto à forma dos original writs (os mais relevantes para o desenvolvimento do common law), era entre aqueles que tutelavam um direito (praecipe writs) e os que sanavam uma injustiça (plaints of wrong). A primeira formulação a aparecer para tutelar direitos foi a chamada praecipe, que era aquela pela qual se emitia um comando, normalmente a um funcionário local, para que efetivasse o direito de alguém. $\mathrm{O}$ tipo principal, chamado praecipe in capite, tinha por objeto a restituição de terras e continha a frase praecipe quod reddat (“...praecipe A. quod juste et sine dilatione reddat B. unum messuagium...”). Esse modelo admitia algumas variantes, as quais podiam ser utilizadas, por exemplo, para determinar o pagamento de dívidas de valor (“...praecipe A. quod juste et sine dilatione reddat B. centum solidos quos ei debet...”) ou a prestação de contas por valores recebidos (“...praecipe A. quod reddat B. rationabilem compotum [suum] de tempore quo fuit receptor denariorum ipsius [B]...”). A variante praecipe quod permittat determinava que o réu permitisse ao autor fazer algo, tal como fruir de uma área de pastagem (“...praecipe A. quod juste et sine dilatione permittat B. habere communiam pasturam...”). Também a forma praecipimus tibi era utilizada para as hipóteses em que o tribunal real emitia um comando ao senhor feudal, como no caso do breve de recto ("...praecipimus tibi quod sine dilatione plenum rectum teneas $A$. de B. de uno mesuagio et viginti acris terrae cum pertinentiis in I., quae clamat tenere de te per liberum servitium unius denarii per annum, pro omni servitio, quod W. de T. ei 
o acesso aos tribunais reais, princípio que perdurou, mesmo que de forma mitigada, até o início do seculo $\mathrm{XX}^{62}$.

deforciat...”) ou do replevin (“...praeicipimus tibi quod juste et sine dilatione replegiari facias B. quendam equum suum quod D. cepit et injuste detinet..."). Essas formas determinavam um processo lento e solene que permitia ao réu inúmeras possibilidades de não comparecimento em juízo, motivo pelo qual logo foram substituídas pelos writs que sanavam injustiças e pelo procedimento da Court of Chancery (cf. capítulo 3.2.3 infra). Os plaints of wrong, por sua vez, utilizavam uma fórmula parecida, porém o procedimento era mais célere. Assim era o caso com o assize of novel disseisin (“...Et ideo tibi praecipimus quod si praedictus A. fecerit te securum de clamore suo prosequendo, tunc facias tenementum illud reseisiri de catallis quae in ipso capta fuerunt et ipsum tenementum esse in pace...”). Também existia a possibilidade de determinar que o réu comparecesse diante do tribunal para dar explicações acerca da sua conduta, em cujo caso inseria-se a cláusula ostensurus quare, como no caso do breve de ejectione (“...si A. fecerit te securum...tunc pone per vadium et salvos plegios B. quod sit coram justiciariis nostris...ostensurus quare vi et armis manerium de I....intravit...”).

De qualquer forma, fica claro que o agrupamento de ações cujo objeto era de natureza muito diversa sob uma mesma forma ou procedimento geral acabou influenciando as próprias categorias de direito material.

Para uma exposição dos vários tipos de writs e suas funções, bem como dos fragmentos citados acima, cf. J. H. BAKER, An Introduction cit. (nota 12 supra), pp. 57-70 e 538-545.

${ }^{62}$ Cf. F. W. MAITLAND, Equity cit. (nota 12 supra), p. 299. Não se pode perder de vista que, ao longo do tempo, o sistema das forms of action foi se transformando e, junto com ele, o próprio common law. Assim, de 1066 a 1154 (de Guilherme I a Henrique II) ocorre o período formativo das forms of action, com o predomínio das cortes locais, dado que a sede dos tribunais reais ainda não fora estabelecida; os litígios dizem respeito, principalmente, a disputas entre os tenants in chief do rei, questões de interesse da própria Coroa e falhas na administração da justiça local.

De 1154 a 1189 (reinado de Henrique II) tem lugar a abertura e expansão do sistema para todos os súditos que possam enquadrar sua demanda no marco de um writ, sendo dessa época o estabelecimento da regra de que "no one need answer for his freehold without the king's writ", bem como o desenvolvimento da principal ação reivindicatória, iniciada pelo breve de recto ou writ of right, os principais interditos possessórios, influenciados pelos interditos romanos e iniciados por assize of novel disseisin (na hipótese de esbulho recente), mort d'ancestor (concedida ao herdeiro de quem tivesse morrido seisitus ut de feodo, ou seja, na posse da terra a título de concessão feudal hereditária), darrein presentment - também chamado de ultima presentatione, dizia respeito ao direito do senhor da terra de nomear o presbítero local, cf. D. M. WALKER, The Oxford Companion cit. (nota 8 supra), p. 335 (no verbete "darrein presentment") - e juris utrum (para dirimir conflitos de competência entre a Igreja e o Estado em relação em matéria de bens imóveis), bem como outras ações de menor incidência.

De 1189 a 1272 (morte de Henrique II até Eduardo II) surge o breve de ingressu (espécie de tertium genus também chamado writ of entry, pelo qual o demandante contestava o título do possuidor e que veio a gerar a legendária confusão no direito inglês entre as ações reivindicatórias relativas ao title e os interditos possessórios relativos à seisin), é criado o quare ejecit infra terminum (concedida ao possuidor for a term of years, elevando sua pretensão ao status de um direito real e estabelecendo o início da distinção entre seisin e possession); começam a surgir as personal actions, inclusive a action of trespass, utilizada para tutelar as mais variadas pretensões, tais como a proteção da integridade física da pessoa, a restituição de bens móveis (chattels) e a proteção contra esbulho nos bens imóveis.

O período de 1272 a 1307 (reinado de Eduardo I, o "Justiniano inglês") caracterizou-se pela intensa atividade legislativa e pela criação estatutária de vários writs novos, tal como o breve de forma donationis concedido aos descendentes de um tenant in tail quando a terra estivesse na posse de terceiro carente de título, cf. D. M. WALKER, The Oxford Companion cit. (nota 8 supra), p. 482 (no verbete "formedon") -, o que gerou a "esclerose" (stiffening) do common law que levou à promulgação do Statute of Westminster II e ao começo da paulatina ampliação da action of trespass, por isso mesmo apelidada "the fertile mother of actions", e seu desdobramento em várias espécies de actions on the case, a partir das quais desenvolveu-se a responsabilidade civil no direito inglês, cf. D. M. WALKER, The Oxford Companion cit. (nota 8 supra), pp. 21-22 e 1237-1238 (nos verbetes "action on the case" e "trespass").

Por último, no período de 1307 a 1833 dá-se o desenvolvimento posterior das forms of action, em larga medida com base nas formas dos antigos writs; assim, ocorre a substituição, mediante a adoção de um procedimento fictício, das ações reivindicatórias (real actions) e interditos possessórios (possessory assizes) pela action of ejectment; desenvolvem-se as vários várias espécies de personal actions, tais como replevin (para a reintegração na posse de bens móveis esbulhados, normalmente gado ou animais de carga, mediante promessa de comparecer em juízo), detinue (concedida em face do detentor indevido para a devolução de bens móveis ao seu dono - por isso similar a uma real action), debt (para a cobrança de valor pecuniário certa a qualquer título - a causa debendi eventualmente dando origem à doctrine of consideration), account (ação de prestação de contas 
Em outras palavras, já a partir do século XIII, no common law tinha se estabelecido firmemente o princípio de que toda pretensão, para ser considerada um direito, devia ter uma ação correspondente, mesmo que fosse in consimili $\operatorname{casu}^{63}$, sem a qual o ordenamento não a reconhecia ${ }^{64}$.

No entanto, desde o século XIX a doutrina jurídica inglesa vem fazendo notáveis esforços para sistematizar e racionalizar o sistema do common law ${ }^{65}$, inclusive no que diz

entre sócios - pouco utilizada em função da competência da Court of Chancery, muito mais eficiente para tais casos), covenant (concedida em caso de descumprimento de covenant under seal, espécie de contrato solene escrito surgido, incialmente, para atestar um term of years, mas que depois passou a se aplicar a qualquer acordo solene escrito - pouco usado por ser muito formal); também a action of trespass vi et armis (ação indenizatória de dano causado com violência) consolida seu desdobramento na action on the case, surgindo daí a action of assumpsit (cujo objeto originariamente era a indenização por dano decorrente de descumprimento de obrigação estabelecida por contrato que não fosse under seal, mas que posteriormente estendeu-se a todos os casos de descumprimento contratual, substituindo a action of debt, pois esta permitia ao réu o trial by battle), a action of trover (ação para a recuperação da propriedade de bens móveis concedida com base na ficção de houvera um contrato entre as partes - eventualmente substituiu a action of detinue, também porque esta permitia ao réu o trial by battle).

Sobre esse desenvolvimento, uma ótima explicação pode ser encontrada em F. W. MAITLAND, Equity cit. (nota 12 supra), pp. 314-366. Uma narrativa um pouco mais pormenorizada pode ser vista em T. F. T. PluCKNETT, A Concise History cit. (nota 12 supra), pp. 353-378.

${ }^{63}$ A expressão encontra-se no célebre Statute of Westminster II [=Stat. 13 Edw. I (1285), c. 24] e constitui uma tentativa, de fato não muito bem sucedida, de evitar o engessamento do sistema devido ao volume excessivo de ações ajuizadas coram rege. O texto em questão estabelece: "Et quotienfcumque de cetero evenerit in Cancellaria quod in uno cafu reperitur breve \& in confimili cafu cadente fub eodem jure \& fimili indigente remedio, concordent clerici de Cancellaria in brevi faciendo vel atterminent querentes in proximo parliamento $\&$ fcribant cafus in quibus concordare non poffunt \& referant eos ad proximum parliamentum \& de confenfu jurifperitorum fiat breve ne contingat de cetero quod curia diu deficiat querentibus in juftitia perquirenda" (E, de agora em diante, todas as vezes que na Chancelaria ocorra que num caso for encontrado um breve e $<$ noutro $>$ caso semelhante que se subordina ao mesmo direito não exista remédio similar, que concordem os clérigos da Chancelaria em fazer um breve, ou que suspendam os <procedimentos iniciados pelos $>$ requerentes até o próximo parlamento e escrevam os casos acerca dos quais não possam concordar e os referenciem para o próximo parlamento, e que pelo consenso dos peritos do direito seja feito o breve, para que de agora em diante não ocorra que o tribunal durante longo tempo falte aos requerentes com a justiça requerida). Mesmo não tendo atingido os resultados esperados dele, esse statute forneceu a base legal para o desenvolvimento da ação denominada trespass on the case, cf. F. W. MAITLAND, Equity cit. (nota 12 supra), pp. 345-346.

${ }^{64}$ Cf. J. H. BAKER, An Introduction cit. (nota 12 supra), p. 56.

${ }^{65}$ Cf. J. Gordley, Foundations of Private Law cit. (nota 1 supra), pp. 44 e 49. O principal elemento da alteração sofrida pelo common law foi a abolição do sistema das forms of actions, o qual previa um número limitado de ações (actions) reconhecidas pelos tribunais e estabelecia um procedimento específico para cada uma.

O sistema foi abolido por uma série de atos do Parlamento denominados Common Law Procedure Acts e inspirados nas sugestões apresentadas por duas comissões encarregadas de estudar a reforma do sistema processual inglês: a Common Law Commission 1928 e a Common Law Commission 1950. Em relação às real actions (incluídas as chamadas mixed actions), o primeiro desses atos foi Stat. 3 \& 4 Will. IV (1833), c. 27, s. 36, que enumera sessenta actions que não mais poderiam ser ajuizadas a partir de 31 de dezembro de 1834 (apesar de que, na prática, a action of ejectment já havia substituído quase todas as ações mencionadas no statute): "And be it further enacted, That no Writ of Right Patent, Writ of Right Quia dominus remisit curiam, Writ of Right in capite, Writ of Right in London, Writ of Right Close, Writ of Right de rationabili parte, Writ of Right of Advowson, Writ of Right upon Disclaimer, Writ De rationalibus divisis, Writ of Right Ward, Writ De consuetudinibus et servitiis, Writ of Cessavit, Writ of Escheat, Writ of Quo jure, Writ of Secta ad molendinum, Writ De essendo quietum de theolonio, Writ of Ne injuste vexes, Writ of Mesne, Writ of Quod permittat, Writ of Formedon in descender, in remainder, or in reverter, Writ of Assize of nevel disseisin, Nuisance, Darrein presentment, Juris utrum, or Mort d'ancestor, Writ of Entry sur disseisin, in the quibus, in the per, in the per and cui, or in the post, Writ of Entry sur intrusion, Writ of Entry sur alienation, Dum fuit in prisona, Ad communem 
respeito à real property law, tornando possível a exposição cada vez mais ordenada dos seus principais institutos e inclusive favorecendo a possibilidade de comparação com institutos de outros sistemas ${ }^{66}$.

Assim, muitos institutos que, antes das reformas, somente podiam ser compreendidos em função da sua relação com as ações que os tutelavam podem hoje, a despeito da diversidade terminológica em relação à dos sistemas de base romanística, ser utilizados como referência comparatística. Não parece sequer que a diversidade de conteúdo entre os diversos institutos seja um impedimento para comparações relevantes, desde que se possa compreender a essência daquilo que as palavras técnicas representam.

Cabe destacar que, além das reformas de natureza processual, a transformação da real property law inglesa tem sido facilitada e promovida através de reformas legislativas no âmbito do direito material destinadas, via de regra, a simplificar o sistema de direitos reais baseado nas antigas instituições feudais. Assim, por exemplo, o Tenures Abolition Act $1660^{67}$

legem, In casu proviso, In consimili casu, Cui in vita, Sur cui in vita, Cui ante divortium, or Sur cui ante divortium, Writ of Entry sur abatement, Writ of Entry Quare ejecit infra terminum, or Ad terminum qui praeteriit, or Causa matrimonii praelocuti, Writ of Aiel, Besaiel, Tresaiel, Cosinage, or Nuper obiit, Writ of Waste, Writ of Partition, Writ of Disceit, Writ of Quod ei deforceat, Writ of Covenant real, Writ of Warrantia chartae, Writ of Curia claudenda, of Writ Per quae servitia, and no other Action real or mixed except a Writ of Right of Dower, or Writ of Dower unde nihil habet, or a Quare impedit, or na Ejectment), and no Plaint in the Nature of any such Writ or Action (except a Plaint for Freebench or Dower), shall be brought after the Thirstyfirst Day of December One thousand eight hundred and thirty-four".

As demais real actions (principalmente right of dower, dower, unde nihil habet e quare impedit) foram abolidas, em consonância com as sugestões feitas pela Common Law Commission 1950, pelo Stat. 23 \& 24 Vic. (1860), c. 126, s. 26: "No writ of right of dower or writ of dower unde nihil habet, and no plaint for freebench or dower in the nature of any such writ, and no quare impedit, shall be brought after the commencement of this Act in any Court whatsoever; but where any such writ, action or plaint would now lie, either in a Superior or in any other Court, na action may be commenced by writ of summons issuing out of the Court of Common Pleas in the same manner and form as the writ of summons in an ordinary action (...)".

Por sua vez, as personal actions sofreram seu primeiro golpe com o Stat. 2 \& 3 Will. IV (1832), c. 39, que uniformizou o procedimento, sob a denominação de writ of summons, para as principais dessas actions (debt, detinue, covenant, account, trespass, case, trover, assumpsit, replevin): "Whereas the Process for the Commencement of Personal Actions in His Majesty's Superior Courts of Law at Westminster is, by reason of its great Variety and Multiplicity, very inconvenient in Practice (...) the Process in all such Actions commenced in either of the said Courts (...) shall (...) be according to the Form contained in the Schedule of this Act (...) and shall be called Writ of Summons (...)". Posterioremente, outras modificações foram introduzidas pelo Stat. 15 \& 16 Vic. (1852), c. 76 e pelo Stat. 17 \& 18 Vic. (1854), c. 125 , que simplificaram ainda mais o procedimento nos tribunais do common law. O Stat. 15 \& 16 Vic. (1852), c. 76, s. 3 explicitamente aboliu a necessidade de inserir nos autos o nome da antiga personal action correspondente: "It shall not be necessary to mention any form or cause of action in any writ of summons, or in any notice of writ of summons, issued under the authority of this Act".

O ápice das reformas se deu com a entrada em vigor do Stat. 36 \& 37 Vic. (1873), c. 66 e do Stat. 38 \& 39 Vic. (1875), c. 77.

Acerca das principais reformas do direito processual privado inglês no século XIX, cf. J. STEPHEN (org.), The Common Law Procedure Act 1860 cit. (nota 8 supra), pp. 1-8; F. W. MAITLAND, Equity cit. (nota 12 supra), pp. 295-305.

${ }^{66}$ Cf. S. VAN ERP, Comparative Property Law cit. (nota 1 supra), pp. 1048-1049.

${ }^{67}$ Cf. Stat. 12 Char. II (1660), c. 24. 
e o Law of Property Act $1925^{68}$ marcaram a evolução dos direitos reais de modo a adaptar o ordenamento jurídico às mudanças dos tempos e às necessidades jurídicas do momento.

É a compreensão da estrutura e terminologia de um sistema que permite ao jurista fazer afirmações mais gerais que esclarecem a natureza do direito e das suas fontes ${ }^{69}$. Portanto, para entender a real property law inglesa e, eventualmente, realizar comparações frutíferas, é necessário adentrar nos elementos típicos do sistema do common law, o que pressupõe um conhecimento de dois elementos fundamentais para a formação dos direitos reais ingleses: a "doutrina" das tenures e a dos estates $^{70}$.

${ }^{68}$ Cf. Stat. 15 \& 16 Geo. V (1925), c. 20. O Law of Property Act 1925 foi um dos principais instrumentos por meio do quais se efetuaram as principais reformas do regime jurídico relativo aos direitos reais na Inglaterra. Esse statute faz parte de um conjunto de diplomas legais promulgados no mesmo ano: o Settled Land Act 1925 [=Stat. 15 \& 16 Geo. V (1925), c. 18], o Trustee Act 1925 [=Stat. 15 \& 16 Geo. V (1925), c. 19], o Land Registration Act 1925 [=Stat. 15 \& 16 Geo. V (1925), c. 21], o Land Charges Act 1925 [=Stat. 15 \& 16 Geo. V (1925), c. 22] e o Administration of Estates Act 1925 [=Stat. 15 \& 16 Geo. V (1925), c. 23]. As referências a esses diplomas são bastante freqüentes na doutrina ao tratar da configuração atual da real property law inglesa. Trataremos, especialmente, do Stat. 15 \& 16 Geo. V (1925), c. 20 ao longo deste trabalho conforme surgir a necessidade.

${ }^{69}$ Cf. A. WATSON, Roman Law \& Comparative Law cit. (nota 1 supra), p. 97.

${ }^{70}$ Cf. R. Megarry e W. Wade, The Law of Real Property cit. (nota 1 supra), p. 24. Na verdade, parece tratar-se mais de dogmas do que de doutrinas propriamente ditas, pois os autores nunca duvidam da sua existência. Eles apenas divergem quanto a algumas das suas características. Assim, simplificadamente, conforme analizaremos mais adiante, a doctrine of tenures estabelece que todas as terras pertencem à Coroa, seja direta ou indiretamente, por meio de uma ou mais tenures (tenências), enquanto a doctrine of estates determina a duração de cada tipo de relação sobre essas terras, em função da tenure de que se trate. Referir-nos-emos às tenures e estates como doutrinas, no entanto, para harmonizar o vocabulário do nosso texto com o dos autores. 


\subsection{A estrutura dos direitos reais na Inglaterra: tenures}

\subsubsection{Surgimento e características gerais}

Não se deve desestimar a importância da evolução histórica dos direitos reais para o desenvolvimento tanto do common law $^{71}$ quanto do direito inglês como um todo ${ }^{72}$. De fato, na estrutura da property law no período medieval encontra-se a chave de uma das características marcantes dos primórdios do common law, qual seja, a "fusão" entre o ius publicum e o ius privatum ${ }^{73}$, muito embora a distinção entre essas duas esferas seja mencionada nas fontes ${ }^{74}$.

${ }^{71}$ Cf. G. CRISCUOLI, Introduzione cit. (nota 1 supra), p. 149: “A questo proposito bisogna ancora tener presente che il common law, come diritto essenzialmente fondiario, forniva in larga misura $i$ rimedi per la risoluzione delle questioni giuridiche concernenti o comunque connesse alla terra".

${ }^{72}$ Cf. R. MEGARRY e W. WADE, The Law of Real Property cit. (nota 1 supra), p. 8: "The origin of the law of real property is the origin of the common law itself',

${ }^{73}$ Cf. F. Pollock e F. W. MAITLAND, The History of English Law cit., vol. I (nota 12 supra), pp. $230-231$. Conforme explicam os autores, nas obras de autoridade não se encontra qualquer aplicação prática dessa distinção.

Nesse sentido, não parece acertada a afirmação feita por R. DAVID, Les grands systèmes cit. (nota 1 supra), p. 326, no sentido de que a indistinção entre o direito público e o direito privado seria consequência da preponderância das normas processuais no direito inglês. Parece mais correto atribuir essa característica ao próprio contexto histórico-social em que nasceu o sistema do common law, qual seja, o mundo feudal dos séculos XI e XII.

74 Assim ocorre no seguinte fragmento de Bracton f. 3b: "Est autem ius publicum quod ad statum rei Romanae pertinet, et consistit in sacris, in sacerdotibus et in magistratibus (...) Ius autem privatum est quod ad singulorum pertinet utilitatem principaliter, et secundario pertinet ad rem publicam, unde dicitur: Expedit quidem rei publicae ne quis re sua male utatur. Et sic vice versa quod rei publicae principaliter interest quod sic secundario respiciat utilitatem singulorum. Est etiam huiusmodi ius privatum tripertite collectum aut ex naturalibus praeceptis aut gentium aut civilibus" (O direito publico é aquele que diz respeito ao estado da coisa <pública> romana, e consiste nas <coisas> sagradas, nas <coisas> dos sacerdotes e nas <coisas> dos magistrados (...) O direito privado, por outro lado, é aquele que diz respeito principalmente à utilidade dos individuos, e em segundo lugar diz respeito à coisa pública, de onde se diz: 'Convém à coisa pública que ninguém utilize sua coisa indevidamente'. E assim, ao contrário, aquilo que interessa principalmente à coisa pública <é> aquilo que dessa forma em segundo lugar volta-se para a utilidade dos individuos). Compare-se o fragmento de Bracton com Ulp. 1 inst., D. 1, 1, 1, 2 [= Inst. 1, 1, 4]: "Huius studii duae sunt positiones, publicum et privatum. Publicum ius est quod ad statum rei Romanae spectat, privatum quod ad singulorum utilitatem: sunt enim quaedam publice utilia, quaedam privatim. Publicum ius in sacris, in sacerdotibus, in magistratibus constitit. Privatum ius tripertitum est: collectum etenim est ex naturalibus praeceptis aut gentium aut civilibus". Já se pode observar que, mesmo com a forte influência romana em Bracton, o fragmento realça uma certa ingerência do âmbito público no privado, mesmo que secundariamente (...quod ad singulorum pertinet utilitatem principaliter, et secundario pertinet ad rem publicam...). A estrutura do common law, nas suas origens, também não se coaduna com a noção de direito público encontrada em Pap. 2 quaest., D. 2, 14, 38: “Ius publicum privatorum pactis mutari non potest" (O direito público não pode ser alterado pelos pactos dos <entes> privados). Embora o fragmento se refira, provavelmente, a normas de competência jurisdicional, ele serve de base para o que hoje se considera o âmbito das normas de ordem pública, independentemente da sua identificação com a idéia de ius publicum, cf. M. TALAMANCA, Istituzioni cit. (nota 42 supra), p. 63. Para entender a incompatibilidade dessa noção com o caráter originário do direito inglês, vale lembrar que as normas relativas aos direitos reais sobre bens imóveis, em princípio, eram o resultado da livre negociação entre as partes, e que somente com o passar do tempo se tornaram categorias fixas bem definidas.

Acerca da distinção entre ius privatum e ius publicum nas fontes romanas, cf. A. BERGER, Encyclopedic Dictionary cit. (nota 13 supra), p. 532 (nos verbetes "ius privatum" e "ius publicum") e M. TALAMANCA, 
A indistinção deve-se ao fato de que a property law inglesa desenvolveu seus principais institutos e categorias a partir da segunda metade do século XI, momento em que a palavra dominium, na Inglaterra, podia significar tanto ownership quanto lordship ${ }^{75}$. O poder politico do monarca não se diferenciava das suas faculdades no âmbito privado ${ }^{76}$, e a

Istituzioni cit. (nota 42 supra), pp. 61-64 e M. MARRONE, Istituzioni di diritto romano, $3^{\mathrm{a}}$ ed., Palermo, Palumbo, pp. 4 e 30-32. Acerca da influência romana em Bracton, no que diz respeito a essa classificação, cf. K. E. GÜTERBOCK, Henricus de Bracton cit. (nota 1 supra), pp. 79-80.

${ }^{75}$ Cf. S. F. C. Milsom, Historical Foundations cit. (nota 12 supra), p. 99.

76 Em larga medida, pode-se dizer que a tradicional rejeição de não poucos juristas ingleses ao reconhecimento da influência do direito romano na Inglaterra está relacionada à antiga nebulosidade, mais intensa no século XII na Inglaterra do que no continente, dos limites entre as esferas pública e privada, pois isso tornava tênues os limites de atuação do soberano, cf. K. E. GüTERBOCK, Henricus de Bracton cit. (nota 1 supra), p. 13. Em sentido diverso, no entanto, F. W. MAITLAND, Bracton's Note Book, vol. I, London, Clay \& Sons, 1887, p. 9 sustenta a existência de uma blindagem do common law à influência do direito romano, a qual decorre de uma racionalização da administração da justiça em torno da atividade judicante dos tribunais reais.

Nesse sentido, o receio de uma possível exacerbação do poder real fica claro na clássica obra De laudibus legum Angliae, escrita em 1470 por John Fortescue para Eduardo, Príncipe de Gales e filho do rei Henrique VI (que tinha sido deposto em 1461 durante a Guerra das Duas Rosas), cujo texto em latim e uma tradução ao inglês feita em 1775 podem ser encontrados em J. FORTESCUE, De laudibus cit. (nota 10 supra), pp. 2-274.

Assim, encontra-se em Fortescue 34 [=J. FORTESCUE, De laudibus cit. (nota 10 supra), p. 232]: "Audisti namque superius quomodo inter Leges Civiles praecipua Sententia est, maxima sive Regula, illa quae sic canit 'Quod Principi placuit, Legis habet vigorem'; qualiter non sanciunt Leges Angliae, dum nedum Regaliter, sed et Politice Rex ejusdem dominatur in Populum suum, quo ipse in Coronatione sua ad Legis suae observantiam astringitur Sacramento, quod Reges quidam Angliae aegre ferentes, putantes proinde se non libere dominari in Subditos, ut faciunt Reges Regaliter tantum principantes, qui Lege Civili, et potissime praedicta Legis illius Maxima regulant Plebem suam, quo ipsi ad eorum Libitum Jura mutant, nova condunt, Poenas infligunt et Onera imponunt Subditis suis, propriis quoque Arbitriis, Contendentium, cum velint, dirimunt lites" (Ouviste, em verdade, sobre como nas Leis Civis há um brocardo, máxima ou regra notável, que diz assim: 'aquilo que agradou ao príncipe, tem força de lei'. As leis da Inglaterra não sancionam tal <máxima>, visto que o rei governa sobre seu povo soberanamente e <também> políticamente, pelo qual ele mesmo na sua coroação é obrigado mediante um juramento solene a observar as leis, motivo pelo qual certos reis da Inglaterra são levados a preocupar-se, ao pensar que eles não poderão governar tão livremente sobre os seus súditos quanto o fazem os reis que governam apenas como soberanos, os quais pela Lei Civil, principalmente pelo brocardo mencionado anteriormente, regulam <a vida do $>$ seu povo, <motivo $>$ pelo qual eles próprios mudam as leis ao sabor do seu capricho, outorgam novas <leis $>$, infligem penas e impõem tributos aos seus súditos, pelas suas <meras $>$ vontades e arbítrios, <e > em havendo contendas, dirimem as lides como querem).

O fragmento mencionado em Fortescue 34 é Ulp. 1 inst., D. 1, 4, 1 pr.: "Quod principi placuit, legis habet vigorem: utpote cum lege regia, quae de imperio eius lata est, populus ei et in eum omne suum imperium et potestatem conferat" (Aquilo que agrada ao príncipe, tem o vigor de lei, visto que pela lei régia, que foi promulgada acerca do seu imperium, o povo conferiu a ele e para ele todo o seu imperium e potestas). No pensamento medieval, ele se correlacionava com Ulp. 13 ad leg. Iul. et Pap., D. 1, 3, 31: "Princeps legibus solutus est (...)" (O príncipe está desvinculado das leis (...)). Essa aversão, pode-se perceber, foi mais uma expressão do receio de expansão do poder real - num contexto jurídico-político bastante centralizado - do que o reconhecimento de uma incompatibilidade intrínseca entre o direito romano, tal como se concebia na época, e o direito inglês, cf. A. M. HESPANHA, Cultura Jurídica Européia cit. (nota 19 supra), pp. 262-269.

Desde o século XIX, no entanto, várias obras procuraram, de diversas formas, superar essa rejeição e reaproximar o direito romano e o direito inglês. Apenas como exemplo, podem ser mencionadas as obras de K. E. GÜTERBock, Henricus de Bracton cit. (nota 1 supra), pp. 2-175; J. BRYCE, Studies in History and Jurisprudence, Oxford, Oxford University, 1901, pp. 1-907; T. E. SCRUTTON, The Influence of the Roman Law on the Law of England, Cambridge, Cambridge University, 1885, pp. 1-195; F. PRINGSHEIM, The Inner Relationship Between English Law and Roman Law, in The Cambridge Law Journal, 5 (1933-1935), pp. 347365; W. W. BuCKLAND e A. D. MCNAIR, Roman Law and Common Law cit. (nota 1 supra), pp. 1-341; W. L. BURDICK, The Principles of Roman Law and Their Relation to Modern Law, Rochester, Lawyer's Cooperative, 1938, pp. 1-719. 
consequência desse fenômeno foi que a diferenciação entre as esferas pública e privada fícou relegada a um segundo plano. Assim, aquilo que se poderia denominar public law passou a ser um mero apêndice ao real property law, eventualmente modificado por um law of persons não muito amplo ${ }^{77}$.

Como resultado dessa configuração, um dos principais elementos que diferenciam o sistema de direitos reais inglês do continental ${ }^{78}$ é o fato de os bens imóveis ${ }^{79}$ terem estado, historicamente, sujeitos ao sistema das tenures ${ }^{80}$. Isso teve uma conseqüência fundamental para a real property law: até hoje, todas as terras da Inglaterra pertencem, em

Nesse sentido, é interessante notar que em Fortescue 1 cita-se quase textualmente, para indicar o modo correto de governar, parte da Constitutio Imperatoriam Maiestatem (Proemium de Confirmatione Institutionum): "Imperatoriam maiestatem non solum armis decoratam, sed etiam legibus oportet esse armatam, ut utrumque tempus et bellorum et pacis recte possit gubernari et princeps Romanus victor existat non solum in hostilibus proeliis, sed etiam per legitimos tramites calumniantium iniquitates expellens, et fiat tam iuris religiosissimus quam victis hostibus triumphator" (Convém que a majestade imperial não apenas seja honrada pelas armas, mas que também esteja armada pelas leis, para que tanto no tempo das guerras quanto no da paz se possa governar corretamente e o príncipe romano surja vitorioso não apenas nos combates com os inimigos, mas também rejeitando dos caluniadores por legítimos trámites, e se faça tão religiosíssimo <cumpridor> do direito quanto triunfador sobre os inimigos vencidos).

Diga-se de passagem, uma variação do mesmo fragmento pode ser vista nas primeiras páginas de vários dos tratados jurídicos ingleses mais antigos, dentre os quais os de Glanvill e Bracton, conforme explica A. Amos em J. FORTESCUE, De laudibus cit. (nota 10 supra), p. 2, nt. b. Nesse sentido, cf. Bracton f. 1: "In rege qui recte regit necessaria sunt duo haec, arma videlicet et leges, quibus utrumque tempus bellorum et pacis recte possit gubernari" e Glanvill, Prologus, de modo mais explícito [=R. GLANVILLA, Tractatus de legibus cit. (nota 10 supra), s.n.]: "Regiam potestatem, non folum armis contra rebelles et gentes fibi regnoque infsurgentes, oportet effe decoratam, fed et legibus, ad Jubditos et populos pacifice regendos, decet effe ornatam; ut utraque tempora, Pacis et Belli, gloriofus Rex nofter ita feliciter tranfigat, ut effrenatorum et indomitorum, dextra fortitudinis, elidendo Juperbiam, et humilium et manfuetorum, aequitatis virga, moderando Juftitiam, tam in hoftibus debellandis femper victoriofus exiftat, quam in fubditis tractandis equalis jugiter appareat (...)". Acerca da adoção da Constitutio Imperatoriam Maiestatem em Bracton e Glanvill, cf. T. E. SCRUTTON, The Influence of the Roman Law cit. (nesta nota), pp. 74- 75.

Apenas a título de curiosidade, encontra-se em Fortescue 27 [=J. ForTESCUE, De laudibus cit. (nota 10 supra), p. 235] o famosíssimo brocardo do direito penal: "Malem revera viginti facinorosos Mortem Pietate evadere, quam justum unum injuste condemnari" (Eu preferiria, com efeito, que vinte criminosos escapassem à morte por piedade, a que um único <homem> justo fosse condenado injustamente).

Acerca das origens, diversas interpretações e desenvolvimento histórico-político das doutrinas absolutistas medievais baseadas nas fontes romanas, principalmente no continente europeu, cf. K. PENNINGTON, The Prince and the Law - 1200-1600, California, University of California, 1993, pp. 8-37.

${ }^{77}$ Cf. F. POLlOCK e F. W. MAITLAND, The History of English Law cit., vol. I (nota 12 supra), p. 231.

${ }^{78}$ Cf. K. ZWEIGERT e H. KöTZ, Einführung cit. (nota 1 supra), p. 182.

${ }^{79}$ Cabe ressaltar que o sistema das tenures aplica-se, em princípio, apenas à real property, e não à personal property, na medida em que as antigas formas de domínio e disposição desta foram preservadas e tiveram um desenvolvimento posterior próprio, mesmo após a Conquista, cf. G. SPENCE, The Equitable Jurisdiction cit., vol. I (nota 12 supra), p. 135.

${ }^{80} \mathrm{O}$ vocábulo tenure provém do verbo latino teneo, -es, -ere, - $u i$, -tum, cujo significado básico é "ter" ou "segurar" [="to hold"] algo, cf. P. G. W. GLARE (coord.), OLD cit. (nota 13 supra), pp. 1919-1920 (no verbete "teneo, -es, -ere, -ui, -tum"). No contexto medieval, contudo, designava a relação de um sujeito com uma coisa em função de uma concessão feudal, cf. A. M. BuRRILl, A New Law Dictionary cit., vol. II (nota 13 supra), pp. 974-975 (no verbete "tenure"). Ao termo tenere, em sentido medieval, liga-se a palavra tenementum, que designa o objeto dessa relação. 
última instância e pelo menos formalmente ${ }^{81}$, à $\mathrm{Coroa}^{82}$. Portanto, não existem, desde a Conquista $^{83}$, terras alodiais $\left[=\right.$ allodium $^{84}$ ] fora da esfera real ${ }^{85}$.

Em outras palavras, todos os bens imóveis na Inglaterra, mesmo nos dias de hoje ${ }^{86}$, ou bem se encontram na posse de um terratenente (tenant) que as detém em virtude de uma relação direta ou indireta com a $\mathrm{Coroa}^{87}$, ou se encontram na posse da própria Coroa, em cujo caso se denominam royal demesne $e^{88}$ ou mais modernamente, demesne land ${ }^{89}$.

${ }^{81}$ Cf. nota 97 infra.

${ }^{82}$ Cf. R. MEgarry e W. WADE, The Law of Real Property cit. (nota 1 supra), pp. 22-23. O sistema das tenures pode ser visto como uma estrutura piramidal, no topo da qual se encontrava o monarca, seguido pelos seus tenants in chief e em seguida pelos dependentes destes. O princípio ficou firmemente estabelecido a partir da Conquista normanda, desaparecendo, nesse momento, quaisquer vestígios de terras alodiais, cf. J. H. BAKER, An Introduction cit. (nota 12 supra), p. 224.

Assim, a fórmula básica que definiu, historica e formalmente, os direitos reais sobre bens imóveis na Inglaterra, pode ser expressa na seguinte frase: "A tenet terram illam de... domino Rege", ou seja, todos "tem" a terra do rei, e somente ele é proprietário em sentido estrito, cf. F. POLlOCK e F. W. MAITLAND, The History of English Law cit., vol. I (nota 12 supra), p. 232 e T. F. T. PluCKNETT, A Concise History cit. (nota 12 supra), p. 13. Na verdade, a fórmula podia, em relação a todas as categorias de concessões feudais, até a promulgação do Statutum Quia Emptores Terrarum 1290 [=Stat. 18 Edw. I (1290), c. 1-3], ser estendida indefinidamente: “A tenet terram illam de $B$, qui tenet terram illam de $C$, qui tenet terram illam de..., qui tenet terram illam de domino Rege".

A expressão "tenet...de...", junto com os seus complementos, é uma das pedras de toque no que diz respeito à formação dos direitos reais na Inglaterra medieval, cf. F. POLLOCK e F. W. MAITLAND, The History of English Law cit., vol. I (nota 12 supra), p. 234, nt. 1. Essa formula é encontrada com enorme frequência nas fontes medievais inglesas, conforme se depreende da sua leitura.

${ }^{83}$ Cf. J. H. BAKER, An Introduction cit. (nota 12 supra), p. 224.

${ }^{84}$ No sentido de "terras não submetidas a uma relação entre senhor e tenant" e, portanto, objeto de um direito absoluto de propriedade, cf. D. M. WALKER, The Oxford Companion cit. (nota 8 supra), p. 50 (no verbete “allodial land"). Cf. C. F. Du CANGE, Glossarium cit. (nota 13 supra), t. 1, col. 195a (no verbete "alodium"): "Differt enim Beneficium vel Feudum a Pradio, seu Alodo, quod idem sonat, id est, ab immobili proprio (...)".

${ }^{85}$ Esse fenômeno vem expresso pelo brocardo nulle terre sans seigneur, cf. R. MEGARRY e W. WADE, The Law of Real Property cit. (nota 1 supra), p. 22, nt. 2, e correlaciona-se com a doutrina dos estates, na medida em que a teoria proprietária medieval não admitia uma relação direta entre pessoas e terras, mas exigia a interposição de um estate abstrato, ressalvadas as terras sob o domínio direto do rei, cf. K. GRAY e S. F. GRAY, Elements of Land Law cit. (nota 1 supra), p. 57.

${ }^{86}$ Uma das manifestações modernas da supremacia formal do título investido na Coroa pode ser encontrado no Land Registration Act 2002, c. 9, s. 79 (1): "Her Majesty may grant an estate in fee simple absolute in possession out of demesne land to Herself'. Essa possibilidade somente existe porque a Coroa é considerada a única detentora de um título não dependente de qualquer outro, o que lhe confere a prerrogativa de criar, sobre as terras sob seu domínio absoluto, o direito real mais amplo conhecido no direito inglês, o estate in fee simple absolute in possession, cf. S. VAN ERP, Comparative Property Law cit. (nota 1 supra), p. 1057.

${ }^{87}$ Assim, relata Bl Comm 2, 4, 53 [=W. BLACKSTONE, Commentaries cit., vol. II (nota 10 supra), p. 53]: "The grand and fundamental maxim of all feodal tenure is this: that all lands were originally granted out by the fovereign, and are therefore holden, either mediately or immediately, of the crown".

${ }^{88}$ Cf. F. Pollock e F. W. Maitland, The History of English Law cit., vol. I (nota 12 supra), p. 232. Também Co Litt 1b $(1,1,1)$ [=E. CoKE, The First Part of the Institutes cit., vol. I (nota 10 supra), s. n.]: "For in the law of England we have not, properly, allodium, that is, any subjects land that is not as it is holden (...) And therefore the king in this sense cannot be said to be a tenant, because he hath no superior but God Almighty". O mesmo princípio foi reafirmado, ao discutir a natureza possessória da tomada temporária forçada de um imóvel para fins de defesa nacional, pela High Court of Australia em Minister of State for the Army v Dalziel (1944) 68 CLR 261: "In English law no subject can own lands allodially - he can own only an estate in land".

$\mathrm{O}$ termo demesne provém do anglo-francês antigo demeyne e é, ao que tudo indica, uma corruptela do adjetivo latino clássico dominicus, - $a$, -um, que designava aquilo que pertencia ao dominus, cf. J. A. SIMPSON e E. S. C. WEINER (coord.), OED 4 (1989), p. 436 (no verbete "demesne") e P. G. W. GLARE (coord.), OLD cit. (nota 13 supra), pp. 570-571 (no verbete "dominicus, -a, -um”). Talvez por influência de Bracton f. 263 (cf. nota 
A própria terminologia técnica utilizada nas principais fontes do direito inglês dedicadas ao registro de bens imóveis, tais como o clássico Domesday Book ${ }^{90}$ e o Liber

111 infra), durante muito tempo demesne vinculava-se a mensa. No entanto, essa e outras etimologias foram eventualmente rejeitadas, favorecendo-se a origem a partir de dominicus, cf. H. SPELMANNUS, Glossarium cit. (nota 13 supra), pp. 181-183 (no verbete “dominicum").

${ }^{89}$ Essa é a denominação hoje vigente no Land Registration Act 2002, c. 9, s. 132 (1): “'demesne land' means land belonging to Her Majesty in right of the Crown which is not held for an estate in fee simple absolute in possession".

${ }^{90}$ Essa terminologia é especialmente abundante nos registros medievais de terras. O Domesday Book, primeiro registro de terras da Inglaterra, foi encomendado, por motivos fiscais, por Guilherme I e concluído em 1086, cf. H. ELLIS, A General Introduction to Domesday Book, vol. I, s.1., Public Records Commissioners, 1833, pp. 3-4. A partir do século XVIII, foram publicados vários trabalhos com a transcrição (por extenso) dos registros das várias regiões da Inglaterra.

Assim, por exemplo, os registros de Wiltshire foram recolhidos em H. P. WYNDHAM, Wiltshire Extracted from Domesday Book, Salisbury, Easton, 1788, pp. iii-535; os de Cheshire e Lancashire em W. BEAMONT, A Literal Extension and Translation of the Portion of the Domesday Book Related to Cheshire and Lancashire, London, Vacher \& Sons, 1863, pp. v-91; os de Cornwall (no caso, com os fac-símiles dos manuscritos originais) em H. JAMES, A Literal Extension of the Domesday Book in Relation to the County of Cornwall, London, Vacher \& Sons, 1861, pp. 1-22 e assim muitos outros.

Uma breve exposição de alguns registros bem ilustra a estrutura típica feudal de finais do século XI.

Assim, na parte do Domesday Book dedicada a Wilthsire, sob o título "Terra Regis" constam os registros das terras dominicais da Coroa (qualificadas pelas expressões "...rex tenet..." sem qualquer complemento) com uma breve descrição das suas principais características em três momentos: no último dia do reinado de Eduardo o Confessor (5 de janeiro de 1066), logo após a Conquista (concessões feitas por Guilherme I em 1066) e no momento da elaboração do registro (1086), caso houvesse alguma divergência. Assim, lê-se em H. P. WYNDHAM, Wiltshire Extracted cit. (nesta nota), p. 36: "Rex tenet Cumbe. Ghida tenuit T.R.E. et geldavit pro 23 hidis et dimidio. Terra est 20 carucate. In dominio sunt 11 hida (...)" (O rei tem <a vila de> Cumbe. Ghida a tinha no tempo do rei Eduardo o Confessor e impôs geldum de vinte e três hidae e meia. A terra tem vinte carucatae. Onze hidae estão sob domínio direto <do rei $>(.)$.$) .$

O verbo geldare tem, neste caso, o sentido de impor um tributo, no caso, o geldum, com base na medida da terra, cf. C. F. DU CANGE, Glossarium cit. (nota 13 supra), t. 4, col. 067c (no verbete "gildum ou geldum"): "ex Saxonico gild, Solutio, prastatio, vectigal, tributum". Já o vocábulo carucata significa a medida de terra que pode ser trabalhada em um ano por um arado arrastado por um conjunto de oito bois, cf. D. M. WALKER, The Oxford Companion cit. (nota 8 supra), p. 189 (no verbete "carucate") e C. F. DU CANGE, Glossarium cit. (nota 13 supra), t. 2, col. 191b (no verbete "carrucata"): "Tantum terra, quantum uno aratro coli potest in anno, a ploughland dicunt Angli". O vocábulo hida refere-se a uma unidade de terra correspondente aproximadamente a uma carucata, porém utilizada para fins fiscais, cf. D. M. WALKER, The Oxford Companion cit. (nota 8 supra), p. 566 (no verbete "hide"). A abreviatura T.R.E. é recorrente no Domesday Book e significa "tempore regis Eduardi”, cf. D. Diderot e J. D’ALEMBert, Encyclopédie, vol. V, Paris, Briasson et al., 1755, p. 52. (no verbete "doom's-day-book").

Compare-se o texto acima com o registro das terras pertencentes a um súdito do rei na mesma localidade. Assim, em H. P. WYNDHAM, Wiltshire Extracted cit. (nesta nota), p. 320: "Milo Crifpin tenet de rege Wodeton. Levenod tenuit T.R.E. et geldabat pro 12 hidis. Terra eft 12 carucatae. De ea funt in dominio 6 hida (...)" (Milo Crispin tem <a vila de $>$ Wodeton do rei. Levenod a tinha no tempo do rei Eduardo o Confessor e impunha geldum de doze hidae. A terra tem doze carucatae. Dessas <terras $>$ seis hidae estão sob domínio direto < do senhor> (...)).

O próprio súdito do rei podia ter subtenants, conforme demonstra H. P. WYNDHAM, Wiltshire Extracted cit. (nesta nota), p. 323: "Reinaldus tenet de Milone Cilletone. Comes Heraldus tenuit T.R.E. et geldabat pro 10 hidis. Terra eft 12 carucatae. De ea funt in dominio 6 hida (...)" (Reinaldo tem <a vila de $>$ Cilletone de Milo. O conde Heraldo a tinha no tempo do rei Eduardo o Confessor e impunha geldum de dez hidae. A terra tem doze carucatae. Dessas <terras > seis hidae estão sob domínio direto < do senhor $>(\ldots)$ ).

Em resumo, os três registros em tela apresentam uma cadeia feudal de tenures inglesa típica, na qual o rei mantém algumas das terras da localidade sob seu domínio direto (in dominico ou in demesne) e concede outras a um súdito seu (in servitio). Esse súdito, por sua vez, mantém algumas terras sob seu domínio direto (também in demesne) e concede outras a um terceiro que passa a ser o seu tenant (igualmente in servitio). Em tese, a cadeia, mesmo em relação ao estate in fee simple, podia ser estendida ad infinitum, pelo menos até a promulgação do Statutum Quia Emptores Terrarum 1290 [=Stat. 18 Edw. I (1290), c. 1-3]. 
Feodorum $^{91}$, para fazer referência às relações entre pessoas e bens imóveis, baseia-se nesse pressuposto $^{92}$. Assim, não se diz que alguém é dono [=owns] de uma gleba de terra, mas que alguém a "tem de" ["tenet de" = "holds of"] outrem ${ }^{93}$.

A atribuição à Coroa de um título de propriedade absoluto sobre as terras, no entanto, deve ser entendida cum grano salis, pois, caso contrário, poderia levar à conclusão de que a Coroa é a única titular da absoluta disponibilidade econômica, desde uma perspectiva privatística, dos bens imóveis em solo inglês, o que também não reflete a realidade jurídica contemporânea $^{94}$.

Os manuscritos originais do Domesday Book encontram-se hoje no Arquivo Nacional britânico (National Archives). Uma boa guia, inclusive em relação às melhores e mais modernas edições críticas, pode ser consultada no endereço eletrônico http://www.nationalarchives.gov.uk/records/research-guides/domesday.htm [11-07-2012].

${ }^{91}$ Trata-se de uma compilação de registros de feudal tenancies na Inglaterra, também conhecida como Testa de Nevill, elaborada em 1302 por ocasião do tributo (aid) devido pelos senhores ao rei Eduardo I em razão do casamento da filha mais velha deste, cf. H. C. MAXWELL-LYTE (coord.), Liber Feodorum - The Book of Fees - Commonly Called Testa de Nevill, vol. I, London, His Majesty's Stationary Office, 1920, p. xiv.

Assim, em Lib. Feod. I, 712-725 [=H. C. MAXWELL-LYTE (coord.), Liber Feodorum cit., vol. I (nesta nota), p. 89]: “Robertus de Novo Burgo tenet manerium de Winford' cum pertinenciis, scilicet Lolewrdhe et Bureton' et totum hundredum de Winfrot et duas partes hundredi de Haselore per servicium camerarii in capite de domino rege; antecessores predicti Roberti tenuerunt ista tenementa a tempore Regis Henrici primi per predictum servicium camerarii" (Roberto de Novo Burgo tem do senhor rei o manor de Winford com <as suas> dependências, a saber Lolewrhde e Bureton e todo o hundred de Winfrot e duas partes do hundred de Haselore em razão do serviço de camerarius em chefe; os antecessores do supradito Roberto tinham aqueles tenementa no tempo do Rei Henrique I em razão do supradito serviço de camerarius).

Também no Lib. Feod. II, 117-122 [=H. C. MAXWELL-LYTE (coord.), Liber Feodorum cit., vol. I (nesta nota), p. 73] "Rogerus de Villiers tenet de domino rege feodum dimidii militis in Puttelesword" (Roger de Villiers tem do senhor rei um feudo de meio <serviço> militar em Puttlesword).

Em Lib. Feod. I, 712-725, o termo "camerarius" refere-se ao tipo de service prestado pelo tenant, que era de funcionário tesoureiro do palácio real, cf. C. F. Du CANGE, Glossarium cit. (nota 13 supra), t. 2, col. 048a (no verbete "camerarius"): "Dignitas in palatiis Regum, cui Camerce Regia, id est, Thesauri seu Cimeliorum Regis Cura incumbebat". Já a palavra "militis", presente em Lib. Feod. II, 117-122, refere-se à natureza do serviço, que no caso é militar, cf. C. F. Du CANGE, Glossarium cit. (nota 13 supra), t. 3, col. 472a (no verbete "feudum militare"): "vel Feudum Militis, quod a vassallo Milite possidetur: qui quidem vassallus ad hoc, ut servitium prestet domino in expeditionibus bellicis, Militari cingulo donatus esse tenetur. Feudum unde militare servitium prestandum est". O hundred era uma subdivisão do condado (county) dotada de uma corte local, a qual se especula tenha se originado na época das invasões anglo-saxônicas a partir de agrupamentos de cem casas, cf. D. M. WALKER, The Oxford Companion cit. (nota 8 supra), p. 595 (no verbete "hundred") e B. A. GARNER (coord.), Black's cit. (nota 13 supra), p. 637 (no verbete "hundred").

${ }^{92}$ Somente os senhores mais poderosos, na sociedade feudal de modo geral, não se encontravam em relação de dependência perante outro senhor e podiam dizer, do modo mais amplo possível no contexto feudal, que eram donos das suas terras, cf. T. F. T. PlUCKNETT, A Concise History cit. (nota 12 supra), p. 508.

${ }^{93}$ A terminologia hoje tem se transformado bastante; tecnicamente, porém, ainda é mais correto dizer que "A holds an Blackacre of B", e não que "A owns Blackacre", cf. R. MEGARRY e W. WADE, The Law of Real Property cit. (nota 1 supra), p. 24.

${ }^{94} \mathrm{Na}$ verdade, a discussão acerca da natureza do título do monarca em relação às terras do reino constituiu na Idade Média o cerne das disputas entre o rei e a nobreza inglesa. Nesse sentido, é instrutivo o relato feito em Bl Comm 2, 4, 51-52 [=W. BlaCKSTONE, Commentaries cit., vol. II (nota 10 supra), pp. 51-52]: “(...) it became a fundamental maxim and neceffary principle (though in reality a mere fiction) of our Englifh tenures, 'that the king is the univerfal lord and original proprietor of all the lands in his kingdom'; and that no man doth or can poffess any part of it, but what has mediately or immediately been derived as a gift from him, to be held upon feudal services' (...) And indeed by thus consenting to the introduction of feodal tenures, our English ancestors probably meant no more than to put the kingdom in a ftate of defence by eftablishing a military fy/tem; and to 
Para explicar o fenômeno, a doutrina e a case law estabelecem uma distinção entre o título residual da Coroa à terra (radical title) e a natureza juridical dos estates pertencentes aos diversos tenants (proprietary estates) ${ }^{95}$, de acordo com a qual somente os últimos caracterizam o fenômeno da ownership na acepção mais próxima da propriedade de origem civilística ${ }^{96}$.

Talvez paradoxalmente, essa distinção foi retomada recentemente não pela case law propriamente inglesa, mas pelos tribunais das ex-colônias britânicas ${ }^{97}$ ao lidar com as

oblige themselves (in respect of their lands) to maintain the king's title and territories (...) But, whatever their meaning was, the Norman interpreters (...) gave a very different conftruction to this proceeding (...) as if the Englifh had in fact, as well as theory, owed every thing they had to the bounty of their fovereign lord (...) but (...) Henry I, found it expedient, when he fet his pretenfions to the crown, to promife a reftitution of the laws of king Edward the confeffor, or antient Saxon Jyftem; and accordingly (...) granted a charter, whereby he gave up the greater grievances, but still reserved the fiction of feodal tenure, for the fame military purpofes which engaged his father to introduce it. But this charter was gradually broken through, and the former grievances were revived and aggravated (...) till in the reign of king John they became fo intolerable, that they occaffioned his barons (...) to rise up againft him: which at legth produced the famous great charter at Runing-mead, which, with fome alterations, was confirmed by his fon Henry III (...) And from hence alfo arifes another inference; that the liberties of Englifhmen are not (...) mere infringements of the king's prerogative (...) but a reftoration of that antient conftitution, of which our anceftors had been defrauded by the art and fineffe of the Norman lawyers, rather than deprived by the force of the Norman arms".

A premissa de que todas as terras da Inglaterra são propriedade da Coroa é ainda hoje utilizada como pressuposto interpretativo dos direitos reais pela case law inglesa, cf. Lowe (Inspector of Taxes) v $J$ W Ashmore Ltd [1971] Ch 545, em que um contribuinte quis classificar, para efeitos de determinação do fato gerador, a venda de grama do seu terreno como uma alienação do equitable fee simple correspondente à parte da terra (uma área de seis acres por duas polegadas de espessura) retirada junto com a grama. À margem da questão fiscal envolvida, ficou estabelecido que "it is a fundamental of English land law that nobody save the Crown owns any land". A principal consequência dessa interpretação, no caso em questão, foi a de negar à transação o caráter de uma alienação do fee simple. Entendeu-se que se tratava de profits a prendre, que é uma espécie de percepção das utilidades de um terreno ou de parte dele, cf. D. M. WALKER, The Oxford Companion cit. (nota 8 supra), p. 1005 (no verbete "profit").

${ }^{95}$ Cf. K. GRAY e S. F. GRAY, Elements of Land Law cit. (nota 1 supra), p. 58.

96 Ficam ressalvadas, é claro, as demesne lands sob domínio direto da Coroa, sobre as quais ela é a proprietária tanto formal quanto substancialmente, cf. nota 89 supra.

${ }_{97}$ A tese de que a Coroa é proprietária das terras do reino, e não apenas o poder soberano, foi retomada principalmente nos séculos XVII e XVIII, durante o período de expansão colonial inglesa, e utilizado como artifício político-jurídico para a apropriação das terras colonizadas, cf. K. GRAY e S. F. GRAY, Elements of Land Law cit. (nota 1 supra), p. 58.

Nas colônias inglesas, inicialmente, a doutrina das tenures foi interpretada (ou melhor, reinterpretada) no sentido de atribuir à Coroa um título de propriedade absoluto (absolute beneficial ownership) sobre os territórios das colônias, No entanto, nas décadas finais do século XX, essa afirmação passou a ser contestada, especialmente pelos descendentes dos habitantes originais desses territórios.

Assim, em Wik Peoples v Queensland (1996) 187 CLR 1, a High Court of Australia apreciou o recurso de apelação interposto pelos povos aborígenes coletivamente denominados wik, os quais alegavam serem titulares de direitos reais preexistentes à colonização inglesa. O estado de Queensland sustentou a tese de que o Estado australiano tinha se sub-rogado no direito de propriedade absoluto que a Coroa britânica tinha adquirido, via a occupatio de terra nullius, sobre a totalidade das terras da Austrália. Contudo, o tribunal entendeu, por quatro votos contra três, que a teoria das tenures não tinha sido devidamente aplicada ao contexto da Australia, pois havia povos nativos que já habitavam e exploravam os recursos dessa região antes da chegada dos colonizadores.

De modo bastante interessante, a discussão acerca da natureza jurídica das tenures nas colônias inglesas também provocou uma análise sobre os limites temporais e geográficos do common law, já que as necessidades locais levaram a um desenvolvimento particular do ordenamento jurídico nessa ex-colônia, na qual, em matéria de direitos reais, prevalece a tese da primazia dos statutes. São mencionados especificamente vários tipos de tenures que foram criadas por meio de statutes - especialmente aqueles criados na Austrália pelo Land Act 1910 
questões relativas aos direitos dos povos nativos dessas regiões, na medida em que se pôs em pauta o modo de aquisição das terras coloniais pela Coroa inglesa ${ }^{98}$.

Essa particular estrutura dos direitos reais no direito inglês, baseada no título radical da Coroa, é consequência da doutrina "de natureza dependente e derivativa" ${ }^{99 "}$ das

e pelo Land Act 1962, pelos quais termos como "lease" e "license", embora provenientes do common law, ganharam novos significados - que não têm correspondente no common law tradicional. Como as tenures criadas mediante esses statutes não conferiam ao concessionário um direito real absoluto sobre a terra, o tribunal concluiu que os direitos alegados pelas populações indígenas não teriam sido extintos pelos citados statutes, nem muito menos pela chegada dos colonizadores, na medida em que o título radical da Coroa sobre as terras das colônias teria natureza soberana apenas (sovereignity), e não proprietária (absolute ownership).

Entendimento similar já tinha despontado em outra decisão da High Court of Australia, Mabo $v$ Queensland (No 2) (1992) 175 CLR 1, em relação à ação proposta pelo povo Meriam, nativo da ilha Murray, exigindo o reconhecimento do direito real sobre as terras da ilha. É possível perceber, pelas referências a decisões anteriores da justiça australiana, que o radical title da Coroa, à época da colonização, já era considerado apenas um ficção conveniente na Inglaterra, mas que foi reavivada em relação aos territórios coloniais de ultramar. O motivo dessa retomada da teoria das tenures devia-se, em larga medida, ao fato de a Coroa ter adquirido esses territórios mediante occupatio de terra nullius, e não por meio de conquistas ou cessão pelos proprietários originários. Pressupôs-se, portanto, que a Coroa fosse titular um poder não apenas politicosoberano, mas de um título de propriedade absoluto, pois precisava desse título para poder distribuir as terras e organizar as colônias de acordo com os critérios mais convenientes para a colonização. Essa autoridade somente poderia ser exercida pelo proprietário. Uma vez passada a fase de colonização, passou-se, porém, a discutir a que título a Coroa poderia auto-denominar-se proprietária desses territórios, na medida em que as populações indígenas tinham sido flagrantemente ignoradas. Foi assim que se estabeleceu com maior clareza a distinção entre absolute beneficial ownership e sovereignity, permitindo a atribuição à Coroa de um direito de soberania territorial, sem que para isso tivesse que ser titular de um direito de propriedade.

${ }^{98}$ Uma das principais bases jurídico-teóricas para a apropriação, pela Coroa, de terras colonizadas em novos territórios no final do século XVIII e começo do século XIX foi fornecida por E. VATTEL, Le droit des gens ou Principes de la loi naturelle, I-II, Leiden, Compagnie, 1758 [Reimpr. vol. I, Washington, Carnegie, 1916], pp. 81-83. De acordo com o autor, a Terra pertence, em princípio, a todos os homens, e foi criada para fornecer as necessidades humanas de habitação e alimento. No entanto, com o crescimento da população, tornouse necessário, de modo a promover o cultivo do solo, designar parcelas de terra a pessoas ou grupos de pessoas específicos, surgindo daí as nações, cujo direito sobre o território abrange tanto o domínio (domain), entendido como direito de propriedade, quanto o império (empire), compreendido como o poder político-soberano de uma nação. Sendo essa a origem e o fundamento natural do dominium, segue-se que toda vez que alguém se imite na posse de um território considerado terra nullius, adquire sobre o mesmo um direito natural que abrange ambos esses poderes. Ao discutir o fenômeno da colonização, o autor afirma que a terra também é nullius quando a população indígena não cultivasse devidamente o solo, em cujo caso a Coroa adquiria, no ato de tomar posse da terra, tanto o imperium quanto o dominium sobre o território, desde que promovesse sua efetiva ocupação e desenvolvimento.

Foi assim que se resgatou o substrato proprietário da doutrina das tenures, numa época em que, na própria Inglaterra, já se encontrava em franco declínio, cf. E. JENKS, A History of the Australasian Colonies, Cambridge, Cambridge University, 1912, pp. 58-60, para quem a árida ficção que declarava a Coroa proprietária das terras das colônias nada mais era do que o reavivamento de uma relíquia de teoria feudal, outrora muito útil, mas que apenas rendia homenagem ao conservadorismo inato do povo inglês. É interessante notar que, de acordo com F. PRINGSHEIM, The Inner Relationship cit. (nota 76 supra), pp. 357-358, esse apego à tradição é uma das características que aproximam o direito inglês do direito romano.

${ }^{99}$ Embora não façam parte do desenvolvimento histórico primário da real property law inglesa, exceções à natureza derivada do título sobre bens imóveis existem e são hoje abrangidas pelo instituto da adverse possession (muito similar à usucapião do direito civil), de origem estatutária - especialmente o Real Property Limitation Act 1833 [=Stat. 3 \& 4 Will. IV (1833), c. 27] e o mais recente Limitation Act 1980 -, cf. R. Megarry e W. WAdE, The Law of Real Property cit. (nota 1 supra), pp. 86-87, tratado detalhadamente nas pp. 1409-1464. 
tenures $^{100}$, hoje estranha à privatísitica continental, tal como ela se desenvolveu na Inglaterra medieval a partir da segunda metade do século XI.

Tal doutrina foi implantada pelos normandos e teve como pano de fundo a Conquista $^{101}$ de $1066^{102}$. Guilherme I distribuiu as terras que pertenciam aos antigos senhores

${ }^{100}$ Cf. F. POLlock e F. W. MAITLAND, The History of English Law cit., vol. II (nota 12 supra), p. 234, nt. 1: "We use the phrase 'dependent and derivative nature' instead of saying merely 'tenure', for though English lawyers have been wont to speak as though tenure of land were characteristic of feudalism, we ought to remember that long before there was any feudal tenure the verb tenere, sometimes in conjunction with habere, was currently used to describe the possession of land. What is characteristic of feudalism is not 'tenere terram', but 'tenere terram de $X$ '”.

${ }^{101}$ Trata-se da Batalha de Hastings, na qual Guilherme o Conquistador derrotou Haroldo I, sucessor de Eduardo o Confessor. Ela representa, para a historiografia jurídica inglesa, o marco inicial do common law. Nesse sentido, cf. S. F. C. Milsom, Historical Foundations cit. (nota 12 supra), p. 11; J. H. BAKER, An Introduction cit. (nota 12 supra), p. 12; F. POLlOCK e F. W. MAITLAND, The History of English Law cit., vol. I (nota 12 supra), pp. 79-80. Para uma narrativa e análise militar da Batalha de Hastings, cf. E. WHEELER, The Battle of Hastings: Math, Myth and Melee, in Military Affairs 52 (1998), pp. 128-134. De modo geral, cf. s. v. Battle of Hastings in Encyclopadia Britannica Online (2011), disponível in http://www.britannica.com/EBchecked/topic/256736/Battle-of-Hastings [01-03-2011].

${ }^{102}$ É importante esclarecer que as relações de suserania e vassalagem já existiam na Inglaterra antes da Conquista, com a grande diferença de que era possível fazer um juramento de lealdade sem a intermediação de terras e que estas, caso fossem parte do pacto, podiam ser herdadas pelo descendente do vassalo mediante o pagamento de uma soma em dinheiro denominada relief [=relevatio ou relevium] ou heriot, cf. G. SPENCE, The Equitable Jurisdiction cit., vol. I (nota 12 supra), pp. 38-40.

A origem remota das tenures é atribuída à emphyteusis por G. SPENCE, The Equitable Jurisdiction cit., vol. I (nota 12 supra), pp. 32-34. Mais cautelosamente, W. W. BuCKLAND e A. D. MCNAIR, Roman Law and Common Law cit. (nota 1 supra), p. 60 limitam-se a dizer que a emphyteusis é o instituto de direito romano mais próximo das tenures inglesas.

Em todo caso, a emphyteusis surgiu no periodo pós-clássico do direito romano, no contexto da crise do século III d.C. e teve sua configuração definitiva estabelecida, no Oriente, mediante uma constituição do Imperador Zenão, já no século V d.C.. A praxe do século III d.C. tinha resultado em concessões a longo prazo de terrenos provinciais, pois as locações a curto prazo não mais atendiam às necessidades econômicas do momento. Em princípio, os praedia provincialia eram objeto de dominium populi vel Caesaris (ressalvadas as civitates foederatae, em que predominava o dominium iure peregrino), o que impedia que esses terrenos integrassem o patrimônio dos particulares iure civile. A principal distinção entre o dominium populi vel Caesaris e o dominium ex iure Quiritium era a imposição de um stipendium ou tributum e a possibilidade de revogação da concessão. Isso ocorria porque, a diferença dos terrenos no solo itálico, os das províncias eram objeto não apenas da soberania romana, mas também de um verdadeiro direito de propriedade cujo titular podia ser o aerarium populi Romani ou o fiscus Caesaris.

Uma das formas de exploração econômica desses terrenos provinciais denominava-se ius perpetuum e servia para a concessão por prazo indeterminado de rei privatae. A outra forma era a emphyteusis, aplicável ao patrimonium Caesaris (fundi patrimoniales) e cujo principal objetivo era o de assegurar o cultivo das terras provinciais numa época de crise econômica. A partir do século IV d.C. as duas figuras começaram a se estender às demais formas de propriedade privada, especialmente a eclesiástica, englobando também as concessões de agri vectigales, no contexto da transformação das locações a curto prazo em concessões perpétuas. Com a fusão dos dois institutos, surge um novo contrato de emphyteusis que assegura ao enfiteuta um direito transmissível a título universal ou particular e potencialmente perpétuo. Sobre o tema, cf. M. TALAMANCA, Istituzioni cit. (nota 42 supra), pp. 394-402 e 475-476; M. MARRONE, Istituzioni cit. (nota 74 supra), pp. 371-376; R. ZIMMERMANN, The Law of Obligations - Roman Foundations of the Civilian Tradition (1990), Oxford, Clarendon, 1996, pp. 358-359.

Os principais textos romanos que definem a emphyteusis são Imp. Zen., C. 4, 66, 1 (476-484 d.C.): “Ius emphyteuticarium neque conductionis neque alienationis esse titulis addicendum, sed hoc ius tertium sit constitutum ab utriusque memoratorum contractuum societate seu similitudine separatum, conceptionem definitionemque habere propriam et iustum esse validumque contractum, in quo cuncta, quae inter utrasque contrahentium partes super omnibus vel etiam fortuitis casibus pactionibus scriptura interveniente habitis placuerint, firma illibataque perpetua stabilitate modis omnibus debeant custodiri (...)" (O direito enfiteutico 
saxões entre os guerreiros normandos que o acompanharam na sua campanha contra Haroldo $^{103}$, e o modo pelo qual foram feitas as concessões, que foram o resultado das negociações entre senhores e vassalos ${ }^{104}$, seguiu o modelo feudal de suserania e vassalagem, adotado, sob diversas variantes, em todo o mundo medieval ${ }^{105}$. A natureza dessas concessões e dos direitos e deveres a elas associados, na medida em que compunham um complexo de direitos pessoais e reais ${ }^{106}$, era mais contratual do que real, pelo menos no que diz respeito aos termos da concessão ${ }^{107}$.

No final do século XI, portanto, o principal fator que estabeleceu as diretrizes para o desenvolvimento posterior do direito inglês foi a sujeição do território ao regime feudal de concessão de terras sob certas condições ${ }^{108}$, pelas quais os tenants ficavam sujeitos a

não deve ser incluído nos títulos acerca da locação ou da alienação, mas < determino> que seja constituído um tertium ius independente de associação ou semelhança com os contratos mencionados, que tenha conceito e definição própria e seja um contrato justo e válido, no qual tudo aquilo que entre ambas as partes dos contratantes tenha sido determinado nos pactos tidos por meio de escritura, acima de tudo, ou ainda nos casos fortuitos, por todos os meios se deva observar com firme, ilibada e perpétua estabilidade (...)) e Inst. 3, 24, 3: “ (...) Sed talis contractus quia inter veteres dubitabatur et a quibusdam locatio, a quibusdam venditio existimabatur: lex Zenoniana lata est, quae emphyteuseos contractui propriam statuit naturam neque ad locationem neque ad venditionem inclinantem, sed suis pactionibus fulciendam, et si quidem aliquid pactum fuerit, hoc ita obtinere ac si natura talis esset contractus (...)" (Mas porque entre os antigos se duvidava acerca de tais contratos, e por alguns era considerado uma locação e por outros uma venda, foi promulgada uma lei de Zenão, a qual estabeleceu uma natureza própria para o contrato de enfiteuse que não se inclina nem para a locação nem para a venda, mas que deve se apoiar nos seus próprios pactos, e certamente se algo for pactuado, será observado como se tal fosse a natureza do contrato). O instituto da emphyteusis é regulado em Imp. Zen., C. 4, 66, 1-4 (476-484 d.C.).

${ }^{103}$ Cf. G. SPENCE, The Equitable Jurisdiction cit., vol. I (nota 12 supra), pp. 89-90. O fato vem registrado nas fontes históricas inglesas. Assim, em Hist. Rames. c. 90 [=T. GALE, Historiae Britannicae, Anglicanae, Saxonicae, Anglo-Danicae, Scriptores XV, vol. I, Oxford, 1691, p. 446]: “Cum ergo Rex Willelmus omnem fibi Angliam virtute bellica Jubjugaffet, eundem Sexium, ficut \& alios plerofque Anglos exharedavit, \& jus noftrum fimul cum fuo ei auferens, alium quem voluit inde haredavit" (Dado que o rei Guilherme tivesse subjugado a si toda a Inglaterra pela força das armas, deserdou o mesmo Sexius, assim como muitos outros ingleses, e tirandolhe o seu direito junto com o nosso, desde então herdou aquele outro que ele quis <que herdasse >).

${ }^{104}$ Nesse sentido, já no século XII afirmava R. FITZNIGEL, De necessariis observantiis scaccarii dialogus, edit. por A. Hughes, C. G. CRump e C. Johnson, Oxford, Clarendon, 1902, p. 101: "Sic igitur quisquis de gente subacta fundos vel aliquid huiusmodi possidet, non quod ratione sucessionis deberi sibi videbatur adeptus est, set quod solummodo, meritis suis exigentibus vel aliqua pactione interveniente, obtinuit' (Assim, portanto, qualquer um do povo conquistado que possui terras ou alguma coisa desse gênero, a conseguiu não porque parecia que em razão da sucessão era devida, mas apenas porque exigindo-o seus méritos ou intervindo algum pacto, <assim> a obteve). Em outras palavras, os tenants ingleses estão sujeitos às regras do pacto, e não da herança, o que revela a natureza contratual das tenures, cf. J. H. BAKER, An Introduction cit. (nota 12 supra), p. 225 , nt. 10 .

105 Mesmo havendo inúmeras variantes desse modelo, todas continham o traço peculiar medieval consistente em alguém se tornar l'homme d'un autre homme, cf. M. BLOCH, La société féodal cit. (nota 42 supra), pp. 143-149. O autor explica que essas relações surgiram no contexto do enfraquecimento das instituições após o desmoronamento do Império Romano, momento em que ao legado de Roma misturaram-se tradições germânicas. O autor ressalta, ainda, a centralidade da homagium como o ato pelo qual essa relação, de proteção de um lado e de fidelidade do outro, se estabelecia.

${ }^{106}$ Cf. F. POLlOCK e F. W. MAITLAND, The History of English Law cit., vol. I (nota 12 supra), p. 236.

${ }^{107}$ Cf. J. H. BAKER, An Introduction cit. (nota 12 supra), p. 225.

108 Tende a ser ressaltada, além da natureza feudal das relações nas quais se fundou a real property, o caráter marcadamente militar da ocupação normanda, que teria conferido um sabor ainda mais específico aos 
determinados ônus pelo desfrute da concessão e gozavam de uma série de prerrogativas em face do senhor ${ }^{109}$.

\title{
2.2.2. A articulação das terras em função do regime de concessão feudal
}

\author{
No contexto das tenures, uma importante distinção existia entre os bens imóveis
} mantidos sob regime dominical pelo senhor, denominadas in dominico ${ }^{110}$, e aqueles sujeitos a um regime de prestação de services, chamadas in servitio ${ }^{111}$. Na primeira categoria incluíam-

direitos reais na Inglaterra e ao common law como um todo, cf. L. MocCIA, Il modello inglese cit. (nota 1 supra), p. 71; A. W. B. SIMPSON, An Introduction to the History of Land Law, Oxford, Oxford University, 1961, p. 3.

${ }^{109}$ Cf. F. Pollock e F. W. MAITLAND, The History of English Law cit., vol. I (nota 12 supra), pp. 234-237. $\mathrm{O}$ caráter eminentemente feudal das relações que envolvessem bens imóveis na Inglaterra permeou o ordenamento jurídico inglês de modo muito mais intenso que em outros sistemas, provavelmente por causa do contexto militar em que a sociedade inglesa esteve imersa nas décadas logo após a conquista normanda.

${ }^{110}$ Embora F. POLlock e F. W. MAITLAND, The History of English Law cit., vol. I (nota 12 supra), p. 363 apontem certa ambigüidade nas fontes locais, na perspectiva dos tribunais reais as terras in dominico incluíam as terras in villeinage, ou seja, as terras sujeitas à villein tenure. Assim, por exemplo, encontra-se em Bracton f. 98 : "Item assignanda erit ei tertia pars villenagii quod est quasi dominicum" (Da mesma forma, dever-se-lhe-á atribuir a terceira parte do villenagium, o qual é como se fosse dominicum) e Bracton f. 75b: "Et sciendum quod in divisionem veniunt tam dominica quam villenagia quae dici poterunt dominica" (E deve-se saber que tanto <as terras consideradas> dominicum quanto <aquelas consideradas> villenagium são divisíveis, <ambas> as quais podem ser chamadas dominicum).

${ }^{111}$ A distinção entre terras in dominico e in servitio é desenvolvida em Bracton f. 263, e está ligada, em princípio, ao writ competente para obter a posse em caso de esbulho: "Item dominicum accipitur multipliciter. Est autem dominicum quod quis habet ad mensam suam et proprie, sicut sunt bordlandes Anglice. Item dicitur dominicum villenagium quod traditur villanis, quod quis tempestive et intempestive resumere poterit pro voluntate sua et revocare (...) Et generaliter qualitercumque quis feoffatus fuerit et quacumque hora in feodo sibi et heredibus suis, vel si ex causa successionis, ita quod assisam nova disseisince habere posset si eiectus esset dum viveret, competit heredibus suis assisa mortis antecessoris post mortem suam si seisitus moriatur. Et sciendum quod dominicum dicitur ad differentiam eius quod tenetur in servitio. Et unde dicitur tota die, quod videndum erit quid quis teneat in dominico et quid in servitio. Et regulariter verum est quod dominicum dici potest omne illud tenementum de quo antecessor obiit seisitus ut de feodo (...)" (Da mesma forma <o que seja> dominicum é entendido de diversas formas. É dominicum aquilo que alguém tem para a sua mesa e pessoalmente, tal como o são as boardlands inglesas. Da mesma forma se denomina dominicum o villenagium entregue aos villani, o qual <o senhor > poderá tomar de volta tempestiva ou intempestivamente e revogar conforme a sua vontade (...) E de modo geral, seja como e quando for que alguém tenha recebido uma concessão feudal para si e para os seus herdeiros, ou para si por motivo de sucessão, de tal forma que possa ter $<$ direito a ajuizar> a assisa novae disseisinae se for esbulhado enquanto viver, compete aos seus herdeiros $<$ ajuizar> a assisa mortis antecessoris após a sua morte caso morra na posse < da concessão $>$. E deve-se saber que <essa terra> denomina-se dominicum para diferenciá-la daquela que é tida in servitio. E daí se diz diariamente que se deve ver aquilo que alguém tem in dominico e o que tem in servitio. E normalmente é verdade que se pode denominar dominicum todo o tenementum em relação ao qual o antecessor morreu na posse da concessão feudal (...)).

Assim, o fragmento estabelece que as terras in dominico são aquelas em relação às quais o titular não alienou a concessão a um terceiro mas a reservou para o seu uso pessoal (...ad mensam suam et proprie...), em cujo caso cabe a assisa novae disseisinae se o titular for esbulhado. Note-se que as terras destinadas aos villein tenants são consideradas parte do domínio direto do senhor, conforme se verá no capítulo correspondente infra. O componente central é a manutenção da titularidade da concessão, e a expressão usada para referir-se a essa idéia é seisitus ut de feodo [=seised as offee].

Nesse sentido, atenção especial deve ser dada à expressão “in dominico suo ut de feodo", que qualifica as terras in demesne ou in dominico, ou seja, as terras que o senhor guardava para o seu uso pessoal, sem enfeudálas, cf. F. W. MAITLAND, Equity cit. (nota 12 supra), p. 324. A expressão é parte integrante do breve de recto tenenendo (writ of right), o que pode ser visto em Bracton f. $372 \mathrm{~b}$ : "Et audito brevi de recto secundum quod 
se todas as terras que o senhor feudal mantinha sob seu domínio direto e cuja renda ou proventos ele mesmo percebia ${ }^{112}$. Na segunda, por sua vez, encontravam-se as terras que o senhor objeto de concessão ou subconcessão ${ }^{113}$ aos seus tenants.

Desse modo, o sistema das tenures, do qual derivam os estates in land, estava intimamente ligado aos services ${ }^{114}$ e aos incidents. Os services, pelo fato de constituirem a

fuerit clausum vel apertum, dicat sic petens vel eius advocatus in presentia iustitiariorum pro tribunali residentium: Hoc ostendit vobis A. quod B. iniuste ei deforciat tantum terra cum pertinentiis in tali villa, et ideo iniuste quia quidam antecessor suus C. nomine fuit inde vestitus et seisitus in dominico suo ut de feodo et iure (...)" (E tendo sido ouvido o breve de recto, segundo seja fechado ou aberto, diga assim o demandante ou o seu advogado na presença dos juízes sentados no lugar do tribunal: Isto vos apresenta A, que B injustamente lhe arrebata uma quantia de terra com seus acessórios em tal vila, e por isso injustamente <a detém>, porque um certo antecessor seu chamado $\mathrm{C}$ foi desde então investido e empossado no seu domínio a título de concessão feudal e de direito (...)).

A expressão clausum vel apertum refere-se ao writ, porém não na sua dimensão judicial, mas como ordem emanada do rei, em cujo caso já no século XIII se classificava em três tipos: charters, para a concessão de terras ou liberdades; letters patent, para comissionar funcionários da Coroa, e letters closed and sealed, para comunicar ordens ou informações, cf. D. M. WALKER, The Oxford Companion cit. (nota 8 supra), p. 1309 (no verbete "writ"). Cabe lembrar que o assize of novel dissesin, na época de Bracton, ainda não tinha se generalizado como meio de recuperação da posse independentemente do título, o que veio ocorrer posterioremente, cf. J. H. BAKER, An Introduction cit. (nota 12 supra), pp. 233-234.

De acordo com A. M. BURRILL, A New Law Dictionary cit., vol. I (nota 13 supra), pp. 358-359 (no verbete "demesne"), a frase in dominico suo ut de feodo se traduz ao inglês por in his demesne as of fee e designa, desde a perspectiva das tenures, a maior parcela de direitos que se podia ter em relação a um bem imóvel na Inglaterra, pois pertencia ao senhor e aos seus herdeiros para sempre. Ao comentar o uso dessa frase, o autor critica a passagem Bl Comm 2, 7, 105 por (aparentemente) equiparar o allodium ao dominicum (ver nota 119 infra). Para tanto, cita Bracton f. 46b, que explicitamente utiliza a expressão in dominico suo para refererir-se às terras do tenant: "Item si dicat quod iniuste ingressus sit feodum suum, quia non est feodum suum in dominico sed tenentis illius, et dominus nihil habet in feodo nisi servitium, et sic erit feodum tenentis in dominico et feodum domini in servitio (Da mesma forma caso <o senhor $>$ diga que $<0$ subtenant $>$ tenha ingressado injustamente no seu feudo, porque não é o seu feudo in dominico mas do seu tenant, e o senhor nada tem em relação ao feudo salvo o serviço; de tal forma, o feudo do tenant será in dominico e o feudo do senhor in servitio).

$\mathrm{O}$ fragmento em questão discute a possibilidade de o tenant realizar uma subconcessão feudal, e responde afirmativamente ao dizer que o tenant também tem a titularidade da concessão feudal das terras in dominico suo. A expressão traduz bem o sentido original da property, pois ao mesmo tempo em que estabelece o direito real de maior amplitude, exclui a possibilidade de existirem terras alodiais, o que significa dizer que todas as terras estão sujeitas ao regime qualificado das tenures.

${ }^{112}$ Cf. A. M. BuRRILL, A New Law Dictionary cit., vol. I (nota 13 supra), pp. 360 e 398 (nos verbetes "demesne lands" e "dominicum"). Os termos dominicum, in dominico, in dominico suo, in demesne aplicam-se tanto às terras sob o domínio direto do senhor quanto àquelas sob o controle do liber tenens, desde que este tivesse prestado homagium e fornecesse os serviços devidos ao seu senhor, pois o único interesse jurídico deste na terra eram os services, cf. Bracton f. 46b: “(...) et dominus nihil habet in feodo nisi servitium; et sic erit feodum tenentis in dominico et feodum domini in servitio" ((...) e o senhor nada tem em relação ao feudo salvo o serviço; de tal forma, o feudo do tenant será in dominico e o feudo do senhor in servitio). Daí que a palavra dominicum passasse a designar não apenas as terras dos senhores feudais, mas também a dos seus tenants, que eventualmente podiam ocupara a posição de senhor em outra relação feudal.

${ }^{113} \mathrm{O}$ vocábulo subinfeudation refere-se ao ato de concessão de terras, anterior ao Statutum Quia Emptores Terrarum 1290 [=Stat. 18 Edw. I (1290), c. 1-3], feita por pequenos senhores feudais que já eram tenants de senhores mais importantes, a terceiros que passavam a ser seus subtenants, cf. A. M. BURRILL, A New Law Dictionary cit., vol. II (nota 13 supra), p. 951 (no verbete "subinfeudation") e Bl Comm 2, 6, 91 [=W. BlaCKSTONE, Commentaries cit., vol. II (nota 10 supra), p. 91]: "Before the ftatute of quia emptores, 18 Edw. I, the king's greater barons, who had a large extent of territory held under the crown, granted out frequently fmaller manors to inferior persons to be held of themfelves (...) In imitation whereof, thefe inferior lords began to carve out and grant to others ftill more minute eftates, to be held as of themfelves, and were fo proceeding downwards 'in infinitum"'. 
principal contraprestação ${ }^{115}$ que o senhor feudal podia exigir do seu tenant, eram, inicialmente, o verdadeiro motivo pelo qual o senhor concedia a posse da terra ${ }^{116}$. De fato, a terra era considerada o pagamento pelo service, e não o contrário ${ }^{117}$.

114 Cf. C. F. Du CANGE, Glossarium cit. (nota 13 supra), t. 7, col. 448c (no verbete "servitium"): "Regulariter accipitur pro quolibet obsequio, quod a vasallis et tenentibus debetur ratione feodi vel tenura".

115 Os services mais comuns envolviam assistência militar (tais como o knight-service, castlegard e cornage), serviços pessoais ao rei (grand serjeantry), fornecimento de materiais e provisões ao rei (petty serjeantry), guia espiritual (divine service e frankalmoin) ou produção agrícola (villeinage e socage). Na sociedade medieval, a tenure indicava não apenas um complexo de direitos e deveres, como também o próprio status da pessoa, e não era incomum que uma mesma pessoa ficasse sujeita a vários tipos de service em relação às terras sobre as quais era tenant.

Com base nesses services, as tenures são classificadas em dois grandes grupos: (I) lay, e (II) spiritual. Ao primeiro grupo pertencem as (I.A) base tenures e as (I.B) free tenures. As base tenures subdividiam-se em: (I.A.i) pure villeinage, que envolvia services de natureza indeterminada, e (I.A.ii) villein socage, cujos services eram determinados. As free tenures, por sua vez, subdividiam-se em: (I.B.i) chivalrous, à qual pertenciam as (I.B.i.a) knight's service tenures e as (I.B.i.b) grand serjeantry tenures, e (I.B.ii) non-chivalrous, da qual faziam parte as (I.B.ii.a) petty serjenatry tenures e as (I.B.ii.b) free socage tenures. Por último, as spiritual tenures subdividiam-se em (II.A) frankalmoin, quando o service não fosse específico, tal como um dever geral de fornecer guia espiritual, e (II.B) divine service, quando o service fosse especifico, como seria, por exemplo, o dever de rezar pela alma de alguém.

Já no século XII, a relevância e o valor econômico dos services, pensados e criados para suprir as necessidades de uma sociedade descentralizada e militarizada, entraram em declínio, desaparecendo quase completamente em meados século XIII. Em seu lugar, ganharam importância os incidents, que eram determinados fatos sobre os quais incidia um ônus devido ao senhor feudal. Tal como os services, os incidents eram tutelados e limitados pelo common law. Os principais incidents eram os seguintes: (I) aids, que eram contribuições financeiras que o senhor feudal podia exigir para: (I.a) pagar seu próprio resgate, caso fosse capturado pelo inimigo,; (I.b) pagar pelo custo de admissão do seu primogênito na ordem dos cavaleiros, e (I.c) pagar o dote da sua filha mais velha; (II) fines on alienation, exigido pelo senhor para permitir que o tenant fosse substituído por um terceiro na posse da terra (foi abolido em 1290), salvo para os tenants da Coroa); (III) relief e primer seisin, tributo exigido pelo senhor durante o período entre a morte do tenant e a entrada na posse dessa mesma terra pelo seu herdeiro (foi abolido em 1267, salvo para os tenants da Coroa); (IV) escheat, que era a devolução da terra ao senhor, caso o tenant morresse sem deixar herdeiros; (V) customary dues, obrigações de natureza diversa devidas em razão da morte do tenant ou do senhor; (VI) wardship: caso o tenant deixasse um herdeiro menor de idade, cabia ao senhor feudal assumir sua tutela, em cujo caso, por via de regra (especialmente no caso das tenures militares), o senhor ficava com os frutos da terra; (VII) marriage: enquanto o senhor fosse o tutor (guardian) do herdeiro, podia arranjar-lhe um matrimônio; caso o herdeiro rejeitasse a proposta, devia compensar o senhor pelas perdas ocasionadas pela sua recusa.

Os incidents cujo valor era fixo sofreram, ao longo dos séculos XIV-XV, forte devaluação em consequiência da inflação. Porém, aqueles incidents cujo valor era vinculado ao preço da terra passaram a constituir a principal fonte de renda do senhor feudal. Dentre estes, os mais importantes eram os incidents relacionados à sucessão causa mortis, fato que teve influência decisiva na formação dos uses e dos trusts.

A particularidade das tenures, no que diz respeito à comparação com as categorias de direitos reais nos sistemas de base romanística, reside em que, apesar das grandes transformações que sofreu a sociedade inglesa ao longo do tempo, as antigas instituições feudais da época da invasão normanda continuaram a existir durante muitos séculos. Assim, mesmo com o declínio dos services e depois dos incidents, as tenures continuaram sendo um importante componente do ordenamento jurídico inglês até a entrada em vigor do Law of Property Act 1925 [=Stat. 15 \& 16 Geo. V (1925), c. 20]. A influência do sistema das tenures é tão marcante que até hoje a terminologia do direito de propriedade inglês deriva dele, cf. W. W. BuCKLAND e A. D. MCNAIR, Roman Law and Common Law cit. (nota 1 supra), p. 60.

Sobre services e incidents, na doutrina, cf. J. H. BAKER, An Introduction cit. (nota 12 supra), pp. 226-229 e 238-241; K. E. DigBY, An Introduction to the History of the Real Property, $5^{\text {a }}$ ed., Oxford, Clarendon, 1897, pp. 80-90; R. FRANCESCHELl, Il trust nel diritto inglese, Padova, CEDAM, 1935, pp. $51-67$ (esp. 54-55); S. F. C. MiLSOM, Historical Foundations cit. (nota 12 supra), pp. 208-211; T. F. T. PlUCKNETT, A Concise History cit. (nota 12 supra), pp. 531-545. Sobre o sistema de tenures, cf. J. H. BAKER, An Introduction cit. (nota 12 supra), p. 247 (quadro sinótico) e D. M. WALKER, The Oxford Companion cit. (nota 8 supra), pp. 1210-1211 (nos verbetes "tenure" e "tenures"). Também em Co Litt $64 \mathrm{~b}(2,1,85)$ [=E. COKE, The First Part of the Institutes cit., 
Além das terras pertencentes à Coroa, sobre as quais, sem dúvida alguma, o monarca era titular de dominium absoluto ${ }^{118}$, as terras tidas in dominico por um senhor feudal representavam, no que diz respeito ao sistema das tenures, a categoria mais próxima da propriedade absoluta de base romanística ${ }^{119}$, embora com ela não se confundisse ${ }^{120}$.

Nesse contexto, um dos modos pelos quais é possível articular terminológica e conceitualmente as respectivas esferas do senhor e seu tenant se dá pela distinção, criada pelos juristas medievais continentais ${ }^{121}$, entre o dominium directum e o dominium utile ${ }^{122}$,

vol. I (nota 10 supra), s. n.] encontra-se uma sucinta descrição das tenures, vinculadas aos respectivos services, baseada na obra Tenores Novelli, publicada por T. LITTLETON em 1482.

${ }^{116}$ Cf. J. H. BAKER, An Introduction cit. (nota 12 supra), p. 225.

${ }^{117}$ Cf. S. F. C. MiLsom, Historical Foundations cit. (nota 12 supra), p. 101.

${ }^{118}$ Cf. Co Litt 1b $(1,1,1)$ [=E. CoKE, The First Part of the Institutes cit., vol. I (nota 10 supra), s. n.]: “(...) praedium domini regis est directum dominium, cujus nullus author est nisi Deus (...)".

119 Algumas autoridades parecem equiparar dominium a dominicum, porém sempre diferenciam uma da outra. Assim, em Bl Comm 2, 7, 105 [=W. BlaCKSTONE, Commentaries cit., vol. II (nota 10 supra), p. 105]: "The true meaning of the word fee (feodum) is the fame with that of feud or fief, and in it's original fenfe it is taken in contradiftinction to 'allodium'; which latter the writers on this fubject define to be every man's own land, which he poffesfeth merely in his own right, without owing any rent of fervice to any fuperior. This is property in it's higheft degree; and the owner thereof hath abfolutum et directm dominium, and therefore is faid ot be Seifed thereof abfolutely 'in dominico Juo', in his own demefne (...) And hence it is that, in the moft folemn acts of law, we exprefs the ftrongeft and higheft eftate, that any fubject can have, by thefe words: 'he is feifed thereof in his demefne, as of fee'. It is a man's demefne, 'dominicum', or property, fince it belongs to him and his heirs forever: yet this 'dominicum', property, or demefne, is ftrictly not abfolute or allodial, but qualified or feodal: it is his demefne, 'as of fee', that is, it is not purely and fimply his own, fince it is held of a fuperior lord, in whom the ultimate property refides".

Nesse sentido, parece-nos precipitada a crítica de A. M. BURRILL, A New Law Dictionary cit., vol. I (nota 13 supra), p. 359 (no verbete "demesne"), conforme esboçada acima na nota 111 supra. W. BLACKSTONE, na passagem aqui citada, parece haver cometido apenas uma espécie de slip of the tongue, que prontamente corrige na oração subseqüente.

${ }^{120}$ Cf. K. E. GÜTERBOCK, Henricus de Bracton cit. (nota 1 supra), pp. 87-88, para quem não se deve identificar essa relação com um direito de propriedade absoluto, pois ele sempre depende da inexistência de um terceiro titular de um ius maius.

${ }^{121}$ Cf. H. CoING, Europäisches Privatrecht - Älteres Gemeines Recht (1500 bis 1800), t. I, München, Beck, 1985, pp. 292-293 e 350 (acerca das aplicações da distinção no direito feudal). A distinção foi do entre o dominium directum e o dominium utile foi desenvolvida no contexto do direito feudal continental, de modo a articular as relações entre senhores e vassalos.

As principais fontes que forneceram a base para a elaboração dessa doutrina foram Theo. et Val., C. 11, 62, 12 (de 434), acerca da proteção da posse dos emphyteuticarii patrimoniales independentemente da intermediação de uma operação de compra; Ulp. 53 ad ed., D. 39, 3, 1, 23, que trata das servidões adquiridas longa consuetudine e tuteladas por uma actio utilis; e Paul. 30 ad ed., D. 14, 5, 5, 1, que equipara ao herdeiro o filho que, após ter sido deserdado, fosse restituído na herança em virtude do Senatusconsultum Trebellianum - que concedia uma série de actiones utiles ao fideicommissarius, cf. A. BERGER, Encyclopedic Dictionary cit. (nota 13 supra), p. 699 (no verbete "Senatusconsultum Trebellianum") -, o qual passava a responder como se herdeiro fosse (...quia effectu quodammodo heres est). A dissociação entre o dominium directum e o dominium utile foi o principal instrumento conceitual que permitiu ao senhor, durante a Idade Mèdia, transferir o solo por longos períodos de tempo, reservando-se o direito de perceber determinadas contribuições e receber de volta o imóvel sob determinadas hipóteses.

Nesse sentido, N. EVERARDUS, Loci argumentorum legales, Venetia, Nicolinum, 1567, p. 190 indica quais eram as relações jurídicas que comportavam a transmissão do dominium utile: “(...) sex sunt contractus ex quibus transfertur utile dominium retento directo, quorum quilibet habet nomen diversum: et differunt inter se saltem in aliquo. Primus est contractus superficiarius; secundus est contractus locationis ad longum tempus; tertius est contractus emphyteuticus; quartus est contractus libellarius; quintus est contractus precariae, et sextus est contractus feudalis" ((...) são seis os contratos pelos quais se transfere o dominium utile, ficando retido o 
aquele entendido como o complexo de prerrogativas e direitos atribuídos ao senhor, este como o direito de "ter" ("tenere" = "hold") a terra desse mesmo senhor, sob determinadas condições materiais e temporais ${ }^{123}$. O próprio conceito de feudum ${ }^{124}$, que exerceu não pouca influência na formação da real property law inglesa e ao qual se liga toda a estrutura medieval dos direitos reais ${ }^{125}$, pode ser interpretado com base nessa distinção ${ }^{126}$.

$<$ dominium > directum: cada um dos quais tem um nome diverso: e diferem entre si pelo menos em relação a alguma coisa. O primeiro é o contrato de superfície; o segundo o contrato de locação a longo prazo; o terceiro é o contrato enfitêutico; o quarto é o contrato libelário, o quinto é o contrato de precário, e o sexto é o o contrato feudal).

Acerca do contractus libellarius, cf. C. F. Du CANGE, Glossarium cit. (nota 13 supra), t. 5, col. 088b (no verbete "libellus") "Charta qua pradium in emphyteusin conceditur, qua quidem contractus ac pactionis species frequens olim fuit in pradiis Ecclesiasticis: sub vulgari ac recepta nomenclatura, Precaria et Prestaria”. Como se pode ver, todas as relações enumeradas importam a concessão de um bem imóvel por um longo período de tempo. É essa a característica que marcou o sistema feudal e que, com as devidas ressalvas, serviu de base para a formação dos direitos reais de matriz inglesa.

${ }^{122}$ Cf. G. SPENCE, The Equitable Jurisdiction cit., vol. I (nota 12 supra), pp. 33 e 135 . Negando a possibilidade de utilizar, na Inglaterra, a divisão conceitual entre o dominium directum e o dominium utile, contudo, T. F. T. PluCKNETt, A Concise History cit. (nota 12 supra), p. 543 afirma que a doctrine of tenures, especialmente no que diz respeito ao fee simple, estabelece não um título dividido sobre a mesma coisa, mas dois títulos sobre objetos diferentes: em relação às terras submetidas a uma concessão feudal, o senhor seria titular de um direito senhorial (seignory) enquanto o tenant seria titular da terra in demesne (land in demesne). $\mathrm{O}$ mesmo autor admite, no entanto, a fragmentação do domínio em relação aos estates less than fee simple. Parece-nos, contudo, válida a opinião que afirma a divisibilidade do título no sistema inglês de modo geral, na medida em que os direitos do senhor e do tenant decorrem sempre de uma operação realizada em função de um mesmo bem imóvel, que é a referência central do esquema.

${ }^{123}$ Cf. D. M. WALKER, The Oxford Companion cit. (nota 8 supra), p. 373 (no verbete “dominium”).

${ }^{124}$ Aqui nos referimos, especificamente, ao feudo continental. A grafia feodum é peculiar ao direito inglês, cf. A. M. Burrill, A New Law Dictionary cit., vol. I (nota 13 supra), pp. 479-480 e 484 (nos verbetes "feod", "feodum" e "feudum"). Provém da palavra "feoh", de origem saxônica, que significava "valor a ser pago". As authorities mais antigas - Glanvill, Bracton, Littleton e inclusive Blackstone - usam essa variante para designar uma concessão feudal que descendia aos herdeiros (estate of inheritance), portanto com um sentido muito próximo da palavra feudum no Continente. Eis aí um dos indícios de que as antigas tradições anglo-saxônicas se incorporaram, em alguma medida, às instituições continentais trazidas pelos normandos no século XI. Sobre o vocábulo "foedum", cf. a nota 41 supra.

${ }^{125}$ Cf. M. BLOCH, La société féodal cit. (nota 42 supra), p. 184. O autor atribui a elevação do feudum à categoria dos direitos reais à ampliação do escopo hereditário das concessões feudais: "Ainsi ce privilège d'aînesse, qui devait devenir un des caractères les plus originaux des moeurs sociales anglaises et l'un des plus gros de conséquences, exprima, en son principe, une sorte de sublimation du fief au rang de droit réel, par excellence, des hommes libres".

${ }^{126}$ Uma definição citada na literatura inglesa é a de I. CUIACIUS, Iacobi Cuiacii i.c. praestantissimi operum postumorum quae iure reliquit, t. II, Lvtetiæ Parisiorvm, 1658, p. 593, E: "Quid eft feudum? Ius in pradio alieno in perpetuum vtendi fruendi, quod pro beneficio dominus dat ea lege, vt qui accipit fibi fidem \& militia munus aliudve feruitium exhibeat" (O que é um feudo? <Um feudo é> o direito de usar e fruir em perpetuidade um bem imóvel alheio que o senhor concede a título de benefício mediante condição de que quem recebe <a concessão $>$ para si forneça <um juramento de $>$ fidelidade e os deveres da <tenure > militar ou algum outro serviço).

Nossa tradução baseia-se na intepretação do termo "lege" dada em A. M. BuRRILL, A New Law Dictionary cit., vol. I (nota 13 supra), p. 484 (no verbete "feudum"), no sentido de que a palavra "lege" (lex, legis no ablativo singular) não significa "lei de caráter geral”, e sim as cláusulas condicionais do pacto vassálico, ou seja, "lei entre as partes".

A definição de I. CUiACIUS é reproduzida em H. SPELMAnNus, Glossarium cit. (nota 13 supra), p. 216 (no verbete "feodum"), que ainda acrescenta: "Transfertur \& apud nos ulterius feodum ad fignificandum puram hareditatem, maximum jus poffidendi \& perpetuum rei immobilis dominium, de quo inferius. Primum de primo (...) Feudum igitur proprie non eft ipfum pradium, fed jus in pradium". Para G. SPENCE, The Equitable Jurisdiction cit., vol. I (nota 12 supra), p. 34, a definição e representativa de toda a estrutura dos direitos reais na Inglaterra, especialmente no que se refere às formas de alienação de estates. 
Assim, é possível distinguir, com base na doutrina e as fontes inglesas, quatro noções fundamentais, todas relacionadas à doutrina das tenures, em torno das quais se estruturou a property law inglesa: o dominium absolutum ou allodium, do qual o único titular é a Coroa; o dominicum ou demesne, referente às terras de qualquer senhor feudal, inclusive a Coroa, não submetidas a um pacto feudal; o dominium directum, cuja titularidade pertence a todo senhor feudal sobre as terras dos seus tenants, e o dominium utile, reservado ao tenant.

A dificuldade para articular essas dimensões residia na circunstância de que mais de uma delas pode incidir não apenas sobre o mesmo bem, como também dizer respeito a uma ou várias pessoas ${ }^{127}$.

Pode-se dizer que foi a partir da possibilidade de existir terras in dominico e in servitio que se disseminou a noção de vários "proprietários" sobre o mesmo bem ao longo de toda a cadeia de tenures $^{128}$, o que representa, talvez, uma das características mais marcantes

Tratando do mesmo fragmento, C. BuTler, no comentário a Co Litt 191a (3, 4, 300) [=E. CoKE, The First Part of the Institutes cit., vol. II (nota 10 supra), s. n.], explica que o feodum confere um direito real mais amplo que o usufructus, na medida em que aquele confere ao tenant o direito de modificar a coisa. Ao mesmo tempo, o autor aproxima o feodum da emphyteusis, pois entende que, tal como o tenant, o emphyteuta ficava investido no dominium directum.

Nesse sentido, de acordo com J. STAIR, The Institutions of the Law of Scotland, $2^{\text {nd }}$ ed., Edinburgh, Heir of Andrew Anderson, 1693, lib. II, tit. 3, c. 7, p. 194, os elementos essenciais dos feudos são os seguintes: (i) a cisão entre o dominium directum, atribuído ao senhor, e o dominium utile, cuja titularidade é do vassalo (o autor atribui a origem dos termos directum e utile à antiga distinção romana entre actiones directae e actiones utiles); (ii) o reconhecimento por parte do vassalo de uma posição jurídica de subordinação em face do seu senhor; (iii) o fornecimento de uma contraprestação por parte do vassalo em favor do senhor, a qual podia consistir em serviços, valores pecuniários, orações e suplicações, e (iv) o juramento de fidelidade ao senhor, o qual prevê um dever negativo de não prejudicar o senhor de qualquer forma, e também um dever positivo de avisar-lhe acerca de quaisquer ameaças à sua vida ou reputação.

${ }^{127}$ Um exemplo dessa articulação, por vezes complexa, pode ser vista em Bracton f. 263b-264: “Et unde ex pramissis colligi potest quod unus potest esse seisitus de aliqua terra vel redditu in dominico suo ut de feodo et libero tenemento simul, vel tantum ut de feodo et non in dominico, vel tantum ut de libero tenemento et in dominico, non tamen in feodo, sicut dici poterit de illis qui tantum tenent ad vitam quacumque ratione" (E das premissas pode-se deduzir que um $<$ mesmo indivíduo $>$ pode estar, ao mesmo tempo, na posse de uma terra ou renda no seu dominicum a título de concessão feudal e <também na posse $>$ de um liberum tenementum; ou apenas <na posse > da concessão feudal e não do dominicum; ou apenas <na posse > a título de liberum tenementum e do dominicum, porém não a título de concessão feudal, tal como se diz daqueles que apenas tem $<$ a terra $>$ até $<$ o fim $>$ da vida por qualquer motivo).

$\mathrm{O}$ fragmento trata do assisa mortis antecessoris, porém contém uma das exposições mais representativas da natureza da propriedade feudal, a qual permitia à mesma pessoa ocupar a posição jurídica de senhor e vassalo ao mesmo tempo em relação ao mesmo bem imóvel, porém em relações jurídicas distintas, cf. A. M. BURRILL, $A$ New Law Dictionary cit., vol. I (nota 13 supra), p. 359 (no verbete "demesne"). O fragmento pode ser explicado seguindo as hipóteses por ele apresentadas: (i) seisitus in dominico suo et de feodo: na posse do terreno a título de uma concessão feudal hereditária (seria a posição jurídica do senhor, por exemplo, na hipótese das terras submeitas ao regime de villenagium); (ii) seisitus ut de feodo sed non in dominico: na posse do concessão feudal hereditária, porém não do terreno (corresponde à posição jurídica do senhor após realizar uma concessão feudal hereditária a um terceiro); (iii) seisitus ut de libero tenemento et in dominico sed non in feodo: na posse do terreno a título de concessão feudal não hereditária. Acerca do liberum tenementum, cf. nota 178 infra.

${ }^{128}$ Outro indício do fenômeno dos múltiplos direitos de natureza proprietária sobre o mesmo bem revela-se no fato de que as fontes medievais inglesas atestam uma certa ambiguidade ao tratar do titular da concessão feudal, o que dá a entender que tanto o senhor quanto o tenant, que pode simultaneamente ser senhor de outro tenant, têm um direito que pode ser considerado real sobre a terra (hold the land), cf. F. POLLOCK e F. W. 
do feudalismo e, por extensão, das bases estruturais, conceituais e terminológicas dos direitos reais na Inglaterra, dado que não apenas o rei, mas qualquer tenant, em princípio, podia ter suas terras submetidas ao regime jurídico in dominico [=in demesne] ou in servitio, desde que fizesse uma concessão de parte do seu domínio a um ou mais terceiros, reservando para si a outra parte ${ }^{129}$.

O sistema das tenures foi, ao longo dos séculos, perdendo a sua força. Já no século XIII os services tinham, em larga medida, sido suplantados por contraprestações pecuniárias $^{130}$. A complicada massa de tenures feudais foi transformada em socage tenure

MAITLAND, The History of English Law cit., vol. I (nota 12 supra), p. 237: "What has been said of the demesne tenant's immediate lord, may be said also of that lord's lord; he also has rights in the land and the land is in some sort his".

Conforme explica o autor, essa noção fica mais evidente ao se discutir a possibilidade de o mesmo tenant (que é ao mesmo tempo senhor de outro tenant) ser demandado em relação a um terreno tido em parte para uso próprio (in dominico ou demesne) e em parte para uso de outro tenant (in servitio). Assim, em Bracton f. $432 \mathrm{~b}$ : "Item cum petens totum petat in dominico, tenens respondere potest et cognoscere quod totum non tenet in dominico, sed partim in dominico et partim in servitio" (Da mesma forma, dado que o demandante pede tudo <a título de > dominicum, o tenant pode responder e reconhecer que não tem tudo in dominico, mas $<$ que tem $>$ parte in dominico e parte in servitio). A énfase aqui é no fato de que o tenant "tem" (...non tenet...sed...) tanto as terras in demesne quanto as in service (...in dominico...in servitio).

Isso também ocorria em relação à posse a título de concessão feudal (seisin) da terra, que podia permanecer com o senhor mesmo que seu tenant detivesse o terreno a título de services, cf. Bracton f. 81 (referente ao writ que o senhor podia impetrar caso fosse repudiado pelo seu tenant): "Si autem per breve de recto ut quidam dicunt, videtur quod non possit, sive nisi ipse vel antecessores sui in seisina fuerint de tenemento illo in dominico vel servitio" (Se, porém, <o tenant for demandado> mediante um breve de recto, como dizem alguns, parece que $<$ o senhor $>$ não possa $<$ fazê-lo $>$, a menos que ele mesmo ou os seus antecessores tenham estado na posse a título de concessão feudal daquele tenementum <seja a título de $>$ demesne ou $<$ a título de $>$ servitio).

A mesma possibilidade é reafirmada ao se discutir a situação do menor de idade órfão diante do ajuizamento de um breve de warantia - destinado a conferir efetividade à obrigação do senhor de defender a posse do seu tenant ou entregar-lhe terras equivalentes caso as perdesse, cf. D. M. WALKER, The Oxford Companion cit. (nota 8 supra), p. 1291 (no verbete "warranty") -, cf. Bracton, f. 392: "Item cum minor non teneatur de aliquot respondere de quo pater vel mater vel alius antecessor obiit seisitus ut de feodo in dominico vel in servitio ante plenam atatem (...)" (Da mesma forma, dado que o menor < de idade> não é obrigado a responder antes da maioridade acerca daquilo em cuja posse a título de concessão feudal o pai ou a mãe ou outro antecessor morreu, <seja> in dominico ou in servitio (...)). À margem do regime de garantia da concessão feudal, o que chama a atenção da doutrina é que nas próprias fontes o senhor pudesse ser titular tanto das terras in dominico quanto daquelas in servitio.

${ }^{129}$ Cf. F. Pollock e F. W. Maitland, The History of English Law cit., vol. I (nota 12 supra), p. 237: "This, when regarded from the standpoint of modern jurisprudence, is perhaps the most remarkable characteristic of feudalism: several different persons, in somewhat different senses, may be said to have and to hold the same piece of land".

${ }^{130} \mathrm{Um}$ dos principais expoentes do declínio das tenures é a evolução do knight's service. De acordo com T. F. T. PluCKNETT, A Concise History cit. (nota 12 supra), pp. 531-533, a transformação dessa tenure pode ser dividida em três estágios. Num primeiro momento (1066-1166 aprox.) a instituição estava em pleno vigor, e os tenants in chief prestavam pessoalmente o serviço militar devido ao rei. Numa segunda etapa (1166-1266 aprox.) os tenants in chief passaram a abonar a sua ausência mediante o pagamento ao rei de valor pecuniário denominado scutage [="scutagium"], com o qual o monarca contratava mercenários que substituíssem os tenants in chief. Já num terceiro estágio (1266-1660 aprox.), os military services passaram a ser um anacronismo destinado a abastecer os cofres reais, especialmente em função dos incidents relativos à wardship, primer seisin e relief, cf. Bl Comm 2, 5, 67 e Bl Comm 2, 5, 76 [=W. BlaCKSTONE, Commentaries cit., vol. II (nota 10 supra), pp. 67 e 76]. As demais tenancies, embora fossem menos nobres, sofreram uma evolução similar, marcada pela transformação de serviços em contraprestações pecuniárias. 
pelo Tenures Abolition Act $1660^{131}$, restando, a partir de então, apenas duas categorias de tenures na Inglaterra: freeholds e copyholds ${ }^{132}$. O Law of Property Act $1922^{133}$, por fim, converteu os copyholds em freeholds, com o qual todas as terras passaram à categoria de free and common socage, a denominação moderna para a freehold tenure ${ }^{134}$.

No entanto, essa noção de titularidade difusa gerou a concepção, do ponto de vista estrutural, dos direitos reais não como controle direto do titular sobre a própria coisa, mas como a titularidade de um ius sobre essa coisa, o qual pode ser mais ou menos amplo, especialmente em relação à sua extensão temporal. É nessa idéia mais difusa e multifacetária de property que se funda a doctrine of estates ${ }^{135}$. Pode-se perceber, inclusive, que o surgimento e desenvolvimento dos uses, e depois dos trusts, esteve em muitos aspectos vinculado à possibilidade de desmembramento do dominium e à atribuição de titularidades e faculdades específicas a pessoas distintas ${ }^{136}$.

\subsubsection{O elemento material da concessão feudal: seisin}

Outro elemento característico da estrutura feudal da real property law inglesa é a $\operatorname{seisin}^{137}$. Ela reflete a orientação empírica do direito inglês na sua época de formação e sua

${ }^{131}$ Cf. Stat. 12 Char. II (1660), c. 24, s. 4: "And that all tenures hereafter to be created by the Kings Majestie his Heires or Successors upon any gifts or grants of any Mannours Lands Tenements or Hereditaments of any Estate of Inheritance at the common law shall be in free and common Soccage, and shall be adjudged to be in free and common Soccage onely, and not by Knight service or in Capite, and shall be discharged of all Wardship value and forfeiture of Marriage Livery Primer-Seizin Ouster le main Aide pur faier fitz Chivalier \& pur file marrier, Any Law Statute or reservation to the contrary thereof any wise notwithstanding". A única exceção foi a frankalmoin, que, no entanto, tornou-se obsoleta, cf. R. MEGARRY e W. WADE, The Law of Real Property cit. (nota 1 supra), p. 30 e acabou sendo abolida pelo Administration of Estates Act 1925 [=Stat. 15 \& 16 Geo. V (1925), c. 23], sch. 2, pt. 1.

${ }^{132}$ Cf. capítulo 2.3.1 infra.

${ }^{133}$ Cf. Stat. 12 \& 13 Geo. V (1922), c. 16, s. 128: "As from the commencement of this Act, every parcel of copyhold land shall, by virtue of this Act be enfranchised and cease to be of copyhold or customary tenure, and land so enfranchised is in this Act referred to as enfranchised land" e sch. 12, (1) (a): "The following provisions shall, from and after the commencement of this Act, apply with respect to the enfranchised land: (a) The land shall be freehold land and be free from liability for forfeiture for the conveyance or attempted conveyance of an estate of freehold in the land, or for alienation without licence, whether by way of sale lease, mortgage or otherwise". No texto, a palavra enfranchised tem o sentido de "livre dos ônus feudais", cf. D. M. WALKER, The Oxford Companion cit. (nota 8 supra), p. 402 (no verbete "enfranchise").

${ }_{134}$ Cf. R. Megarry e W. WADE, The Law of Real Property cit. (nota 1 supra), p. 31.

${ }^{135}$ Cf. capítulo 2.2.4 infra.

${ }^{136} \mathrm{Cf}$. capítulo 3.1 infra.

${ }^{137} \mathrm{O}$ termo seisin provém do vocábulo saisine (mais especificamente do provençal sazina), que surgiu no francês do século XIII para fazer referência ao fato da posse, cf. J. A. SIMPSON e E. S. C. WEINER (coord.), OED 14 (1989), p. 894 (no verbete "saisin"). Embora, de acordo com J. WILLIAMS, The Seisin of Freehold, London, Chancery Lane, 1878, pp. 2-3, a palavra seisin tenha parentesco com o verbo seize, cujo significado pode significar "tomar pela força", "arrebatar" ou "confiscar", cf. J. A. SIMPSON e E. S. C. WEINER (coord.), OED 14 (1989), pp. 896-897 (no verbete "seize"), e o termo inicialmente se aplicasse inclusive à posse de coisa móvel furtada, cf. F. W. MAITLAND, The Seisin of Chattels, in H. A. L. FISHER, The Collected Papers of Frederic 
preferência, em relação à atribuição de direitos sobre bens imóveis, por uma construção jurídica cujo ponto de partida era o fato material da posse, e não um título abstrato ou documental $^{138}$.

Uma análise baseada nas fontes acerca das origens desse instituto, mesmo que perfunctória, ajuda a explicar a relação histórica entre possession e ownership, relação que até hoje tem capturado a atenção da doutrina comparatística contemporânea ${ }^{139}$, a qual, apesar de sempre mencionar a origem feudal do fenômeno, até hoje não tem se empenhado em efetivamente consultar as fontes medievais inglesas para desvendá-lo ${ }^{140}$.

Na Inglaterra do século XIII o termo seisin era utilizado, principalmente, como sinônimo do vocábulo possessio ${ }^{141}$, muito embora já apareça em Bracton com um sentido particular ao mundo medieval ${ }^{142}$ inglês, ou seja, o de articular as relações feudais de suserania

William Maitland, vol. I, Cambridge, Cambridge University, 1911, pp. 333-335, o sentido consagrado na doutrina é justamente o oposto, ou seja, peace and quiet, cf. R. MEGARRY e W. WADE, The Law of Real Property cit. (nota 1 supra), p. 44.

${ }^{138}$ Cf. K. GRAY e S. F. GRAY, Elements of Land Law cit. (nota 1 supra), p. 151.

139 Cf. L. Moccia, Il modello inglese cit. (nota 1 supra), pp. 60-72. Mesmo admitindo uma recente relativização da distinção entre posse e propriedade na tradição civilística, o autor ressalta o rapporto di connessione entre ownership e possession no direito inglês à par de un rapporto di opposizione entre posse e propriedade no direito civil.

A relação íntima entre posse e título no direito inglês estaria ligada à seisin medieval e sua relação com os remédios postos a disposição do possuidor, na medida em que o common law nunca desenvolveu qualquer procedimento para a reivindicação da propriedade pura e simples. É elucidativo, a respeito do tema, observar que os autores ingleses, ao tratar do tema, fazem sempre alusão ao aspecto processual da questão, cf. F. POLLOCK e R. S. Wright, An Essay on Possession in the Common Law, Oxford, Clarendon, 1888, p. 5: "The Common Law never had any adequate process in the case of land, or any process at all in the case of goods, for the vindication of ownership pure and simple. So feeble and precarious was property without possession, or rather without possessory remedies, in the eyes of medieval lawyers, that Possession largely usurped not only the substance but the name of Property (...)" e W. S. HoLDSWORTH, A History of English Law cit., vol. III (nota 12 supra), p. 89: "(...) the common law has not, and never has had, any theory of ownership like that of the Roman law. It had no action like the Roman 'vindicatio', which protected an abstract form of 'dominium'. The writ of right simply decided the question of better right to possession as between the demandant and the tenant".

${ }^{140}$ Referimo-nos especificamente à literatura comparatística privatística mais recente, que parece derivar suas noções mais abrangentes acerca da natureza do sistema de direitos reais no common law da análise quase exclusiva de tratados mais modernos sobre o tema, ou, na melhor das hipóteses, na case law inglesa. Há uma dimensão de fontes medievais históricas sobre o assunto, essencial para a compreensão do direito inglês, que parece ter sido negligenciada por essa mesma literatura, tal como S. VAN ERP, Comparative Property Law cit. (nota 1 supra), pp. 1043-1070; L. MocCIA, Il modello inglese cit. (nota 1 supra), pp. 35-145; J. GORDLEY, Foundations of Private Law cit. (nota 1 supra), pp. 49-65, apenas como exemplos. É essa dimensão que pretendemos apresentar, mesmo que de forma sucinta, neste trabalho.

${ }^{141}$ Cf. K. E. GÜTERBOCK, Henricus de Bracton cit. (nota 1 supra), p. 90; F. W. MAITlAND, The Seisin of Chattels cit. (nota 137 supra), p. 330. Nesse sentido, a equiparação já aparece em Bracton f. 38b: “(...) numquam erit perfecta donatio antequam donatarius plenam habuerit possessionem, sive seisinam (...) Sed quoniam possessio sive seisina multiplex est, imprimis videndum erit qua sit possessio et qualiter dividatur" ((...) nunca será perfeita a doação antes que o donatário tenha plena posse, ou seisin (...) Mas dado que a posse ou seisin é <de> múltiples <espécies> em primeiro lugar dever-se-á ver o que seja a posse de cómo se divide).

${ }^{142}$ Cabe lembrar que, mesmo no âmbito do direito feudal continental, seisin significava a posse material da terra por aquele que efetivamente a ocupava, cujo direito se fortalecia com ao longo do tempo, cf. D. M. WALKER, The Oxford Companion cit. (nota 8 supra), p. 1127 (no verbete "seisin"). 
e vassalagem pelas quais se constituíam os direitos reais sobre a terra ${ }^{143}$, especialmente no plano processual $^{144}$.

De fato, muitas das classificações ${ }^{145}$ da posse que constam nas principais fontes inglesas da época e suas consequências jurídicas se articulam com a própria gradação das tenures sobre bens imóveis no direito inglês medieval desse período ${ }^{146}$.

143 Essa articulação encontra ressonância, inclusive, na distinção entre a possessio iusta e a possessio iniusta, que ocorre em Bracton f. 195b: "Item rem alienam potest quis iuste possidere, ut si quis ex aliqua causa adquisitionis iuste, sicut ex causa donationis vel venditionis, fuerit in seisina per non dominum, iuste possidet et iniuste sed tamen secundum diversos respectus. Iuste quantum ad feoffatorem suum et alios omnes qui ius non habent, iniuste tamen quantum ad ipsum qui ius habet, scilicet verum dominum" (Da mesma forma, alguém pode ter a posse justa de uma coisa alheia, como quando alguém, em razão de alguma causa de aquisição, tal como uma doação ou venda, tenha sido imitido na posse justa por quem não é o dono, <em cujo caso o possuidor $>$ tem tanto uma posse justa quanto injusta, porém segundo aspectos diversos. $<$ A posse é $>$ justa quanto ao seu concedente <não dono $>$ e todos os demais que não têm um direito <sobre essa coisa>; <a posse é> injusta, porém, quanto àquele que tem um direito <sobre essa coisa >, tal como o verdadero dono).

O fragmento em questão trata da venda a non domino não da terra em si, mas de um ius sobre a terra, nos moldes de uma concessão feudal, e define a posse justa não como um conceito fixo, mas como uma categoria dependente da titularidade de uma concessão feudal da parte contrária, conforme se depreende da distinção entre o feoffator (aquele que realizou a concessão) e o dominus (o verdadeiro titular da concessão). Neste ponto, discordamos da opinião de K. E. GÜTERBOCK, Henricus de Bracton cit. (nota 1 supra), p. 92, para quem a distinção entre possessio iusta et iniusta depende exclusivamente do ius possidendi.

${ }_{144}$ Assim, como se pode perceber em Bracton f. 263b-264 (cf. nota 127 supra), a seisin ou possessio é utilizada como elemento caracterizador da titularidade da concessão feudal, o que já aparece na própria definição geral, dada em Bracton f. 38b: "Quid sit possessio videndum. Et sciendum quod possessio est corporalis rei detentio, id est corporis et animi cum iuris adminiculo concurrente" (Deve-se ver o que seja a posse. E deve-se saber que a posse é a detenção de uma coisa corpórea, isto é, <a detenção > do corpus e do animus com a concorrência de um suporte jurídico).

Um caso que ilustra bem a dificuldade, e ao mesmo tempo a importância, de estabelecer quem de fato estava "seised", ou seja, na posse em função de uma concessão feudal, pode ser visto em Nereford v Walter Son of Humphrey (1200-1201), in J. H. BAKER e S. F. C. MILSOM, Sources of English History cit. (nota 9 supra), p. 2: o autor da demanda (Peter) exige do réu (Walter) o fornecimento dos knight services contratados entre os pais do autor (Geoffrey) e do réu (Humphrey). O réu alegou ter sido esbulhado (disseised) do referido imóvel pelo fato de o autor não ter prestado a homagium (homage) nem fornecido os seus services ao conde de Clare, de quem o autor detinha as referidas terras, e que por isso ele (o réu) não devia quaisquer services. O autor alegou não ter perdido ainda a posse em função da concessão feudal (seisin) do imóvel e que, portanto, o réu também ainda a detinha. O réu fez homagium (homage) e forneceu os services devidos. A particularidade do caso reside em que o subtenant (Walter) ainda estava na posse a título de concessão feudal (seised) apesar de ter sido esbulhado, porque o seu senhor imediato (Geoffrey) também o estava. O esbulho foi provocado pelo senhor mediato do réu (Conde de Clare), pelo inadimplemento dos serviços e a não prestação da homagium devidos pelo autor (Geoffrey), porém não impediu que o réu prestasse homagium e pagasse o relief [=relevium] ao seu senhor imediato, pois ambos ainda estavam, formalmente, na posse a título de concessão feudal (seised).

${ }^{145}$ Para uma exposição simplificada das classificações da possessio em Bracton (especialmente aquelas externas à gradação em função das concessões feudais), cf. A. M. BuRRILl, A New Law Dictionary cit., vol. II (nota 13 supra), pp. 810-811 (no verbete "possessio").

${ }^{146}$ Cf. K. E. GütERBOCK, Henricus de Bracton cit. (nota 1 supra), pp. 99-100. O autor apresenta uma gradação que se baseia em Bracton f. 39, Bracton f. 160, Bracton f. 206b e Bracton f. 372b: (i) possessio quae minimum habet possessionis et omnino nihil iuris, neque aliquam iuris scintillam, nuda pedis positio (daquele que toma posse ilicitamente de uma haereditas iacens ou da vacua possessio); (ii) a posse com parum possessionis et nihil iuris (no caso da posse violenta, clandestina ou precária); (iii) a posse com aliquid possessionis et nihil iuris (do titular de uma concessão feudal por período determinado de anos [=tenant for years], entre outros); (iv) a posse com multum possessionis et nihil iuris (no caso da concessão feudal ao homem livre durante sua vida [=freehold for life]); (v) a posse com plus possessionis et multum iuris (na hipótese da concessão feudal hereditária [=fee to a man and his heirs]); (vi) plurimum possessionis et plurimum iuris, o que caracterizava a coniunctio seisinae cum iure (no caso do titular de uma concessão feudal que tinha a posse e também podia provar seu título). 
Dada a necessidade de articular essas relações jurídicas complexas, muitas vezes vinculadas aos termos de concessões de terras e pactos vassálicos realizados na época da Conquista, as principais fontes do século XIII distinguem, formalmente, entre seisin e possessio, de um lado, e proprietas, do outro ${ }^{147}$, porém esta sempre entendida no contexto das concessões feudais na Inglaterra ${ }^{148}$.

$\mathrm{O}$ ponto de divergência em relação à concepção civilística da posse está, justamente, nas diversas correlações entre posse e direito, cf. A. M. BuRRILl, A New Law Dictionary cit., vol. I (nota 13 supra), p. 811 (no verbete "possession"). Sobre as classificações da possessio no direito inglês do século XIII e sua relação com os writs, cf. J. REEVES, History of the English Law cit., vol. II (nota 12 supra), pp. 113-115.

${ }^{147}$ No continente, o vocábulo proprietas e seus derivados eram normalmente utilizados, mesmo na Idade Média, para referir-se ao allodium, mas também significavam os bens recebidos em função de herança, o que já é mais próximo do sentido encontrado nas fontes inglesas, cf. C. F. DU CANGE, Glossarium cit. (nota 13 supra), t. 7, col. 448c (no verbete "proprietates"): "Alodia, patrimonia, bona qua ex successione parentum alicui obveniunt". Como na Inglaterra não existia o allodium fora da esfera proprietária da Coroa, o direito mais amplo que alguém podia ter era o feodum simplex, que era aquele "which a person holds inheritable to him and his heirs forever", cf. A. M. BURRILL, A New Law Dictionary cit., vol. I (nota 13 supra), p. 476 (no verbete "fee simple").

148 Pode-se ver a distinção, de natureza eminentemente processual, em Bracton f. 113b: "Item incidit quandoque quastio proprietatis in actionem intentatam super ipsa possessione, si possessorium intentetur causa recuperanda possessionis, sicut in assisa nova disseisina, vel adispicenda possessionis, sicut in assisa mortis antecessoris. Et quo casu simul quandoque intentatur proprietas cum petitorio iudicio quoad cognitionem possessionis et non quoad pronuntiationem super proprietate. Et sapius inquirendum erit de ipsa proprietate ut de possessione magis constare possit, et sic nihil commune habet possessio cum proprietate quoad pronuntiationem, licet quoad cognitionem" (Da mesma forma, às vezes incide a questão da propriedade numa ação intentada com base na própria posse, caso seja intentado o <interdito> possessório para a recuperação da posse, tal como na assisa nova disseisince, ou para a aquisição da posse, como na assisa mortis antecessoris. E nesse caso às vezes intenta-se simultaneamente <à ação possesória outra ação para o conhecimento da> propriedade com um juízo petitório no que diz respeito ao reconhecimento da posse e não no que diz respeito à <prolação de uma> sentença sobre a propriedade. E com maior frequência dever-se-á inquirir acerca da mesma propriedade para que se possa conhecer mais acerca da posse; e, assim, nada em comum tem a posse com a propriedade no que diz respeito à sentença, <mas> se permite <dizer que o tenha> no que diz respeito ao conhecimento).

O vocábulo proprietas, neste fragmento, não significa controle absoluto sobre a coisa, e sim a titularidade de um ius sobre a coisa, conforme a gradação feudal dos direitos reais sobre bens imóveis, cf. K. E. GÜTERBOCK, Henricus de Bracton cit. (nota 1 supra), pp. 86-88. O uso desse termo, portanto, não deve ser confundido com a propriedade civilística. A palavra pronuntiatio tem o sentido de sentença judicial, cf. A. M. BURRILL, A New Law Dictionary cit., vol. II (nota 13 supra), p. 835 (no verbete "pronunciatio"). O fragmento Bracton f. 113b baseiase diretamente em Ulp. 70 ad ed., D. 41, 2, 12, 1: "Nihil commune habet proprietas cum possessione: et ideo non denegatur ei interdictum uti possidetis, qui coepit rem vindicare: non enim videtur possessioni renuntiasse, qui rem vindicavit" (Nada em comum tem a posse com a propriedade. E por esse motivo não se denega o interdito uti possidetis àquele que começou a reivindicar a coisa, pois não parece ter renunciado à posse quem reivindicou a coisa).

De acordo com F. W. MAITLAnd, The Mystery of Seisin, in H. A. L. FiSHER, The Collected Papers of Frederic William Maitland, vol. I, Cambridge, Cambridge University, 1911, p. 359, a distinção entre as noções de possession e ownership (tal como era compreendida na Inglaterra medieval) seria tanto mais evidente quanto mais próximo se estiver da época de Bracton. Pode-se ver, no entanto, que mesmo no século XIII essa distinção não era tão clara, dada a articulação da posse com os diversos tipos de tenures.

O fragmento Bracton f. $113 \mathrm{~b}$ representa, a bem da verdade, uma das grandes diferenças entre o direito inglês medieval e o direito romano, no sentido de que este não permitia que se conhecesse da questão relativa à propriedade em sede de interdito possessório, enquanto no common law, já desde o século XIII, isso era possível, cf. W. W. BuCKLAND e A. D. MCNAIR, Roman Law and Common Law cit. (nota 1 supra), p. 65. 
O sentido mais básico de seisin, portanto, nos primórdios do common law, era o de "posse de uma coisa"149, da qual derivava um direito extensível no tempo sobre ela ${ }^{150}$. Foi adotada, inicialmente, para designar a posse das terras em virtude de qualquer tipo de concessão feudal. Assim, tanto o freeholder quanto o leaseholder tinham seisin, muito embora posteriormente ela ficasse restrita à posse do freeholder [=libere tenente ${ }^{151}$ ], ou seja, do homem livre e, portanto, considerado capaz de ser titular de uma concessão feudal ${ }^{152}$.

Apesar da natureza marcadamente feudal do common law na sua fase de estruturação, a caracterização da seisin-possessio nas fontes inglesas foi, em muitos aspectos, influenciada pelo contato com fontes romanas ${ }^{153}$.

${ }^{149}$ Cf. F. POllock e F. W. MaItLAnd, The History of English Law cit., vol. II (nota 12 supra), p. 30.

Cabe ressaltar que A. M. BuRrILl, A New Law Dictionary cit., vol. II (nota 13 supra), p. 811 (no verbete "possessio"") deriva esse sentido da idéia expressa em Paul. 54 ad ed., D. 41, 2, 1 pr.: "Possessio appellata est, ut et Labeo ait, a sedibus quasi positio, quia naturaliter tenetur ab eo qui ei insistit (...)" (Denominou-se possessio, como também diz Labeão, <a posse > de uma sede tomada como posição, porque naturalmente é tida por aquele que nela se mantém (...)). O autor explica que a terminologia adotada no direito inglês baseia-se na expressão quasi pedum positio - que aparece na Vulgata de Bolonha, cf. I. GARCíA DEL CORRAL, Cuerpo del Derecho Civil Romano, vol. III, Barcelona, Jaime Molinas, 1897, p. 319, nt. 6 -, ou seja, na “colocação dos pés", o que teria dado preeminência à prática de um ato material de imissão na posse como elemento caracterizador da seisin. De acordo com A. M. BURRILL, apesar da influência desse entendimento na doutrina e a jurisprudência inglesas, a expressão verdadeiramente representativa desse instituto seria ponere sedem, cujo significado é "fixar o lugar de moradia ou residência", e não a mera prática de um ato de apreensão material.

${ }^{150} \mathrm{O}$ que, a nosso ver, se depreende claramente do uso em Bracton da palavra saisina para referir-se à posse animo tantum, ou seja, àquela posse de quem não tem a apreensão material da coisa, mas recebeu a concessão feudal mediante livery of seisin.

${ }^{151}$ Cf. C. F. Du CANGE, Glossarium cit. (nota 13 supra), t. 8, col. 058b (no verbete "tenentes libere”): "Qui liberum tenementum tenent vel possident". O termo correspondente em inglês é freeholder, que, conforme veremos em maior detalhe, no direito inglês designa uma espécie de concessionário feudal, i.e., aquele que é titular de um freehold estate, cf. A. M. BURRILl, A New Law Dictionary cit., vol. I (nota 13 supra), p. 521 (no verbete "freeholder").

Cabe destacar que, já no século XIII, uma concessão de terras sujeita a esse regime tornava um villein num homem livre, cf. Bracton f. 24b: "Item si in carta contineatur etiam sine manumissione expressa, 'habendum et tenendum libere, quiete et pacifice, sibi et heredibus suis', licet homagium non intervenerit, innuitur per huiusmodi verba et vehementer prasumitur quod donator voluit eum esse liberum cui donatum est" (Da mesma forma, <a concessão é válida > se a carta <de concessão > contiver <a cláusula>, mesmo sem manumissão expressa, "para que $<$ o concessionário $>$ tenha e detenha $<$ a terra $>$ livre, mansa e pacificamente, para si e para os seus herdeiros", embora a homagium não tenha sido prestada, fica implícito por essa espécie de palavras e presume-se veementemente que o concedente quis que o concessionário fosse livre).

${ }^{152}$ Cf. J. Williams, The Seisin of Freehold cit. (nota 137 supra), p. 4. Assim, em Bracton f. 326: "Inter cetera in fine notandum quod cum quis firmarius petierit seisinam propriam, hoc facere poterit etsi non habuerit ius in re sive in tenemento (...)" (Entre outras coisas, finalmente deve-se notar que caso um firmarius peça sua própria seisin, poderá fazê-lo mesmo que não tenha tido um direito à coisa ou ao tenementum). Pode-se ver claramente no fragmento que o firmarius [=leaseholder], cf. A. M. BuRRILL, A New Law Dictionary cit., vol. I (nota 13 supra), p. 495 (no verbete "firmarius"), que no século XV já não se considera que tenha seisin, pode, em razão da concepção ampla de seisin no século XIII, pedir a posse da coisa submetida a esse regime jurídico de detenção.

${ }^{153}$ Essa influência resulta evidente ao se comparar certos fragmentos de Bracton com fontes romanas. Assim, por exemplo, em Bracton f. 41b, acerca da aquisição da posse: "Et sciendum quod animo et corpore simul adquiritur possessio, et non corpore per se nec animo per se (...)" (E deve-se saber que a posse se adquire pela concorrência do animus e o corpus, e não somente pelo corpus ou pelo animus), que segue a regra inscrita em Paul. 54 ad. ed., D. 41, 2, 3, 1: "Et apiscimur possessionem corpore et animo, neque per se animo aut per se corpore (...)" (E alcançamos a posse <das coisas $>$ pelo corpus e pelo animus, e não pelo animus <sem o corpus $>$ 
Já ao longo do século XV ocorreu uma diferenciação terminológica. De um lado, seisin passou a referiri-se à posse do freeholder exclusivamente; do outro, possessio (possession) passou a aplicar-se somente à posse dos bens móveis (chattels) ${ }^{154}$. Em outras

ou pelo corpus <sem o animus> (...)); Bracton f. 38b-39, quanto à perda da posse: “(...) et sicut non potest possessio nisi animo et corpore adquiri, sic non potest nisi utroque amitti, et cum utroque adquiratur licet corpore amittatur, animo solo poterit retineri" ((...) e tal como não se pode adquirir a posse salvo pelo animus e o corpus, assim também não pode ser perdida a menos que ambas <estejam ausentes $>$, e embora seja adquirida por ambos <esses elementos $>$, é permitido que se perca corpore, <em cujo caso > poderá ser ser retida <a posse > pelo animus <sem o corpus>), que segue a mesma lógica de Paul. 65 ad ed., D. 41, 2, 8: "Quemadmodum nulla possessio adquiri nisi animo et corpore potest, ita nulla amittitur, nisi in qua utrumque in contrarium actum est", (Da mesma forma em que não se pode adquirir qualquer posse salvo pelo animus e o corpus, da mesma forma nenhuma <posse> pode-se perder, salvo aquela na qual se agiu contra ambas); Bracton f. $375 b$, acerca das pessoas que não podem ser possuidoras: "Tales enim cum animum non habuerint adquirendi in tali statu adquirere non poterunt seisinam" (Tais <pessoas>, evidentemente, dado que não têm animus adquirendi, em tal estado não poderão adquirir a posse), baseado em Paul. 54 ad. ed., D. 41, 2, 1, 3: "Furiosus, et pupillus sine tutoris auctoritate, non potest incipere possidere, quia affectionem tenendi non habent (...)" (O furioso e o pupilo não podem começar a possuir sem a autorização do tutor, porque não têm affectio tenendi (...)); Bracton f. 40, acerca da traditio ou livery of seisin: “(...) et ubi non est necesse omnes glebas circu[m]ire, nec ubique nec undique pedem ponere, fieri debet traditio per ostium et per haspam vel per anulum, et sic erit in possessione de toto ex (...)" ((...) e onde não é necessário caminhar em torno de todas as glebas, nem pôr os pés em todo e por todo lugar, a traditio deve ser feita pela entrada <da casa $>$ e pela aspa ou o anel, e assim entrará <o tenant $>$ na posse do todo (...)), inspirado em Paul. 54 ad. ed., D. 41, 2, 3, 1: “(...) Quod autem diximus et corpore et animo adquirere nos debere possessionem, non utique ita accipiendum est, ut qui fundum possidere velit, omnes glebas circumambulet: sed sufficit quamlibet partem eius fundi introire, dum mente et cogitatione hac sit, uti totum fundum usque ad terminum velit possidere" (Porém, aquilo que dissemos, < no sentido de $>$ que nós devemos adquirir a posse tanto pelo corpus quanto pelo animus, não deve sempre ser entendido de tal forma que quem queira possuir um imóvel dê uma volta por todas as glebas; mas <deve-se entender no sentido de> que é suficiente que entre na parte que quiser desse imóvel, desde que seja com a intenção e o propósito de que queira possuir todo o imóvel até o término <da sua extensão>); Bracton f. 44, acerca da traditio symbolica: "Item si claves cellula, vivaria, vel horreorum tradiderit quis domino vel procuratori, vina et merces tradi videntur (...)" (Da mesma forma, caso alguém entregue a chave de uma adega, de um viveiro ou de um celeiro ao dono ou ao <seu> representante, os vinhos e as mercadorias consideram-se entregues), baseado em Paul. 54 ad ed., D. 41, 2, 1, 21: “(...) et vina tradita videri, cum claves cellae vinariae emptori traditae fuerint” ((...) e se consideram entregues os vinhos quando tenham sido entregadas as chaves da adega de vinhos ao comprador); Bracton f. 41 (acerca da traditio brevi manu): "Et si quod ad vitam vendam tibi in feodo, et sic mutaverim causam possessionis, hoc fieri poterit sine mutatione possessionis. Ex hoc enim quod patior rem meam esse tuam ex alia causa, vel apud te esse, videor tradere" (E caso eu te venda uma concessão feudal pela duração da $<$ tua $>$ vida, e assim altere a <tua> causa possessionis, isto poderá ser feito sem alteração da posse. Por isso, evidentemente, na medida em que tolero que uma coisa minha seja tua em função de outra causa, ou que fique contigo, considera-se que a entreguei), com base em Gai. 2 rer. cott. aur., D. 41, 1, 9, 5: "Interdum etiam sine traditione nuda voluntas domini sufficit ad rem transferendam, veluti si rem, quam commodavi aut locavi tibi aut apud te deposui, vendidero tibi: licet enim ex ea causa tibi eam non tradiderim, eo tamen, quod patior eam ex causa emptionis apud te esse, tuam efficio" (Às vezes também a simples vontade do dono sem a tradição é suficiente para transferir a coisa; como se eu tiver te vendido uma coisa que te <entreguei> a título de comodato ou de locação ou de depósito; pois é permitido que eu não te tenha entregado a coisa em função dessa causa; contudo, pelo fato de que eu tolero que a coisa esteja contigo por causa da venda, a convirto em tua).

Sobre a influència das fontes romanas em Bracton, cf. K. E. GÜTERBOCK, Henricus de Bracton cit. (nota 1 supra), pp. 48-51 e 90-100 e T. E. SCRUTTON, The Influence of the Roman Law cit. (nota 76 supra), pp. 79-121.

${ }^{154}$ Cf. F. W. Maitland, The Mystery of Seisin cit. (nota 148 supra), p. 359 e W. S. HoldSWORTH, A History of English Law cit., vol. II (nota 12 supra), p. 581, nt. 2. Ao que tudo indica, essa distinção remonta ao século XV e já aparece em Litt 324 [=E. WAMBAUGH, Littleton's Tenures - In English cit. (nota 10 supra), p. 152]: "Also, when a man shall show a feoffment made to him, or a gift in tail, or a lease for life of any lands or tenements, there he shall say by force of which feoffment, gift, or lease, he was seised \&c, but when one will plead a lease or grant made to him of a chattel real or personal, there he shall say by force of which he was possessed, \&c". 
palavras, o vocábulo seisin passou a se aplicar apenas à real property, e a palavra possession passou a se identificar com a posse da personal property ${ }^{155}$.

O instituto da seisin, dada a sua ligação com a proteção conferida ao tenant, foi um elemento essencial para o desenvolvimento das doutrinas das tenures e dos estates, bem como para a real property law de modo geral ${ }^{156}$, a tal ponto que, durante o período formativo do common law, a ausência de um conceito claro de propriedade (ownership) estava ligada à tênue proteção conferida a quem não estivesse na seisin do bem em questão ${ }^{157}$.

Assim, no contexto das tenures, não se pode dizer que o tenant tivesse um direito de propriedade (ownership) sobre a terra. O máximo que ele tinha era uma garantia condicionada de seisin, ou seja, a tutela da continuidade de sua posse mansa e pacífica a título de concessão feudal, desde que atendesse aos requisitos dessa mesma concessão ${ }^{158}$. Essa

${ }^{155}$ Cf. H. W. CHALlis, Law of Real Property cit. (nota 1 supra), pp. 98-99.

${ }^{156}$ Embora a seisin fosse um elemento típico dos diretos reais sobre bens imóveis no contexto das concessões feudais, o termo também foi utilizado nas fontes mais antigas para fazer referência à posse sobre bens móveis, cf. F. W. MAITLAND, The Seisin of Chattels cit. (nota 137 supra), pp. 329-357.

157 Cf. F. W. Maitland, The Mystery of Seisin cit. (nota 148 supra), p. 360 e F. Pollock e F. W. MAITLAND, The History of English Law cit., vol. II (nota 12 supra), p. 77.

${ }^{158}$ Cf. T. F. T. PluCKNETT, A Concise History cit. (nota 12 supra), p. 536. Uma importante característica das tenures era que, sob determinadas hipóteses, as respectivas terras eram devolvidas ao senhor (escheated to the lord). As principais aplicações desse princípio ocorriam quando o tenant falecia sem deixar quaisquer herdeiros (escheat propriamente dito) ou quando era condenado à morte por ter cometido um crime capital (forfeiture). O inadimplemento dos services, embora fosse inicialmente considerado um crime (felony), logo deixou de sê-lo. No entanto, o Statute of Gloucester 1278 [=Stat. 6 Edw. I (1278), c. 4] conferiu legitimidade ao senhor para impetrar um writ of cessavit, por meio do qual podia recuperar o terreno (distrain the land) em caso de não prestação dos services (que já naquela época tinham se convertido no pagamento anual de um valor pecuniário), devendo-se lembrar, contudo, que esses services perderam, ao longo do século XII, sua importância econômica diante dos incidents, cf. J. H. BAKER, An Introduction cit. (nota 12 supra), pp. 237-238.

A palavra escheat, de acordo com A. M. BuRrILL, A New Law Dictionary cit., vol. I (nota 13 supra), p. 430 (no verbete "escheat"), provém do latim cado, -is, -ere, cecidi, casum, cujo significado básico é "cair", cf. P. G. W. GLARE (coord.), OLD cit. (nota 13 supra), pp. 247-249 (no verbete "cado, -is, -ere, cecidi, casum"). Ao longo da Idade Média filtrou-se nas várias línguas romances e adquiriu vários sentidos, cf. C. F. DU CANGE, Glossarium cit. (nota 13 supra), t. 3, col. 294a (no verbete "escaeta”): “Eschaeta', 'escheta', 'escheuta', 'excaeta', 'escadentia', 'escasura'. Adde 'escaanchia', 'escaauntia', 'escaducha', 'escaduta', 'escaementum', 'escahentia', 'excadentice' et 'excaducum', qua voces suis locis videnda sunt. Horum vocabulorum non una semper, sed varia et diversa est significatio. Nam interdum, et ut plurimum, sic appellantur bona, pradia, immobilia vel mobilia quavis, qua ex delicto et forisfactura vassalli vel alio quolibet casu cadunt in fiscum Domini feudi".

O equivalente na língua inglesa é escheat, que, de acordo com A. M. BURRILL, pode ser dividido em dois tipos: (i) propter defectum sanguinis, na hipótese de devolução das terras ao senhor em caso de morte do tenant sem deixar herdeiros, e (ii) propter delictum tenentis, em caso de cometimento de crime capital, especialmente traição, em cujo caso é mais comum, nas fontes, encontrar a palavra forfeiture. Acerca do instituto do escheat, cf. também Co Litt 13a $(1,1,4)$ e Co Litt 92b (2, 5, 131) [=E. CoKE, The First Part of the Institutes cit., vol. I (nota 10 supra), s. n.] e Bl Comm 2, 5, 72-73 [=W. BlaCKSTONE, Commentaries cit., vol. II (nota 10 supra), pp. 72-73].

A devolução por forfeiture foi abolida pelo Forfeiture Act 1870 [=Stat. 33 \& 34 Vict. (1870), c. 23], s. 1: "From and after the passing of this Act no confession, verdict, inquest, conviction or judgement of or for any treason (...) shall cause (...) any forfeiture or escheat (...)". O escheat ficou restrito ao âmbito da Coroa (salvo raras exceções) pelo Stat. 15 \& 16 Geo. V (1925), c. 23, s. 45 (1) (d): "With regard to the real estate and personal inheritance of every person dying after the commencement of this Act, there shall be abolished: (...) (d) 
relatividade da situação jurídica do tenant decorria, em larga medida, da própria gradação das actions que tutelavam as diversas pretensões e sua correspondência com a antiguidade e a qualidade da $\operatorname{seisin}^{159}$.

Daí o uso recorrente, especialmente em Bracton, da expressão seisitus ut de feodo para referir-se à concessão hereditária do tenant cuja situação demandava a tutela do common $l a w^{160}$. Seria essa a situação jurídica, dentro da lógica das tenures, que de alguma forma se aproximaria à noção civilística de propriedade, mesmo com as ressalvas feitas em relação à estrutura dos direitos reais de natureza feudal, na medida em que a tutela dos direitos reais estava ligada, num primeiro momento, à seisin da terra em função da concessão feita por um senhor ao seu tenant.

A preponderância do elemento material da concessão feudal, resultado da preferência dos tribunais reais pela proteção não daquele que conseguisse provar o melhor título, mas daquele que, em última análise, demonstrasse ter a melhor posse ${ }^{161}$, encontra-se na

Escheat to the Crown (...) or to a mesne lord for want of heirs" e s. 46 (1) (vi), que estabeleceu uma ordem de vocação hereditária para a sucessão legítima, em cuja falta o estate é devolvido à Coroa: "In default of any person taking na absolute interest under the foregoing provisions, the residuary estate of the intestate shall belong to the Crown (...)". O escheat, portanto, ainda produz efeitos toda vez que um freehold se extingue, pois a possibilidade de devolução é inseparável da idéia de tenure em que se baseia a estrutura dos direitos reais ingleses, ao assegurar que nenhum imóvel fique sem dono, cf. Ho Young v Bess [1995] UKPC: “(...) the law abhors a vacuum and that title to land must always be in someone (...)". Acerca das demais hipóteses específicas de escheat, especialmente na área do direito empresarial, cf. R. MEGARRY e W. WADE, The Law of Real Property cit. (nota 1 supra), pp. 31-33.

${ }^{159}$ Cf. F. POLlOCK e F. W. MAITLAND, The History of English Law cit., vol. II (nota 12 supra), pp. 74-75.

De acordo com esses autores, pode ser estabelecida uma espécie de hierarquia dos writs destinados à tutela dos direitos sobre bens imóveis, conforme a causa de pedir se aproxime mais ou menos da questão relativa a um título de propriedade abstrato ou da posse efetiva da terra. Assim, começando pela base da hierarquia, temos: (i) a assisa novae disseisinae, que é uma ação puramente possessória, sumária e punitiva; (ii) a assisa mortis antecessoris, ação menos sumária e baseada na posse de alguém já falecido; (iii) o breve de ingressu, mais sumário que o breve de recto, pois excluía as hipóteses de dilação de comparecimento do réu mais demoradas (essoins) e o trial by battle, e baseado na contestação pelo autor do título do possuidor-réu, e (iv) o breve de recto, cuja causa de pedir é o título alegado pelo autor. De modo correspondente, a seisin pode ser hierarquizada, principalmente em relação à sua antiguidade: tem a melhor seisin quem puder provar a posse mais antiga, princípio que, dada a sua estreita ligação com o fundamento da pretensão de cada writ, impediu a formação de uma noção absoluta de propriedade (ownership).

${ }^{160} \mathrm{Um}$ dado que evidencia a importância da seisin na configuração da real property law inglesa é a frequência do uso do termo seisitus ut de feodo em Bracton. Assim, a expressão aparece em Bracton f. 103b, Bracton f. 213, Bracton f. 252, Bracton f. 256, Bracton f. 263, Bracton f. 264, Bracton f. 268b, Bracton f. 269, Bracton f. 270, Bracton f. 271, Bracton f. 274b, Bracton f. 275, Bracton f. 275b, Bracton f. 280b, Bracton f. 281, Bracton f. 283, Bracton f. 283b, Bracton f. 285, Bracton f. 309, Bracton f. 310b, Bracton f. 325, Bracton f. 326b, Bracton f. 327b, Bracton f. 345, Bracton f. 347, Bracton f. 373, Bracton f. 376b, Bracton f. 390, Bracton f. 392, Bracton f. 397, Bracton f. 422b, Bracton f. 423, Bracton f. 429, Bracton f. 431b e Bracton f. 433b, sempre em referência à tutela jurisdicional conferida àquele que está na posse do bem a título de concessão feudal (normalmente pelo breve de recto) ou o seu herdeiro (no caso da assisa mortis antecessoris), seja em função da posse direta do terreno com a concorrência da titularidade da concessão feudal, seja apenas pela titularidade da concessão aliada a uma posse indireta.

${ }^{161}$ Uma clara indicação da proponderãncia da seisin como elemento caracterizador da tutela jurisdicional em matéria de direitos reais é o fato de que, até a entrada em vigor do Real Property Act 1845 [=Stat. 8 \& 9 Vic. (1845), c. 106], s. 6, o titular da concessão, caso fosse esbulhado, não podia ceder seu direito à ação de 
raíz daquilo que a doutrina comparatística contemporânea identifica como um dos traços característicos do common law, qual seja, a relativização e gradação do conceito de ownership em função da sua relação com a possession ${ }^{162}$, situação que se verifica mesmo nos dias de hoje $\mathrm{e}^{163}$.

Em contrapartida à concessão da terra, o tenant ficava obrigado, mediante um oath of fealty, ou juramento de fidelidade ${ }^{164}\left[=\right.$ fidelitas $\left.^{165}\right]$, acompanhado da realização de

reintegração de posse (right of entry) a um terceiro, pois não teria como realizar a livery of seisin, a qual exigia a posse efetiva do bem imóvel em questão, cf. R. MEGARRY e W. WADE, The Law of Real Property cit. (nota 1 supra), p. 88, nt. 23.

${ }_{162}$ Cf. L. MocCIA, Il modello inglese cit. (nota 1 supra), pp. 69-70. A despeito dessa relativização, contudo, de acordo com J. GoRDLEY, Foundations of Private Law cit. (nota 1 supra), pp. 49-52, o surgimento da action of ejectment no início do século XVI, destinada a tutelar o direito de um leaseholder sobre um bem imóvel, teria marcado o reconhecimento, pelo common law, do título como fundamento único e exclusivo para o sucesso da ação. O motivo dessa observação é que, na action of ejectment, o tribunal dava ganho de causa à parte que conseguisse provar seu título de leaseholder, independentemente de quem estivesse seised. Assim, afastado o requisito da seisin, o leaseholder adquiria, segundo J. GORDLEY, um direito de propriedade absoluto sobre a coisa. R. MEgARRY e W. WADE, The Law of Real Property cit. (nota 1 supra), pp. 90-92 e 95-97, por outro lado, negam que a action of ejectment conferisse um título de propriedade absoluto sobre a coisa, na medida em que, mesmo no âmbito dessa ação, quem estivesse na posse do imóvel podia opô-la a qualquer terceiro, e após o prazo prescricional de vinte anos estabelecido para a action of ejectment, adquiria o melhor título e nem o antigo leaseholder podia recuperar o imóvel. Nesse sentido, a própria decisão apontada por J. GORDLEY, Asher $v$ Whitlock (1865) LR 1 QB 1, na qual o Queen's Bench entendeu que o herdeiro de um possuidor sem título tem melhor direito (e portanto deve ser imitido na posse do imóvel) do que outro possuidor sem título cuja posse seja posterior no tempo, demonstra que os tribunais, além de discutir a posse na action of ejectment, davam ganho de causa àquele que provasse ter um título derivado da melhor posse.

É nossa opinião que, a bem da verdade, o cerne da questão encontra-se no fato de que, no direito inglês, posse e título podem ser discutidos na mesma ação, o que não ocorre nos sistemas de base romanística. Isso leva a uma fusão conceitual entre posse e propriedade. De um lado, J. GORDLEY tem razão ao afirmar que, na prática, os resultados atingidos pelo common law são similares aos do direito civil; porém, isso não significa o reconhecimento, conceitualmente, de um direito abstrato de propriedade. Tal reconhecimento somente poderia ocorrer mediante a separação, no âmbito processual, das ações destinadas à discussão da posse e aquelas destinadas à discussão da propriedade. Uma verdadeira mudança no conceito de ownership talvez venha a ocorrer - embora seja cedo para fazer qualquer afirmação a respeito - a raíz dos recentes avanços em matéria de registro de bens imóveis, especialmente aqueles relacionados ao Land Registration Act 2002, cf. K. GRAY e S. F. GRAY, Elements of Land Law cit. (nota 1 supra), p. 180.

${ }^{163}$ Cf. R. MEgarry e W. WADE, The Law of Real Property cit. (nota 1 supra), p. 88: "The concept of ownership was never really disentangled from that of possession".

${ }^{164}$ No continente, o juramento de fidelidade [=fidelitas], cujo teor era religioso, surgiu posteriormente à homagium, provavelmente após o período carolíngio, nos séculos IX-X. O juramento estabelecia o dever de fidelidade ao senhor e para realizá-lo o tenant punha a mão sobre os evangelhos ou as relíquias e recitava uma fórmula solene. A fidelitas passou a incorporar o ato solene pelo qual se estabelecia a relação vassálica, mantendo-se, contudo, a supremacia da homagium. Em muitos casos era possível fazer um juramento de fidelidade sem celebrar a homagium, porém não existia homagium sem fidelitas, cf. M. BLOCH, La société féodal cit. (nota 42 supra), pp. 144-145. Na Inglaterra, o oath of fealty impunha o dever de preservar e não prejudicar a integridade física ou moral do senhor, bem como prestar os services devidos, para o qual o tenant colocava a mão direita sobre um livro e recitava uma fórmula solene, cf. D. M. WALKER, The Oxford Companion cit. (nota 8 supra), p. 461 (no verbete "fealty").

É interessante notar, conforme sustenta J. REEVES, History of the English Law cit., vol. I (nota 12 supra), pp. 238-242, que a implantação do regime feudal normando, o qual eliminou as terras alodiais existentes no período anglo-saxão e firmou o título proprietário da Coroa, se deu mediante a promulgação de duas leis que obrigavam todos os vassalos ingleses a praticar um juramento de fidelidade (oath of allegiance). São essas as leis mencionadas em Bl Comm 2, 4, 51-52 [=W. BlaCKSTONE, Commentaries cit., vol. II (nota 10 supra), pp. 51-52] ao se referir ao juramento de fidelidade feito pelos senhores anglo-saxões ao rei Guilherme I, posteriormente intepretadas pelos juristas normandos no sentido de conferir um verdadeiro título de propriedade à Coroa. De 
uma cerimônia denominada homage ${ }^{166}\left[\right.$ homagium $\left.^{167}\right]$ no caso das tenures mais elevadas, a fornecer determinados services ao seu senhor ${ }^{168}$, cuja natureza e conteúdo podiam variar grandemente. As tenures, via de regra, recebiam a denominação do respectivo serviço ${ }^{169}$.

É ilustrativo o tratamento dado à homagium nas fontes jurídicas inglesas ${ }^{170}$, na medida em que a própria terminologia evidencia o aspecto pessoal ${ }^{171}$ e a marcada natureza

acordo com Bl Comm 2, 4, 48-49 [=W. BLACKSTONE, Commentaries cit., vol. II (nota 10 supra), pp. 48-49], a interpretação normanda giraria em torno do sentido da palavra conquisitio, que em latim medieval tem o significado de "compra" ou "aquisição", e não "conquista pelas armas”, já que provém do verbo latino clássico conquiro, -is, -ire, -quisivi, -quisitum, que significa "buscar diligentemente", cf. A. M. BURRILL, A New Law Dictionary cit., vol. I (nota 13 supra), p. 261 (no verbete “conquest”) e P. G. W. GLARE (coord.), OLD cit. (nota 13 supra), p. 410 (no verbete "conquiro, -is, -ire, -quisivi, -quisitum"). Em sentido contrário, opina G. SPENCE, The Equitable Jurisdiction cit., vol. I (nota 12 supra), p. 89 que o que houve foi um confisco (seizure) com mera aparência de legalidade. De qualquer forma, a conclusão é a mesma: a Coroa, seja ex vi et armis, seja pela aquiesência dos súditos ingleses, passou a ser a única titular de um dominium de natureza alodial na Inglaterra.

Ambos os textos podem ser encontrados em B. THORPE e R. PRICE (org.), Ancient Laws and Institutes cit. (nota 8 supra), pp. 211 e 212, bem como no texto do J. REEVES mencionado nesta nota.

${ }^{165}$ Sobre o oath of fealty, especificamente, cf. Bl Comm 1, 10, 367 [=W. BLACKSTONE, Commentaries cit., vol. I (nota 10 supra), p. 367], H. SPELMANNUS, Glossarium cit. (nota 13 supra), pp. 224-227 (no verbete "de fidelitate et fidelitatis sacramentis"): "Fidelitas eft fidei, obfequii, \& fervitii ligamen, quo generaliter fubditus Regi, particulariter vaffallus domino aftringitur". O autor distingue entre o vínculo geral com o rei e o particular com o senhor, cf. A. M. BuRRILl, A New Law Dictionary cit., vol. I (nota 13 supra), pp. 574-575 (no verbete "fealty"). W. BLACKSTONE, no fragmento citado nesta nota, distingue entre o oath of allegiance, devido exclusivamente ao rei, e o oath of fealty, devido ao senhor.

166 Cf. A. M. Burrill, A New Law Dictionary cit., vol. I (nota 13 supra), pp. $574-575$ (nos verbetes "homage" e "homagium"). Também Co Litt 64b (2, 1, 85) [=E. COKE, The First Part of the Institutes cit., vol. I (nota 10 supra), s. n.]: “'Homage' is derived of [a] 'homo'; and it is called homage, because when he doth this service, he saith, 'Jeo deveigne vostre home; I become your man'. And in English homage is called manhood, so as the manhood of his tenants all one". O assunto é tratado em detalhes pelas authorities. Assim, em Bracton $\mathrm{f}$. 77b-84, Fleta 3, 16 [=Fleta seu Commentarius cit. (nota 10 supra), pp. 204-211], Litt 85-90 [=E. WAMBAUGH, Littleton's Tenures - In English cit. (nota 10 supra), p. 39-42].

167 Cf. C. F. DU CANGE, Glossarium cit. (nota 13 supra), t. 4, col. 213c (no verbete "homagium"): "Obsequium, cultus". Também o substantivo hominium tem o sentido de profissão de lealdade e serviço prestado pelo vassalo ao seu senhor, cf. C. F. DU CANGE, Glossarium cit. (nota 13 supra), t. 4, col. 215 b (no verbete "hominium”): “(...) est servitium, seu obsequium, quod homo, seu cliens, vel servus, domino suo prastare tenetur (...) Hominium, seu Homagium, dicta fuit professio illa fidei et obsequii, quam homo, seu vassallus, domino suo feudali prastat ratione feudi, quod ab eo tenet". O autor, inclusive, faz referência a Bracton f. 78b para conceituar o vocábulo em questão.

${ }^{168}$ Cf. H. SpelmanNus, Glossarium cit. (nota 13 supra), pp. 294-297 (no verbete “homagium”). O autor afirma que o dever de prestar services não se estabelece pela homagium, mas pela fidelitas: "In homagio enim praeftando non jurat vaffallus, fed in fidelitate (...)”. A observação é importante, na medida em que as tenures mais humildes não envolviam a celebração da homagium, mas simplesmente da fidelitas, que estabelecia a obrigação de prestar o respectivo serviço em troca da posse da terra.

${ }^{169}$ Assim, por exemplo, se o serviço vinculado a uma tenure fosse knight's service, a própria tenure era chamada tenure by knight's-service. Nesse caso em particular, o tenant ficava obrigado a fornecer um determinado número de cavaleiros armados por quarenta dias ao ano, cf. T. F. T. PLUCKNETT, A Concise History cit. (nota 12 supra), pp. 531-532. Acerca do feodum militis ou militare, cf. nota 176 infra.

${ }^{170}$ A cerimônia da homagium é mencionada abundantemente nas fontes jurídicas inglesas medievais.

Uma das definições mais representativas encontra-se em Bracton f. 78b: "Quid sit homagium? Sciendum [est] quod homagium est iuris vinculum quo quis tenetur et astringitur ad warantizandum, defendendum, et adquietandum tenentem suum in seisina sua versus omnes per certum servitium in donatione nominatum et expressum, et etiam vice versa quo tenens reobligatur et astringitur ad fidem domino suo servandam et servitium debitum faciendum" (O que seja a homagium? Deve-se saber que a homagium é o vínculo jurídico pelo qual alguém é obrigado e adstrito a prestar garantia <pela evicção>, defender e dar quitação < dos serviços prestados> ao seu tenant na sua seisin em face de todos por um serviço certo denominado e expresso em uma doação; e também, recíprocamente, <homagium é o ato> pelo qual o tenant, em contrapartida, é obrigado e adstrito a 
contratual $^{172}$ do ato e, por extensão, das relações que regulavam o uso e gozo das terras e deram origem aos direitos reais na Inglaterra.

manter fidelidade ao seu senhor e prestar o serviço devido). O fragmento é repetido, quase ipsis litteris, em Fleta 3, 16, 8 [=Fleta seu Commentarius cit. (nota 10 supra), p. 205].

No fragmento acima, a palavra warantia refere-se à obrigação, imposta ao senhor, de defender em juízo a posse do tenant em função da titularidade da concessão feudal, ou, caso fosse evicto, de indenizá-lo mediante a entrega de terras do mesmo valor, cf. A. M. BURRILL, A New Law Dictionary cit., vol. II (nota 13 supra), pp. 1056, 1058-1059 (nos verbetes "warantia", "warantus", "warrantizare", "warrantus" e "warranty"), sendo uma espécie de responsabilidade por evicção, cf. C. F. DU CANGE, Glossarium cit. (nota 13 supra), t. 8, col. 403a (no verbete "warantus"): "Qui alteri tenetur ad evictionem".

O tema é tratado em Bracton f. 380b: "Et sciendum quod warantizare nihil aliud est quam defendere et adquietare tenentem qui warantum vocavit in seisina sua (...) Sed cum voluntas tenentis vel iudicium intervenerit, tunc statim et non ante transfertur seisina rei petitce ad petentem, et tenens de re waranti excambium habeat ad valentiam" (E deve-se saber que garantir nada mais é que defender e manter na posse mansa e pacífica o tenant que chamou a juízo <seu senhor> garantidor da sua posse (...) Porém, intervindo a vontade do tenant ou uma sentença judicial, então imediatamente, e não antes, transfere-se a posse da res petita ao demandante, e o tenant terá <direito> à substituição pelo valor da coisa garantida). Em Bracton 380b, excambium significa o dever de substituir as terras perdidas em juízo pelo tenant por outras do mesmo valor, cf. A. M. BURRILl, A New Law Dictionary cit., vol. I (nota 13 supra), p. 449 (no verbete "excambium"). Já em Bracton f. 78b, o verbo acquietare significa impedir que serviços não devidos sejam cobrados do tenant, cf. A. M. BURRILL, A New Law Dictionary cit., vol. I (nota 13 supra), pp. 18-19 (no verbete "acquietare") e C. F. DU CANGE, Glossarium cit. (nota 13 supra), t. 1, col. 059c (no verbete "acquietare"): "Quietum seu securum reddere".

${ }^{171}$ A natureza pessoal de relação entre senhor e tenant já aparece em Glanvill 9, 1 [=R. GLANVILLA, Tractatus de legibus cit. (nota 10 supra), p. 138]: "Fieri autem debet homagium Jub hac forma, fcilicet ut is qui homagium facere debet ita fiat homo Domini fui, quod fidem illi portet de illo tenemento unde homagium fuum praftat, et quod ejus in omnibus terrenum honorem fervet, falva fide debita domino Regi et haredibus fuis" (A homagium deve ser feita sob esta forma, evidentemente, para que aquele que deve fazer a homagium desse modo se faça homem do seu senhor, <para > que lhe deva lealdade acerca daquele tenementum em razão do qual presta sua homagium, e <para $>$ que preserve a honra terrena dele em todas as coisas, ressalvada a lealdade devida ao senhor Rei e aos seus herdeiros).

${ }^{172}$ Note-se a semelhança da construção de Bracton f. $78 \mathrm{~b}$ com a dos principais fragmentos nas fontes romanas que definem a obligatio. Assim, Inst. 3, 13 pr.: "Obligatio est iuris vinculum, quo necessitate adstringimur alicuius solvendae rei, secundum nostrae civitatis iura" (A obrigação é o vínculo jurídico pelo qual nos sujeitamos a adimplir alguma coisa a alguém, segundo o direito da nossa cidade) e Paul. 2 inst., D. 44, 7, 3 pr.: "Obligationum substantia non in eo consistit, ut aliquod corpus nostrum aut servitutem nostram faciat, sed ut alium nobis obstringat ad dandum aliquid vel faciendum vel praestandum" (A substância das obrigações não consiste em que alguma coisa ou alguma servidão se faça nossa, mas em sujeitar alguém a nos dar, fazer ou prestar alguma coisa).

$\mathrm{O}$ uso em Bracton f. $78 \mathrm{~b}$ do verbo adstringo, -is, -ere, -inxi, -ctum, junto à preposição ad seguida da enumeração dos deveres das partes no gerúndio acusativo revela tratar-se da finalidade ou o escopo da obrigação, que no caso é o de prestar garantia pela evicção, defender o tenant em juízo e impedir que lhe sejam cobrados services indevidos. Mesmo que não seja mencionado o bem imóvel na posse do qual o tenant será imitido, o fato de que a homagium, por fazer parte do complexo de atos necessários para que o senhor pudesse conseguir services e incidents em relação às tenures mais elevadas, era sempre celebrada no contexto da concessão feudal de terras, cf. G. SPENCE, The Equitable Jurisdiction cit., vol. I (nota 12 supra), p. 137, fornece evidência suficiente de que as relações entre lords e tenants tinham, pelo menos em parte, natureza contratual, cf. J. H. BAKER, An Introduction cit. (nota 12 supra), p. 225.

A cerimônia e as fórmulas verbais pronunciadas pelo tenant e o senhor encontram-se descritas em Bracton f. 80: "Et sic debet homagium ei facere: debet quidem tenens manus suas utrasque ponere inter utrasque manus domini sui, per quod significatur ex parte domini protectio, defensio et warantia, ex parte tenentis, subiectio et reverentia. Et dicere debet haec verba: 'Devenio homo vester de tenemento quod de vobis teneo', vel aliter, 'quod de vobis tenere debeo, et fidem vobis portabo de vita et membris de terreno honore', secundum quosdam, vel aliter secundum alios, "de corpore et catallis et terreno honore, et fidem vobis portabo contra omnes gentes, quae vivere poterunt et mori', secundum quosdam, 'salva fide debita domino regi et heredibus suis'. Et statim post faciat domino suo sacramentum fidelitatis hoc modo...'Hoc audis domine N. quod fidem portabo de vita et membris, corpore et catallis et terreno honore, sic me deus adiuvet et haec santa'. Et quidam hic adiciunt in sacramento et bene, quod fideliter et sine diminutione, contradictione vel impedimento et dilatione iniusta, 
A realização desse ato, aliada à transferência da seisin (livery of seisin) da terra em questão, é o que caracterizava a investidura do tenant e a tutela da sua pretensão ${ }^{173}$. Nesse sentido, a exigência, desde a época fundacional do common law, de uma relação material com a coisa como conditio sine qua non para a caracterização de um direito real não se deve a uma incapacidade intelectual de abstração dos juristas medievais ${ }^{174}$, mas ao próprio contexto feudal dos séculos XI a XIII, no qual as relações pessoais se sobrepunham às reais.

Cabe ressaltar que, em termos estritos, a realização da homagium reservava-se, em princípio, para as tenures consideradas mais prestigiosas ${ }^{175}$, ou seja, para as concessões feudais feitas por senhores a homens livres que se comprometiam a fornecer serviços de

terminis statutis faciet servitium suum domino suo et heredibus suis" (E assim deve <o tenant> fazer-lhe homagium <ao seu senhor>: o tenant deve certamente colocar ambas as suas mãos entre as duas mãos do seu senhor, pelo qual manifesta-se proteção, defesa e garantia por parte do senhor, <e> sujeição e reverência por parte do tenant. E deve dizer estas palavras: 'passo a ser o vosso homem em relação ao tenementum que tenho de vós', ou de outro modo, 'que devo ter de vós, e vos deverei lealdade quanto à vida, membros e honra terrena', segundo alguns, e segundo outros, 'quanto ao corpo e bens e honra terrena, e vos deverei lealdade em face de todas as pessoas que podem viver e morrer', segundo outros, 'ressalvada a fidelidade devida ao senhor rei e aos seus herdeiros. E imediatamente após, que <o tenant $>$ faça ao seu senhor o sacramento de fidelidade deste modo...' 'Ouve isto, senhor N., que vos deverei lealdade quanto à <minha $>$ vida e membros, corpo e bens e honra terrena, assim me ajude Deus <a fazê-lo > e estas santas <relíquias>’. E alguns acrescentam isto ao sacramento, e $<$ fazem > bem, que fielmente e sem diminuição, contradição ou impedimento nem dilação injusta, pelos termos estatuídos preste seu serviço ao seu senhor e aos seus herdeiros).

Note-se que o sentido do verbo porto, -as, -are, -avi, -atum - na expressão portare fidem, presente em Bracton f. 80 e Glanvill 9, 1 - nos fragmentos acima, não é de "levar alguma coisa" (sinônimo do verbo fero, fers, ferre, tuli, latum), mas de "dever uma prestação a alguém”, cf. C. F. DU CANGE, Glossarium cit. (nota 13 supra), t. 6, col. 421b (no verbete "portare"): "Debere, certis prastationibus adstringi", ou seja, dever alguma coisa ou estar obrigado a adimplir uma certa prestação. Quanto ao substantivo catallium, presente nos fragmentos, trata-se de "bens móveis", cf. C. F. Du CANGE, Glossarium cit. (nota 13 supra), t. 2, col. 218b (no verbete "catallium"): "Idem quod Capitale, Bona omnia qua in pecudibus sunt. Ex Capitale enim formata vox Captale; et ex Captale, Catallum, ut ex Chaptel Gallico, Chatel et Catel. Exinde usus invaluit, ut hacce appellatione bona omnia mobilia, cujuscumque generis sint, intelligantur. Chattel, in Legibus vernaculis Willelmi Nothi cap. 4. Ibi plane eodem sensu quo Capitale in lege Salica". Também a dicção "vita et membrum" referia-se específicamente à importância dada à proteção da vida e da integridade física do tenant, cf. C. F. DU CANGE, Glossarium cit. (nota 13 supra), t. 5, col. 334c (no verbete "vita et membrum"): "Formula usitata in hominiis, qua vassallus domino cavet, ne vita ei eripiatur, aut in membris ladatur, curam pracipuam se adhibiturum".

${ }^{173}$ De acordo com Bracton f. 79, a homagium somente era válida se fosse acompanhada, antes ou depois da prática do ato, da seisin: "Item quando quis possit homagium facere? Et sciendum quod in principio donationis, tam ante seisinam habitam quam post seisinam. Sed si ante et seisina non sequatur, homagium effectum non habebit (...)" (Da mesma forma, em que momento pode alguém prestar a homagium? E deve-se saber que $<$ deve ser prestada $>$ no começo <do ato $>$ da doação, seja antes da obtenção da seisin, seja depois. Mas se <a homagium for prestada> antes e a seisin não vier depois, a homagium não terá efeito (...)).

${ }^{174}$ Parece inexata, a respeito desse assunto, a afirmação de L. MoCCIA, Il modello inglese cit. (nota 1 supra), p. 64, para quem a imbricação da ownership e da possession deve-se à " tendenza, tipica della cultura giuridica medievale, a materializzare nomi e concetti, rivestendoli di segni esteriori di riconoscimento; la quale si traduceva, nel nostro caso, in un atteggiamento mentale incapace di concepire il diritto astratto de proprietà, senza il supporto concreto, ovvero fuori dell'involucro visibile di un esercizio effetivo o possesso, appunto, che ne facesse da titolo; ossia, che valesse come apparena del diritto stesso".

${ }^{175}$ Cf. Litt 85 [=E. WAMBAUGH, Littleton's Tenures - In English cit. (nota 10 supra), p. 39]: "Homage is the most honorable service, and most humble service of reverence, that a franktenant may do to his lord (...)". 
natureza militar [=feodum militis ${ }^{176}$. Nesse contexto, a seisin foi o elemento que caracterizou, ao longo do tempo, uma das categorias mais clássicas dos direitos reais no sistema do common law: o freehold ${ }^{177}$ [=liberum tenementum $]^{178}$. Contudo, outros tipos de concessão passaram, ao longo do tempo, a receber uma tutela jurisdicional equiparada e a incorporar-se, desse modo, à categoria de direitos reais ${ }^{179}$.

Ao longo dos séculos, mesmo com o surgimento, a partir da evolução da livery of $\operatorname{seisin}{ }^{180}$, de mecanismos abstratos de transferência da seisin e dos direitos reais a ela associados, a importância da possession e a relativização da ownership continuam sendo traços característicos do sistema de direitos reais de matriz inglesa ${ }^{181}$, diferenciando-o dos sistemas de base romanística ${ }^{182}$. A noção de seisin, nesse sentido, constituiu um elemento

${ }^{176}$ Cf. Bl Comm 2, 5, 62 [=W. Blackstone, Commentaries cit., vol. II (nota 10 supra), p. 62]: "The firft, moft univerfal, and efteemed the moft honourable fpecies of tenure, was that by knight-fervice, called in Latin 'Servitium militare', and in law French 'chivalry', or 'Service de chivaler' (...)'. Ver também A. M. BURRILL, A New Law Dictionary cit., vol. I (nota 13 supra), p. 479 (no verbete "feodum"). O serviço de natureza militar também existiu, durante a Idade Média, no continente europeu, cf. nota 91 supra.

177 Cf. Litt 90 [=E. WAMBAugh, Littleton's Tenures - In English cit. (nota 10 supra), p. 41]: “Note, none shall do homage but such as have an estate in fee simple, or fee tail, in his own right, or in the right of another". Ficavam excluídos, portanto, os demais estates. Para ver a classificação dos estates in land antes Law of Property Act 1925 [=Stat. 15 \& 16 Geo. V (1925), c. 20], cf. nota 192 infra.

${ }^{178} \mathrm{O}$ termo liberum tenementum é utilizado, nas fontes jurídicas inglesas, para designar tanto o status do terreno cujo titular fosse um homem livre quanto para distinguir o villenagium dos estates de duração indeterminada, cf. A. M. BurRILl, A New Law Dictionary cit., vol. II (nota 13 supra), p. 683 (no verbete "liberum tenementum"). O tema será tratado mais detalhadamente nos capítulos subsequentes.

${ }^{179}$ Cf. os capítulos 2.3 .1 e 3.4 infra.

${ }^{180} \mathrm{Na}$ Inglaterra medieval, o termo livery of seisin utilizava-se para designar a tradição simbólica (similar à traditio simbolica do direito romano) de um terreno para fins de constituição de um direito real (feoffment) sobre o mesmo, mediante a entrega de algum objeto ligado a este, tais como um graveto, a trava de uma porteira, um anel, uma cruz ou uma faca (livery in deed) e à desocupação do terreno em questão. Tal como ocorreu no direito romano, eventualmente o direito inglês chegou a reconhecer como válida a transferência do estate (conveyancing) feita exclusivamente mediante a entrega de documentos (livery at law).

Acerca da livery of seisin, cf. W. S. HolDSwORTH, A History of English Law cit., vol. III (nota 12 supra), pp. 219-225; Litt 59-60 [=E. WAMBAUGH, Littleton's Tenures - In English cit. (nota 10 supra), pp. 26-27]; D. M. WALKER, The Oxford Companion cit. (nota 8 supra), p. 773 (no verbete "livery of seisin"); A. M. BURRILL, A New Law Dictionary cit., vol. II (nota 13 supra), pp. 689-690 (no verbete "livery of seisin"); cf. Bl Comm 2, 20, 315-316 [=W. BlaCKSTONE, Commentaries cit., vol. II (nota 10 supra), pp. 315-316]; Co Litt 48a $(1,7,59)$ [=E. COKE, The First Part of the Institutes cit., vol. I (nota 10 supra), s. n.].

${ }^{181}$ Cf. nota 162 supra.

${ }^{182}$ Cf. W. W. BuCKLAND e A. D. MCNAIR, Roman Law and Common Law cit. (nota 1 supra), pp. 86-92. O autor reconhece a influência romana sobre o o direito inglês, no que diz respeito à exigência, durante o período formativo do common law, de um ato formal para conferir validade à transmissão, de natureza primacialmente contratual, de direitos reais sobre bens imóveis. No entanto, o direito inglês exigia, além da formalidade, uma efetiva apreensão física (an actual entry) da coisa para dotar o ato de plena efetividade, e nisso difere do direito romano, que desde cedo reconhecia a plena eficácia da transferência meramente formal ou simbólica de bens imóveis mediante a mancipatio e a in iure cessio. Nisso acompanha a opinião de F. Pollock e F. W. MAITLAND, The History of English Law cit., vol. II (nota 12 supra), pp. 88-89, para quem a possibilidade de transferência meramente formal e documental dos bens imóveis se deu por influência, principalmente, da atuação dos tribunais. Um dos fragmentos que demonstram a importância da transferência efetiva do imóvel, nesse período de formação do common law, é Bracton f. 38-38b: "Poterit enim homagium pracessisse, et quod carta rite facta sit et vera et bona, et cum solemnitate recitata et audita, tamen numquam valebit donatio nisi tunc demum cum fuerit traditio subsecuta, et sic poterit carta esse vera, sed sine seisina nuda" (A homagium poderá ter sido obtida, e <até poderá ocorrer> que a escritura, feita pelo rito, seja válida e autêntica, e recitada e 
fundamental para a formação dos direitos reais e sua configuração específica no sistema do common law ${ }^{183}$.

\subsubsection{As categorias baseadas na seisin e sua extensão temporal: estates of freehold}

O termo seisin passou a aplicar-se, especificamente, aos terrenos submetidos ao regime de freehold $[=\text { liberum tenementum }]^{184}$, ou seja, ao regime jurídico decorrente da posse de bens imóveis que, originariamente, tinham sido concedidos a tenants cuja condição pessoal era de homens livres ${ }^{185}$.

A denominação freehold, no entanto, pode tanto referir-se ao regime de tenure ao qual um terreno está submetido, em cujo caso se opõe ao copyhold [=villenagium] ${ }^{186}$, quanto ao próprio regime temporal que regula sua duração. Neste último caso, o significado de estate of freehold passa a ser o de um direito sobre um bem imóvel transmissível por herança, cuja característica distintiva é sua duração indeterminada ${ }^{187}$.

É a partir desse segundo sentido que é possível compreender as principais categorias que compõem o universo possível de direitos reais, no âmbito da real property law, no sistema do common law. Um dos elementos essenciais para essa compreensão é o estate ${ }^{188}$,

ouvida com solenidade, porém a doação nunca será válida a menos que seja seguida, logo após, pela tradição; e, assim, poderá a escritura ser válida, mas <a doação>, sem seisin, <será> ineficaz).

${ }^{183}$ Cf. R. MEgarry e W. WADE, The Law of Real Property cit. (nota 1 supra), p. 46.

${ }^{184}$ Cf. Co Litt 17b $(1,1,10)$ [=E. COKE, The First Part of the Institutes cit., vol. I (nota 10 supra), s. n.]: "'Seised'. Seisitus, commeth of the French Word seisin, i.e. possessio, saving that in the common law seised or seisin is properly applied to freehold, and possessed of possession properly to goods and chattels, although sometime the one os used instead of the other". Daí que os requistios da seisin, de acordo com R. MEGARRY e W. WADE, The Law of Real Property cit. (nota 1 supra), p. 45, sejam: (i) que o titular da concessão seja detentor de um estate of freehold; (ii) que o bem imóvel em questão esteja sujeito ao regime da freehold tenure, e (iii) que o titular esteja na posse do imóvel ou que um copyholder ou leaseholder o detenham dele (dado que estes não tinham seisin).

${ }^{185}$ Cf. A. M. BurriLl, A New Law Dictionary cit., vol. I (nota 13 supra), p. 521 (no verbete "freehold").

${ }^{186}$ Cf. Bracton f. 207: "Item dicitur liberum tenementum ad differentiam eius quod est villenagium, quia tenementorum aliud liberum aliud villenagium" (Da mesma forma, se diz liberum tenementum para diferenciá-lo daquilo que é um villenagium, porque alguns tenementa são livres, outros villenagia).

${ }^{187}$ Cf. Bracton f. 207: "Et sciendum quod liberum tenementum est id quod quis tenet sibi et heredibus suis in feodo et hereditate, vel in feodo tantum sibi et heredibus suis. Item ut liberum tenementum, sicut ad vitam tantum vel eodem modo ad tempus indeterminatum absque aliqua certa temporis prafinitione (...)" (E deve-se saber que o liberum tenementum é aquele que alguém tem para si e os seus herdeiros a título de concessão feudal e herdade, ou apenas a título de concessão feudal para si próprio e os seus herdeiros. Da mesma forma <aquilo que se tem> como liberum tenementum, tal como durante a vida apenas, ou, do mesmo modo, durante um prazo indeterminado, sem alguma limitação certa de tempo).

188 A palavra estate provém do vocábulo latino clássico status, -us, cuja acepção abstrata indicava as circunstâncias de tempo, lugar e posição jurídica, social ou econômica de uma pessoa, cf. P. G. W. GLARE (coord.), OLD cit. (nota 13 supra), pp. 1816-1817 (no verbete "status, -us"). No direito inglês, passou a designar 
que compõe a peça central, no que diz respeito aos interests in land, do sistema de extensões temporais diferenciadas dos direitos reais de matriz inglesa ${ }^{189}$.

Os três principais estates of freehold, dos quais hoje o único verdadeiramente relevante é o estate in fee simple $e^{190}$, articulam-se de modo a estabelecer os critérios que determinam essa extensão temporal ${ }^{191}$.

Nesse sentido, pode-se dizer que é graças à abstração criada por meio dos estates in land e sua rica taxonomia ${ }^{192}$ que o direito inglês conseguiu compatibilizar uma estrutura de

a posição jurídica em que uma pessoa se encontra em relação a uma coisa, cf. A. M. BURRILL, A New Law Dictionary cit., vol. I (nota 13 supra), pp. 434-435 (no verbete "estate").

189 Uma descrição do sistema de estates in land muito citada na doutrina pode ser encontrada em Walsinghams's Case (1573) 2 Plowd 547, caso julgado no Queen's Bench na época da rainha Elizabete I acerca do esbulho cometido pelo herdeiro de um concessionário (Thomas Walsingham) a título de fee simple, cujas terras tinham revertido em favor da rainha Maria I em razão do crime de traição perpetrado pelo primeiro concessionário, cujo título era in fee tail. Aquele tinha recebido a concessão in fee simple de um terceiro, que por sua vez a tinha recebido do primeiro concessionário. A questão principal era saber qual era o direito que o terceiro concessionário tinha recebido sobre o terreno em questão, pois isso determinaria se o herdeiro tinha ou não direito à posse da terra. De modo geral, considera-se que o fee tail é um direito menos abrangente que o fee simple, dada a possibilidade de reversão em caso de ausência de herdeiros. Surge, assim, a discussão acerca da temporalidade dos estates: "(...) but the Land itself is one Thing, and the Estate in the Land is another Thing, for an Estate in the Land is a Time in the Land, or Land for a Time, and there are Diversities of Estates, which are no more than Diversities of Time, for he who has a Fee-simple in Land has a Time in the Land without End, or the Land for Time without End, and he who has the land in Tail has a Time in the Land or the Land for Time as long as he has Issues of his Body, and he who has an Estate in Land for Life has no Time in it longer than for his own Life, and so of him who has an Estate in Land for the Life of another, or for Years".

${ }^{190}$ De acordo com K. GRAY e S. F. GRAY, Elements of Land Law cit. (nota 1 supra), p. 63, as reformas promovidas pelo Law of Property Act 1925 [=Stat. 15 \& 16 Geo. V (1925), c. 20] confirmaram uma tendência já perceptível havia muito tempo. Um dos mecanismos jurídicos que estabeleceram definitivamente essa supremacia (primacy of the fee simple estate) foi a presunção de concessão in fee simple, independentemente do uso, no instrumento de alienação, das palavras "to his heirs", denominadas words of limitation. Assim, toda alienação (conveyance) que não limite expressamente a natureza da concessão estabelece um estate in fee simple em favor do concessionário, cf. Stat. 15 \& 16 Geo. V (1925), c. 20, s. (60) (1): "A conveyance of freehold land to any person without words of limitation, shall pass to the grantee the fee simple or other the whole interest which the grantor had power to convey in such land, unless a contrary intention appears in the conveyance".

${ }^{191}$ Embora ao longo dos séculos outras categorias de estates of freehold tenham sido criadas, as três principais até hoje citadas pela literatura inglesa que trata do tema são mesmo o estate in fee simple, o estate in fee tail e o life estate. Apenas como exemplo, cf. R. MEGARRY e W. WADE, The Law of Real Property cit. (nota 1 supra), pp. 38-39 e K. GRAY e S. F. GRAY, Elements of Land Law cit. (nota 1 supra), pp. 59-60.

${ }^{192}$ De acordo com D. M. WALKER, The Oxford Companion cit. (nota 8 supra), p. 432 (no verbete "estates in land"), os estates in land nasceram ao longo da Idade Média para referir-se ao conjunto de direitos sobre o mesmo bem imóvel que pertenciam a cada um dos integrantes do encadeamento feudal de tenancies entre a Coroa e o último tenant, o que pressupõe que nenhum - salvo a Coroa em relação aos terrenos do royal demesne - deles fosse o dono absoluto desse bem. Essa configuração só era possível graças ao sistema feudal, o qual, conforme estudado acima, baseava-se na concessão de terras feita por um senhor em favor do seu vassalo, em troca da sua lealdade e determinados serviços, em princípio de natureza militar, cf. A. WATSON, Roman Law \& Comparative Law cit. (nota 1 supra), p. 141.

Até a entrada em vigor da Law of Property Act 1925 [=Stat. 15 \& 16 Geo. V (1925), c. 20], em $1^{\circ}$ de janeiro de 1926, os principais estates in land, no que diz respeito à sua duração, podiam ser classificados da seguinte forma: (I) estates of freehold (freehold era o termo utilizado para referir-se ao estado de vinculação vitalícia de um freeman ao seu senhor, em oposição aos villeins, que ficavam sujeitos a um regime jurídico análogo ao de um escravo), de duração indeterminada, e (II) estates less than freehold, de duração determinada ou determinável. Cabe mencionar que cada subcategoria estava relacionada ao tipo de cláusula contida no documento de transferência (deed). 
direitos reais, ainda hoje baseada em tenures feudais, com as necessidades impostas pelo tráfico jurídico contemporâneo, ao demarcar a dimensão temporal da concessão feita a um

A primeira categoria subdividia-se em: (I.A) freeholds of inheritance, de natureza hereditária, que, por sua vez subclassificava-se em (I.A.i) estates in fee simple, transmissíveis por herança e sem restrições quanto à sua alienabilidade (com a claúsula "to A and his heirs"); (I.A.ii) estates in fee tail, transmissíveis por herança com certas restrições quanto à sua alienabilidade (com a cláusula "to A and the heirs of his body" ou "to A and the male heirs of his body" etc.), e (I.A.iii) estates in frankmarriage, transmissíveis por herança com restrições relativas ao casamento; (I.B) freeholds not of inheritance, que, por sua vez, subdividia-se em: (I.B.i) estates for life, que se extinguiam com a morte do tenant (com a cláusula "to A for life"); (I.B.ii) estates per autre vie, que se extinguiam com a morte de uma pessoa diversa do tenant, normalmente a pessoa de quem este tinha obtido o estate (com a cláusula "to A for the life of B"); (I.B.iii) estates of tenant by the curtsey, que passavam ao marido após a morte da esposa pela duração da vida daquele, desde que houvesse herdeiro nascido em justas núpcias, e (I.B.iv) estates of tenant in dower, referente ao percentual do terreno (que podia ser de um terço, metade ou até a totalidade das terras, dependendo do costume local) do marido que, caso viesse morrer antes da sua mulher, ficavam com esta.

A segunda categoria subdividia-se em: (II.A) leases for a fixed term of years, que eram concessões de terras feitas por um número determinado de anos, e (II.B) leases from year to year, que eram concessões de terras renováveis a cada ano.

A doutrina inglesa não sistematiza rigorosamente todas as categorias apontadas acima, podendo ser encontradas algumas variações em diversas obras, Assim, por exemplo, no quadro sinótico apresentado em J. H. BAKER, An Introduction cit. (nota 12 supra), p. 278, os estates not of freehold são subclassificados em: (II.A) term of years, que inclui todas as concessões de duração determinada; (II.B) tenancy at will, que podia ser extinta a critério de qualquer uma das partes, (II.C) tenancy at sufferance, referente à situção daqueles que não tinham qualquer direito reconhecido pelo common law às terras que possuíam, como era o caso do cestui que use. Outro quadro sinótico das categorias de estates (sob o título de "A Figure of the Division of Possession") pode-se encontrar em T. E. ToMLINS, Lyttleton - His Treatise of Tenures - In French and English cit. (nota 10 supra), p. lvi.

As categorias de direitos reais dos sistemas de tradição romanística continental, tais como a propriedade, o usufruto, o uso, a habitação etc., classificam-se, principalmente, em função do seu conteúdo, embora possam variar quanto à sua duração, hereditabilidade e extensão. Os diversos tipos de estates in land, por outro lado, estruturam-se predominantemente em torno de três critérios principais: durabilidade, hereditabilidade e, no período mais remoto, alienabilidade. Isso ocorreu, em larga medida, em razão da própria natureza do sistema feudal de suserania e vassalagem, que impedia que todos os direitos sobre a terra se concentrassem em uma única pessoa. A ownership inglesa é, de certa forma, o resultado da "reificação" das relações contratuais entre o senhor feudal e seus tenants. Sobre o tema, cf. A. WATSON, Roman Law \& Comparative Law cit. (nota 1 supra), pp. 142-143 e S. F. C. MILSOM, Historical Foundations cit. (nota 12 supra), pp. 100-101.

A principal obra que classificou de forma sistemática as tenures feudais foi Tenores Novelli, escrita por Thomas Littleton e publicada pela primeira vez em 1481 ou 1482 (há divergências quanto ao ano de publicação). Originalmente escrita em law French, houve várias reedições e traduções da obra para o inglês. Duas das mais citadas são E. WAMBAUGH, Littleton's Tenures - In English cit. (nota 10 supra), pp. iii-341 e T. E. TOMLINS, Lyttleton - His Treatise of Tenures - In French and English cit. (nota 10 supra), pp. vii-693.

O Stat. 15 \& 16 Geo. V (1925), c. 20, s. 1 aboliu essas classificações e estabeleceu que os únicos estates in land reconhecidos pelo common law são: (i) an estate in fee simple absolute in possession, e (ii) a term of years absolute. Além desses estates, o direito inglês também reconhece interests e charges sobre bens imóveis, tais como aluguéis e hipotecas, sendo todos os demais ônus sobre bens imóveis considerados equitable interests, cf. nota 212 infra.

Esse ato legislativo teve grande impacto no desenvolvimento dos trusts, pois a partir do Statute of Uses 1536 [=Stat. 27 Hen. VIII (1536), c. 10] e do Statute of Wills 1540 [=Stat. 32 Hen. VIII (1540), c. 1], todos os estates reconhecidos pelo common law ganharam um estate equivalente tutelado pela equity. Por isso, desde a eliminação da multiplicidade de estates reconhecidos pelo common law, as formas especiais de devolução, titularidade e limitação correspondentes aos antigos estates somente podem ser obtidas mediante a instituição de um trust, cf. M. LuPOI, s.v. Trusts - Profili generali e diritto straniero, in Enciclopedia Giuridica Treccani 36 (1995), p. 3.

Para uma exposição sucinta dos demais tipos de estate, além daqueles relativos a bens imóveis, cf. B. A. GARNER (coord.), Black's cit. (nota 13 supra), pp. $492-494$ (no verbete "estate"). Uma explicação bem simplificada das cláusulas inseridas nos documentos de transferência (deeds) para cada tipo de estate in land pode ser encontrada em P. S. JAMES, Introduction to English Law, $3^{\mathrm{a}}$ ed., London, Butterworth, 1955, pp. 340342. 
tenant dentro do contexto verticalizado de direitos sobre bens imóveis em cujo ápice encontra-se, invariavelmente, a Coroa ${ }^{193}$.

No que diz respeito a essa gradação temporal, desde a perspectiva da formação dos direitos reais no sistema do common law, as três categorias dos estates of freehold que merecem atenção são o estate in fee simple, o estate in fee tail e o life estate.

\subsubsection{A concessão hereditária perpétua: o estate in fee simple}

Embora originariamente a duração de todas as concessões feudais, em virtude da própria natureza pessoal da concessão, fosse equivalente, no máximo, à extensão da vida do concessionário $^{194}$, no final do século XIII passou-se a entender que, toda vez que no ato de alienação ficasse explicitado que a terra era concedida "para o concessionário e seus herdeiros" [="to A and his heirs"] ${ }^{195}$, o que se transferia era um direito que o novo

${ }^{193}$ Cf. K. GRAY e S. F. GRAY, Elements of Land Law cit. (nota 1 supra), p. 61.

${ }^{194}$ Cf. T. F. T. PluCKNETT, A Concise History cit. (nota 12 supra), pp. 523-524.

195 A fórmula observada para efetuar esse tipo de alienação já aparece em Bracton f. 17b: "Simplex autem et pura dici poterit, ubi nulla adiecta est conditio neque modus, simpliciter enim dicitur dari quod nullo addito datur. Ut si dicatur, Do tali tantam terram in tali villa pro homagio et servitio suo, habendam et tenendam eidem tali et heredibus suis de me et heredibus meis, reddendo inde per annum ipse et heredes sui mihi et heredibus meis tantum ad tales terminos, pro omni servitio et consuetudine et seculari demanda, ita quod certa sit res qua datur, et certa servitia et consuetudines qua domino debentur, licet incerta sint alia qua tacite remittuntur. Et ego et heredes mei warantizabimus, adquietabimus, et defendemus pradictum talem et heredes suos versus omnes gentes per prodictum servitium. Et sic adquirit donatarius rerum dominia ex causa donationis, et heres eius post eum ex causa successionis, quia nihil adquirit ex donatione facta antecessori, quia cum donatario non est feoffatus. Et per hoc quod dicit, tali et heredibus suis, largo sumpto vocabulo heredum, continentur heredes omnes tam propinqui quam remoti, et tam prasentes quam futuri" (<A doação> pode-se dizer simples e pura, onde não há qualquer condição ou modo adjecto, dado que, evidentemente, diz-se ser doado simplesmente aquilo que se doa sem acrescentar nada. Tal como <ocorreria > caso se diga: 'dou a tal <pessoa $>$ tanta terra em tal vila pelo seu homagium e serviço, para que ele e seus herdeiros a tenham e detenham de mim e os meus herdeiros, pagando o mesmo <concessionário > e seus herdeiros por ano, a partir de então, a mim e aos meus herdeiros em tais prazos por todo o serviço, ônus costumeiro e exação secular, de tal forma que seja certa a coisa dada, e certos os serviços e ônus costumeiros devidos ao senhor, embora sejam incertos os outros <serviços> renunciados tacitamente. E eu e os meus herdeiros prestaremos garantia <pela evicção $>$, daremos quitação < dos serviços > e defenderemos o tal supramencionado <concessionário > e os seus herdeiros em face de quaisquer terceiros pelos supramencionados serviços. E assim o donatário adquire os domínios da coisa em função da doação, e seu herdeiro após ele <adquire o domínio $>$ em função da sucessão, porque nada adquire <o herdeiro $>$ em função da doação feita pelo antecessor, porque não foi feito titular da concessão <junto> com o donatário. E por aquilo que diz, 'para tal <pessoa> e seus herdeiros', tomado em acepção ampla o vocábulo 'herdeiro', incluem-se todos os herdeiros, tanto os próximos quanto os distantes, e tanto os presentes quanto os futuros). $\mathrm{O}$ fragmento salienta a hereditabilidade da concessão e estabelece que o herdeiro do concessionário não tem qualquer direito à terra até o momento da sucessão. Daí importância da seisin, pois caso o herdeiro não estivesse na posse do imóvel no momento da morte do de cujus e um terceiro a obtivesse antes dele, o herdeiro somente poderia impetrar um breve de mortis antecessoris se o de cujus tivesse estado na posse no momento da sua morte.

Ao mesmo tempo, ao estabelecer que o herdeiro recebe ex causa sucessionis et non donatione, o fragmento reforça outra regra do common law, segundo a qual o herdeiro não adquire o direito até o momento da morte do de cujus, cujo principal efeito, até a entrada em vigor do Statute of Wills 1540 [=Stat. 32 Hen. VIII (1540), c. 1], foi o de precluir a transmissão testamentária de um estate. 
concessionário-posssuidor podia transmitir causa mortis aos herdeiros, ou seja, um direito que, em princípio, podia estender-se ad infinitum, desde que o primeiro concedente tivesse herdeiros vivos ${ }^{196}$.

Já no século XIV, provavelmente em função da maior liberdade de alienação concedida pelo Statutum Quia Emptores Terrarum $1290^{197}$, firmou-se o entendimento de que o concessionário era titular de um direito que podia alienar livremente, e que, portanto, o concessionário-possuidor continuava na titularidade da concessão independentemente da existência de herdeiros vivos do primeiro concedente ${ }^{198}$.

Nasce, assim, o fee simple [=feodum simplex $\left.{ }^{199}\right]$, um direito real sobre bens imóveis de duração, em princípio, infinita, cujo regime constitui, pelo menos no que diz respeito à sua extensão temporal e à sua alienabilidade, um verdadeiro direito de propriedade $(\text { ownership })^{200}$.

Nesse sentido, lê-se em Glanvill 7, 1 [=R. Glanvilla, Tractatus de legibus cit. (nota 10 supra), p. 94]: "Poteft itaque quilibet fic totum queftum donare in vita fua, fed nullum haredem inde facere poteft, neque Collegium, neque aliquem hominem; quia folus Deus haredem facere poteft, non homo" (Pode, desse modo, quem quer que seja doar toda <a terra > adquirida durante a sua vida, mas não pode instituir, daí, <como> herdeiro uma corporação ou qualquer homem; porque somente Deus pode instituir um herdeiro, não o homem).

Note-se que, no fragmento citado, o sentido da palavra questus é "terra adquirida pela compra ou pelo próprio esforço", em oposição às terras adquiridas em função da herança, cf. A. M. BURRILL, A New Law Dictionary cit., vol. II (nota 13 supra), p. 852 (nos verbetes “questus"). O termo provém do verbo quaero, -is, ere, -ivi/-sii, -situm, que, mesmo no latim clássico, podia significar "adquirir alguma coisa pelo próprio esforço", cf. P. G. W. GLARE (coord.), OLD cit. (nota 13 supra), p. 1533 (no verbete "quaero, -is, -ere, -ivi/-sii, -situm"). Conforme visto acima, um dos seus compostos, conquestus, teve grande repercussão na elaboração da teoria das tenures e na eleminação das terras alodiais na Inglaterra a partir da Conquista. De fato, de acordo com $\mathrm{H}$. SPELMANNUS, Glossarium cit. (nota 13 supra), p. 145 (no verbete "conqueftus"), o próprio epíteto "conquestor", atribuído ao rei Guilherme I, era fruto da sua condição jurídica de adquirente das terras da Inglaterra a pedido (by quest and conquest) do rei Eduardo o Confessor - muito embora a disputa entre ele e Haroldo fosse a respeito dos direitos de sucessão à Coroa -, e não do fato de ter vencido o sucessor da antiga dinastia anglo-saxônica: "Conqueftor dicitur qui Angliam conquifivit, i. acquifivit, 'purchased', non quod fubegit".

196 Cf. J. H. BAKER, An Introduction cit. (nota 12 supra), pp. 262-263. A possibilidade de efetuar a alienação de uma concessão feudal que se estendesse para além da vida do concedente significou a incorporação da concessão feudal ao patrimônio do concessionário, no sentido apontado por M. BLOCH, La société féodal cit. (nota 42 supra), pp. 185 e ss. De fato, se a relação vassálica tivesse conservado seu caráter primacialmente pessoal, não haveria como retirar bens imóveis do patrimônio familiar, pois a primeira concessão somente ficaria desfeita com a extinção de todos os herdeiros do concedente. A possibilidade de alienar não apenas a concessão, mas também seu caráter hereditário, se bem que passou a prejudicar o herdeiro do concedente (pois deixava de ter qualquer direito real sobre a terra em questão), contribuiu de modo decisivo para aumentar a fluidez do patrimônio imobiliário.

${ }^{197}$ Cf. W. S. Holdsworth, A History of English Law cit., vol. III (nota 12 supra), p. 107.

${ }^{198}$ Cf. R. MEgARry e W. WAdE, The Law of Real Property cit. (nota 1 supra), p. 36.

${ }^{199}$ Cf. Litt 1 [=E. WAMBAUGH, Littleton's Tenures - In English cit. (nota 10 supra), p. 391]: “Tenant in fee simple is he which hath lands or tenements to hold to him and his heirs forever. And it is called in Latin 'feodum simplex', for 'feodum' is the same that inheritance is, and 'simplex' is as much as to say lawful or pure. And so 'feodum simplex' signifies a lawful or pure inheritance. For if a man would purchase lands or tenements in fee simple, it behoveth him to have these words in his purchase, 'to have and to hold to him and to his heirs'; for these words, 'his heirs', make the estate of inheritance". Aqui já aparece o resultado final da evolução do estate in fee simple, no que se refere à sua hereditabilidade, o que reflete a infinitude, em princípio, da sua duração.

${ }^{200}$ Cf. J. H. BAKER, An Introduction cit. (nota 12 supra), p. 263 e J. WILliAMS, Principles of the Law of Real Property, 23ª ed., London, Sweet \& Maxwell, 1920, pp. 3-4. Para este último autor, o próprio conceito de 
Nesse sentido, o fee simple é, de modo geral, o estate mais amplo que pode recair sobre um bem imóvel ${ }^{201}$. Apesar de ainda estar submetido à estrutura das tenures e, consequentemente, não ter formalmente alcançado o status de domínio pleno, na prática podese dizer que seja o equivalente a um direito de propriedade absoluto ${ }^{202}$, pois essencialmente todos os ônus feudais deixaram de incidir sobre $\operatorname{ele}^{203}$.

Em função da duração, em princípio ad infinitum, do estate in fee simple, as restrições ${ }^{204}$ materiais impostas ao titular não decorrem de qualquer limitação inerente ao seu regime jurídico, mas de disposições legais ou jurisprudenciais ${ }^{205}$, normalmente em função de questões de ordem pública.

ownership, em sentido estrito e absoluto, pressupõe as faculdades de: (i) gozar livre e exclusivamente da coisa, podendo exercer a qualquer momento o direito de excluir quaisquer terceiros da esfera de influência sobre tal coisa; (ii) recuperar a posse da coisa em face de quaisquer terceiros; (iii) dispor da coisa, inclusive alterando-a ou mesmo destruindo-a, e, principalmente (iv) manter a titularidade por prazo indeterminado de tempo. Diante desses requisitos, principalmente o último, a única categoria que pode ser considerada absolute ownership em sentido estrito é o estate in fee simple.

${ }^{201}$ Cf. Litt 11 [=E. WAMBAUGH, Littleton's Tenures - In English cit. (nota 10 supra), p. 6]: “And note, that a man cannot have a more large or a greater estate of inheritance than fee simple". Cf. J. WILLIAMS, Principles of the Law of Real Property cit. (nota 200 supra), p. 6.

${ }^{202}$ Cf. H. W. ChAllis, Law of Real Property cit. (nota 1 supra), pp. 218-219.

${ }^{203}$ Cf. R. MEgARry e W. WAdE, The Law of Real Property cit. (nota 1 supra), p. 52.

${ }^{204}$ A articulação dos diversos tipos de uso e fruição dos bens imóveis no direito inglês, especialmente no que se refere aos estates por tempo determinado, adota como critério central a doctrine of waste, que leva em consideração, como ponto de partida, a duração do estate em questão, conforme explicada infra no capítulo relativo ao life estate.

${ }^{205}$ Assim, por exemplo, a presunção de titularidade proprietária expressa no brocardo cuius est solum, eius est usque ad coelum et ad inferos (<para aquele> de quem é o solo, é dele até o céu e até o inferno), apesar de ser reconhecida como princípio geral no que diz respeito à extensão espacial do estate in fee simple, não encontra aplicação no que se refere ao uso do espaço aéreo. O princípio geral já aparece em Bl Comm 2, 2, 18 [=W. BLACKSTONE, Commentaries cit., vol. II (nota 10 supra), p. 18]: "Land hath alfo, in it's legal fignification, an indefinite extent, upwards as well as downwards. 'Cujus eft folum, ejus eft ufque ad coelum', is the maxim of the law, upwards; therefore no man may erect any building, or the like, to overhang another's land: and, downwards, whatever is in a direct line between the furface of any land, and the center of the earth, belongs to the owner of the surface (...) So that the word 'land' includes not only the face of the earth, but everything under it, or over it'.

O princípio ad coelum et inferos serviu como instrumento interpretativo em Mitchell v Mosley [1914] 1 Ch 438 para definir o alcance de um contrato de concessão (conveyance of a lease) de terras para a exploração de minas de carvão, ficando estabelecido que dita concessão incluía não apenas o direito a explorar o que ficava acima da superfície do solo, mas no subsolo também. Em Bernstein of Leigh v Skyviews \& General Ltd [1978] QB 479, contudo, a Queen's Bench Division entendeu que o princípio ad coelum aplica-se somente a estruturas fixas no solo que invadam o espaço aéreo de um terreno, e não ao uso desse espaço por aeronaves, mesmo que esse mesmo uso constitua uma violação da privacidade do titular do terreno em questão: "The plaintiff claims that as owner of the land he is also owner of the air space above the land, or at least has the right to exclude any entry into the air space above his land. He relies upon the old Latin maxim, 'cujus est solum ejus est usque ad coelum et ad inferos', a colourful phrase often upon the lips of lawyers since it was first coined by Accursius in Bologna in the 13th century. There are a number of cases in which the maxim has been used by English judges, but an examination of those cases shows that they have all been concerned with structures attached to the adjoining land, such as overhanging buildings, signs or telegraph wires, and for their solution it has not been necessary for the judge to cast his eyes towards the heavens; he has been concerned with the rights of the owner in the air space immediately adjacent to the surface of the land. Em tais casos aplica-se, no que diz respeito ao trânsito pelo espaço aéreo, o Civil Aviation Act 1949 [=Stat. 12 \& 13 Geo. VI (1949), c. 67], s. 40 (1): "No action shall lie in respect of trespass or in respect of nuisance by reason only of the flight of an aircraft over any 
Dada essa amplitude, prima facie, do estate in fee simple, o sistema do common law encontrou algumas dificuldades para desenvolver regras que regulem a coexistência de vários estates in fee simple autônomos sobre planos horizontais superpostos no mesmo prédio $^{206}$, chamados "flying freeholds" ${ }^{207}$. Os eventuais conflitos entre os titulares se resolvem de modo similar ao que ocorre nos sistemas jurídicos de base romanísitica em relação à propriedade horizontal, em cujo caso as restrições são de caráter condominial ${ }^{208}$. O titular de um estate in fee simple também não encontra, em princípio, restrições substanciais no que diz respeito ao seu direito de alienação.

A concepção de um direito sobre uma coisa, em oposição à de controle absoluto sobre ela, permitiu a configuração de uma série de fenômenos sui generis no sistema de direitos reais desenvolvido pelo common law. Assim, é particular ao direito inglês a possibilidade de constituir um moveable estate, pelo qual o tenant in fee simple pode ser titular de um estate que se desloque periodicamente sobre um número determinado de imóveis $^{209}$ ou que varie de acordo com algum limite material ${ }^{210}$.

property at a height above the ground, which, having regard to wind, weather and all the circumstances of the case is reasonable (...)".

${ }^{206}$ Cf. Co Litt 48b $(1,7,59)$ [=E. CoKE, The First Part of the Institutes cit., vol. I (nota 10 supra), s. n.]: "A man may have an inheritance in an upper chamber, though the lower buildings and soile be in another, and seeing it is an inheritance corporeal, it shall passe by livery". Ao que tudo indica, essa possibilidade ainda não exisitia no século XV, pois nessa época se considerava que não podia ser objeto de um estate autônomo uma construção físicamente dependente de outra, cf. H. W. CHALLIS, Law of Real Property cit. (nota 1 supra), p. 54.

${ }^{207}$ Cf. R. Megarry e W. WAdE, The Law of Real Property cit. (nota 1 supra), p. 52. É interessante notar que o direito romano também encontrou dificuldades para reconhecer a propriedade horizontal, justamente em função do conceito absoluto de dominium derivado da antiga concepção política da propriedade romana, que estabelecia uma vis attractiva do solo sobre tudo aquilo que de alguma forma a ele se ligasse fisicamente, resultando em dificuldades para transpor o princípio superficies solo cedit, cf. E. C. SILVEIRA MARCHI, A Propriedade Horizontal no Direito Romano, $2^{\mathrm{a}}$ ed., São Paulo, Quartier Latin, 2003, pp. 19-21.

${ }^{208}$ Cf. K. GRAY e S. F. GRAY, Elements of Land Law cit. (nota 1 supra), pp. 16-17. Na Inglaterra em particular é mais comum que a propriedade horizontal esteja submetida ao regime do leashold estate, justamente porque a amplitude e robustez dos direitos atribuídos ao freeholder tornam jurídicamente mais vulnerável qualquer outro imóvel que invada seu espaço (mesmo que se trate de outro freehold), o que enfraquece a possibilidade de tutela jurisdicional em caso de necessidade de reparos e manutenção. O Commonhold and Leasehold Reform Act 2002 é a mais recente tentativa, na Inglaterra, de estabelecer um estatuto mais seguro para a propriedade horizontal sujeita ao regime de freehold, mediante a criação de unidades autônomas dentro de um espaço comum, cf. Commonhold and Leasehold Reform Act 2002, s. 11 (1): "In this Part 'commonhold unit' means a commonhold unit specified in a commonhold community statement in accordance with this section".

${ }^{209}$ Um exemplo desse tipo de disposição pode ser visto em Co Litt 4b $(1,1,1)$ [=E. COKE, The First Part of the Institutes cit., vol. I (nota 10 supra), s. n.]: “(...) and fee simple <is> the most highest and absolute estate that a man can have; yet may the same at severall times moveable (...) sometime in one place, and sometime in another. As for example, if there be 80 acres of meadow which have been used time out of mind of man to be divided betweene certaine persons, and that a certaine number of acres appertaine to every of these persons; as for example, to A 13 acres, to be yearely assigned and lotted out, so as sometime the 13 acres lie in one place, and sometime in another, and so of the rest; A hath a moveable fee simple in 13 acres, and may be parcell of his manor, albeit they have no certaine place, but yearely set out in several places, so as the number only is certaine, and the particular acres or place wherein they lie after the year uncertaine".

O assunto também é tratado em Weldon v Bridgewater (1595) Cro Eliz 421, em que o King's Bench estabeleceu que o coerdeiro de um terreno cujos lotes estavam sujeitos a um regime de rotatividade a cada dois 
O estate in fee simple comporta subclassificações, todas ligadas às diversas possibilidades de determinação da extensão temporal do estate $^{211}$. Modernamente a principal delas, contudo, é o estate in fee simple absolute in possession ${ }^{212}$, cuja característica determinante é, justamente, a ausência de impedimentos jurídicos à duração ad infinitum do estate, aliada ao direito de imissão na posse direta do imóvel a partir do momento em que se realiza a concessão ${ }^{213}$.

anos entre os coerdeiros tinha legitimidade para impetrar uma action of trespass, pois se entendeu que, dada a hereditabilidade do direito sobre a terra, não se tratava de mera percepção de frutos (profits a prendre), mas de um freehold estate.

${ }^{210}$ Cf. Baxendale v Instow Parish Council [1982] Ch 14, em que um concessionário a título de fee simple de um terreno adjacente ao mar ajuizou ação impugnando a anexação registral, promovida pela autoridade local, de uma faixa contígua de terra surgida ao longo de décadas, em função do retrocesso do mar, como terreno público pertencente ao distrito de Devon, onde fica a localidade de Instow. Apesar de não ter dado provimento ao recurso do titular in fee simple, a Chancery Division entendeu que o common law permite, do ponto de vista jurídico, que um terreno a título de fee simple seja demarcado por limites variáveis ao longo do tempo, mesmo havendo uma delimitação esquemática no instrumento de concessão. A possibilidade dessa interpretação depende da construção que se faça a partir dos termos utilizados pelo concedente no instrumento de concessão, para o qual a mera descrição esquemática não é indício suficiente de uma delimitação fixa do terreno. Caso fique reconhecida a delimitação móvel, o titular de qualquer outro terreno contíguo ficaria impossibilitado de adquirir, por acessão, um direito real sobre o novo terreno, pois ele estaria incluído no objeto da concessão in fee simple originária.

${ }^{211}$ Cf. R. Megarry e W. WAde, The Law of Real Property cit. (nota 1 supra), pp. 62-70. O fee simple pode ser subclassificado em: (I) fee simple absolute, e (II) fee simple modified. O primeiro é um estate cuja duração não fica subordinada à ocorrência de qualquer evento futuro, em cujo caso o vocábulo absolute assume o significado de "perpétuo". Já o fee simple modified é uma espécie de propriedade resolúvel cuja característica central é a existência de cláusulas acidentais que imponham um limite possível, porém sempre incerto, à potencial perpetuidade do fee simple. O fee simple modified subdivide-se em duas categorias: (II.A) determinable fee simple, e (II.B) conditional fee simple. A principal distinção entre a determinabilidade ou a condicionalidade do estate reside nas palavras utilizadas para descrever o evento que põe fim ao direito. Assim, palavras no instrumento de alienação que indiquem duração (i.e. while, during, as long as, until etc.) criam um determinable fee, enquanto conjunções adversativas (i.e. provided that, on condition that, but if, if it happen that etc.) estabelecem um conditional fee.

A distinção, que também cabe no caso de equitable interests, já foi motivo de motivo de críticas na Chancery Division, ao se discutir a validade de uma cláusula de rescisão automática em caso de transferência do benefício num plano de aposentadoria envolvendo um trust, pelo fato de ser excessivamente formal, cf. Re Trusts of the Scientific Investment Pension Plan [1998] 3 All ER 154: "The distinction is not a particularly one, being based on form rather than substance". No entanto, as consequencias jurídicas decorrentes de cada regime de fee simple modified são bastante diversas, uma das mais importantes sendo que, enquanto o determinable fee automaticamente devolve o imóvel ao concedente, o conditional fee apenas confere ao concedente o direito de imitir-se na posse do imóvel, permanecendo o fee simple caso não o faça.

A nosso ver, as discussões relativas ao fee simple modified resultam de uma superimposição conceitual dos accidentalia negotii (especialmente no que diz respeito às condiciones) às categorias inglesas de direitos reais, no contexto das restrições impostas pelo concedente à alienabilidade do bem, fenômeno que os tribunais ingleses regulam de modo a impedir a inalienabilidade absoluta do imóvel, cf. K. GRAY e S. F. GRAY, Elements of Land Law cit. (nota 1 supra), pp. 228-229.

${ }_{212}$ De fato, é essa uma das duas que podem ser mantidas e criadas at common law (em sentido estrito) de acordo com o disposto no Stat. 15 \& 16 Geo. V (1925), c. 20, s. 1 (1) (a): "The only estates in land which are capable of subsisting or of being conveyed or created at law are: (a) an estate in fee absolute in possession; $(b)$ a term of years absolute". O term of years absolute pretence à categoria dos leaseholds, que tiveram uma evolução histórica completamente distinta dos freeholds e foram historicamente classificados como chattels (bens movéis), cf. B. A. GARNER (coord.), Black's cit. (nota 13 supra), p. 766 (no verbete "leasehold").

${ }^{213}$ Quanto ao momento em que o concessionário passa a perceber as utilidades (enjoy) do imóvel, os estates são classificados em in possession, in remainder e in reversion, cf. Bl Comm 2, 11, 163 [=W. BLACKSTONE, Commentaries cit., vol. II (nota 10 supra), pp. 163]: "We are now to confider them <the estates> 
Em suma, pode-se dizer que, desde a perspectiva dos estates in land e fora da esfera proprietária da Coroa, a categoria que hoje mais se aproxima do direito de propriedade [=dominium absolutum] de base romanística é, no sistema do common law inglês, a concessão "feudal" hereditária (fee) desvinculada da continuidade hereditária do concedente (simple) isenta de cláusulas condicionais que limitem a sua potencial perpetuidade (absolute) e imediatamente passível de imissão na sua posse pelo concessionário-possuidor (in possession $)^{214}$.

\subsubsection{A concessão hereditária condicional inalienável: o estate in fee tail}

in another view, with regard to the time of their enjoyment; when the actual pernancy of the profits (that is, the taking, perception, or receipt, of the rents and other advantages arifing therefrom) begins. Eftates therefore, with refpect to this confideration, may either be in poffesfion, or in expectancy; and of the expectancies there are two forts; one created by act of the parties, called remainder; the other by act of law, and called a reverfion". A dicção in possession, portanto, diferencia o fee simple absolute da categoria dos estates in remainder e estates in reversion, cf. K. GRAY e S. F. GRAY, Elements of Land Law cit. (nota 1 supra), p. 212.

$\mathrm{O}$ estate in remainder confere ao titular um direito de gozo futuro da coisa, no sentido de que o remainderman somente é impedido de tomar a posse da coisa imediatamente em virtude de um estate pertencente a outrem, cf. Bl Comm 2, 11, 164 [=W. BLACKSTONE, Commentaries cit., vol. II (nota 10 supra), pp. 164]: "An eftate then in remainder may be defined to be an eftate limited to take effect and be enjoyed after another eftate is determined"; Co Litt 143a $(2,12,215)$ [=E. COKE, The First Part of the Institutes cit., vol. I (nota 10 supra), s. n.]: "'Remainder', in legall Latine, is 'remanere', coming of the Latine word 'remaneo'; for that is a remainder or remnant of an estate in lands or tenements, expectant upon a particular estate created together with the same at one time (...)"; H. W. CHALLIS, Law of Real Property cit. (nota 1 supra), pp. 78-79.

Já o estate in reversion representa a totalidade dos direitos sobre o imóvel mantidos pelo concedente após ter realizado a concessão, ou seja, o resíduo de interesses juridicamente protegidos ainda pertencentes ao concedente, cf. Bl Comm 2, 11, 175 [=W. BlaCKSTONE, Commentaries cit., vol. II (nota 10 supra), pp. 175]: "An eftate in reverfion is the refidue of an eftate left in the grantor, to commence in poffesfion after the determination of fome particular eftate granted out by him"; Co Litt 22b $(1,2,19)[=\mathrm{E}$. COKE, The First Part of the Institutes cit., vol. I (nota 10 supra), s. n.]: "A reversion is where the residue of the estate always doth continue in him that made the particular estate, or where the particular estate is derived out of his estate"; Co Litt 142b (2, 12, 215) [=E. COKE, The First Part of the Institutes cit., vol. I (nota 10 supra), s. n.]: "'Reversion', Reversio, cometh of the Latine word revertor, and signifieth a returning againe"; H. W. CHALLIS, Law of Real Property cit. (nota 1 supra), p. 78.

Embora hoje façam parte da dinâmica do fee simple, os estates in remainder e in reversion nasceram a partir do fee tail, que nada mais é do que uma espécie de conditional fee.

${ }^{214}$ Dadas essas características, concordamos com a opinião de L. MOCCIA, Il modello inglese cit. (nota 1 supra), p. 76, para quem o tenant in fee simple pode ser considerado um owner of the land. No mesmo sentido, J. GORDLEY, Foundations of Private Law cit. (nota 1 supra), p. 50. 

resolutiva $^{217}$ [="to $A$ and to the heirs of his body", ou "to A and to the heirs of his body

${ }^{215}$ De acordo com J. A. SIMPSON e E. S. C. WEINER (coord.), OED 17 (1989), pp. 547-548 (no verbete

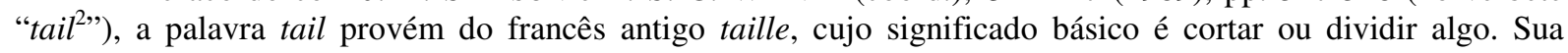
origem, aparentemente, é o vocábulo talea, utilizado no latim medieval para designar uma tábua quadrada de madeira, dividida em duas metades, na qual se mantinham os registros contábeis mediante a aposição de cortes, cf. C. F. DU CANGE, Glossarium cit. (nota 13 supra), t. 8, col. 016b (no verbete "talea"): "Voces unius ejusdemque originis, qua nostris Tesseram ligneam significant, in duas partes fissam, in quarum utraque debitum continetur, transversaria quadam casura denotatum, altera penes emtorem vel debitorem, altera penes venditorem vel creditorem remanente: nostris vulgo "Taille". Daí que também pudesse significar um tributo ou exação de natureza fiscal, cf. H. SPELMANNUS, Glossarium cit. (nota 13 supra), p. 216 (no verbete "tallia, -ae"): "Cenfus vel tributum quod viritim exigitur (...)". Conforme explica T. F. T. PluCKNETT, A Concise History cit. (nota 12 supra), pp. 556-557, no que diz respeito aos estates, o termo denota a divisão da concessão hereditária (fee) entre os vários titulares de um direito sobre o bem sujeito a esse regime.

${ }^{216}$ Essa é a classificação mais apropriada para os entails criados a partir de 1926, pois desde então eles somente podem existir através de um trust, cf. R. MEGARRY e W. WADE, The Law of Real Property cit. (nota 1 supra), p. 39. De modo geral, contudo, os termos fee tail, estate tail, entail e entailed interest são intercambiáveis.

${ }^{217}$ De acordo com T. F. T. PluCKNETT, A Concise History cit. (nota 12 supra), pp. 549-550, toda a parte relacionada às concessões condicionais em Bracton foi influenciada pelo romanismo do autor, muito embora a tônica sempre fosse de natureza feudal, cf. K. E. GÜTERBOCK, Henricus de Bracton cit. (nota 1 supra), pp. 116117. Mesmo sem entrar em todos os detalhes das concessões condicionais, pode-se ver essa influência, principalmente em relação a Inst. 3, 15, pr.-7 e Inst. 3, 19, pr.-27, na própria nomenclatura e classificação das condições, cf. Bracton f. 19: "Fieri autem poterit donatio sub condicione sine modo, ut si dicam, 'Do tibi rem istam si ita factum sit vel non factum', et si conferatur condicio in futurum, licet prasentia et praterita [nos sint incerta] non sint in pendenti sicut futura, quia statim condicio infirmat obligationem, vel omnino non differt. Tunc [aut] est condicio possibilis aut impossibilis. Si autem possibilis et potestativa, ut si dicam, 'Do tibi talem rem si dederis mihi decem', valet donatio, et suspenditur donec existat condicio. Ut si tu petas rem, excipere possum quod tu mihi decem non dederis. Item si condicio fuerit impossibilis, ut si dicam, 'Do tibi istam rem si coelum digito tetigeris', non valet donatio, et pro non adiecta habeatur condicio. Item non valet donatio ab initio sed est in pendenti in alterius potestatem collata condicione, ut si dicam, 'Do tibi hanc rem si Titius voluerit', vel 'arbitratus fuerit', vel 'quid tale fecerit', quia nisi hoc fecerit, donatio non valebit. Item si condicio casualis fuerit, ut si dicam, 'Do tibi talem rem si navis venerit ex Asia, vel si Titius consul factus fuerit', erit donatio in pendenti quia huiusmodi donationes dependent ex insidiis fortunce. Si autem condicio fuerit mixta et disiunctiva, ut si in parte fuerit potestativa et in parte casualis, ut si dicam, 'Do tibi hanc rem si mihi decem dederis', sufficit unum istorum adimpleri. Sed si plures condiciones ascripta sint donationi coniunctim, ut si dicatur, 'Si illud et illud factum sit', omnibus est parendum, si divisim, ut pradictum est, cuilibet vel alteri eorum satis est obtemperare. Item condicionum alia expressa et fit verbis negativis, ut si dicatur, 'Si Titius heres non sit tu heres esto', vel 'si tu de corpore tuo heredes non habueris, tunc terra sic data revertatur ad tales', unum vel plures, simul vel successive" (Contudo, poderá ser feita uma doação sob condição sem <estipular> um encargo, como no caso em que eu estipule: "Dou-te esta coisa se assim for feito ou não for feito", se a condição se referir ao futuro, $<$ pois> embora as coisas presentes e passadas sejam para nós incertas, não estão pendentes, tal como < ocorre com> as coisas futuras, dado que a condição invalida imediatamente a obrigação ou não a defere sob qualquer hipótese. Então, a condição é possível ou impossível. Se <for $>$, no entanto, possível e potestativa, como no caso em que eu estipule: "Dou-te tal coisa se tu me deres dez", a doação é válida, e fica suspensa até que ocorra a condição. De tal forma que, caso tu me peças a coisa, posso opor exceção <alegando> que tu não tenhas me dado os dez. Assim também, se a condição for impossível, como no caso em que eu diga: "Dou-te esta coisa se tocares o céu com o dedo", a doação não é válida, e a condição deverá ser tida por inexistente. Assim também, a doação é inválida $a b$ initio, mas encontra-se pendente $<$ quando $>$ a condição aposta $<$ depender $>$ da vontade de um terceiro, como no caso em que eu diga: "Dou-te essa coisa se Tício quiser", ou "<se Tício > o julgar assim", ou "<se Tício> fizer aquilo de tal forma", porque a menos que <Tício> faça isso, a doção não será válida. Da mesma forma, se a condição for casual, como no caso em que eu diga: "Dou-te tal coisa se o navio vier da Ásia, 
male/female", ou "to A and B and the heirs of their bodies" etc.], pela qual o bem imóvel reverteria em favor do concedente caso o concessionário morresse sem deixar descendentes vivos na linha reta ${ }^{218}$.

O principal instituto a partir do qual surgiu o estate in fee tail denominava-se maritagium $^{219}$ e consistia numa concessão condicionada de terras, feita ao marido ${ }^{220}$, que

ou se Tício se eleger cônsul", a doação ficará suspensa, porque essas espécies de doações dependem dos acidentes da fortuna. Se, no entanto, a condição for mista e disjuntiva, sendo, por exemplo, em parte potestativa e em parte casual, como no caso em que eu diga: "Dou-te esta coisa se tu me deres dez", basta que apenas uma dessas <condições> seja adimplida <para que o negócio seja válido>. Mas se várias condições forem apostas à doação conjuntivamente, como no caso em que se diga: "Se tal coisa e tal outra forem feitas", todas <as condições $>$ deverão ser obedecidas; se disjuntivamente, conforme foi dito acima, basta observar uma ou outra delas. Da mesma forma, dentre as condições, alguma pode ser expressa e elaborada com palavras negativas, como no caso em que se diga: "Se o Tício não for o herdeiro, sejas tu o herdeiro", ou "se tu não tiveres herdeiros do próprio corpo, então que a terra assim doada reverta em favor de tais <pessoas>”, <seja> um ou vários, simultânea ou sucessivamente).

${ }^{218}$ Cf. R. Megarry e W. WADE, The Law of Real Property cit. (nota 1 supra), p. 71.

219 A palavra maritagium, no direito inglês, comporta várias acepções. Assim, de acordo com A. M. BurRILl, A New Law Dictionary cit., vol. II (nota 13 supra), p. 705 (no verbete “maritagium”), pode significar o direito que um senhor feudal tinha de oferecer um menor sob a sua guarda (custodia) em casamento, cf. Bracton f. 89: "Cum autem heres minor et non maritatus extiterit sub custodia domini, masculus vel femina, sicut de feodo militari, ad dominum capitalem sub cuius custodia ipse fuerint pertinebit maritagium pleno iure" (Existindo um herdeiro menor de idade sob a guarda do senhor, <seja do sexo > masculino ou feminino, tal como no caso do feodum militaris, o <direito $>$ de maritagium pertence de pleno direito ao senhor chefe sob cuja cuja guarda eles estiverem). Conforne explicado em J. BEAMES, A Translation of Glanville cit. (nota 10 supra), $\mathrm{p}$. 113, nt. 1, o termo também pode referir-se ao matrimônio, no sentido moderno da palavra.

Já o sentido histórico adotado toda vez que se trata do fee tail é o de uma doação de terras feita por um senhor que acompanha a mulher, normalmente a própria filha, oferecida em casamento, cf. H. SPELMANNUS, Glossarium cit. (nota 13 supra), p. 216 (no verbete "maritagium"): "Dicitur id quod viro datur cum uxore; dotem enim appellamus Angli, non quod vir accipit, fed quod fomina. Glanvil. lib. 7 cap. I. In alia acceptione accipitur dos fecundum leges Romanas (Jecundum quas proprie appellatur dos) id quod muliere datur viro, quod vulgariter dicitur maritagium".

H. SPELMANNUS faz referência a um deslocamento nominal muito comum entre os juristas medievais ingleses, que designavam por meio da palavra dos não o patrimônio entregue ao marido para auxiliá-lo no sustento do núcleo familiar (como ocorria no direito romano), mas os bens doados (até um terço do seu patrimônio) por um homem livre à sua futura mulher na porta da igreja, logo antes do casamento, com o objetivo de constituir um patrimônio que servisse para o sustento e educação dos filhos do casal caso o marido morresse antes da mulher, cf. Bracton f. 92: "Et sciendum quod dos est id quod liber homo dat sponsae suae ad ostium ecclessiae propter onus matrimonii et nuptias futuras, ad sustentationem uxoris et educationem liberorum cum fuerint procreati, si vir praemoriatur" (E deve-se saber que o dote é aquilo que o homem livre dá do seu patrimônio na porta da igreja em razão do ônus do matrimônio e das núpcias futuras, para o sustento da sua mulher e a educação dos filhos que eles tenham produzido, caso o homem morra antes < da mulher>).

Em Glanvill 6, 1 [=R. Glanvilla, Tractatus de legibus cit. (nota 10 supra), p. 77], contudo, já se advertia que na Inglaterra a palavra dos tinha um significado particular: "Dos duobus modis dicitur. Dos enim dicitur vulgariter, id quod aliquis líber homo dat fponfa fuce ad Oftium Ecclefia tempore defponfationis fua" (O $<$ termo $>$ dote se usa de duas formas. $<$ O termo $>$ dote, usado vulgarmente, $<$ designa $>$ aquilo que um homem livre dá <à sua futura mulher> do seu patrimônio na porta da igreja no momento do seu casamento).

Essa particularidade semântica do direito inglês exige uma distinção conceitual e terminológica, pela qual o vocábulo dowry, adequadamente entendido, significa dos, ou seja, o patrimônio que a mulher entregava ao marido em função do casamento. Já a palavra dower, que inicialmente era a doação feita pelo marido à futura esposa na porta da igreja, com o tempo passou a ser o terço do patrimônio do marido que o common law destinava ex lege à viúva, independentemente de uma doação expressa antes do casamento, cf. A. M. BURRILL, $A$ New Law Dictionary cit., vol. I (nota 13 supra), pp. 400 e 401 (nos verbetes “dower" e "dowry"). De acordo com H. SPELmannus, Glossarium cit. (nota 13 supra), pp. 174-175 (no verbete "doarium"), a palavra dower é derivada do francês medieval douaire. Acerca do dower, cf. Co Litt 30a $(1,5,36)$ [=E. CoKE, The First Part of the Institutes cit., vol. I (nota 10 supra), s. n.], Litt 36 [=E. WAMBAUGH, Littleton's Tenures - In English cit. 
acompanhava uma filha que não fosse herdeira entregue em matrimônio ${ }^{221}$, de modo a fornecer um patrimônio que auxiliasse a nova família a estabelecer-se economicamente ${ }^{222}$.

\author{
Já no século XII ${ }^{223}$, essa concessão normalmente assumia a forma denominada
}

frank marriage [=liberum maritagium], em cujo caso o marido não prestava homagium, de

(nota 10 supra), p. 16] e Bl Comm 2, 8, 129-130 [=W. BlACKSTONE, Commentaries cit., vol. II (nota 10 supra), pp. 129-130].

${ }^{220}$ De acordo com W. S. HoldSwORTH, A History of English Law cit., vol. III (nota 12 supra), p. 111, a concessionária era a própria filha ou mulher dada em casamento. Porém, essa afirmação não condiz com as fontes a respeito do tema, que são claras ao afirmar que tais concessões eram feitas a alguém junto com a mulher dada em casamento - tal como em Glanvill 7, 18 [=R. GLANVILLA, Tractatus de legibus cit. (nota 10 supra), p. 120]: “(...) aliquis liber homo aliquam partem terrae fuce dat cum aliqua muliere alicui in maritagium (...)”-, donde se infere que a concessão era feita ao marido.

${ }^{221}$ Caso a futura esposa fosse herdeira, aplicava-se outro estate do direito inglês denominado tenancy by the curtesy of England, pelo qual o marido, caso sua mulher falecesse antes dele, tinha o direito de manter-se na posse dos bens da esposa até o momento da sua morte, desde que tivesse nascido pelo menos um herdeiro com vida, cf. T. F. T. PluCKNETT, A Concise History cit. (nota 12 supra), pp. 568-569. O instituto é mencionado em Glanvill 7, 18 [=R. Glanvilla, Tractatus de legibus cit. (nota 10 supra), p. 121] ainda como parte do maritagium: "Cum quis itaque terram aliquam cum uxore fua in maritagium ceperit, fi ex eadem uxore fua haredem habuerit filium vel filiam, clamantem et auditum infra quator parietes; fi idem vir uxorem fuam supervixerit, five vixerit hares five non, illi in vita fua remanet maritagium illud; poft mortem vero ipfius ad donatorem vel ejus haredes eft reverfurum" (Tendo alguém de tal modo adquirido alguma terra junto com a sua mulher em maritagium, <e > caso tenha <ele > produzido um herdeiro com a mesma mulher $<$ do sexo $>$ masculino ou feminino que haja chorado e sido ouvido ente quatro paredes, se o mesmo homem sobreviver à sua mulher, independentemente de o herdeiro viver ou não, permanece aquele maritagium durante a sua vida $<\mathrm{e}>$, certamente, após a morte < do viúvo> haverá de reverter ao doador ou aos seus herdeiros).

$\mathrm{O}$ instituto também é mencionado em Bracton f. 438: “(...) quod tenet per legem Angliae ad vitam suam ratione pueri qui auditus fuit clamare inter quatuor parietes (...)" ((...) que tem em virtude do direito da Inglaterra durante a sua vida em razão de uma criança que foi ouvida chorar entre quatro paredes (...)). De acordo com T. F. T. PluCKNETT, A Concise History cit. (nota 12 supra), p. 569, nt. 1, o mais plausível é que essa tenure tenha surgido como um modo de favorecer os cavaleiros normandos de condição econômica humilde que se casavam com as filhas de anglo-saxões ricos.

${ }^{222}$ Cf. J. H. BAKER, An Introduction cit. (nota 12 supra), p. 271. O autor também considera que um dos objetivos do maritagium fosse obter um marido de boa condição sócio-econômica para a filha não herdeira. Contudo, parece que essa suposição seja mais apropriada à função que desempenharia uma promessa antes do casamento, nos moldes dos espousals [=sponsalia], os quais, no entanto, não tinham conteúdo econômico per se - embora pudessem gerar conseqüências jurídicas de conteúdo econômico -, pois constituíam uma simples promessa de casamento, cf. A. M. BURRILL, A New Law Dictionary cit., vol. I (nota 13 supra), p. 432 (no verbete "espousals").

${ }^{223}$ Cf. Glanvill 7, 18 [=R. Glanvilla, Tractatus de legibus cit. (nota 10 supra), pp. 120-121]: "Maritagium autem aliud nominatur liberum, aliud fervitio obnoxium. Liberum dicitur maritagium, quando aliquis liber homo aliquam partem terre fuce dat cum aliqua muliere alicui in maritagium, ita quod ab omni fervitio terra illa fit quieta, et a fe et horedibus fuis verfus capitalem Dominum acquietanda. Et in hac quidem libertate ita ftabit terra illa ufque ad tertium haredem, nec interim tenebuntur haredes inde facere aliquod homagium; poft tertium vero haredem ad debitum fervitium terra ipfa revertetur et homagium inde capietur; quia fi fuerit pars Feodi militaris, pro quantitate terra fervitium Feodi inde preftabit. Solet autem quandoque terra aliqua dari in maritagium, falvo et retento debito quidem fervitio ipfi capitali Domino; et tunc quidem tenebuntur maritus mulieris ipfius et heredes fui fervitium illud facere, fed fine homagio, ufque ad tertium haredem. Tertius vero hares primo inde faciat homagium et omnes haredes fui postmodum. Alia tamen fidelitas, fub fidei vel facramenti interpofitione, a mulieribus vel earum haredibus interim fere fub eadem forma et eifdem verbis, quibus homagium fieri folet, preftari debet (...)" (O maritagium denomina-se "livre" ou "gravado de serviço". Diz-se liberum maritagium quando algum homem livre dá uma certa parte da sua terra $<$ junto> com uma mulher a alguém < a título de> maritagium, de modo que aquela terra seja imune em relação a todo serviço e livre de qualquer ônus para ele e seus herdeiros em face do senhor chefe. Certamente, nessa liberalidade ficará aquela terra até o terceiro herdeiro, e durante esse tempo os herdeiros não ficarão obrigados a prestar qualquer homagium por aquele lugar. Após o terceiro <herdeiro $>$, no entanto, a mesma terra voltará <a 
modo a impedir que os parentes do concessionário na linha colateral herdassem a terra em função da sua $\operatorname{seisin}^{224}$.

Na ausência da homagium, o concedente mantinha-se na seisin do imóvel, com o qual esperava a reversão do imóvel, em favor dele mesmo ou dos seus herdeiros, caso o concessionário não deixasse herdeiros vivos na linha reta ${ }^{225}$. Em contrapartida, o concessionário e seus descentes ficavam isentos, no caso do liberum maritagium, da prestação de services durante três gerações. Caso se tratasse do maritagium servitio obnoxium, o senhor fazia a concessão mediante a prestação de um juramento de lealdade (oath of fealty) e exigia a prestação de services. Em todo caso, somente o terceiro descendente do concessionário na

ficar sujeita $>$ ao serviço devido e será recebida a homagium por aquele lugar; e caso <o terreno $>$ tenha sido parte de um feodum militaris, <o tenant $>$ prestará o serviço do feudo de acordo com a quantidade de terra. Costumase, no entanto, às vezes dar-se alguma terra <a título de> maritagium, certamente ressalvado e retido o < direito à prestação do $>$ serviço devido ao próprio senhor chefe; e então, de fato, o próprio marido da mulher e seus herdeiros ficarão obrigados a prestar aquele serviço, porém sem <prestar> homagium, até o terceiro herdeiro. $\mathrm{O}$ terceiro herdeiro, certamente, deverá prestar homagium pela primeira vez e todos os seus herdeiros daí em diante. Contudo, durante esse período deverá ser prestada uma outra fidelitas, pelas mulheres ou os seus herdeiros, mediante a interposição de um juramento ou de um sacramento <realizado> sob aproximadamente a mesma forma e as mesmas palavras pelas quais a homagium costuma ser feita).

${ }^{224}$ Cf. T. F. T. PluCKNETT, A Concise History cit. (nota 12 supra), p. 547.

${ }^{225}$ Além das concessões feudais feitas a título de maritagium, no século XIII as doações de terras feitas a filhos menores também passaram a adotar a mesma forma. Na Inglaterra, as normas costumeiras medievais favoreciam, de modo a evitar a fragmentação do patrimônio familiar, a concentração do patrimônio hereditário na pessoa do filho primogênito, excluindo os ascendentes e desfavorecendo as mulheres, cf. K. E. GÜTERBOCK, Henricus de Bracton cit. (nota 1 supra), pp. 125-126.

Daí que, caso o senhor quisesse doar terras a um filho menor (i.e., não primogênito), tinha que fazer uma concessão ainda em vida, pois na época era ainda vedada a transmissão testamentária de terras, cf. Glanvill 7, 1 [=R. GlanVILla, Tractatus de legibus cit. (nota 10 supra), p. 92]: "Licet autem ita generaliter cuilibet de terra fua rationabilem partem pro fua voluntate, cuicunque voluerit, libere in vita fua donare; in extremis tamen agenti non eft cuiquam hactenus permiffum, quia poffit tunc immodica fieri horeditatis diftributio, fi fuiffet hoc permiffum" (De modo geral é lícito a qualquer um doar livremente, estando ainda com vida, uma parte razoável da sua terra como bem entender; no leito de morte, no entanto, até hoje não se permite a alguém agir <assim>, porque $<$ o concedente $>$ poderia nesse momento fazer uma distribuição irracional da herança, caso isso lhe fosse permitido).

Nesse contexto, quando o senhor queria conceder terras a um filho menor era comum acrescentar uma cláusula condicional resolutiva que restringia a transmissão hereditária do bem imóvel aos filhos do concessionário com uma esposa ainda indeterminada [= "to $H$ and the heirs of his body begotten"] ou com uma esposa determinada [= "to $H$ and to his wife $W$ and to the heirs of $H$ begotten on $W$ '], junto com uma cláusula de reversão em favor do herdeiro do concedente, cf. J. H. BAKER, An Introduction cit. (nota 12 supra), p. 272. O motivo para a inserção dessa condição parece ter sido a regra que impedia a alguém ser senhor e herdeiro ao mesmo tempo, inscrita em Glanvill 7, 1 [=R. GLANVILLA, Tractatus de legibus cit. (nota 10 supra), p. 97], ao estabelecer a impossibilidade de reversão, em favor do pai concedente ainda vivo ou do seu herdeiro, de uma concessão condicional, mesmo que descumprida a condição: "Sed fciendum, quod pater ipfe terram illam nullo modo de jure regni retinere poteft, quia non poteft fimul effe hares et Dominus (...)" (Mas deve-se saber que o próprio pai não pode, sob qualquer hipótese, de acordo com o direito do reino, reter aquela terra, porque não pode ao mesmo tempo ser herdeiro e senhor (...)).

Em suma, no caso das concessões feitas aos filhos menores, a intenção do concedente era permitir o gozo do imóvel ao filho menor, sem, no entanto, correr o risco de eventualmente ter o patrimônio familiar fragmentado entre parentes mais distantes, o que inevitavelmente ocorreria se a concessão fosse in fee simple, sem qualquer condição, e o filho menor morresse sem deixar filhos após a morte do seu pai, em cujo caso o imóvel iria para os colaterais do filho menor, sem voltar para o primogênito. Cabe ressaltar que para S. F. C. MILSOM, Historical Foundations cit. (nota 12 supra), pp. 172-173 a necessidade de evitar a fragmentação da herança seria a força motriz por trás da criação do fee tail. 
linha reta adquiria o direito de prestar homagium, de modo a estabilizar a sua situação e tornar uma conditional fee num fee simple ${ }^{226}$.

A principal consequência da condição aposta à concessão era tornar insegura e instável jurídicamente, enquanto não fosse prestada a homagium, qualquer alienação do terreno a terceiros feita pelo concessionário, o que constituía uma dificuldade para o tráfico jurídico de bens imóveis, em função da sempre latente possibilidade de reversão em favor do concedente originário ou os seus herdeiros ${ }^{227}$.

No século XIII, no entanto, aparecem indícios nas fontes de que tais concessões condicionadas se tornavam livremente alienáveis após o nascimento do primeiro herdeiro ${ }^{228}$. Em razão disso, cresceu o descontentamento entre os concedentes originários e, principalmente, entre os seus herdeiros, dado que a condição sob a qual a concessão tinha sido feita não estava dotada de qualquer eficácia ${ }^{229}$.

${ }^{226}$ Cf. S. F. C. Milsom, Historical Foundations cit. (nota 12 supra), pp. 171-172.

${ }^{227}$ Cf. J. H. BAKER, An Introduction cit. (nota 12 supra), pp. 272-273. Os autores em geral, no entanto, não são claros em relação ao grau de alienabilidade dos bens imóveis sujeitos a esse regime, provavelmente porque as fontes a respeito do tema também são um tanto erráticas. Um exemplo é Loppington v Lestrange (1221), in J. H. BAKer e S. F. C. Milsom, Sources of English History cit. (nota 9 supra), pp. 43-44, em que o réu venceu uma demanda pela posse da terra em face do seu tio, pelo fato de que o réu era filho de um casal de concessionários a título de maritagium e que as terras tinham sido concedidas pelo pai do autor. A decisão em si era de se esperar, na medida em que a reversão somente ocorreria caso os concessionários originais não tivessem descendentes diretos vivos além da terceira geração. O réu representava a segunda geração, motivo pelo qual, apesar de ter um título dificilmente alienável, ainda tinha direito à posse da terra a título de uma concessão condicionada. O que torna o juízo algo inconsistente é que, ao prolatar a sentença, o júri declara que o réu e os seus herdeiros serão concessionários do autor para sempre, o que não faz sentido no contexto do maritagium, dada a possibilidade de reversão caso o réu não tivesse herdeiros da classe prescrita, ou a possibilidade de alienação a um terceiro caso os tivesse.

${ }^{228}$ Apesar de R. MEgARRY e W. WADE, The Law of Real Property cit. (nota 1 supra), p. 71 considerar que a livre alienabilidade dos imóveis concedidos in fee tail provocada pelo nascimento de um filho se aplicasse somente aos casos de maritagia, a verdade é que a literatura historiográfica é praticamente uníssona ao afirmar que todos os conditional fees, fossem maritagia ou concessões feitas aos filhos menores, desde meados do século XIII até a promulgação do Statutum de Donis Conditionalibus 1285 [=Stat. 13 Edw. I (1285), c. 1] eram considerados alienáveis pelos tribunais reais, desde que o concessionário in tail tivesse tido um filho, pois se considerava adimplida a condição aposta à concessão, cf. J. H. BAKER, An Introduction cit. (nota 12 supra), pp. 272-273; S. F. C. MILSOM, Historical Foundations cit. (nota 12 supra), pp. 174-175.

${ }^{229}$ Cf. F. Pollock e F. W. MaItLAnd, The History of English Law cit., vol. II (nota 12 supra), pp. 17-18. De acordo com T. F. T. PluCKNETT, A Concise History cit. (nota 12 supra), pp. 550-551, essa tendência já é perceptível em Bracton f. 18: "Et unde si huiusmodi heredes procreati fuerint, ipsi tantum vocantur ad successionem, et si taliter feoffati aliquem ulterius inde feoffaverint, tenet feoffamentum, et heredes tenentur ad warantiam, cum ipsi nihil clamare possint nisi ex successione et descensu parentum, quamvis quibusdam videatur quod ipsi feoffati sint cum parentibus, quod non est verum" (E daí <entende-se que> caso tenham nascido herdeiros desta espécie <(i.e., os herdeiros previstos na cláusula condicional)>, somente eles são chamados à sucessão, e se depois os que receberam a concessão dessa forma tiverem feito uma outra concessão < do mesmo imóvel> a alguém, <este> tem a concessão <validamente>, e os herdeiros são obrigados a prestar garantia, dado que nada podem exigir salvo a título de sucessão e descendência dos seus pais, embora a alguns pareça que os mesmos <herdeiros $>$ tenham recebido a concessão junto com os seus pais, o que não é verdade).

$\mathrm{O}$ aspecto fundamental deste fragmento é que se considera que os herdeiros do tenant in tail não tem qualquer direito adquirido em relação às terras submetidas ao regime do conditional fee. Eles apenas teriam uma mera expectativa de direito, e portanto não poderiam recuperar a posse da terra após a morte dos seus pais, tornando a alienação da terra a terceiros plenamente válida. 
Tal descontentamento veio à tona numa petição dos grandes nobres elaborada em 1258, na qual reclamavam da falta de eficâcia das condições apostas às concessões a título de maritagium e pediam a criação de um remédio nos tribunais reais. Pedia-se um remédio judicial nos tribunais reais ex aequitate, pelo qual os concedentes pudessem recuperar a posse dos terrenos submetidos a esse regime ${ }^{230}$.

O estate in fee tail, no entanto, tal como ficou configurado no contexto jurídico do common law, nasceu como consequência indireta do Statutum de Donis Conditionalibus 1285, promulgado durante o reinado de Eduardo $\mathrm{I}^{231}$. O diploma retira do titular da concessão

${ }^{230}$ A Petition of the Barons 1258 é uma longa lista de reclamações dos nobres em face do rei, a maior parte das quais estava ligada à observância das disposições estabelecidas pela Magna Carta 1215 e suas reedições, cf. W. STuBbS, Select Charters cit. (nota 8 supra), p. 373. A parte relevante para o surgimento do fee tail é Petitio Baronum 1258, c. 27: "Item petunt remedium de maritagiis alienatis, videlicet in tali casu: si aliquis dederit alicui unam carucatam terrae in maritagio cum filia vel sorore habendam et tenendam eis et haeredibus de praedictis filia vel sorore exeuntibus, ita videlicet quod, si praedicta filia vel soror obierit sine haerede de corpore suo, terra cum pertinentiis integre revertatur ad ispum qui terram dederit in maritagium vel ad haeredes suos; et cum praedictum donum non sit absolutum sed conditionale, tamen mulieres post mortem virorum suorum in viduitate sua dant vel vendunt praedicta maritagia et infeodant pro voluntate sua, licet haeredes de corpore suo non habuerint, nec hujusmodi feofamenta hucusque aliquatenus fuerunt revocata. Unde petunt quod ex aequitate juris, ratione praedictae conditionis, sive per breve de ingressu, vel aliquo alio modo competenti provideatur remedium ad revocandum hujusmodi feofamenta, et quod in tali casu procedatur ad judicium pro ipso petente" (Da mesma forma, <os nobres $>$ pedem um remédio para os maritagia alienados, tal como neste caso: se alguém tiver dado a outrem uma carucata de terra a título de maritagium junto com a sua filha ou a sua irmã para que seja tida e detida por elas e pelos herdeiros nascidos das supramencionadas filha e irmã, de tal forma que, caso a supradita filha ou irmã faleçam sem deixar herdeiros <nascidos $>$ do próprio corpo, a terra e os seus acessórios revertam integralmente em favor da mesma pessoa que tenha concedido a terra a título de maritagium ou aos seus herdeiros, dado que a supramencionada doação não é absoluta mas condicional; mesmo assim, as mulheres, após a morte dos seus maridos <e > durante a sua viuvez doam e vendem os supraditos maritagia e fazem concessões feudais ao seu bel prazer, muito embora não tenham tido herdeiros nascidos do próprio corpo, nem até agora as concessões dessa espécie tenham sido de qualquer forma revogadas. Motivo pelo qual <os nobres $>$ pedem, com base na equidade do direito, em razão das supramencionadas condições <apostas a tais concessões>, seja meidante um breve de ingressu, ou por qualquer outro meio competente, seja fornecido um remédio para a revogação dessa espécie de concessão, e que em tal caso se conceda um julgamento em favor do mesmo demandante).

231 Trata-se do Statutum de Donis Conditionalibus 1285 [=Stat. 13 Edw. I (1285), c. 1]: "In primis, de tenementis quae multotiens dantur sub conditione, videlicet cum aliquis dat terram suam alicui viro et ejus uxori et haeredibus de ipsis viro et muliere procreatis, adjecta conditione expressa tali, quod si hujusmodi vir et mulier sine haerede de ipsis viro et muliere procreato obissent, terra sic data ad donatorem vel ad ejus haeredem revertatur; in casu etiam cum quis dat tenementum in liberum maritagium quod donum habet conditionem annexam, licet non exprimatur in carta doni, quae talis est, quod si vir et mulier sine haerede de ipsis viro et muliere procreato obierint, tenementum sic datum ad donatorem vel ad ejus haeredem revertatur; in casu etiam cum quis dat tenementum alicui et haeredibus de corpore suo exeuntibus, durum videbatur et adhuc videtur hujusmodi donatoribus et haeredibus donatorum quod voluntas ipsorum in donis suis expressa non fuerit prius nec adhuc est observata. In omnibus enim praedictis casibus post prolem suscitatam et exeuntem ab ipsis quibus tenementum sic fuit datum conditionaliter, hucusque habuerunt hujusmodi feoffati potestatem alienandi tenementum sic datum, et exhaeredandi de tenemento exitum ipsorum contra voluntatem donatorum et formam de dono expressam; et praeterea cum deficiente exitu de hujusmodi feoffatis, tenementum sic datum ad donatorem vel ad ejus haeredem reverti debuit per formam in carta de dono expressam, licet exitus, si quis fuerit, obisset, per factum et feoffamentum ipsorum, quibus tenementum sic fuit datum sub conditione, exclusi fuerunt hucusque de reversione eorundem tenementorum, quod manifeste fuit contra formam doni sui. Propter quod Dominus Rex, perpendens quod necessarium et utile est in praedictis casibus apponere remedium, statuit quod voluntas donatoris secundum formam in carta doni sui manifeste expressam de caetero observetur; ita quod non habeant illi, quibus tenementum sic fuit datum sub conditione, potestatem alienandi tenementum sic 
condicionada (o tenant in tail), definitivamente, a legitimidade para alienar o terreno, e estabelece, ao mesmo tempo, que a vontade do concedente deverá ser respeitada, seja pela reversão da concessão, em caso de ausência de herdeiros na linha reta, seja pela permanência da concessão com os herdeiros nascidos de acordo com a condição estipulada ${ }^{232}$.

datum, quominus ad exitum illorum quibus tenementum sic fuerit datum remaneat post eorum obitum, vel ad donatorem vel ad ejus haeredem si exitus deficiat per hoc quod nullus sit exitus omnino, vel si aliquis exitus fuerit, per mortem deficiet, haerede hujusmodi exitus deficiente (...)" (Em primeiro lugar, acerca dos tenementa que muitas vezes são doados sob condição, isto é, quando alguém doa sua terra a um marido e à sua esposa e aos herdeiros nascidos desse mesmo marido e dessa mesma mulher, aposta uma condição expressa <estabelecendo> que, caso o marido e a mulher morram sem herdeiro nascido deles próprios, a terra assim doada reverta em favor do doador ou do seu herdeiro; também acerca do caso em que alguém doa um tenementum em liberum maritagium, doação essa que tem uma condição anexa, embora não esteja expresso na carta de doação que é desta natureza <a condição>: que se o marido e a mulher morrerem sem herdeiros nascidos dos próprios $<$ corpos>, o tenementum doado dessa forma reverta em favor do doador ou do seu herdeiro; também acerca do caso em que alguém doa um tenementum a alguém e aos herdeiros provindos < do próprio corpo $>$, parecia penoso e até hoje parece aos doadores e aos herdeiros dos doadores que a sua vontade, expressa $<$ na dita cláusula > da sua doação, não tenha sido anteriormente observada nem ainda hoje <o seja >. Evidentemente, em todos os casos supramencionados, uma vez nascida e reconhecida a prole daqueles mesmos a quem o tenemenentum foi doado condicionalmente, os concessionários dessa espécie até agora tiveram o poder de alienar o tenementum assim doado e de deserdar, em relação ao tenementum, seus próprios descendentes, <mesmo> contra a vontade dos doadores e a forma expressa da doação; e, além disso, quando os concessionários dessa espécie carecem de descendentes, <em cujo caso > o tenementum assim doado deve reverter em favor do doador ou do seu herdeiro, em razão da forma expressa na carta de doação, mesmo que a descendência, caso tenha havido alguma, tenha morrido, por meio de um ato e de uma concessão daqueles a quem o tenementum foi doado sob condição, <os doadores e os seus herdeiros $>$ tem sido privados da reversão dos seus tenementa, o que era manifestamente contra a forma da doação. Por tal motivo, o senhor rei, julgando que é necessário e útil fornecer remédio para os supraditos casos, estabelece que a vontade dos doadores, conforme expressa manifestamente na forma da sua carta de doação seja, de agora em diante, observada; de tal forma que aqueles a quem o tenementum foi doado sob essa condição não tenham poder para alienar o tenementum doado, mas que $<$ o tenementum $>$ permaneça, após as suas mortes, para a descendência para a qual foi doada, ou $<$ reverta $>$ para o doador ou seu herdeiro se faltar descendência pelo fato de não existir qualquer descendente, ou ainda, caso tenha havido descendência, <porém> esta tenha deixado de existir por ter morrido, carecendo desse modo de descendente herdeiro (...)). Cabe notar que o sentido da palavra tenementum, neste statutum em particular, tem um significado amplo que inclui não apenas o direito à posse do imóvel a título de concessão, como também quaisquer rendas e direitos sucessórios provenientes dele, cf. K. E. DiGBY, An Introduction cit. (nota 115 supra), p. 226, nt. 3. No texto, a palavra exitus tem o sentido de "descendentes", cf. A. M. BurriLl, A New Law Dictionary cit., vol. I (nota 13 supra), pp. 457-458 (no verbete "exitus").

${ }^{232} \mathrm{O}$ remédio concedido é o formedon in the descender [=breve de forma donationis], pelo qual o herdeiro do concedente podia exigir o cumprimento da condição estipulada na concessão, cf. S. F. C. MILsOM, Historical Foundations cit. (nota 12 supra), p. 175.

Sua formulação básica era: "Rex vicecomiti M. salutem. Praecipe A. quod juste et sine dilatione reddat B. manerium de $N$. cum pertinenttis quod $C$. dedit D. et E. uxori ejus et haeredibus de corporibus ipsorum D. et E. exeuntibus et quod post mortem praedictorum D. et E. praefato B. filio et haeredi praedictorum $D$. et $E$. descendere debet per formam donationis praedicti, ut dicit. Et nisi fecerit etc." (O rei ao sheriff de $\mathrm{M}$., saudações. Comanda que A. com justiça e sem dilação entregue a B. o manor de N. com os seus acessórios, o qual C. deu a D. e E. sua mulher e aos herdeiros provenientes dos próprios corpos de D. e E., e que após as mortes dos supraditos D. e E. deve transmitir-se por descendência ao supramencionado B., filho e herdeiro dos supraditos D. e E., de acordo com a forma da supradita doação, tal como <B. $>$ alega. E caso assim não se faça etc.). Cf. J. H. BAKER, An Introduction cit. (nota 12 supra), pp. 540 e 541. 
Em função das disposições do statutum $^{233}$, a interpretação dos tribunais reais relativa a esses negócios, ao longo dos séculos XIV e XV, tornou essas concessões subordinadas a uma cláusula condicional num estate perpetuamente intransferível ${ }^{234}$, criando, de fato, um regime jurídico de inalienabilidade ad infinitum para os imóveis a ele submetido $^{235}$. Assim, a partir da vigência do statutum, essa concessão condicionada (conditional fee) passou a ser conhecida como fee tail ou entail ${ }^{236}$, o qual, por ser um estate

233 As palavras do statutum que permitiam essa interpretação eram, especificamente, aquelas que determinavam a ilegitimidade do concessionário para alienar o imóvel (...ita quod non habeant illi, quibus tenementum sic fuit datum sub conditione, potestatem alienandi tenementum sic datum...) em função do cumprimento da cláusula de restrição da classe de herdeiros (...quominus ad exitum illorum quibus tenementum sic fuerit datum remaneat post eorum obitum...) ou da cláusula de reversão ao doador ou seus herdeiros em caso de ausência de herdeiros da classe especificada (...vel ad donatorem vel ad ejus haeredem si exitus deficiat per hoc quod nullus sit exitus omnino, vel si aliquis exitus fuerit, per mortem deficiet, haerede hujusmodi exitus deficiente...).

De acordo com J. BiAnCALANA, The Fee Tail and the Common Recovery in Medieval England - 11761502, Cambridge, Cambridge University, 2001, pp. 87-88, o surgimento do regime de inalienabilidade perpétua deveu-se, num primeiro momento, ao fato de que o diploma não faz referência ao limite de três gerações para a vigência da cláusula de restrição hereditária, assim como também não menciona as consequiências jurídicas da observância da mesma cláusula. O statutum apenas se limita a estabelecer a impossibilidade de alienação em função da manutenção de um direito, em princípio perpétuo, de reversão em favor do concedente originário ou os seus herdeiros (e eventualmente aqueles que se subrogassem nos seus direitos), o que exigiria, por implicação lógica, uma inalienabilidade ad infinitum do estate.

${ }^{234}$ Uma tendência no sentido de alargar as premissas do Statutum de Donis Conditionalibus 1285 [=Stat. 13 Edw. I (1285), c. 1] pode ser vista em Belyng v Anonymous (1312), in J. H. BAKER e S. F. C. MILSOM, Sources of English History cit. (nota 9 supra), pp. 57-58, em que o réu alegou que a restrição à alienação do fee tail não se aplicava além da primeira geração do tenant in tail (nos moldes do que ocorria antes da vigência do statutum), mas o Court of Common Pleas entendeu que os descendentes do tenant in tail estavam incluídos no âmbito da proibição de alienação imposta pelo statutum.

Em sentido similar, em Helton v Kene (1344), in J. H. BAKER e S. F. C. MILSOM, Sources of English History cit. (nota 9 supra), pp. 59-61 o tribunal rejeitou a alegação de que o nascimento de um herdeiro constituia adimplemento da condição numa concessão in fee tail.

${ }^{235}$ Cf. J. Biancalana, The Fee Tail cit. (nota 233 supra), pp. 88-89. Para esse autor, um dos fatores que levou os tribunais a autorizar essa interpretação foi que a questão da sucessão e a questão da alienabilidade começaram a ser tratadas separadamente. Daí que a evolução do fee tail e sua transformação num estate inalienável se desse por meio de alterações no processo dos tribunais que permitiram o alargamento da proteção jurídica concedida ao fee tail. Tal alargamento ocorreu em duas frentes. De um lado, quanto ao direito à sucessão dos herdeiros do tenant in fee tail, os tribunais deixaram de exigir que o demandante provasse toda a sua linhagem, permitindo que fosse mencionado apenas o último ascendente na posse do bem (seised). De outro, no que diz respeito às restrições à alienação, a legitimidade para contestar uma alienação do fee tail foi concedida a qualquer descendente, independentemente de grau.

${ }^{236}$ Cf. F. POLlOCK e F. W. MAITLAND, The History of English Law cit., vol. II (nota 12 supra), p. 19, embora para J. H. BAKER, An Introduction cit. (nota 12 supra), p. 272 mesmo antes do statutum as denominações feodum talliatum e conditional fee significassem a mesma coisa.

A opinião no sentido de que a denominação mudou a partir do Statutum de Donis Conditionalibus 1285 [=Stat. 13 Edw. I (1285), c. 1] aparece também em Litt 13 [=E. WAMBAUGH, Littleton's Tenures - In English cit. (nota 10 supra), p. 7]: "Tenant in fee tail is by force of the statute of Westminster II, cap. 1; for before the same statute, all inheritaces were fee simple; for all gifts which be specified in that statute were fee simple conditional at the common law, as appeareth by the rehearsal of the same statute. And now by this statute, tenant in tail is in two manners, that is to say, tenant in tail general, and tenant in tail special".

Ao que tudo indica, já no século XV, época em que escreveu Thomas Littleton, as cláusulas do fee tail já tinham sido tipificadas, e podiam ser classificadas em tail general e tail special. No primeiro caso, podiam herdar os descendentes do concessionário, fosse este do sexo masculino ou feminino, independentemente de quem fosse o cônjuge; no segundo, somente podiam herdar os descendentes do casal especificado no instrumento, cf. Litt 14-17 [=E. WAMBAUGH, Littleton's Tenures - In English cit. (nota 10 supra), p. 7-8]. 
menos amplo que o fee simple $e^{237}$, deixava sempre um resíduo revertível (reversion) no primeiro concedente, que este ou os seus herdeiros podiam alienar a um terceiro mediante a criação de uma remanescência (remainder) ${ }^{238}$.

O tenant in tail, por outro lado, somente tinha o equivalente a uma concessão vitalícia (life estate). Isso ocorria porque, após a morte do tenant in tail, qualquer alienação que ele tivesse feito em vida podia ser desfeita. Assim, se o tenant in tail deixasse descendentes vivos, estes podiam recuperar o imóvel mediante o writ of formedon in the descender. Por outro lado, se o tenant in tail não deixasse herdeiros da classe prescrita, a condição considerava-se violada e o imóvel revertia em favor do concedente originário, seus herdeiros (reversioners) ou eventuais alienatários (remaindermen) ${ }^{239}$.

A inalienabilidade dos bens imóveis submetidos ao regime do estate in fee tail criou uma série de impedimentos para a circulação do capital fundiário ${ }^{240}$. Essa situação durou, aproximadamente, até o século XVI, momento em que os tribunais reais começaram a desenvolver mecanismos para destruir as perpetuidades criadas pelos entails.

${ }^{237}$ Essa menor amplitude existe apenas em relação à alienabilidade, pois em sentido material, ou seja, em relação aos diversos modos de uso e fruição do imóvel, o tenant in tail tem os mesmos direitos do tenant in fee simple, cf. R. MEGARRY e W. WADE, The Law of Real Property cit. (nota 1 supra), pp. 73-74.

${ }^{238}$ Cf. H. W. CHALlis, Law of Real Property cit. (nota 1 supra), p. 298.

${ }^{239}$ Cf. R. MEgarRy e W. WADE, The Law of Real Property cit. (nota 1 supra), p. 71, nt. 338. A pretensão dos reversioners e os remaindermen, ou seja, do concedente originário e dos seus herdeiros, bem como a pretensão dos seus alienatários, eram tuteladas mediante os writs denominados formedon in the reverter e formedon in the remainder, cf. W. S. HOLDSWORTH, A History of English Law cit., vol. III (nota 12 supra), p. 18 e F. POLlOCK e F. W. MAITLAND, The History of English Law cit., vol. II (nota 12 supra), p. 23, nt. 2.

${ }^{240}$ Algumas das principais conseqüências indesejadas dos estates in fee tail são expostas em B1 Comm 2, 7 , 116 [=W. Blackstone, Commentaries cit., vol. II (nota 10 supra), pp. 129-130]: “(...) Children grew difobedient when they knew they could not be fet afide; farmers were oufted of ther leafes made by the tenants in tail, for, if fuch leafes had been valid, then under colour of long leafes the iffue might have been virtually difinherited; creditors were defrauded of their debts, for, if tenant in tail could have charged his eftate with their payment, he might alfo have defeated his iffue, by mortgaging it ofr as much as it was worth; unnumerable latent entails were produced to deprive purchafers of the lands they had fairly bought (...) So that they were juftly branded, as the fource of new conventions, and mifchiefs unknown to the common law, and almoft univerfally confidered as the common grievance of the realm".

Provavelmente o autor tenha exagerado ao atribuir aos tenants in fee tail todas as consequências sócioeconômicas indesejáveis decorrentes da inalienabilidade. Na verdade, o mais provável é que os interesses dos próprios tenants in tail também estivessem sendo prejudicados, pois não mais conseguiam concluir negócios que envolvessem seus bens imóveis, o que, no fundo, representava um conflito de interesses intergeneracional, pois enquanto os pais muitas vezes desejavam alienar tais imóveis para auferir recursos em espécie, os filhos, em regra, preferiam recebê-los a título de herança, cf. S. F. C. MILsOM, Historical Foundations cit. (nota 12 supra), pp. $178-180$.

Por outro lado, alguns consideravam benéfico manter um sistema patrimonial que assegurasse a continuidade de uma elite dirigente, como bem demonstra a frase atribuída ao homem de letras Samuel Johnson, cf. J. BoswelL, The Life of Samuel Johnson, vol. II, London, National Illustrated Library, 1851, p. 276: “Entails are good, because it is good to preserve in a country a series of men, to whom the people are accustomed to look up as their leaders". Contudo, J. Boswell, o interlocutor, expressa as preocupações de natureza econômica, mesmo no século XIX (em que já existia a possibilidade de destruir os entails), relativas à criação de perpetuidades, cf. J. Boswell, The Life of Samuel Johnson cit., vol. II (nesta nota), p. 277: “(...) there should be one-third, or perhaps one half of the land of one country kept for free commerce; that the proportion allowed to be entailed, should be parcelled out so that no family should be allowed to entail above a certain quantity". 


\section{De um lado, surge o common recovery ${ }^{241}$, espécie de ação fictícia ${ }^{242}$ por meio da}

qual se podia destruir a concessão condicionada e constituir um novo regime de fee simple

sobre o patrimônio em questão, com o qual este ficava livre de quaisquer ônus em face dos herdeiros do tenant in tail $^{243}$.

${ }^{241} \mathrm{O}$ procedimento é descrito em numerosas fontes do direito inglês, sendo uma das mais notáveis a encontrada em Bl Comm 2, 21, 358-360 [=W. BlaCKSTONE, Commentaries cit., vol. II (nota 10 supra), pp. 358360].

O alienatário, tendo entrado previamente em acordo com o tenant in tail, propunha uma ação, denominada praecipe quod reddat, em face deste perante o Court of Common Pleas. O autor então alegava ter sido esbulhado de um imóvel seu a título de fee simple (na verdade, o imóvel in fee tail) por um terceiro, o qual, posteriormente, teria transferido a posse do imóvel em questão ao réu. O réu, portanto, não teria qualquer título no qual basear a sua posse da terra. Na audiência perante o tribunal realizava-se uma espécie de encenação. $\mathrm{O}$ réu chamava a juízo o herdeiro do concedente originário, ou seja, o herdeiro daquele que teria criado a concessão em seu favor e, portanto, estava obrigado a atestar a validade do seu título em juízo ou entregar-lhe terras do mesmo valor (escambium), ou mesmo pagar-lhe o valor equivalente em dinheiro, caso ele, o réu, perdesse a demanda (cf. nota 170 supra). $\mathrm{O}$ ato pelo qual o réu chamava a juízo o concedente originário denominava-se vouch to the warranty, e o concedente, no processo, era denominado voucher. Naquele momento, entrava no tribunal o voucher (o qual, na verdade, era um funcionário do tribunal dedicado a essa função, às vezes apelidado man of straw) e o autor pedia permissão ao juiz para conversar reservadamente com ele (imparl). Após alguns instantes, o autor voltava à audiência, porém sem o voucher. A seguir, o tribunal declarava a revelia do voucher e adjudicava o terreno ao autor, que agora passava a ser titular de um estate in fee simple. O réu, por outro lado, passava a ter um direito de regresso contra o voucher, o qual, contudo, não era mais do que um funcionário do tribunal. É claro, a transação dos valores reais era realizada entre as partes fora do tribunal. A livery of seisin era realizada pela autoridade local, com base no título judicial apresentado pelo autor, agora tenant in fee simple.

${ }^{242}$ A common recovery já foi comparada à manumissio vindicta e, principalmente, à in iure cessio do direito romano pela literatura comparatística, cf. A. WATSON, Roman Law \& Comparative Law cit. (nota 1 supra), pp. 261-263. O autor utiliza como referência para a comparação o procedimento da cessão em juízo descrito em Gai. 2, 24: "In iure cessio autem hoc modo fit: apud magistratum populi Romani uelut praetorem urbanum [aut praesides prouinciae] is, cui res in iure ceditur, rem tenens ita dicit: HVNC EGO HOMINEM EX IVRE QVIRITIVM MEVM ESSE AIO; deinde postquam hic uindicauerit, praetor interrogat eum, qui cedit, an contra uindicet; quo negante aut tacente tunc ei, qui uindicauerit, eam rem addicit; idque legis actio uocatur. hoc fieri potest etiam in prouinciis apud praesides earum" (A in iure cessio, no entanto, se faz deste modo: diante do magistrado do povo romano, tal como o pretor urbano, ou o governador da província, aquele a quem a coisa é cedida em juízo, segurando a coisa, diz assim: EU DECLARO QUE ESTE HOMEM É MEU PELO DIREITO DOS QUIRITES; depois, após <o cessionário> tê-lo reivindicado, o pretor pergunta ao cedente se reclama a coisa em oposição <à alegação do cessionário $>$; $<$ e $>$ respondendo $<$ o cedente $>$ que não $<$ tem o quê reclamar $>$ ou silenciando, então <o pretor $>$ adjudica a coisa àquele que a tenha reivindicado; e isso denomina-se legis actio).

Para A. WATSON, tanto a common recovery inglesa quanto a in iure cessio romana são a resposta do ordenamento jurídico a uma falha do Estado, que não fornece meios adequados para determinadas transações entre particulares. Porém, se diferenciam na medida em que a in iure cessio e a manumissio vindicta não provocam qualquer prejuízo a terceiros não representados no processo, enquanto a common recovery sempre é realizada em prejuízo dos eventuais herdeiros, sejam os do tenant in tail, sejam os do concedente originário. Acerca das características gerais da in iure cessio e da manumisso vindicta, cf. W. W. BUCKLAND, A Textbook of Roman Law, Cambridge, Cambridge University, 1921, pp. 233-234; M. TALAMANCA, Istituzioni cit. (nota 42 supra), pp. 93, 434-435 e M. MARRONE, Istituzioni cit. (nota 74 supra), pp. 133-134 e 200-201.

${ }^{243}$ Cf. Taltarum's Case (1472), in J. H. BAKER e S. F. C. MILSOM, Sources of English History cit. (nota 9 supra), pp. 67-71. O caso é um bom exemplo do método de hermenêutica utilizado pela jurisprudência inglesa. A parte autora ajuizou ação reivindicando seu direito à posse do imóvel em virtude de ser o titular de um estate in fee tail. Alegou, ainda, que o réu possuidor do imóvel tinha realizado uma common recovery e que esse procedimento era fictício. O Court of Common Pleas deu ganho de causa ao autor, pois considerou que o réu não tinha adquirido a seisin do imóvel mediante a livery of seisin, o que precluia sua investidura. No entanto, ficou reconhecido, contrario sensu, que caso o réu tivesse adquirido a seisin, o procedimento do common recovery teria sido considerado válido. Daí o fato de esse caso ser considerado o leading case que estabeleceu a possibilidade de destruir um estate in fee tail e convertê-lo num estate in fee simple (barring the entails). Um 
De outro, passou a ser possível a conversão do estate in fee tail num estate in fee simple mediante um acordo judicial entre as partes homologado pelo tribunal, denominado fine $^{244}$. Esses procedimentos, aos poucos, foram aperfeiçoados e eventualmente substituídos por outros mais simples e eficazes ${ }^{245}$.

\section{Com a entrada em vigor do Law of Property Act $1925^{246}$, os estates in fee tail}

passaram a poder ser criados somente por meio de um trust, com o qual a titularidade do direito pertence ao trustee, que tem a obrigação de administrá-lo em favor do beneficiary, que,

comentário sobre o mesmo caso pode ser lido em H. W. CHALLIS, Law of Real Property cit. (nota 1 supra), pp. 309-310.

${ }^{244}$ Cf. J. Williams, Principles of the Law of Real Property cit. (nota 200 supra), p. 73, nt. z. Trata-se, em essência, do procedimento da finalis concordia (cf. nota 319 infra), utilizado para destruir as perpetuidades, em razão da validade absoluta da coisa julgada material.

Embora inicialmente fosse um acordo num processo litigioso, com o tempo passou a ser mais uma ação fictícia pela qual as partes obtinham um título judicial que legitimava uma transação fundiária. Embora tivesse sido explicitamente proibida a destruição de entails mediante esse procedimento (proibição imposta pelo Stat. 13 Edw. I (1285), c. 1, s. 4: "Et si finis super hujusmodi tenementum imposterum levetur, ipso jure sit nullus"), os tribunais passaram a fazer, a partir do século XV, uma interpretação extensiva do Statute of Fines 1489 [=Stat. 4 Hen. VII (1489), c. 24], que atribuía, de modo geral, força de coisa julgada material aos acordos homologados nos tribunais reais, sem que, no entanto, houvesse consenso a respeito da eficácia desse procedimento.

A questão ficou pacificada em favor da possibilidade de destruição dos entailed estates via fines pelo Stat. 32 Hen. VIII (1540), c. 36, que tratou do tema especificamente: “(...) all and fingular Fines (...) by any perfon or perfons of full age (...) of any Manors, Lands, Tenements or Hereditaments (...) Shall be (...) fufficient Bar and Difcharge for ever againft the faid Perfon and Perfons and their Heirs claiming the fame Land Tenements and Hereditaments or any Parcel thereof only by Force of any fuch Entail (...). Cf. B1 Comm 2, 21, $354-355$ [=W. BlaCKSTONE, Commentaries cit., vol. II (nota 10 supra), pp. 354-355].

${ }^{245}$ Cf. R. MEgarRy e W. WADE, The Law of Real Property cit. (nota 1 supra), p. 73. Uma das principais dificuldades era a limitação da eficácia subjetiva das fines (que não destruíam os estates in remainder ou in reversion, ou seja, a pretensão do remainderman e o reversioner), cf. Margaret Podger's Case (1613) 9 Co Rep 104a: “(...) And therefore, if a tenant for life accept a fine (...) it does not deveft the eftate of him in reverfion or remainder (...)". O que restava era denominado base fee, que era a concessão que podia ser herdada por qualquer herdeiro (não apenas os descendentes diretos), mas não tornava o alienatário em titular da concessão in fee simple, pois tal título ficava com o remainderman ou o reversioner (o que configurava uma restrição atenuada à alienação, pois o remainderman ou reversioner ainda podia exigir judicialmente a retomada do imóvel se o base tenant não deixasse quaisquer herdeiros, mesmo contrariando uma disposição testamentária), cf. H. W. CHALLIS, Law of Real Property cit. (nota 1 supra), p. 325.

A outra dificuldade era a possibilidade de criação de disposições, no instrumento de alienação, que impedissem a destruição dos entails. Os tribunais, no entanto, passaram a entender que qualquer cláusula tendente a evitar a destruição de um entail era nula. A simplificação definitiva (e o barateamento) do procedimento para destruir os entails se deu mediante o Fines and Recoveries Act 1833 [=Stat. 3 \& 4 Will. IV (1833), c. 74], s. 15: “(...) every actual tenant in tail, whether in possession, remainder, contingency or otherwise, shall have full power to dispose of for an estate in fee simple absolute, or for any less estate, the lands entailed, as against all persons claiming the lands entailed by force of any estate tail (...)", e s. 40: "Every disposition of lands under this Act by a tenant in tail thereof shall be effected by some one of the assurances (not being a will) by which such tenant in tail thereof could have made the disposition if his estate were an estate at law in fee simple absolute".

Mediante essas disposições, o tenant in tail passou a ter liberdade para converter seu patrimônio in fee tail em fee simple absolute, ficando, assim, livre para alienar seus bens como bem entendesse. A única restrição foi em relação ao levantamento do entail mediante disposição testamentária, mas isso foi remediado pelo Stat. 15 \& 16 Geo. V (1925), c. 20, s. 176 (1): “A tenant in tail of full age shall have power to dispose by will, by means of a devise or bequest referring specifically either to the property or to the instrument under which it was acquired or to entailed property generally".

${ }^{246}$ Cf. Stat. 15 \& 16 Geo. V (1925), c. 20. 
no caso, é o próprio tenant in tail ${ }^{247}$. Contudo, desde 1997 não mais é possível, na Inglaterra, criar um estate in fee taill ${ }^{248}$, na medida em que qualquer ato de disposição pelo qual o alienante pretenda criar um entailed interest transfere não um estate in tail, mas um absolute estate in trust ${ }^{249}$. Portanto, quaisquer entails ainda existentes devem ter sido criados, necessariamente, antes de 1997.

Apesar de hoje virtualmente extinto, a evolução do estate in fee tail é um dos principais expoentes da tensão histórica, no direito privado inglês, entre o interesse individual em controlar o futuro do próprio patrimônio de modo a evitar sua fragmentação, especialmente no âmbito familiar ${ }^{250}$, e o interesse social na flexibilização do regime jurídico dos direitos reais de modo a atender às exigências sócio-econômicas coletivas, tensão essa que foi regulada, ao longo do tempo, pela atividade jurisdicional dos tribunais reais ${ }^{251}$ combinada com a promulgação de legislação estatutária ${ }^{252}$.

${ }^{247}$ Essa restrição é o resultado da exclusão dos estates in fee tail do rol dos legal estates, cf. Stat. 15 \& 16 Geo. V (1925), c. 20, s. 1 (3): "All other estates, interests, and charges in or over land take effect as equitable interests". Assim, conforme visto acima, a partir da vigência desse statute, é mais correta a denominação entailed interest, ao invés de estate in fee tail.

${ }^{248}$ Cf. Trusts of Land and Appointment of Trustees Act 1996, sch. 1, s. 5 (1) - (2): "Where a person purports by an instrument coming into operation after the commencement of this Act to grant to another person an entailed interest in real or personal property, the instrument (a) is not effective to grant an entailed interest, but (b) operates instead as a declaration that the property is held in trust absolutely for the person to whom an entailed interest in the property was purportedly granted. Where a person purports by an instrument coming into operation after the commencement of this Act to declare himself a tenant in tail of real or personal property, the instrument is not effective to create an entailed interest".

${ }^{249} \mathrm{O}$ que, no fundo, nada mais é do que um estate in fee simple aplicável no âmbito dos trusts, tanto em relação à personal property (que foi entailable somente no período compreendido entre 1925 e 1996) quanto à real property, cf. R. MEGARRY e W. WADE, The Law of Real Property cit. (nota 1 supra), pp. 50 e 74-75.

${ }^{250}$ Cf. M. RHEInsteIn, Some Fundamental Differences cit. (nota 1 supra), pp. 625-633. O autor explica que as limitações ao poder de alienar (restraints on alienation) também existiam no continente europeu até o século XIX, porém nunca chegaram ao grau de desenvolvimento atingido na Inglaterra. Essas restrições à alienação, no continente, podiam ser impostas mediante a substituição fideicomissária, que permitia ao testador controlar, de modo mais limitado do que na Inglaterra, o destino do patrimônio após a sua morte. No entanto, no continente essas disposições somente podiam ser feitas por meio de um testamento, e não por meio de um negócio inter vivos, como era comum que se fizesse na Inglaterra. $\mathrm{O}$ autor aponta que fideicomissum familiarum foi uma tentativa, levada a cabo entre os séculos XVII e XVIII, de criar um regime patrimonial similar ao dos family settlements ingleses. Após a Revolução Francesa e a promulgação dos primeiros códigos civis, no entanto, o instituto ou bem foi abolido, ou sofreu sérias restrições, firmando-se o princípio da livre alienação do patrimônio pelo titular que estiver na posse do mesmo.

${ }^{251}$ A posição dos tribunais reais, que ao longo do tempo desenvolveram uma verdadeira antipatia em relação às perpetuidades, foi bem resumida por Lord Nottingham em Duke of Norfolk's Case (1681) 2 Swans 454: “(...) the law hath so long laboured to defeat perpetuities, that now it is become a sufficient reason of itself against any settlement, to say it tends to a perpetuity. (...) such perpetuities fight against God, by affecting a stability which human providence can never attain to, and are utterly against the reason and policy of the common law". No caso concreto, discutia-se a validade das cláusulas de remanescência contingente (contingent remainders) num testamento que estabelecia um trust durante um período de duzentos anos, durante os quais, por meio de uma série de hipóteses condicionadas, o autor do testamento teria o poder de determinar o destino do seu patrimônio até dois séculos após a sua morte.

${ }^{252}$ Apesar da forte tendência dos tribunais ingleses, a partir do século XV, no sentido de impedir a criação de restrições à alienação (restraints on alienation) mediante uma política de oposição às perpetuidades (policy against perpetuities), cf. R. MEgarRY e W. WADE, The Law of Real Property cit. (nota 1 supra), pp. 71 e 314- 


\subsubsection{A concessão vitalícia: o life estate}

Conforme vimos, originariamente as concessões feudais tinham um caráter, no máximo, vitalício ${ }^{253}$. Daí que o life estate ${ }^{254}$ possa ser pensado, de certa forma, como uma projeção dessa característica das concessões feudais no sistema de direitos reais de matriz inglesa $^{255}$.

315, a legislação tem operado em favor da acumulação patrimonial em alguns casos específicos. Assim, por exemplo, estabeleceram-se regimes de inalienabilidade absoluta (unbarrable entails) em favor do Duque de Marlborough e o Duque de Wellington, por via legislativa, em reconhecimento dos serviços prestados à nação, cf. Stat. 6 Anne (1706), c. 6, s. 6: "Provided always and be it further enacted by the Authority aforesaid That neither the said Duke of Marlborough or the Heires Males of his Body nor any of his Daughters of the Heires Males of their Bodyes or any other Person to whom the Premises shall com or descend by virtue of the Limitations aforesaid shall have any Power by Fine of Recovery or any other Act Assurance Conveyance in the Law to hinder bar or disinherit any Person or Persons to or upon whom the said Manors House Lands Tenements Hereditaments or Premisses are hereby vested (...)" e Stat. 54 Geo. III (1814), c. 161, s. 28: "And be it further enacted, that so long as the said Title, Honor and Dignity of Duke of Wellington shall endure (...) neither the said Duke of Wellington, nor any of the Heirs (...) shall have any power by Fine or Recovery (...) to discontinue the Estate of, or to hinder, bar or disinherit (...)".

${ }^{253}$ A esse respeito, convém citar o comentário de C. BuTLER a Co Litt 266b $(3,8,448)$ [=E. COKE, The First Part of the Institutes cit., vol. II (nota 10 supra), s. n.]: "It is known that fees were held originally at the will of the lord; then for the life of the tenant; that afterwords they were descendible to some particular heirs of the body of the tenant, then to all the heirs of his body; and that in succession of time the tenant had the complete dominion or power over the fee".

$\mathrm{O}$ autor refere-se à gradual evolução histórica do fee simple, explicando que, a bem da verdade, originou-se a partir de uma concessão feudal de natureza precária, que logo se converteu numa concessão vitalícia, passando depois a ser de natureza hereditária. De acordo com a S. F. C. MiLSOM, Historical Foundations cit. (nota 12 supra), p. 103 e J. H. BAKER, An Introduction cit. (nota 12 supra), p. 259, a própria palavra freehold [=liberum tenementum] denotava, originariamente, a vitaliciedade da investidura do tenant in fee, muito embora no século XIII o termo já tivesse adquirido o significado de "herdade" e fosse distinto da concessão vitalícia, cf. Bracton f. 207, já visto acima (notas 186 e 187 supra).

${ }^{254}$ Apesar de preferirmos o termo life estate para nossa exposição, hoje é mais correto utilizar a nomenclatura life interest, na medida em que a concessão vitalícia, a partir da legislação de 1925 , somente pode existir através de um trust como um equitable interest, cf. Stat. 15 \& 16 Geo. V (1925), c. 20, s. 1 (3), cf. nota 247 supra.

${ }^{255}$ Cf. W. S. Holdsworth, A History of English Law cit., vol. III (nota 12 supra), p. 120. Em sentido contrário, cf. T. F. T. PLUCKNETT, A Concise History cit. (nota 12 supra), p. 569, para quem o life estate nasceu a partir dos institutos de dower e curtesy (que já na época de Littleton surgiam ex lege). Algumas disposições estatutárias, no entanto, reforçam a tese de W. S. HOLDSWORTH en favor do caráter primacialmente vitalício das primeiras concessões feudais na Inglaterra.

Assim, na Carta Coronationis promulgada por Henrique I em 1100 (Charter of Liberties 1100, c. 2) [=W. STUBBS, Select Charters cit. (nota 8 supra), p. 118]: "Si quis baronum, comitum meorum sive aliorum qui de me tenent, mortuus fuerit, haeres suus non redimet terram suam sicut faciebat tempore fratris mei, sed justa et legitima relevatione relevabit eam. Similiter et homines baronum meorum justa et legitima relevatione relevabunt terras suas de dominis suis" (Se morrer algum dos meus barões, condes ou qualquer outro que tenha $<$ terras > de mim, seu herdeiro não redimirá a sua terra como o fazia no tempo do meu irmão <Guilherme II>, mas a resgatará mediante $<$ o pagamento de $>$ um relevium justo e legítimo. De modo similar, os homens dos meus barões resgatarão as suas terras dos seus senhores mediante <o pagamento de $>$ um relevium justo e legítimo).

O texto trata do pagamento, denominado relief [=relevium] (cf. nota 319 infra) realizado pelo herdeiro do tenant, normalmente o filho, de modo a receber a investidura da concessão feudal. De acordo com o próprio T. F. T. PLUCKNETT, A Concise History cit. (nota 12 supra), p. 524, o fragmento acima é um forte indício de que o princípio hereditário, já no início do século XII, era admitido entre os senhores chefes (tenants in chief), donde se generalizou ao longo de toda a cadeia feudal. 
A cláusula que, no ato de alienação, define o estate vitalício depende de quem seja a pessoa cuja vida sirva de referência para a determinação do estate. Assim, se o critério determinante for a duração da vida do próprio concessionário, no ato de disposição as palavras operantes são "para A durante a sua vida" [="to A for life"], em cujo caso cria-se um estate for the life of the tenant. É também possível, no entanto, adotar como critério não a vida do concessionário, mas a de um terceiro ${ }^{256}$, em cujo caso as palavras que regem a concessão são "para A durante a vida de X" [=“"to A for the life of X"], com o qual se estabelece um estate per autre vie ${ }^{257}$.

Quanto ao seu conteúdo, a principal distinção entre o life estate e o estate in fee simple também é conseqüência da adoção de critérios distintos para demarcar a sua extensão temporal $^{258}$. É aqui que entra em jogo a doctrine of waste $^{259}$, instituto desenvolvido pelo

O valor do relevium, que foi fonte de disputas nesse período, foi fixado pela Magna Carta 1215, c. 2: "Si quis comitum vel baronum nostrorum, sive aliorum tenentium de nobis in capite per servitium militare, mortuus fuerit, et cum decesserit haeres suus plenae aetatis fuerit et relevium debeat, habeat haereditatem suam per antiquum relevium; scilicet haeres vel haeredes comitis de baronia comitis integra per centum libras; haeres vel haeredes baronis de baronia integra per centum libras; haeres vel haeredes militis de feodo militis integro per centum solidos ad plus; et qui minus debuerit det secundum antiquam consuetudinem feodorum" (Se morrer algum dos nossos condes ou barões, ou quaisquer outros que tenham <terras $>$ de nós capitalmente a título de serviço militar, e tendo morrido <uma dessas pessoas $>$ seu herdeiro tiver atingido a maioridade e deva $<$ pagar $>0$ relevium, <ordenamos> que <esse herdeiro> tenha a sua herdade pelo <valor $>$ do antigo relevium; isto é, o herdeiro ou herdeiros de um conde <terão > todo o baronato de um condado por cem libras; o herdeiro ou herdeiros de um barão <terão $>$ todo o baronato por cem libras; o herdeiro ou herdeiros de um cavaleiro <terão $>$ todo o feudo militar por cem solidi no máximo; e quem dever menos, que pague de acordo com o antigo costume dos feudos). Ao que parece, T. F. T. PlUCKNETT adota como ponto de partida do life estate não a natureza feudal do sistema das tenures, mas a estruturação da doutrina dos estates, que ocorreu no século XV.

${ }^{256} \mathrm{O}$ que normalmente ocorre quanto o life tenant aliena a sua concessão a um terceiro, em cujo caso a referência para determinar a duração do estate é a vida do primeiro concessionário, cf. K. GRAY e S. F. GRAY, Elements of Land Law cit. (nota 1 supra), p. 60.

${ }^{257}$ A distinção já aparece em Litt 56 [=E. WAMBAUGH, Littleton's Tenures - In English cit. (nota 10 supra), p. 24]: "Tenant for term of life, is where a man letteth lands or tenements to another for term of the life of the lessee, or for term of the life of another man. In this case the lessee is tenant for term of life. But by common speech, he which holdeth for term of his own life, is called tenant for term of his life [=tenaunt pur terme de vie]; and he which holdeth for term of another's life, is called tenant for term of another man's life [=tenaunt pur terme dautre vie]".

Ao comentar a fonte em questão, T. E. TomLINS, Lyttleton - His Treatise of Tenures - In French and English cit. (nota 10 supra), pp. 67-68 explica que o uso dos termos lessor [=lessour] e lessee [=lessé], cuja utilização seria mais própria para tratar de um leasehold, e não de um estate of freehold, deixa implícito que a tenancy for life exige um ato de disposição praticado tanto para alienar um leasehold quanto um freehold, que é a livery of seisin. Com isso estaria equiparando, em termos de tutela legal e regime jurídico, duas subcategorias de life estate, a saber, os legal life estates (dower e curtesy, que na época de Littleton já surgiam by operation of the law, i.e. ex lege) e o conventional life estate, i.e. o life estate.

A principal consequiência dessa equiparação seria, justamente, a aplicação do regime de waste ao life estate. A verdade é que o uso desses termos resulta da nomenclatura utilizada por Littleton para tentar distinguir os estates de acordo com a amplitude material do direito, o que não impediu que o life estate ficasse classificado entre os estates of freehold, cf. Co Litt 43b $(1,7,58)$ [=E. COKE, The First Part of the Institutes cit., vol. I (nota 10 supra), s. n.]: "'Freehold'. Here appeareth that tenant in fee, tenant in taile, and tenant for life, are said to have a franktenement, a freehold, so called, because it doth distinguish it from termes of yeares, chattels upon incertaine interests, lands in villeinage, or customary or copyhold lands".

${ }^{258}$ Ao que parece, no entanto, as alterações do terreno promovidas pelo life tenant do século XIII, dada a sua investidura na concessão por meio da seisin, somente seriam ilícitas se fossem de grande magnitude, cf. T. F. 
direito inglês para regular, justamente, os diversos modos de utilização, alteração e transformação dos bens imóveis sujeitos a um regime temporário de concessão ${ }^{260}$.

Nesse sentido, as restrições relativas ao uso e fruição (enjoyment) do bem imóvel

impostas ao life tenant decorrem da proteção que o ordenamento confere aos titulares de um direito de reversão (pertencente ao concedente ou aos seus herdeiros) ou de remanescência ${ }^{261}$

T. PLUCKNETT, A Concise History cit. (nota 12 supra), pp. 569-560. A tese se baseia em Bracton f. 316b: "Item est proprium ut si quis teneat ad vitam suam tantum, ubi tenens habuerit liberum tenementum tantum et alius proprietatem, et sic utitur tenens quodam modo in proprio quoad rationabile estoverium propter liberum tenementum, et sic non facit vastum nec iniuriam utendo per mensuram" (Da mesma forma, considera-se "próprio", como no caso em que alguém tenha <um terreno> durante a sua vida apenas, onde o tenant tiver somente o liberum tenementum e outra <pessoa $>$ o título hereditário, e assim o tenant usa aquilo que de algum modo, por causa do liberum tenementum, é seu, na medida do que seja razoável para o seu sustento, e assim não comete destruição nem dano usando <a terra $>$ com moderação).

Cabe lembrar que, de acordo com Bracton f. 263b-264 (cf. nota 127 supra), o titular de uma concessão ad vitam tantum, embora tivesse a seisin, não tinha o terreno de feodo (i.e., a concessão não se transmitia aos herdeiros). Assim, o life tenant tinha a sua disposição as actiones in rem, porém somente durante a sua vida, cf. F. Pollock e F. W. Maitland, The History of English Law cit., vol. II (nota 12 supra), pp. 9-10. Neste fragmento, o termo proprietas, portanto, é usado no sentido de "título hereditário", de modo a diferenciar a concessão hereditária da vitalícia. O termo estoverium designa o direito do life tenant de retirar do imóvel madeira para uso não comercial, cf. A. M. BURRILL, A New Law Dictionary cit., vol. I (nota 13 supra), pp. 438439 (no verbete "estovers").

T. F. T. PLUCKNETT também aponta o caso descrito em BNB pl. 607 - também mencionado em Bracton f. $316 \mathrm{~b}$-, no qual fica consignado que o life tenant somente responde pela alteração substancial do terreno: " $E t$ quia querela est de tam parva re, consideratum est quod Petrus inde sine die (...)" (E como a demanda é acerca de uma coisa tão pequena, declarou-se que Pedro <fosse > absolvido). No caso, o termo sine die significa “absolver", cf. A. M. BURRILL, A New Law Dictionary cit., vol. II (nota 13 supra), p. 935 (no verbete "sine die").

${ }^{259}$ Essa denominação aparece em K. GRAY e S. F. GRAY, Elements of Land Law cit. (nota 1 supra), p. 62, embora seja mais comum encontrar na literatura jurídica apenas a referência a waste. Técnicamente, waste pode ser definido como quaisquer atos que importem na alteração do imóvel, independentemente de produzir ou não uma melhora, cf. R. MEgARRY e W. WADE, The Law of Real Property cit. (nota 1 supra), pp. 78-79. A doutrina mais antiga classificava a waste em dois tipos: voluntary e permissive - Co Litt 53a $(1,7,67)$-, porém modernamente foram acrescentadas mais duas categorias: ameliorating e equitable. Voluntary waste é definido pela doutrina como "doing that which ought not to be done", e corresponde a toda alteração que importe numa diminuição do valor da coisa; permissive waste, definido como "not doing that which ought to be done" é a omissão, por parte do tenant, da prática dos atos necessários para a manutenção do imóvel; ameliorating waste, apesar do oxímoro, significa toda alteração do imóvel que importe num aumento da utilidade da coisa (improvement), daí a proximidade com as benfeitorias do direito civil; finalmente, equitable waste designa a destruição ou degradação dolosa do imóvel, provocada por um concessionário vitalício expressamente isento de responsabiliade por waste no instrumento de concessão (unimpeachable life tenant) que o homem médio não cometeria.

${ }^{260}$ Cf. R. A. EPSTEIN, Past and Future - The Temporal Dimension in the Law of Property, in Washington University Law Review 64 (1986), pp. 707-710. Para o autor, as normas relativas à alteração do imóvel pelo life tenant são a manifestação mais concreta dos problemas criados pela cisão de interesses diferidos sobre um mesmo bem. A função da doctrine of waste, portanto, é regular, na ausência de normas dispositivas entre as partes, o limiar temporal que existe entre o concessionário vitalício (life tenant) e o titular do direito remanescente (remainderman). O período de tempo durante o qual cada um dos sucessivos titulares tem a fruição do terreno é tratado separadamente, de modo que qualquer benefício auferido do imóvel que importe numa diminuição do seu valor para o próximo tenant é considerado uma transferência compulsória de riqueza. A doctrine of waste opera de modo a distribuir, normalmente em favor do titular do direito reversionário (remainderman), essa riqueza entre titulares sucessivos no tempo.

${ }^{261}$ A proteção jurídica do titular de um direito remanescente (remainderman) configura, de fato, a hipótese mais comum. A tutela dessa pretensão, no caso específico do life tenant, se deu por uma série de percalços ao longo da história do direito inglês. Pode-se perceber essa evolução ao comparar a situação do life tenant com a dos tenants in dower e os tenants by the curtesy, dado que, desde cedo, estes podiam, a diferença do que ocorria com o life tenant, serem demandados pela prática de atos que diminuíssem o valor do imóvel. De acordo com E. 
(pertencente a terceiros e seus descendentes, na hipótese de o concedente ou os seus herdeiros terem alienado ou de alguma forma transferido o seu direito de reversão a um terceiro) ${ }^{262}$.

A jurisprudência inglesa já tem manifestado uma atitude favorável ao life tenant diante de determinados tipos de alteração do imóvel, especialmente no que diz respeito à ameliorating waste, a qual, grosso modo, corresponde àquilo que nos ordenamentos de base

COKE, The Second Part of the Institutes of the Laws of England, London, Brooke, 1797, p. 299, isso ocorria porque a tenancy in dower e a tenancy by the curtesy eram criadas ex lege, enquanto a life tenancy surgia mediante um ato de vontade do concedente, motivo pelo qual este podia, no ato de alienação, "(...) provide againft the doing of wafte by the leffee, and if he did not, it was his negligence and default".

A tutela da pretensão do reversioner ou remainderman de uma concessão vitalícia voluntária (voluntary life estate) foi estabelecida mediante intervenção legislativa que inverteu essa lógica, estabelecendo a responsabilidade por waste como elemento natural para esse tipo de concessão, cf. Stat. 52 Hen. III (1267), c. 23: "Item firmarii tempore firmarum suarum vastum, vendicionem seu exilium non faciant, in domibus, boscis, hominibus, neque de aliquibus ad tenementa quam ad firmam habent spectantibus, nisi specialem habuerint concessionem per scripturam sive convencionis mencionem habentis quod hoc facere potest. Et si fecerint et super hoc convincantur dampna plene refundent, et graviter per misericordiam puniantur" (Da mesma forma, $<$ determinamos que > os concessionários a termo, durante o prazo da sua concessão, não provoquem a alteração dos bosques, a venda das casas ou a expulsão dos servos, nem <provoquem tais concessionários a alteração $>$ de qualquer outra coisa dos tenementa sujeitos a termo que <eles $>$ detêm, salvo quando tiverem uma autorização especial por escrito ou uma cláusula no acordo estabelecendo que $<$ o concessionário a termo $>$ pode fazê-lo. E se o fizerem e forem condenados por disso, que ressarçam integralmente os danos e que sejam punidos severamente mediante a imposição de multa).

O termo firmarius, no contexto do statutum citado, engloba tanto locatários a longo prazo (leaseholders) quanto life tenants, cf. E. COKE, The Second Part of the Institutes cit. (nesta nota), p. 145. A palavra dampnum é uma corruptela de damnum, cf. A. M. BURRILL, A New Law Dictionary cit., vol. I (nota 13 supra), p. 317 (no verbete "dampnum"). Por sua vez, a expressão per misericordiam significa "impor uma multa de valor pecuniário", cujo valor o juiz arbitrava de acordo com a gravidade do ilícito, cf. C. F. Du CANGE, Glossarium cit. (nota 13 supra), t. 5, col. 410a (no verbete "misericordia"): "vox forensis: Pona seu mulcta de quovis crimine, aut quavis forisfactura, nullis definita legibus, sed judicis relicta arbitrio, qui minorem vel majorem in reum pro delicti modo, decernit". Uma multa no triplo do valor do dano causado pelo life tenant foi introduzida pelo Stat. 6 Edw. I (1278), c. 5, embora o statutum não explicite a qual espécie de waste dita multa se aplique. Apesar da substituição do remédio processual efetuada por Stat. $3 \& 4$ Will. IV (1833), c. 27, s. 36 (cf. nota 65 supra), ainda hoje a case law inglesa entende que são aplicáveis os princípios gerais estabelecidos no século XIII, cf. Woodhouse v Walker (1880) 5 QB D 404 (nota 269 infra).

${ }^{262}$ Cf. Co Litt 53a $(1,7,67)$ [=E. COKE, The First Part of the Institutes cit., vol. I (nota 10 supra), s. n.]: "An action of wast doth lie against tenant by the curtesie, tenant in dower, tenant for life, for yeares, or half a yeare, or guardian in chivalry, by him that hath the immediate estate of inheritance, for wast or destruction in houses, gardens, woods, trees, or in lands, meadows \&c". Também Litt 67 [=E. WAMBAUGH, Littleton's Tenures - In English cit. (nota 10 supra), pp. 29-30]. O vocábulo waste provém do verbo latino clássico vasto, -as, -are, avi, -atum, que significa devastar ou destruir, cf. P. G. W. GLARE (coord.), OLD cit. (nota 13 supra), pp. 20142015 (no verbete "vasto, -as, -are, -avi, -atum"), o qual, no âmbito da real property law, passou a designar o dano causado a um bem imóvel em prejuízo do titular de um direito de reversão (reversion) ou remanescência (remainder), cf. A. M. BURRILL, A New Law Dictionary cit., vol. II (nota 13 supra), pp. 1060-1061 (no verbete "waste"). No ordenamento jurídico inglês, a doctrine of waste tem adquirido uma conotação um tanto arcaica em relação aos leaseholds, pois a ação cabível para esses casos tem como causa de pedir o chamado covenant to repair, ou seja, as disposições estabelecidas entre as partes em relação à manutenção do imóvel, cf. Mancetter Developments Ltd v Garmanson [1986] QB 1212: "Waste is a somewhat archaic subject, now seldom mentioned; actions in respect of disrepair are now usually brought on the covenant". No entanto, ainda é plenamente aplicável às alterações do imóvel realizadas pelo life tenant, cf. Edward Seymour's Case (1612) 10 Co Rep 95b, em que ficou estabelecido que uma das principais distinções entre os estates of inheritance e o life estate, em qualquer das suas modalidades, é que neste caso o tenant responde pelas alterações que realizar no imóvel. 
romanística se denomina benfeitorias úteis ${ }^{263}$. Nesse sentido, o life tenant pode promover alterações substanciais no imóvel, mesmo contra a vontade expressa do titular de um direito de reversão (reversion) ou remanescência (remainder), desde que dita alteração resulte no aumento do valor econômico do imóvel.

Assim, por exemplo, a transformação de prédios dilapidados em unidades de moradia $^{264}$ e a construção de estufas para o cultivo de hortaliças em terras destinadas ao cultivo extensivo de grãos ${ }^{265}$ têm sido consideradas benfeitorias úteis às quais o concedente não pode se opor.

O raciocínio que embasa esse entendimento apóia-se na presunção de que toda transformação não autorizada do terreno provoca uma transferência ilícita de riqueza ${ }^{266}$, gerando um dano patrimonial ao titular do direito de reversão (reversioner) ou remanescência

${ }^{263}$ Uma diferença notável, no que diz respeito ao regime das benfeitorias úteis e a ameliorating waste é que o life tenant não tem o ius retentionis sobre o imóvel. De fato, não faria sentido que o tivesse, pois se a concessão termina com a morte do tenant, este não terá como exercer o direito de retenção após a morte, nem seus eventuais herdeiros, na medida em que o life estate não pode, por definição, ser objeto de transmissão causa mortis. O mais comum é que o titular do direito de reversão (reversioner) ou remanescência (remainderman) procure a concessão de uma medida liminar de urgência para impedir que o life tenant altere o imóvel, ou que busque uma indenização por perdas e danos após o término do período da concessão, cf. R. MEGARRY e W. WADE, The Law of Real Property cit. (nota 1 supra), p. 78.

${ }^{264}$ Muitos dos leading cases apontados pela doutrina inglesa em matéria de waste tratam, a bem da verdade, de locações de longo prazo (leaseholds); porém, as regras neles desenvolvidas aplicam-se por analogia às life tenancies, especialmente no que diz respeito ao regime jurídico das benfeitorias úteis (ameliorating waste). Assim, em Doherty v Allman (1878) 3 App Cas 709 a House of Lords estabeleceu que o locador (landlord) não tem direito a indenização por perdas e danos nem à concessão de liminar (injunction) contra o locatário (lessee) para impedir que este realize obras que aumentem o valor do imóvel, a menos que a benfeitoria modifique a natureza essencial do imóvel e altere a sua identidade: "Here the alleged waste is really meliorating waste; there is nothing but the caprice of the landlord, which objects to what is proposed, and what will really make the property much more valuable".

${ }^{265}$ Cf. Meux v Cobley [1892] 2 Ch 253, em que um locatário a longo prazo (lessee) transformou parte de um terreno destinado à atividade agropecuária numa estufa destinada à produção de hortaliças para o mercado de abastecimento de Londres. O locador (lessor) se opôs à modificação, alegando que, por disposição expressa no contrato de concessão, o terreno devia ser destinado única e exclusivamente à atividade agropecuária. Alegou ainda que o locatário estava cometendo waste em prejuízo dos eventuais herdeiros do locador e pediu o deferimento de uma liminar para a derrubada das estufas. A liminar foi indeferida sob o argumento de que não se tinha configurado o dano, dado que o locatário tinha transformado o terreno com o objetivo de exercer a atividade mais lucrativa no contexto econômico do momento: "To obtain na injunction against a defendant on the ground of 'waste', the plaintiff must prove that what the defendant is doing is prejudicial to the inheritance; if it improves the value of the land it is not waste".

${ }^{266}$ Cf. K. GrAY e S. F. GRAY, Elements of Land Law cit. (nota 1 supra), p. 62. Pode haver, é claro, conflitos derivados do valor subjetivo do bem imóvel para cada um dos titulares, em cujo caso o problema pode tornar-se insolúvel, cf. R. A. EPSTEIN, Past and Future cit. (nota 260 supra), p. 708. No entanto, eventuais conflitos podem ser resolvidos, ou pelo menos reduzidos, por meio de cláusulas contratuais, dada a ampla liberdade de negociação que o direito inglês confere às partes em matéria de direitos reais.

A questão relativa à waste ganha maior importância no tocante às locações de longo prazo (leaseholds), e o ordenamento prevê um conjunto de normas que regulam essas relações na ausência de disposições em contrário estipuladas pelas partes. Um estudo pormenorizado dessas normas pode ser visto em R. MEGARRY e W. WADE, The Law of Real Property cit. (nota 1 supra), pp. 845-870 
(remainderman). Logo, como as benfeitorias úteis não importam dano patrimonial, entende-se que não cabe a tutela jurisdicional em favor do concedente ${ }^{267}$.

Uma das características que realça o caráter proprietário do life estate é o fato de que o life tenant somente é responsável pelo dano provocado pela falta de manutenção (permissive waste) do imóvel ${ }^{268}$ se a obrigação for explicitamente imposta pelos termos da concessão $^{269}$.

Por outro lado, o life tenant responde, ressalvadas as hipóteses de extração de recursos para uso não comercial ${ }^{270}$, pelos atos deliberados que resultem numa diminuição do valor econômico do imóvel ${ }^{271}$ (voluntary waste) $^{272}$ e, mesmo quando tenha sido isentado

${ }^{267}$ Cf. Doherty v Allman (1878) 3 App Cas 709: “(...) the waste, to be of any sort of effect with a view to an injunction, must be a waste resulting in substantial damage".

${ }^{268}$ Cf. Re Cartwright (1889) 41 Ch D 532, em que o concessionário vitalício, ao longo da sua vida, provocou a ruína do imóvel pela falta de manutenção. Após o falecimento do concessionário vitalício, o titular do direito remanescente (remainderman) exigiu do testamenteiro (executor of the will) compensação pecuniária equivalente ao valor da desvalorização do imóvel decorrente do desleixo do life tenant. A Chancery Division entendeu que não cabia indenização, na medida em que não constava qualquer obrigação expressa de manutenção do imóvel no instrumento de concessão, que, no caso, era um testamento.

O tribunal, no caso, seguiu a orientação, mutatis mutandis, já expressa em E. COKE, The Second Part of the Institutes cit. (nota 261 supra), p. 145: “(...) for he that fuffereth a houfe to decay, which he ought to repaire, doth the wafte; and therefore if a man maketh a leafe for yeares by indenture of a houfe and lands, upon condition, that if it happen the leffee to do any wafte, that the leffor shall reenter, in this cafe if the leffe fuffer the houfes to be wafted, the leffor Shall reenter (...)".

${ }^{269}$ Cf. Woodhouse v Walker (1880) 5 QB D 404, que estabeleceu a responsabilidade do life tenant pela deterioração do imóvel (permissive waste) como elemento acidental do ato de disposição. No caso concreto, o titular do direito remanescente (remainderman) ajuizou ação na Queen's Bench Division em face do espólio do life tenant pedindo o ressarcimento das despesas feitas para recuperar o imóvel, o qual tinha sofrido grave deterioração em função da falta de manutenção durante a vida do life tenant. O tribunal condenou o espólio a ressarcir o titular do direito remanescente (remainderman) pelas despesas, pois o instrumento de concessão continha cláusula explícita (...keeping the houses in repair...) que determinava a responsabilidade do life tenant pela manutenção do imóvel.

${ }^{270}$ Trata-se dos estovers [=estoverium, cf. nota 258 supra], destinados, salvo disposição em contrário entre as partes, ao life tenant, cf. Co Litt $41 \mathrm{~b}(1,6,56)$ [=E. CoKE, The First Part of the Institutes cit., vol. I (nota 10 supra), s. n.]: "Note that to every tenant for life, the law as incident to his estate without provision of the party giveth him three kinde of estovers, (that is) housebote which is twofold, viz. 'estoverium aedificandi et ardendi'; ploughbote, that is 'estoverium arandi'; and lastly haybote, that is 'estoverium claudendi', and these estovers must be reasonable, 'estoveria rationabilia".

${ }^{271}$ Nessa hipótese, caso o life tenant tenha lucrado com a desvalorização do imóvel, como ocorre nos casos de derrubada de árvores para a exploração comercial da madeira (timber), o titular do direito de reversão (reversion) ou remanescência (remainder) pode ajuizar ação reclamando a transferência de todos os lucros auferidos dessa atividade. Assim, em Seagram v Knight (1867) 2 Ch App 628, numa ação proposta pelo autor (remainderman) em face dos testamenteiros do espólio seu avô (life tenant), a Court of Chancery entendeu que todos os lucros auferidos pelo life tenant em razão da atividade que desvalorizou o imóvel devem reverter em favor do titular do direito de remanescência (remainderman), pois "If a tenant for life impeachable for waste cuts timber without leave of the Court, he will never be permitted to derive any advantage from his wrongful act".

${ }^{272}$ Exemplos de voluntary waste são: a remoção, pelo life tenant, de pertenças que não sejam suas, ou a não reparação do dano causado pela remoção das pertenças que sejam suas, cf. Mancetter Developments Ltd $v$ Garmanson [1986] QB 1212; a abertura e exploração de uma mina, embora o life tenant possa explorar uma mina que já tenha sido aberta anteriormente pelo concedente, cf. Saunder's Case 5 Co Rep 12a; a derrubada de árvores com o intuito de comercializar a madeira (timber), cf. Honywood v Honywood (1874) LR 18 Eq 306. 
dessa responsabilidade no instrumento de concessão (unimpeachable for waste) ${ }^{273}$, responde pelos atos dolosos (equitable waste) que provoquem dano ao imóvel em prejuízo do titular do direito de reversão (reversioner) ou remanescência (remainderman) ${ }^{274}$.

Embora pouco estudada ou discutida na doutrina comparatística, a doctrine of waste é fundamental para a articulação do sistema de direitos reais de matriz inglesa e representa um dos traços distintivos de uma estrutura categorial conceitualmente organizada em torno da extensão temporal dos direitos reais sobre bens imóveis ${ }^{275}$.

\subsection{Heranças do sistema das tenures na real property law inglesa}

Embora modernamente a doutrina das tenures não mais produza os mesmos efeitos práticos típicos da Idade Média ${ }^{276}$, ainda constitui a espinha dorsal dos direitos reais na Inglaterra. Ela nunca foi formalmente revogada ${ }^{277}$, e ainda gera consequiências em determinadas situações ${ }^{278}$. Além de sempre imprimir uma orientação mais empírica em relação à própria definição e atribuição dos direitos reais no sistema do common law, o elemento seisin-possession também foi um dos principais responsáveis pela marcada distinção no desenvolvimento de categorias que, em princípio, eram externas ao esquema das tenures, mas que a ele se incorporaram em razão da ação dos tribunais reais.

O desenvolvimento histórico das concessões desprovidas de seisin representa o caso clássico de uma relação num primeiro momento não abrangida pela tutela jurisdicional

${ }^{273}$ Excepcionalmente, o life tenant pode ser isentado da responsabilidade por equitable waste mediante cláusula expressa nesse sentido, cf. Stat. 15 \& 16 Geo. V (1925), c. 20, s. 135: "An equitable interest for life without impeachment of waste does not confer upon the tenant for life any right to commit waste of the description known as equitable waste, unless an intention to confer such right expressly appears by the instrument creating such equitable interest".

${ }^{274}$ Cf. Vane v Lord Barnard (1716) 2 Vern 738, em que o réu foi demandado pelo próprio filho por praticar atos de caráter marcadamente emulativo. Lord Barnard constituiu um life estate em seu favor sobre um dos seus castelos, eximindo-se, mediante cláusula expressa, da responsabilidade por qualquer alteração no imóvel. Pelo mesmo ato estabeleceu um direito de remanescência (remainder) em favor do filho. Após um desentendimento com este, Lord Barnard contratou duzentos funcionários para que retirassem do castelo todos os acessórios, e até partes integrantes do mesmo ("...stript the castle of the lead, iron, glass-doors, and boards \&c..."). A Court of Chancery entendeu que, apesar da cláusula excludente de responsabilidade por waste, o life tenant não pode cometer atos dolosos de caráter emulativo que diminuam o valor do imóvel em prejuízo do titular de um direito reversionário ou remanescente, cabendo o deferimento de uma liminar de urgência (injunction) tanto para impedir ou interromper o cometimento de tais atos quanto para obrigar o life tenant a restituir o imóvel ao statu quo ante.

${ }^{275}$ Cf. R. A. EpsteIn, Past and Future cit. (nota 260 supra), p. 707: "The law of waste is designed primarily to police the temporal boundary between the life tenant and the remainderman".

${ }^{276}$ Cf. J. REEVES, History of the English Law cit., vol. I (nota 12 supra), pp. 242-244.

277 Cf. R. MEgarRY e W. WADE, The Law of Real Property cit. (nota 1 supra), p. 24: "But even today it is in one sense true to say that all land in England is vested in the Crown; a subject can only hold it as a tenant".

${ }^{278} \mathrm{Cf}$. nota 158 supra. 
dispensada aos estates of freehold, mas que, ao longo do tempo, alcançou o status de um direito real mediante a atuação dos tribunais reais.

\subsubsection{A concessão sem seisin: unfree tenure}

Um dos principais expoentes do particular desenvolvimento histórico dos direitos reais de matriz inglesa com base na doctrine of tenures encontra-se num antigo instituto utilizado no âmbito do manor $^{279}$, em certos aspectos similar ao precarium romano ${ }^{280}$, denominado unfree tenure $^{282}$ [=villeinage ou villenagium]. Essa categoria opõe-se, no contexto das tenures, ao freehold, já estudado acima.

279 A palavra manor provém da palavra manoir do francês antigo, cf. C. F. DU CANGE, Glossarium cit. (nota 13 supra), t. 5, col. 216b (no verbete "manerium"): "Habitatio cum certa agri portione, a manendo dicta, Gallis, Manoir: quomodo in Consuetudinibus nostris municipalibus vulgo accipitur pro pracipua feudi domo, qua cum universo ipsius ambitu penes primogenitum esse debet'. O termo originou-se a partir do verbo latino maneo, -es, -ere, mansi, mansum, que significa permanecer, morar ou residir, cf. P. G. W. GLARE (coord.), OLD cit. (nota 13 supra), p. 1072 (no verbete "maneo, -es, -ere, mansi, mansum").

A partir da conquista normanda, o vocábulo designava uma unidade de produção agrícola, ou seja, uma unidade autónoma de terras cultiváveis dotada de uma comunidade e administrada por um cavaleiro ou uma corporação eclesiástica, as quais com o passar do tempo passaram a pertencer ao respectivo administrador, ficando sob a sua jurisdição, cf. D. M. WALKER, The Oxford Companion cit. (nota 8 supra), p. 803 (no verbete “manor") e B. A. GARNER (coord.), Black's cit. (nota 13 supra), p. 823 (no verbete “manor").

Os elementos constitutivos do manor eram as terras do senhor (demesne land), incluindo um núcleo predial (manor house) e as terras cultiváveis em sua volta; terras concedidas a tenants em regime de free tenure ou unfree tenure e terras para a pastagem de animais (waste land), cf. R. MEGARRY e W. WADE, The Law of Real Property cit. (nota 1 supra), p. 26.

Acerca dos manors, de modo geral, cf. F. Pollock e F. W. MAitland, The History of English Law cit., vol. I (nota 12 supra), pp. 594-605.

${ }^{280}$ De fato, apesar das conotações semânticas que aproximam a unfree tenure inglesa [=villenagium] à escravidão romana, esses dois institutos não são equivalentes. De acordo com W. W. BUCKLAND e A. D. MCNAIR, Roman Law and Common Law cit. (nota 1 supra), pp. 27-28, o motivo da evolução tão distinta dessas duas instituições é o fato de que o villenagium, desde cedo, aplicou-se quase exclusivamente ao âmbito fundiário. Além disso, os autores atribuem o desaparecimento precoce da escravidão na Inglaterra a uma predisposição natural do common law em favor da liberdade, o que não deixa de ser um argumento ideológico; o mais provável é que a distinção entre as classes servis e senhoriais, dada a grande fluidez entre elas, já desde o século XI fosse de natureza mais social e política do que jurídica, cf. M. BLOCH, La société féodal cit. (nota 42 supra), pp. 312-314.

A semelhança entre o precarium romano e o villenagium inglês, no sentido aqui adotado, deve-se à ausência de um writ que tutelasse a posição jurídica do villein diante do senhor da terra perante os tribunais reais, tornando sua situação semelhante à do precarista romano, cf. M. TALAMANCA, Istituzioni cit. (nota 42 supra), p. 548 e M. MARrone, Istituzioni cit. (nota 74 supra), pp. 483-485. Cabe mencionar que, mesmo antes da Conquista, os detentores das chamadas laen lands também estavam sujeitos a um regime muito similar ao do precarium, cf. T. F. T. PluCKNETT, A Concise History cit. (nota 12 supra), pp. 519-520.

${ }^{281}$ Note-se que o adjetivo "unfree", embora inicialmente se referisse à condição pessoal do indivíduo que trabalhava as terras, passou a referir-se não ao status do tenant, e sim à natureza indeterminada dos services, cf. F. POLlOCK e F. W. MAITLAND, The History of English Law cit., vol. I (nota 12 supra), pp. 371-372.

${ }^{282}$ Cf. nota 115 supra. 
Inicialmente, a duração desse tipo de concessão de terras ficava sujeita ao arbítrio do senhor feudal. Dizia-se que o villein ${ }^{283}$ tenant (a denominação do possuidor da terra nessa situação $)^{284}$ ficava, em relação à posse e desfrute da terra, à mercê do seu senhor, ou "at the will of the lord" [=ad voluntatem domini" $]^{285}$.

${ }^{283}$ Introduzido no inglês jurídico por meio do law French, o termo villein designava, originariamente, o servo rural inteiramente submetido a um senhor feudal (villein in gross) ou vinculado a um manor (villein regardant), cf. J. A. SIMPSON e E. S. C. WEINER (coord.), OED 19 (1989), p. 637 (no verbete “villein"). De acordo com A. M. BURRILl, A New Law Dictionary cit., vol. II (nota 13 supra), pp. 1041-1042 (no verbete "villein"), a palavra encontra sua raiz no vocábulo latino villa, -ae, que designa um imóvel rural e as suas dependências, cf. P. G. W. GLARE (coord.), OLD cit. (nota 13 supra), p. 2063 (no verbete "villa, -ae").

Em Bl Comm 2, 6, 92-93 [=W. Blackstone, Commentaries cit., vol. II (nota 10 supra), pp. 92-93], especula-se que a categoria dos villeins tenha sido criada após a Conquista por meio da admissão dos antigos servos que travalhavam as folklands anglo-saxãs no âmbito de proteção dos senhores normandos, o que se fazia pelo oath of fealty [=fidelitas]; tais villeins podiam ser concessionários de terras, porém ficavam à mercê do senhor (at the mere will of the lord).

Os villeins também são mencionados em Bracton f. 6b, embora A. M. BuRRILL entenda que a descrição seja algo exagerada: "Servi autem sub potestate dominorum sunt, nec solvitur dominica potestas quamdiu manentes fuerint in villenagio levantes et cubantes, sive terram tenuerint sive non. Item etsi non manentes in villenagio sed vagantes per patriam, euntes et redeuntes, semper sub potestate dominorum sunt quamdiu redierint. Et cum consuetudinem revertendi habere desierint, incipiunt esse fugitivi, ad similitudinem cervorum domesticorum" (Os servos, no entanto, estão sob a potestade dos seus senhores, e não se desfaz a potestade dominical enquanto permanecerem no <terreno sujeito a > villenagium dia e noite, tenham ou não <a concessão de > uma terra. Da mesma forma, se não permanecerem no <terreno sujeito a > villenagium, mas vagarem pelo país, indo e vindo, estão <mesmo assim> sempre sob a potestade dos seus senhores enquanto retornarem. E deixando de ter o hábito de retornar, começam a ser fugitivos, a semelhança dos cervos domesticados).

A expressão levantes et cubantes [=levant et couchant] aplicava-se, normalmente, ao gado que passava um dia e uma noite em terreno alheio, podendo, após esse prazo, ser confiscados pelo titular da concessão do terreno, cf. Bl Comm 3, 1, 8-9 [=W. BlaCKSTONE, Commentaries cit., vol. III (nota 10 supra), pp. 8-9]. Apesar da opinião de A. M. BurriLl, o uso da expressão levantes et cubantes em Bracton oferece uma idéia da condição social e jurídica diminuída do villein no século XIII, e o provável motivo pelo qual o villenagium não exigia a celebração da homagium nem a investidura na concessão do imóvel (seisin).

${ }^{284}$ Cabe mencionar que, apesar da conotação originária da expressão villein tenant, desde finais do século XI tais concessionários já não eram necessariamente servos sujeito pessoalmente ao senhor. Apesar de o instituto ser denominado unfree tenure, e de originariamente ter se aplicado exclusivamente aos villeins (cujo status jurídico era análogo ao de um servo), os autores são unânimes ao ressaltar a freqüente desvinculação, desde cedo, entre o status pessoal do tenant e a tenure de que era titular, cf. P. VINOGRADOFF, Villeinage in England, Oxford, Oxford University, 1892, pp. 77-80 e F. POLlOCK e F. W. MAITLAND, The History of English Law cit., vol. I (nota 12 supra), pp. 357-358.

Esse entendimento firmou-se cedo, como mostra a distinção entre status e tenure em Bracton f. 26b: “(...) Item tenementum non mutat statum liberi non magis quam servi. Poterit enim liber homo tenere puram villenagium faciendo quidquid ad villenagium pertinebit, et nihilominus liber erit cum hoc faciat ratione villenagii et non ratione persona sua (...)" (Da mesma forma, o tenementum não muda o status do $<$ homem $>$ livre mais do que o <status $>$ do servo. Portanto, um homem livre poderá ter um villenagium puro fazendo aquilo que será pertinente ao villenagium, e não será menos livre, dado que o faz em razão do villenagium e não em razão da sua pessoa).

${ }^{285}$ Nesse sentido, cf. Anger Son of Hugh v Gilbert Son of Harald (1218), in J. H. BAKER e S. F. C. MILSOM, Sources of English History cit. (nota 9 supra), p. 217, em que o autor alegou ter sido esbulhado do seu terreno injustamente, julgando-se improcedente a demanda pelo fato de tratar-se de um terreno sob o regime de villenagium e não de um liberum tenementum.

No mesmo sentido, cf. Nicholas Son of Norman v Hemfrid Serjeant of the Castellan of Bergues (1214), in J. H. BAKER e S. F. C. MILSOM, Sources of English History cit. (nota 9 supra), p. 217 e Aldwin Son of Robert v Bishop of Winchester (1203), in J. H. BAKER e S. F. C. MILSOM, Sources of English History cit. (nota 9 supra), p. 218. 
Entre os séculos XI e XIII, uma parte considerável das terras cultiváveis na Inglaterra encontrava-se sob esse regime ${ }^{286}$, na medida em que praticamente a totalidade da produção agrícola era realizada por villein tenants, ou seja, por aqueles que estavam na posse de terras submetidas ao regime do villenagium ${ }^{287}$.

A investidura da concessão feudal (seisin) das terras submetidas ao regime da unfree tenure pertencia exclusivamente ao senhor, o que excluia, em princípio, a seisin do villein tenant, por isso mesmo considerado mero detentor in nomine alieno ${ }^{288}$. O villein tenant, portanto, não tinha, em princípio, legitimidade para impetrar um writ nos tribunais reais para recuperar a posse da terra, caso fosse esbulhado pelo senhor ${ }^{289}$, embora lhe fosse reconhecido o direito a permanecer no terreno enquanto prestasse os respectivos services ${ }^{290}$.

${ }^{286}$ Bracton $\mathrm{f} .7$ oferece uma explicação da origem desse regime de tenure sobre terras: “(...) In dominico domini regis plura sunt genera hominium. Fuerunt enim ibi servi sive nativi, ante conquestum, in conquestum et post. Et tenuerunt villenagia et per villana servitia et incerta, qui usque in hodiernum diem villanas faciunt consuetudines et incertas, et quidquid eis praeceptum fuerit, dum tamen licitum et honestum. Fuerunt etiam in conquestu liberi homines qui libere tenuerunt tenementa sua per libera servitia, vel liberas consuetudines, et cum per potentiores eiecti essent, postmodum reversi receperunt eadem tenementa sua tenenda in villenagio, faciendo inde opera servilia, sed certa et nominata" (No dominium do senhor rei são muitos os gêneros de homens. Aí, certamente, houve servos ou escravos de nascença antes da conquista, na conquista e após <a conquista $>$. E detiveram < terras sob o regime de $>$ villenagium em troca de serviços incertos e de baixa condição, e eles prestam, até os dias de hoje, <serviços oriundos de> costumes incertos e de baixa condição, bem como $<$ fazem $>$ qualquer coisa que lhes seja ordenada, desde que $<$ seja $>$ lícita e honesta. Houve também na conquista homens livres que detinham livremente seus tenementa em razão de serviços < de natureza $>$ livre, ou <oriundos de $>$ costumes livres, e que, dado que tinham sido expulsos pelos mais poderosos e depois retornado, receberam seus mesmos tenementa para serem detidos em regime de villenagium, prestando daí serviços costumeiros $<$ de natureza> servil, porém certos e nominados). A palavra nativus refere-se, nos textos ingleses medievais, àqueles nascidos na condição de escravos, cf. A. M. BURRILL, A New Law Dictionary cit., vol. II (nota 13 supra), p. 736 (no verbete "nativus").

${ }^{287}$ Cf. W. S. HoldsworTH, A History of English Law cit., vol. III (nota 12 supra), pp. 198-199.

${ }^{288}$ Cf. F. W. MAITLAND, Equity cit. (nota 12 supra), p. 349.

${ }^{289}$ Cf. R. MEgarry e W. WADE, The Law of Real Property cit. (nota 1 supra), p. 26. De acordo com F. Pollock e F. W. MAITLAND, The History of English Law cit., vol. I (nota 12 supra), p. 362, o fato de não haver remédio legal para essa situação nos tribunais reais não era considerado uma injustiça durante os primeiros séculos do common law, na medida em que os meios judiciais postos a disposição pelos tribunais do rei, mesmo aquelas medidas de maior envergadura - como era o caso dos writs de natureza possessória -, eram considerados uma mera liberalidade do monarca, cf. Bracton f. 164b: “(...) de beneficio principis succurritur ei per recognitionem assisa nova disseisina, multis vigiliis excogitatam et inventam, recuperanda possessionis (...)" ((...) pelo favor do príncipe ele é socorrido pelo reconhecimento da assisa novae disseisinae, durante muitas vigílias imaginada e inventada, para a recuperação da posse (...)).

${ }^{290}$ Algumas demandas relativas a terras submetidas ao regime do villenagium foram conhecidas pelos tribunais reais no início do século XIII, concedendo-se tutela à pretensão do villein tenant, provavelmente pelo fato de que, apesar de as terras terem sido concedidas sob o regime de villenagium, em muitos casos o tenant era um homem livre que mantinha em dia sua prestação dos devidos services, cf. P. VINOGRADOFF, Villeinage in England cit. (nota 284 supra), p. 80.

Assim, em BNB pl. 70 e BNB pl. 88 encontram-se os registros de duas demandas ajuizadas por Martinus de Bestenora, homem livre na posse de um terreno sob o regime de villenagium, em face de Johannus de Monte Acuto, senhor do terreno em questão, nas quais fica reconhecido o direito de o tenant permanecer no terreno, mesmo contra a vontade do senhor, desde que aquele esteja disposto a prestar os serviços devidos, cf. BNB pl. 70: “(...) Consideratum est quod terra illa est vilenagium ipsius [Johannis], et quod si Martinus voluerit terram tenere faciat consuetudines quas pater suus fecit (...)" ((...) Entendeu-se que aquela terra é do mesmo Johannus, e que, caso Martinus queira ter a terra, que preste os serviços que o seu pai prestou (...)) e BNB pl. 88: “(...) Et quia curia recordatur quod nullum erat placitum in curia domini Regis de vilenagio corporis ipsius Martini nisi 
Os services e incidents a que estavam sujeitos os terrenos submetidos ao regime da unfree tenure ficavam normalmente registrados na corte local e representavam o costume de cada manor ${ }^{291}$, e em muitos casos os senhores dos manors, mesmo após a Conquista, continuaram respeitando esses costumes. Assim, embora os tribunais reais não tivessem, em princípio, competência para conhecer ações cuja causa de pedir fosse uma relação de unfree tenure, como normalmente o senhor feudal observava as regras estabelecidas pelo costume do

tantum de vilenagio et consuetudinibus predicte terre, consideratum est quod si idem Martinus voluerit terram predictam tenere, tunc faciat predictas consuetudines quas pater suus fecit (...)" ((...) E porque na curia $<$ regis > está registrado que não havia qualquer demanda no tribunal do senhor rei acerca da condição pessoal de villanus do próprio Martinus, mas apenas acerca do regime de villenagium e dos serviços <devidos> pela supramencionada terra, entendeu-se que caso o mesmo Martinus tenha querido ter a supramencionada terra, então que preste os supramencionados serviços que o seu pai prestou (...)).

Note-se que em BNB pl. 70 a palavra consuetudo tem o sentido de um service baseado no costume, cf. C. F. Du CANGE, Glossarium cit. (nota 13 supra), t. 2, col. 524a (no verbete "consuetudo"): "Prastatio, pensitatio qua ex consuetudine prostatur, cujus initium ignoratur, et a quo inducta (...) Prastatio sive pecunia, sive aliis rebus, aut etiam servitiis". Mesmo o villein tenant tem direito a permanecer na terra, sempre que preste os devidos services, conforme atesta BNB pl. 1103, em que Willelmus, filho de Henricus ajuizou uma ação em face de Bartholomeus filho de Eustachius, acerca de um terreno tido a título de villenagium: “(...) Et ideo consideratum est quod Willelmus convictus est de vilenagio et si facere voluerit predictas consuetudines teneat illam bovatam terre per easdem consuetudines (...)" ((..) E por esse motivo entendeu-se que Willelmus foi condenado acerca do <seu status pessoal de> villenagium e caso tenha querido prestar os supramencionados serviços que tenha aquela bovata de terra pelos mesmos serviços (...)).

Em BNB pl. 1103, o termo bovata designa, de modo geral, um terreno cultivável cujo tamanho corresponde à medida que pode ser trabalhada por um boi em um ano, cf. C. F. DU CANGE, Glossarium cit. (nota 13 supra), t. 1, col. 719c (no verbete "bovata terrae"): "Modus agri, sic dictus quod tantum terrce contineat, quantum bos unus (vel par boum) arare potest, spatio unius scilicet anni".

$\mathrm{O}$ princípio de que o villein tenant não tinha legitimidade para impetrar um writ na jurisdição real, no entanto, já é reafirmado, mesmo com as ressalvas relativas ao costume local e à prestação dos serviços, em Litt 77 [=E. WAMBAUGH, Littleton's Tenures - In English cit. (nota 10 supra), pp. 34-35]: "And although that some such tenants have an inheritance according to the custom of the manor, yet they have but an estate but at the will of the lord acording to the course of the common law. For it is said, that if the lord do oust them, they have no other remedy but to sue to their lords by petition; for if they should have any other remedy, they should not be said to be tenants at will of the lord according to the custom of the manor. But the lord cannot brake the custom which is reasonable in theses cases. (...) if such tenant by custom paying his services be ejected by the lord, he shall have an action of trespass against him (...) tenant by custom is as well to have his land according to the custom, as he which hath a freehold at the common law". No entanto, cabe ressaltar que a alusão aos services e a equiparação ao freehold são, ao que tudo indica, uma interpolação, cf. F. POLlOcK e F. W. MAITLAND, The History of English Law cit., vol. I (nota 12 supra), p. 359.

Apesar dessas primeiras manifestações dos tribunais reais a respeito do villenagium, pode-se perceber que, já na época de Henrique III, os juristas que confeccionaram a Magna Carta não tiveram a intenção de tutelar essa relação, pois embora inicialmente se conferisse tutela a qualquer um que fosse esbulhado de um terreno, em edições posteriores a redação foi alterada de modo a fazer referência explícita ao liberum tenementum. Comparem-se, nesse sentido, Magna Carta 1215, c. 39: "Nullus liber homo capiatur, vel imprisonetur, aut dissaissiatur, aut utlagetur, aut exuletur, aut aliquo modo destruatur, nec super eum ibimus, nec super eum mittemus, nisi per legale judicium parium suorum vel per legem terrae" (Nenhum homem livre seja colhido, ou preso, ou esbulhado, ou banido, ou exilado, ou de qualquer outro modo arruinado, nem sobre ele iremos, nem sobre ele enviaremos, salvo mediante o sentença judicial dos seus pares e pela lei da terra) e Magna Carta 1217, c. 35: "Nullus líber homo capiatur vel imprisonetur, aut dissaissietur de líbero tenemento suo vel libertatibus el liberis consuetudinibus suis (...)".

O verbo utlagare, de origem saxônica, tem o sentido de "denegar a proteção da lei a alguém" e equivale ao verbo to outlaw na língua inglesa, cf. A. M. BURRILL, A New Law Dictionary cit., vol. II (nota 13 supra), p. 1018 (no verbete "utlagare").

${ }^{291}$ Cf. W. S. W. S. Holdsworth, A History of English Law cit., vol. III (nota 12 supra), p. 201. 
respectivo manor, não surgiu imediatamente a necessidade de tutela jurisdicional centralizada $^{292}$.

A partir do século $\mathrm{XV}$, no entanto, os tribunais reais, especialmente a Court of Chancery $^{293}$ e a Court of Requests ${ }^{294}$, começaram a tutelar essas relações jurídicas, dando efetividade à regra, já existente nas jurisdições locais, porém convenientemente esquecida pelos senhores feudais, que impedia que o villein tenant fosse despejado sem que tivesse cometido algum ato que justificasse a medida ${ }^{295}$.

Desse modo, a tenure in villeinage, posteriormente conhecida como copyhold ${ }^{296}$, que por volta do século $\mathrm{XVI}^{297}$ já havia se tornado uma forma bastante comum de gozo de

292 Cf. S. F. C. MiLSOM, Historical Foundations cit. (nota 12 supra), pp. 101-102.

${ }^{293}$ Cf. Anonymous (1453/54), in J. H. BAKER e S. F. C. MILSOM, Sources of English History cit. (nota 9 supra), p. 218, em que a Court of Chancery concedeu uma subpoena ao copyholder em face do senhor que cometesse esbulho.

${ }^{294}$ Um dos leading cases que melhor ilustra a solução adotada pelo direito inglês em relação a esses conflitos entre tenants e senhores, decidido na citada Court of Requests - tribunal real em funcionamento nos séculos XIV a XVI, semelhante à Court of Chancery, com competência para julgar demandas com base na equity ajuizadas por pessoas de baixa renda, cf. G. SPENCE, The Equitable Jurisdiction cit., vol. I (nota 12 supra), pp. 351-352 e A. F. POLLARD, The Growth of the Court of Requests, in EHR 56 (1941), pp. 300-303 -, é Inhabitants of Whitby $v$ York (1553), in I. S. LEADAM, Select Cases in the Court of Requests cit. (nota 9 supra), pp. 198-201, em que os tenants da cidade de Whitby ingressaram com um demanda contra o senhor das suas terras, um cavaleiro pelo nome de York, pelo fato de este ter aumentado o valor das suas anuidades e lhes imposto altas multas. Apesar de esses aumentos e as multas terem sido legitimamente impostos com base no poder senhorial do senhor das terras, e mesmo tendo esses novos valores e as multas sido confirmados na corte do senhor, a Court of Requests deu provimento ao pedido dos tenants, determinando sua manutenção na posse dos terrenos nos termos dos seus títulos (copies) "payeng theyr Rentes and ffermes accustomed without any his intervpcion to the contrary or anye other by him or in his name or procurement". Cumpre ressaltar que, neste caso, o valor médio do aumento da anuidade pela posse da terra foi da ordem de 100\%, como no caso de um tal Robert Stor, cuja anuidade tinha passado de 23 shillings, 5 pence a 50 shillings, 2 pence, além de uma multa de 15 shillings.

${ }^{295}$ Nesse sentido, entendeu-se que o regime jurídico e a tutela da pretensão à posse do villein tenant (que já na época denominava-se copyholder) não ficavam sujeitos ao mero arbítrio do senhor, ou seja ad voluntatem domini, mas ad voluntatem domini secundum consuetudinem manerii, cf. Brown's Case (1581) 4 Co Rep $21 \mathrm{a}$. O caso, julgado pela Court of Common Pleas, versa sobre a hereditabilidade do copyhold, e a discussão gira em torno da possibilidade de o herdeiro do copyholder herdar as terras sob o regime de copyhold sem que tivesse havido admittance, ou seja, sem que o senhor o tivesse aceito como o seu tenant, cf. D. M. WALKER, The Oxford Companion cit. (nota 8 supra), pp. 32-33 (no verbete "admittance"). Responde-se de modo afirmativo ao estabelecer-se que o herdeiro do copyholder herda da mesma forma que o freeholder, embora por um fundamento diverso, qual seja, o costume local, motivo pelo qual a transmissão causa mortis aos herdeiros sofria certas restrições, principalmente em relação à comunicabilidade dos bens ao cônjuge e a sujeição desse patrimônio à pretensão dos credores do de cujus. Da mesma forma, o tenant $\mathrm{e}$ o seu herdeiro passaram a poder alienar o copyhold a terceiros, desde que não ficasse prejudicado o pagamento de uma fine, que nessa acepção significa o valor devido ao senhor em função da substituição do copyhold tenant, cf. D. M. WALKER, The Oxford Companion cit. (nota 8 supra), p. 471 (no verbete "fine"). É interessante notar que, apesar da ampliação da tutela do interesse do copyhold tenant, o juízo reconhece explicitamente que o tenant não tem seisin, ou seja, que não está na posse em função de uma concessão feudal, mas em função da vontade do senhor e do costume local.

${ }^{296}$ A denominação provém da expressão "tenure by copy of the court roll", pois o título somente podia ser transferido mediante uma sentença do tribunal do senhor, da qual o tenant recebia uma cópia (daí chamar-se copyhold), cf. R. MEgarRY e W. WADE, The Law of Real Property cit. (nota 1 supra), p. 27. Sobre essa denominação e sua origem, cf. Litt 73-74 [=E. WAMBAUGH, Littleton's Tenures - In English cit. (nota 10 supra), p. 33]: "Tenant by copy of the court roll, is, as if a man be seised of a manor, within which manor there is a custom which hath been used time out of mind of man, that certain tenants within the same manor have used to have lands and tenements, to hold to them and their heirs in fee simple, or fee tail, or for term of life, \&c., at the 
direitos reais sobre bens imóveis na Inglaterra ${ }^{298}$, elevou-se à categoria de um direito real reconhecido pelos tribunais reais ${ }^{299}$.

Apesar da abolição dos copyholds provocada pela sua conversão em freeholds ${ }^{300}$, alguns dos efeitos jurídicos desse regime foram preservados, salvo disposição em contrário entre as partes ${ }^{301}$. Assim, várias consequências das origens feudais do instituto ficaram plasmadas nas normas que regulam as terras que antes estavam submetidas a esse regime jurídico concessão, dando lugar a situações que podem parecer algo paradoxais.

É o caso, por exemplo, dos direitos sobre os minérios extraídos ${ }^{302}$ dos terrenos submetidos ao regime do copyhold, cuja titularidade pertence ao senhor, embora este não possa retirá-los sem o consentimento do tenant ${ }^{303}$.

will of the lord and according to the custom of the same manor. And such a tenant may not alien his land by deed, for then the lord may enter as into a thing forfeited unto him. But if he will alien his land to another, it behoveth him after the custom to surrender the tenements in court, \&c., into the hands of the lord, to the use of him that shall have the estate (...)".

${ }^{297} \mathrm{O}$ reconhecimento da prevalência do regime de copyhold no século XVI já aparece em Heydon's Case (1584) 3 Co Rep 7a: "Forasmuch as great part of the land within the realm, is in grant by copy (...)".

${ }^{298}$ Em larga medida, a transformação da unfree tenure em copyhold, com a consolidação dos direitos do villein tenant, ocorreu devido à conversão de terras aráveis em terras para a pastagem de animais produtores da lã, matéria prima nas tecelagens de Flandres, no contexto dos primeiros passos da agricultura capitalista (capitalist farming) nos séculos XV-XVI, que alcançaria plena força nos séculos XVIII e XIX, cf. W. Cunningham, The Growth of English Industry and Commerce in Modern Times, Cambridge, Cambridge University, 1892, pp. 362-363. O que de fato ocorreu é que pessoas com capital disponível para investir em agropecuária passaram a deter essas terras dos senhores, e o regime de villeinagium era inadequado para esse fim, dada a sua inerente precariedade jurídica, cf. J. H. BAKER, An Introduction cit. (nota 12 supra), pp. 307-308.

Tais tenants figuravam, na verdade, entre os principais produtores econômicos da época, e os senhores das terras passaram a exigir-lhes, sob pena de despejo (que muitas vezes mirava a uma eventual enclosure), aumentos consideráveis das anuidades tradicionalmente pagas, na medida em que valor da contraprestação pelo uso da terra tinha se mantido praticamente inalterado, apesar da constante desvalorização da moeda. Os principais fatores que contribuíram para isso foram o empobrecimento das classes senhoriais, decorrente das guerras externas travadas pela Inglaterra no século XVI, o enriquecimento das classes produtoras e comerciais, e a transição (já completada nos séculos antecedentes) de uma economia de services para uma de pagamentos anuais em dinheiro. Dada a grande disseminação desse tipo de tenure, a proteção dos interesses dos villein tenants passou a ser uma questão de interesse público, e, com o passar do tempo, o regime jurídico das tenures in villeinage passou a ser praticamente igual ao do freehold, cf. W. S. HOLDSWORTH, A History of English Law cit., vol. III (nota 12 supra), pp. 206-212.

${ }^{299}$ A última fase desse reconhecimento ficou plasmada em Melwich v Luter (1588) 4 Co Rep 26a, julgado no King's Bench, em que o tribunal reconheceu a legitimidade do locatário (lesee) do copyhold tenant para intentar uma action of ejectment com o objetivo de determinar a quem deve ser concedida a posse do imóvel, ficando estabelecido que o copyholder pode ser equiparado, para os fins de proteção possessória, ao freeholder.

${ }^{300}$ Cf. nota 133 supra.

${ }^{301}$ Cf. R. MEgarRY e W. WAde, The Law of Real Property cit. (nota 1 supra), pp. 33-35. O Law of Property Act 1922 [=Stat. $12 \& 13$ Geo. V (1922), c. 16], sch. 12 (4)-(6) preservou por prazo indeterminado os direitos do senhor a minas, minérios, exploração de feiras e mercados, e a prática de esportes (mines, minerals, fairs, markets e sporting) nos terrenos anteriormente submetidos ao regime de copyhold. Também foram preservados os direitos do tenant a usufruir das áreas comuns de pastagem (rights of common). Por último, manteve-se o regime de responsabilidade do senhor ou do tenant pela manutenção de repressas, valas, muros de contenção, pontes etc. (upkeep of dykes, ditches, sea walls, bridges and the like).

${ }^{302}$ Cf. Eardley v Earl Granville (1876) 3 Ch D 826. No caso em questão, a parte autora, que era detentora de um copyhold sobre o terreno em questão, ajuizou uma demanda perante a Chancery Division e pediu que o réu fosse impedido de continuar suas atividades de transporte de minérios a través de um túnel construído 
Cabe mencionar que as tenures rurales ${ }^{304}$ na França pré-revolucionária eram em muitos aspectos similares às inglesas ${ }^{305}$. De fato, o sistema das tenures inglês, apesar da influência das antigas instituições anglo-saxãs, encontra as suas origens estruturais nas instituições feudais normandas ${ }^{306}$, e mesmo no século XII o contexto fundiário e os direitos sobre o solo na Inglaterra ainda se mantinham bastante semelhantes à situação vigente na França $^{307}$.

Nesse sentido, ao comparar a decadência do sistema feudal na Inglaterra e na França, percebe-se que um dos motivos pelos quais na Inglaterra não houve, por assim dizer, uma "revolução francesa", foi o gradual esvaziamento da jurisidição senhorial ao longo dos

embaixo do seu terreno, sob o argumento de que se tratava de turbação (trespass), dado que o réu não estava extraindo minérios do terreno, mas apenas ocupando o espaço que pertencia ao copyholder. A Chancery Division julgou procedente a demanda e se manifestou da seguinte forma em relação à questão em tela: "The estate of a copyholder in an ordinary copyhold (for it is an estate) is an estate in the soil throughout, except as regards for this purpose timber-trees and minerals. As regards the trees and minerals, the property remains in the lord, but, in the absence of custom, he cannot get either the one or the other, so that the minerals must remain unworked, and the trees must remain uncut. The possession <of the trees and minerals $>$ is in the copyholder; the property is in the lord".

${ }^{303}$ Cf. Bourne $v$ Taylor (1808) 10 East 189, em que a parte autora, que era copyholder do terreno em questão, ajuizou uma action of trespass em face do réu, pelo fato de este ter ingressado no seu terreno sem a sua autorização com o objetivo de extrair minérios. O King's Bench estabeleceu que o senhor do manor não pode ingressar nem autorizar terceiros a ingressar no terreno do seu copyholder sem a autorização deste, mesmo para extrair minérios (carvão, no caso) que lhe pertencem, pois estaria cometendo turbação (trespass) e o copyholder tem uma action of trespass contra ele.

Já em Whitechurch v Holworthy (1815) 19 Ves 213, discutido e julgado na Court of Chancery, estabeleceuse que, em relação ao corte de madeira para uso comercial (timber), aplicou-se a mesma regra apontada em relação aos minérios: ressalvadas eventuais normas locais em contrário, o senhor do manor tem direito à madeira das árvores plantadas no terreno, porém nele não pode ingressar sem o consentimento do copyhld tenant.

Cabe ressaltar que os direitos do senhor sobre a madeira destinada a fins comerciais em terrenos anteriormente submetidos ao regime de copyhold foram preservados até 1935 pelo Stat. 12 \& 13 Geo. V (1922), c. 16, s. 140, sendo concedida uma extensão até 1950 do prazo prescricional para que o senhor ingressasse com pedido de indenização pecuniária pela perda desse direito.

${ }^{304}$ Acerca do tema das tenures rurales na França, cf. M. BLOCH, La société féodal cit. (nota 42 supra), pp. 238-243.

${ }^{305}$ Cf. H. A. TAINE, Les origines de la France contemporaine, vol. I, Paris, Hachette, 1876, pp. 37-38, muito embora o autor, ao comparar o ancien régime francês com as tenures inglesas, pareça adotar uma atitude um tanto idílica das relações entre tenants e landlords na Inglaterra, as quais em muitos casos eram bastante antagônicas. Nesse sentido, nota W. S. HoldSwORTH, A History of English Law cit., vol. III (nota 12 supra), p. 211 que as reclamações dos tenants franceses, que detinham as terras sob um regime muito similar ao inglês, esteve entre as principais causas da Revolução Francesa, no que acompanha a opinião de H. S. MAINE, Dissertations cit. (nota 60 supra), pp. 307-308.

${ }^{306}$ Cf. M. BLOCH, La société féodal cit. (nota 42 supra), pp. 182-184. O autor inclui mesmo admitindo um desenvolvimento próprio das instituições jurídicas inglesas, as tenures inglesas entre les féodalités d'importation, especificamente no que se refere à clássica divisão dos bens imóveis (ou melhor, dos direitos reais sobre bens imóveis) em terres libres (freehold tenures) e terres non-libres (unfree tenures).

${ }^{307}$ Cf. M. BLOCH, La société féodal cit. (nota 42 supra), pp. 259-260. O autor, no entanto, ressalta a maior capacidade do senhor inglês para manter seus villeins nas suas terras, e atribui essa maior eficiência à presença, desde cedo, de um sistema judiciário centralizado que facilitava a busca dos servos fugitivos - como ocorria com o breve de nativo habendo, cf. J. H. BAKER, An Introduction cit. (nota 12 supra), pp. 538-539 - e à instituição denominada "frankpledge", pela qual a comunidade era dividida em agrupamentos de dez homens que respondiam civil e coletivamente pelo não comparecimento em juízo de qualquer um deles, cf. D. M. WALKER, The Oxford Companion cit. (nota 8 supra), p. 488 (no verbete "frankpledge"). 
séculos XV e XVI provocado pela centralização da atividade judiciária nos tribunais reais, o que resultou na gradual tutela de muitas das reivindicações feitas pelos tenants ${ }^{308}$.

De fato, o conceito de propriedade como controle absoluto sobre uma coisa, apresentado como antítese à configuração feudal dos direitos reais ${ }^{309}$, foi um dos principais focos da Revolução Francesa ${ }^{310}$, ao passo que a transformação da real property law inglesa não se deu mediante um processo revolucionário, mas de forma lenta e gradual, preservandose, assim, sua terminologia e inclusive certas feições feudais.

Cabe ressaltar que a ausência de uma alteração deliberada e repentina na estrutura e concepção dos direitos reais na Inglaterra figura, do ponto de vista comparatístico, entre um dos traços distintivos do sistema do common law ${ }^{311}$. Ao que tudo indica, essa característica se manifesta ainda mais claramente no desenvolvimento do instituto da unfree tenure.

${ }^{308}$ Cf. H. S. MAINE, Dissertations cit. (nota 60 supra), pp. 291-328. Para o autor, na França, ao contrário do que ocorreu na Inglaterra, os senhores feudais nunca deixaram de exercer a jurisdição senhorial, facilitando a prática de abusos, principalmente de natureza fiscal, que culminaram nos distúrbios populares que deflagraram a Revolução Francesa de 1789.

${ }^{309}$ Cf. M. RHEInSTEIN, Some Fundamental Differences cit. (nota 1 supra), p. 625, para quem o processo de destruição e reconstrução dos ordenamentos europeus continentais, pautado pela elaboração e promulgação dos códigos civis, teve maior impacto no ramo dos direitos reais sobre bens imóveis. As linhas mestras dessa reestruturação teriam sido, de um lado, o desejo de suprimir o poder político da aristocracia fundiária; de outro, a influência das idéias econômicas liberais, de acordo com as quais o bem comum seria atingido mais eficientemente dentro de um contexto jurídico que facilitasse ao máximo a circulação econômica dos bens imóveis, de modo a que eles sempre se encontrassem em poder das pessoas mais capazes de aproveitá-los econômicamente.

${ }^{310}$ Cf. H. A. TAINE, Les origines de la France cit. (nota 305 supra), p. 386, "Aussi bien, quels que soient les grands noms, liberté, egalité, fraternité, dont la Révolution se décore, elle est par essence une translation de la proprieté: en cela consiste son support intime, sa force permanente, son moteur premier, et son sens historique". Acerca da transição, na França, do sistema de propriedade feudal (féodalité) para o de propriedade absoluta (propriété), cf. D. R. KELLEY e B. G. SMITH, What Was Property? Legal Dimensions of the Social Question in France, in Proceedings of the American Philosophical Society 128 (1984), pp. 200-212, para quem as principais forças que moldaram os debates acerca do direito de propriedade, na França da primeira metade do século XIX, foram a questão da indenização devida aos émigrés pelas terras confiscadas durante a Revolução, as crescentes restrições impostas aos novos proprietários em nome da utilidade pública e os desafios trazidos pela Revolução Industrial.

A transformação intelectual dos direitos de natureza feudal num regime de propriedade absoluta, no entanto, foi o resultado de uma longa evolução influenciada, em grande parte, pelas obras de juristas como R. J. POTHIER, quem, por exemplo, traçou, ainda no século XVIII, a distinção entre o domínio feudal e o usufruto, atribuindo ao titular do dominium utile a propriedade absoluta do bem, cf. R. J. POTHIER, Traité des obligations, 1761, in A. Dupin, Oeuvres de R. J. Pothier, vol. V, Bruxelles, Tarlier, 1831, p. 210: “C'est à l'égard des heritages, le domaine utile qui s'appelle domaine de propriété. Celui qui a ce domaine utile, se nomme propriétaire, ou seigneur utile; celui qui a le domaine direct, s'appelle simplement seigneur. Il est bien le propriétaire de son droit de seigneurie; mais ce n'est pas lui, c'est le seigneur utile qui est proprement le propriétaire de l'heritage. Le domaine de propriété est ainsi appelé, parce que c'est le droit par lequel une chose m'est 'propre', et m'appartient privativement à tous autres. Ce droit de propriété, considéré par rapport à ses effets, doit se définir le droit de disposer à son gré d'une chose, sans donner néanmoins atteinte au droit d'autrui, ni aux lois: 'Jus de re libere disponendi', ou 'jus utendi et abutendi'".

${ }^{311}$ Cf. K. ZWEIGERT e H. KÖTZ, Einführung cit. (nota 1 supra), p. 181. 


\subsubsection{Statutum Quia Emptores Terrarum 1290}

Uma das provas mais convincentes da permanência de elementos feudais na configuração dos direitos reais na Inglaterra é a vigência de normas que somente fazem sentido dentro da lógica medieval de direitos reais de natureza derivativa e qualificada. É o caso, justamente, do statutum que passamos a analisar nas seguintes páginas, o qual ainda é vigente na Inglaterra e produz efeitos toda vez que um bem imóvel é alienado in fee simple (conveyance in fee simple) $^{312}$.

O próprio contexto em que surgiu esse statute é típico do período formativo da real property law inglesa, na medida em que muitos dos institutos mencionados fazem parte da estrutura que até hoje domina a terminologia dos direitos reais ingleses e a distingue da dos direitos reais de matriz romanística ${ }^{313}$.

$\mathrm{Na}$ Inglaterra medieval não havia, pelo menos em teoria, um limite ao número de mesne lords $^{314}$ que podiam existir entre o rei e o tenant na posse efetiva do terreno ${ }^{315}$. Em função disso, nos primeiros séculos após a Conquista passou a ser comum o processo de subinfeudation, pelo qual um tenant, normalmente um senhor da baixa nobreza ${ }^{316}$, concedia o direito à posse e gozo da terra a um terceiro em troca de uma renda (normalmente anual) ou certos services, com o qual se estabelecia, do ponto de vista formal, uma nova relação de suserania e vassalagem entre os dois, tornando-se aquele senhor deste ${ }^{317}$.

Alternativamente, o tenant, no entanto, podia simplesmente optar pela prática da substitution, uma espécie de novação pela qual o terceiro o substituía na relação feudal, a qual, no entanto, trazia a grande desvantagem ${ }^{318}$ de não poder ser realizada sem o

312 Cf. R. Megarry e W. WAde, The Law of Real Property cit. (nota 1 supra), p. 29.

${ }^{313}$ Cf. S. VAN ERP, Comparative Property Law cit. (nota 1 supra), pp. 1057-1058.

${ }^{314}$ A palavra mesne significa, de modo geral, "intermediário" e pode aplicar-se tanto a pessoas quanto a coisas, cf. J. A. SIMPSON e E. S. C. WEINER (coord.), OED 9 (1989), pp. 648-649 (no verbete "mesne"). Na nomenclatura juridica medieval inglesa, a expressão mesne lord é utilizada para designar todos os concessionários feudais que se encontravam entre a Coroa e o tenant que ocupava o imóvel e que, portanto, detinham uma concessão feudal de um senhor superior e eram, simultaneamente, senhores feudais dos tenants que deles detinham terras, cf. D. M. WALKER, The Oxford Companion cit. (nota 8 supra), pp. 836 (no verbete "mesne"). De acordo com A. M. BuRrILl, A New Law Dictionary cit., vol. II (nota 13 supra), p. 715 (no verbete "mesne"), mesne equivale ao latim medius, - $a$, -um, e se aplica àquele que é senhor e tenant ao mesmo tempo.

${ }^{315}$ Cf. R. MEgarry e W. WADE, The Law of Real Property cit. (nota 1 supra), p. 27.

316 Cf. A. M. BurRILl, A New Law Dictionary cit., vol. II (nota 13 supra), p. 951 (no verbete "subinfeudation").

${ }^{317} \mathrm{Na}$ verdade, a possibilidade de praticar-se a subinfeudation era congênita ao sistema feudal inglês, que nasceu num contexto militar no qual cada senhor feudal buscava recrutar, por meio de concessões de terras, cavaleiros que o acompanhassem em suas expedições militares, cf. F. POLLOCK e F. W. MAITLAND, The History of English Law cit., vol. I (nota 12 supra), p. 344.

${ }_{318}$ No período mais remoto do common law, em que a principal função das tenures era assegurar o fornecimento de homens para a guerra, também podia representar uma eventual desvantagem para o senhor 
consentimento do respectivo senhor, além de excluir a possibilidade de o tenant concedente obter os benefícios jurídicos e econômicos decorrentes da criação de um novo feudo ${ }^{319}$.

feudal a substituição do tenant por outro que não tivesse as mesmas qualidades pessoais e fosse menos apto para a vida militar, cf. R. MEGARRY e W. WADE, The Law of Real Property cit. (nota 1 supra), p. 28.

${ }^{319}$ Cf. S. F. C. MiLsom, Historical Foundations cit. (nota 12 supra), p. 111. O autor explica que, a bem da verdade, a substitution não era uma única operação horizontal, mas duas operações verticais. Assim, o tenant devolvia a concessão ao senhor, e este fazia uma nova concessão ao novo tenant. Esse tipo de transação proliferou-se apenas em relação às unfree tenures, provavelmente porque as free tenures ficavam sob a jurisdição dos tribunais reais, que podiam imitir na posse o herdeiro do tenant original, dado que este tinha tido a seisin do imóvel, e ainda obrigar o senhor a indenizar o terceiro substituto.

Daí que as poucas substitutions realizadas no século XIII fossem concluídas perante os tribunais reais mediante um procedimento de jurisdição voluntária denominado finalis concordia, no qual as partes manifestavam sua concordância em relação à transação, sendo os termos desta inseridos nos registros da corte, cf. D. M. WALKER, The Oxford Companion cit. (nota 8 supra), pp. 471-472 (no verbete "fine"). Os registros desses processos nos séculos XII e XIII, denominados feet of the fines [=pedes finium] e similares à nossa certidão de objeto e pé, deixam claro que, ao alienar a terra, o terceiro tornava-se tenant do senhor do alienante, e não do alienante em si.

Assim, por exemplo, demonstra o registro encontrado em J. HUNTER, Fines sive pedes finium sive finales concordiae in curia dominis regis, vol. I, s.1., Public Records Commission, 1835, p. 54: “(...) Et sciendum quod praedictus Johannus dedit et concessit Rogerio Peiure et heredibus suis totam praedictam terram cum pertinentiis tenendam de priorissa de la Celle et successoribus suis in perpetuum per servicium quod ad terram illam pertinet (...)" ((...) E saiba-se que o supramencionado João deu e concedeu a Rogério Peiure e aos seus herdeiros toda a supramencionada terra com os seus acessórios a ser tida da prioresa de Celle e dos seus sucessores perpetuamente pelo serviço que diz respeito àquela terra(...)).

O procedimento da finalis concordia já é mencionado nas fontes mais antigas. Assim, em Glanvill 8, 1 [=R. GlanviLla, Tractatus de legibus cit. (nota 10 supra), pp. 124-125]: “Contingit autem multotiens, loquelas motas in Curia domini Regis per amicabilem compofitionem et finalem Concordiam terminari, fed ex confenfu et licentia domini Regis, vel ejus Jufticiariorum, undecunque fuerit placitum, five de terra five de alia re. Solet autem plerunque Concordia talis in communem fcripturam redigi et per communem affenfum partium; et per illam fcripturam coram Jufticiis domini Regis in Banco refidentibus recitari, et coram eis utrique parti, fua fcriptura per omnia alii concordans, liberari: et erit fub hac forma facta" (Ocorre, contudo, muitas vezes, que as causas movidas na corte do senhor rei concluem-se por meio de uma composição amigável e um acordo final, porém com o consentimento e a autorização do senhor rei ou seus Justiciars, qualquer que seja origem da demanda, seja acerca de um terreno ou de alguma outra coisa. Porém, normalmente costuma-se reduzir a termo tal acordo <feito > em comum e mediante a aprovação conjunta das partes, bem como ler esse termo em voz alta diante dos Justiciars do senhor rei no tribunal do Common Pleas, e diante deles é liberado o termo correspondente a cada parte, concordando sobre todas as coisas uma com a outra).

Em Glanvill 8, 1 a palavra loquela, assim como placitum, significa causa ou ação judicial, cf. C. F. DU CANGE, Glossarium cit. (nota 13 supra), t. 5, col. 141b (no verbete "loquela"): "idem est, quod placitum, causa, aut causa prosecutio judicialis, actio juris"; a expressão "in Banco residentibus" refere-se não ao King's Bench (como seria natural supor), mas ao Court of Common Pleas, cuja denominação na época de Glanvill era bancus, que com a criação do bancus regis - futuro King's Bench -, passou a denominar-se communis bancus, cf. A. M. BURRILl, A New Law Dictionary cit., vol. I (nota 13 supra), pp. 128-129 (no verbete "bancus"). Também em Glanvill 8, 2 [=R. GlanviLla, Tractatus de legibus cit. (nota 10 supra), p. 125]: "Hace est finalis Concordia, facta in Curia Regis (...) de tota terra illa et de pertinentiis (...)" (Esta é a finalis concordia feita na curia regis (...) acerca de toda aquela terra e dos seus acessórios (...)); e, incidentalmente, em Glanvill 9, 3 [=R. GLANVILLA, Tractatus de legibus cit. (nota 10 supra), pp. 141-142]: “Quaeri autem poteft fi quis aliquod tenementum verfus aliquem per Concordiam factam in Curia diracionaverit, qui tenementum id prius releviaverit versus capitalem Dominum; utrum ille, qui diracionavit, debeat tenementum illud [iterum] releviare" (Pode-se perguntar, no entanto, caso alguém tenha provado <ser seu $>$ um tenementum mediante um acordo feito na curia $<$ regis $>\mathrm{em}$ face de alguém que tenha pago o relevium desse tenementum ao senhor chefe, se porventura aquele, que provou $<$ ser seu o tenenentum $>$, deva pagar de novo o relevium relativo àquele tenementum).

Em Glanvill 9, 3 o verbo dirationare é uma corruptela do verbo latino tardio disrationare que, embora mais propriamente signifique "provar em contrário", nos textos de Bracton e Glanvill significa simplesmente provar alguma coisa, cf. A. M. BURRILL, A New Law Dictionary cit., vol. I (nota 13 supra), pp. 382-383 (no verbete "disrationare"). O relevium ou relevatio, que em inglês deu origem à palavra relief, era o incident feudal devido ao senhor pelo herdeiro do tenant falecido para poder herdar a titularidade da concessão, cf. D. M. WALKER, The Oxford Companion cit. (nota 8 supra), p. 1055 (no verbete “relief'). 
Poder-se-ia perguntar por que o senhor feudal prefereriria permitir que seu tenant efetuasse uma subconcessão, mesmo com o risco de perder os incidents, ao invês de facilitar o procedimento de substitution mediante a aceitação do novo tenant por meio da realização de uma homagium, acompanhada do devido oath of fealty e da livery of seisin. O mais provável é que o senhor quisesse evitar os riscos associados à possibilidade, sempre presente, de ser eventualmente demandado, no âmbito da jurisdição real, pelo herdeiro do tenant substituído com base na anterior seisin do de cujus ${ }^{320}$.

A subinfeudation começou a criar sérios problemas aos senhores no topo da hierarquia feudal, pois seus tenants passaram a praticá-la em troca de meros nominal services $^{321}$, ou seja, a terra era alienada mediante uma nova concessão feudal cujos services não tinham qualquer valor em si, dado que a estrutura da economia fundiária inglesa já tinha mudado e o pagamento em dinheiro representava um negócio mais atraente para o tenant concedente ${ }^{322}$.

O valor de quaisquer benefícios decorrentes de um eventual incident baseava-se no valor dos services, os quais, após a alienação por subinfeudation, frequentemente eram apenas nominais. Isso constituia, em termos mais modernos, um mecanismo de elisão

Também em Bracton f. 310-310b: “(...) concordia in foro seculari idem est quod transactio. Et est transactio de re dubia et lite incerta aliquo dato vel promisso vel retento a lite transactio" ((...) o acordo no foro secular é o mesmo que a transação. E a transação é um acordo acerca de uma coisa duvidosa e uma lide $<$ de desfecho $>$ incerto, <ou acerca de> alguma coisa dada, prometida ou retida em função da lide), bem como em Bracton f. 435b: “(...) quae dicitur finalis concordia, et ideo finalis quia imponit finem litibus (...)” ((...) que é denominado acordo final, e por isto <é chamada> final: porque impõe o fim às lides (...)).

Apesar das controvérsias acerca da sua origem, de acordo com J. HUNTER, Fines sive pedes finium cit., vol. I (nesta nota), pp. v-xvii, é provável que o procedimento da finalis concordia tenha sido derivado das fontes romanas, encontrando suas origens remotas no título 15 do livro 2 do Digesto, especialmente em Ulp. 40 ad ed., D. 2, 15, 1: "Qui transigit, quasi de re dubia et lite incerta neque finita transigit (...)" (Aquele que transige, transige como se fosse de acerca de uma coisa duvidosa e de uma lide incerta e não acabada (...)).

${ }^{320}$ Cf. S. F. C. MiLsOM, Historical Foundations cit. (nota 12 supra), p. 115.

${ }^{321}$ Cf. R. Megarry e W. WADE, The Law of Real Property cit. (nota 1 supra), p. 28 e S. F. C. MiLsOM, Historical Foundations cit. (nota 12 supra), p. 113. Era muito comum fazer uma nova concessão feudal cujo service anual era descrito como uma rose at midsummer, evidenciando que o interesse não era o serviço em si (pois uma rosa no solstício de verão era uma redundância em termos), mas o pagamento em espécie feito pelo novo tenant. Essa prática não se restringia aos libera tenementa de que trata o statutum aqui analisado.

Exemplos desse tipo de nominal services, relativos a concessões não abrangidas pelo Statutum Quia Emptores Terrarum 1290 [=Stat. 18 Edw. I (1290), c. 1-3], podem ser vistos nas descrições de registros contidas em H. C. MaXwell-Lyte, A Descriptive Catalogue of Ancient Deeds in the Public Record Office, vol. IV, London, Mackie \& Co., 1902, pp. 263-276, especialmente os registros A-8107: "Indenture of demise by William (...) rent, for the first eight years, a rose at Midsummer (...)"; A-8116: "Feoffment by William (...) by the rent of a rose at Midsummer (...)"; A-8117: "Feoffment by Hugh (...) by the rent of a rose at Midsummer (...)"; A-8141: "Indenture of demise by Robert (...) at the rent of a rose at Midsummer (...)". A obra em questão reúne uma coleção muito variada de documentos particulares depositados em diversos locais. Embora não haja uma transcrição do texto original em latim, a descrição do documento em inglês serve para ilustrar em que consistiam os nominal services, já que nesses casos o interesse do concedente não eram os services, mas um pagamento em espécie aliado à retenção da condição de senhor sobre o bem imóvel em questão, cf. M. W. HEMMEON, Burgage Tenure in Medieval England, Cambridge, Harvard University, 1914, p. 88.

322 Cf. J. H. BAKER, An Introduction cit. (nota 12 supra), p. 241. 
fiscal $^{323}$. Portanto, os maiores prejudicados eram, invariavelmente, os grandes senhores, na medida em que eram privados do seu principal interesse econômico nas concessões feudais de bens imóveis, isto é, os incidents ${ }^{324}$.

Diversas medidas foram adotadas pela Coroa para atender às reclamações dos senhores feudais, sem muito sucesso ${ }^{325}$. Uma delas foi a promulgação, já em 1217, de uma norma que vedava as alienações que não deixassem resíduo suficiente para evitar a desvalorização dos services devidos ao respectivo senhor ${ }^{326}$. Também o Statutum de Marleberge 1267 continha provisões a respeito do tema ${ }^{327}$.

${ }^{323}$ Cf. S. F. C. MiLSOM, Historical Foundations cit. (nota 12 supra), p. 114.

324 Pode-se ilustrar a situação do senhor mediante uma ilustração hipotética, encontrada em T. F. T. PluCKnetT, A Concise History cit. (nota 12 supra), p. 539. Seja "A" o senhor, "B" seu tenant, e "C" um eventual subtenant. Enquanto a relação feudal entre "A" e "B" durar, "A" terá direito a uma renda regular em função dos services, além de somas substanciais em razão dos incidents, pois se "B" falecer e o herdeiro for menor de idade, "A" tem custodia sobre ele e percebe todos os frutos da terra enquanto durar a minoridade; se "B" falecer e o herdeiro for maior de idade, "A" tem direito ao relevium e receberá uma soma do herdeiro; se "B" falecer sem deixar herdeiros, ou se cometer um crime, "A" recebe a concessão do terreno de volta por escheat ou forfeiture. Agora, supondo-se que "B" aliene, mediante uma subconcessão, o terreno a "C", embora a relação entre "A" e "B" continue inalterada, "A" somente terá direito àquilo que a sua senhoria (seignory) sobre "B" lhe concede: o valor de um incident com base nos services produzidos sobre o terreno. Assim, por exemplo, quando "B" falecesse, "A" recebia, a título de relief [=relevium], um valor com base naquilo que "B" ainda mantinha: os nominal services prestados por " $C$ ", que frequentemente não passavam da coleta anual de algumas rosas.

${ }^{325}$ Cf. R. MEgARry e W. WADE, The Law of Real Property cit. (nota 1 supra), p. 28.

${ }^{326}$ Cf. Magna Carta 1217, c. 39: "Nullus liber homo de cetero det amplius alicui vel vendat de terra sua quam ut de residuo terrae suae possit sufficienter fieri domino feodi servitium ei debitum quod pertinet ad feodum illud" (Nenhum homem livre, de agora em diante, dê ou venda a outrem mais da sua terra do que <o necessário $>$ para que do resíduo da sua terra possa suficientemente ser fornecido ao senhor do feudo o serviço a ele devido $<$ e $>$ que pertence àquele feudo).

${ }^{327}$ Cf. Statutum de Marleberge 1267 [=Stat. 52 Hen. III (1267), c. 6]: "De hiis autem qui primogenitos et heredes suos infra etatem existentes feoffare solent de hereditate sua, ut per hoc amitterent domini feodorum custodias suas, provisum est et concorditer concessum ut occasione hujusmodi feoffamenti nullus capitalis dominus custodiam suam amittat. De hiis insuper qui de terris suis, quas tradere volunt ad terminum annorum, et ut Domini feodorum amittant custodias suas, falsa confingunt feoffamenta continencia quod eis satisfactum est de summa servicii in illis contenti usque ad terminum aliquem, et quod post dictum terminum solvere teneantur huiusmodi feoffati summam aliquam valorem terrarium illarum in multo excedentem, ut sic post terminum illum terra eorum revertatur ad ipsos, eo quod nemo eas pro tanto tenere curaret, provisum est et concessum, ut per hujusmodi fraudem nullus capitalis dominus amittat custodiam suam (...)" (Acerca daqueles que costumam fazer uma concessão feudal da sua herança aos seus primogênitos e herdeiros enquanto <estes> são menores de idade, para que desse modo os senhores dos feudos perdessem suas guardas, foi providenciado e concedido de bom acordo que nesse tipo de circunstância nenhum senhor chefe perca sua guarda. Ainda acerca daqueles que, sobre as terras que desejam entregar por um termo de anos e, para que os senhores dos feudos percam suas guardas, forjam falsas concessões feudais contendo <uma declaração $>$ de que lhes foi satisfeita $<$ a prestação $>$ de todos os serviços contidos nesses $<$ feudos $>$ até $<$ a ocorrência de $>$ um certo termo, e que após dito termo os concessionários feudais fiquem assim obrigados a pagar alguma soma muito superior ao valor daquele terreno, para que assim a terra, após aquele termo, reverta a eles próprios, visto que ninguém tenha interesse em deté-las por tanto <serviço $>$, foi providenciado e concedido que por essa espécie de fraude nenhum senhor chefe perca sua guarda $(. .$.$) ).$

A palavra custodia, no statutum acima, equivale à palavra wardship em inglês, e significa a prerrogativa do senhor de ter a guarda do herdeiro durante a minoridade, o que conferia àquele o direito de perceber todos os frutos do terreno, sem prestar quaisquer contas, até o herdeiro atingir vinte e um anos, se fosse do sexo masculino, ou dezesseis, se do sexo feminino, cf. A. M. BurRILl, A New Law Dictionary cit., vol. II (nota 13 supra), p. 1057 (no verbete “wardship”) e C. F. DU CANGE, Glossarium cit. (nota 13 supra), t. 8, col. 404c (no 
Dada a ineficácia das medidas adotadas para atender às demandas dos senhores $^{328}$, foi promulgado o Statutum Quia Emptores Terrarum 1290, cujo teor passamos a $\operatorname{expor}^{329}$ :

Stat. 18 Edw. I (1290), c. 1: Quia emptores terrarum et tenementorum de feodis magnatum et aliorum dominorum, in prejudicium eorundem, temporibus retroactis, multotiens in feodis suis sunt ingressi, quibus libere tenentes eorundem magnatum et aliorum terras et tenementa sua vendiderunt, tenenda in feodo sibi et heredibus suis de feoffatoribus suis, et non de capitalibus dominis feodorum, per quod iidem capitales domini eschaetas, maritagia, et custodias terrarum et tenementorum de feodis suis existentium saepius amiserunt: quod quidem eisdem magnatibus et aliis dominis quam plurimum durum et difficile videbatur; et in hoc casu exhereditatio manifesta; dominus rex in parliamento suo apud Westmonasterium post Pascha anno regni sui decimo octavo, videlicet in quindena Sancti Johannis Baptistae, ad instantiam magnatum regni sui, concessit, providit et statuit, quod de cetero liceat unicuique libero homini terram suam seu tenementum sive partem inde pro
Stat. 18 Edw. I (1290), c. 1: Porquanto os compradores de terras e tenementa relativas a feudos de grandes <homens> e outros senhores, em prejuízo dos mesmos, em tempos passados, tantas vezes ingressaram nos seus feudos, aos quais os libere tenentes dos mesmos grandes <homens> e outros venderam suas terras e tenementa, para serem tidas dos seus concedentes a título de concessão feudal para si e os seus herdeiros, e não <tidas> dos senhores chefes dos feudos, pelo qual os mesmos senhores chefes muitas vezes perderam as eschaeta, maritagia e custodiae das terras e tenementa provenientes dos seus feudos, o que certamente parecia aos mesmos grandes <homens> e aos outros senhores tanto mais duro e difícil, e neste caso manifesta deserdação, o senhor rei, no seu parlamento junto a Westminster após a Páscoa, no décimo oitavo ano do seu reinado, a saber, na quinzena de São João Batista, por instância dos grandes <homens> do seu reino, concedeu, providenciou e estatuiu, que de

verbete "warda"): "Custodia pupillorum nobilium, quae regi, aut domino feudali competit". A respeito da custodia, ver também Bl Comm 2, 5, 67-71 [=W. BLACKSTONE, Commentaries cit., vol. II (nota 10 supra), pp. 67-71]. O verbo feoffare, cuja raiz é, ao que tudo indica, o vocábulo anglo-saxão "feoh" (cf. nota 124 supra), refere-se à operação jurídica pela qual a concessão feudal hereditária se transfere a terceiros, cf. A. M. BURRILL, A New Law Dictionary cit., vol. I (nota 13 supra), p. 480 (no verbete "feoffare").

No caso, o statutum em questão trata de duas práticas adotadas pelos tenants para evitar o pagamento dos incidents. Assim, a concessão feudal feita aos herdeiros menores de idade - o que era jurídicamente possível, dada a capacidade de fato mais ampla que o common law atribuía aos menores de idade, cf. T. F. T. PLUCKNETT, A Concise History cit. (nota 12 supra), pp. 544-545 -, bem como as concessões temporárias cujos services eram fixados num valor exorbitante a partir de um determinado número de anos (term of years), de modo a justificar a posterior retomada pelo concedente.

Diga-se de passagem, o Statutum de Marleberge 1267 [=Stat. 52 Hen. III (1267)] é o mais antigo statute ainda vigente, em parte, no Reino Unido. Assim, estão vingentes ainda os capítulos 1, c. , 4, 15, que estabelecem a proibição de auto-tutela e a competência exclusiva dos tribunais reais na hipótese de responsabilidade por dano (damages), e o capítulo 23, que proíbe o dano ou a alteração substancial (waste) das terras para cultivo por parte dos tenants. Sobre as disposições ainda vigentes do Statute of Marlborough 1267, cf. http://www.legislation.gov.uk/aep/Hen3cc1415/52/1/contents http://www.legislation.gov.uk/aep/Hen3c23/52/23 [07-08-2012].

${ }^{328}$ De fato, o que tinha acontecido é que uma grande parte das subinfeudations eram praticadas fora do contexto tradicional feudal, ou seja, eram realizadas por tenants que se tornavam senhores somente em nome, sem exercer jurisdição ou ter qualquer outra atribuição senhorial. Tratava-se de uma artificialidade cuja origem era o fato de que os tenants no século XIII já eram vistos como efetivos titulares de direitos reais sobre os terrenos que possuiam e os vendiam mediante pagamento único através das formalidades da homage e do oath of fealty porque lhes trazia mais vantagens do que a substitution, cf. S. F. C. MILSOM, Historical Foundations of the Common Law, $2^{\mathrm{a}}$ ed., Oxford, Oxford University, 1981, p. 114.

329 O texto original do Statutum Quia Emptores Terrarum 1290 [=Stat. 18 Edw. I (1290), c. 1-3] foi redigido em latim abreviado e reproduzido em Statutes of the Realm cit., vol. I (nota 8 supra), p. 106, com as abreviaturas indicadas mediante símbolos tipográficos específicos. Como não foi possível encontrar os caracteres tipográficos correspondentes em meio eletrônico, reproduzimos, após a devida conferência, o texto por extenso encontrado em W. STUBBS, Select Charters cit. (nota 8 supra), pp. 473-474. 
voluntate sua vendere; ita tamen quod feoffatus teneat terram illam seu tenementum de eodem capitali domino et per eadem servitia et consuetudines per quae feoffator suus illa prius tenuit. agora em diante seja lícito a qualquer homem livre vender sua terra ou tenementum, ou uma parte <delas $>$, conforme a sua vontade, de tal forma que o concessionário tenha aquela terra ou tenementum do mesmo senhor chefe, pelos mesmos serviços e costumes pelos quais obrigou-se anteriormente o seu concedente.

O primeiro capítulo do statutum explicita os motivos que levaram à sua promulgação, fazendo referência, em primeiro lugar, aos prejuízos causados pelas operações de compra de terrenos e tenementa ${ }^{330}$, subentendidos os imóveis submetidos ao regime de freehold [=libera tenementa], por parte de terceiros (Quia emptores terrarum et tenementorum de feodis...). O statutum refere-se aos freeholders [=libere tenentes ${ }^{331}$ ] tanto na qualidade de vendedores de ditas terras (...quibus libere tenentes eorundem magnatum et aliorum terras et tenementa sua vendiderunt...) quanto na de concedentes feudais $\left[=\right.$ feoffatores $\left.^{332}\right]$ (...tenenda in feodo...de feoffatoribus suis...).

Note-se que na primeira parte do texto do statutum evita-se equiparar a situação juridica dos compradores à de um concessionário feudal, para o qual se deveria utilizar a feoffatus $^{333}$. A palavra somente aparece após a exposição dos motivos, ao se fazer referência à autorização de venda dos terrenos em questão (...ita tamen quod feoffatus teneat terram illam seu tenementum...).

O principal interesse dos grandes senhores feudais na promulgação do statutum, que era evitar a evasão dos incidents mais proveitosos para o senhor, também é explicitado no texto (...per quod iidem capitales domini eschaetas, maritagia, et custodias...amiserunt...).

${ }^{330}$ A palavra tenementum designa o objeto de uma tenure, e após ter oscilado entre várias grafias (tenura, tenuitura) no século XII, o termo se estabeleceu no século XIII com a grafia tenementum (diferente de terra, referente às terras destinadas ao cultivo), cf. F. POLLOCK e F. W. MAITLAND, The History of English Law cit., vol. I (nota 12 supra), p. 236, nt. 3. O termo correlato em inglês é tenement, que pode referir-se tanto a um "terreno tido de outrem (held of another) a título de serviço (service)", quanto ter o significado mais amplo referente a qualquer coisa de natureza permanente que possa ser tida de outrem (held of another), tais como aluguéis (rents), terras de uso comum e outros direitos, cf. A. M. BURRILL, A New Law Dictionary cit., vol. II (nota 13 supra), p. 975 (nos verbetes "tenement" ${ }^{1}$ " "tenement $t^{2 "}$ ).

O instituto também é mencionado em C. F. DU CANGE, Glossarium cit. (nota 13 supra), t. 8, col. 058b (no verbete "tenementum"): "Pradium urbanum, quo de domino tenetur. Skenæus ait, Tenementum communiter accipi pro hareditate vel feudo; liberum vero tenementum idem esse cum usufructu, tametsi sapissime confunduntur, atque hac differentia minime observatur".

${ }^{331} \mathrm{Cf}$. nota 151 supra.

${ }^{332}$ Cf. C. F. DU CANGE, Glossarium cit. (nota 13 supra), t. 3, col. 479c (no verbete "feoffator"): "Dominus, qui terram ad feodum concedit, vel qui pradium tenentis in feudum simplex erigit, aut certe qui investit aut donat". O vocábulo era utilizado para indicar o concedente de um feudo hereditário (feoffor), ou seja, de um grant in fee, cf. A. M. BurRILl, A New Law Dictionary cit., vol. I (nota 13 supra), p. 480 (no verbete "feoffator").

333 Cf. C. F. DU CANGE, Glossarium cit. (nota 13 supra), t. 3, col. 479c (no verbete "feoffatus"): "Donatarius, vel qui feudo investitur". No direito inglês, o termo designa, especificamente, o concessionário in fee, i.e., o concessionário de um feudo hereditário ou feoffee, cf. A. M. BURRILL, A New Law Dictionary cit., vol. I (nota 13 supra), p. 480 (nos verbetes "feoffare" e "feoffatus"). 
Esses incidents eram, especialmente, a devolução das terras ao senhor quando o tenant morresse sem deixar herdeiros ou tivesse cometido um crime grave (eschaeta ${ }^{334}$ ) ou quando as terras tivessem sido concedidas isentas de services até a terceira geração (maritagium ${ }^{335}$ ), bem como a guarda do menor herdeiro do tenant durante a minoridade (custodia ${ }^{336}$ ).

Segue a essência do statutum. A eficácia das operações de venda ${ }^{337}$ de terras sujeitas ao regime de freehold não mais dependem da autorização dos respectivos senhores dos vendedores (...quod de cetero liceat unicuique libero homini terram suam seu tenementum sive partem inde pro voluntate sua vendere...). Em contrapartida, tais vendas comportam uma espécie de subrogação, pela qual o comprador automaticamente passa a ser tenant não do vendedor, mas do senhor deste e sob as mesmas condições (...ita tamen quod feoffatus teneat terram illam seu tenementum de eodem capitali domino et per eadem servitia et consuetudines per quae feoffator suus illa prius tenuit...).

Em outras palavras, o comprador substitui, ex vi lege, o tenant vendedor na sua condição de concessionáro feudal e assume as mesmas obrigações e ônus originariamente estabelecidos entre o senhor e o tenant vendedor.

Stat. 18 Edw. I (1290), c. 2: Et si partem aliquam earundem terrarum seu tenementorum suorum alicui vendiderit, feoffatus illam teneat immediate de capitali domino, et oneretur statim de servitio quantum pertinet sive pertinere debet eidem domino pro particula illa, secundum quantitatem terrae seu tenementi venditi; et sic in hoc casu decidat capitali domino ipsa pars servitii capienda per manum feoffatoris, ex quo feoffatus debet eidem capitali domino, juxta quantitatem terrae seu tenementi venditi de particula illa servitii sic debiti esse intendens ${ }^{338}$ et respondens.
Stat. 18 Edw. I (1290), c. 2: E caso <o tenant> venda a alguém uma parte dessas suas terras ou tenementa, <determina-se> que o concessionário feudal tenha <dita terra $>$ diretamente do senhor chefe, e seja logo onerada <a título de tanto $>$ serviço quanto corresponde ou deve corresponder ao mesmo dono por aquela parcela $<$ de terra $>$, segundo a quantidade de terra ou tenementum vendida. $\mathrm{E}$ assim, neste caso, fique com o senhor chefe a mesma parte do serviço a ser obtida pela mão do concedente, pela qual o concessionário feudal deve ser quem responde e fornece $<0$ dito serviço $>$ ao mesmo senhor chefe acerca da quantidade de terras ou de um tenementum vendida em relação àquela parcela de serviço assim devido.

${ }^{334}$ Acerca do escheat, cf. nota 158 supra.

${ }_{335}$ Acerca do maritagium, cf. capítulo 2.2.4.2 supra.

${ }^{336}$ Acerca da custodia, cf. nota 327 supra.

${ }^{337}$ Cabe ressaltar que, tecnicamente, a palavra venditio, no vocabulário jurídico inglês, pode tanto significar o contrato de compra e venda (emptio venditio), quanto qualquer espécie de alienação de um direito real sobre uma coisa, cf. A. M. BURRILl, A New Law Dictionary cit., vol. II (nota 13 supra), p. 1025 (no verbete "venditio"). O texto do statutum adota o segundo sentido.

${ }^{338}$ No sentido dado em C. F. DU CANGE, Glossarium cit. (nota 13 supra), t. 4, col. 387c (no verbete "intendere 8 [alicui de re aliqua]"): "Hanc illi ad suum commodum prabere", ou seja, fornecer algo para o proveito de outrem. 
O segundo capítulo do statutum trata da hipótese de venda, por parte do mesmo tenant, não do terreno como um todo, mas apenas de uma parcela dele (...si partem aliquam earundem terrarum seu tenementorum suorum alicui vendiderit...). Fica estabelecido que os services deverão ser proporcionais ao tamanho da parcela em questão, tomando como referência os services devidos pelo tenant vendedor em funçã do terreno inteiro (...in hoc

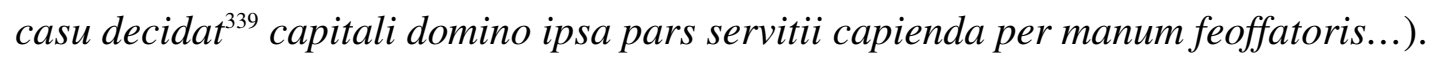

Stat. 18 Edw. I (1290), c. 3: Et sciendum est quod per praedictas venditiones sive emptiones terrarum seu tenementorum, seu partis alicujus eorundem, nullo modo possunt terrae seu tenementa, in parte vel in toto, ad manum mortuam devenire, arte vel ingenio contra formam statuti super hoc dudum editi. Et sciendum quod istud statutum locum tenet de terris venditis tenendis in feodo simpliciter tantum; et quod se extendit ad tempus futurum.
Stat. 18 Edw. I (1290), c. 3: E deve-se entender que pelas supracitadas vendas ou compras de terras ou de tenementa, ou de alguma parte delas, de nenhum modo podem as terras ou tenementa, em parte ou no todo, passar para manum mortuam, seja pela arte ou pelo engenho, contra a forma do estatuto acima editado recentemente. E deve-se entender que este estatuto tem aplicação apenas em relação às terras vendidas <que sejam $>$ tidas <a título $>$ de feudum simplex, e que se estende ao tempo futuro.

No seu terceiro e último capítulo, o statutum faz referência, em primeiro lugar, à vedação das doações de terras em favor de entidades religiosas, pois na época essa era uma transação normalmente praticada não em função do fervor religioso, mas do desejo de livrarse das inconveniências dos incidents ${ }^{340}$. A seguir, define-se o alcance das disposições da lei,

339 O verbo decido, -is, -ere, -cidi, -cisum, no contexto do statutum, adquire o sentido de "fixar" ou "estabelecer", cf. P. G. W. GLARE (coord.), OLD cit. (nota 13 supra), p. 490 (no verbete "decido, -is, -ere, -cidi, -cisum").

${ }^{340}$ Aqui o statutum faz uma alusão ao Statutum De Viris Religiosis, também conhecido como o Statute of Mortmain 1279 [=Stat. 7 Edw. I (1279), c. 2], pelo qual foram estabelecidas, como forma de fortalecer o status da nobreza, severas limitações às alienações feitas em favor da Igreja, tendo em vista que na sua grande maioria tais alienações eram consideradas fraudulentas, pois o intuito do doador normalmente era tornar-se tenant da Igreja de modo a evitar os pesados incidents das tenures seculares, cf. W. STUBBS, Select Charters cit. (nota 8 supra), pp. 451-452. As terras doadas à Igreja não mais podiam ser objeto de herança, pois, sendo uma corporação, a Igreja era imortal e não podia ter herdeiros, donde a denominação "mortmain" [= "manus mortua"], cf. J. H. BAKER, An Introduction cit. (nota 12 supra), p. 241.

Eis o fragmento relevante do citado statutum: “(...) providimus, statuimus et ordinavimus, quod nullus religiosus aut alius quicunque terras aut tenementa aliqua emere vel vendere, aut sub colore donationis aut termini vel alterius tituli cujuscunque, ab aliquo recipere, aut alio quovis modo, arte vel ingenio, sibi appropriare praesumat, sub forisfactura eorundem, per quod ad manum mortuam terrae et tenementa hujusmodi deveniat quoquo modo. Providimus etiam quod si quis religiosus aut alius, contra praesens statutum, aliquo modo, arte vel ingenio, venire praesumpserit, liceat nobis, et aliis immediatis capitalibus dominis feodi taliter alienati, illud infra annum a tempore alienationis hujusmodi ingredi et tenere in feodo haereditate" ((...) providenciamos, estatuímos e ordenamos que nenhuma $<$ pessoa $>$ religiosa ou qualquer outra $<$ pessoa $>$ pretenda comprar ou vender, ou sob o disfarce de uma doação ou de um termo, ou mesmo de qualquer outro título, receber de alguém, ou por qualquer outro modo, arte ou engenho apropriar para si quaisquer terras ou tenementa, sob $<$ pena de $>$ confisco das mesmas, por cujo <motivo $>$ as terras e tenementa por qualquer modo passem para manum mortuam. Providenciamos também que caso alguma $<$ pessoa $>$ religiosa ou outra $<$ pessoa $>$ pretenda ir contra o presente estatuto, por qualquer modo, arte ou engenho, seja lícito a nós, e aos outros senhores chefes imediatos do feudo assim alienado, ingressar desta maneira nela antes de <decorrido > um ano do tempo da alienação e tê-la a título de concessão feudal como herança).

De acordo com C. H. Chambers, A Treatise on Leases and Terms for Years, London, Strahan, 1819, pp. 42-43, as alienações temporárias de longo prazo (long term leases) tinham se tornado um modo comum de burlar 
que se aplica exclusivamente no âmbito do feudum simplex, ou seja, das concessões feitas in fee simple $e^{341}$.

Desde uma perspectiva político-juíridica, o Statutum Quia Emptores Terrarum 1290 foi o resultado de uma transigência dos nobres, que consentiram em permitir a alienação irrestrita dos terrenos sujeitos ao regime das tenures in fee simple, em troca da abolição da subinfeudation e a preservação do valor dos seus incidents ${ }^{342}$.

O statutum alterou consideravelmente o desenvolvimento da estrutura da real property inglesa. A partir da vigência do diploma, a cadeia de tenures in fee simple, que até o momento podia crescer verticalmente ad infinitum, passou a encolher-se, na medida em que não mais é possível realizar um concessão feudal desse tipo, e as concessões criadas até então pouco a pouco passaram a ser devolvidas ao seus senhores originários ou à Coroa, através dos mecanismos do escheat e forfeiture ${ }^{343}$. A homagium, portanto, passou a ser praticada somente pelo herdeiro para imitir-se na posse da herança ${ }^{344}$.

O diploma não menciona o monarca como destinatário da norma, nem explícita nem implicitamente, donde se deduz que, além de se aplicar exclusivamente às tenures in fee

a norma prevista em Magna Carta 1217, c. 43, que devolvia automaticamente o imóvel ao senhor chefe toda vez que o tenant o doasse a uma ordem religiosa e o retomasse como concessionário da mesma ordem: "Non liceat alicui de cetero dare terram suam alicui domui religiosae ita quod illam resumat tenendam de eadem domo, nec liceat alicui domui religiosae terram alicujus sic accipere quod tradat eam illi a quo eam receperit tenendam. Si quis autem de cetero terram suam alicui domui religiosae sic dederit et super hoc convincatur, donum suum penitus cassetur et terra illa domino suo illius feodi incurratur" (<Determina-se $>$ que não seja permitido a qualquer pessoa, a partir de agora, doar a sua terra a qualquer casa religiosa, de tal forma que <essa pessoa $>$ a recupere para detê-la da mesma casa, bem como que não seja permitido a qualquer casa religiosa receber a terra de qualquer pessoa para que seja detida por aquele de quem tenha sido recebida. Assim, caso alguém, a partir de agora, doe dessa forma sua terra a qualquer casa religiosa e seja condenado acerca daquilo <que foi dito $>$ acima, <determina-se> que sua doação seja completamente anulada e que aquela terra seja confiscada em favor do senhor daquele feudo).

No caso, o verbo cassare ou quassare tem o sentido de "anular um ato jurídico", cf. C. F. Du CANGE, Glossarium cit. (nota 13 supra), t. 6, col. 604a (no verbete "quassare"): "Irritum facere, abrogare". Já o verbo incurrere tem o sentido de "confiscar", cf. C. F. DU CANGE, Glossarium cit. (nota 13 supra), t. 4, col. 336a (no verbete "incurrere"): "Confiscationi obnoxium esse". Dessa disposição surgiu o princípio geral, vigente durante a Idade Média, de que as doações de bens imóveis feitas em favor de ordens religiosas são ilícitas, ressalvados os casos de concessões de natureza estritamente religiosa (frankalmoign), cf. C. T. CARR, The General Principles of the Law of Corporations, Cambridge, University Press, 1905, pp. 35-36.

${ }^{341}$ Cf. T. F. T. PluCKNETT, A Concise History cit. (nota 12 supra), pp. 543-544. Para esse autor, o Statutum Quia Emptores Terrarum 1290 [=Stat. 18 Edw. I (1290), c. 1-3] contribuiu para separar ainda mais as tenures in fee simple das demais. Assim, ao invés de atribuir, como o fazem F. POLLOCK e F. W. MAITLAND, The History of English Law cit., vol. I (nota 12 supra), p. 237, a fragmentariedade do domínio ao sistema das tenures como um todo, T. F. T. PLUCKNETT considera que essa fragmentação somente ocorria em relação aos estates less than fee simple, ou seja, àqueles estates não abrangidos pelo statutum.

${ }^{342}$ Cf. W. S. HoldSWORTH, A History of English Law cit., vol. I (nota 12 supra), p. 337.

${ }^{343}$ Cf. R. MEgarRy e W. WADE, The Law of Real Property cit. (nota 1 supra), p. 29.

${ }^{344}$ Cf. T. G. WATKIN, Quia Emptores and the Entail, in TR 59 (1993), p. 367. 
simple, suas disposições não se aplicam à $\operatorname{Coroa}^{345}$. De fato, as consequências jurídicas da inclusão da Coroa entre os destinatários da norma levaria à conclusão de que qualquer alienação de bens imóveis pertencentes à monarquia importaria numa transferência de allodium a um particular, o que não condiz com um dos pressupostos mais básicos dos direitos reais sobre imóveis na Inglaterra: a inexistência de terras alodiais fora da esfera real $^{346}$.

A relevância do statutum reside, desde uma perspectiva comparatística, na clareza com que expõe um aparente paradoxo da real property inglesa que, muito provavelmente, explica a marcada complexidade dos direitos reais baseados no common $l a w^{347}$ e a resistência à influência do direito de matriz civilística ${ }^{348}$.

De um lado, o Statutum Quia Emptores Terrarum 1290 pôs fim à expansão do sistema das tenures ${ }^{349}$ em relação às concessões in fee simple, a principal categoria de direitos reais sobre bens imóveis, e estabeleceu um importante marco na consolidação de uma das faculdades atribuídas ao titular de um dominium de base romanística: a capacidade de alienar a coisa sem a anuência do senhor ${ }^{350}$.

De outro, no entanto, é um dos principais expoentes da vigência e operação de normas jurídicas criadas num contexto histórico hoje inexistente, impondo um vocabulário e

${ }^{345}$ Cf. Litt 140 [=E. WAMBAUGH, Littleton's Tenures - In English cit. (nota 10 supra), pp. 69-70]: “(...) But the king may give lands or tenements in fees simple to hold in frankalmoign, or by other services, for he is out of the case of that statute"; W. S. HOLDSWORTH, A History of English Law cit., vol. III (nota 12 supra), p. 84.

${ }^{346}$ Cf. capítulo 2.2.1 supra.

${ }^{347}$ Cf. A. WATSON, Roman Law \& Comparative Law cit. (nota 1 supra), pp. 142-143. Seria justamente o declínio do feudalismo que se encontraria na raiz da complexidade do sistema "aparentemente" feudal dos direitos reais ingleses. Para o autor, a preeminência da atividade judiciária foi um dos fatores que assegurou a permanência formal das instituições feudais, impedindo a implantação de mudanças conceituais importantes ao longo dos séculos. Assim, a longa ausência da sucessão testamentária em matéria de bens imóveis, bem como o favorecimento da primogenitura na sucessão legítima, seriam o resultado direto de uma cultura jurídica que relegava aos juízes (que o atutor denomina subordinate lawmakers) a tarefa de adaptar as antigas instituições feudais aos novos contextos sociais e econômicos enfrentados pela sociedade.

${ }^{348}$ Cf. R. Michaels, s.v. Property, in J. Basedow, K. Hopt e R. Zimmermann, The Max Planck Encyclopedia cit., vol. I (nota 4 supra) pp. 1371-1372.

${ }^{349}$ Cf. W. STUBBS, Select Charters cit. (nota 8 supra), p. 473: "The importance of this act is chiefly prospective: consisting in the greater facilites afforded for the division of estates; the multiplication of tenants 'in capite' of the crown; and at the same time of socage tenants also; the stereotyping of local divisions; the stopping the creation of manors, and of new grades of middle-men between the chief lord and the cultivator; and the fusion of the rural population without distinction of tenure (...) 'Quia Emtpores' is one of the few acts of legislation which, being passed with a distinct view to the interests of a class, have found to work for the advantage of the nation generally".

${ }^{350}$ Cf. S. F. C. MiLsOM, Historical Foundations cit. (nota 12 supra), p. 110. 
uma estrutura lógico-conceitual próprios do feudalismo ${ }^{351}$, mesmo que, em termos práticos, o sistema jurídico tenha evoluído e se tornado mais racionalizado ${ }^{352}$.

Em suma, se bem que a permanência de estruturas feudais no sistema inglês de direitos reais não impediu sua transformação e adaptação conforme as necessidades e exigências do tempo ${ }^{353}$, as divergências categoriais e semânticas também podem apresentar entraves à tarefa de integração dos sistemas jurídicos baseados no common law inglês com os de base romanística ${ }^{354}$.

${ }^{351}$ Um exemplo do uso desse referencial é o Land Registration Act 2002, s. 132 (1), que incorporou o sentido da expressão "estates in land" dado pelo Stat. 15 \& 16 Geo. V (1925), c. 20, s. 205 (1) (ix): "Land' includes land of any tenure (...)” $\mathrm{e}(\mathrm{x})$ : “'Legal estates' mean the estates, interests and charges, in or over land (...)".

${ }^{352}$ Cf. K. GRAY e S. F. GRAY, Elements of Land Law cit. (nota 1 supra), p. 67: “(...) the last implications of tenurial orthodoxy have all but disappeared. Tenure of land for an estate in fee simple is tantamount to absolute ownership of the land (...)".

${ }^{353}$ Cf. S. VAN ERP, Comparative Property Law cit. (nota 1 supra), p. 1059.

${ }^{354}$ Cf. L. MocCIA, Il modello inglese cit. (nota 1 supra), p. 38, para quem, conforme já mencionado acima, o problema relativo ao confronto entre os modelos romanístico e inglês de propriedade consiste, justamente, na incompatibilidade "gramatical" entre os respectivos sistemas, resultado da permanência, na Inglaterra, das estruturas jurídicas privadas feudais. 


\section{A FORMAÇÃO HISTÓRICA DA EQUITY E DOS TRUSTS}

\subsection{Os trusts e a comparação entre sistemas}

Os trusts ${ }^{355}$ representam uma das criações jurídicas mais típicas do common law, resultado da atividade jurisdicional do Chancellor exercida na Court of Equity ${ }^{356}$. Sua natureza híbrida, oscilante entre os direitos de natureza obrigacional e os direitos de natureza real, bem como os múltiplos fins a que o instituto se presta, tem gerado controvérsias na doutrina no que diz respeito à sua definição ${ }^{357}$.

De modo preliminar e simplificado, no entanto, pode-se entender o trust como a relação jurídica pela qual um bem ou conjunto de bens é administrado por um titular formal (denominado trustee) em benefício de um terceiro (denominado beneficiary), também titular de direitos reais sobre o mesmo bem ou conjunto de bens ${ }^{358}$.

À margem da definição adotada, uma das características marcantes do trust é a aparente atribuição, a sujeitos distintos, de um direito de "propriedade" sobre o mesmo patrimônio, fenômeno denominado dual ownership. Essa particular disribuição dos direitos reais só é possível graças ao particular desenvolvimento histórico do common law, que permitiu o gradual aumento da proteção concedida ao beneficiary, quase sempre em detrimento do trustee.

A particular estrutura do trust gera conseqüências jurídicas diferenciadas, normalmente relacionadas à proteção dos interesses do beneficiary ${ }^{359}$. Assim, por exemplo, o patrimônio pessoal do trustee não se confunde com o trust, que constitui um complexo de bens autônomo, e eventuais credores do trustee não podem satisfazer seu crédito com o patrimônio que faz parte dele. Apenas os credores do beneficiary podem fazê-lo. Da mesma forma, o trustee pode alienar os bens do trust, porém o valor arrecadado reverte em favor do

355 Apesar da eventual utilização, ao longo deste trabalho, do termo trust, e não trusts, como seria mais correto, estamos cientes da crítica feita pela doutrina ao uso do termo no singular. Nossa opção pela primeira variante, em determinados contextos, corresponde a uma simplificação que visa a facilitar a compreensão da matéria. A respeito do tema, cf. M. LUPOI, Trusts cit. (nota 1 supra), pp. 5-8.

${ }^{356}$ Nesse sentido, cabe lembrar as palavras de F. W. MAITLAND, Equity cit. (nota 12 supra), p. 23: "Of all the exploits of Equity the largest and the most important is the invention and development of the trust".

${ }^{357}$ Para uma visão panorâmica das diversas definições do trust elaboradas pelos autores do common law, cf. G. W. KeEton, The Law of Trusts, $4^{\mathrm{a}}$ ed., London, Sir Isaac Pitman \& Sons, 1947, pp. 1-4.

${ }^{358}$ Cf. M. C. MALAGUTI, Il trust cit. (nota 1 supra), p. 183.

${ }^{359}$ Cf. F. W. MAITLAND, Equity cit. (nota 12 supra), p. 23. 
beneficiary, e se a alienação for a título gratuito, ou se houver má-fé, o adquirente passa a ser trustee em relação ao bem assim adquirido ${ }^{360}$.

Em suma, a proteção jurídica dispensada ao beneficiary decorre das regras da equity elaboradas e aplicadas pelo Chancellor, o que possibilitou a constituição de um conjunto de direitos reais em favor do beneficiary, sempre ao lado da titularidade formal do trustee, tutelada pelo common law.

Nos países pertencentes a sistemas jurídicos de base romanística os trusts têm capturado a atenção de vários comparatistas ${ }^{361}$. A intensificação das relações entre países de tradições jurídicas divergentes tem resultado na penetração do trust em ordenamentos de base romanística, levando países como a Itália ${ }^{362}$, Luxemburgo, Malta, Mônaco, Holanda e Suíça a aderir à Convenção da Haia de $1985^{363}$ sobre o direito aplicável aos trusts ${ }^{364}$. A expansão do tráfico jurídico para além das fronteiras do Estado nacional, dentro do contexto da crescente complexidade da vida moderna, tem aumentado o interesse pelo estudo das relações de semelhança e complementaridade entre os ordenamentos jurídicos pertencentes às diversas famílias de direito espalhadas pelo globo.

Mesmo sem apelar para a intensificação do tráfico jurídico ente as nações do mundo contemporâneo, alguns ordenamentos podem ser classificados como "mistos" pelas características que lhes são inerentes. É o caso da Escócia e da África do Sul, cujos ordenamentos possuem traços típicos da tradição romanística, porém combinados com elementos próprios do sistema do common $\operatorname{law}^{365}$. Tais ordenamentos apresentam grande

${ }^{360}$ Cf. M. C. MalaguTI, Il trust cit. (nota 1 supra), p. 187.

361 Uma das principais obras a tratar sistematicamente do trust do ponto de vista comparatístico contemporâneo é M. LUPOI, Trusts cit. (nota 1 supra), pp. 1-386. Uma tentativa de harmonizar o trust de acordo com as categorias do direito civil pode ser vista em P. LEPAULLE, Traite theorique et pratique des trusts cit. (nota 1 supra), pp. 1-442. Para uma exposição dos principais esforços comparatísticos ao longo dos últimos anos, cf. R. HELMHOLZ e R. ZiMMERMANN (org.), Itinera Fiduciae cit. (nota 1 supra), pp. 27-542.

${ }^{362}$ A possibilidade de reconhecimento dos trusts na Itália é estabelecida pelo artigo 11 da lei no 364/1989.

${ }^{363}$ O trust é definido pela Convenção da Haia de 1985 no artigo $1^{\circ}$ : "For the purposes of this Convention, the term "trust" refers to the legal relationships created - inter vivos or on death - by a person, the settlor, when assets have been placed under the control of a trustee for the benefit of a beneficiary or for a specified purpose".

${ }^{364}$ Cf. A. GUARINO, Diritto privato romano, $12^{\mathrm{a}}$ ed., Napoli, Jovene Napoli, 2001, pp. 861, nt. 74.3.3.

${ }^{365}$ Para uma apresentação sintética dos traços característicos desses dois sistemas, cf. O. MORÉTEAU e J. VANDERLINDEN (org.), La structure des systèmes juridiques: collection des rapports - XVI congrès de l'Académie internationale de droit comparé, Bruxelles, Bruylant, 2003, pp. 17-431; K. REID, D. VISSER e R. ZIMMERMANN, Mixed Legal Systems in Comparative Perspective - Property and Obligations in Scotland and South Africa, Oxford, Oxford University, 2004, pp. 1xxiii-33; D. VISSER e R. ZIMMERMANN, Southern Cross Civil Law and Common Law in South África, Oxford, Clarendon, 1996, pp. 1-29 (especificamente sobre o ordenamento jurídico da África do Sul). 
interesse científico, na medida em que as soluções neles adotadas podem servir de modelo para a elaboração de uma teoria a respeito do trust em sistemas de base romanística ${ }^{366}$.

Tendo em vista as particularidades dos sistemas de direito inglês e romanístico, pode-se estabelecer um núcleo de características que devem estar presentes para configurar o trust num sistema de tradição romanística: (i) um trustee que ocupe uma posição fiduciária, agindo com fidelidade e lealdade no interesse de um terceiro; (ii) a separação entre o patrimônio pessoal do trustee e o patrimônio do trust; (iii) uma operação de sub-rogação real que assegure que o produto da venda de qualquer bem do trust, bem como qualquer bem que substitua outro pertencente ao trust, fique sujeito ao trust; (iv) a profissionalização da atividade do trustee $e^{367}$.

De acordo com esses parâmetros, a recepção dos trusts em sistemas de tradição romanística pressupõe a superação da concepção de uma propriedade cindida (divided title) como elemento imprescindível à configuração dos trusts. Os fins visados pelos trusts podem ser alcançados por meio de outras figuras jurídicas presentes nos sistemas de direito romanogermânico $^{368}$, a exemplo do que ocorreu em países como Liechtenstein, México e Panamá, bem como nos estados da Louisiana, nos Estados Unidos, e do Quebec, no Canadá, que introduziram o instituto pela via legislativa na década de $1920^{369}$.

Nosso objetivo, ao longo da exposição que segue, é apresentar a origem histórica da equity e dos trusts, de modo a facilitar a sua compreensão e contribuir para o diálogo entre os sistemas do common law e os de base romanística.

\subsection{A formação da equity na Inglaterra}

A análise jurídica dos trusts passa, como o resto da real property law inglesa, pelo estudo dos seus aspectos históricos. Sendo assim, torna-se indispensável conhecer a

\footnotetext{
${ }^{366}$ Cf. M. J. WAAL, Comparative Succession Law cit. (nota 1 supra), p. 1089. Cabe destacar que, na Escócia, o trust não foi recepcionado diretamente do direito anglo-saxão; o instituto surgiu no século XVII e foi desenvolvido, provavelmente, a partir das figuras de depositum, mandatum, e fideicomissum. Já na África do Sul, o trust foi introduzido pelos colonos ingleses durante o século XIX, mas foi posteriormente desenvolvido e adaptado para adequar-se aos conceitos de direito civil, mediante o uso dos conceitos de fideicomissum (para o trust testamentário) e stipulatio alteri (para o trust celebrado mediante negócio inter vivos).

${ }^{367}$ Cf. M. J. WAAL, Comparative Succession Law cit. (nota 1 supra), p. 1089.

${ }^{368}$ A comparação de institutos de origem romana com o trust foi objeto de estudos no passado. Apenas a título de exemplo, cf. P. LEPAUlle, Civil Law Substitutes for Trusts cit. (nota 1 supra), pp. 1126-1147; D. Johnston, Trusts and Trust-like Devices in Roman Law, in R. HELMHOLZ e R. ZiMMERMANN (org.), Itinera Fiduciae cit. (nota 1 supra), pp. 45-56; C. H. VAN RHEE, Trusts cit. (nota 1 supra), pp. 453-462.

${ }^{369}$ Cf. M. J. WAAL, Comparative Succession Law cit. (nota 1 supra), pp. 1090-1093. O autor menciona a fiducia cum amico, o bewind no direito holandês e o Treuhand no direito alemão, como institutos que se assemelham ao trust no que diz respeito aos objetivos perseguidos pelo instituto.
} 
equity jurisdiction, que foi um dos principais fatores que influenciaram o desenvolvimento dos trusts. Por sua vez, para compreender adequadamente a equity jurisdiction, é necessário um prelúdio histórico que descreva, mesmo que modo sucinto, a estrutura básica do sistema judiciário inglês medieval partir do reinado de Guilherme I, o Conquistador, que teve início em $1066^{370}$.

Na verdade, o common law se desenvolveu a partir de instituições que já existiam antes de Guilherme $\mathrm{I}^{371}$. A Inglaterra do século XII, diferentemente da Normandia, já era uma nação unificada em torno de um governo central administrado por oficiais locais (sheriffs) responsáveis perante o rei. Existia também uma burocracia administrativa rudimentar ${ }^{372}$. No entanto, até então não havia um conjunto de normas aplicadas uniformemente em todo o território $^{373}$. A ascensão ao trono de Guilherme I alterou profundamente a cultura jurídica inglesa e marcou o início da intensificação centralizadora da coroa, a qual resultou, com o passar do tempo, no desenvolvimento de um corpo de direito homogêneo na Inglaterra ${ }^{374}$.

\subsubsection{A justiça itinerante}

Após a Conquista, devido às freqüentes ausências dos primeiros reis normandos da Inglaterra, a autoridade real era freqüentemente delegada ao Chief Justiciar ${ }^{375}$, uma espécie de primeiro ministro ${ }^{376}$ que agia em nome do rei e era, portanto, hierarquicamente superior aos demais oficiais e funcionários da corte. Seus poderes iam muito além dos assuntos judiciais, estendendo-se para as esferas administrativa e política ${ }^{377}$. Dadas as largas

\footnotetext{
${ }^{370}$ Cf. nota 101 supra.

${ }^{371}$ Para um percurso histórico das institutições jurídico-políticas de origem escandinava, inglesa e danesa existentes na Inglaterra antes da Conquista, cf. P. VINOGRADOFF, English Society in the Eleventh Century Essays in English Medieval History, Oxford, Clarendon, 1908, pp. 1-13.

${ }_{372}$ Cf. J. H. BAKER, An Introduction cit. (nota 12 supra), p. 12.

${ }^{373}$ Cf. S. F. C. MiLSOM, Historical Foundations cit. (nota 12 supra), pp. 11-12.

${ }^{374}$ A historiografia jurídica inglesa, no entanto, tende a adotar a idéia de uma lenta transformação e racionalização do direito consuetudinário inglês preexistente, cf. J. H. BAKER, An Introduction cit. (nota 12 supra), pp. 1 e 12.

${ }_{375}$ Para um resumo histórico e uma lista dos Chief Justiciars, cf. E. B. FRYDE et al., Handbook of British Chronology, $3^{\mathrm{a}}$ ed., Cambridge, Cambridge University, 1986, pp. 69-72 e o quadro sinótico no final deste trabalho.

${ }^{376}$ Para W. S. HOLDSWORTH, A History of English Law cit., vol. I (nota 12 supra), pp. 86-87, o justiciar era originalmente o lugar-tenente ou vice-rei na ausência do rei, e os principais homens que ocuparam esse cargo são considerados os fundadores do common law. Dentre eles destaca-se Ranulf de Glanvill, a quem boa parte da historiografia inglesa atribui a autoria da obra Tractatus de legibus et consuetudinibus regni Angliae, escrita entre 1187 e 1189 e inovadora pelo fato de sistematizar o direito vigente nas cortes reais na época e estabelecer o sistema de writs. Para uma breve explicação, na perspectiva de um jurista continental, sobre a importância dessa obra para o desenvolvimento do direito inglês, cf. G. CRISCUOLI, Introduzione cit. (nota 1 supra), pp. 495-496.

377 Cf. J. H. BAKER, An Introduction cit. (nota 12 supra), pp. 14-15. Além do chamado Chief Justiciar, houve também, durante um curto período, justiciars locais, os quais desapareceram, no entanto, na época de Glanvill (c. 1180-1189).
} 
prerrogativas derivadas da sua autoridade, o poder desses ministros chegou a ameaçar a autoridade do próprio monarca, motivo pelo qual o cargo de Chief Justiciar foi extinto em 1265 , assumindo o Chancellor as suas funções a partir de então ${ }^{378}$.

Uma das primeiras estruturas judiciárias instituídas pelos normandos para administrar a justiça na Inglaterra foram as cortes itinerantes (também denominadas eyre $e^{379}$ courts $)^{380}$. Durante a época dos Chief Justiciars, alguns dos juízes da Curia Regis, em princípio presidida pelo rei ou, na sua ausência, pelo Chief Justiciar, regularmente visitavam os condados para administrar a justiça nos âmbitos civil e criminal, cobrar tributos e punir as ofensas cometidas pelos sheriffs ${ }^{381}$ locais $^{382}$. Essa prática foi brevemente abandonada e $\operatorname{logo}$ reinstituída por Henrique II, que dividiu a Inglaterra em seis circuitos ( circuits $^{383}$ ) e designou três juízes itinerantes para cada um deles.

Os juízes designados para esses circuitos eram chamados justiciae errantes e depois justiciarii in itinerae. Com o passar do tempo, o crescente descontentamento com os impostos cobrados por meio dessas cortes itinerantes levou à sua extinção no século XIV, sendo substituído pelo sistema de assizes $^{384}$ e nisi prius ${ }^{385}$.

${ }^{378} \mathrm{O}$ cargo perdeu muito da sua importância após a queda do justiciar Hubert de Burgh, em 1232, mas ainda era suficientemente importante como para que os barões exigissem, em 1258, que o justiciar fosse eleito anualmente com a sua aprovação. Para um percurso histórico do cargo de justiciar, cf. D. M. WALKER, The Oxford Companion cit. (nota 8 supra), p. 694 (no verbete "justiciar").

${ }^{379}$ A palavra de origem normanda eyre encontra raízes etimológicas no verbo latino itero, -as, -are, -avi, atum, que significa repetir, reiterar, cf. P. G. W. GLARE (coord.), OLD cit. (nota 13 supra), pp. 975-976 (no verbete "itero, -as, -are, -avi, -atum"). No francês arcaico, no entanto, adquiriu o sentido de visita aos condados e localidades pelos juízes designados pela Coroa, cf. J. A. SIMPSON e E. S. C. WEINER (coord.), OED 5 (1989), p. 635 (no verbete "eyre"), que é mais próximo da palavra iter, -ineris, cujo significado mais comum é "ato de viajar" ou "viagem”, cf. P. G. W. GLARE (coord.), OLD cit. (nota 13 supra), p. 975 (no verbete "iter, -ineris").

${ }^{380}$ A principal fonte de informações históricas sobre a origem das cortes itinerantes são os chamados Pipe Rolls, que até hoje são mantidos no Arquivo Nacional britânico (National Archives). Trata-se dos registros contábeis da coroa, mantidos de forma quase ininterrupta desde 1129 até 1883 . Neles ficavam consignados, em latim abreviado, os valores recebidos pela coroa, inclusive a título de multas judiciais (amercements). De acordo com J. A. SiMPSON e E. S. C. WEINER (coord.), OED 14 (1989), p. 42 (no verbete "roll”), a palavra roll provém do latim rotula, ae - também rotulus, $i$, cf. P. G. W. GlARE (coord.), OLD cit. (nota 13 supra), p. 1663 (no verbete "rotula, ae") -, que é o diminutivo da palavra rota, ae, que significa, entre outras coisas, "rolo". O vocábulo pipe - "cano" em português - foi acrescentado em razão da aparência que tinham esses documentos ao serem enrolados para arquivamento.

${ }^{381}$ A palavra sheriff provém do inglês arcaico scírঠeréfa - posteriormente shire-reeve - e era utilizada para designar, já antes da Conquista, o funcionário encarregado da administração da justiça local e de exercer outras funções administrativas. Com o passar do tempo, passou a ser equivalente a vicecomes, ou "visconde", cf. J. A. SIMPSON e E. S. C. WEINER (coord.), OED 15 (1989), pp. 245-247 (no verbete “sheriff').

${ }^{382}$ De acordo com S. F. C. MILSOM, Historical Foundations cit. (nota 12 supra), p. 32, as cortes itinerantes (eyres) configuravam verdadeiras auditorias fiscais realizadas pelos oficiais e funcionários do monarca.

383 O vocábulo circuit tem origem latina, cf. J. A. SIMPSON e E. S. C. WEINER (coord.), OED 3 (1989), pp. 229-230 (no verbete "circuit"), pois provém do verbo composto circu(m)+ire, o qual significa, dentre outras coisas, visitar em seqüência, cf. P. G. W. GLARE (coord.), OLD cit. (nota 13 supra), p. 320 (no verbete "circu $(m)+e o,-(m) i i,-(m)$ ire, $-(m) i u i,-(m) i t u m ")$.

${ }^{384} \mathrm{O}$ termo significa, literalmente, "sessão", normalmente realizada por doze homens incumbidos de investigar e, às vezes, julgar um caso; o termo, no entanto, possui vários sentidos, mais ou menos relacionados 
Embora o principal objetivo das eyre courts fosse a manutenção da paz no reino, a resolução de litígios também representava uma atividade rentável para a coroa. Ao mesmo tempo, a justiça dispensada pelo rei, embora envolvesse considerável custo, era preferida pelo fato de ser mais eficaz e confiável ${ }^{386}$.

A importância das cortes itinerantes reside no fato de que elas constituíram um dos primeiros mecanismos de centralização administrativa e judiciária utilizados pelos reis normandos, contribuindo, assim, para a formação do common law ${ }^{387}$. Do ponto de vista do nosso estudo, a figura do Chief Justiciar é a antecessora do Chancellor, que cumpriu um papel fundamental no desenvolvimento dos trusts.

\subsubsection{Os tribunais do common law}

No início do século XIII, o núcleo central do governo era a Curia Regis, que era composta pelos assessores e funcionários que assistiam o rei na administração do reino. A Curia Regis desenvolveu-se a partir do witenagemot ${ }^{388}$ anglo-saxão (a congregação dos witan = "membros do conselho nacional anglo-saxão",389), posteriormente dando origem ao Privy Council ${ }^{390}$ e o Parlamento.

ao sentido original, dependendo das circunstâncias e da época, cf. D. M. WALKER, The Oxford Companion cit. (nota 8 supra), pp. 86-88 (no verbete "assise") e B. A. GARNER (coord.), Black's cit. (nota 13 supra), pp. 109110 (no verbete “assize”). De acordo com J. A. SIMPSON e E. S. C. WEINER (coord.), OED 1 (1989), pp. 716-717 (no verbete "assize"), a palavra assize provém do vocábulo francês arcaico asise ou assise, que denota o ato de sentar-se ou fixar alguma coisa. No sentido aqui utilizado, o vocábulo refere-se às sessões de julgamento realizadas fora da sede dos tribunais reais, nas quais se formava um jurado de pelo menos doze homens da localidade para decidir as questões de fato. Acerca do seu funcionamento, cf. J. H. BAKER, An Introduction cit. (nota 12 supra), pp. 72-95.

${ }^{385}$ Por meio desse sistema, os juízes itinerantes podiam interromper uma sessão local e remeter o caso ao King's Bench ou ao Common Pleas, onde ficava marcado o julgamento, a menos que antes da data estipulada (nisi prius) o caso tivesse sido decidido localmente por uma comissão enviada para tal propósito. Já em uso desde o século XII apenas para casos da competência do Court of Common Pleas, o Stat. 13 Edw. I (1285), c. 30 estendeu sua aplicação para litígios iniciados no King's Bench, cf. D. M. WALKER, The Oxford Companion cit. (nota 8 supra), p. 882 (no verbete "nisi prius"). O objetivo desse recurso processual era conciliar a centralização da justiça com a necessidade de colher provas e ouvir testemunhas localmente, cf. J. H. BAKER, An Introduction cit. (nota 12 supra), pp. 20-21 e W. S. HolDSWORTH, A History of English Law cit., vol. I (nota 12 supra), pp. 278-280.

${ }^{386}$ Cf. J. H. BAKER, An Introduction cit. (nota 12 supra), p. 14.

${ }^{387}$ Cf. S. F. C. MiLsOM, Historical Foundations cit. (nota 12 supra), p. 26.

${ }^{388} \mathrm{O}$ witenagemot era o conselho supremo da nação anglo-saxônica antes da invasão normanda, do qual participavam o rei, a nobreza, a Igreja e os principais líderes do povo, tendo poderes para decidir casos em última instância, aprovar leis e criar impostos, bem como para eleger o rei e até depô-lo por má administração, cf. D. M. WALKER, The Oxford Companion cit. (nota 8 supra), p. 1304 (no verbete "witenagemot").

${ }^{389}$ Cf. J. A. SIMPSON e E. S. C. WEINER (coord.), OED 20 (1989), p. 437 (no verbete “witan”).

${ }^{390}$ O Privy Council é o conselho de ministros britânico que reúne os conselheiros oficiais do monarca. Seus integrantes são nomeados de forma vitalícia pelo rei ou rainha e suas funções dizem respeito ao uso das prerrogativas reais. 
Os juízes itinerantes dos séculos XIII e XIV eram membros da Curia Regis, e aos poucos passaram a desempenhar suas funções num local fixo, normalmente em Westminster. No início do século XII, a primeira seção a estabelecer-se em Westminster foi o Exchequer of Pleas ou Court of the Exchequer ${ }^{391}$, seguido pelo King's Bench e o Court of Common Pleas ${ }^{392}$ na segunda metade do século XIII, durante os reinados de Henrique II e Ricardo I ${ }^{393}$.

De modo bastante simplificado, o Court of Common Pleas tinha competência para julgar os litígios entre particulares envolvendo personal actions ou real actions, os casos que envolvessem os próprios funcionários da corte e os recursos interpostos das decisões proferidas pelas cortes locais ${ }^{394}$. O King's Bench, em matéria civil, tinha competência originária para julgar as ações que envolvessem o uso de força ou ofensas pessoais ${ }^{395}$, bem como, até a consolidação do King's Council $^{396}$ como última instância de apelação, os recursos das decisões dos demais tribunais ${ }^{397}$. Já o Exchequer of Pleas tinha competência para julgar todos os assuntos fiscais da Coroa, bem como os assuntos concernentes aos funcionários dessa corte ${ }^{398}$.

Embora exista ainda hoje, suas funções são principalmente cerimoniais, salvo no que diz respeito às atividades desenvolvidas pelo Judicial Committee, ao qual cabe julgar os recursos em última instância provenientes dos territórios anexos à Coroa britânica e dos países da Comonwealth que ainda reconhecem a Coroa como a suprema autoridade judiciária.

A respeito do tema, cf. B. A. GARNER (coord.), Black's cit. (nota 13 supra), p. 1037 (no verbete "Privy Council"). Maiores informações podem ser encontradas no portal eletrônico oficial do órgão, disponível in http://www.privy-council.org.uk/output/page2.asp [15-03-2011].

391 A palavra exchequer refere-se à mesa coberta por um mantel quadriculado ("scaccarium" ou "exchequer" = "chequered table") em que se fazia a contabilidade da coroa na época dos primeiros reis normandos, cf. C. F. DU CANGE, Glossarium cit. (nota 13 supra), t. 7, col. 324c (no verbete "scacarium"): “(...) certe a mensa cui adsidebant judices, a qua Scacarium Anglicanum denominatum testatur Gervasius Tilleberiensis: 'Scacarium, inquit, tabula est quadrangula, qua longitudine quasi decem pedum, et quinque latitudine ad modum mensa circunsedentibus apposita, undique habet limbum latitudinis quasi 4. digitorum. Supponitur (f. superponitur) Scacario pannus in termino Pasche emptus, non quilibet, sed niger, virgis distinctus, distantibus a se virgis, vel pedis, vel palma spatio",.

Por um processo de metonímia, o tribunal recebeu o nome da mesa em que se faziam as contas do reino, a qual ficava na sala que a esse tribunal passou a ocupar no início do século XII, cf. B. A. GARNER (coord.), Black's cit. (nota 13 supra), p. 506 (no verbete "Exchequer").

392 Cabe mencionar a tradução ao português desses tribunais que aparece em J. GILISSEN, Introduction historique cit. (nota 14 supra), p. 210: Tribunal do Banco do Rei (Court of King's Bench), Tribunal das Queixas Comuns (Court of Common Pleas) e Tribunal do Tesouro (Exchequer of Pleas). Decidimos referir-nos a essses tribunais pela sua denominação original em inglês, por acreditarmos que essa opção não deve prejudicar a exposição da matéria.

${ }_{393}$ Cf. J. H. BAKER, An Introduction cit. (nota 12 supra), pp. 17-18.

${ }^{394}$ Cf. W. S. HoldSwORTH, A History of English Law cit., vol. I (nota 12 supra), pp. 197-203.

395 Com base na alegação de que o ato tinha sido realizado "in breach of the King's peace", cf. D. M. WALKER, The Oxford Companion cit. (nota 8 supra), pp. 1237-1238 (no verbete "trespass”).

${ }^{396}$ Essa instituição mais tarde deu origem ao Privy Council e, em certa medida, ao Parlamento inglês, cf. D. M. WALKER, The Oxford Companion cit. (nota 8 supra), p. 703 (no verbete "King's Council”).

${ }^{397}$ Para uma explicação mais detalhada da competência desse tribunal, cf. W. S. HoLDSWORTH, A History of English Law cit., vol. I (nota 12 supra), pp. 212-231.

${ }^{398}$ Para maiores detalhes sobre a competência desse tribunal, cf. W. S. HOLDSWORTH, A History of English Law cit., vol. I (nota 12 supra), pp. 238-242. 
Assim, cada tribunal tinha uma jurisdição que lhe era própria. Com o tempo, no entanto, as respectivas competências foram se ampliando e entrelaçando entre si a tal ponto que, no final da Idade Média, freqüentemente os demandantes podiam propor a mesma ação em mais de um tribunal e esperar a mesma resolução em qualquer um deles, pois o conjunto de normas por eles aplicadas tinha se tornado bastante uniforme ${ }^{399}$. As normas aplicadas por esses tribunais eram em parte normas positivadas, em parte normas costumeiras ${ }^{400}$.

\subsubsection{A Court of Chancery e a atividade jurisdicional do Chancellor}

Nas primeiras décadas da ocupação normanda, as funções que hoje seriam catalogadas como administrativas eram desempenhadas por duas instituições. De um lado, o Exchequer of Pleas exercia, além das suas funções judiciárias, tarefas administrativas e contábeis $^{401}$. De outro, a Chancery funcionava como uma espécie de secretaria executiva, cuja função, entre outras, era permitir o acesso à jurisdição real mediante a emissão de writs $^{402}$.

Os três tribunais reais vistos acima configuraram, com diversos ajustes e mudanças nas suas respectivas jurisdições, o curso regular do common law desde o século XIII até o século $\mathrm{XIX}^{403}$. Mesmo com as limitações impostas ao rei pelo princípio do due process of law, inscrito e desenvolvido em numerosos statutes e atos do Parlamento ${ }^{404}$, o

${ }^{399}$ Isso era verdade, principalmente, no que dizia respeito às common pleas (queixas comuns), que já no século XVII podiam ser discutidas e julgadas, por meio dos mais variados e por vezes exóticos mecanismos jurídicos, em qualquer um dos três tribunais do common law. Os Judicature Acts 1873 e 1875 [=Stat. 36 \& 37 Vic. (1873), c. 66 e Stat. 38 \& 39 Vic. (1875), c. 77] eliminaram as distinções restantes, criando a Supreme Court of Judicature, cuja competência passou a englobar todas as matérias antes afetas aos antigos tribunais do common law. Para uma narrativa dos recursos processuais utilizados nesse sentido, cf. J. H. BAKER, An Introduction cit. (nota 12 supra), pp. 37-51.

${ }^{400}$ Cf. F. W. MAITLAND, Equity cit. (nota 12 supra), p. 2.

${ }^{401}$ De fato, o Exchequer originariamente era o centro administrativo do reino em matéria fiscal, e foi apenas com o tempo que passou a exercer funções jurisdicionais, cf. S. F. C. MiLsom, Historical Foundations cit. (nota 12 supra), p. 32.

${ }^{402}$ Cf. F. W. MAITLAND, Equity cit. (nota 12 supra), pp. 2-3.

Embora inicialmente sua função não fosse jurisdicional, em muitos aspectos o Chancellor encarregava-se de administrar a justiça. Os writs (cf. capítulo 2.1 supra), pelos quais se dava início às ações nas jurisdições locais e, na maior parte dos casos, nos tribunais reais, eram redigidos pela Chancery. Tais writs eram lacrados com o selo do rei. Caso alguém quisesse propor uma ação, era necessário que solicitasse antes um writ dos secretários da Chancery (cursitors) e pagasse a devida taxa. A prerrogativa da Chancery para emitir novos writs foi limitada em grande medida pelo Statute of Westminster II [=Stat. 13 Edw. I (1285), c. 24] (cf. nota 63 supra), que autorizava a emissão de writs apenas in consimili casu. O Chancellor ouvia apenas o pedido do autor inaudita altera parte e, caso emitisse o writ, o mesmo podia, em princípio, ser cassado pelas cortes locais por ser contrário às leis da terra (contrary to the laws of the land).

${ }^{403}$ Cf. J. H. BAKER, An Introduction cit. (nota 12 supra), p. 97.

${ }^{404}$ O principal documento escrito que se coloca como referência desse princípio é Magna Carta 1215, c. 39 [=Magna Carta 1225, c. 29] (cf. nota 290 supra).

O mesmo princípio vem explicitado em Stat. 28 Edw. III (1354), c. 3: "Item, qe nul homme, de quel eftate ou condicion qil foit, ne foit ofte de terre ne de tenement, ne pris, nemprifone, ne defherite, ne mis a la mort, faunz eftre mefne en refpons par due proces de lei" (Da mesma forma, que nenhum homem, de qualquer estado 
monarca ainda tinha a incumbência de remediar as deficiências do ordenamento, e portanto mantinha um poder residual derrogatório para administrar a justiça fora do sistema regular, desde que não infringisse as limitações estabelecidas pelo direito estatutário ${ }^{405}$.

Nos casos em que não houvesse outro remédio legal nos tribunais reais nem nas cortes locais, cabia ao Chancellor administrar as petições feitas diretamente ao rei. Já no fim do século XIII, em virtude do grande o número de petições feitas diretamente ao rei, o Chancellor passou a apreciá-las e a exercer de fato a função de julgá-las. Ele era, de fato, o primeiro-ministro do rei e o membro de mais alta patente no seu Conselho. A atividade jurisdicional do Chancellor nasce da apreciação dessas petições dirigidas ao rei ${ }^{406}$.

Desde o início o Chancellor era, portanto, um oficial do estado e um ministro da coroa. Quase todos os homens que ocuparam o cargo durante a Idade Média eram também bispos ou arcebispos; já a partir do século XVI, no entanto, os Chancellors passaram a ser juristas que, até a unificação das cortes, dedicavam a maior parte do tempo ao julgamento de casos e, portanto, desenvolveram um corpo definido de normas ${ }^{407}$. Além de ser um cargo de caráter político, suas atribuições não eram muito bem delimitadas ${ }^{408}$, pois não recebia

ou condição que seja, seja expulso de terra nem tenência, nem levado, nem preso, nem deserdado, nem enviado à morte, sem ser trazido para responder pelo devido processo da lei) e Stat. 42 Edw. III (1368), c. 3: “(...) eft affentu et accorde pur le bone government de la commune qe nul homme foit mis a refpondre fanz prefentement devant Juftices ou chofe de record ou per due preceffe et brief original folonc launcien leye de la terre (...)" ((...) Fica assentado e acordado, para o bom governo dos comuns, que nenhum homem seja enviado a responder sem apresentar-se diante dos Magistrados, ou coisa de registro, ou pelo devido processo e breve original, segundo as leis antigas da terra (...)).

${ }^{405}$ Cf. J. H. BAKER, An Introduction cit. (nota 12 supra), p. 98.

${ }^{406}$ Cf. F. W. MAITLAND, Equity cit. (nota 12 supra), pp. 3-4. Os poderes jurisdicionais da Chancery Court (também chamada Curia Cancellariae) compreendem duas vertentes: a inglesa, vinculada à aplicação do common law, e a latina, ligada às normas da equity.

Exemplo da primeira vertente eram os casos envolvendo a devolução de terras à Coroa pelo fato de o vassalo não ter deixado herdeiros (escheat). Como o monarca não podia ser demandado mediante a impetração de um writ - pois não existiam writs contra o rei -, o único que podia cuidar de tais casos era o Chancellor, que gradualmente estabeleceu um procedimento em latim para eles. Caso surgisse uma questão de fato, o caso era ouvido por um jury convocado e presidido pelo King's Bench.

A vertente inglesa dos poderes do Chancery Court, por outro lado, ligava-se aos casos em que alguém peticionava perante o rei para obter um remédio judicial em face de outro particular, ou seja, alguém que não fosse o próprio rei. O demandante alegava que por algum motivo - tal como idade avançada, condição econômica inferior à da outra parte, ou até suborno do magistrado - o procedimento comum não produziria um resultado justo.

Sobre essas duas vertentes, ver também J. H. BAKER, An Introduction cit. (nota 12 supra), pp. 100-103.

${ }^{407}$ Cf. F. W. MAITLAND, Equity cit. (nota 12 supra), p. 8.

${ }^{408}$ Nesse sentido, J. BENTHAM, Bentham's Draught for the Organization of Judicial Establishments Compared with that of the National Assembly with a Commentary on the Same, in J. BowRING, The Works of Jeremy Bentham, vol. IV, Edinburgh, Simpkin Marshall \& Co., 1843, p. 381, a propósito da crítica à acumulação do encargo de magistrado com outros cargos políticos, atribuiu ao Chancellor as seguintes funções: "( $i$ ) a single judge, controlling in civil matters the several jurisdictions of the twelve great judges; (ii) a necessary member of the cabinet, the chief and the most constant adviser of the king in all matters of law; (iii) the perpetual president of the highest of the two houses of legislature; (iv) the absolute proprietor of a prodigious mass of ecclesiastical patronage; $(v)$ the competitor of the minister for almost the whole patronage of the law; (vi) the keeper of the 
qualquer incumbência em particular do monarca. Sua autoridade e relevância para o desenvolvimento do direito inglês derivam, em grande parte, da sua designação como Keeper of the Great Seal ${ }^{409}$.

O estabelecimento da função judicial da Chancery ocorreu paulatinamente. Em face das restrições à emissão de novos writs para iniciar uma ação, pouco a pouco os demandantes passaram a procurar o Chancellor não mais para que emitisse um writ, mas para que ouvisse o réu pessoalmente, estabelecendo-se, aos poucos, um procedimento específico e regular $^{410}$.

A peça inicial era o bill ${ }^{411}$, e a ordem de citação do réu denominava-se subpoena, pois aquele era conduzido ao tribunal sob pena (sub poena) de multa pecuniária caso se negasse a fazê-lo. O procedimento era bem diverso daquele estabelecido por meio dos writs, baseando-se em larga medida no procedimento sumário dos tribunais eclesiásticos utilizado para julgar casos de heresia ${ }^{412}$, em que o réu prestava juramento perante o Chancellor, que decidia todas as questões de fato e de direito.

Originariamente, o procedimento era bastante informal. $\mathrm{O}$ autor apresentava a demanda por escrito ou verbalmente. O réu era citado por meio de um writ of subpoena, pelo qual ficava obrigado a pagar uma multa caso não comparecesse. Na prática, essa penalidade era raramente aplicada, mas o réu ausente podia responder por crime de desobediência (contempt). O processo era conduzido em língua inglesa e, embora se adotasse o linguajar jurídico do common law, era livre de tecnicalidades. A prova podia ser escrita ou oral, e não havia jury para a apreciação dos fatos. Além disso, o tribunal estava sempre aberto, pelo

great seal, a transcendent, multifarious, and indefinable office; (vii) the possessor of a multitude of heterogeneous scraps of power, too various to be enumerated".

${ }^{409}$ Cf. W. S. HoldSwORTH, A History of English Law cit., vol. I (nota 12 supra), p. 396; J. H. BAKER, An Introduction cit. (nota 12 supra), p. 99.

${ }^{410}$ Cf. F. W. Maitland e F. C. Montague, A Sketch of English Legal History, New York, Putnam's Sons, 1915, p. 121 e F. W. MAITLAND, Equity cit. (nota 12 supra), p. 5.

${ }^{411}$ A palavra bill, cf. D. M. WALKER, The Oxford Companion cit. (nota 8 supra), pp. 129-130 (no verbete "bill") deriva, provavelmente, do francês libelle, e designa, de modo geral, qualquer documento escrito lacrado com um selo oficial. No entanto, de acordo com J. A. SIMPSON e E. S. C. WEINER (coord.), OED 2 (1989), pp. 190-192 (no verbete "bill"), a palavra deriva do vocábulo latino bulla, ae, que pode significar "bolha", "maçaneta" ou "amuleto pendurado no pescoço", cf. P. G. W. GLARE (coord.), OLD cit. (nota 13 supra), pp. 244-245 (no verbete "bulla, -ae"). Em latim medieval, a palavra designava, dentre outras coisas, o selo utilizado para lacrar documentos oficiais, cf. C. F. DU CANGE, Glossarium cit. (nota 13 supra), t. 1, col. 773b: "Sigillum, seu typus sigillarius, quo bullae ipsae imprimuntur". Por um processo de metonímia, o vocábulo passou a denominar o próprio documento, e foi nesse sentido que entrou no vocabulário jurídico inglês da Chancery.

${ }^{412}$ Cf. J. H. BAKER, An Introduction cit. (nota 12 supra), p. 103 sugere que o procedimento adotado na Chancery inspirou-se na denuntiatio evangelica. 
menos nominalmente, e podia funcionar em qualquer local, inclusive na residência do próprio Chancellor $^{413}$.

A maior celeridade e o menor custo das demandas ajuizadas na Court of Chancery permitiam ao Chancellor operar um sistema de solução de conflitos que atendia às necessidades dos pobres e oprimidos ${ }^{414}$.

Além disso, os amplos poderes de que dispunha o Chancellor tornavam a execução das decisões muito mais eficaz, sem que isso, pelo menos em princípio, significasse uma alteração do conteúdo do common law, já que as medidas da Court of Equity operavam in personam ${ }^{415}$. Assim, pela equity o Chancellor podia confiscar os bens do réu e imitir o autor na sua posse, porém não era competente para declarar quem era o titular do direito de propriedade sobre esses mesmos bens, pois essa questão era determinada pelo common law ${ }^{416}$.

É interessante notar que a literatura jurídica inglesa assemelha, em muitos aspectos, a atividade jurisdicional do Chancellor com a do praetor romano ${ }^{417}$, na medida em

${ }^{413}$ Cf. J. H. BAKER, An Introduction cit. (nota 12 supra), pp. 103-104.

${ }^{414}$ Porém, com o passar do tempo, a alegação de que a hipossuficiência econômica ou jurídica do autor impediria a prolação de uma sentença justa passou a configurar uma mera formalidade para remeter a causa à Court of Chancery, cf. F. W. MAitland e F. C. Montague, A Sketch cit. (nota 410 supra), p. 122. No início do século XVI, a competência para julgar ações que envolvessem abuso de poder passou para o Star Chamber (camera stellata), tribunal surgido a partir da jurisdição do King's Council, cf. J. H. BAKER, An Introduction cit. (nota 12 supra), pp. 105 e 118.

${ }^{415}$ Cf. F. W. MAITLAND, Equity cit. (nota 12 supra), p. 258.

416 Cf. W. Ashburner, Principles of Equity, London, Butterworth, 1902, pp. 59-60. De acordo com o autor, essa é uma das questões mais contraditórias da equity, pois embora não houvesse uma revogação explícita dos direitos de propriedade conferidos pelo common law, na prática o beneficiário das medidas (equitable relief) aplicadas pela Court of Chancery passava a ser titular de um direito real erga omnes.

Cabe mencionar que o conteúdo da dicotomia ius in personam/ius in rem não corresponde, necessariamente, à divisão civilística continental entre direitos obrigacionais/direitos reais. Na verdade, conforme já visto acima, a terminologia inglesa relativa ao property rights pauta-se muito mais por considerações de direito processual do que de direito material. Por isso, to act in personam significa que as medidas e os remédios processuais da equity dirigem-se sempre imediatamente a uma ou mais pessoas, e apenas mediatamente a um bem.

Em nossa opinião, uma análise mais atenta revela que a interpretação dada ao princípio equity acts in personam (e não in rem) é um dos mecanismos conceituais que possibilitou o desenvolvimento da equity ao lado do common law, na medida em que impede a revogação formal das regras do common law (que conferem ao titular um ius in rem) pelas medidas aplicadas no âmbito da equity, mesmo quando o resultado prático no caso concreto produz um efeito análogo ao de uma revogação.

Acerca dos efeitos erga omnes decorrentes da execução forçada de um contrato para a entrega de bem imóvel, cf. J. STORY, Commentaries on Equity cit. (nota 23 supra), pp. 313-338.

${ }^{417}$ Um dos indícios mais claros dessa associação na historiografia inglesa é o frequiente uso explícito, ao tratar do Chancellor, da expressão encontrada em Pap. 2 def., D. 1, 1, 7, 1: "Ius praetorium est quod praetores introduxerunt adiuvandi vel supplendi vel corrigendi iuris civilis gratia propter utilitatem publicam (...)" (O direito pretoriano é o que os pretores introduziram para auxiliar, suprir ou corrigir o direito civil, por causa da utilidade pública (...)). Assim, e apenas como exemplo, W. W. BUCKLAND e A. D. MCNAIR, Roman Law and Common Law cit. (nota 1 supra), pp. 3-5 e W. S. HoldSWORTH, A History of English Law cit., vol. I (nota 12 supra), p. 467. Outros autores, por sua vez, acentuam, de forma bastante genérica, as semelhanças entre essas duas figuras, com é o caso de W. L. BURDICK, The Principles of Roman Law cit. (nota 76 supra), p. 79 e J. BRYCE, Studies in History cit. (nota 76 supra), p. 698. 
que ambos foram responsáveis por modificações substanciais nos seus respectivos ordenamentos jurídicos mediante o exercício das suas prerrogativas para administrar a justiça no caso concreto ${ }^{418}$. O Chancellor incorporava as funções do juiz e do júri, podendo analisar as circunstâncias do caso particular até onde a sua consciência o indicasse, sem distinguir claramente as situações de fato das de direito ${ }^{419}$.

\section{As matérias que se inseriam na competência da Court of Chancery também}

foram se fixando e definindo gradualmente, e podem ser agrupadas em três categorias: a common law jurisdiction, a equitable jurisdiction e miscellaneous branches of jurisdiction ${ }^{420}$.

Por outro lado, G. PUGLIESE, Ius honorarium a Roma ed equity nei sistemi di common law, in Revista Trimestrale di Diritto e Procedura Civile 42 (1988), pp. 1105-1126, detecta um conjunto de importantes distinções entre os dois magistrados. Assim, quanto ao fundamento de autoridade, o praetor apoiava-se no seu imperium, enquanto a atividade jurisdicional do Chancellor estava vinculada às prerrogativas reais, motivo pelo qual este último tinha maior discricionariedade para agir de acordo com a sua consciência do que aquele, que, pelo menos nominalmente, ficava sujeito às leges publicae; quanto ao contexto social em que se inserem uma e outra magistratura, o Chancellor não lidava com questões relativas aos estrangeiros, diferentemente do praetor (pelo menos o praetor peregrinus), que delas cuidava; por outro lado, o praetor não ficava vinculado às próprias decisões no caso concreto, o que não ocorria com o Chancellor, que passou a estar sujeito, a partir de determinado momento, à regra do stare decisis; por último, também são diversos os ramos do direito em que cada magistrado atuou, pois enquanto o praetor concentrou boa parte da sua atividade na tutela da traditio, de modo que produzisse efeitos erga omnes por ser tutelada por uma actio in rem, o Chancellor voltou-se principalmente para a tutela do contract, que produz apenas efeitos inter partes. Em sentido muito próximo, cf. G. CRISCUOLI, Introduzione cit. (nota 1 supra), pp. 34-37 e F. PRINGSHEIM, The Unique Character cit. (nota 38 supra), p. 61.

Algumas críticas podem ser feitas tanto aos que equiparam o praetor ao Chancellor, quanto a quem os distingue radicalmente. As equiparações dos autores ingleses são muito genéricas, e não levam em conta as diferenças entre as culturas jurídicas e sociais em que cada um desses magistrados estava inserido, o que resulta em generalizações pouco frutíferas. Por outro lado, se bem existem marcadas distinções entre o praetor e o Chancellor, também não se pode dizer que houvesse tanta diferença entre a natureza da tutela que o praetor dispensava à traditio e a da tutela que o Chancellor concedia aos contratos, visto que os uses e os trusts eram, em princípio, relações contratuais que somente passaram a produzir efeitos reais e fazer parte do property law graças à intervenção da equitable jurisdiction of the Court of Chancery.

418 Pode-se encontrar, inclusive, uma comparação entre o fidecomissum e o trust, porém pouco desenvolvida, em J. BRYCE, Studies in History cit. (nota 76 supra), p. 704. O autor salienta que tanto no caso do fideicomissarius quanto no do trustee, um dever de natureza moral passa a ter força vinculante por força da atividade dos magistrados.

${ }^{419}$ Cf. J. H. BAKER, An Introduction cit. (nota 12 supra), p. 106.

${ }^{420}$ Cf. W. S. HoldSWORTH, A History of English Law cit., vol. I (nota 12 supra), pp. 446-447.

Cabe mencionar que, na língua inglesa, a palavra jurisdiction tem sentido diverso, em vários aspectos, da palavra jurisdição na língua portuguesa. Na linguagem jurídica processual, o termo jurisdição é definido pela doutrina como "função do Estado, destinada à solução imperativa de conflitos e exercida mediante a atuação da vontade do direito em casos concretos", cf. C. R. DINAMARCO, Instituições de Direito Processual Civil, vol. I, $5^{\text {a }}$ ed., São Paulo, Malheiros, 2005, p. 330, ou como "l'attività degli organi dello Stato diretta a formulare e ad attuare praticamente la regola giuridica concreta che, a norma del diritto vigente, disciplina una determinata situazione giuridica", cf. E. T. LIEBMAN, Manuale di diritto processuale civile, $2^{\mathrm{a}}$ ed., vol. I, Milano, Giuffrè, 1968, p. 10. Assim, pode-se perceber que o vocábulo em questão, nos sistemas de base romanística, diz respeito à atividade jurisdicional desempenhada exclusivamente pelo Poder Judiciário e diferente das atividades exercidadas pela Administração e pelo Poder Legislativo.

Por sua vez, o termo jurisdiction pode tanto denotar o poder estatal geral sobre pessoas e coisas num determinado território, ou o poder de um órgão jurisdicional para decidir casos concretos e emitir ordens judiciais. No primeiro caso, o conceito é mais amplo do que em português, pois se aplica tanto à atividade dos órgãos do Poder Judiciário quanto aos atos da Administração; já no segundo sentido, jurisdiction possui significado análogo a competência, que, nos sistemas jurídicos de base romanística, pode ser definida como "la 
Dentre elas, a que interessa para o estudo dos trusts é a segunda, pois quase toda a matéria relativa a esse instituto foi desenvolvida com base na equitable jurisdiction da Court of Chancery $^{421}$, na medida em que as decisões desse tribunal normalmente não se pautavam nas normas do common law $^{422}$.

No que diz respeito às regras de direito material, apesar de a equity, em sentido estrito, ter chegado a ser um corpo de regras bem definido, inicialmente era o resultado da opinião do Chancellor, a qual normalmente era muito mais uma questão de convicção pessoal do que de conhecimento jurídico ${ }^{423}$. Foi a partir do século XVII que a equity tornou-se um conjunto definido e coerente de regras e princípios jurídicos ${ }^{424}$, e em matéria de trusts as regras eram tão objetivas quanto as do common law ${ }^{425}$.

quantità di giurisdizione assegnata in esercizio a ciascun organo, ossia la 'misura della giurisdizione”", cf. E. T. LIEBMAN, Manuale di diritto processuale civile cit., vol. I (nesta nota), p. 107.

Acerca dos vários significados específicos da palavra jurisdiction, cf. B. A. GARNER (coord.), Black's cit. (nota 13 supra), pp. 730-734 (no verbete "jurisdiction").

${ }^{421}$ Acerca do fundamento da competência da Court of Chancery, a literatura jurídica inglesa cita com frequiência The Earl of Oxford's Case in Chancery [1615] 21 ER 485: "The Cause why there is a Chancery is, for that Mens actions are divers and infinite, That it is impossible to make any general Law which mat aptly meet with every particular act, and not fail in some Circmstances. The Office of the Chancellor is to correct Mens Consciences for Frauds, Breach of Trusts, Wrongs and Oppressions, of what nature soever they be, and to soften and mollify the Extremity of the Law, which is called Summum Jus. And for the Judgment, \&c., Law and Equity are distinct, both in their Courts, their Judges, and the Rules of Justice; and yet they both aim at one and the same End, which is; to do Right; as Justice and Mercy differ in their Effects and Operations, yet both join in the Manifestaion of God's Glory". O fragmento, da autoria do Lord Chancellor Ellesmere, fornece uma idéia da natureza da jurisdição da Court of Chancery e, quando comparado com Pap. 2 def., D. 1, 1, 7, 1, apresenta uma visão mais clara da sua função no ordenamento jurídico anglo-saxão e do motivo pelo qual a doutrina compara a equity ao ius honorarium romano, cf. W. L. BURDICK, The Principles of Roman Law cit. (nota 76 supra), pp. 7980.

${ }^{422}$ Segundo a doutrina inglesa, a particularidade do direito anglo-saxão, no que diz respeito à distinção entre o common law e a equity, não é tanto o fato de existir a possibilidade de evitar a aplicação do direito estrito por meio do apelo à equidade ou à moral. $\mathrm{O}$ traço que caracteriza o direito anglo-saxão é o fato de que fosse um tribunal específico que se dedicasse a buscar soluções fora do âmbito do direito convencionalmente aceito como vigente, cf. W. S. HOLDSWORTH, A History of English Law cit., vol. I (nota 12 supra), p. 447 e A. WATSON, Roman Law \& Comparative Law cit. (nota 1 supra), pp. 253-254.

${ }^{423}$ Nesse sentido, é bastante ilustrativa a conhecidíssima frase dita no século XVII, atribuída a John Selden e publicada postumamente em R. MILWARD, Table-Talk: Being the Discourses of John Selden, London, Smith, 1689 [reimp. por E. ARBER, John Selden: Table-Talk, London, Murray \& Son, 1869], p. 46: "Equity is a Roughifh thing, for Law we have a meafure, know what to truft to, Equity is according to Confcience of him that is the Chancellor, and as that is larger or narrower, fo is Equity, 'Tis all one as if they fhould make the Standard for the meafure, we call a Chancellor's foot, what an uncertain meafure would this be? One Chancellor has a long Foot, another a fhort Foot, another an indifferent Foot. 'Tis the fame thing in the Chacellor's Confcience". Acerca do mesmo período, também Bl Comm 1, 2, 61-62 [=W. BLACKSTONE, Commentaries cit., vol. I (nota 10 supra), pp. 61-62]: "Equity thus depending, effentially, upon the particular circumftances of each individual cafe, there can be no eftablifhed rules and fixed precepts of equity laid down, without deftroying its very effence, and reducing it to a pofitive law".

${ }^{424}$ Cf. W. S. HOLDSwORTH, A History of English Law cit., vol. I (nota 12 supra), p. 468. No mesmo sentido, Bl Comm 3, 27, 432 [=W. BlaCKSTONE, Commentaries cit., vol. I (nota 10 supra), p. 432]: "Whereas the $\int y$ ftem of our courts of equity is a laboured connected fy/tem, governed by eftablifhed rules, and bound down by precedents, from which they do not depart".

${ }^{425}$ Cf. J. H. BAKER, An Introduction cit. (nota 12 supra), pp. 108 e 110. 
Embora a coexistência entre os tribunais reais e a Court of Chancery fosse inicialmente pacífica, em vários momentos aqueles se ressentiram da interferência do Chancellor nos assuntos de competência do common law ${ }^{426}$. Superada a fase de rivalidade com o common law, no entanto, a equity conseguiu firmar a sua competência sobre determinadas questões, dentre as quais a mais importante, pelo menos para o nosso estudo, foi a dos uses e os trusts ${ }^{427}$.

Apesar do papel fundamental que a Court of Chancery desempenhou não apenas no desenvolvimento dos trusts, como também na formação e no refinamento dos institutos jurídicos do direito inglês ${ }^{428}$, por ironia do destino o tribunal veio a sofrer dos mesmos defeitos de que padeciam os antigos tribunais do common law. Com o passar do tempo, tanto

${ }^{426}$ A época da rivalidade com o common law, iniciada no final do século XV, chegou ao seu ápice no século XVII, com o embate entre Lord Chancellor Ellesmere e Lord Chief Justice Edward Coke. Os tribunais do common law tinham começado a oferecer uma denúncia penal (indictment) contra quem apelasse das suas decisões para a Court of Chancery, que normalmente emitia uma sentença mandamental (injuction) para evitar que fosse executada a sentença proferida no tribunal do common law. Edward Coke declarou que consideraria ilegal qualquer prisão por desobediência a uma injuction emitida pela Court of Chancery para evitar a execução de uma sentença emitida por um tribunal do common law, pois dois statutes [Stat. 27 Edw. III (1353), c. 1 e Stat. 4 Hen. IV (1402), c. 23] impediam que as partes entrassem com qualquer recurso uma vez prolatada a sentença definitiva pelos tribunais reais, salvo no caso de ter havido error. A disputa foi decidida pelo rei Jaime I em 1616, após consulta a Francis Bacon e outros juristas, no sentido de que a Court of Chancery tinha competência para emitir injuctions, legitimando, assim, as pretensões desse tribunal. Acerca dessa disputa, de modo geral, cf. W. S. HoldsworTH, A History of English Law cit., vol. I (nota 12 supra), pp. 459-465 e J. P. DAwson, Coke and Ellesmere Disinterred: The Attack on the Chancery in 1616, in Illinois Law Review of Northwestern University 36 (1941), pp. 127-152.

427 A competência da Court of Chancery pode ser dividida em dois grupos. De um lado, havia a common law jurisdiction, ou seja, matérias do common law que ficavam sob a competência da Court of Chancery, tais como certas questões relativas à emissão e processamento de alguns writs, casos que envolvessem o rei ou um dos seus concessionários e os casos que envolvessem funcionários do próprio tribunal. De outro lado estava a equitable jurisdiction, muito mais abrangente e representativa da função típica desse tribunal. A função mais importante da equitable jurisdiction foi a tutela da posição jurídica do cestui que use (posteriormente o beneficiary), pois ela dotou o sistema das tenures da elasticidade necessária para atender às necessidades da vida jurídica. Além dos uses e trusts, a Court of Chancery também tinha competência em matéria de contratos que não fossem por escrito e lacrados, e que, portanto, não eram tutelados pelo common law (foi apenas a partir do século XIV que o common law desenvolveu a teoria do contrato como um agreement provido de consent e consideration). Também tinha competência em matéria de fraude (fraud), falsificação (forgery), coação (duress), erro (mistake) e força maior (accident), podendo também decretar sentenças mandamentais para cumprimento específico de uma obrigação (decrees for specific performance e injunctions). Um exemplo da incapacidade dos tribunais do common law para lidar com esse tipo de situações é o fato de que os mesmos não tinham meios jurídicos de exigir que o promissário-credor devolvesse a nota promissória ao promitente-devedor uma vez paga a dívida, permitindo, assim, que aquele executasse o devedor mesmo após ter recebido o pagamento da dívida, coisa que o Chancellor, com base no princípio da boa-fé (good faith) e da honestidade nos negócios (honest dealing), não permitia que acontecesse. Sobre o tema, de modo geral, cf. W. S. HoLDSWORTH, A History of English Law cit., vol. I (nota 12 supra), pp. 452-459 e J. STORY, Commentaries on Equity cit. (nota 23 supra), pp. 32-38.

${ }^{428}$ Cf. D. KERLY, An Historical Sketch of the Equitable Jurisdiction of the Court of Chancery, Cambridge, Cambridge University, 1890, pp. 180-181. 
o procedimento adotado no tribunal quanto as regras de direito material solidificaram-se a tal ponto que a palavra “Chancery” passou a ser sinônimo de gasto, demora e desespero ${ }^{429}$.

Por causa da excessiva burocratização do tribunal, bem como da necessidade de reformar o procedimento dos tribunais do common law ${ }^{430}$, várias medidas legislativas foram adotadas, culminando nos Judicature Acts de 1873-1875 ${ }^{431}$. A partir de então, a distinção entre o common law e a equity passou a consistir no conjunto de normas que cada um dos antigos tribunais aplicava, excluídas as normas de aplicação comum ${ }^{432}$. Para todos os demais fins, tinha-se operado a fusão dos dois sistemas ${ }^{433}$, ou melhor, da administração do common

${ }^{429}$ De fato, nos séculos XVII e XVIII o Court of Chancery dava sinais de sobrecarga, chegando a ter de 10.000 a 20.000 processos em andamento ao mesmo tempo e demorando até trinta anos para concluir um caso. As principais causas dessa morosidade eram duas: (i) o processo era centralizado na pessoa do Chancellor, quem não se dedicava exclusivamente à sua atividade jurisdictional pois, além das suas funções jurisdicionais, também participava ativamente da vida política do país e (ii) o sistema da Chancery era fortemente dependente dos funcionários do tribunal, que eram remunerados por tarefa, e não por um salário fixo, motivo pelo qual não tinham qualquer interesse em tornar o procedimento menos burocrático e mais célere, cf. J. H. BAKER, An Introduction cit. (nota 12 supra), pp. 111-112.

${ }^{430}$ Essa necessidade já era evidente no início do século XIX, principalmente no que diz respeito à insuficiència de meios processuais nos tribunais do common law, quando comparados com os poderes da Court of Chancery, para determinar a produção de prova testemunhal e documental ex officio, garantir a efetividade das suas próprias sentenças, exigir o cumprimento específico dos contratos (mediante a expedição de mandamus), determinar a abstenção da prática de atos lesivos ao direito de qualquer das partes (mediante a expedição de injunctions), aceitar defesas fundadas na equity (equitable defences) e evitar o ajuízamento concorrente de ação com idêntico fundamento (mas com pedido diferente, portanto não chegando a caracterizar litispendência) num tribunal do common law e noutro da equity, cf. J. STEPHEN (org.), The Common Law Procedure Act 1860 cit. (nota 8 supra), pp. 6-8 e 14-15.

${ }^{431}$ Cf. Stat. 36 \& 37 Vic. (1873), c. 66, s. 3: "From and after the time appointed for the commencement of this act, the several courts hereinafter mentioned (that is to say), the High Court of Chancery of England, the Court of Queen's Bench, the Court of Common Pleas at Westminster, the Court of Exchequer, the High Court of Admiralty, the Court of Probate, the Court of Divorce and Matrimonial Causes, and the London Court of Bankruptcy, shall be united and consolidated together, and shall constitute, under and subject to the provisions of this act, one Supreme Court of Judicature in England", alterado pelo Stat. 38 \& 39 Vic. (1875), c. 77 e o Stat. 54 \& 55 Vic. (1891), c. 53.

Esses statutes reformaram profundamente o sistema judiciário inglês, abolindo a Chancery, o Queen's Bench, o Common Pleas, o Exchequer, o Court of Probate, o Court of Divorce e o Court of Admiralty, que foram todos substituídos por um High Court of Justice, acima da qual encontrava-se a High Court of Appeal. O High Court of Justice, por sua vez, continha cinco Divisions, que de certa forma representavam os antigos tribunais: (i) Chancery; (ii) Queen's Bench; (iii) Common Pleas; (iv) Exchequer, e (v) Probate, Divorce and Admiralty. Os statutes citados foram revogados pelo Constitutional Reform Act 2005, que reestruturou o sistema judiciário inglês de modo a compatibilizá-lo com o sistema continental; dentre outras medidas, foi criada uma Supreme Court of the united Kingdom, cuja competência engloba as matérias anteriormente apreciadas pela House of Lords.

Para uma exposição mais aprofundada das mudanças provocadas pelos Judicature Acts 1873 e 1875 [=Stat. 36 \& 37 Vic. (1873), c. 66 e Stat. 38 \& 39 Vic. (1875), c. 77], cf. J. M. LELY e W. D. I. FoulKES (orgs.), The Judicature Acts cit. (nota 8 supra), pp. xxvii-lxiv; J. STORY, Commentaries on Equity cit. (nota 23 supra), pp. 29-31; F. W. MAITLAND, Equity cit. (nota 12 supra), pp. 15-16; D. KeRLY, An Historical Sketch cit. (nota 428 supra), pp. 293-295.

${ }^{432}$ Cf. F. W. MAITLAND, Equity cit. (nota 12 supra), p. 1: "We have no longer any courts which are merely courts of equity. Thus we are driven to say that Equity now is that body of rules administered by our English courts of justice which, were it not for the operation of the Juicature Acts, would be administered only by those courts which would be known as Courts of Equity".

${ }^{433}$ Cf. T. F. T. PluCKNETT, A Concise History cit. (nota 12 supra), p. 707. 
law e da equity ${ }^{434}$, estabelecendo-se regras para a aplicação de cada conjunto de normas no caso concreto $^{435}$.

Portanto, pode-se dizer que hoje o conjunto das regras da equity compõe o ordenamento jurídico inglês ao lado das normas do common law, porém não como um sistema rival a este ${ }^{436}$, e sim como um corpo de regras plenamente desenvolvido ${ }^{437}$ que, a partir da interpretação de certos princípios, adota determinadas medidas diante de situações específicas $^{438}$.

\subsubsection{Princípios diretores da equity: maxims of equity}

Os princípios adotados pela equity encontram-se encapsulados em certos brocardos jurídicos $^{439}$ coletivamente denominados maxims of equity ${ }^{440}$. Apesar de outrora

${ }^{434}$ Cf. P. H. PETTIT, Equity cit. (nota 1 supra), pp. 8-12. A expressão escolhida pelo autor é "fusion of the administration of law and equity", para enfatizar que as regras da equity ainda são distintas das regras do common law, porém são ambas aplicadas pelos mesmos tribunais, de acordo com as regras estabelecidas para tanto.

${ }^{435}$ As normas para a resolução de conflitos entre o common law e a equity vêm expressas em Stat. 36 \& 37 Vic. (1873), c. 66, s. 24 e s. 25, hoje revogadas e substituídas pelo Senior Courts Act 1981, s. 49. Após tratar das diversas hipóteses de aplicação das normas da equity, a s. 25 (11) estabelecia: "Generally in all matters not hereinbefore particularly mentioned, in which there is any conflict or variance between the rules of equity and the rules of common law with reference to the same matter, the rules of equity shall prevail'. Já o Senior Courts Act 1981, s. 49 (1) confirma essa regra: "Subject to all the provisions of this or any other Act, every court exercising jurisdiction in England or Wales in any civil cause or matter shall continue to administer law and equity on the basis that, wherever there is any conflict or variance between the rules of equity and the rules of the common law with reference to the same matter, the rules of equity shall prevail".

Na prática, no entanto, não são frequentes os problemas nesse sentido, pois mesmo antes dos Judicature Acts a equity já tinha desenvolvido regras para solucionar eventuais conflitos com as normas do common law.

${ }^{436}$ Cf. F. W. MAITLAND, Equity cit. (nota 12 supra), p. 19.

${ }^{437}$ Quanto à possibilidade de a equity criar novos equitable interests, ou seja, novos direitos reais a serem por ela tutelados, a opinião preponderante hoje é que, em princípio, isso não seja possível. O papel criativo da equity hoje está confinado à interpretação dos precedentes judiciais com base nos princípios já assentados da equity, conforme estabelecido em Cowcher v Cowcher [1972] 1 All ER 943.

438 As principais medidas que diferenciam a equity do common law são de natureza processual, especialmente as sentenças de cumprimento de dever específico (specific performance) e as sentenças mandamentais de fazer ou não fazer (injunctions), cf. P. H. PETTIT, Equity cit. (nota 1 supra), pp. 7-8.

${ }^{439}$ Acerca do desenvolvimento e utilização de brocardos jurídicos em ordenamentos de base romanística, pode-se consultar o artigo elaborado por D. R. MARTINS RODRIGUES, Das Regulae Iuris aos Brocardos Jurídicos, in Revista da Faculdade de Direito de São Bernardo do Campo 13 (2007), pp. 77-94. Embora uma comparação entre os brocardos de origem romana e os de origem inglesa esteja fora do escopo de estudo do presente trabalho, as maxims inglesas fornecem o material ideal para o estudo do fenômeno de generalização, mediante a articulação da casuística com um processo de graus sempre crescentes de abstração, de regras jurídicas a partir de casos concretos.

${ }^{440} \mathrm{O}$ surgimento na doutrina das maxims of equity no formato atual data do século XVIII, e deve-se em grande parte à obra publicada em 1728 por R. FRANCIS, intitulada Maxims of Equity - Collected From and Proved by Cases Out of the Books of the Best Authority in the High Court of Chancery. Uma edição que reproduz as maxims originais com comentários pode ser encontrada em R. FRANCIS, Maxims of Equity Collected From and Proved by Cases Out of the Books of the Best Authority in the High Court of Chancery, to Which is Added the Case of the Earl of Coventry, in W. W. HENING, Maxims in Law and Equity, Richmond, Shepherd and Pollard, 1823, pp. 2-87. 
terem sido elevados à categoria de princípios fundamentais da equity, hoje se entende que cumprem a função de diretrizes que orientam a atividade jurisdicional no caso concreto e a produção de regras criadas pelo case law ${ }^{441}$.

Assim, não se trata de um conjunto sistematizado ou logicamente coordenado de regras jurídicas, mas de princípios jurídicos de conteúdo amplo que norteiam a atividade do juiz ao interpretar os fatos do caso concreto e aplicar as normas da equity ${ }^{442}$.

Resulta instrutivo estudar as maxims of equity, na medida em que muitos dos principais temas relativos aos trusts estão relacionados aos princípios nelas expressos.

As doze principais são as seguintes ${ }^{443}$ :

(i) "equity will not suffer a wrong to be without a remedy": seu significado é principalmente histórico e faz referência à intervenção do Chancellor nas questões para as quais o common law não possuía remédio ${ }^{444}$, tal como as medidas judicias destinadas a tutelar o interesse do beneficiary ${ }^{445}$;

(ii) "equity follows the law" 446 : significa que a equity, mesmo quando corrige e complementa o common law e o statute law, não deixa de reconhecê-los como fontes legítimas do direito, criando interesses e estates equivalentes àqueles já existentes no common $l a w^{447}$; assim, a equity nunca revoga ou nega a existência dos direitos subjetivos reconhecidos

${ }^{441}$ Cf. M. LUPOI, Trusts cit. (nota 1 supra), p. 58 e P. H. PETTIT, Equity cit. (nota 1 supra), p. 25.

${ }^{442}$ Cf. F. PRINGSHEIM, The Inner Relationship cit. (nota 76 supra), p. 352, para quem a relutância dos juristas ingleses em transformar maxims em normas rígidas é uma das características que o direito clássico romano e o direito inglês compartilham. Para uma exposição das maxims of equity e suas aplicações, cf. P. H. PeTTIT, Equity cit. (nota 1 supra), pp. 25-28 e G. CRISCUOLI, Introduzione cit. (nota 1 supra), pp. 226-234. Para uma crítica à estrutura interpretativa das maxims of equity, cf. M. LUPOI, Trusts cit. (nota 1 supra), pp. 57-74.

${ }^{443}$ Mesmo já tendo sido enumerados até dezoito deles, a doutrina hoje normalmente menciona doze, pois considera que as que foram excluídas são uma duplicação ou especificação das doze principais, cf. G. CRISCUOLI, Introduzione cit. (nota 1 supra), p. 227. Cabe observar que R. FRANCIS, Maxims of Equity cit. (nota 440 supra), pp. 2-87 cita quatorze maxims.

${ }^{444}$ É com base nessa maxim que são deferidas, por exemplo, as medidas judiciais (injunctions) destinadas a impedir a comissão ou repetição de ato ilícito, cf. P. H. PETTIT, Equity cit. (nota 1 supra), p. 25. Sobre a concessão de equitable relief no caso concreto, cf. League Against Cruel Sports Ltd v Scott [1986] QB 240, em que, além de indenização por danos, o juízo deferiu uma injunction para impedir que caçadores ingressassem em terreno destinado à proteção de animais silvestres. Também Esso Petroleum Co Ltd v Kingswood Motors (Addlestone) Ltd [1974] QB 142, em que a liminar (injunction) foi deferida para impedir o descumprimento de cláusula contratual de exclusividade de fornecimento de combustível.

${ }^{445}$ Cf. P. H. PETTit, Equity cit. (nota 1 supra), p. 25.

${ }^{446}$ Convém apontar que o verbo "follow" é utilizado em duas acepções. No que diz respeito à criação de interesses equivalentes aos do common law, o verbo "follow" não significa "seguir" mas "imitar", no sentido de que a equity modela suas regras no common law, cf. M. LUPOI, Trusts cit. (nota 1 supra), pp. 57-58. Já em relação ao caráter complementar da equity em face do common law, o mesmo verbo adquire o significado de "acompanhar".

${ }^{447}$ Cf. G. CRISCUOLI, Introduzione cit. (nota 1 supra), pp. 228-229. 
pelas regras do common law, limitando-se a retirar-lhes sua efetividade mediante a adoção de medidas de natureza processual ${ }^{448}$;

\section{(iii) "where equities are equal, the first in time prevails": essa maxim} corresponde ao brocardo latino qui prior est tempore, potior est iure, e refere-se à adoção do critério temporal de antecedência para a solução de conflitos entre dois ou mais equitable estates $^{449}$;

${ }^{448} \mathrm{O}$ procedimento denominado equitable tracing, por meio do qual o beneficiary persegue o patrimônio indevidamente alienado a terceiros pelo trustee, bem ilustra a relação entre a equity e o common law expressa no brocardo equity follows the law, na medida em que o objetivo da ação é a recuperação do bem em questão ou do valor em que este tenha sido transformado, mediante a adoção de técnicas de rastreamento do patrimônio inexistentes no common law, porém sem desconstituir o título de propriedade do terceiro adquirente, não obstante se declare que este é proprietário em favor do beneficiary, cf. M. LuPOI, Trusts cit. (nota 1 supra), p. 60 .

Um estudo comparado entre o equitable tracing e as missiones in possessionem pode ser encontrado em D. Johnston, The Roman Law of Trusts, Oxford, Clarendon, 1988, pp. 227-233. Mesmo reconhecendo a inexistência no direito romano de um procedimento perfeitamente equiparável ao equitable tracing, o autor encontra semelhanças entre a regra do direito inglês que protege o comprador de boa-fé a título oneroso (bona fide purchaser for value without notice) e uma das hipóteses de concessão pelo pretor da missio in possesionem em favor do fideicommissarius, com base no seguinte fragmento: Pauli Sent. 4, 1, 15: "Rem fideicommissam si heres vendiderit eamque sciens compararit, nihilo minus in possessionem eius fideicommissarius mitti iure desiderat" (Se o herdeiro tiver vendido a coisa em fideicomisso e alguém ciente <da existência do fideicomisso $>$ a tiver comprado, o fidecomissário, no entanto, requereria com direito ser imitido na posse dela).

$\mathrm{O}$ fragmento trata de venda, pelo fiduciário, de bem deixado em fideicomisso, e estabelece que o fideicomissário pode ser imitido na posse do bem se o terceiro adquirente tiver tido ciência do ônus fideicomissário no momento da compra. Em outras palavras, o fideicommissarius, que ocuparia posição jurídica análoga à do beneficiary de um trust, somente poderia perseguir a coisa vendida indevidamente pelo fiduciarius, ou trustee, quando o comprador não tivesse tido conhecimento de que a coisa em questão estava sujeita ao fideicomisso, ou seja, quando o ato tivesse sido praticado de má-fé.

Mesmo não se tratando de um remédio in rem, a hipótese descrita no fragmento acima destoaria da orientação geral verificada nas fontes acerca da possibilidade de o fideicommissarius perseguir a própria coisa: Pauli Sent. 4, 1, 18: "Ius omne fideicommissi non in vindicatione, sed in petitione consistit" (Todo o direito do fideicomisso consiste não <em exercer a $>$ vindicatio, mas <em exercer a $>$ petitio).

Apesar das controvérisas acerca da natureza da tutela concedida ao fideicommissarius, pode-se dizer que este gozava de maior proteção que o legatário, na medida em que as disposições fideicomissárias eram tuteladas pela cognitio extra ordinem, que permitia, diferentemente do que ocorria no procedimento per formulas, a condenação do réu ao cumprimento de dever específico, cf. D. JohnSton, Trusts and Trust-like Devices in Roman Law, in R. Helmholz e R. ZimmermanN (org.), Itinera Fiduciae cit. (nota 1 supra), pp. 50-51; M. TALAMANCA, Istituzioni cit. (nota 42 supra), pp. 751-752.

${ }^{449}$ Essa maxim comporta uma série de sub-regras para determinar qual, dentre vários estates concorrentes, deve ter preferência. De modo simplificado, as principais sub-regras são as seguintes: (i) se não houver circunstâncias especiais, os estates e interests mais antigos terão preferência sobre os mais novos; (ii) um legal estate ou legal interest pode ter preferência sobre um equitable interest mais antigo, quando aquele tenha sido adquirido a título oneroso e de boa-fé (bona fide purchaser for value without notice), ou seja, sem conhecimento da existência do equitable interest (iii) o titular de um legal estate será preterido se praticar fraude, prestar falsa declaração ou for negligente; (iv) quando houver equitable interests concorrentes, os mais antigos terão preferência, desde que não tenha havido fraude, falsa declaração ou negligência, e (v) quando houver concorrência entre um equitable interest (direito tutelado pela equity) e uma mere equity (expectativa de um direito tutelado pela equity), o primeiro prevalece sobre a segunda somente se tiver sido adquirido a título oneroso e de boa-fé, ou seja, sem conhecimento da existência da mere equity, cf. P. H. PETTrT, Equity cit. (nota 1 supra), pp. 23-24.

A regra geral (i) foi aplicada em Cave v Cave (1880) $15 \mathrm{Ch}$ D 639, em que o trustee adquiriu terrenos com recursos do trust em violação dos seus deveres, registrando o bem imóvel em nome do seu irmão de modo a induzir terceiros à crença de que este era titular de um direito real absoluto, ou seja, sem encargos em favor de terceiros, sobre esses bens imóveis, gravando-os primeiro de uma hipoteca legal (legal mortgage) e depois de 
(iv) "where the equities are equal, the law shall prevail": para solucionar eventuais conflitos entre um equitable estate e um legal estate pertencentes a sujeitos diferentes, aplica-se o critério material pelo qual prevalece este último ${ }^{450}$, desde que o titular do legal estate tenha agido corretamente ${ }^{451}$; é o caso da aquisição da legal ownership a título oneroso por adquirente de boa-fé, que prevalece sobre quaisquer equitable estates, mesmo que tenham sido anteriores no tempo ${ }^{452}$;

(v) "he who seeks equity must do equity": a parte, ao procurar um equitable remedy, deve estar disposta a cumprir suas equitable obligations em relação ao objeto do

várias hipotecas equitativas (equitable mortgage) como garantia real para a obtenção de empréstimos de dinheiro; o juízo decidiu que tanto os cestuis que trust quanto os credores hipotecários tinham agido de boa-fé ("all equities being equal"), motivo pelo qual os cestuis teriam prioridade, já que seu direito tinha sido constituído primeiro no tempo.

Já em Rice v Rice (1854) 2 Eq Rep 341, os vendedores de um leasehold estate deram quitação e entregaram a escritura do imóvel ao comprador sem ter recebido o valor integral da contraprestação, sendo posteriormente o imóvel gravado de hipoteca pelo comprador e entregue a escritura ao credor hipotecário; o juízo entendeu que o equitable interest do credor hipotecário tinha preferência sobre o direito de retenção (vendor's lien) daqueles, apesar de ter sido constituído em momento posterior ao direito dos vendedores, pois a conduta destes (ter dado quitação e entregado a escritura, que agora estava em poder do credor hipotecário) tinha induzido o credor hipotecário a acreditar, de boa-fé, que não existia outro equitable interest concorrente.

A regra (v) foi desenvolvida e aplicada pela High Court of Australia em Latec Investments Ltd $v$ Hotelr Terrigan Pty Ltd (1965) 113 CLR 265. Nesse caso, o credor hipotecário, tendo o devedor entrado com pedido de falência, alienou indevidamente o bem imóvel hipotecado a uma filial sua (wholly-owned subsidiary), oferecendo o mesmo imóvel, logo após, como garantia numa emissão de debêntures junto com resto do patrimônio da empresa (floating charge), a qual foi à falência algum tempo depois. Cinco anos após a alienação indevida do imóvel, o devedor hipotecário ajuizou demanda para anular a venda. No acórdão, o juízo entendeu que, mesmo sendo o direito dos titulares das debêntures (que era uma mere equity) mais limitado e posterior no tempo em relação ao direito do devedor hipotecário (que era um equitable estate), o primeiro devia prevalecer, pois os titulares das debêntures eram adquirentes de boa-fé a título oneroso sem aviso, motivo pelo qual não se aplicaria a regra geral qui prior est tempore, potior est iure.

Apesar da complexidade das regras para determinar qual estate deve ter prioridade, parece bastante claro que o principal critério é o da boa-fé do adquirente a título oneroso sem aviso (bona fide purchaser for value without notice), cujo interesse prevalece perante o daqueles que tenham agido com dolo ou culpa, mesmo que se trate de culpa levíssima. No caso em que todos estejam de boa-fé, ou que ninguém o esteja ("all equities being equal"), dá-se preferência ao direito constituído primeiro no tempo. Não há, pelo menos a primeira vista, uma distinção entre os diversos graus de culpabilidade do agente para fins de estabelecer preferência entre estates ou interests concorrentes.

${ }^{450}$ Cf. G. CRISCUOLI, Introduzione cit. (nota 1 supra), p. 229.

${ }^{451}$ Pode-se ver claramente que esta maxim, bem como a anterior, diz respeito à determinação da prioridade entre estates concorrentes, motivo pelo qual prevalece o critério da boa-fé do adquirente a título oneroso sem aviso (bona fide purchaser for value without notice), cf. P. H. PETTIT, Equity cit. (nota 1 supra), p. 25.

${ }^{452}$ Cf. Pilcher v Rawlins (1872) LR 7 Ch App 259. Neste caso, os trustees de um family settlement fizeram um empréstimo do dinheiro afetado pelo trust, recebendo como garantia uma hipoteca sobre certos imóveis. Com o intuito de obter um segundo empréstimo de terceiros, esses mesmos imóveis foram gravados de nova hipoteca fraudulentamente, mediante a omissão, por parte do trustee sobrevivente e o primeiro tomador do empréstimo, as referências à primeira hipoteca, porém tendo sido entregues aos novos credores hipotecários as escrituras dos imóveis em questão. Em primeira instância, considerou-se que as hipotecas dos os cestuis que trust tinham preferência, porém em segunda instância ficou determinado que o direito do adquirente de boa-fé a título oneroso sem aviso (bona fide purchaser for value without notice), quando lastreado na escritura (titles) recebida do alienante, mesmo que adulterada, prevalece sobre quaisquer outros direitos, inclusive os do cestui que trust. 
litígio $^{453}$, e agir com honestidade e lealdade perante a outra parte, pois, a diferença do que determinam as regras do common law, pelas normas da equity o juiz não é obrigado a conceder uma medida favorável a quem não esteja disposto a honrar as obrigações assumidas perante a outra parte ou tenha adotado práticas negociais agressivas ${ }^{454}$, mesmo que a parte requerente tenha preenchido todos os requisitos legais para tanto;

(vi) "he who comes into equity must come with clean hands": se a maxim anterior tem como referência a conduta futura da parte, esta leva em consideração a conduta da parte antes da propositura da demanda ${ }^{455}$; assim, o interesse da parte não será tutelado se a sua conduta no passado tiver sido torpe ${ }^{456}$, ou seja, se antes da propositura da demanda ela tiver agido de má-fé $^{457}$.

${ }^{453}$ Cf. Measures Bros Ltd v Measures [1910] 2 Ch 248, em que uma empresa contratou um direto r, obrigando-se, no instrumento de contratação, a mantê-lo no cargo durante sete anos, prorrogáveis por mais sete, ficando o diretor, em contrapartida, obrigado a não exercer atividade concorrente fora da empresa por um prazo de sete anos após o término do contrato. Seis anos após a assinatura do contrato, a empresa entrou em processo de falência, exonerando o diretor do seu cargo e suspendendo o pagamento do seu salário. Diante dessa situação, o diretor passou a exercer, imediatamente após a sua exoneração, a mesma atividade de modo autônomo. A empresa ajuizou demanda pleiteando a expedição de ordem judicial para que o réu se abstivesse de exercer essa atividade. Em segunda instância, o tribunal entendeu que a empresa não podia exigir o cumprimento da cláusula de não concorrência, pois não ela mesma não era capaz nem estava disposta a cumprir sua parte do acordo.

É importante salientar que, no caso acima, o fundamento da decisão foi a impossibilidade de a empresa honrar o contrato de trabalho no futuro, e não a demissão do diretor antes da propositura da demanda.

${ }^{454} \mathrm{Cf}$. Willan $v$ Willan (1810) 16 Ves 72, em que o Chancellor declarou inválido o contrato assinado entre as partes por entender que, embora a parte beneficiada pelo acordo não tivesse tido a intenção de lesar (fraud), ela teria se comportado de modo oportunista (surprise) e induzido a outra, que já estava em estado de convalescência e sem o pleno domínio das suas faculdades mentais, a celebrar um acordo de alta complexidade poucos dias antes de falecer. 26.

${ }^{455}$ Cf. G. CRISCUOLI, Introduzione cit. (nota 1 supra), p. 230 e P. H. PetTIT, Equity cit. (nota 1 supra), p.

${ }^{456}$ A nosso ver, o princípio enunciado por meio dessa maxim é a variante inglesa do princípio expresso no brocardo latino "nemo potest venire contra factum proprium".

${ }^{457}$ Cf. Overton v Banister (1844) 3 Hare 503, em que duas cestuis que trust menores de idade, com o consentimento dos pais, declararam falsamente terem atingido a maioridade para obter de um dos trustees uma parte dos valores objeto do trust, pois pelos termos estabelecidos os beneficiaries somente receberiam suas quotas após atingir vinte e um anos de idade. As cestuis que trust deram quitação ao trustee pelo valor recebido, reconhecendo que o restante seria pago pelo outro trustee, que era o próprio pai das cestuis. Sete anos mais tarde, as cestuis que trust ajuizaram uma demanda contra o trustee que tinha pago o valor com base nas suas declarações falsas de maioridade, exigindo prestação de contas e pagamento do restante do valor afetado pelo trust. O Chancellor deferiu o pedido de prestação de contas e condenou o réu ao pagamento dos valores restantes, deixando claro, no entanto, que a parte autora não poderia exigir os valores já entregues pelo trustee às cestuis que trust, independentemente da quitação ter sido assinada por menores de idade.

A torpeza, no entanto, deve estar diretamente relacionada ao objeto da demanda, conforme estabelecido em Duchess of Argyll v Duke of Argyll [1967] Ch 302, no qual a requerente pleiteou a expedição de ordem judicial para que o ex-marido se abstivesse de divulgar informações e assuntos confidenciais relativos à época em que ainda eram casados. Mesmo tendo sido o adultério da requerente que deu causa ao divórcio, o juízo deferiu a medida porque a conduta torpe da mesma requerente era posterior ao período ao qual as informações em questão se referiam.

O mesmo já tinha sido decidido em Dering v Earl of Winchelsea [1775-1802] All ER Rep 140, em que o juízo rejeitou o argumento de que o co-fiador solidário (joint and several surety) não teria direito de regresso contra os demais co-fiadores pelo fato de ter estimulado o devedor principal a realizar gastos com apostas. 
(vii) "delay defeats equities": corresponde ao brocardo latino vigilantibus non dormientibus aequitas subvenit, e refere-se às situações ${ }^{458}$ em que a inércia da parte ${ }^{459}$ exclui a tutela do seu interesse pela equity ${ }^{460}$.

(viii) "equality is equity": o princípio da igualdade aplica-se, principalmente, nos casos de pluralidade de titulares sobre um mesmo estate ${ }^{461}$ e ausência de qualquer regulamentação entre as partes, a equity prefere a tenancy in common ao invés da joint tenancy ${ }^{462}$, assegurando o tratamento igualitário a todos os co-titulares ${ }^{463}$;

${ }^{458}$ Uma clara hipótese de aplicação dessa maxim diz respeito à anulabilidade dos contratos em que uma das partes encontra-se numa relação de dependência técnica perante a outra (tais como os contratos celebrados entre médico e paciente, advogado e cliente, tutor e pupilo etc.), já que nessas relações existe uma relação de confiança (fiduciary relationship) em razão da qual a parte mais forte pode exercer uma influência indevida (undue influence) sobre a outra. O juízo pode rejeitar o pedido de anulação se entender que a parte requerente não agiu dentro de um prazo razoável, cf. G. CRISCUOLI, Introduzione cit. (nota 1 supra), p. 231.

Em Allcard v Skinner [1886-1890] All ER Rep 90, a Chancery Division negou provimento ao recurso interposto em ação anulatória contra sentença que declarava plenamente válida a doação feita em favor de um convento da Igreja Anglicana por uma das suas ex-noviças, sob o fundamento de que, apesar de não ter tido a oportunidade de obter assessoria jurídica externa e imparcial na época em que fez a doação (configurando uma hipótese de undue influence), a demora da autora em propor a demanda (a qual foi ajuizada mais de cinco anos após a parte autora ter abandonado o convento) importava a confirmação tácita do ato de doação.

${ }^{459}$ De modo genérico, a doutrina inglesa denomina a inércia do autor em apresentar a demanda "laches", que significa a demora irrazoável e injustificada do autor em buscar a satisfação do seu direito, caracterizada pela aceitação tácita do ato praticado em seu prejuízo, cf. D. M. WALKER, The Oxford Companion cit. (nota 8 supra), p. 708 (no verbete "laches").

É importante ressaltar que as regras e os prazos prescricionais e decadenciais relativos à responsabilidade do trustee têm sido fixados, na maior parte dos ordenamentos jurídicos do common law, por meio de statutes, como é o caso do Limitation Act 1980, ss. 21-22 na Inglaterra. No entanto, nos casos não abrangidos pela legislação, o juiz pode declarar a ocorrência da prescrição com base nas circunstâncias específicas do caso, em especial a conduta prévia das partes.

${ }^{460}$ Cf. G. CRISCUOLI, Introduzione cit. (nota 1 supra), pp. 231-232 e P. H. PETTIT, Equity cit. (nota 1 supra), pp. 529-535.

${ }_{461}$ Cabe destacar que não se verifica no direito inglês, no âmbito dos direitos reais, a aversão à pluralidade de sujeitos de direito sobre a mesma coisa que caracteriza os sistemas de tradição romanística, no qual, já desde o período clássico do direito romano, a actio communi dividundo era o destino natural do condomínio, cf. $\mathrm{M}$. TALAMANCA, Istituzioni cit. (nota 42 supra), p. 412.

$462 \mathrm{O}$ vocábulo tenancy é utilizado para fazer referência à relação de um sujeito com determinado interesse jurídico (legal interest). As expressões joint tenancy e tenancy in common exprimem a relação de vários sujeitos com o mesmo interesse sobre determinada coisa. A principal distinção entre esses institutos é que, no primeiro caso, ao falecer qualquer dos co-titulares a quota-parte correspondente acresce à dos co-titulares sobreviventes em partes iguais, enquanto no segundo a quota-parte do de cujus transmite-se aos seus descendentes, cf. D. M. WALKER, The Oxford Companion cit. (nota 8 supra), p. 1210 (no verbete "tenancy").

A joint tenancy encontra algumas semelhanças na co-propriedade romana, particularmente no que diz respeito ao ius accrescendi, se bem que no direito inglês este não se restringe aos casos de inexistência de quaisquer herdeiros necessários, cf. W. W. BuCKLAND e A. D. MCNAIR, Roman Law and Common Law cit. (nota 1 supra), p. 81.

O motivo pelo qual a equity, diante da ausência de disposição contrária entre as partes, estabelece a aplicação do regime da tenancy in common e não o da joint tenancy é que este, ao favorecer sempre o último cotitular sobrevivente, cria desigualdade entre as partes, cf. P. H. PETTIT, Equity cit. (nota 1 supra), pp. 26-27.

O princípio em questão foi invocado pela Chancery Division em MacDonald v MacDonald [1957] 2 All ER 690, para fundamentar a presunção da existência de uma tenancy in common e não de uma joint tenancy. No caso em questão o marido, sua mulher e a sogra do marido contribuiram, de diversas formas e em proporções desiguais, para a compra de um imóvel com o intuito de nele constituir a moradia dos três. Vários anos depois, após o divórcio, na ação reivindicatória proposta pela agora ex-mulher, o juízo entendeu que, na ausência de 
(ix) "equity looks to the intent rather than the form": a equity atende mais à intenção das partes do que à forma do ato, ou seja, dá preferência à interpretação do ato com base no conteúdo do negócio e não apenas na forma ${ }^{464}$;

(x) "equity looks on that as done which ought to be done": o princípio encontra aplicação na execução do contrato preliminar ${ }^{465}$, ou seja, na conversão do contrato preliminar em definitivo ${ }^{466}$.

disposição a respeito entre as partes, a autora tinha direito a uma quota-parte de dois terços do imóvel, pois teria herdado a parte da mãe, que tinha morrido intestada, ficando um terço com o marido e seus herdeiros.

Um caso peculiar de aplicação desse princípio pode ser visto em Re Dickens [1935] Ch 267, cujo objeto foi o direito dos herdeiros e legatários do famoso escritor Charles Dickens ao produto da cessão dos direitos autorais relativos à publicação póstuma de um dos seus livros, "The Life of Our Lord". Ficou estabelecido que, quando um escritor deixa em testamento a um legatário o direito à utilização econômica de sua obra como um todo (copyright), deixando a outro legatário a propriedade de um único manuscrito original e inédito (o que torna necessário o consentimento deste para publicar a obra), na ausência de qualquer disposição a respeito entre as partes, o produto da venda dos direitos à publicação da obra deve ser distribuído em partes iguais.

${ }^{463}$ Nesse sentido, cf. Jones v Maynard [1951] Ch 572, em que a Chancery Division decidiu que, diante da ausência de prévio acordo entre o marido e mulher acerca da partilha dos valores depositados em conta conjunta, após o divórcio o saldo restante deveria ser distribuído em partes iguais, independentemente de ter sido o marido que fez os depósitos de maior valor, pois tais valores integravam o patrimônio conjunto do casal e a mulher tinha direito à meação (moiety) sobre a conta, motivo pelo qual o marido foi declarado trustee dos valores por ele retirados indevidamente ao encerrar a conta após a separação.

${ }^{464}$ No âmbito dos trusts, essa maxim é de grande utilidade, na medida em que os tribunais, ao interpretar determinado negócio jurídico, podem declarar a existência de um trust, mesmo que as partes não tenham feito uma declaração explícita nesse sentido.

Assim, em Re Kayford Ltd [1975] 1 All ER 604, uma empresa de compra por correspondência depositou os valores pagos pelos consumidores numa conta bancária separada das demais contas da empresa, com o intuito de constituir um trust em favor dos consumidores que ainda não tivessem recebido os produtos pelos quais pagaram, pois a empresa se encontrava em grandes dificuldades financeiras e sua liquidação era iminente. Após a liquidação, a Chancery Division entendeu que esses valores efetivamente constituíam um trust em favor dos consumidores, apesar de não ter havido disposição expressa nesse sentido por parte da empresa. Vale notar que o reconhecimento da existência de um trust em favor dos consumidores significou, na prática, a preferência destes em face dos demais credores da empresa.

O tema da prevalência da intenção sobre a forma do negócio também tem grande relevância na sucessão testamentária, em especial no que diz respeito a qualquer disposição do testador que indique ao herdeiro ou legatário uma destinação ou utilização específica para determinado bem. A discussão gira em torno das palavras ou expressões (precatory words) que poderiam constituir um trust, nos casos em que o testador não o faz expressamente. Mesmo sem haver consenso na jurisprudência inglesa quanto a essa questão, a tendência é dar sempre preferência à provável vontade do testador no momento da feitura do testamento. Assim, em Re Adams and The Kensington Vestry (1884) 27 Ch D 394, ficou estabelecido que a cláusula testamentária pela qual o testador deixa todo o seu patrimônio à sua mulher "com a plena confiança de que ela o distribuirá adequadamente entre os meus filhos, seja em vida, seja por testamento" ("in full confidence that she will do what is right as to the disposal thereof between my children, either in her lifetime, or by will after the decease"), não constituía um trust, pois o testamento, quando considerado como um todo, implicava na reconstrução da vontade do testador de tal forma que, no caso, autorizava a esposa a dispor do patrimônio da forma que lhe parecesse mais conveniente.

Essa decisão vem lastreada em Lambe v Eames (1871) 27 Ch D 394, em que o Court of Appeal entendeu que a cláusula testamentária que deixava o patrimônio à mulher do testador "para que ela dispusesse dele da forma que lhe pareça mais apropriada para benefício seu e da sua família" ("to be at her disposal in any way she may think best for the benefit of herself and family"), não constiuía um trust, pois o conteúdo do restante do testamento deixava claro que a vontade do testador era no sentido de deixar a distribuição do seu patrimônio ao arbítrio da esposa.

${ }^{465}$ Cf. G. CRISCUOLI, Introduzione cit. (nota 1 supra), p. 233.

${ }^{466}$ Cabe observar que a execução de contrato preliminar, no direito inglês, vai além da mera declaração de um dever contratual, sendo em muitos casos associada à conversão de um direito obrigacional (ius in personam) 
(xi) "equity imputes an intention to fulfill an obligation": essa maxim siginifica que a equity, na ausência de manifestação expressa em contrário, interpreta os atos de liberalidade do devedor em relação a qualquer credor em favor do adimplemento da obrigação $^{467}$, dando preferência à compensação do débito ${ }^{468}$.

(xii) "equity acts in personam": esse princípio, um dos mais característicos da equity, é considerado predominantemente sob o aspecto objetivo e diz respeito à natureza das medidas processuais típicas da equity, no sentido de que elas operam sempre in personam, e

em direito real sobre alguma coisa (ius in rem), cf. N. STOCKWELL e R. EDWARDS, Trusts and Equity, $7^{\mathrm{a}}$ ed., Harlow, Pearson Longman, 2005, pp. 115-116.

Um caso de aplicação dessa maxim é Walsh v Lonsdale [1881-5] All ER Rep Ext 1690. O autor e o réu, após ter negociado as cláusulas e definido a minuta do contrato de locação (lease) de um imóvel para fins industriais, comprometeram-se a assinar e lacrar o instrumento (sign and seal the parchment) em momento futuro. Mesmo sem ter celebrado o contrato de locação, o locatário tomou posse do imóvel e pouco tempo depois o locador, em conformidade com uma das cláusulas negociadas preliminarmente, cobrou do locatário, além do aluguel devido pelo período da locação já transcorrido, o valor equivalente a um ano de aluguel antecipado. O locatário ajuizou demanda na Chancery Division alegando que a cobrança antecipada era indevida pelo fato de não ter sido formalizado o contrato. O juízo converteu o contrato preliminar em contrato definitivo, assegurando ao locador o direito de agir nos termos acordados preliminarmente.

O mesmo princípio também serviu como base para a regra elaborada em Howe v Earl of Dartmouth [17751802] All ER Rep 24, segundo a qual, sob determinadas circunstâncias, o juiz pode converter personal property em real property e vice versa. Uma conhecida aplicação dessa regra (denominada "doctrine of conversion") ocorre nos casos em que uma das partes num contrato de compra e venda de bem imóvel falece antes de realizada a tradição (conveyance). Se o vendedor falecer antes da tradição, embora ainda seja titular de um legal title, seus sucessores terão direto ao valor da compra (purchase price), e não um direito real sobre esse imóvel. Inversamente, se o comprador falecer antes da tradição, seus successores terão direito real sobre o imóvel, desde que demonstrem capacidade de pagar as prestações faltantes, caso existam (no caso de uma compra a prazo), cf. P. H. PetTit, Equity cit. (nota 1 supra), cap. 30, Conversion and Reconversion, p. 1, disponível in http://www.oup.com/uk/orc/bin/9780199561025/resources/chapters/ [13-07-2011]. Sobre a doctrine of conversion, cf. M. LUPOI, Trusts cit. (nota 1 supra), pp. 69-70.

No entanto, em Re Anstis (1886) 31 Ch D 596, a Court of Appeal estabeleceu que o bem imóvel não transferido pelo testador durante sua vida a um marriage trust, mesmo em descumprimento de cláusula de pacto antenupcial (marriage settlement) que obriga o cônjuge a transferir ao trust todo o patrimônio superveniente, não pode ser reclamado pelo herdeiro necessário (heir-at-law), pois a sua pretensão não tem relação com a causa (consideration) do pacto antenupcial, que tinha sido celebrado tendo em vista os cônjuges e eventuais filhos do casal.

${ }^{467}$ Cf. G. CRISCUOLI, Introduzione cit. (nota 1 supra), pp. 233-234.

${ }^{468} \mathrm{O}$ princípio em questão está relacionado à regra elaborada em Talbot v Duke of Shrewsbury (1714) 25 ER 62, segundo a qual o legado deixado pelo devedor ao seu credor presume-se, na ausência de disposição expressa do testador em sentido diverso, deixado como pagamento da dívida. Para que ocorra essa presunção, certos requisitos devem ser atendidos: a dívida deve ser anterior à feitura do testamento; o legado não pode estar sujeito a condição; seu valor deve ser igual ou superior ao da dívida; o legado deve ser do mesmo gênero que a dívida, e as condições de pagamento do legado não podem ser menos vantajosas do que as de pagamento da dívida pelo próprio espólio. Caso o valor do legado seja compensado com o valor da dívida, fica vedado ao credor receber também como legatário, podendo, no entanto, afastar a presunção mediante a renúncia ao crédito.

Sobre o tema, cf. P. H. PetTiт, Equity cit. (nota 1 supra), cap. 31, Satisfaction, Ademption and Performance, pp. 1-7, disponível in http://www.oup.com/uk/orc/bin/9780199561025/resources/chapters/ [13-072011].

Cabe destacar que, no direito brasileiro, a presunção, em caso de legado deixado pelo testador ao seu credor, é a oposta, conforme estabelece o artigo 1.919 caput do CC brasileiro: "Não o declarando expressamente o testador, não se reputará compensação da sua dívida o legado que ele faça ao credor". 
não in $\mathrm{rem}^{469}$; já do ponto de vista subjetivo, significa que a valoração da conduta do agente leva em consideração seu estado psicológico ${ }^{470}$.

\subsection{Os antecedentes dos trusts: os uses}

No direito inglês, os trusts são um instituto da real property law. Nos sistemas de direito civil esse campo corresponde, grosso modo, à categoria dos direitos reais. A property law, conforme visto acima, foi fortemente influenciada pela cultura jurídica medieval, de onde provém suas categorias e conceitos fundamentais.

Uma das conseqüências dessa particular influência é o modo em que se configuram e desmembram os direitos reais. Assim, pode-se afirmar que o fundamento do sistema moderno de propriedade sobre bens imóveis na Inglaterra (e, portanto, nos ordenamentos jurídicos baseados no direito inglês) descansa na distinção legal entre legal

469 A intepretação do princípio em questão constitui um assunto muito relevante para o nosso estudo, na medida em que se relaciona à inserção da posição jurídica do beneficiary na categoria dos direitos obrigacionais (ius in personam) ou reais (ius in rem).

De fato, nem a doutrina inglesa é unânime quanto à natureza jurídica dos trusts, no que diz respeito aos direitos do cestui que trust e, portanto, às medidas processuais adotadas pela equity para tutelar seus interesses. De acordo com F. W. MAITLAND, Equity cit. (nota 12 supra), pp. 112-121, de certa forma representando o que hoje se considera a opinião mais tradicional, a equity confere ao beneficiary um ius in personam sobre o patrimônio afetado pelo trust, se bem que, ao longo dos séculos, a atividade jurisdicional do Chancellor tenha lhe atribuído feições análogas às de um ius in rem. O principal argumento é que o interesse do beneficiary nunca prevalece diante do adquirente de boa-fé a título oneroso sem aviso (bona fide purchaser for value without notice), evidenciando que aquele não pode opor seu direito erga omnes, mas apenas em face de sujeitos determinados. Sendo assim, o interesse do cestui que trust pode ser definido de duas formas: (i) como um direito pessoal oponível em face do trustee, do adquirente a título gratuito (volunteer) e do adquirente de boa-fé a títúlo oneroso com aviso (bona fide purchaser for value with notice), ou (ii) como um direito real oponível em face de todos, exceto o adquirente de boa-fé a título oneroso sem aviso (bona fide purchaser for value without notice). $\mathrm{O}$ autor declara sua preferência pela primeira alternativa, pois considera que a enumeração dos sujeitos em face dos quais o cestui que trust pode opor seu direito é mais fiel à realidade histórica e ao desenvolvimento dos trusts.

Essa visão tradicional, no entanto, tem sido criticada por vários doutrinadores, dentre os quais se destaca A. W. ScOTt, The Nature of the Rights of the Cestui Que Trust, in Columbia Law Review 17 (1917), pp. 269-290. De acordo com o autor, a tutela dos interesses do cestui que trust pela jurisdição da equity desenvolveu-se historicamente no sentido de lhe conferir, pouco a pouco, um direito real oponível erga omnes sobre a res sujeita ao trust. Para ele, dizer que o cestui que trust tem um direito erga omnes não significa que seu direito seja oponível contra toda e qualquer pessoa, mas que sua pretensão é oponível diante de pessoas indeterminadas. Inversamente, o titular de um ius in personam pode opor o seu direito a pessoas determinadas. Dessa forma, a supremacia do direito do adquirente de boa-fé a título oneroso sem aviso (bona fide purchaser for value without notice) não descaracteriza a natureza real da pretensão do cestui que trust, mas é, na verdade, o resultado de uma política judiciária que busca dotar as transações comerciais de maior segurança jurídica. Além disso, o autor sustenta que o fato de o Chancellor ter evitado reconhecer o cestui que trust como proprietário (owner) da res sujeita ao trust tinha por objetivo evitar que outras consequencias jurídicas decorrentes do sistema feudal (tais como a incidência de tributos) o atingissem. Por último, o princípio equity acts in personam não implica, necessariamente, que a equity não seja capaz de tutelar ius in rem, pois as medidas judiciais típicas da equitable juridiction (injunctions e specific performance), se bem se dirigem a uma determinada pessoa, indiretamente produzem efeitos erga omnes.

${ }^{470}$ Cf. G. CRISCUOLI, Introduzione cit. (nota 1 supra), p. 234. Nesse sentido, o significado dessa maxim é bem próximo do sentido da anterior: equity imputes an intention to fulfill an obligation. 
ownership e beneficial ownership ${ }^{471}$, ressaltando que essas categorias entrelaçam-se ainda com a posse (seisin), que no direito inglês não se distingue da propriedade (ownership) com a mesma clareza característica do direito romano ${ }^{472}$. As origens dessa classificação remontam a um conjunto de situações que adquiriram o reconhecimento do ordenamento jurídico ao longo do tempo.

Tais situações surgiam quando um feudal tenant ficava pessoalmente obrigado, por força de um contrato ou das exigências da boa-fé, a permitir que um terceiro ficasse com o beneficial enjoyment de terras que lhe pertenciam ${ }^{473}$. Dizia-se que o tenant tinha as terras ${ }^{474}$

${ }^{471}$ Um dos elementos ligados a essa distinção são os próprios estates in land, cf. nota 192 supra.

${ }^{472}$ Cf. W. W. BuCKLAND e A. D. MCNAIR, Roman Law and Common Law cit. (nota 1 supra), pp. 62-63.

${ }^{473}$ Cf. F. POLlOCK e F. W. MAITLAND, The History of English Law cit., vol. II (nota 12 supra), p. 231. As situações envolvendo esse tipo de relação eram as mais variadas. Assim, por exemplo, um soldado que saísse em campanha para as Cruzadas podia deixar suas terras ao seu irmão, porém para o benefício dos seus descendentes, ou da sua mulher e da sua irmã; da mesma forma, as doações feitas à Igreja muitas vezes tinham uma destinação específica (como a manutenção de uma biblioteca ou de um hospital), em cujo caso a instituição religiosa devia destinar as terras ou o patrimônio em questão àquele fim estabelecido pelo doador. A utilização em larga escala desse instituto ocorreu no século XIII, com a chegada da Ordem dos Franciscanos (Ordo Fratrum Minorum) à Inglaterra e o aparecimento das doações feitas à comunidade (borough community) em favor da Ordem, na medida em que os frades franciscanos, em virtude do seu voto de probreza, não podiam ser titulares de qualquer direito de propriedade. Esse direito ao "uso" de bens materiais foi objeto das bulas Quo elongati (1230), do Papa Gregório IX, e Ordinem vestrum (1245), do Papa Inocente IV, as quais, baseando-se na distinção romana entre dominium e usus, atribuíam à Santa Sé o primeiro (“...cum tam immobilium, quam mobilium hujusmodi jus, proprietas \& dominium...nullo medio ad Ecclesiam ipsam spectent...”) e à ordem franciscana o segundo (“...ordo habeat usum...").

A busca por fontes primárias que atestem o desenvolvimento dos uses a partir do usus tem sido em vão, cf. J. Biancalana, Medieval Uses, in R. Helmholz e R. Zimmermann (org.), Itinera Fiduciae cit. (nota 1 supra), p. 113. Contudo, ainda não há consenso quanto a um possível parentesco entre os dois institutos. Parte da doutrina nega qualquer parentesco entre o usus e os uses, cf. S. F. C. Milsom, Historical Foundations cit. (nota 12 supra), p. 203. Outra parte identifica o usus dos frades franciscanos como uma forma arcaica de use, mesmo negando o parentesco entre as palavras usus e use - o que em nossa opinião é uma contradição, pois o regime jurídico adotado pelos franciscanos claramente era o do usus de origem romana, e reconhecê-lo como uma forma arcaica de use implica admitir algum parentesco entre as expressões usus e use e até entre os dois institutos -, cf. T. F. T. PluCKNETT, A Concise History cit. (nota 12 supra), p. 575-577 e F. W. MAITLAND, Equity cit. (nota 12 supra), pp. 24-25. Já outra parte da doutrina vislumbra uma relação mais íntima entre os institutos, porém fazendo a ressalva de que o usus clerical não era idêntico ao usus romano, já que aquele impunha um dever fiduciário ao proprietário que atribuía ao usuário certas prerrogativas reais sobre o patrimônio afetado, aproximando-o da figura do beneficiary, cf. S. HERMAnN, The Canonical Conception of the Trust, in R. Helmholz e R. ZimmermanN (org.), Itinera Fiduciae cit. (nota 1 supra), pp. 92-96. Acerca das controvérsias jurídicas relativas à pobreza na Igreja Católica, bem como o seu impacto no desenvolvimento do pensamento jurídico ocidental, cf. G. TARELlO, Povertà, in NDI 13, Torino, UTET, 1957, pp. 520-523.

${ }^{474}$ Cabe fazer uma distinção entre a utilização da expressão ad opus em relação a bens móveis (chattels) e bens imóveis (lands). A expressão ad opus - ou às vezes ad usum, ou até ad opus et usum - surgiu numa época em que a posse era mais relevante, do ponto de vista jurídico, do que a titularidade do direito de propriedade sobre a coisa. As ações para recuperar a coisa em caso de furto ou roubo cabiam ao possuidor, e só com o passar do tempo passaram a levar em consideração a titularidade do proprietário. No caso dos bens móveis, o common law desenovolveu o instituto da agency; já em relação aos bens imóveis, o instituto desenvolvido para enfrentar o problema do possuidor sem título foi o use, cf. F. POLlOCK e F. W. MaITLAND, The History of English Law cit., vol. I (nota 12 supra), pp. 29-30. 
ad commodum ou ad opus of the beneficiary ${ }^{475}$, permanecendo o dono nominal (nominal owner) e tendo a obrigação de observar a confiança que nele tinha sido depositada ${ }^{476}$.

\author{
Inicialmente de caráter temporal (pois as terras held ad opus ficavam nessa
}

situação somente até que o tenant fosse substituído), a operação pela qual o tenant transferia o beneficial enjoyment a um terceiro passou a adquirir, com o passar do tempo, caráter permanente. No mais das vezes, o principal objetivo era facilitar a transferência feudal $\left(\right.$ feoffment $t^{477}$ ) de um bem imóvel a outra pessoa sem o consentimento expresso do senhor, que podia opor-se a qualquer alienação que lhe fosse prejudicial.

475 A locução "ad opus (meum, tuum, suum)" já era utilizada pelos francos no continente mesmo antes da Conquista, no contexto de doações feitas em favor da Igreja, como no fragmento encontrado em K. ZEUMER, Formulae Merovingici et Karolini Aevi, in MGH, Hannover, 1886, p. 115: “(..) Insuper etiam petimus benivolentiam vestram, ut nobis aliquid de silva ad opus ecclesiae nostrae vel monasterium nostrum restaurandum dare iubeatis, quantum vobis possiblis fuerit (...)". Aparece também em algumas leis carolíngias para os lombardos, como no seguinte fragmento do Lib. Papiens., ed. BoreTIUs, Pappini, 28 (30) [=MGH, t. IV, Hannover, 1868, p. 520]: “(...) si comites ipsas causas commoverint ad requerendum, illi tertiam partem ad eorum percipiant opus, duas vero ad palatium (...)".

A expressão passou para os land-books anglo-saxões, que eram registros escritos de doações feitas por senhores anglo-saxões à Igreja, cf. F. POLLOCK e F. W. MAITLAND, The History of English Law cit., vol. I (nota 12 supra), p. 28, conforme atesta o seguinte texto de Cenwulf of Mercia (809 d.C.) [=Cod. Dipl. 1025]: “(...) Item in alio loco in Cantia dedi eidem venerabili viro ad opus praefatae Christi aecclesiae et monachorum ibidem deo servientium terram (...)", bem como o seguinte fragmento atribuído a Beornwulf of Mercia (822 d.C.) [=Cod. Dipl. 1028]: “(...) Beornulfus rex dedit aecclesiae Christi et Wulfredo archiepiscopo ad opus monachorum in eadem aecclesia deo servientibus villam Godmeresham", cf. J. M. KEMBLE, Codex Diplomaticus Aevi Saxonici, vol. V, London, Sumptibus Societatis, 1847, pp. 66-67 e 69.

A partir da Conquista a expressão ad opus passou à língua jurídica escrita na Inglaterra, onde aparece no Domesday Book e em diversos charters para fazer referência específica à concessão de terras. Em francês medieval a expressão passa a ser al os ou al oes. Especula-se que a palavra use em sentido jurídico tenha surgido a partir da palavra oeps do francês medieval, a qual, perdendo o $p$, passou a ser oes, cf. F. W. MAITLAND, Equity cit. (nota 12 supra), p. 24.

A expressão também aparece numa coletânea de decisões judiciais na qual a tradição inglesa acredita que Henry de Bracton tenha baseado sua obra De legibus et consuetudinibus angliae, intitulada The Notebook of Bracton, referindo-se a Robertus, um tenant primogênito que parte para lutar nas Cruzadas e transfere suas terras para o seu irmão em favor dos seus próprios filhos: “(...) Idem Hanesgod tunc tenuit de Priore tota vita sua et habuit duos filios Robertum primogenitum et Wydonem postnatum, et Robertus post mortem patris sui tenuit eandem terram de eadem domo et habuit filios et ivit in terram sanctam, et commisit terram illam custodiendam Wydoni fratri suo ad opus puerorum suorum (...)". Guido nega-se a entregar o imóvel ao seu sobrinho (o texto não diz o que aconteceu com o outro filho), fazendo-se um acordo pelo qual a metade da terra ficaria com o tio e a outra metade com o sobrinho, cf. BNB pl. 999. Outro caso também pode ser encontrado em BNB pl. 1851, no qual Jordanus compra terras em benefício da sua mulher Alicia e de seus descendentes: “(...) Juratores dicunt quod predictus Jordanus emit terram illam postquam desponsavit ipsam Aliciam de predicta Idonea, et quod predictus Jordanus emit terram illam ad opus ipsius Alice et heredum ipsius Alice de ipso Roberto (...)". Outras ocorrências da expressão podem ser vistas em BNB pl. 1683, BNB pl. 641, BNB pl. 754 e BNB pl. 1244. Como se pode ver, a expressão era utilizada em contextos muito diversos, porém a fórmula básica pode ser reduzida a “A. tenet ad opus B.", que significa “A. tem para o benefício de B.”, cf. T. F. T. PlucKnetT, A Concise History cit. (nota 12 supra), p. 576. Acerca da utilização da expressão ad opus nas fontes antigas inglesas, cf. F. POLLOCK e F. W. MAITLAND, The History of English Law cit., vol. II (nota 12 supra), pp. 233-239.

${ }^{476}$ Cf. J. H. BAKER, An Introduction cit. (nota 12 supra), p. 248.

477 Tal como originariamente ocorria em relação aos demais tipos de transação sobre bens imóveis no contexto feudal, o negócio em questão era visto como uma simples doação, dado que, em princípio, o vassalo não pagava qualquer valor pecuniário pela terra, devendo apenas fornecer certos serviços ao seu senhor, cf. C. F. DU CANGE, Glossarium cit. (nota 13 supra), t. 3, col. 479b (no verbete "feoffamentum"): "Datio ad feodum, donatio feudi, sape simplex donatio". 
Conforme estudado em detalhe acima, no final do século XIII essa prerrogativa do senhor feudal foi eliminada ${ }^{478}$. Contudo, a proibição contra a transferência de freehold land, a categoria conceitualmente mais ampla de direitos reais, mediante testamento ${ }^{479}$ ainda apresentava uma séria dificuldade para o tráfico jurídico de terras ${ }^{480}$.

Foi a necessidade de evadir essa proibição que deu impulso ao desenvolvimento dos uses. Um tenant (feoffor ${ }^{481}$ ) podia outorgar em confiança (grant on trust) sua terra a um grupo de amigos ou vizinhos (feoffees ${ }^{482}$ ) para que estes a transferissem, após a sua morte, a quem ele tivesse indicado.

As vantagens desse arranjo eram múltiplas: além de permitir ao tenant escolher o seu sucessor, o que não era possível pelo direito feudal estrito, evitava-se também os pesados ônus que incidiam sobre a transmissão causa mortis, de acordo com o sistema das tenures ${ }^{483}$. Os feoffees se comprometiam a seguir as instruções do feoffor tanto durante a vida deste quanto após a sua morte. Isso permitia que o tenant alienasse suas terras sem que o nominal owner pudesse intervir, na medida em que, formalmente, o único elemento da relação feudal que tinha mudado era a identidade do beneficiary, a qual, em termos estritamente jurídicos, não tinha relevância ${ }^{484}$.

O instituto, de caráter permanente, resultante da operação descrita acima, denominou-se $u s e^{485}$. O beneficiário, quando não se tratasse do próprio feoffor, chamava-se

478 Trata-se do Statutum Quia Emptores Terrarum 1290 [=Stat. 18 Edw. I (1290), c. 1-3], estudado no capítulo correspondente, cf. capítulo 2.3.2 supra.

${ }^{479}$ Cf. F. W. MAITLAND, Equity cit. (nota 12 supra), p. 26. A principal função dessa probição era assegurar ao senhor feudal maior controle sobre as suas terras e garantir seus direitos relativos aos services e incidents, cf. A. WATSOn, Roman Law \& Comparative Law cit. (nota 1 supra), p. 142 e P. S. JAMES, Introduction to English Law cit. (nota 192 supra), p. 338. Acerca dos services e incidents, de modo geral, cf. nota 115 supra.

${ }^{480}$ Cf. J. H. BAKER, An Introduction cit. (nota 12 supra), p. 249.

${ }^{481}$ Cf. nota 332 supra.

${ }^{482}$ Cf. nota 333 supra.

${ }^{483}$ Cf. capítulo 2.2 supra.

${ }^{484}$ Cf. J. H. BAKER, An Introduction cit. (nota 12 supra), p. 250.

${ }^{485}$ Boa parte da literatura jurídica inglesa a respeito do tema sustenta a tese de que o substantivo use em sentido jurídico não encontraria raízes etimológicas no particípio passado do verbo depoente utor, uteris, uti, usus sum, cujo significado é usar, utilizar ou fazer uso de algo algo para algum propósito, nem do susbstantivo usus, us, que na sua acepção jurídica significa o direito de usar alguma coisa cujo domínio pertence a outrem, excluído o gozo dos frutos, cf. P. G. W. GLARE (coord.), OLD cit. (nota 13 supra), pp. 2119-2120 (no verbete "utor, -i, usus") e pp. 2111-2112 (no verbete "usus, -us"). Portanto, o verbo inglês to use não teria parentesco etimológico com o vocábulo use em sentido jurídico, na medida em que aquele provém do verbo latino citado acima, cf. J. A. SIMPSON e E. S. C. WEINER (coord.), OED 19 (1989), pp. 350-355 (no verbete “use”).

Acerca da origem do termo use em sentido jurídico, cf. T. F. T. PLUCKNETT, A Concise History cit. (nota 12 supra), pp. 575-576; F. POLLOCK e F. W. MAITLAND, The History of English Law cit., vol. II (nota 12 supra), pp. 228-229; J. H. BAKER, An Introduction cit. (nota 12 supra), p. 250, n. 8; S. F. C. MILSOM, Historical Foundations cit. (nota 12 supra), p. 200. 
cestui que use $e^{486}$. Grosso modo, e fazendo uma analogia com a possessio do direito romano, o use poderia ser equiparado a uma situação de fato, que somente ganhou reconhecimento e proteção jurídicos com o passar do tempo ${ }^{487}$. Foi a ação do Chancellor que deu efetividade legal ao instituto, convertendo o interesse do beneficiary num tipo novo de estate ${ }^{488}$.

Cabe destacar que o common law não reconhecia a validade do feoffment em favor do cestui que use nem reconhecia os direitos deste ${ }^{489}$, particularmente quando o use tivesse o condão de evitar que ocorresse algum incident, pois entendiam os tribunais reais que em tal caso havia um feoffment by collusion, ou seja, um feoffment celebrado com o único objetivo de privar o senhor feudal de sua renda de forma fraudulenta ${ }^{490}$.

No entanto, para evitar que os feoffees pudessem burlar, de mã-fé, ou mesmo interpretar erroneamente as disposições feitas pelo feoffor, a Court of Chancery passou a obrigar aqueles a cumprir as instruções que tinham sido dadas por este ${ }^{491}$. Caso não o

\footnotetext{
${ }^{486}$ A expressão cestui que use provém da frase que, traduzida, significa "aquele em favor de quem o uso foi feito" [=“cestui a que use le feoffment fuit fait"].

${ }^{487}$ Cf. T. F. T. PluCKNETT, A Concise History cit. (nota 12 supra), p. 579. O autor observa que os uses, incialmente, eram "a situation rather than an institution". Já de acordo com J. H. BAKER, An Introduction cit. (nota 12 supra), p. 250: "The trusting offeoffees with lands to be held in use was a fact of life long before it had any legal consequences".

${ }^{488}$ Os modos pelos quais o interesse do beneficiary era protegido eram vários: caso os feoffees falecessem,
} o vínculo de confiança transmitia-se ao herdeiro do último feoffee sobrevivente; se a terra fosse alienada a um terceiro, o comprador ficava sujeito ao mesmo vínculo de confiança, salvo quando a tivesse adquirido desconhecendo a existência do use; mesmo que o legal owner vendesse as terras sem declarar expressamente a existência de um use, considerava-se que este existia implicitamente e vinculava o vendedor, sendo o Chancellor competente para determinar a entrega compulsória do bem. Acerca do tema, cf. J. H. BAKER, An Introduction cit. (nota 12 supra), p. 251.

${ }^{489}$ Cf. S. F. C. Milsom, Historical Foundations cit. (nota 12 supra), p. 205 e P. H. PetTit, Equity cit. (nota 1 supra), p. 13.

${ }^{490}$ Cf. St. Edmunds v Anon. (1375), in J. H. BAKER e S. F. C. MiLsOM, Sources of English History cit. (nota 9 supra), p. 103: Thomas de St. Edmund, cavaleiro, ajuizou ação no Court of Common Pleas contra J., feoffee do seu tenant L. W., alegando que o use constituído entre estes últimos era fraudulento, pois seu único objetivo era privá-lo do seu direito de tutela (wardship) sobre o corpo de John, herdeiro de J., e suas terras, com o qual o juízo concordou, declarando o direito do autor à tutela do herdeiro de seu tenant e das suas terras.

Em Kyrkeby v Salle (1384), in J. H. BAKER e S. F. C. MILSOM, Sources of English History cit. (nota 9 supra), pp. 104-105, John Kyrkeby ajuizou ação no Court of Common Pleas contra John Salle, vicário de Horndon, e mais duas pessoas, requerendo a tutela (wardship) do manor de Nurnstead na qualidade de tutor (guardian) de John Mockyng, cujo pai era seu tenant by knight-service. Os réus alegaram que o tenant não tinha patrimônio ao falecer, pois transferira todos os seus bens aos feoffees. O autor alegou que o feoffment tinha sido feito dez dias antes da morte do tenant, durante o período da sua convalescência, e que suas instruções eram um ato de última vontade cujo intuito era beneficiar seus dois filhos e duas filhas, até que atingissem a maioridade, dessa forma lesando o direto do autor à tutela (wardship) mediante fraude. O juízo foi extinto em função da morte de um dos réus, porém já tinha sido rejeitado o argumento, apresentado pela defesa, de que a lei não estabelecia que o feoffment em questão era fraudulento.

${ }^{491}$ Cf. S. F. C. MiLsom, Historical Foundations cit. (nota 12 supra), pp. 212-216. Na hipótese levantada pelo autor, a origem mais remota da jurisdição do Chancellor em matéria de uses não se encontra na má-fé dos feoffees, e sim num problema de interpretação da vontade do feoffor. A dúvida surgiria, principalmente, nos casos em que este tivesse instituído um use em favor de alguém (normalmente seu herdeiro) e depois vendido o mesmo terreno objeto desse use a um terceiro. O Chancellor seria a pessoa mais indicada para resolver essa dúvida, em função da sua posição de autoridade. Seria por causa da natureza consultiva das primeiras intervenções do Chancellor em matéria de feoffment to uses que praticamente não existem registros de decisões 
fizessem, seriam condenados por crime de desobediência (contempt of court ${ }^{492}$ ) e presos até estarem dispostos a executar a vontade do feoffor ${ }^{493}$.

Com o objetivo de proteger o terceiro comprador de um estate das conseqüências indesejáveis da compra do terreno de um cestui que use (que não tinha título sobre o terreno), Ricardo III promulgou um statute que considerava válidas as alienações feitas por um cestui que use, mesmo que em detrimento dos seus feoffees ${ }^{494}$, dando assim impulso ao reconhecimento jurídico do interesse dos cestuis que use, que passou a ser paulatinamente elevado a um estate e, portanto, equiparável ao que, na tradição civilística, é considerado um direito real ${ }^{495}$.

suas de caráter jurisdicional emitidas pela Chancery antes da metade do século XV. Em sentido contrário, cf. R. Helmholz, Trusts in the English Ecclesiastical Courts 1300-1640, in R. Helmholz e R. ZimmermanN (org.), Itinera Fiduciae cit. (nota 1 supra), p. 157.

${ }^{492}$ Esse é o sentido dado à expressão em M. LUPOI, Trusts cit. (nota 1 supra), pp. 71-72.

${ }^{493}$ Cf. Prioress of Thetford v Wychyngham (c. 1426), in J. H. BAKER e S. F. C. MILSOM, Sources of English History cit. (nota 9 supra), pp. 105-106: A prioresa das freiras de Thetford moveu ação na Court of Chancery requerendo a expedição de um writ determinando o comparecimento de Thomas Empole perante o Chancellor, pois vinte e seis anos antes o réu tinha recebido de Nicholas Wychyngham, junto com outros já falecidos, o manor de Westhall no condado de Suffolk, com o encargo de transferi-lo às ditas freiras ou de vendê-lo em benefício das mesmas, o que não foi feito, tendo o réu usufruído do bem até a data da propositura. O Chancellor emitiu um writ, ordenando que o réu se apresentasse perante o King's Council até a data especificada, sob pena de multa de $£ 100$. Convém mencionar que a renda anual pelo uso da terra era de $£ 10$.

${ }^{494}$ Cf. Stat. 1 Ric. III (1483), c. 1: "Forafmuch as by privy and unknown Feoffments, great Unfurety, Trouble, Cofts, and grievous Vexations daily grow among the King's Subjects, infomuch that no Man that buyeth any Lands, Tenements, Rents, Services, or other Hereditaments, nor Women that have Jointures or Dowers in any Lands, Tenements, or other Hereditaments, nor Men's laft Wills to be performed, nor Leafes for Term of Life, or of Years, nor Annuities granted to any Perfon or Perfons for their Services for Term of their Lives or otherwife, be in perfect Surety, nor without great Trouble and Doubt of the Same, becaufe of the faid privy and unknown Feoffments: For Remedy whereof, be it ordained, eftablifhed, and enacted, by the Advice of the Lords Spiritual and Temporal, and by the Commons of this prefent Parliament affembled, and by the Authority of the fame, that every Eftate, Feoffment, Gift Releafe, Grant, Leafes and Confirmations of Land, Tenements, Rents, Services, or Hereditaments, made or had, or hereafter to be made or had by any Perfon or Perfons being of full Age, of whole Mind, at large, and not in dure/s, to any Perfon or Perfons; and all Recoveries and Executions had or made, Jhall be good and effectual to him to whom it is fo made, had or given, and to all other to his Ufe, againft the Seller, Feoffor, Donor, or Grantor thereof, and againft the Sellers, Feoffors, Donors, or Grantors, his and their Heirs, claiming the fame only as Heir or Heirs to the Same Sellers, Feoffors, Donors, or Grantors, and every of them, and againft all other having or claiming any Title or Intereft in the fame, only to the Ufe of the fame Seller, Feoffor, Donor, or Grantor, Sellers, Feoffors, Donors, or Grantors, or his or their faid Heirs at the Time of the Bargain, Sale, Covenant, Gift or Grant made; faving to every Perfon or Perfons fuch Right, Title, Action or Intereft, by reafon of any Gift in Tail thereof made, as they ought to have had, if this Act had not been made". Comentando esse dispositivo, F. W. Maitland, Equity cit. (nota 12 supra), p. 34 salienta que, ao mencionar as disposições de última vontade (“...nor men's laft Wills to be performed...”), o estatuto de fato passou a permitir que tanto o feoffee quanto o cestui que use pudessem criar direitos reais sobre a coisa (make an estate).

${ }^{495}$ A eficácia jurídica e a relevância histórica do Feoffments to Uses Act 1483 [=Stat. 1 Ric. III (1483), c. 1] na época da sua promulgação foram minimizadas por F. BACON, The Learned Reading of Sir Francis Bacon, One of Her Majefties Learned Coufell at Law, upon the Statute of Uses, London, Matthew Walbancke e Laurence Chapman, 1642, p. 20: "For though by the Statute of Richard 3 he might alter his Feoffees, yet that was not the scope of the Statute, but to make good his affurance to other perfons, and the other came in 'Et obliquo"'. Hoje, porém, admite-se que essa lei tenha sido um importante marco legal no processo histórico do reconhecimento da validade dos feoffments e do fortalecimento do status jurídico do beneficiary, situação que já 
A relevância do instituto fica clara já no início do século XVI: não seria um exagero afirmar que a maior parte das terras da Inglaterra estava sujeitas ao regime jurídico do $u^{4} e^{496}$.

\subsection{A transformação dos uses em trusts: Statute of Uses 1536}

A flexibilidade dos uses trouxe, no entanto, dois grandes problemas. De um lado, a informalidade do ato de disposição gerava insegurança jurídica, pois o mesmo podia ser inclusive verbal e carecer de livery of $\operatorname{seisin}^{497}$, o qual dotava o ato da devida publicidade, já que na Inglaterra medieval a regra, desde o século XIII, era a da livre alienação inter vivos de terras, no sentido de que a validade da alienação não dependia do consentimento de eventual herdeiro do tenant (que poderia sentir-se lesado) nem do senhor feudal (que desde 1290 não mais interferia nessas transações $)^{498}$.

De outro, a evasão dos incidents feudais, principalente aqueles ligados à sucessão, privava os senhores feudais das rendas deles decorrentes (que pouco tempo após a ocupação normanda passaram a superar em importância os services feudais devidos pelos seus tenants $)^{499}$, pois a pluralidade de feoffees evitava a transmissão causa mortis, na medida em que o direito do falecido acrescia ao dos demais ${ }^{500}$.

Essa última característica tornou os uses imensamente populares como meio de contornar os ônus feudais sobre as terras, porém diminuiu, na mesma proporção em que se alastravam pelo país, as rendas dos senhores feudais ${ }^{501}$.

se verificava na prática, cf. H. G. HANBURY, The Legislation of Richard III, in AJLH 95 (1962), pp. 98-101 e J. H. BAKER, An Introduction cit. (nota 12 supra), pp. 251-252.

${ }^{496}$ Cf. J. H. BAKER, An Introduction cit. (nota 12 supra), p. 251. Deve-se lembrar que qualaquer espécie de tenure, em princípio, podia estar sujeita a um use, pois esta era uma categoria de superposição às demais, na medida em que qualquer estate podia ser alienado dessa forma, cf. K. GRAY e S. F. GRAY, Elements of Land Law cit. (nota 1 supra), p. 69: "It came to be recognised that each estate could itself be the subject of ownership both at law and in equity".

${ }^{497}$ Cf. nota 180 supra.

${ }^{498}$ Cf. W. S. Holdsworth, A History of English Law cit., vol. III (nota 12 supra), pp. 73-78. Para esse autor, um dos principais fatores que levaram à gradual eliminação das limitações a essa liberdade de alienação inter vivos foi a influência da noção de dominium romana, de caráter absoluto. No entanto, não apresenta qualquer prova a respeito dessa afirmação.

${ }^{499}$ Cf. nota 130 supra.

${ }^{500}$ Cf. S. F. C. MILSOM, Historical Foundations cit. (nota 12 supra), pp. 210-211. Cabe destacar que, além desses problemas, também era comum estabelecer uses com o objetivo de praticar fraude contra credores.

${ }^{501}$ Além de evitar os incidents e permitir a sucessão testamentária de bens imóveis (o que era impossível pelo common law), a flexibilidade dos uses, cuja celebração dispensava a utilização das formas técnicas do common law, ofereciam outras vantagens ao cestui que use em relação à administração do seu patrimônio. Assim, por exemplo, podia-se realizar o loteamento parcial de um terreno para pagar as dívidas do de cujus, o que não era admitido pelo common law. Sobre esses benefícios, cf. T. F. T. PluCKNETT, A Concise History cit. (nota 12 supra), p. 582. 
Henrique VII foi o primeiro monarca a fazer um esforço considerável para solucionar esse problema ${ }^{502}$. Assim, da mesma forma que o statute promulgado por Ricardo III $^{503}$ tinha declarado válidas as transferências (conveyances) feitas pelo beneficiary, os statutes de Henrique VII sujeitaram-no aos mesmos ônus fiscais do nominal owner em matéria de sucessão legítima ${ }^{504}$.

Porém, coube a Henrique VIII promulgar um dos statutes mais conhecidos a respeito do tema, o Statute of Uses $1536^{505}$. Sua promulgação corporifica o ápice do chamado "feudalismo fiscal", termo utilizado para referir-se às medidas adotadas por Henrique VIII para restabelecer o sistema de incidents feudais com o objetivo de abastecer os cofres da coroa $^{506}$.

Os motivos que levaram o monarca a impor uma legislação tão onerosa põem em evidência a estrutura da propriedade feudal: o monarca, por não estar sujeito a qualquer outro senhor, não tinha como compensar as perdas provocadas pela evasão aos incidents, o que não ocorria com os demais nobres, que, embora não recebessem as rendas dos incidents dos seus tenants, também não pagavam incidents ao rei nem a eventuais mesne lords, pois eles também mantinham as suas terras in $u s e^{507}$.

O Statute of Uses 1536 aboliu a possibilidade de transmitir estates sobre bens imóveis por testamento ${ }^{508}$ (o que, até então, se fazia por meio de uma cláusula testamentária

502 Trata-se, evidentemente, da sucessão legítima, pois o common law não reconhecia a sucessão testamentária em matéria de bens imóveis nessa época.

${ }_{503}$ Cf. Stat. 1 Ric. III (1483), c. 1.

${ }^{504}$ Cf. Stat. 4 Hen. VII (1488), c. 17: “The Heir or 'Cestui que use' holding his Lands by Knight's Service within Age, Jhall be in Ward, and of full Age, Jhall pay Relief (...)" e Stat. 19 Hen. VII (1503), c. 15, II: "And over that, be it ordained by the faid Authority, That the Lords of whom any fuch Lands or Tenements be holden in Socage, Jhall from henceforth after the Death of him to whofe Ufe any Perfon or Perfons, as is afore faid, be feifed (and no Will thereof declared) have his Relief, Heriot, and all other Duties, like as the faid Lord ought or might have had, if he had died feifed of the fame".

${ }^{505}$ Cf. Stat. 27 Hen. VIII (1536), c. 10.

506 Cf. J. H. BAKER, An Introduction cit. (nota 12 supra), p. 254. Na época havia duas linhas de entendimento em relação ao instituto: a primeira entendia que os uses eram regulados pelo common law, e que portanto qualquer testamento que mencionasse um use seria inválido, dado que os testamentos de terras não eram permitidos at common law; a outra considerava a divisão entre a propriedade legal (legal ownership) e a beneficiária (beneficial ownership) uma fraude por natureza, e que a tolerância em larga escala dessa fraude pelos Chancellors teria enfraquecido a autoridade do common law. Ambos argumentos foram a base da legislação dessa época destinada a eliminar os uses.

${ }^{507}$ Cf. S. F. C. MiLSOM, Historical Foundations cit. (nota 12 supra), p. 219.

${ }^{508}$ Cf. J. H. BAKER, An Introduction cit. (nota 12 supra), p. 255. 
que transferia o use, e não a terra em si, ao sucessor ${ }^{509}$ ) e, conseqüentemente, eliminou a disposição diferida de terras ${ }^{510}$.

O mecanismo utilizado para conseguir esse resultado foi uma ficção denominada "executing the use", pela qual toda vez que alguém tivesse em seu poder terras em favor (“...to the use, trust or confidence...”) de outrem, considerar-se-ia que este, o beneficiary, passara a ocupar a posição jurídica do feoffee (“...shall from henceforth stand and be seised, deemed and adjudged in lawful seisined estate and possession of..."), efetivamente executando o use $^{511}$.

Em outras palavras, o statute efetuava, por meio de uma ficção jurídica pela qual se considerava consumado o livery of seisin, a conversão, para todos os fins de direito (“...to all intents, constructions and purposes in the law...") do beneficial owner em nominal owner $^{512}$, abolindo, dentro do âmbito da sua incidência, a distinção feudal entre legal ownership e beneficial enjoyment ${ }^{513}$.

${ }^{509}$ Cf. T. F. T. PluCKNETT, A Concise History cit. (nota 12 supra), p. 582.

${ }^{510} \mathrm{O}$ termo técnico em inglês é devise, que significa "ato de disposição, geralmente de bens imóveis, feito mediante testamento", cf. D. M. WALKER, The Oxford Companion cit. (nota 8 supra), p. 355 (no verbete "devise").

${ }^{511}$ Cf. Stat. 27 Hen. VIII (1536), c. 10, s. 1: “(...) That where any Perfon or Perfons ftand or be feized, or at any Time hereafter fhall happen to be feized, of and in any Honours Caftels Manors Lands Tenements Rents Services Reverfions Remainders or other Hereditaments, to the Ufe Confidence or Truft of any other Perfon or Perfons or of any Body Politick, by reafon of any Bargain Sale Feoffment Fine Recovery Covenant Contact Agreement Will or otherwife by any manner Means whatfoever it be; that in every fuch Cafe all and every fuch Perfon and Perfons, and Bodies Polytick, that have or hereafter fhall have any fuch Ufe Confidence or Truft in Fee-fimple Fee-tail for Term of Life or for Years, or otherwife, or any Ufe Confidence or Truft in Remainder or Reverter, Jhall from henceforth ftand and be feized deemed and adjudged in lawful Seifin Eftate and Poffeffion of and in the fame Honours Caftles Manors Lands Tenements Rents Services Reverfions Remainders and Hereditaments, with their Appurtenances, to all Intents Conftructions and Purpofes in the Law of and in fuch like Eftates as they had or Jhall have in Ufe Truft or Confidence of or in the fame; and that the Eftate Title Right and Poffeffion that was in fuch Perfon or Perfons that were, or hereafter fhall be feized of any Lands Tenements or Hereditaments, to the Ufe Confidence or Truft of any fuch Perfon or Perfons, or of any Body Politick, be from henceforth clearly deemed and adjudged to be in him or them that have, or hereafter fhall have, fuch Ufe Confidence or Truft, after fuch Quality Manner Form and Condition as they had before, in or to the Ufe Confidence or Truft that was in them".

${ }^{512}$ Cf. J. H. BAKER, An Introduction cit. (nota 12 supra), p. 256. Em termos estritamente jurídicos, a doutrina inglesa teve uma opinião muito positiva do Statute of Uses 1536 [=Stat. 27 Hen. VIII (1536), c. 10], chegando a considerar que fosse uma obra prima de redação jurídica, como foi o caso de F. BACON, The Learned Reading cit. (nota 495 supra), p. 25: "This Statute (as it is the Statute which of all other hath the greateft power and operation over the Heritages of the Realme, fo howfoever it hath beene by the humour of the time perverted in expofition, yet in it felfe is moft perfectly and exactly conceived and penned of any Law in the Booke (...)" $\mathrm{e}$ de T. F. T. PluCKNETT, A Concise History cit. (nota 12 supra), pp. 588-589.

Contudo, ele não foi bem recebido pela população e foi um dos fatores que levou a uma crise política e social - no mesmo ano em que foi promulgado o Statute of Uses 1536 [=Stat. 27 Hen. VIII (1536), c. 10] ocorreu a "Peregrinação da Graça", uma marcha até Londres realizada por milhares de pessoas em protesto contra várias medidas econômicas, jurídicas e religiosas adotadas por Henrique VIII - que provocou duras críticas contra o statute, que chegou a ser considerado "a pior lei jamais promulgada" ("the worst act ever made") pelo Duque de Norfolk, o que de certa forma bem resumia a opinião pública desse statute na época em que foi promulgado, cf. E. HERBERT OF CHERBURY, The Life and Reigne of King Henry the Eighth, London, Thomas Whitaker, 1649, p. 564. Sobre a "Peregrinação da Graça", cf. M. H. DodDS e R. DodDS, The 
Contudo, em razão do grande descontentamento causado pelo statute entre os tenants, muitos dos quais eram senhores feudais ou terratenentes proeminentes, Henrique VIII teve que ceder, promulgando o Statute of Wills $1540^{514}$, que pela primeira vez permitiu a livre disposição de terras (e não mais apenas de uses) por testamento ${ }^{515}$. Eventualmente, o feudalismo fiscal instaurado por Henrique VIII deixou de existir ${ }^{516}$, mas não sem antes deixar a sua marca no desenvolvimento dos trusts.

Mesmo com todo o esforço feito por Henrique VIII para coibir os uses, várias situações jurídicas não eram abrangidas pela legislação ${ }^{517}$. Isso acontecia, em larga medida, porque o Statute of Uses 1536, apesar de ter convertido os uses sobre freehold land em legal estates, não chegou a abolir os deveres de natureza moral $\left(\right.$ conscience $\left.^{518}\right)$ nem erradicar os

Pilgrimage of Grace 1536-1537 and The Exeter Conspiracy, vol. I, Cambridge, Cambridge University, 1915, pp. $1-388$.

${ }^{513}$ Cf. T. F. T. PluCKNETT, A Concise History cit. (nota 12 supra), p. 588.

${ }^{514}$ Cf. Stat. 32 Hen. VIII (1540), c. 1, s. 1: “(...) That all and every Perfon and Perfons having or which hereafter Shall have any Manors Lands Tenements or Hereditaments holden in Soccage, or of the Nature of Soccage Tenure and not having any Manors Lands Tenements or Hereditaments holden of the King our Sovereign Lord by Knights Service by Soccage Tenure in chief or of the Nature of Soccage Tenure in chief nor of any other Perfon or Perfons by Knights Service, from the twentieth day of July in the Year of our Lord God M.D.X.L. Shall have full and free Liberty Power and Authority to give difpofe will and devife as well by his laft Will and Teftament in Writing or otherwife by any Act or Acts lawfully executed in his Life all his faid Manors Lands Tenements or Hereditaments or any of them at his free Will and Pleafure; any Law Statute or other Thing heretofore had made or ufed to the contrary notwithftanding". Ficavam excetuados os terrenos sujeitos ao knight's service, que deviam reservar pelo menos um terço do valor do imóvel para o sucessor legítimo, cf. Stat. 32 Hen. VIII (1540), c. 1, s. 2.

515 Cabe mencionar que em algumas localidades (boroughs) o common law já reconhecia o direito de sucessão testamentária de bens imóveis, de acordo com o costume local, cf. T. F. T. PLUCKNETT, A Concise History cit. (nota 12 supra), p. 564.

${ }^{516} \mathrm{O}$ principal instrumento legal que pôs fim ao feudalismo fiscal foi o Tenures Abolition Act 1660 [=Stat. 12 Char. II (1660), c 24, ss. 2-3]: "And that the same shall for ever hereafter stand and be discharged of all Tenure by Homage Escuage Voyages Royall and charges for the same Wardships incident to Tenure by Knights service and values and forfeitures of marriage and all other charges incident to tenure by Knights service And of and from Aide pur file marrier \& Aide pur faier fitz Chivalier Any Law Statute Custome or Usage to the contrary in any wise notwithstanding. And that all conveyances and devises of any Mannours Lands Tenements and Hereditaments made since the said twentyfourth of February shall be expounded to be of such effect as if the same Mannours Lands Tenements and Hereditaments had beene then held and continued to be holden in free and common Soccage onely Any LawStatute Custome or usage to the contrary hereof any wise notwithstanding. And bee it further Ordained and Enacted by Authority of this present Parliament that one Act made in the raigne of King Henry the Eight intituled An Act for the establishment of the Court of the Kings Wards, And alsoe one Act of Parliament made in the three and thirtyeth yeare of the Raigne of the said King Henry the Eighth concerning the Officers of the Court of Wards and Liveries and every Clause Article and matter in the said Acts contained shall from henceforth be repealed and utterly void".

${ }^{517}$ De acordo com a doutrina e os tribunais ingleses, as seguintes situações jurídicas não eram abrangidas nem "executadas" pelo statute: (i) active uses, que estabeleciam deveres em concreto para o feoffee, tais como realizar cobranças, pagamentos, administração dos bens etc.; (ii) uses estabelecidos sobre quaisquer bens que não fossem freehold land, tais como leases (os quais a doutrina e os tribunais sempre consideraram chattels para fins de direito, sendo que tecnicamente o lessee não era sujeito de qualquer obrigação perante o beneficiário de um use), copyholds (terrenos que concedidos pelo senhor feudal a villeins para cultivo e acerca dos quais os tribunais manoriais mantinham um registro) e personal property de modo geral; (iii) uses upon uses, os quais serão vistos infra, cf. S. F. C. MILSOM, Historical Foundations cit. (nota 12 supra), pp. 233-239.

${ }^{518}$ Originariamente, o termo conscience estava ligado ao pensamento teológico medieval, de acordo com o qual a faculdade de raciocinar moralmente ligava-se ao termo synderesis, enquanto a capacidade de aplicar essa 
direitos reais baseados na equity (equitable interests) nos casos em que a letra da lei não incidia $^{519}$.

Convém mencionar que, além das motivações de natureza fiscal, a legislação da época em matéria de uses teve também a finalidade de resolver outros problemas. Conforme já foi visto, a falta de publicidade das transações envolvendo uses representava uma séria dificuldade no século XVII, e um statute do mesmo período ${ }^{520}$ exigiu que todas as compras e vendas de terrenos deviam ser registradas por escrito nos tribunais reais ou nos condados ${ }^{521}$.

O Statute of Uses 1536 foi um dos atos legislativos de maior impacto no desenvolvimento dos trusts por dois motivos. De um lado, as provisões desse statute, junto com as do Statute of Wills 1540, introduziram um grau de flexibilidade no direito de propriedade inglês que até então só podia ser atingido mediante a constituição de um use, dessa forma favorecendo, nesse âmbito, o distanciamento conceitual do common law das suas

faculdade a casos concretos denominava-se conscience, cf. M. MACNAIR, Equity and Conscience, in OJLS 27 (2007), pp. 661-662. Já em sentido jurídico, conscience significa "regra moral que exige o tratamento justo e honesto entre as pessoas", cf. B. A. GARNER (coord.), Black's cit. (nota 13 supra), p. 276 (no verbete "conscience") e "a faculdade ou capacidade mental que julga a qualidade moral da conduta ou da motivação própria ou de outrem, de modo a condená-la por ser errada ou aprová-la por ser boa”, cf. D. M. WALKER, The Oxford Companion cit. (nota 8 supra), p. 272 (no verbete "conscience"). Conforme já foi visto, o fundamento da autoridade jurisdicional do Chancellor era o fato de ele ser o Keeper of the King's Conscience, assunto obviamente não abrangido pelo Statute of Uses 1536 [=Stat. 27 Hen. VIII (1536), c. 10].

${ }^{519}$ Cf. J. H. BAKER, An Introduction cit. (nota 12 supra), p. 290.

${ }^{520}$ Cf. Statute of Enrolments 1536 [=Stat. 27 Hen. VIII (1536), c. 16]: “(...) no Manors Lands Tenements or other Hereditaments Jhall paff alter or change from one to another, whereby any Eftate of Inheritance of Freehold Shall be made or take Effect in any Perfon or Perfsons, or any Ufe thereof to be made, by reafon only of any Bargain and Sale thereof, except the fame Bargain and Sale be made by Writing indented fealed and inrolled in one of the King's Courts of Record at Weftminfter; or elfe within the fame County or Counties where the fame Manors Lands or Tenements fo bargained and fold lie or be, before the Cuftos Rotulorum and two Juftices of the Peace and the Clerk of the Peace of the fame County or Counties, or two of them at the leaft, whereof the Clerk of the Peace to be one; and the fame Inrollement to be had and made within fix Months next after the Date of the fame Writings indented (...)".

${ }^{521}$ A execução automática dos uses efetuada pelo Statute of Uses 1536 [=Stat. 27 Hen. VIII (1536), c. 10] teria, de fato, piorado o problema já existente em relação ao contrato de compra e venda de terrenos (bargain and sale of land). Alguns anos antes da promulgação do referido statute, a doutrina já tinha estabelecido que, toda vez que fosse celebrado um contrato de compra e venda, estabelecia-se um use em favor do comprador até que ocorresse a tradição (livery of seisin), cf. C. SAINT GERMAIN, Dialogues Between a Doctor of Divinity and a Student in the Laws of England, 1518, rev. e corr. por W. MuCHALL, The Doctor and Student, Cincinnati, Robert Clarke \& Co., 1874, Diálogo II, c. 22, pp. 168-169. Como o referido statute executava imediatamente o use, o comprador adquiriria o terreno com a conclusão do contrato, independentemtente de ter ocorrido ou não a tradição, o que equivaleria a uma compra e venda real. Para evitar os evidentes transtornos que essa situação geraria, o Statute of Enrolments 1536 foi promulgado junto com o Statute of Uses 1536. Mesmo assim, várias situações não foram abrangidas pelo primeiro (tais como as doações vinculadas ao casamento - family settlements - e a constituição e transferência de estates not of freehold), gerando novas formas de tradição ficta (conveyance) que, eventualmente, culminaram no reconhecimento da livre alienação de direitos sobre bens imóveis mediante a entrega de documentos [=Stat. 4 \& 5 Vic. (1841), c. 21 e Stat. 8 \& 9 Vic. (1845), c. 106], cf. S. F. C. MILSOM, Historical Foundations cit. (nota 12 supra), pp. 223-225. 
raízes feudais. De outro, as situações jurídicas não abrangidas pelo statute providenciaram uma primeira plataforma a partir da qual os trusts se desenvolveram ${ }^{522}$.

Nesse sentido, a mais relevante das situações sobre as quais a legislação relativa aos uses não incidia era aquela em que se criava um use upon a use $e^{523}$. Por meio desse mecanismo, um bem ou patrimônio ficava a cargo de alguém em benefício de outrem (ou de si mesmo), quem por sua vez ficava a cargo do mesmo bem ou patrimônio em benefício de outra pessoa. Mediante essa manobra legal evitava-se a incidência do Statute of Uses 1536 sobre o segundo use (denominado trust para diferenciá-lo do primeiro), que passou a ser reconhecido e tutelado pela Court of Chancery ${ }^{524}$.

Foi assim que o Chancellor, mediante o exercício das suas prerrogativas jurisdicionais no âmbito da equity, interveio para evitar os abusos cometidos pelo proprietário. Configurou-se, dessa forma, o que muitos consideram ser a estrutura dualista típica do trust, pela qual o direito real do trustee deriva do common law, enquanto o direito real do beneficiary deriva da equity ${ }^{525}$.

A partir do final do século XVI houve uma considerável expansão dos objetivos perseguidos pelos trusts, nos moldes apontados acima. O reconhecimento pelo common law

${ }^{522}$ Cf. G. MofFAT, Trusts Law cit. (nota 1 supra), p. 42.

${ }^{523}$ Para criar um use upon a use (também chamado "double use") era comum a utilização de uma cláusula com a seguinte fórmula: "to A and his heirs unto and to the use of B (or A) and his heirs in trust nevertheless for $C$ " (Para "A" e seus herdeiros em benefício de "B" (ou "A") e os seus herdeiros; em confiança, no entanto, para "C”), cf. J. H. BAKER, An Introduction cit. (nota 12 supra), p. 291.

${ }^{524} \mathrm{O}$ case law relativo ao reconhecimento do segundo use, e portanto do trust moderno, é um tanto tortuoso. Em Tyrrel's Case (1557), in A. W. SCOTT, Select Cases cit. (nota 9 supra), p. 10, ao julgar o caso de uma viúva que concedia seus bens imóveis em benefício do seu filho, que por sua vez os recebia em benefício da sua mãe, a Court of Wards and Liveries - tribunal especializado criado por Henrique VIII para cuidar de assuntos fiscais, mediante Stat. 32 Hen. VIII (1540), c. 46 e Stat. 33 Hen. VIII (1541), c. 22 - estabeleceu que, no caso de dois uses sucessivos, o primeiro era abrangido pelo Statute of Uses 1536 [=Stat. 27 Hen. VIII (1536), c. 10], enquanto o segundo era nulo, impedindo que a mãe fosse beneficiária (beneficiary) do seu próprio filho.

No entanto, já em Bartie v Herenden (1560), in J. H. BAKER e S. F. C. MILSOM, Sources of English History cit. (nota 9 supra), pp. 142-144, o segundo use é reconhecido, apesar de ter sido secreto e suas disposições contrárias às cláusulas expressas no primeiro use. O caso, de fato, não deixa de apresentar um viés politico: tratava-se de Katharine Bartie, Duquesa de Willoughby d'Eresby, que em 1555 teve que fugir da Inglaterra e se instalar temporariamente no Continente para evitar ser vítima de perseguição religiosa, pois a rainha católica Maria I (apelidada Bloody Mary em razão das suas célebres Perseguições Marianas contra os protestantes) mandara confiscar seus bens. Prevendo essa situação, em 1554 a Duquesa tinha feito um use em favor de um advogado, Walter Herenden, tornando-o o beneficiário ostensivo do patrimônio em questão. À par desse use "ostensivo", foi celebrado um segundo use em segredo, segundo o qual Herenden administraria todo o patrimônio em benefício da Duquesa, comprometendo-se a devolvê-lo caso a mesma retornasse à Inglaterra. Isto efetivamente ocorreu, porém Herenden não cumpriu o disposto no segundo use, motivo pelo qual foi movido o pleito. Em 1559, o Privy Council expediu mandado impedindo que Herenden recebesse as rendas do patrimônio em questão. Em 1560, a Court of Chancery julgou válido e mandou executar o segundo use em detrimento do primeiro, devolvendo os bens à Duquesa. O caso é considerado por J. H. BAKER, An Introduction cit. (nota 12 supra), p. 291, como o primeiro a reconhecer o trust no sentido mais moderno da palavra.

${ }_{525}$ Cf. M. C. MALAGUTI, Il trust cit. (nota 1 supra), p. 186. 
da sucessão testamentária em matéria de bens imóveis ${ }^{526}$, bem como a obsolescência do sistema feudal dos incidents ${ }^{527}$, eliminaram a principal razão de ser dos uses até então. Nessa fase mais recente do seu desenvolvimento, um dos principais atrativos dos trusts passou a ser sua capacidade de evitar as regras que impeçam ou limitem a perpetuação do patrimônio familiar ao longo de gerações sucessivas ${ }^{528}$.

Cabe observar que o desenvolvimento histórico dos uses e dos trusts demonstra que a suposição mais básica de uma parte não pequena da literatura comparatística, no sentido de que o direito inglês é o resultado quase exclusivo da atividade dos juízes, deve ser considerada com a devida parcimônia. Os uses (e posteriormente os trusts) foram moldados, em momentos decisivos da sua formação como institutos jurídicos, por normas resultantes da atividade legislativa.

${ }^{526}$ Cf. Stat. 32 Hen. VIII (1540), c. 1.

527 Apesar de inicialmente ter sido bem-sucedida, a campanha empreendida por Henrique VIII para captar rendas feudais para os cofres da Coroa não se sustentou por muito tempo, na medida em que outras formas mais racionais de tributação e captação de recursos para o Estado foram se estabelecendo, cf. J. H. BAKER, An Introduction cit. (nota 12 supra), p. 257. Conforme já visto, o feudalismo fiscal foi abolido oficialmente pelo Stat. 12. Char. II (1660), c. 24, que pôs fim à tenure by knight's service.

${ }^{528}$ Os mecanismos jurídicos criados por meio desse tipo de trust entram na categoria family settlement, que comporta uma série de cláusulas contingentes relativas ao direito das sucessões. Assim, no caso dos contingent remainders (cláusulas que instituem como herdeiro pessoa ainda não nascida ou indeterminada), os trusts serviam para impedir que a ausência da posse contínua (seisin) prejudicasse a linha sucessória. Também instituía-se um trust para impedir os efeitos do dower (instituto pelo qual um terço das terras do marido automáticamene passavam a pertencer à mulher a partir do casamento), já que os uses tinham cumprido essa mesma função até o advento do Statute of Uses 1536 [=Stat. 27 Hen. VIII (1536), c. 10], bem como para evitar a operação da regra estabelecida em Wolfe v Shelley (1581), in J. H. BAKER e S. F. C. MILSOM, Sources of English History cit. (nota 9 supra), pp. 163-169, pela qual o herdeiro por substituição (remainderman) tornava-se o proprietário absoluto do estate, podendo aliená-lo sem restrições. Sobre as diversas funções desempenhadas pelos trusts após a entrada em vigor do Statute of Uses 1536, cf. J. H. BAKER, An Introduction cit. (nota 12 supra), pp. 290-293. Acerca dos contingent remainders e o dower, cf. T. F. T. PLUCKNETT, A Concise History cit. (nota 12 supra), pp. 562-564; 590-592 (contingent remainders) e 566-568 (dower). 


\section{CONCLUSÃO}

A estrutura e peculiar terminologia dos direitos reais de matriz inglesa são o resultado da forte vinculação formal do sistema do common law com as suas raízes feudais. A manutenção de uma lógica e um vocabulário próprios, em muitos aspectos alheios à estrutura dos direitos reais construída pela civilística continental, tem dificultado o diálogo entre os sistemas baseados no direito inglês e aqueles de base romanística.

O principal fator que determinou a particular formação histórica da real property law inglesa foi a implantação, a partir da segunda metade do século XI, de um modelo feudal de concessão de terras de marcada natureza contratual, desenvolvido e articulado por uma jurisdição real pautada, até o século XIX, pelo sistema processual das forms of action. As características originárias desse sistema de concessão fundiária impõem certas premissas lógicas e uma terminologia técnico-jurídica que moldam toda estrutura da real property law inglesa.

Assim, até os dias de hoje, adota-se como critério interpretativo lógico-formal o princípio da inexistência de terras alodiais fora do dominium absolutum da Coroa, o que exclui a possibilidade de declarar, formalmente, a existência de um âmbito de domínio absoluto individual, nos moldes do direito de propriedade de matriz civilística. A essa premissa liga-se a terminologia técnica caracterizadora do common law, pela qual ninguém pode ser proprietário em sentido absoluto ("dominus" = "owner") de uma coisa, mas apenas "ter" ("tenere de" = "hold of") algo de alguém.

Essa terminologia, propriamente feudal, baseia-se na doctrine of tenures, que estabelece não a possibilidade de controle absoluto sobre um bem, mas a titularidade de um ius sobre ele, o qual pode ser mais ou menos amplo em função dos termos da concessão que lhe deu origem. O grau máximo de controle que o titular de um direito real pode atingir, portanto, fica sempre formalmente subordinado à estrutura dependente e derivativa das tenures.

À par da rejeição de uma concepção absoluta de domínio fora da esfera real, no entanto, a real property law se fundou num sistema que permite, desde as suas origens, um desmembramento sui generis da titularidade de direitos reais entre vários sujeitos, dando 
lugar a um conjunto de situações jurídicas que, embora submetidas à natureza dependente das tenures, atribuem ao titular um ius in rem que o torna, na exata medida e extensão desse ius, uma espécie de "proprietário".

A principal expressão dessa multiplicidade de títulos sobre o mesmo bem encontra-se na antiga distinção entre as terras tidas in dominico e in servitio, que permitia a vários sujeitos constituírem uma pluralidade de direitos reais sobre o mesmo bem imóvel. Pode-se dizer que foi graças a essa característica das tenures que o common law encontrou solo fértil para eventualmente criar um regime jurídico de concessão equiparável, se não formalmente, pelo menos substancialmente, ao dominium de origem romana. Essa figura é, hoje, o estate in fee simple absolute in possession.

Dada a multiplicidade de iura possíveis sobre o mesmo bem, o modelo feudal de concessão de terras sempre favoreceu uma construção fundada na relatividade dos títulos. No período formativo do common law, a legitimidade de um sujeito para reclamar o exercício da tutela jurisdicional real em seu favor se dava em função da sua investidura na concessão feudal (seisina ut de feodo) sobre o bem em questão, e as várias categorias de direitos sobre as terras foram classificados em função dessa investidura. A relevância do binômio ownershippossession, considerado um dos traços característicos da real property law inglesa, manifestase, mesmo nos dias de hoje, na ampla proteção que o common law confere ao possuidor sem título.

A fundamental importância atribuída à seisin no âmbito dos tribunais do common law excluiu, durante séculos, as categorias de concessão de terras desprovidas de seisin, sendo o copyhold [=villenagium] um dos casos mais notáveis. Historicamente, no entanto, a jurisdição real mostrou-se capaz de intervir nos momentos decisivos em favor do concessionário, elevando, mediante o reconhecimento da titularidade de um direito real, o copyhold à categoria de um estate.

Se do ponto de vista estrutural a real property law inglesa se baseia na doutrina das tenures, desde uma perspectiva temporal o elemento determinante é a doctrine of estates. A origem contratual dos direitos reais sobre bens imóveis resultou na derivação e tipificação das categorias jurídicas a partir das diversas cláusulas às quais se subordinava cada concessão. Tais cláusulas destinavam-se, principalmente, a regular a extensão temporal do direito ao gozo (enjoyment) do imóvel. Daí que o direito inglês não classifique seus estates em função do substrato material da concessão, mas em função de fatores como a temporalidade, hereditariedade e alienabilidade do direito real em questão. 
Uma análise dos estates of freehold estudados, isto é, da concessão hereditária perpétua [=estate in fee simple ou feodum simplex], da concessão hereditária condicional inalienável [=estate in fee tail ou feodum talliatum] e da concessão vitalícia [=life estate], demonstra claramente a influência predominante do fator temporal na delimitação, articulada pela doctrine of waste, dos direitos do concessionário.

Além de influir de modo determinante na formação das suas categorias conceituais e na incorporação de uma terminologia tipicamente medieval, a estruturação da real property law inglesa a partir de concessões feudais reguladas por meio de um sistema judicial centralizado conferiu um alto grau de plasticidade e adaptabilidade aos direitos reais de matriz inglesa. Nesse sentido, os tribunais reais cumprem um papel fundamental, ajustando e moldando, ao longo do tempo, as relações entre pessoas e coisas.

Contudo, não é apenas à atividade dos tribunais reais que se deve a formação da real property law. A atividade legislativa freqüentemente esteve, com diversos graus de intensidade, presente nos momentos críticos. A respeito desse fenômeno, chamam a atenção dois aspectos.

Em primeiro lugar, percebe-se que os motivos históricos, muitas vezes de natureza fiscal, que levaram à promulgação dos principais statutes a respeito da matéria tornaram-se irrelevantes com o passar do tempo. Mesmo assim, esses diplomas independentemente de se encontrarem ainda em vigor ou não - fazem parte do continuum histórico ininterrupto no qual se baseia o arcabouço conceitual da real property law. Estudálos e entendê-los ainda é uma das chaves para a compreensão da terminologia e dos conceitos fundamentais relativos aos direitos reais no sistema do common law.

Em segundo lugar, nota-se a resiliência de certas normas que preservam, justamente, o que resta da estrutura que deu origem à real property law. É o caso, notadamente, do Statutum Quia Emptores Terrarum 1290, que continua vigente e ainda rende tributo a uma estrutura e terminologia medievais. Nesse sentido, a permanência de normas dessa natureza ao lado de outras mais recentes destinadas à racionalização dos direitos reais tais como as que aboliram as forms of action, o Tenures Abolition Act 1660 e o Law of Property Act 1925 - configura um dos desafios que o direito comparado deve enfrentar ao buscar uma aproximação entre o sistema do common law e os direitos de base romanística.

A transformação dos uses em trusts constitui um fenômeno de elevação de uma situação de fato à categoria de um direito real reconhecido juridicamente. Essa evolução 
expõe a maleabilidade da real property law inglesa e sua predisposição para adaptar e reinterpretar as normas estatutárias, freqüentemente transpondo o escopo originário da legislação. Nesse sentido, pode-se perceber, mais uma vez, a simbiose entre a statutory law e a case law. O direito legislado, dentro do seu escopo de incidência, provoca mudanças pontuais e muitas vezes imediatas. A jurisprudência inglesa, por sua vez, molda e transforma os institutos ao longo do tempo.

Desde uma perspectiva comparatística, um dos benefícios que se podem extrair de um estudo desta natureza é o destaque que ganham certos elementos dos direitos reais - e mesmo da propriedade em sentido absoluto - que muitas vezes passam despercebidos. $\mathrm{O}$ direito inglês, ao rejeitar um conceito abstrato e absoluto de propriedade, põe em evidência os elementos que compõem a própria absoluticidade da propriedade de base romanística.

Assim, o estate in fee simple absolute in possession é o resultado de uma evolução histórica que, justamente por ocorrer num contexto em que prevalecem os direitos reais condicionados (basta comparar o estate in fee simple com o estate in fee tail e o life estate), permite vislumbrar com maior clareza as características de um direito absoluto sobre uma res. As faculdades que, nos sistemas de base romanística, compõem o próprio conceito de propriedade - usar, fruir, dispor, perseguir etc. -, no direito inglês somente existiram, durante o período formativo da real property law, de modo incidental. Daí que a própria denominação do regime jurídico que mais se aproxima da propriedade de matriz civilística carregue as marcas dos obstáculos à concentração da plena disponibilidade econômica e jurídica de bem num único sujeito.

Nesse sentido, a pesquisa histórica baseada no estudo das fontes do common law oferece uma valiosa oportunidade para melhor identificar os entraves para um eventual diálogo entre sistemas. Futuros esforços comparatísticos no campo dos direitos reais deverão produzir bons resultados se direcionados ao confronto dos elementos formantes de cada sistema jurídico, com especial atenção à formação histórica de cada instituto. 


\section{APÊNDICE I - QUADROS SINÓTICOS}

\section{A. Estates in land}

\section{ESTATES AT COMMON LAW}

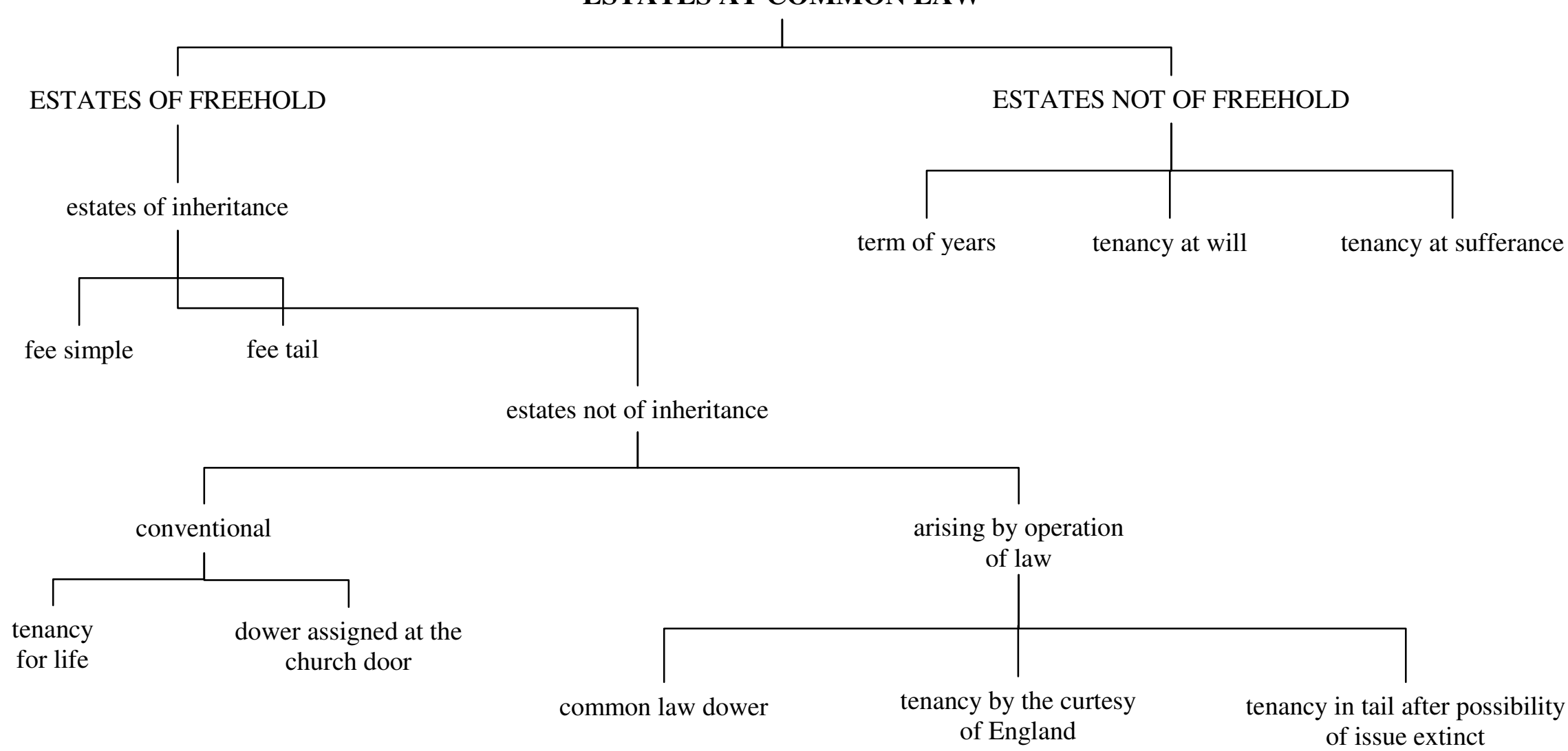

* Cf. J. H. BAKER, Introduction cit. (nota 12 supra), p. 278. 


\section{B. Types of tenure*}

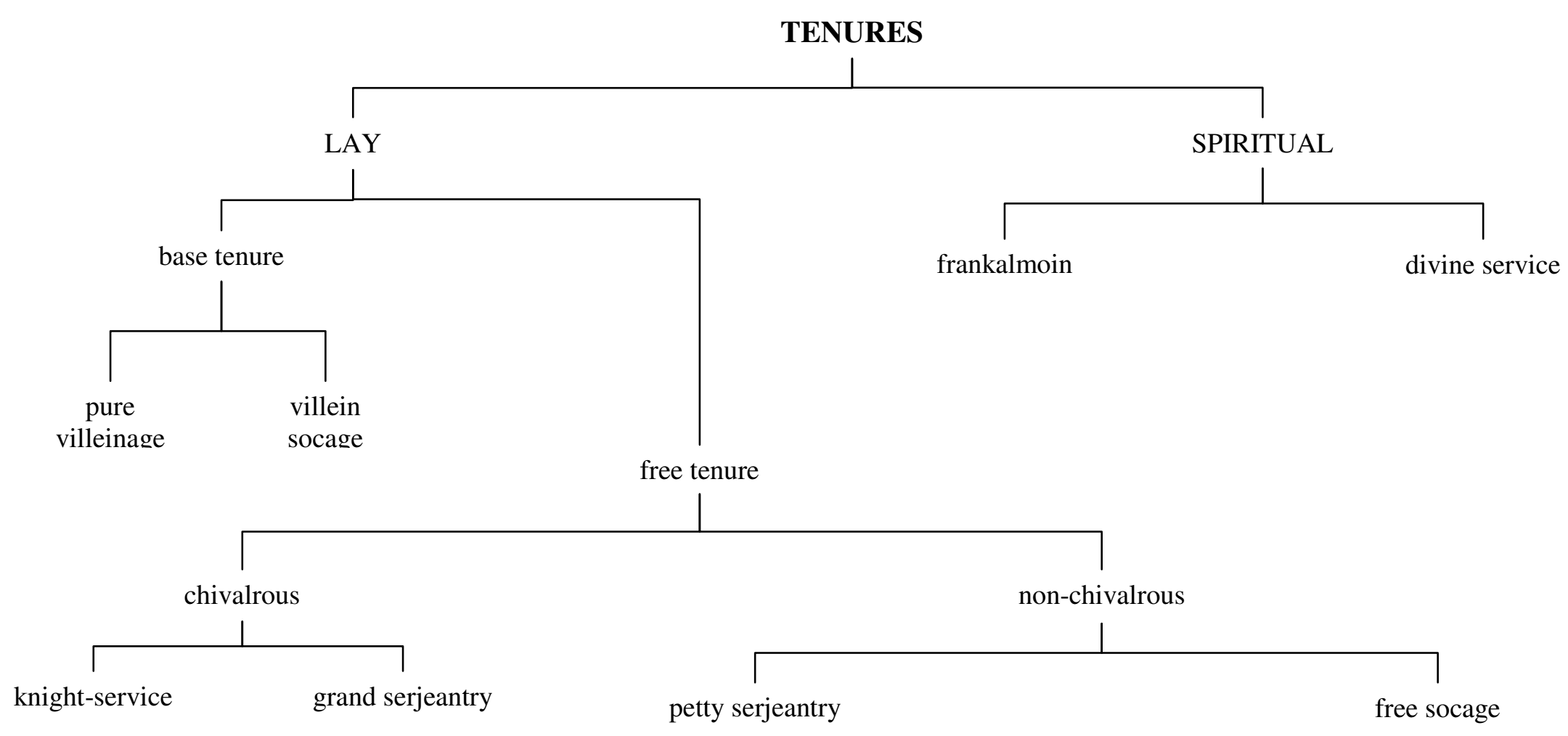

* Cf. J. H. BAKER, Introduction cit. (nota 12 supra), p. 247. 


\section{Principal types of original writ}

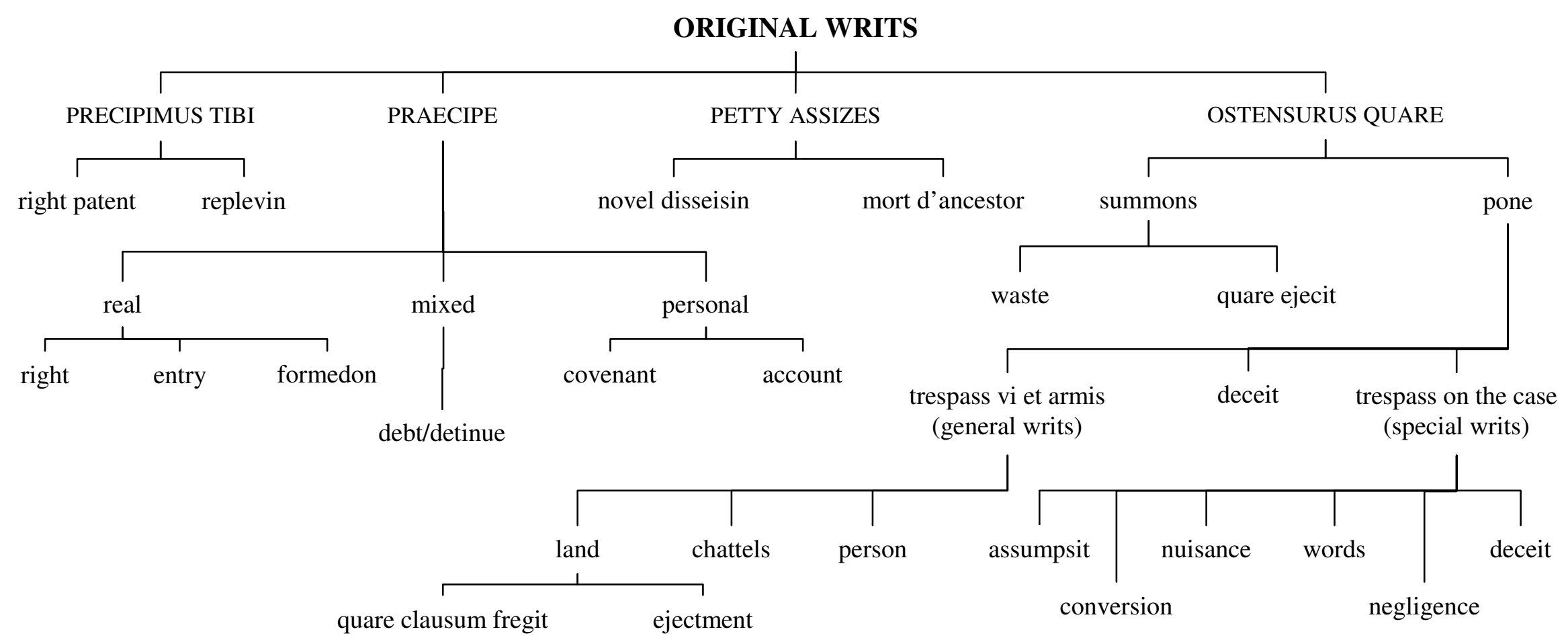

* Cf. J. H. BAKER, Introduction cit. (nota 12 supra), p. 70. 


\section{Types of property ${ }^{*}$}

\section{THINGS IN HUMAN DOMINION}

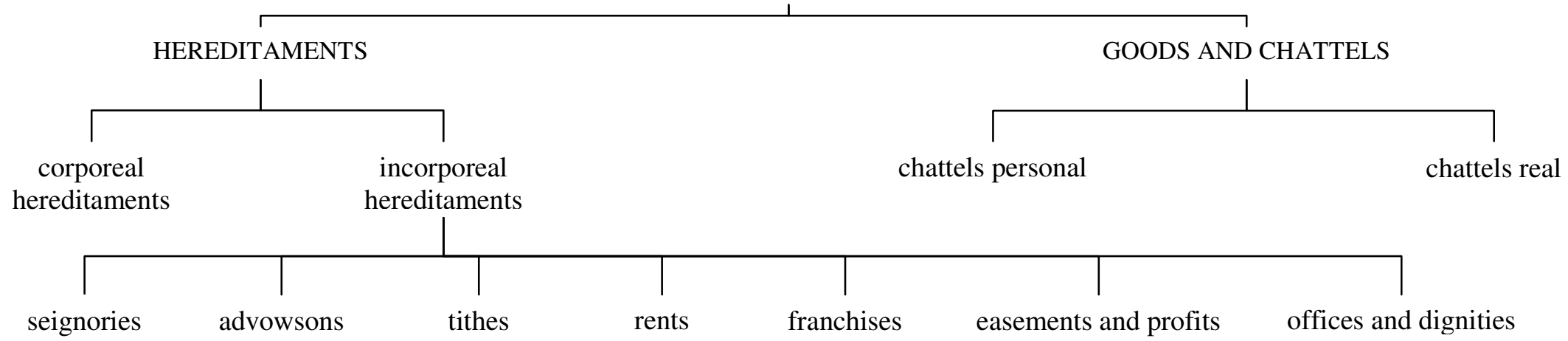

* Cf. J. H. BAKER, Introduction cit. (nota 12 supra), p. 246. 


\section{APÊNDICE II - TABELAS CRONOLÓGICAS}

\section{A. CRONOLOGIA DOS MONARCAS INGLESES A PARTIR DA CONQUISTA NORMANDA 529}

\begin{tabular}{|c|c|c|c|c|}
\hline Nome do monarca & Nome em português & Data de ascensão ao trono & Duração & Dinastia \\
\hline William I & Guilherme I & 14 de outubro de 1066 & 21 & \multirow{4}{*}{ Normanda } \\
\hline William II & Guilherme II & 26 de setembro de 1087 & 13 & \\
\hline Henry I & Henrique I & 5 de agosto de 1100 & 36 & \\
\hline Stephen & Estevão & 26 de dezembro de 1135 & 19 & \\
\hline Henry II & Henrique II & 19 de dezembro de 1154 & 35 & \multirow{8}{*}{ Plantageneta } \\
\hline Richard I & Ricardo I & 19 de setembro de 1189 & 10 & \\
\hline John & João & 27 de maio de 1199 & 18 & \\
\hline Henry III & Henrique III & 28 de outubro de 1216 & 57 & \\
\hline Edward I & Eduardo I & 20 de novembro de 1272 & 35 & \\
\hline Edward II & Eduardo II & 8 de julho de 1307 & 20 & \\
\hline Edward III & Eduardo III & 25 de janeiro de 1326 & 51 & \\
\hline Richard II & Ricardo II & 22 de junho de 1377 & 23 & \\
\hline Henry IV & Henrique IV & 30 de setembro de 1399 & 14 & \multirow{3}{*}{ Lancaster } \\
\hline Henry V & Henrique V & 21 de março de 1413 & 10 & \\
\hline Henry VI & Henrique VI & 1 de setembro de 1422 & 39 & \\
\hline Edward IV $V^{530}$ & Eduardo IV & 4 de março de 1461 & 23 & \multirow{3}{*}{ York } \\
\hline Edward $V$ & Eduardo V & 9 de abril de 1483 & 3 meses & \\
\hline Richard III & Ricardo III & 26 de junho de 1483 & 3 & \\
\hline Henry VII & Henrique VII & 22 de agosto de 1485 & 24 & Tudor \\
\hline
\end{tabular}

${ }^{529}$ A tabela cronológica dos monarcas ingleses pode ser encontrada num grande número de obras inglesas. Consultamos as seguintes para a confecção da tabela: E. B. FRYDE et al., Handbook cit. (nota 375 supra), pp. 29-49; H. C. BLACK, A Law Dictionary, $2^{\mathrm{a}}$ ed., Saint Paul, West Publishing, 1910, p. vii; G. CRISCUOLI, Introduzione cit. (nota 1 supra), pp. 523-524.

${ }^{530}$ Durante o reinado de Eduardo IV, o rei Henrique VI, que tinha sido deposto em 1461, foi restaurado ao trono de 3 de outubro de 1470 até 11 de abril de 1471 , data em que foi definitivamente deposto por Eduardo IV, cf. E. B. FRYDE et al., Handbook cit. (nota 375 supra), p. 41. Muitas tabelas cronológicas simplesmente não inserem essa informação porque o reinado e Eduardo IV é normalmente considerado uma unidade ininterrupta. 


\begin{tabular}{|c|c|c|c|c|}
\hline Henry VIII & Henrique VIII & 22 de abril de 1509 & 38 & \\
\hline Edward VI & Eduardo VI & 28 de janeiro de 1547 & 7 & \\
\hline Mary I & Maria I & 6 de julho de 1553 & 6 & \\
\hline Elizabeth I & Elizabete I & 17 de novembro de 1558 & 45 & \\
\hline James I & Tiago I & 24 de março de 1603 & 23 & \multirow{6}{*}{ Stuart } \\
\hline Charles I & Carlos I & 27 de março de 1625 & 24 & \\
\hline Charles $I I^{531}$ & Carlos II & 29 de maio de 1660 & 37 & \\
\hline James II & Tiago II & 6 de fevereiro de 1685 & 4 & \\
\hline William III and Mary II ${ }^{532}$ & Guilherme III e Maria II & 13 de fevereiro de 1689 & 14 & \\
\hline Anne & Ana & 8 de março de 1702 & 13 & \\
\hline George I & Jorge I & 1 de agosto de 1714 & 13 & \multirow{6}{*}{ Hanover } \\
\hline George II & Jorge II & 11 de junho de 1727 & 34 & \\
\hline George III ${ }^{533}$ & Jorge III & 25 de outubro de 1760 & 60 & \\
\hline George IV & Jorge IV & 29 de janeiro de 1820 & 11 & \\
\hline William IV & Guilherme IV & 26 de junho de 1830 & 7 & \\
\hline Victoria & Vitória & 20 de junho de 1837 & 64 & \\
\hline Edward VII & Eduardo VII & 22 de janeiro de 1901 & 9 & \multirow{5}{*}{ Windsor } \\
\hline George V & Jorge V & 6 de maio de 1910 & 26 & \\
\hline Edward VIII & Eduardo VIII & 20 de janeiro de 1936 & 11 meses & \\
\hline George VI & Jorge VI & 11 de dezembro de 1936 & 16 & \\
\hline Elizabeth II & Elizabete II & 6 de fevereiro de 1952 & - & \\
\hline
\end{tabular}

${ }^{531}$ O rei Carlos II subiu ao trono em 29 de maio de 1660, após os períodos conhecidos como o Commonwealth (1649-1653) e o Protectorate (1653-1660). Seu reinado, no entanto, reinado computa-se desde o momento em que Carlos I foi executado, ou seja, desde 30 de janeiro de 1649, cf. G. CRISCUOLI, Introduzione cit. (nota 1 supra), p. 524 , nt. 3 .

${ }_{532}$ A rainha Maria II faleceu em 28 de dezembro de 1694. Seu marido, Guilherme III, continuou no trono até a sua morte em 8 de março de 1702 , cf. E. B. FRYDE $e t$ al., Handbook cit. (nota 375 supra), p. 45.

${ }^{53} \mathrm{O}$ rei Jorge III foi declarado incapaz em 5 de fevereiro de 1811, constituindo-se a regência em favor do seu filho e sucessor, Jorge IV, cf. E. B. FRYDE et al., Handbook cit. (nota 375 supra), p. 47. Jorge II continuou, no entanto, oficialmente no trono até a sua morte em 29 de janeiro de 1820. 


\section{B. CRONOLOGIA DOS CHIEF JUSTICIARS}

\begin{tabular}{|c|c|c|}
\hline Chief Justiciars $^{534}$ & Investidura & Monarca \\
\hline \multirow{2}{*}{$\begin{array}{l}\text { Roger (bispo de Salisbury 1102-1139) } \\
\text { Mantido no cargo }\end{array}$} & \multirow{2}{*}{$1102 ?$} & Henrique I \\
\hline & & Estevão \\
\hline $\begin{array}{l}\text { Robert (Conde de Leicester) } \\
\text { Sir Richard de Luci - no cargo até } 1168\end{array}$ & 1154 & \multirow[t]{2}{*}{ Henrique II } \\
\hline Ranulf de Glanville & \multirow{2}{*}{$1179 ?$} & \\
\hline Mantido no cargo & & \multirow{6}{*}{ Ricardo I } \\
\hline $\begin{array}{l}\text { William de Mandeville (Conde de Essex) } \\
\text { Hugh de Puiset (bispo de Durham 1153-1195) }\end{array}$ & 1189 & \\
\hline William de Longchamp (bispo de Ely 1189-1197) & 1190 & \\
\hline Walter de Coutances (arcebispo de Rouen 1184-1207) & 1191 & \\
\hline Hubert Walter (bispo de Salisbury 1189-1193; arcebispo de Canterbury 1193-1205) & 1193 & \\
\hline Geoffrey Fitz Peter (Conde de Essex 1199) & \multirow{2}{*}{1198} & \\
\hline Mantido no cargo & & \multirow{3}{*}{ João } \\
\hline Peter des Roches (bispo de Winchester 1205-1238) & 1214 & \\
\hline $\begin{array}{l}\text { Hubert de Burgh (Conde de Kent 1227) } \\
\text { Mantido no cargo }\end{array}$ & 1215 & \\
\hline Sir Stephen Seagrave & $1234 ?$ & \multirow{5}{*}{ Henrique III } \\
\hline Sir Hugh Bigod & 1258 & \\
\hline Sir Hugh le Despenser & 1260 & \\
\hline Sir Phillip Basset & 1261 & \\
\hline Sir Hugh le Despenser & 1263 & \\
\hline
\end{tabular}

\footnotetext{
${ }^{534}$ As informações utilizadas para construir a tabela foram extraídas de E. B. FRYDE et al., Handbook cit. (nota 375 supra), p. $69-72$.
} 


\section{CRONOLOGIA DOS LORD CHANCELLORS AND KEEPERS OF THE GREAT SEAL ${ }^{535}$}

\begin{tabular}{|c|c|c|}
\hline Lord Chancellors e Lord Keepers of England & Investidura & Monarca \\
\hline Herfast (bispo de Elmham 1070-1085) & 1069 & \multirow{4}{*}{ Guilherme I } \\
\hline Osmund (bispo de Salisbury 1078-1099) & $1070 ?$ & \\
\hline Maurice (arquidiácono de Le Mans; bispo de Londres 1085-1107) & $1078 ?$ & \\
\hline Gerard (preceptor de Rouen; bispo de Hereford 1096-1100; arcebispo de York 1100-1108) & \multirow{2}{*}{$1085-1086 ?$} & \\
\hline Mantido no cargo & & \multirow{3}{*}{ Guilherme II } \\
\hline Robert Bloet (bispo de Lincoln 1093-1123) & 1091 & \\
\hline $\begin{array}{l}\text { William Giffard (bispo de Winchester 1100-1129) } \\
\text { Mantido no cargo }\end{array}$ & 1094 & \\
\hline Roger (bispo de Salisbury 1102-1139) & 1101 & \multirow{5}{*}{ Henrique I } \\
\hline Waldric (bispo de Laon 1107-1112) & 1102 & \\
\hline Ranulf & 1107 & \\
\hline Geoffrey Rufus (bispo de Durham 1133-1141) & 1123 & \\
\hline [Robert de Sigillo (bispo de Londres 1141-1150) - keeper of the seal] & 1133 & \\
\hline Roger le Poer & 1135 & \multirow{4}{*}{ Estevão } \\
\hline Philip de Harcourt (decano de Lincoln; bispo de Bayeux 1142-1163) & 1139 & \\
\hline Robert de Ghent (decano de York) & 1140 & \\
\hline William Fitz Gilbert & 1141 & \\
\hline Thomas Becket (arquidiácono de Canterbury; arcebispo de Canterbury 1162-1170) & 1155 & \multirow{4}{*}{ Henrique II } \\
\hline Geoffrey Ridel (arcebispo de Canterbury; bispo de Ely 1173-1189) & 1162 & \\
\hline Ralph de Warneville (tesoureiro de York; bispo de Lisieux 1181?-1192) & 1173 & \\
\hline $\begin{array}{l}\text { Geoffrey (filho ilegítimo de Henrique II; arcebispo de York 1189-1212) } \\
\text { [Walter de Coutances (arcebispo de Oxford; bispo de Lincoln 1183-1184; arcebispo de Rouen 1184-1207; keeper of the seal } \\
\text { 1173-1189] }\end{array}$ & 1181 & \\
\hline William Longchamp (bispo de Ely 1189-1197) & 1189 & \multirow{3}{*}{ Ricardo I } \\
\hline [Eustace (vice chancellor 1194-1197; decano de Salisbury; bispo de Ely 1197-1215); keeper of the seal] & 1197 & \\
\hline Eustace (bispo de Ely) & 1198 & \\
\hline Hubert Walter (arcebispo de Canterbury) & 1199 & \multirow{3}{*}{ João } \\
\hline Walter de Gray (bispo de Worcester 1214-1215; arcebispo de York 1215-1255) & 1205 & \\
\hline Richard Marsh (arcebispo de Northumberland; Bispo de Durham 1217-1226) & 1214 & \\
\hline
\end{tabular}

${ }^{535}$ Até o ano 1979, a tabela se baseia nas informações encontradas em E. B. FRYDE et al., Handbook cit. (nota 375 supra), pp. 82-92. As informações relativas ao período de 1979 a 1997 foram colhidas em G. CRISCUOLI, Introduzione cit. (nota 1 supra), p. 533. Daí até a entrada em vigor do Constitutional Reform Act 2005, que modificou as competências do Chancellor, as infrmações foram extraídas de http://webarchive.nationalarchives.gov.uk/ [18-09-2012]. 
[Ralph Neville (decano de Lichfield; bispo de Chichester 1222-1244; keeper of the seal in France)]

Mantido no cargo

Ralph Neville

[vários substitutos entre 1238-1240]

1226

Richard le Gras (abade de Evesham; keeper of the seal)

Ralph Neville

Silvester de Everdon (arcebispo de Chester; bispo de Carlisle 1245-1254; keeper of the seal)

1240

John Mansel (reitor de Beverley; keeper of the seal)

Sir John Lexington (keeper of the seal)

John Mansel (reitor de Beverley; keeper of the seal)

Sir John Lexington (keeper of the seal)

William de Kilkenny (arcebispo de Coventry; bispo de Ely 1254-1256; keeper of the seal)

Henry Wingham (decano de St. Martin's-le-Grand; bispo de Londres 1259-1262)

Nicholas de Ely (arcebispo de Ely; bispo de Worcester 1266-1268; bispo de Wincester 1268-1280)

Walter Merton (arcebispo de Bath; bispo de Rochester 1274-1277; keeper of the seal)

Nicholas de Ely (arcebispo de Ely; bispo de Worcester 1266-1268; bispo de Wincester 1268-1280)

John Chishull (arcebispo de Londres; decano de St. Paul 1268-1273; bispo de Londres 1273-1280)

Thomas Cantilupe (arcebispo de Stafford; bispo de Hereford 1275-1282)

Ralph Sandwich (keeper of the seal)

Walter Giffard (bishop de Bath e Wells 1264-1266; arcebispo de York 1266-1279)

Godfrey Giffard (arcebispo de Wells e York; bispo de Worcester 1268-1302)

John Chishull (arcebispo de Londres; decano de St. Paul 1268-1273; bispo de Londres 1273-1280)

Richard Middleton (arcebispo de Northumberland)

Walter Merton (arcebispo de Bath; bispo de Rochester 1274-1277; keeper of the seal)

Robert Burnell, (arcebispo de York; bispo de Bath e Wells 1275-1292)

John Langton (cânon de Lincoln; bispo de Chichester 1305-1337)

William Greenfield (decano de Chichester; arcebispo de York 1304-1315)

William Hamilton (decano de York)

Ralph Baldock (bispo de Londres 1304-1313)

Mantido no cargo

John Langton (cânon de Lincoln; bispo de Chichester 1305-1337)

Walter Reynolds (bispo de Worcester 1307-1313; arcebispo de Canterbury 1313-1327; keeper of the seal)

John Sandall (cânon de Lincoln e St. Paul; bispo de Winchester 1323-1333; arcebispo de Canterbury 1333-1348)

John Hotham (bispo de Ely 1316-1337)

John Salmon (bispo de Norwich 1299-1325)

Robert Baldock (arcebispo de Middlesex)

[William Airmyn (bispo de Norwich 1325-1336; keeper of the seal)]

\begin{tabular}{|c|c|}
\hline 1226 & \multirow{20}{*}{ Henrique III } \\
\hline 1240 & \\
\hline 1242 & \\
\hline 1244 & \\
\hline 1246 & \\
\hline 1247 & \\
\hline 1248 & \\
\hline 1249 & \\
\hline 1250 & \\
\hline 1255 & \\
\hline 1260 & \\
\hline 1261 & \\
\hline 1263 & \\
\hline 1263 & \\
\hline 1264 & \\
\hline 1265 & \\
\hline 1267 & \\
\hline 1267 & \\
\hline 1268 & \\
\hline 1269 & \\
\hline 1272 & \multirow{6}{*}{ Eduardo I } \\
\hline 1274 & \\
\hline 1292 & \\
\hline 1302 & \\
\hline 1305 & \\
\hline 1307 & \\
\hline 1307 & \multirow{7}{*}{ Eduardo II } \\
\hline 1310 & \\
\hline 1314 & \\
\hline 1318 & \\
\hline 1320 & \\
\hline 1323 & \\
\hline 1326 & \\
\hline
\end{tabular}




\begin{tabular}{|c|c|c|}
\hline John Hotham (bispo de Ely 1316-1337) & 1327 & \multirow{19}{*}{ Eduardo III } \\
\hline Henry Burghersh (bispo de Lincoln 1320-1340) & 1328 & \\
\hline John Stratford (bispo de Winchester 1323-1333; arcebispo de Canterbury 1333-1348) & 1330 & \\
\hline Richard Bury (bispo de Durham 1333-1345) & 1334 & \\
\hline John Stratford (bispo de Winchester 1323-1333; arcebispo de Canterbury 1333-1348) & 1335 & \\
\hline Robert Stratford (bispo de Chichester 1337-1362) & 1337 & \\
\hline Richard Bintworth, (bispo de Londres 1338-1339) & 1338 & \\
\hline John Stratford (bispo de Winchester 1323-1333; arcebispo de Canterbury 1333-1348) & 1340 & \\
\hline Robert Stratford (bispo de Chichester 1337-1362) & 1340 & \\
\hline Sir Robert Bourchier & 1340 & \\
\hline Sir Robert Parving & 1341 & \\
\hline Sir Robert Sadington & 1343 & \\
\hline John Offord (decano de Lincoln; arcebispo de Canterbury 1348-1349) & 1345 & \\
\hline John Thoresby (bispo de St. David's 1347-1349; bispo de Worcester 1349-1352; arcebispo de York 1352-1373) & 1349 & \\
\hline William Edington (bispo de Winchester 1345-1366) & 1356 & \\
\hline Simon Langham (bispo de Ely 1362-1366; arcebispo de Canterbury 1366-1368) & 1363 & \\
\hline William Wykeham (bispo de Winchester 1366-1404) & 1367 & \\
\hline Sir Robert Thorpe & 1371 & \\
\hline Sir John Knyvet & 1372 & \\
\hline $\begin{array}{l}\text { Adam Houghton (bispo de St David's 1362-1389) } \\
\text { Mantido no cargo }\end{array}$ & 1377 & \multirow{14}{*}{ Ricardo II } \\
\hline Richard Scrope (Lord Scrope of Bolton) & 1378 & \\
\hline Simon Sudbury (bispo de Londres 1361-1375; arcebispo de Canterbury1375-1381) & 1380 & \\
\hline [Hugh Segrave (keeper of the seal)] & 1381 & \\
\hline William Courtenay (bispo de Hereford 1369-1375; bispo de Londres1375-1381; arcebispo de Canterbury 1381-1396) & 1381 & \\
\hline Richard Scrope (Lord Scrope of Bolton) & 1381 & \\
\hline Robert Braybrooke (bispode Londres 1381-1404) & 1382 & \\
\hline Michael de la Pole (Lord de la Pole, posteriormente Conde de Suffolk) & 1383 & \\
\hline Thomas Arundel (bispo de Ely 1373-1388; arcebispo de York 1388-1396; arcebispo de Canterbury 1396-1397 e 1399-1414) & 1386 & \\
\hline William Wykeham (bispo de Winchester 1366-1404) & 1389 & \\
\hline Thomas Arundel (bispo de Ely 1373-1388; arcebispo de York 1388-1396; arcebispo de Canterbury 1396-1397 e 1399-1414) & 1391 & \\
\hline Edmund Stafford (bispo de Exeter 1395-1419) & 1396 & \\
\hline Thomas Arundel (bispo de Ely 1373-1388; arcebispo de York 1388-1396; arcebispo de Canterbury 1396-1397 e 1399-1414) & 1399 & \\
\hline \multirow{2}{*}{$\begin{array}{l}\text { John Scarle (arquidiácono de Lincoln) } \\
\text { Mantido no cargo }\end{array}$} & \multirow{2}{*}{1399} & \\
\hline & & \multirow[t]{3}{*}{ Henrique IV } \\
\hline Edmund Stafford (bispo de Exeter 1395-1419) & 1401 & \\
\hline Henry Beaufort (bispo de Lincoln 1398-1404; bispo de Winchester 1404-1447; cardeal 1426) & 1403 & \\
\hline
\end{tabular}




\begin{tabular}{|c|c|c|}
\hline Thomas Langley (diácono de York; bispo de Durham 1406-1437) & 1405 & \\
\hline Thomas Arundel (bispo de Ely 1373-1388; arcebispo de York 1388-1396; arcebispo de Canterbury 1396-1397 e 1399-1414) & 1407 & \\
\hline Sir Thomas Beaufort & 1410 & \\
\hline Thomas Arundel (bispo de Ely 1373-1388; arcebispo de York 1388-1396; arcebispo de Canterbury 1396-1397 e 1399-1414) & 1412 & \\
\hline Henry Beaufort (bispo de Lincoln 1398-1404; bispo de Winchester 1404-1447; cardeal 1426) & 1413 & \multirow{2}{*}{ Henrique V } \\
\hline $\begin{array}{l}\text { Thomas Langley (diácono de York; bispo de Durham 1406-1437) } \\
\text { Renomeado em } 1422\end{array}$ & 1417 & \\
\hline Henry Beaufort (bispo de Lincoln 1398-1404; bispo de Winchester 1404-1447; cardeal 1426) & 1424 & \multirow{8}{*}{ Henrique VI } \\
\hline $\begin{array}{l}\text { John Kemp (bispo de Rochester 1419-1421; bispo de Chichester 1421; bispo de Londres 1421-1425; arcebispo de York } 1425- \\
\text { 1454; cardeal 1439) }\end{array}$ & 1426 & \\
\hline John Stafford (bispo de Bath e Wells 1424-1443; arcebispo de Canterbury 1443-1452) & 1432 & \\
\hline $\begin{array}{l}\text { John Kemp (bispo de Rochester 1419-1421; bispo de Chichester 1421; bispo de Londres 1421-1425; arcebispo de York } 1425- \\
\text { 1454; cardeal 1439) }\end{array}$ & 1450 & \\
\hline Richard Nevill (Conde de Salisbury) & 1454 & \\
\hline Thomas Bourchier (bispo de Worcester 1433-1443; bispo de Ely 1443-1454; arcebispo de Canterbury 1454-1486; cardeal 1467) & 1455 & \\
\hline William Waynflete (bispo de Winchester 1447-1486) & 1456 & \\
\hline George Neville (bispo de Exeter 1456-1465; arcebispo de York 1465-1476) & \multirow[t]{2}{*}{1460} & \\
\hline $\begin{array}{l}\text { Renomeado em } 1461 \\
\text { Robert Stillington (bispo de Bath e Wells 1461-1491) }\end{array}$ & & Eduardo IV \\
\hline George Neville (bispo de Exeter 1456-1465; arcebispo de York 1465-1476) & 1470 & Henrique VI \\
\hline Robert Stillington (bispo de Bath e Wells 1461-1491) & 1471 & \multirow{5}{*}{ Eduardo IV } \\
\hline Laurence Booth (bispo de Durham 1457-1476; arcebispo de York 1476-1480) & 1473 & \\
\hline Thomas Rotherham (bispo de Rochester 1468-1472; bispo de Lincoln 1472-1480; arcebispo de York 1480-1500) & 1474 & \\
\hline John Alcock (bispo de Rochester 1472-1476; bispo de Worcester 1476-1486; bispo de Ely 1486-1500) & 1475 & \\
\hline Thomas Rotherham (bispo de Rochester 1468-1472; bispo de Lincoln 1472-1480; arcebispo de York 1480-1500) & \multirow{2}{*}{1475} & \\
\hline Mantido no cargo & & \multirow[t]{2}{*}{ Eduardo V } \\
\hline $\begin{array}{l}\text { John Russell (bispo de Rochester 1476-1480; bispo de Lincoln 1480-1494) } \\
\text { Renomeado em } 1483\end{array}$ & 1483 & \\
\hline Thomas Rotherham (bispo de Rochester 1468-1472; bispo de Lincoln 1472-1480; arcebispo de York 1480-1500) & 1485 & \multirow{4}{*}{ Henrique VII } \\
\hline John Alcock (bispo de Rochester 1472-1476; bispo de Worcester 1476-1486; bispo de Ely 1486-1500) & 1485 & \\
\hline John Morton (bispo de Ely 1479-1486; arcebispo de Canterbury 1486-1500; cardeal 1493) & 1487 & \\
\hline William Warham (bispo de Londres 1502-1503; arcebispo de Canterbury 1503-1532; keeper of the seal) & \multirow{2}{*}{1504} & \\
\hline Mantido no cargo & & \multirow[t]{4}{*}{ Henrique VII } \\
\hline $\begin{array}{l}\text { Thomas Wolsey (bispo de Lincoln 1514; bispo de Bath e Wells 1518-1524; bispo de Durham 1524-1529; bispo de Winchester } \\
\text { 1529-1530; arcebispo de York 1514-1530; cardeal 1515) }\end{array}$ & 1515 & \\
\hline Sir Thomas More & 1529 & \\
\hline Thomas Audley (Lord Audley 1538; keeper of the seal) & 1532 & \\
\hline
\end{tabular}




\begin{tabular}{|c|c|c|}
\hline $\begin{array}{l}\text { The Lord Wriothesley (Lord Wriothesly 1544; keeper of the seal) } \\
\text { Mantido no cargo }\end{array}$ & 1544 & \multirow{4}{*}{ Eduardo VI } \\
\hline [William Paulet (Lord St John; Mariscal de Winchester 1551; keeper of the seal)] & 1547 & \\
\hline Richard Rich (Lord Rich 1547) & 1547 & \\
\hline Thomas Goodrich (bispo de Ely 1534-1554; keeper of the seal) & 1552 & \\
\hline Stephen Gardiner (bispo de Winchester 1531-1551 e 1553-1555) & 1553 & \multirow{3}{*}{ Maria I } \\
\hline [Sir Nicholas Hare e outros] & 1555 & \\
\hline Nicholas Heath (bispo de Rochester 1540-1543; bispo de Worcester 1543-1551 e 1553-1555; arcebispo de York 1555-1559) & 1556 & \\
\hline [Nicholas Bacon (lord keeper of the seal)] & 1558 & \multirow{5}{*}{ Elizabete I } \\
\hline Sir Thomas Bromley & 1579 & \\
\hline Sir Christopher Hatton & 1587 & \\
\hline Em comissão & 1591 & \\
\hline [Sir John Puckering (lord keeper of the seal)] & 1592 & \\
\hline $\begin{array}{l}\text { [Sir Thomas Egerton (Barão Ellesmere 1603, Visconde Brackley 1616; lord keeper of the seal] } \\
\text { Renomeado em } 1603\end{array}$ & 1596 & \multirow{3}{*}{ Tiago I } \\
\hline Sir Francis Bacon (Lord Verulam 1618; Viscount St Alban 1621) & 1617 & \\
\hline Em comissão & 1621 & \\
\hline $\begin{array}{l}\text { [John Williams (bispo de Lincoln 1621-1641; arcebispo de York 1641-1650)] } \\
\text { Mantido no cargo }\end{array}$ & 1621 & \multirow{7}{*}{ Carlos I } \\
\hline [Sir Thomas Coventry (Lord Coventry 1628; lord keeper of the seal)] & 1625 & \\
\hline [Sir John Finch (Lord Finch 1640; lord keeper of the seal)] & 1640 & \\
\hline [Sir Edward Littleton (Lord Lyttleton de Mounslow 1641)] & 1641 & \\
\hline [Sir Richard Lane (lord keeper of the seal)] & 1645 & \\
\hline [Sir Richard Herbert] & 1653 & \\
\hline [Sir Edward Hyde (Lord Hyde 1660; Conde de Clarendon 1661)] & 1658 & \\
\hline [Sir Edward Hyde (Lord Hyde 1660; Conde de Clarendon 1661)] & 1660 & \multirow{4}{*}{ Carlos II } \\
\hline [Sir Orlando Bridgeman (lord keeper of the seal)] & 1667 & \\
\hline Anthony Ashley Cooper (Conde de Shaftesbury 1672) & 1672 & \\
\hline Sir Heneage Finch (Lord Finch 1674; Conde de Nottingham 1681; lord keeper of the seal) & 1673 & \\
\hline [Sir Francis North (Lord Guilford 1683; lord keeper of the seal)] & \multirow{2}{*}{1682} & \multirow[b]{2}{*}{ Tiago II } \\
\hline $\begin{array}{l}\text { Mantido no cargo } \\
\text { George Jeffreys (Lord Jeffreys 1685) }\end{array}$ & & \\
\hline Em comissão & 1085 & \multirow{3}{*}{ Guilherme III e Maria II } \\
\hline Sir John Somers (Lord Somers 1697; lord keeper of the seal) & 1693 & \\
\hline Sir Nathan Wright (lord keeper of the seal) & \multirow{2}{*}{1700} & \\
\hline Mantido no cargo & & \multirow[t]{2}{*}{ Ana } \\
\hline William Cowper (Lord Cowper 1706; Conde Cowper 1718; lord keeper of the seal) & 1705 & \\
\hline
\end{tabular}




\begin{tabular}{|c|c|c|}
\hline Em comissão & 1708 & \multirow{5}{*}{ Jorge I } \\
\hline $\begin{array}{l}\text { Sir Simon Harcourt (Lord Harcourt 1711; Visconde de Harcourt 1721; lord keeper of the seal) } \\
\text { Mantido no cargo }\end{array}$ & 1710 & \\
\hline William Cowper (Lord Cowper 1706; Conde Cowper 1718; lord keeper of the seal) & 1714 & \\
\hline Thomas Parker (Lord Macclesfield; Conde de Macclesfield 1721) & 1718 & \\
\hline Em comissão & 1725 & \\
\hline $\begin{array}{l}\text { Peter King (Lord King 1725) } \\
\text { Mantido no cargo }\end{array}$ & 1725 & \multirow{5}{*}{ Jorge II } \\
\hline Charles Talbot (Lord Talbot de Hensol 1733) & 1733 & \\
\hline Phillip Yorke (Lord Hardwicke; Conde de Hardwicke 1754) & 1737 & \\
\hline Em comissão & 1756 & \\
\hline $\begin{array}{l}\text { [Sir Robert Henley (Lorde Henley 1760; Conde de Northington 1764; lord keeper of the seal)] } \\
\text { Mantido no cargo }\end{array}$ & 1764 & \\
\hline Charles Pratt (Lord Camden 1765; Conde de Camden 1786) & 1766 & \multirow{12}{*}{ Jorge III } \\
\hline Charles Yorke & 1770 & \\
\hline Em comissão & 1770 & \\
\hline Henry Bathurst (Lord Apsley 1771; Conde de Bathurst 1775 & 1771 & \\
\hline Edward Thurlow (Lord Thurlow 1778) & 1778 & \\
\hline Em comissão & 1783 & \\
\hline Edward Thurlow (Lord Thurlow 1778) & 1783 & \\
\hline Em comissão & 1792 & \\
\hline Alexander Wedderburn (Lord Loughborough, Conde de Resslyn 1801) & 1793 & \\
\hline John Scott (Lord Eldon, Conde de Eldon 1821) & 1801 & \\
\hline Thomas Erskine (Lord Erskine 1806) & 1806 & \\
\hline John Scott (Lord Eldon, Conde de Eldon 1821) & \multirow{2}{*}{1807} & \\
\hline Mantido no cargo & & Jorge IV \\
\hline $\begin{array}{l}\text { John Singleton Copley (Lord Lyndhurst 1827) } \\
\text { Mantido no cargo }\end{array}$ & 1827 & \multirow{5}{*}{ Guilherme IV } \\
\hline Henry Brougham (Lord Brougham e Vaux 1830) & 1830 & \\
\hline John Singleton Copley (Lord Lyndhurst 1827) & 1834 & \\
\hline Em comissão & 1835 & \\
\hline Sir Charles Christopher Pepys (Lord Cottenham 1836; Conde de Cottenham 1850) & \multirow{2}{*}{1836} & \\
\hline Mantido no cargo & & \multirow[t]{5}{*}{ Vitória } \\
\hline John Singleton Copley (Lord Lyndhurst 1827) & 1841 & \\
\hline Sir Charles Christopher Pepys (Lord Cottenham 1836; Conde de Cottenham 1850) & 1846 & \\
\hline Sir Thomas Wilde (Lord Truro 1850) & 1850 & \\
\hline Sir Edward Burtenshax Sugden (Lord St. Leonards 1852) & 1852 & \\
\hline
\end{tabular}




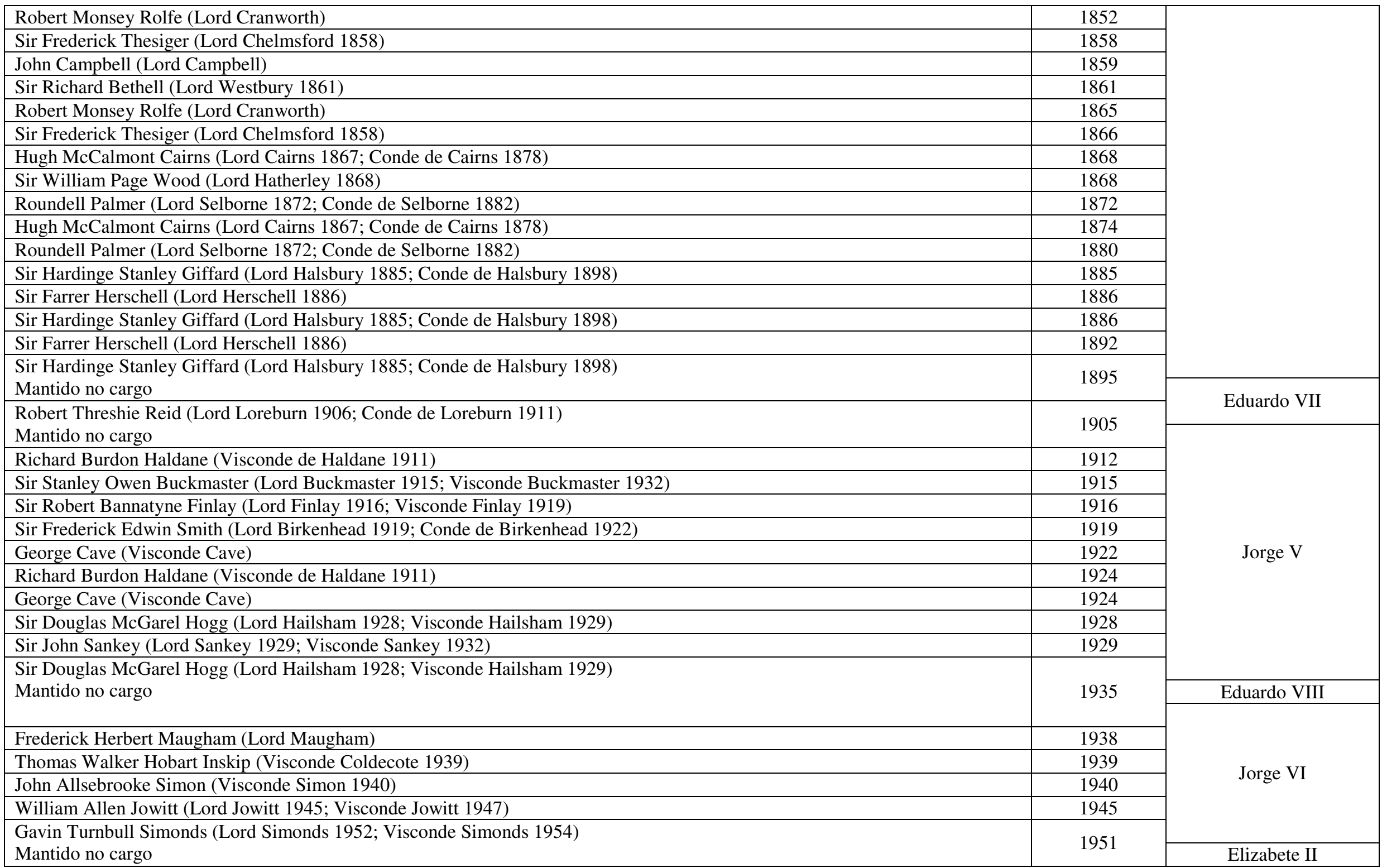


David Patrick Maxwell Fyfe (Visconde Kilmuir 1954)

1954

Reginald Edward Manningham-Buller (Visconde Dilhorne)

Gerald Austin Gardiner (Lord Gardiner)

Quintin McGarel Hogg (Lord Hailsham de St. Marylebone)

1964

Frederick Elwyn-Jones (Lord Elwyn-Jones)

Quintin McGarel Hogg (Lord Hailsham de St. Marylebone)

Lord Havers

Lord MacKay of Clashfern

Lord Irvine of Lairg

Lord Falconer of Thoroton 


\section{ÍNDICE DE AUTORES}

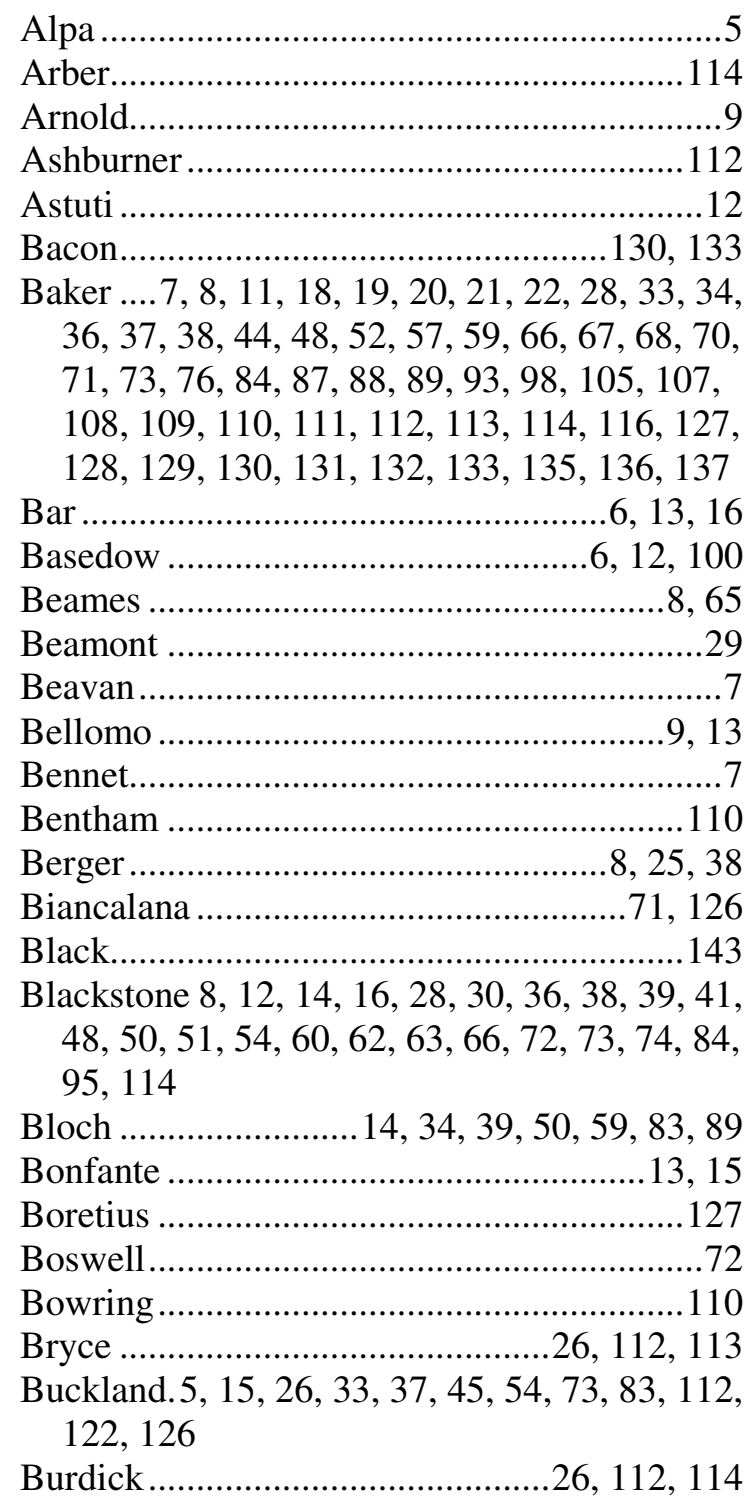

Burrill .8, 20, 27, 36, 38, 39, 40, 44, 45, 46, 48, $51,52,54,55,56,59,65,66,70,78,79,84$, $85,86,91,92,94,95,96,97$

Butler $8,40,76$

Caenegem $10,17,18$

Capogrossi Colognesi..................................15

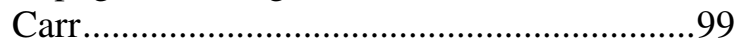

Challis......................... $5,48,60,61,63,72,74$

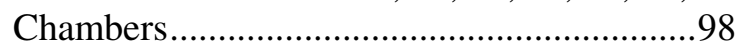

Clive ..................................................... 13, 16

Coing ........................................................38

Coke 7, 8, 28, 37, 38, 40, 48, 51, 54, 55, 61, 63, $65,76,77,79,81$

Criscuoli5, 7, 25, 105, 113, 118, 120, 121, 122, $123,124,125,143,144,146$

Croke . .7

Crump.

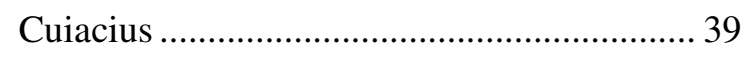

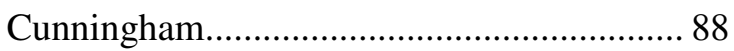

D'Alembert ..................................................... 29

David ................................... 5, 8, 17, 25, 165

Dawson ...................................................... 115

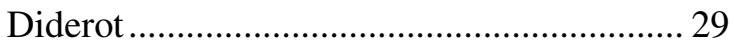

Digby ................................................ 37, 70

Dinamarco ...................................................... 113

Dodds...................................................... 133

Du Cange ... 8, 9, 14, 17, 20, 28, 29, 30, 37, 39, $45,46,48,51,52,53,64,79,83,86,92,94$, $96,97,99,108,111,127$

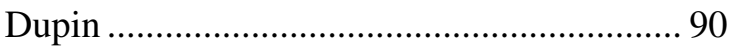

East …............................................................ 7

Edwards ..................................................... 124

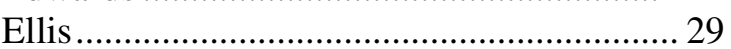

Epstein .................................... 78, 80, 82

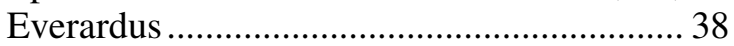

Finlason .................................................. 7

Fisher .................................................... 17, 42

Fitzherbert............................................... 18

FitzNigel .................................................... 34

Forsyth ........................................................ 17

Fortescue..................................... 8, 26, 27

Foulkes............................................ 7, 116

Franceschelli ................................................ 37

Francis ............................................ 117, 118

Fryde....................... 105, 143, 144, 145, 146

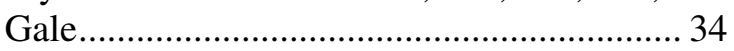

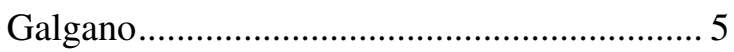

García del Corral............................................... 46

Garner 8, 10, 30, 57, 62, 83, 107, 108, 114, 135

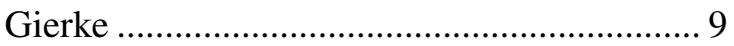

Gilissen ................................................. 9, 108

Glanvilla ........ 8, 17, 27, 52, 59, 65, 66, 67, 92

Glare ...8, 27, 28, 48, 51, 55, 59, 79, 83, 84, 98, $106,111,128$

Gordley

$5,16,22,43,50,63$

Grossi....................................................... 15

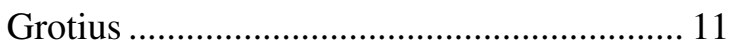

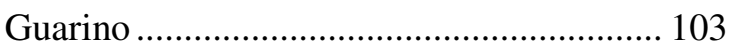

Güterbock . 5, 18, 26, 38, 43, 44, 45, 47, 64, 67

Hanbury ............................................ 131

Hare …........................................................ 7

Hargrave ....................................................... 8

Helmholz ............... 5, 103, 104, 119, 126, 130

Hemmeon..................................................... 93

Hening ....................................................... 117

Herbert of Cherbury ...................................... 133

Hermann ................................................. 126

Hespanha ............................................... 10, 26 
Holdsworth8, 11, 43, 47, 54, 59, 66, 72, 76, 85, $86,88,89,99,100,105,107,108,111,112$, $113,114,115,131$

Holmes .10

Hopt $6,12,100$

Horak .19

Hughes .34

Hunter. $.92,93$

James $29,57,128$

Jenks . .32

Johnson 104,119

Johnston

K. Gray6, 12, 28, 31, 43, 50, 56, 58, 61, 62, 63, $77,78,80,101,131$

Keeton 102

Kelley . .90

Kemble 127

Kerly.... 115,116

Koschaker . .15

Kötz $5,6,12,27,90$

Leadam .7, 87

Lely..... .7, 116

Lepaulle $5,103,104$

Liebman $.113,114$

Littleton 8,38

Long . .14

Lupoi ...5, 16, 57, 102, 103, 118, 119, 124, 130 MacNair. .135

Maine $20,89,90$

Maitland8, 9, 10, 11, 17, 18, 21, 22, 23, 25, 26, $27,28,33,34,35,41,42,43,45,46,47,48$, $49,54,68,71,72,78,83,84,85,86,91,96$, $99,102,109,110,111,112,116,117,125$, $126,127,128,130$

Malaguti $5,12,102,103,136$

Marrone $26,33,73,83$

Martins Rodrigues. . .117

Maxwell-Lyte ..... 30,93

McNair .5, 15, 26, 33, 37, 45, 54, 83, 112, 122, 126

Megarry ....5, 24, 25, 28, 30, 32, 42, 43, 49, 50, $55,56,59,60,61,62,64,65,68,72,74,75$, $78,80,82,83,85,87,88,91,92,93,94,99$

Meredith ...5

Michaels . .100

Milsom8, 18, 26, 33, 37, 38, 44, 57, 67, 68, 70, $71,72,73,76,84,87,92,93,94,95,100$, 105, 106, 107, 109, 126, 128, 129, 130, 131, $132,134,135,136,137$

Milward . .114

Moccia $5,6,15,35,43,50,53,63,101$

Moffat. 6,136

Montague. 111,112

Moréteau 103

Muchall. 135
Nolan 5

Pennington ................................................... 27

Pettit.6, 117, 118, 119, 120, 121, 122, 124, 129

Pickering.

Plowden 7

Plucknett .. 8, 13, 22, 28, 30, 37, 39, 41, 48, 51, $58,64,66,67,68,76,77,78,83,94,95,99$, $116,126,127,128,129,131,133,134,137$

Pollard...................................................... 87

Pollock 8, 25, 27, 28, 33, 34, 35, 40, 41, 43, 46, $48,49,54,68,71,72,78,83,84,85,86,91$, $96,99,126,127,128$

Pothier. 90

Price. 7,51

Pringsheim $13,26,32,113,118$

Pugliese 113

Reeves. $8,45,50,51,82$

Reid...... 103

Reimann 5

Rescigno 15

Rheinstein $5,75,90$

Ruffhead 7

S. F. Gray. 6, 12, 28, 31, 43, 50, 56, 58, 61, 62, $63,77,78,80,101,131$

Saint Germain 135

Scott $7,125,136$

Scrutton $26,27,47$

Shelford $5,7,10,61$

Silveira Marchi 7

Simpson ... 8, 10, 14, 17, 28, 35, 42, 64, 84, 91, $106,107,111,128$

Smith

Spelmannus.......... 8, 20, 29, 39, 51, 59, 64, 65 Spence............ 8, 14, 27, 33, 34, 39, 51, 52, 87

Stair... 40

Stephen $7,23,116$

Stockwell 124

Story..... $11,112,115,116$

Stubbs $7,19,76,95,98,100$

Swanston 89,90

Taine $14,25,33,73,83,119,122$

Talamanca. $14,25,33,73,83,119,122$

Tarello

Thier. 12

Thorne. 7,51

Thorpe. $8,57,77$

Tomlin 19

Van Erp. .. $5,6,16,23,28,43,91,101$

van Rhee 5,104

Vanderlinden ................................................ 103

Vattel ...... 32

Vernon 7

Vesey ......

Vinogradoff $84,85,105$ 
Visser

Vogenauer

Waal ..... 5,104

Wade...5, 24, 25, 28, 30, 32, 42, 43, 49, 50, 55, $56,59,60,61,62,64,65,68,72,74,75,78$, $80,82,83,85,87,88,91,92,93,94,99$

Walker....7, 8, 9, 10, 12, 14, 15, 17, 21, 28, 29, $30,31,36,37,39,41,42,43,50,54,56,79$, $83,87,89,91,92,106,107,108,111,122$, 133,135

Wambaugh $8,47,51,53,54,57,59,60,65,71$, $77,79,86,87,100$

Watkin . .99
Watson 5, 17, 18, 24, 56, 57, 73, 100, 114, 128

Weiner ... 8, 10, 14, 17, 28, 42, 64, 84, 91, 106, $107,111,128$

Wheeler.

33

Williams...... $42,46,59,60,74$

Woodbine ... 8

Wright ...................................................... 43

Wyclif .............................................................. 9

Wyndham...................................................29

Zeumer....................................................... 127

Zimmermann . 5, 6, 12, 33, 100, 103, 104, 119, 126,130

Zweigert

$5,6,12,27,90$ 


\section{ÍNDICE DE FONTES}

\section{FONTES INGLESAS}

A. FONTES JURÍDICAS

a) Statutes

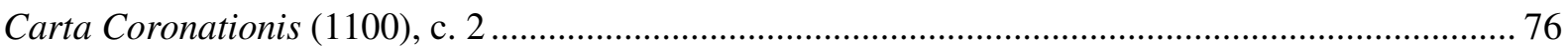

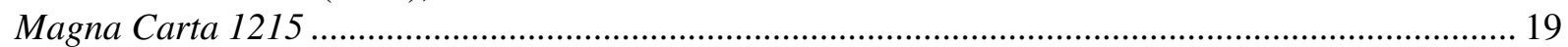

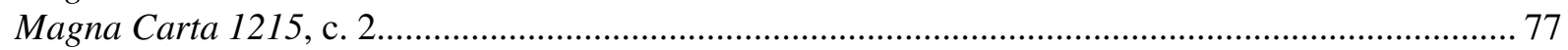

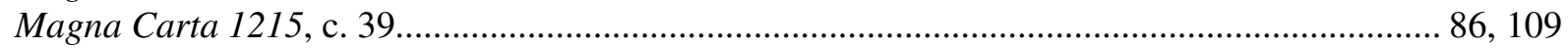

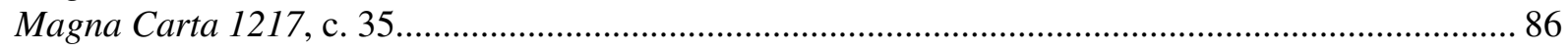

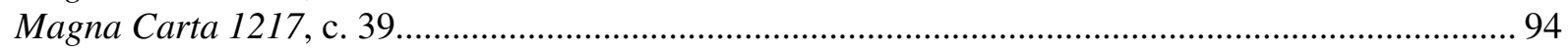

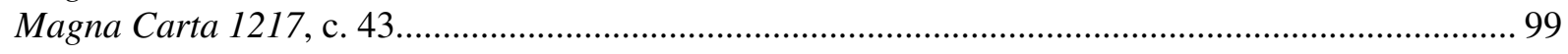

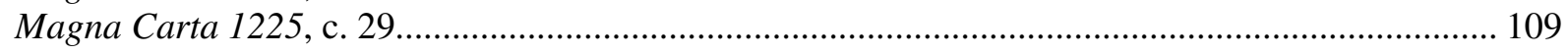

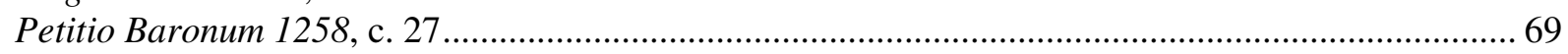

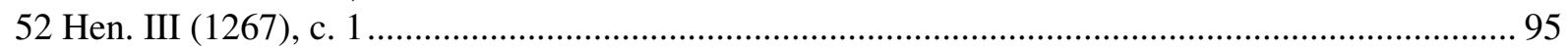

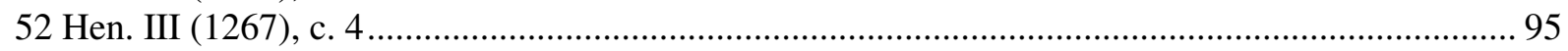

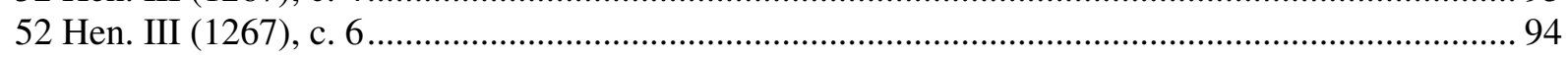

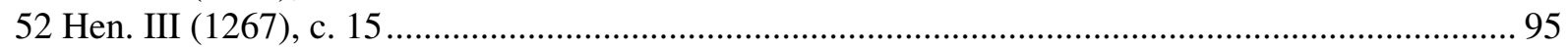

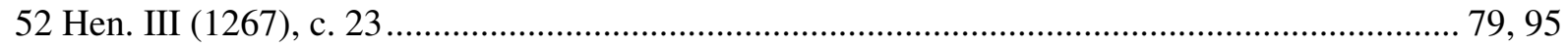

6 Edw. I (1278), c. 4

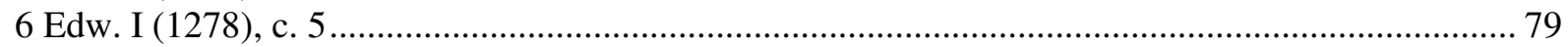

7 Edw. I (1279), c. 2

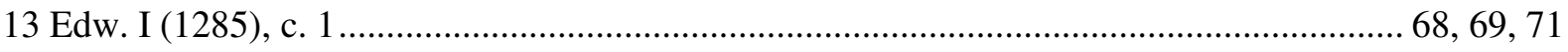

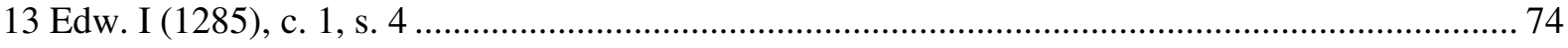

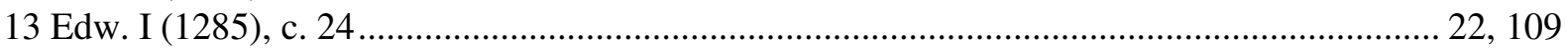

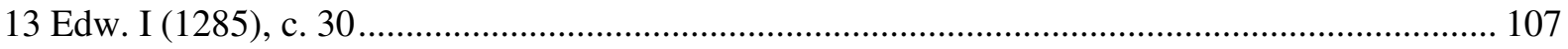

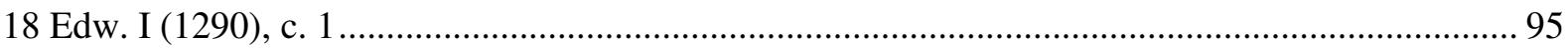

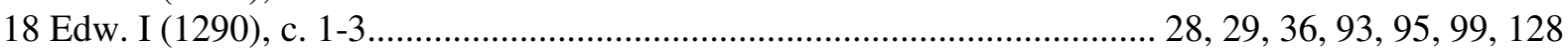

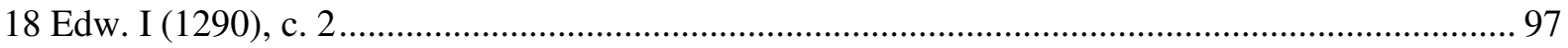

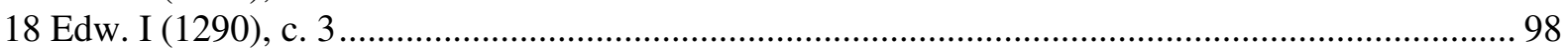

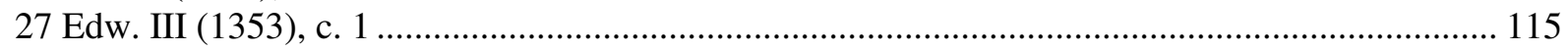

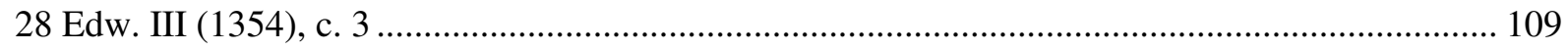

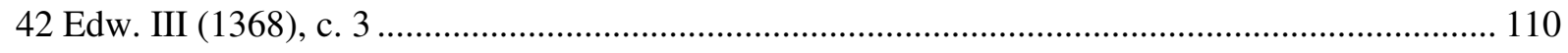

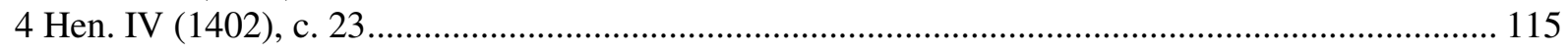

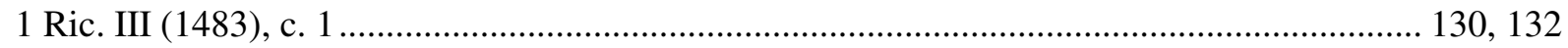

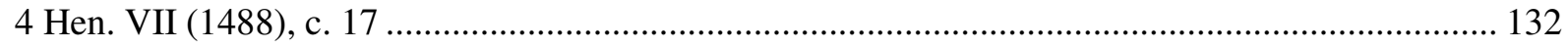

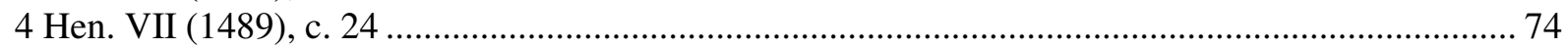

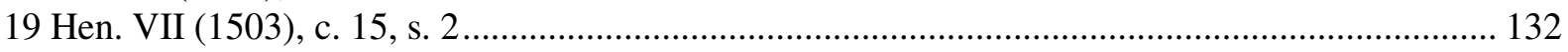

27 Hen. VIII (1536), c. 10 .................................................................57, 132, 133, 135, 136, 137

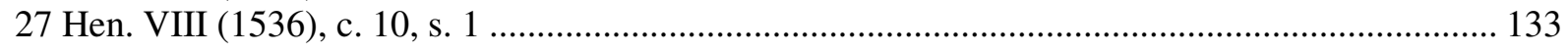

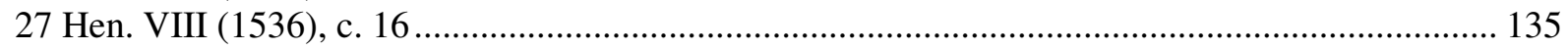

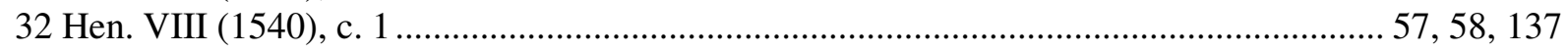

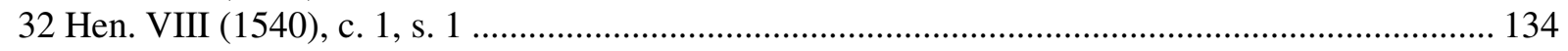

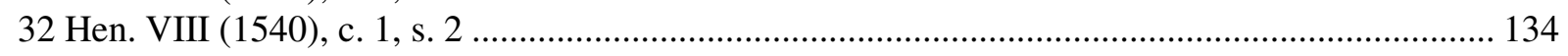

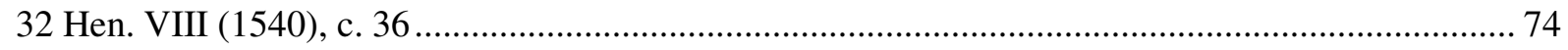

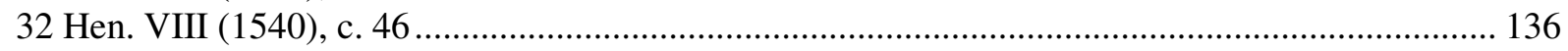

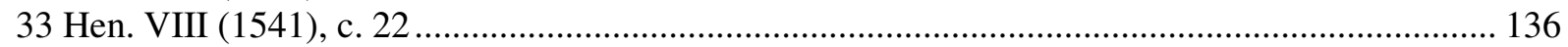


12 Char. II (1660), c. 24

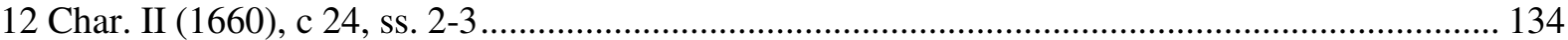

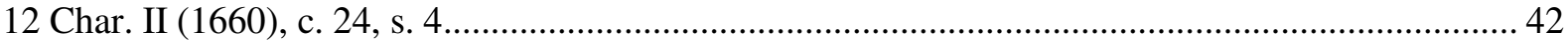

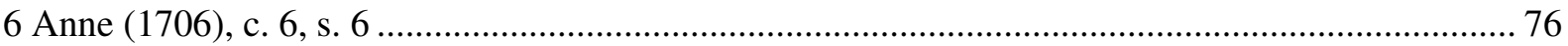

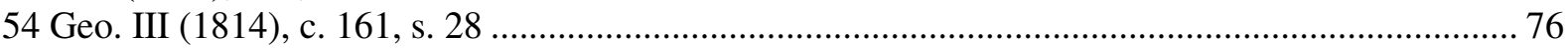

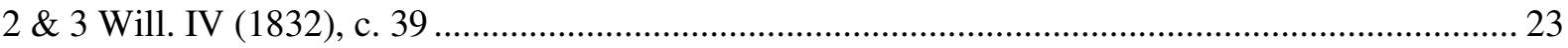

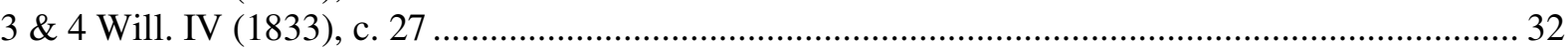

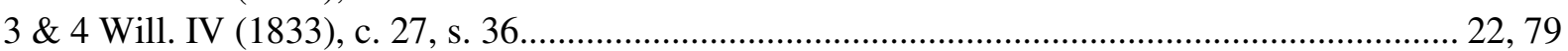

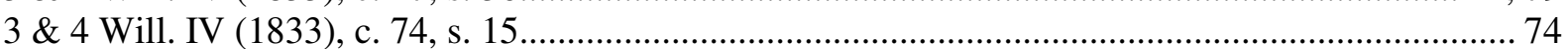

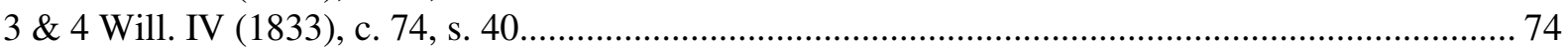

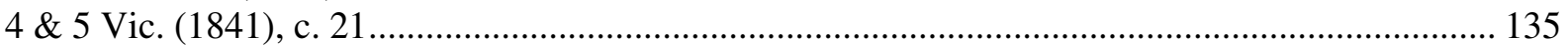

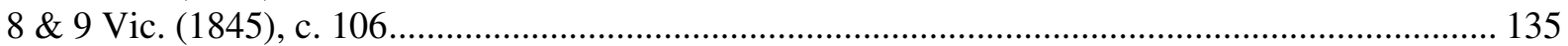

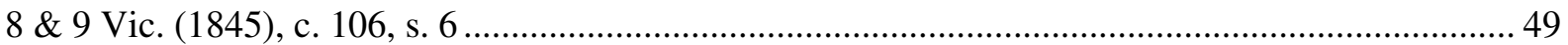

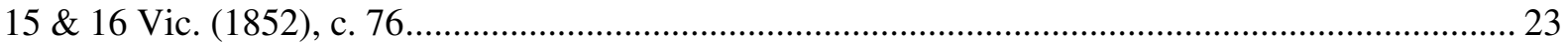

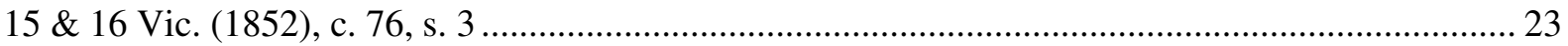

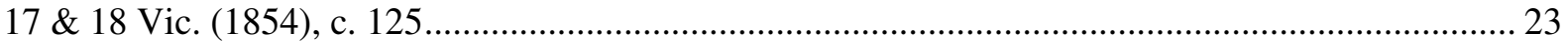

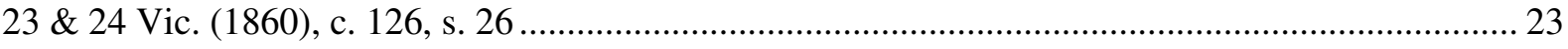

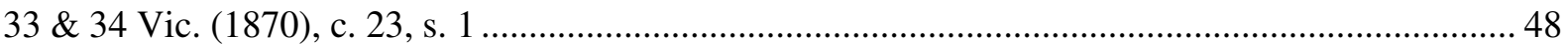

36 \& 37 Vic. (1873), c. 66........................................................................ 11, 20, 23, 109, 116

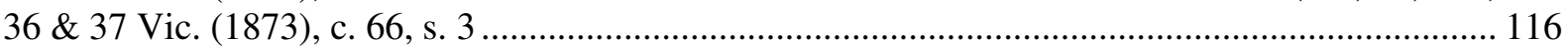

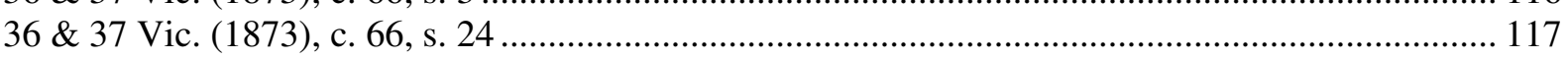

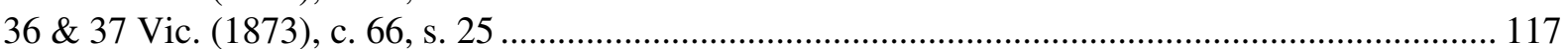

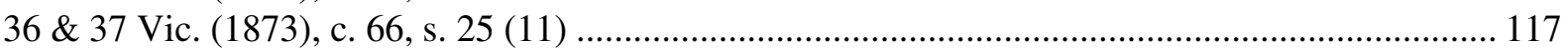

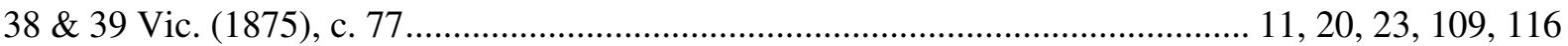

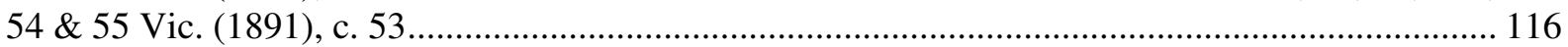

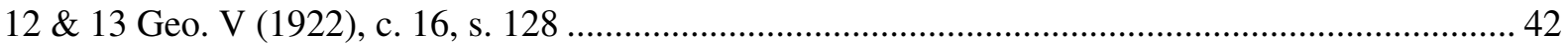

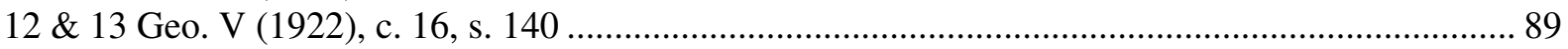

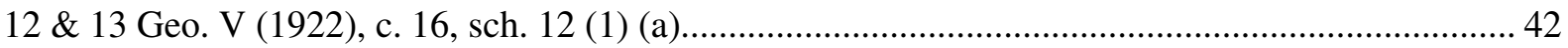

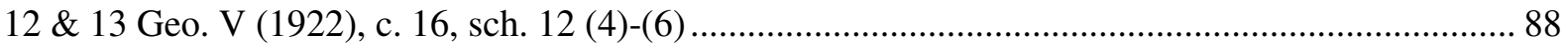

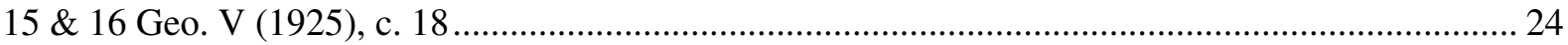

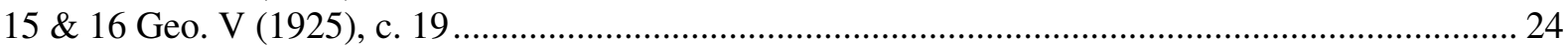

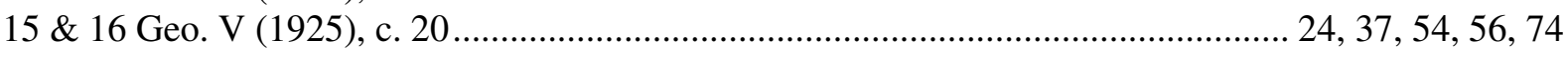

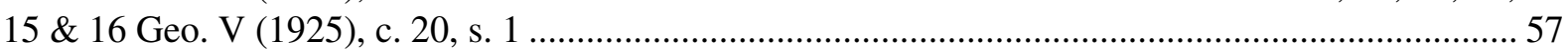

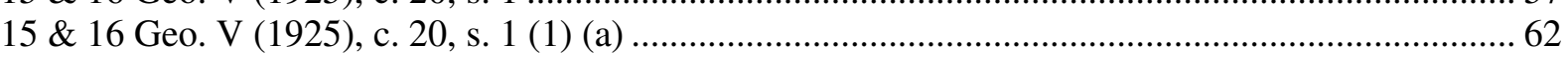

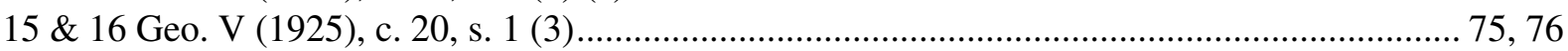

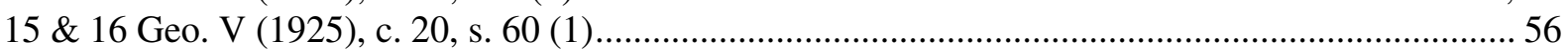

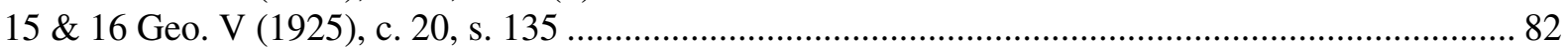

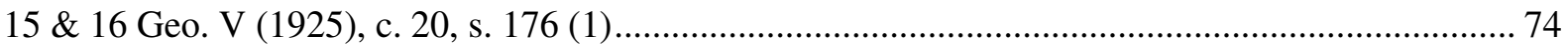

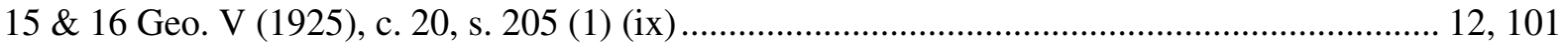

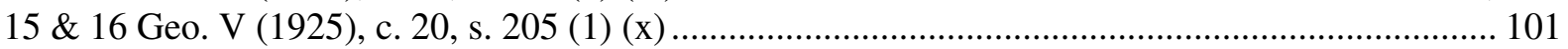

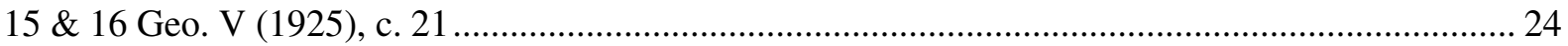

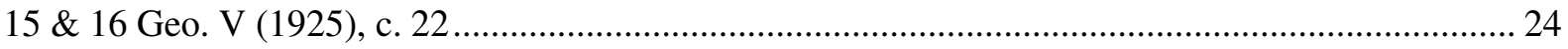

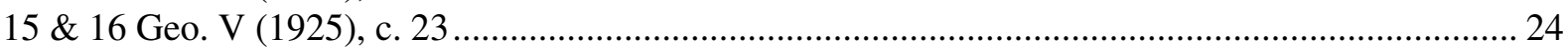

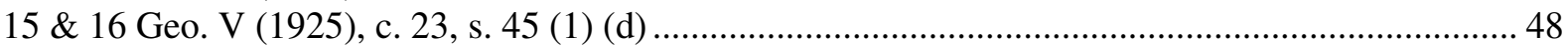

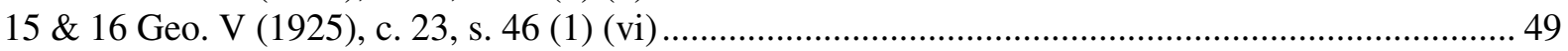

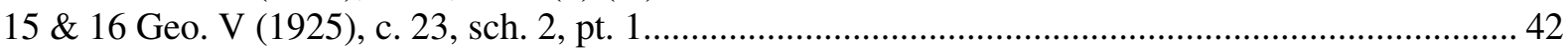

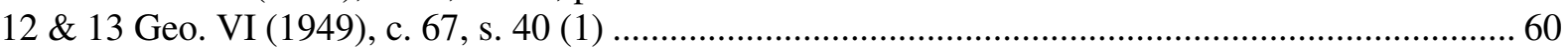

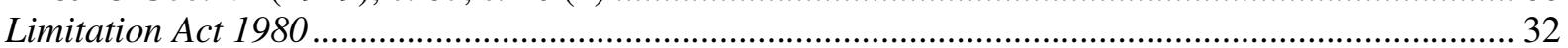

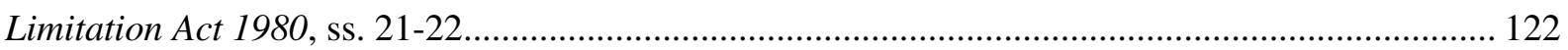

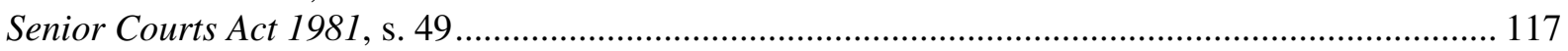

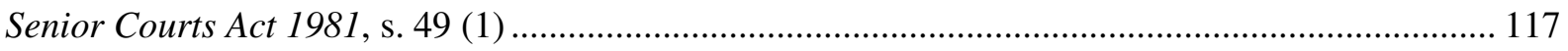

Trusts of Land and Appointment of Trustees Act 1996, sch. 1, s. 5 (1) - (2) ........................................ 75

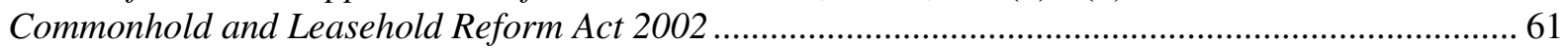

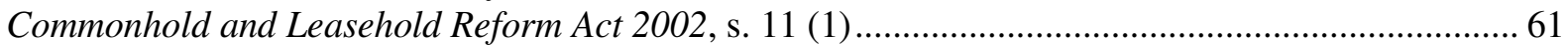

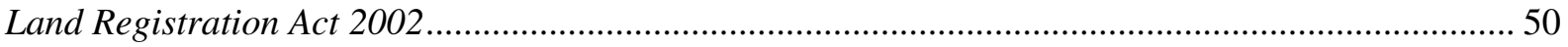




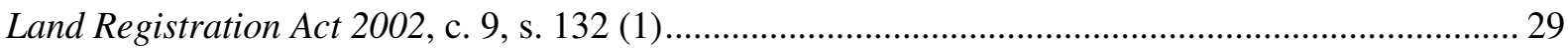

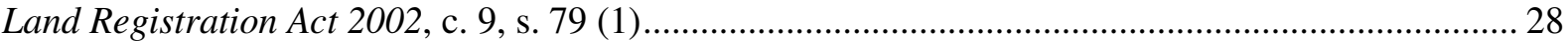

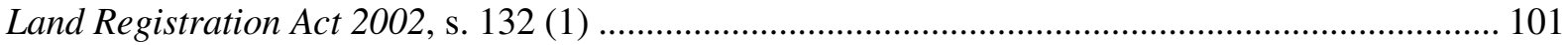

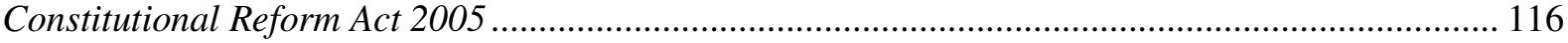

\section{b) Cases}

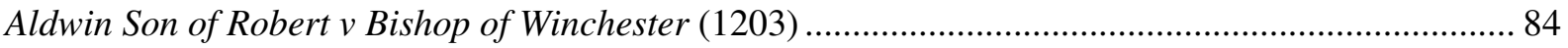

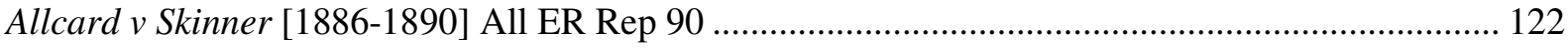

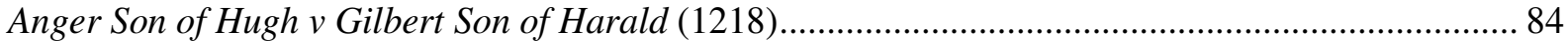

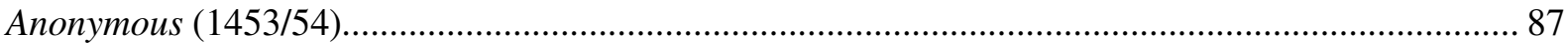

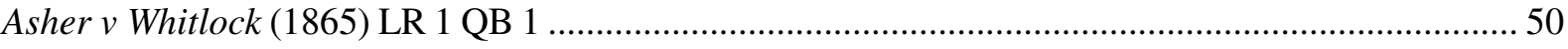

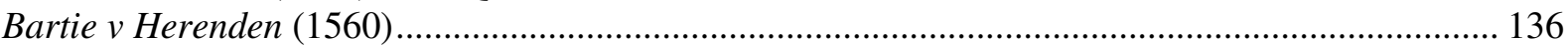

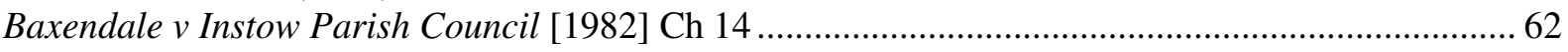

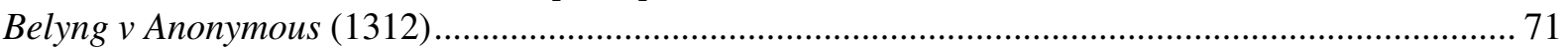

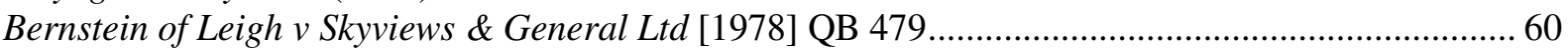

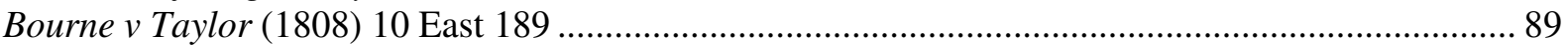

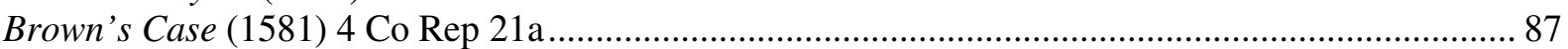

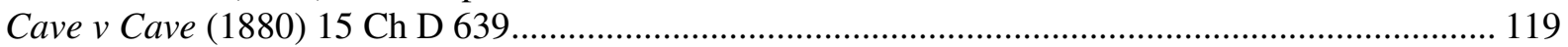

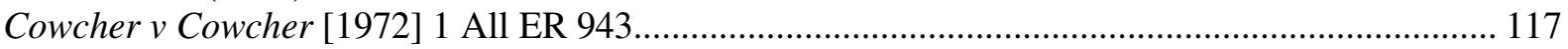

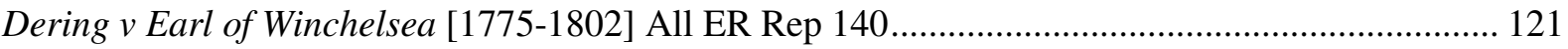

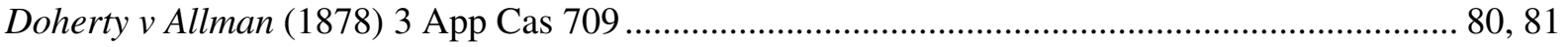

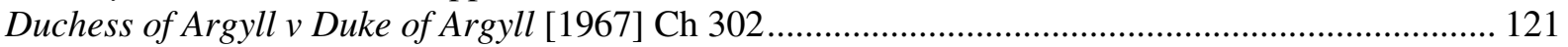

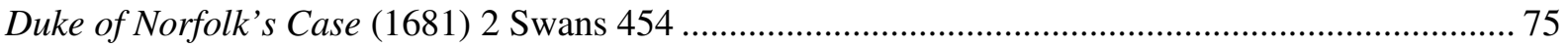

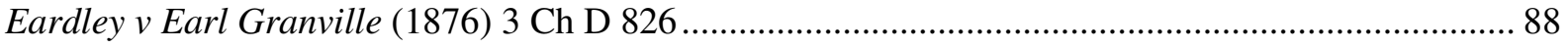

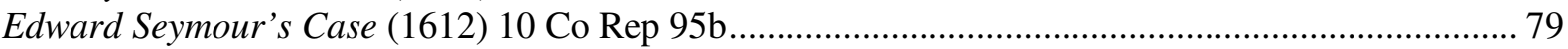

Esso Petroleum Co Ltd v Kingswood Motors (Addlestone) Ltd [1974] QB 142................................ 118

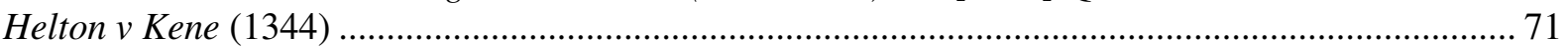

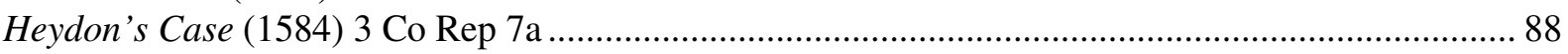

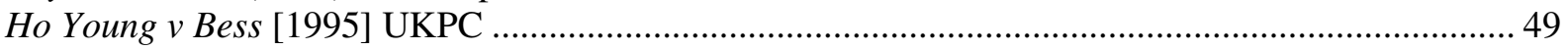

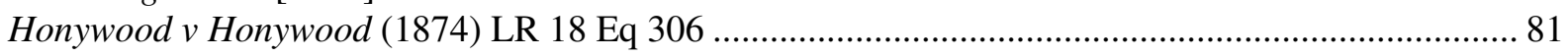

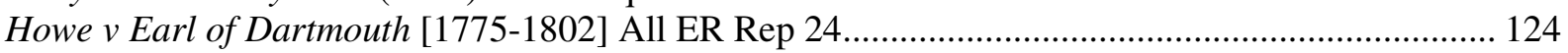

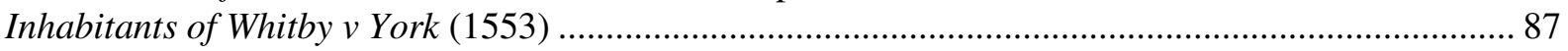

Latec Investments Ltd v Hotelr Terrigan Pty Ltd (1965) 113 CLR 265........................................... 120

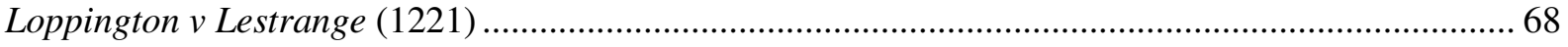

Lowe (Inspector of Taxes) v J W Ashmore Ltd [1971] Ch 545................................................... 16, 31

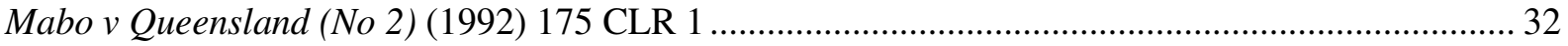

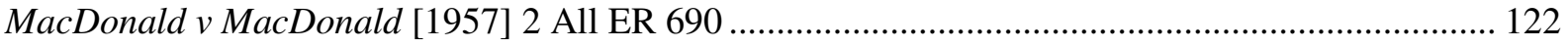

Mancetter Developments Ltd v Garmanson [1986] QB 1212 .................................................. 79, 81

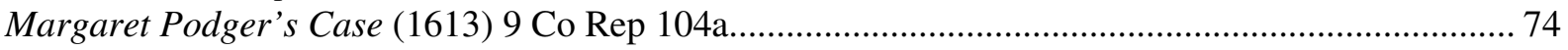

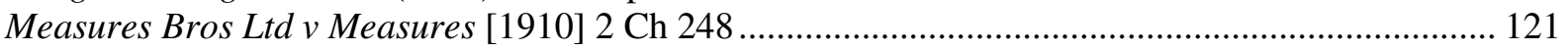

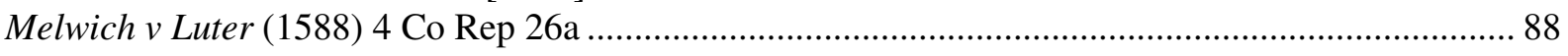

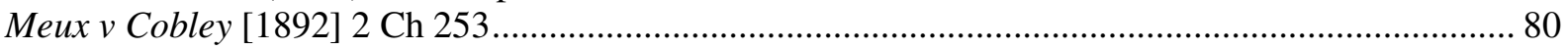

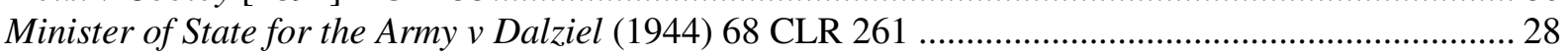

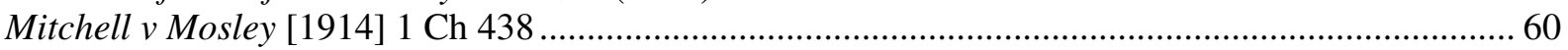

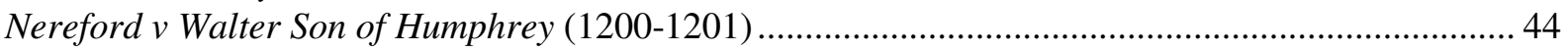

Nicholas Son of Norman v Hemfrid Serjeant of the Castellan of Bergues (1214) ............................... 84

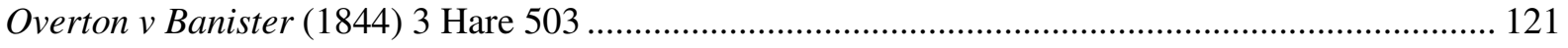

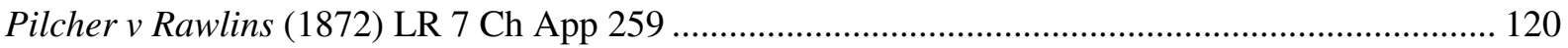

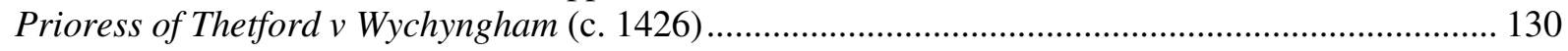

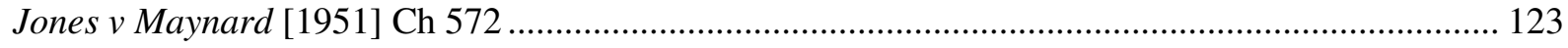

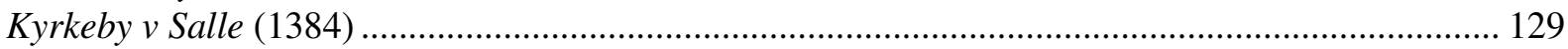

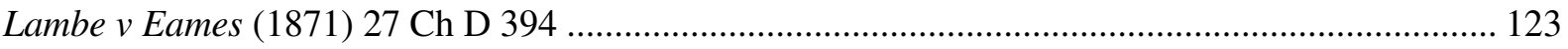




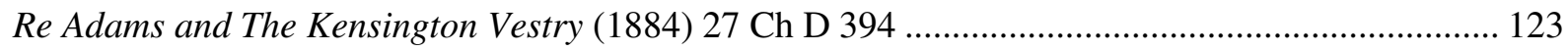

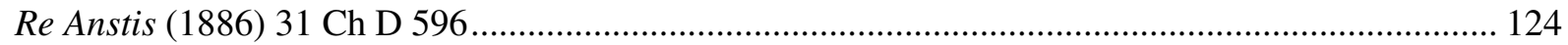

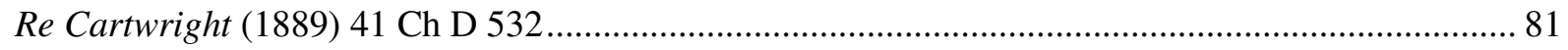

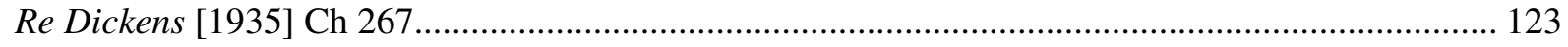

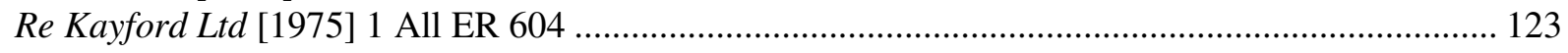

Re Trusts of the Scientific Investment Pension Plan [1998] 3 All ER 154 ......................................... 62

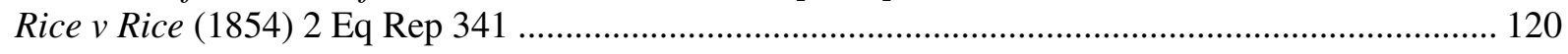

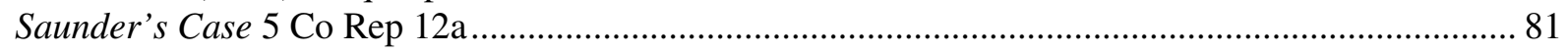

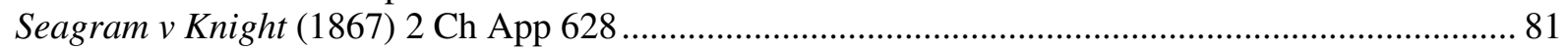

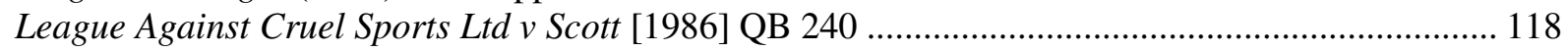

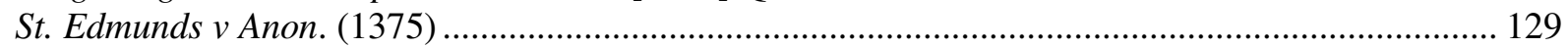

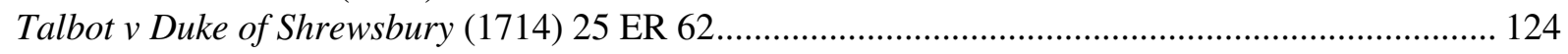

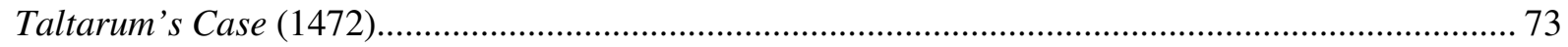

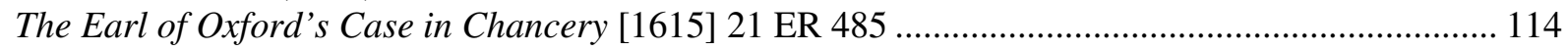

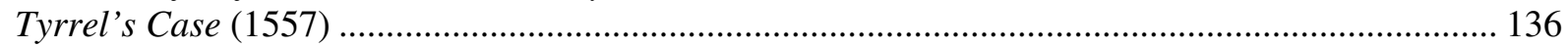

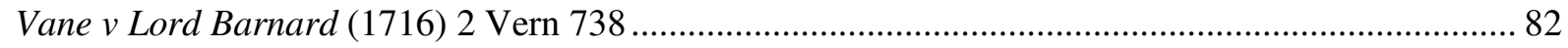

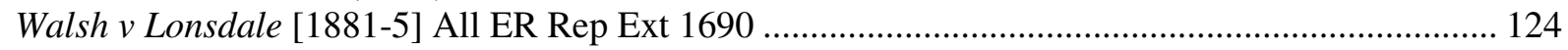

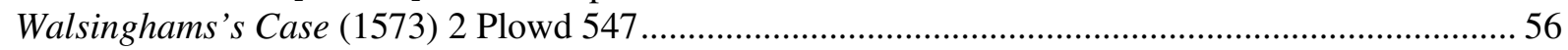

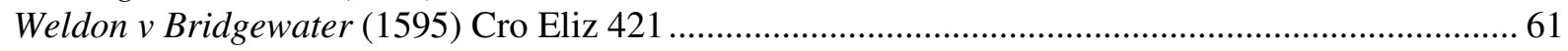

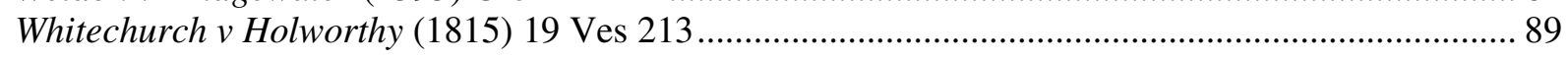

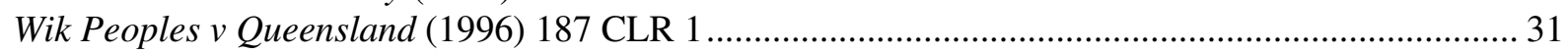

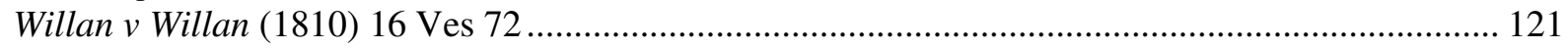

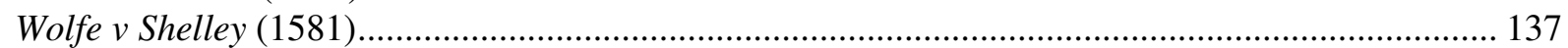

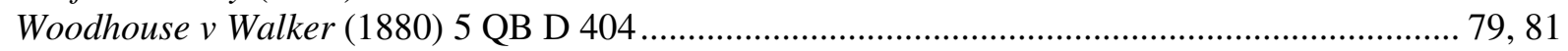

c) Books of Authority

\section{Blackstone - Commentaries on the Laws of England}

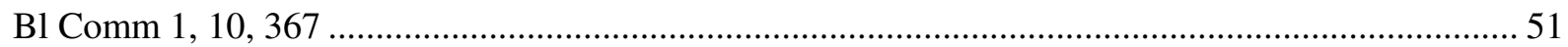

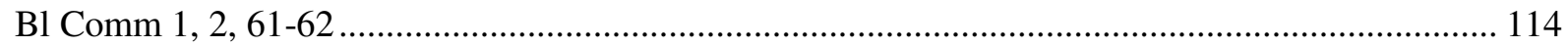

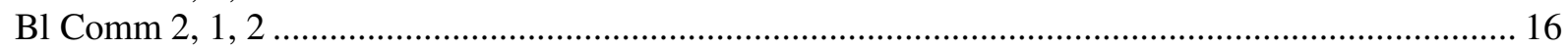

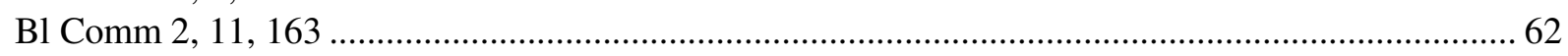

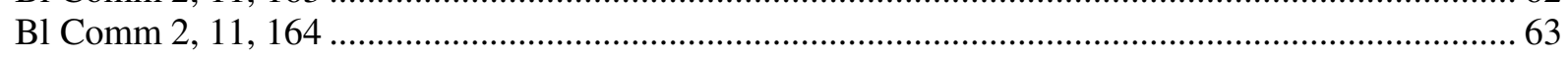

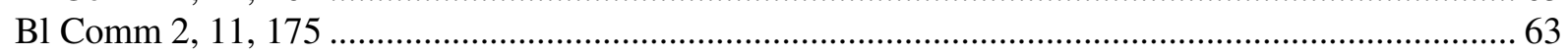

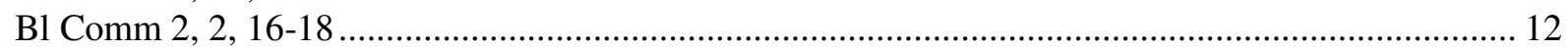

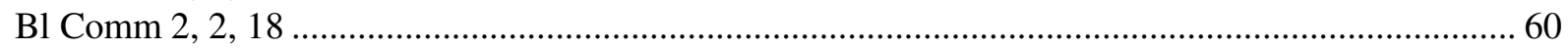

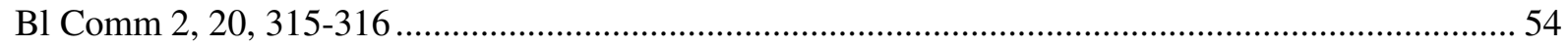

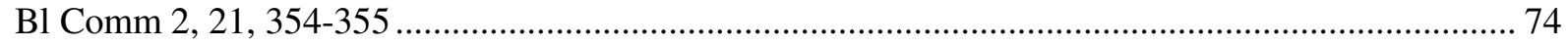

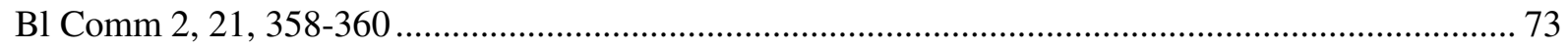

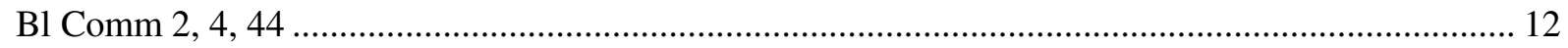

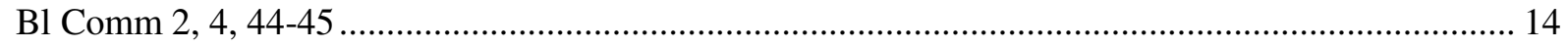

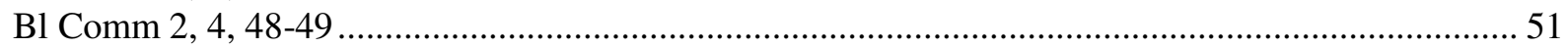

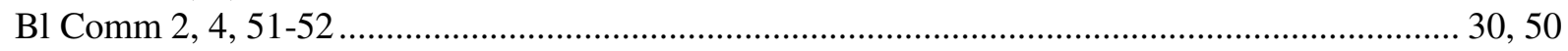

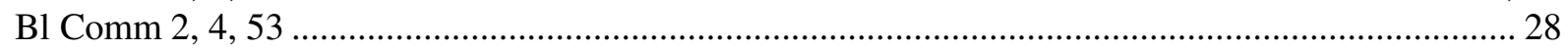

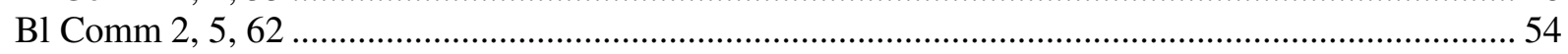

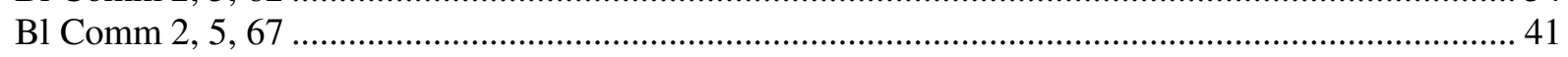

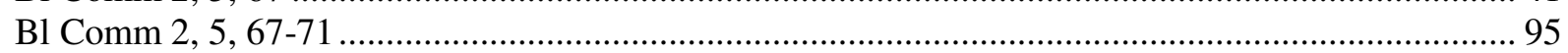

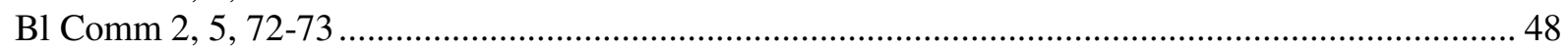

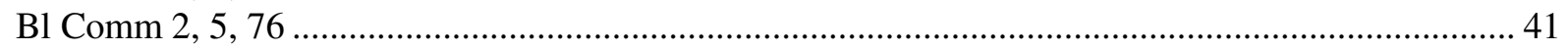

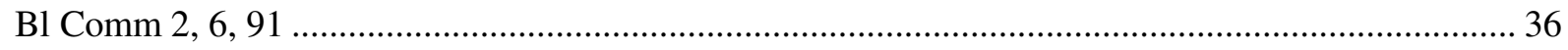

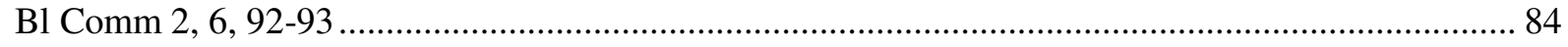

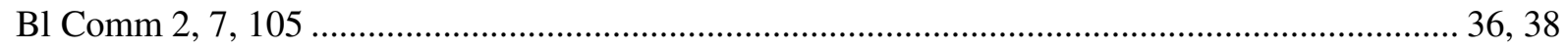


Bl Comm 2, 7, 116

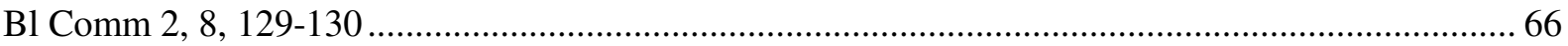

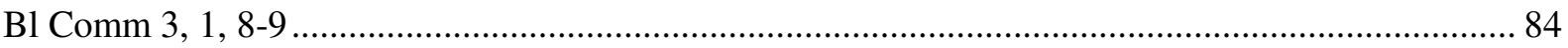

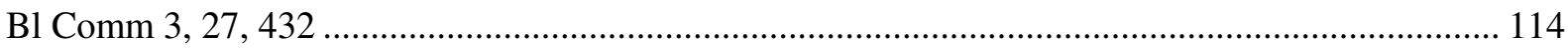

\section{Bracton - De legibus et consuetudinibus Angliae}

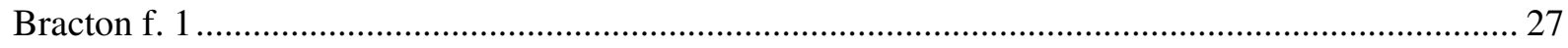

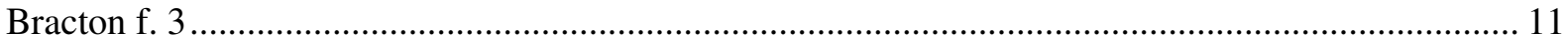

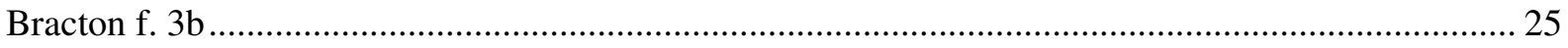

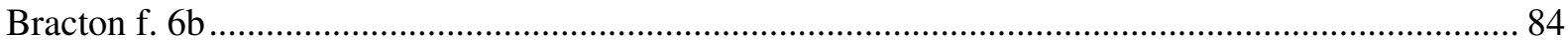

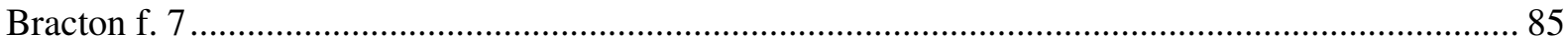

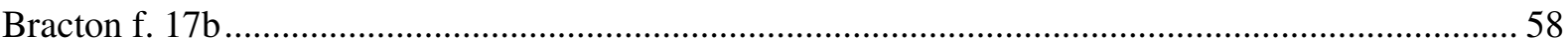

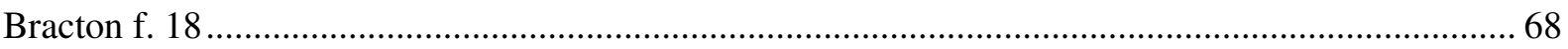

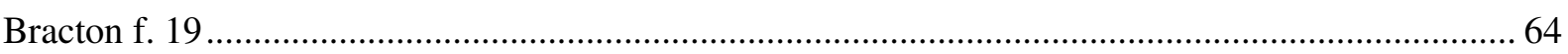

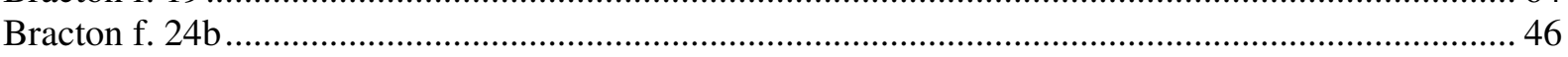

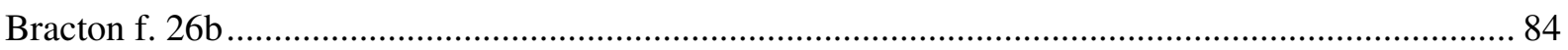

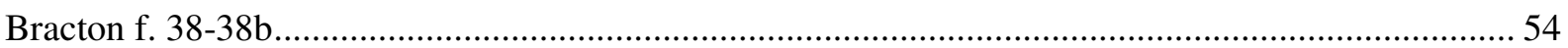

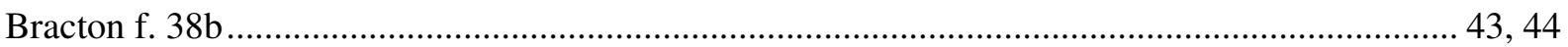

Bracton f. 38b-39

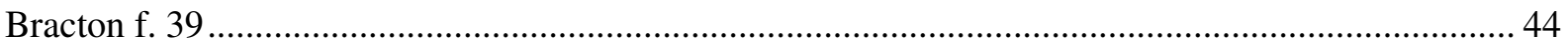

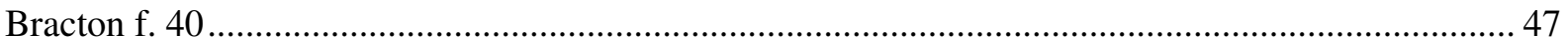

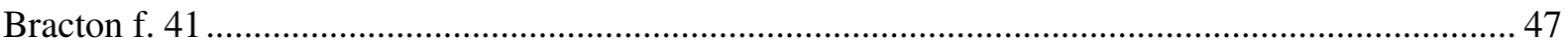

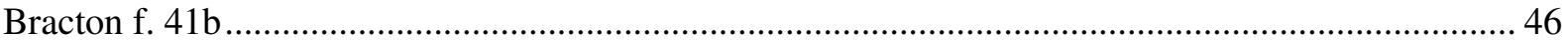

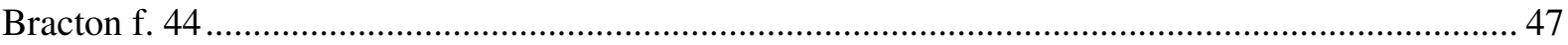

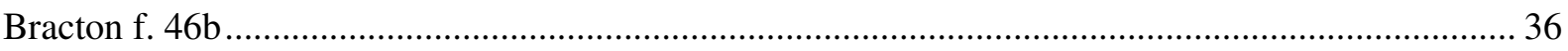

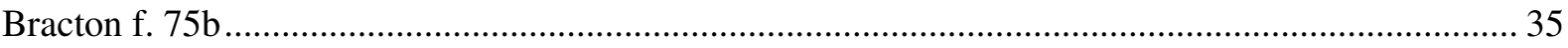

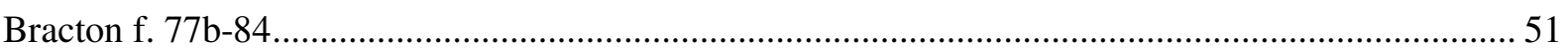

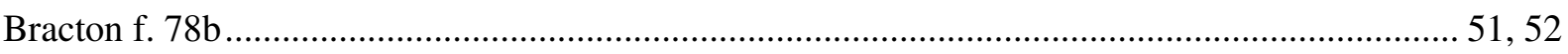

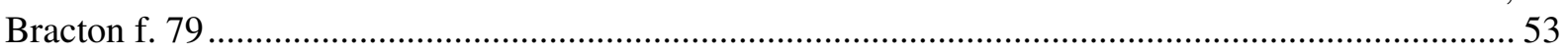

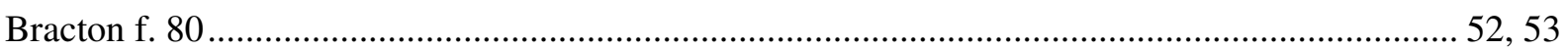

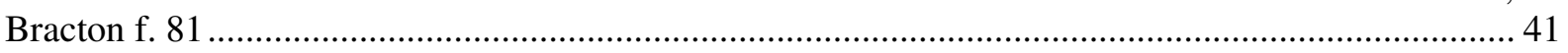

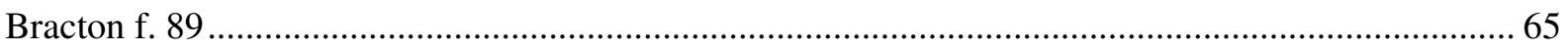

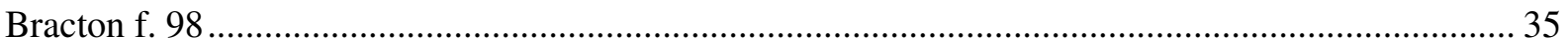

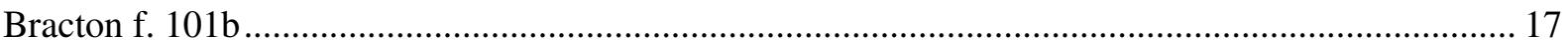

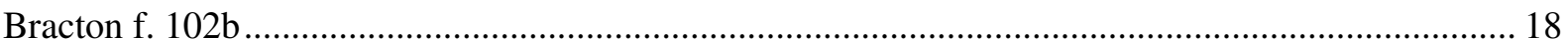

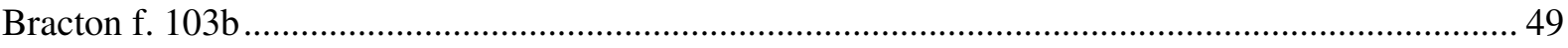

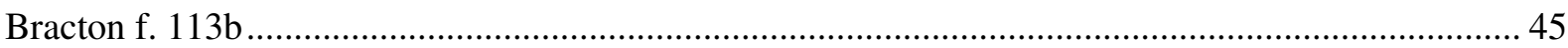

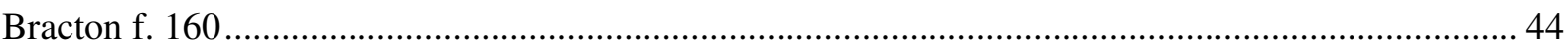

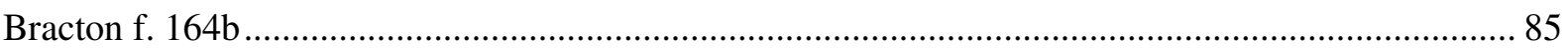

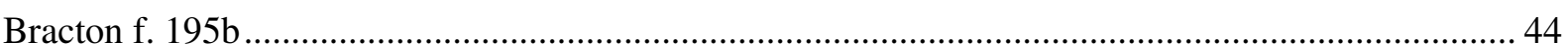

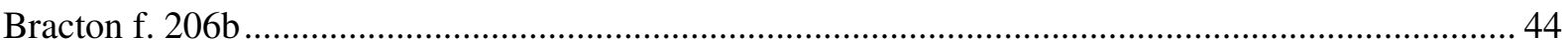

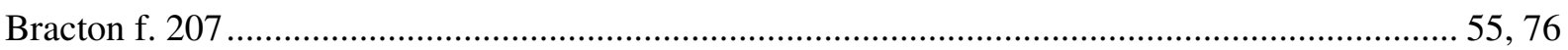

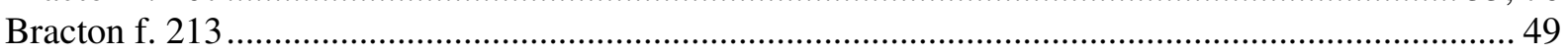

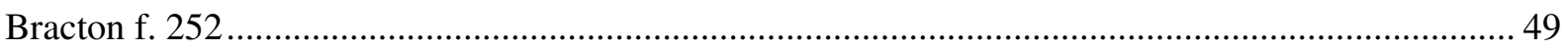

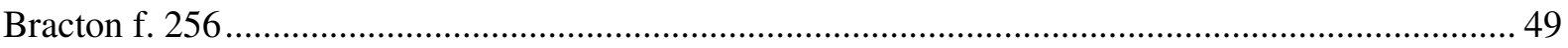

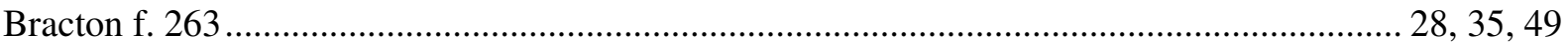

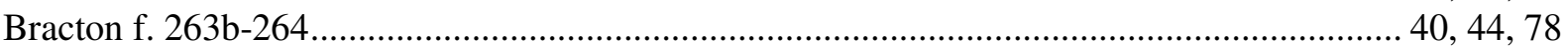

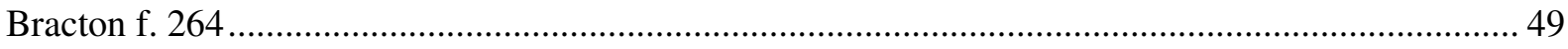

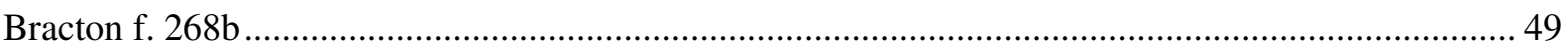

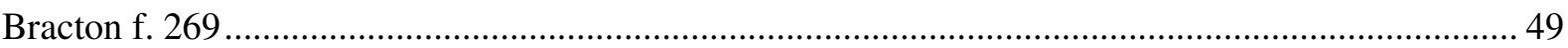

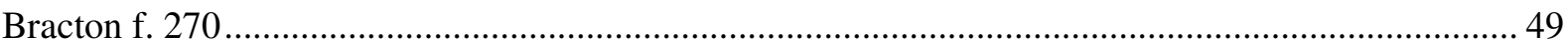

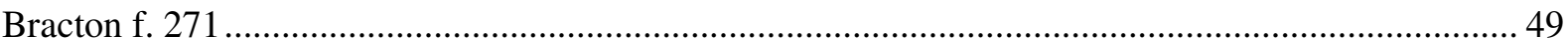




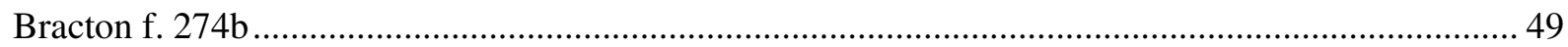

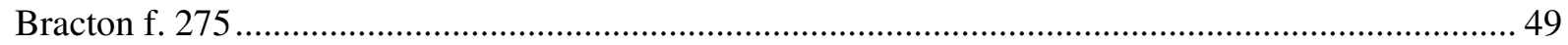

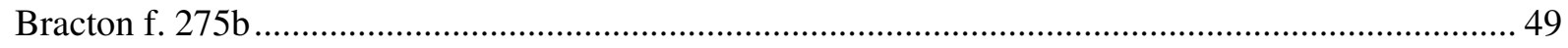

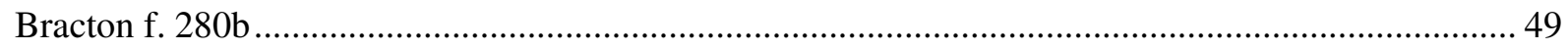

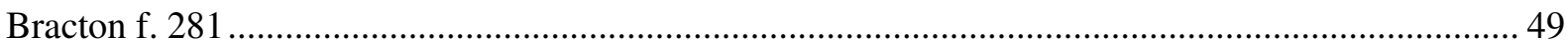

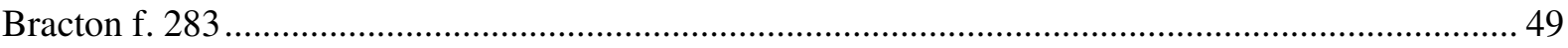

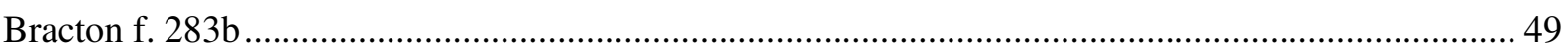

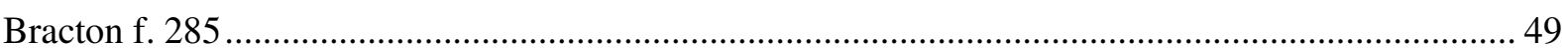

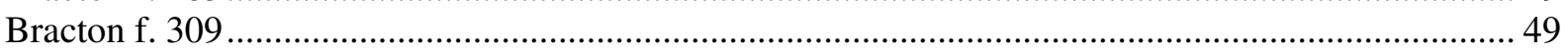

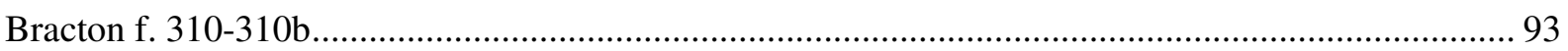

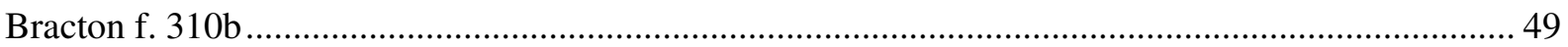

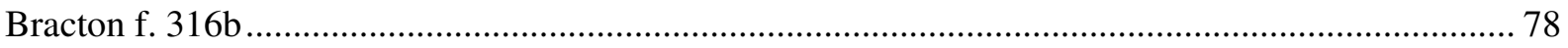

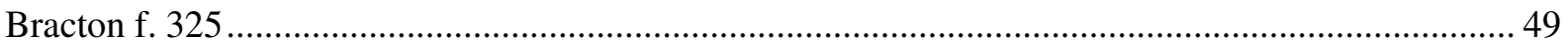

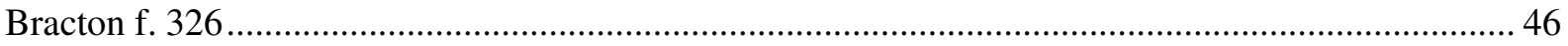

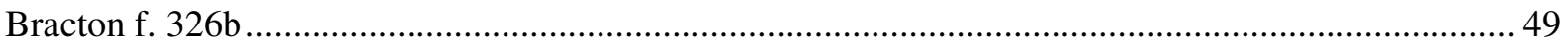

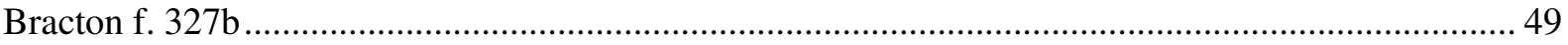

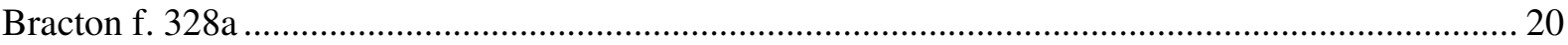

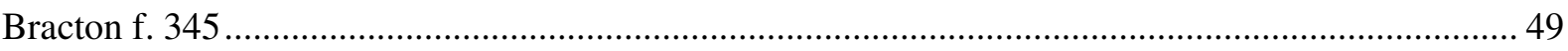

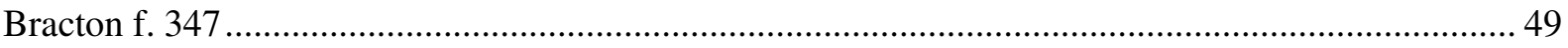

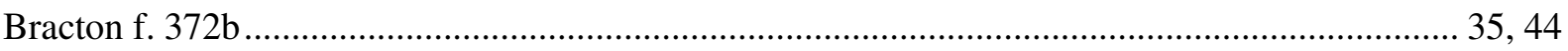

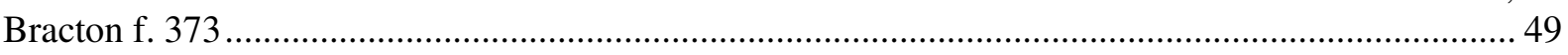

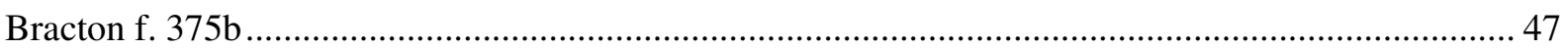

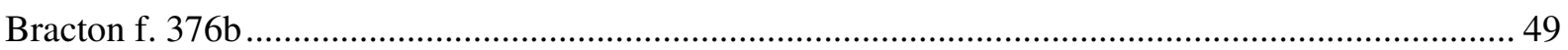

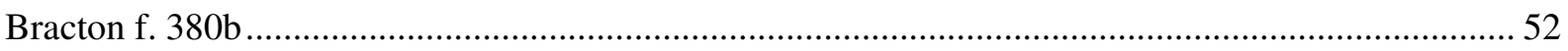

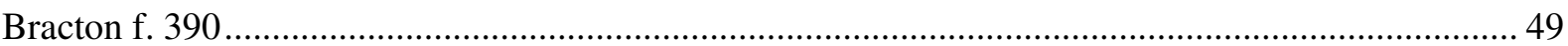

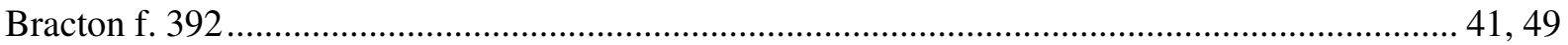

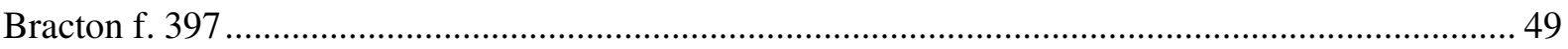

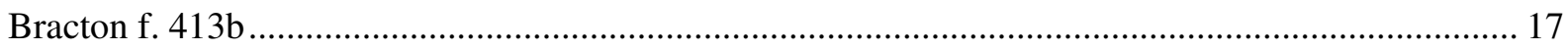

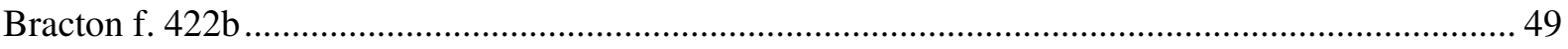

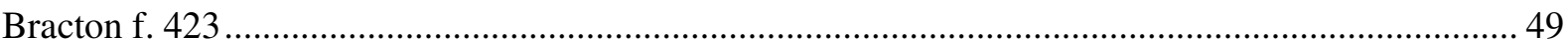

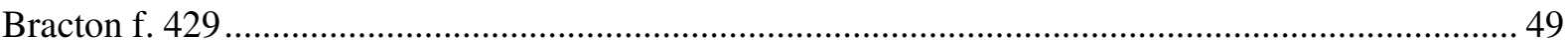

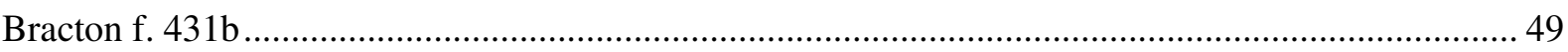

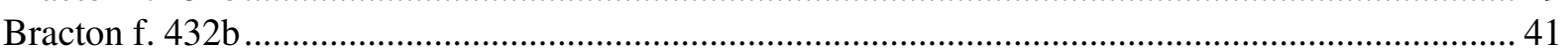

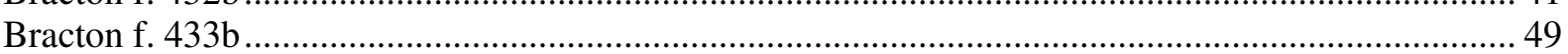

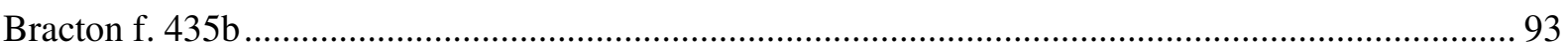

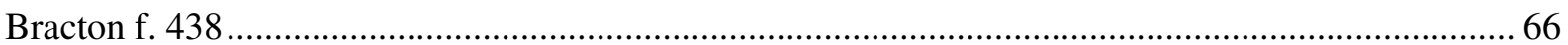

\section{Bracton's Note Book}

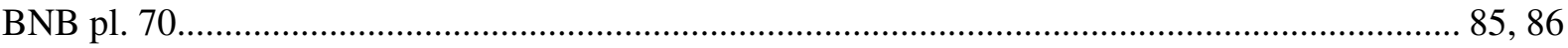

BNB pl. 88

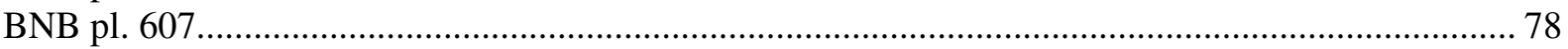

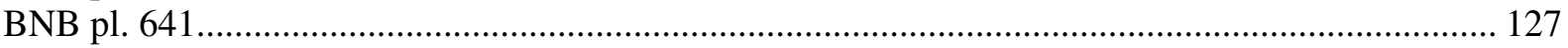

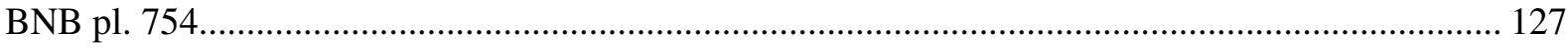

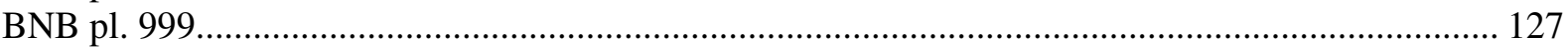

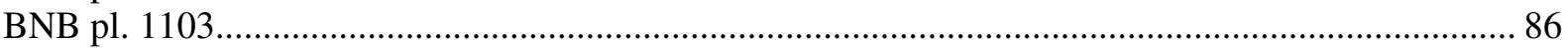

BNB pl. 1244

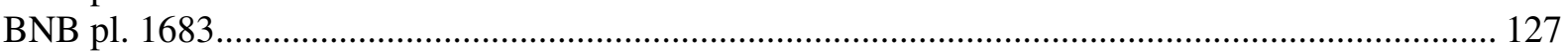

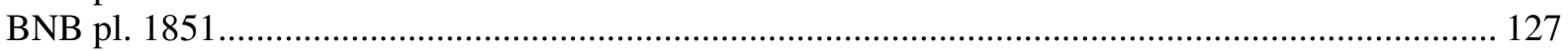

Coke - A Commentary upon Littleton 


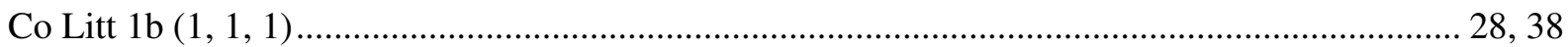

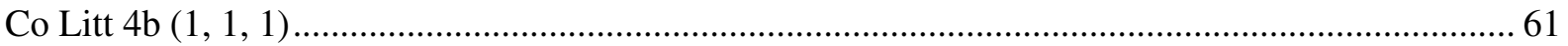

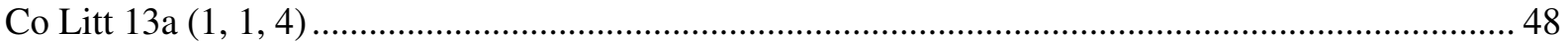

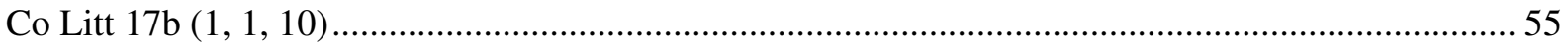

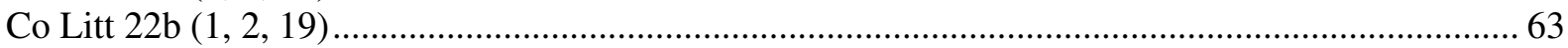

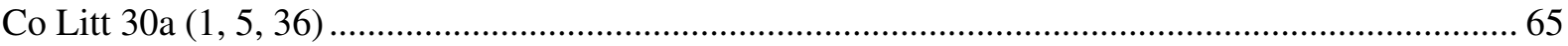

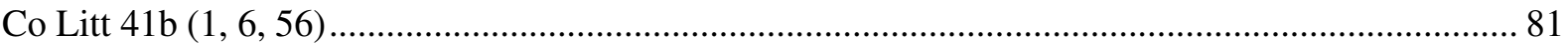

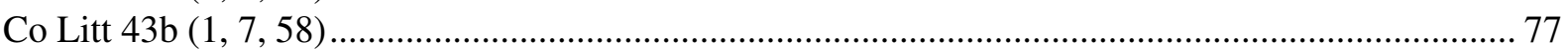

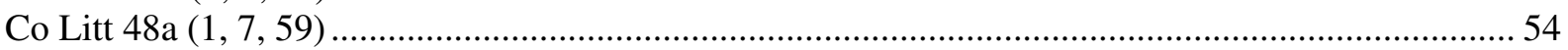

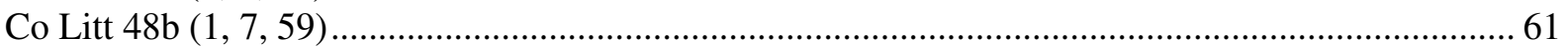

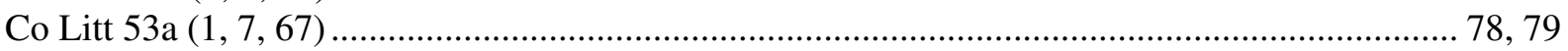

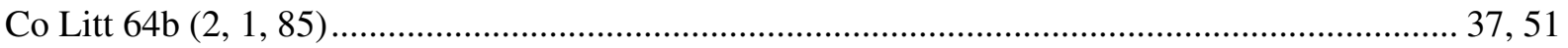

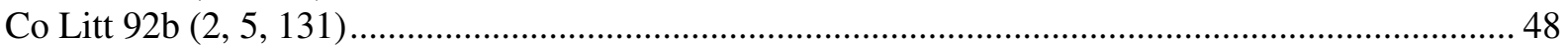

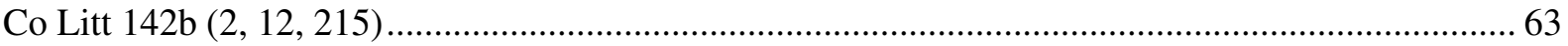

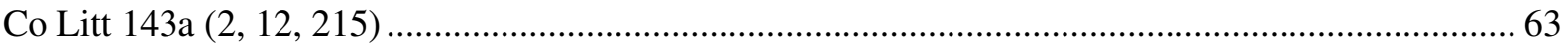

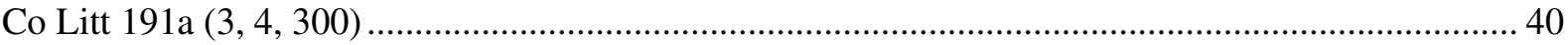

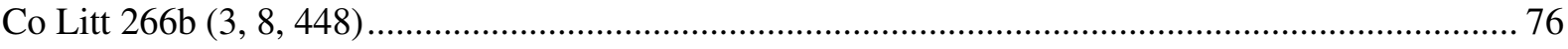

\section{Fleta seu Commentarius Juris Anglicani}

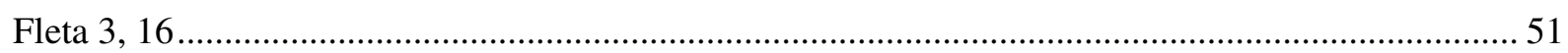

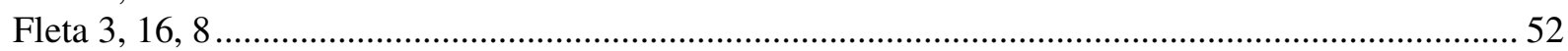

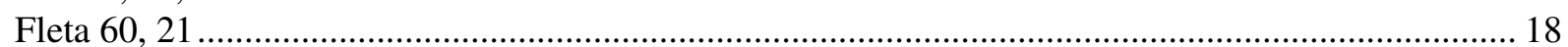

\section{Fortescue - De Laudibus Legum Angliae}

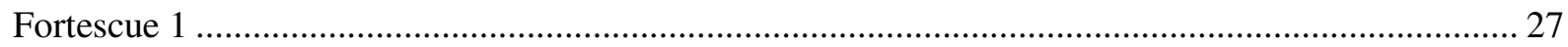

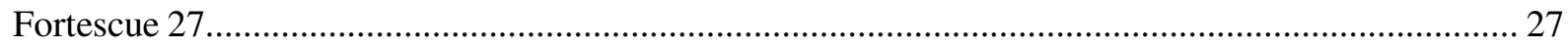

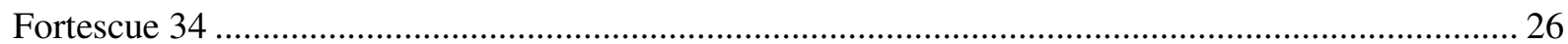

\section{Glanvill - Tractatus de legibus et consuetudinibus regni Angliae}

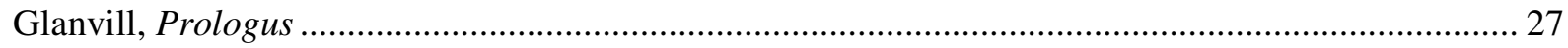

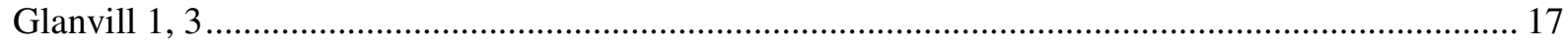

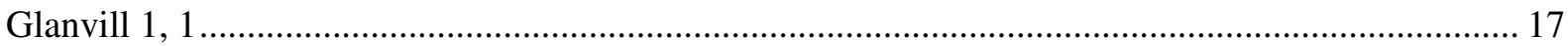

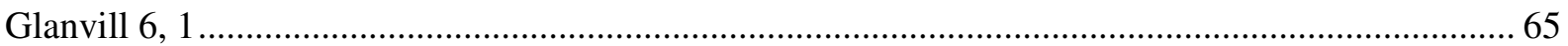

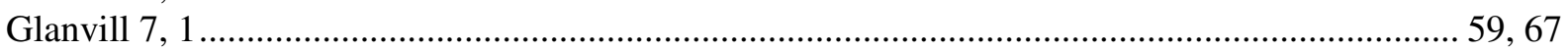

Glanvill 7, 18

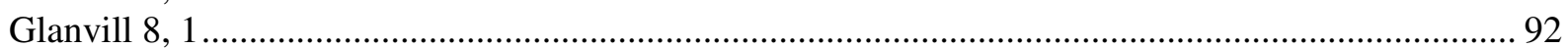

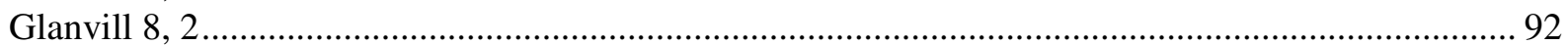

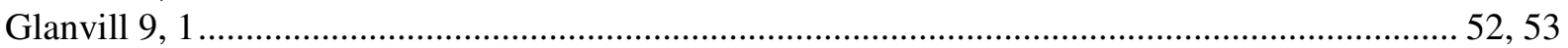

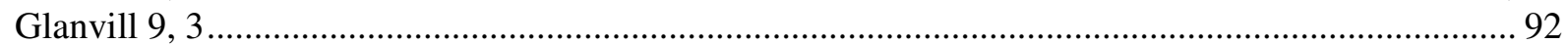

\section{Littleton - Tenores Novelli}

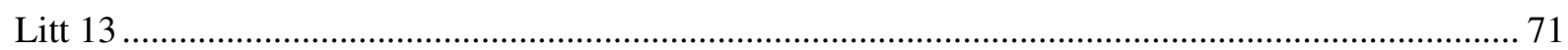

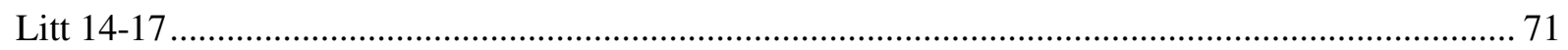

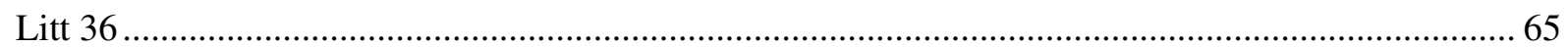

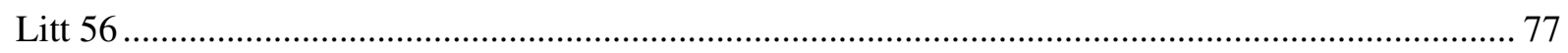

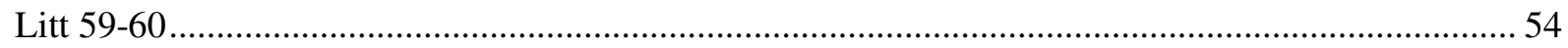




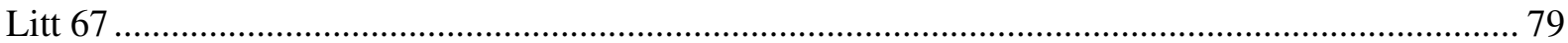

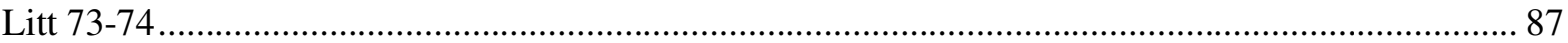

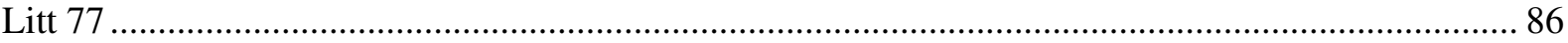

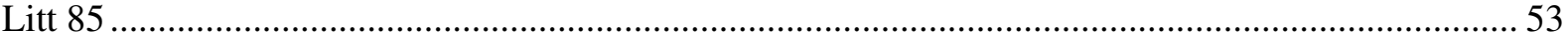

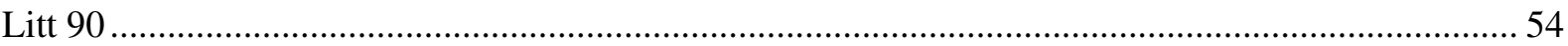

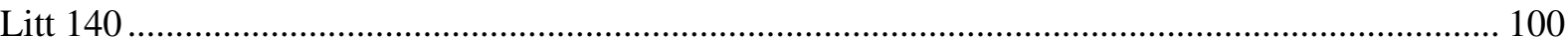

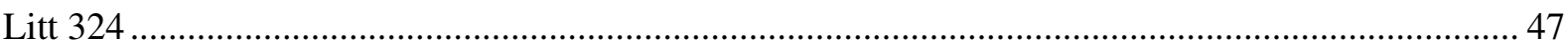

B. FONTES LITERARIAS E DOCUMENTAIS

\section{Codex Diplomaticus Aevi Saxonici}

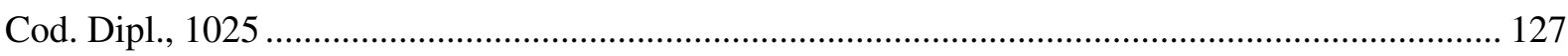

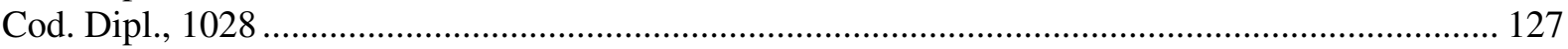

\section{Descriptive Catalogue of Ancient Deeds}

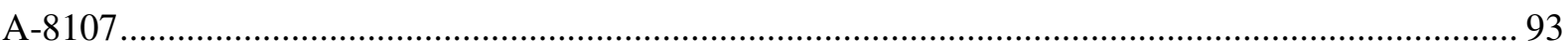

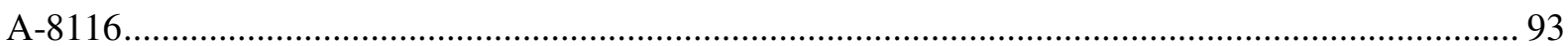

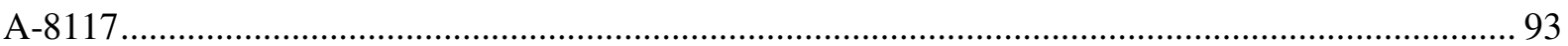

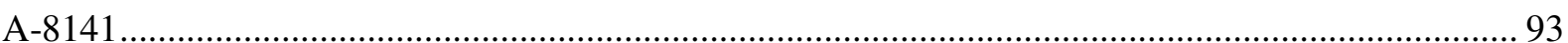

\section{Domesday Book}

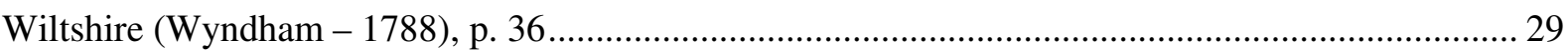

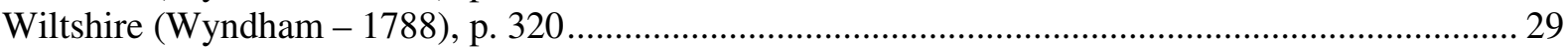

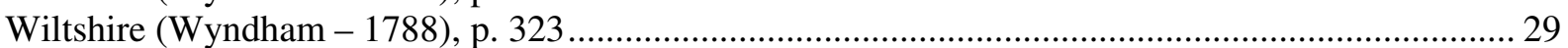

\section{Historia Ramesiensis}

Hist. Rames. c. 90

\section{Liber Feodorum - Testa de Nevill}

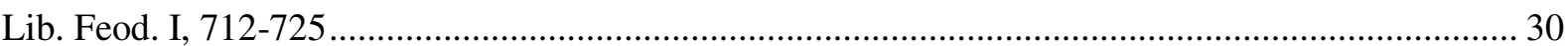

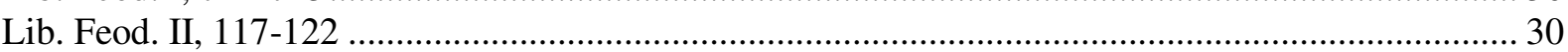




\section{FONTES ROMANAS}

A. FONTES JURÍDICAS

a) Fontes pré-justinianéias

\section{Gai institutiones}

Gai. 2, 24

\section{Pauli sententiae}

Pauli sent. 4, 1, 15

\section{b) Corpus Iuris Civilis}

\section{Proemium de confirmatione institutionum}

pr.

\section{Institutiones}

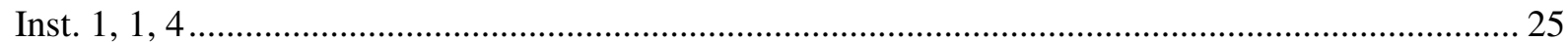

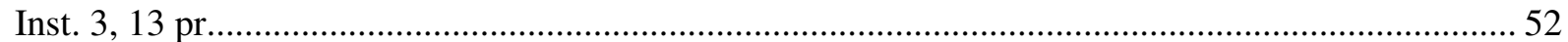

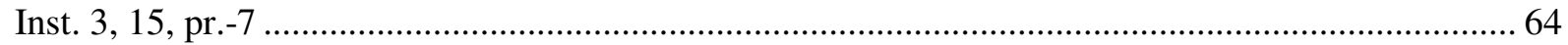

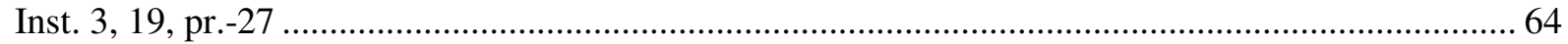

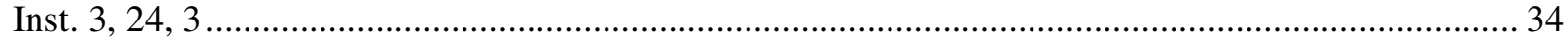

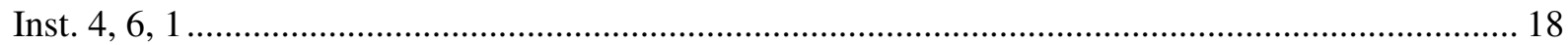

\section{Digesta}

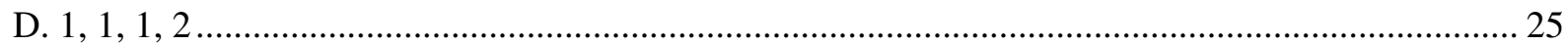

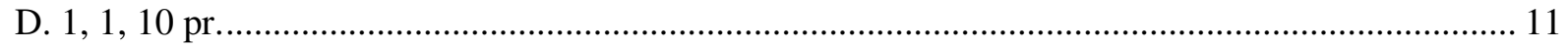

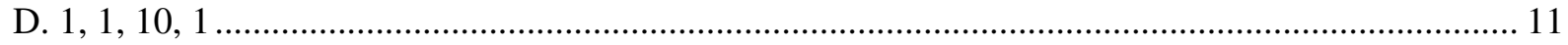

D. $1,1,11 \ldots \ldots$

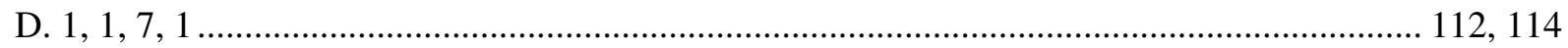

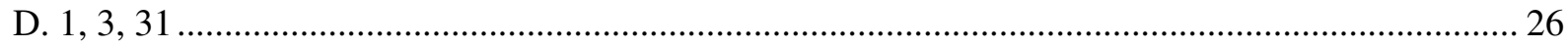

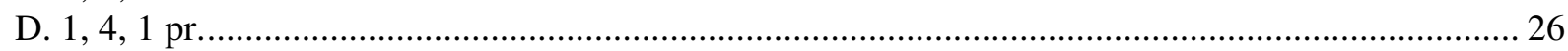

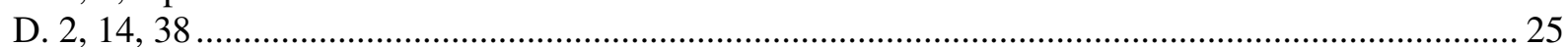

D. $2,15,1 \ldots \ldots \ldots$

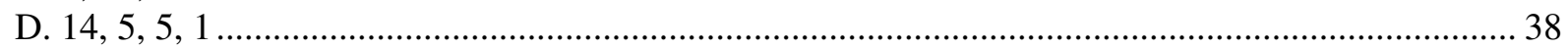

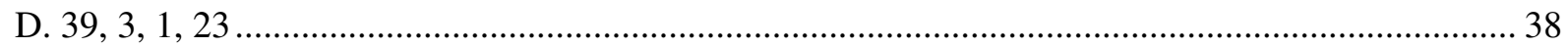

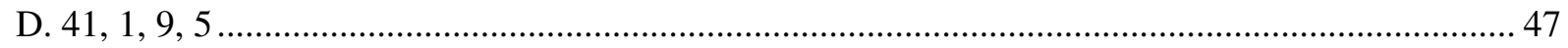




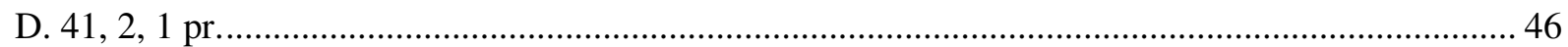

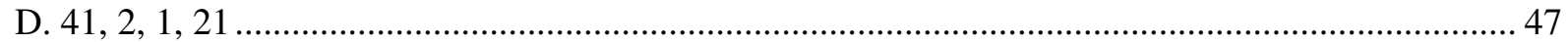

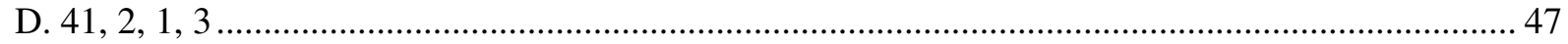

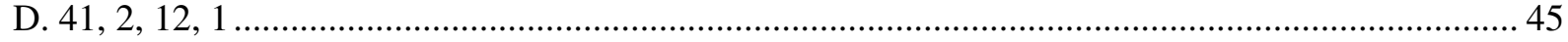

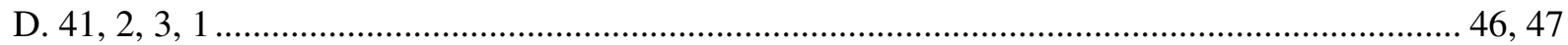

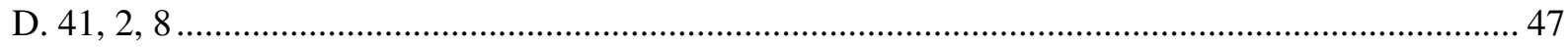

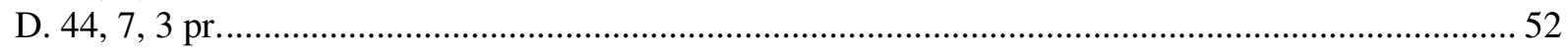

\section{Codex}

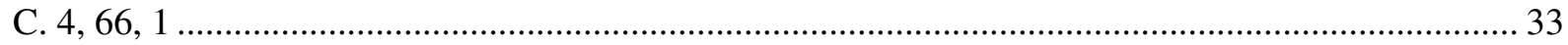

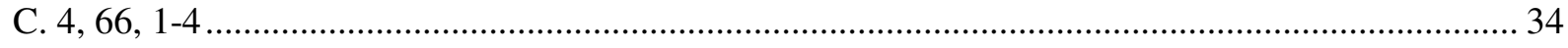

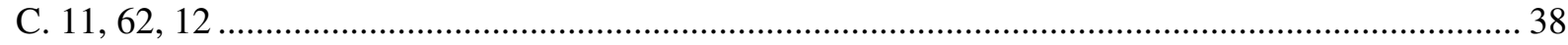

B. FONTES LITERARIAS

\section{Florus}

Epit.

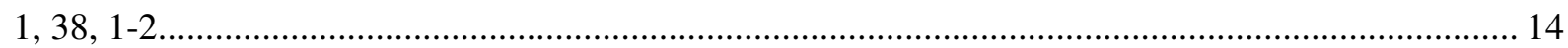

III. FONTES JURÍDICAS CONTINENTAIS INTERMÉDIAS

a) Monumenta Germaniae Historica

\section{Liber Papiensis}

Pappini 28 (30)

b) Bulas papais

Quo elongati (1230).

126

Ordinem vestrum (1245)

\section{FONTES JURÍDICAS NÃO INGLESAS MODERNAS}

A. NACIONAIS 


\section{Alemanha}

CC

$\S 903$ BGB.

\section{Brasil}

CC

artigo 1.228

14

artigo 1.919 , caput.

\section{Espanha}

CC

artigo 348

\section{França}

$C C$

artigo 544

\section{Itália}

CC

artigo 832

Lei $n^{\circ} 364 / 1989$

artigo 11

B. INTERNACIONAIS

\section{Draft Common Frame of Reference}

artigo VIII.-1:202..

\section{Convenção da Haia de 1985}


$\operatorname{artigo} 1^{\circ}$ 


\section{BIBLIOGRAFIA}

(somente das obras consultadas)

A Collection of the Public General Statutes Passed in the Second and Third Year of the Reign of Her Majesty Queen Victoria, London, Richards \& Co., 1839.

A Collection of the Public General Statutes Passed in the Third and Fourth Year of the Reign of His Majesty King William the Fourth, London, Richards \& Co., 1833.

ASHBURNER, Walter, Principles of Equity, London, Butterworth, 1902.

BACON, Francis, The Learned Reading of Sir Francis Bacon, One of Her Majefties Learned Coufell at Law, upon the Statute of Uses, London, Matthew Walbancke \& Laurence Chapman, 1642.

BAKER, John Hamilton e MiLsOM, Stroud Francis Charles, Sources of English History:

Private Law to 1750, $2^{\mathrm{a}}$ ed., Oxford, Oxford University, 2010.

BAKER, John Hamilton, An Introduction to English Legal History, 4a ed., Oxford, Oxford University, 2002.

BAKER, John Hamilton, The Common Law Tradition, London, Hambledon, 2000.

Bar, Christian e Clive, Eric, Principles, Definitions and Model Rules of European Private Law, vol. V, München, Sellier, 2009.

BASEDOw, Jürgen, Hopt, Klaus e ZimMERMAnn, Reinhard, The Max Planck Encyclopedia of European Private Law, vols. I-II, Oxford, Oxford University, 2012.

BEAmES, John, A Translation of Glanville, Washington, John Byrne \& Co., 1900.

Beamont, William, A Literal Extension and Translation of the Portion of the Domesday Book Related to Cheshire and Lancashire, London, Vacher \& Sons, 1863.

BeAvan, Charles, Reports of Cases in Chancery, vols. I-XXXVI [1838-1866], London, Saunders \& Benning., 1840-1869.

Bellomo, Manlio, L'Europa del diritto commune, 1988, trad. ing. de Cochrane, Lydia G., The Common Legal Past of Europe, Washington, Catholic University, 1995.

BENNET, William Heath et al., The Equity Reports, vols. I-III [1853-1855], London, Benning \& Co., 1853-1855. 
Bentham, Jeremy, Bentham's Draught for the Organization of Judicial Establishments Compared with that of the National Assembly with a Commentary on the Same, in J. BowrING, The Works of Jeremy Bentham, vol. IV, Edinburgh, Simpkin Marshall \& Co., 1843, pp. 3-594.

BERGER, Adolf, Encyclopedic Dictionary of Roman Law, in Transactions of the American Philosophical Society, 43 (1953), pp. 333-809.

Biancalana, Joseph, Medieval Uses, in R. Helmholz e R. Zimmermann (org.), Itinera Fiduciae: Trust and Treuhand in Historical Perspective, Berlin, Duncker \& Humblot, 1998, pp. 111-152.

Biancalana, Joseph, The Fee Tail and the Common Recovery in Medieval England - 11761502, Cambridge, Cambridge University, 2001.

Black, Henry Campbell, A Law Dictionary, 2a ed., Saint Paul, West Publishing, 1910.

Blackstone, William, Commentaries on the Laws of England, vols. I-IV, Oxford, Clarendon, 1768-1770.

Bloch, Marc, La société féodal (1939), Paris, Pierre Palpant, 2005 [=L'évolution de l'Humanité, vols. XXXIV-XXXIVbis, Paris, Albin Michel, 1982].

Bonfante, Pietro, Istituzioni di diritto romano, 10ª ed., Torino, Giappichelli, 1946.

Boswell, James, The Life of Samuel Johnson, vol. II, London, National Illustrated Library, 1851.

BRYCE, James, Studies in History and Jurisprudence, Oxford, Oxford University, 1901.

BuCKLAND, William Warwick e MCNAIR, Arnold Duncan, Roman Law and Common Law A Comparison in Outline, Cambridge, Cambridge University, 1936.

BucKland, William Warwick, A Textbook of Roman Law, Cambridge, Cambridge University, 1921.

Burdick, William L., The Principles of Roman Law and Their Relation to Modern Law, Rochester, Lawyer's Cooperative, 1938.

BURRILL, Alexander Mansfield, A New Law Dictionary, vols. I-II, New York, John Voorhies, 1850-1851.

CaEnegem, Raoul Charles, The Birth of the English Common Law, Cambridge, Cambridge University Press, 1997.

CAPOgrossi Colognesi, Luigi, s.v. Proprietà (dir. rom.), in ED 37 (1988), pp. 160-226. 
CARr, Cecil Thomas, The General Principles of the Law of Corporations, Cambridge, University Press, 1905.

CHALlis, Henry William, Law of Real Property, $3^{\mathrm{a}}$ ed., London, Butterworth, 1911.

CHAMBers, Charles Harcourt, A Treatise on Leases and Terms for Years, London, Strahan, 1819.

CoING, Helmut, Europäisches Privatrecht - Älteres Gemeines Recht (1500 bis 1800), t. I, München, Beck, 1985.

COKE, Edward, The First Part of the Institutes of the Laws of England or A Commentary Upon Littleton, 1628, vols. I-II, anot. e coment. por HARGRAVE, Francis e BUTLER, Charles, $19^{\mathrm{a}}$ ed., Philadelphia, Small, 1853.

CoKE, Edward, The Reports of Sir Edward Coke, vols. I-VI, [1572-1616], London, Butterworth, 1826.

CoKE, Edward, The Second Part of the Institutes of the Laws of England, London, Brooke, 1797.

CRISCUOLI, Giovanni, Introduzione allo studio del diritto inglese - le fonti, $3^{\mathrm{a}}$ ed., Milano, Giuffrè, 2000.

CROKE, George, Reports of Sir George Croke Kinght Formerly One of the Justices of the Courts of King's Bench and Common Pleas of Such Select Cases as Were Adjudged in the Said Courts During the Reign of Queen Elizabeth, vols. I-II [1582-1603], London, Brooke \& Whieldon, 1790.

CUIACIUS, Iacobus, Iacobi Cuiacii i.c. praestantissimi operum postumorum quae iure reliquit, t. II, Lvtetiæ Parisiorvm, 1658.

Cunningham, William, The Growth of English Industry and Commerce in Modern Times, Cambridge, Cambridge University, 1892.

DAVID, René, Les grands systèmes du droit contemporains, $3^{\mathrm{a}}$ ed., Paris, Dalloz, 1969.

DAVID, René, Les grands systèmes du droit contemporains, trad. port. de Carvalho, Hermínio A., Os Grandes Sistemas de Direito Contemporâneo, $4^{\mathrm{a}}$ ed., São Paulo, Martins Fontes, 2002.

Dawson, John P., Coke and Ellesmere Disinterred: The Attack on the Chancery in 1616, in Illinois Law Review of Northwestern University, 36 (1941), pp. 127-152.

Diderot, Denis e D’Alembert, Jean le Rond, Encyclopédie, vol. V, Paris, Briasson et al., 1755.

Digby, Kenelm Edward, An Introduction to the History of the Real Property, $5^{\mathrm{a}}$ ed., Oxford, Clarendon, 1897. 
Dinamarco, Cândido Rangel, Instituições de Direito Processual Civil, vol. I, $5^{\text {a }}$ ed., São Paulo, Malheiros, 2005.

DoDDs, Madeleine Hope e DoDDS, Ruth, The Pilgrimage of Grace 1536-1537 and The Exeter Conspiracy, vol. I, Cambridge, Cambridge University, 1915.

Du CANGE, Charles du Fresne, Glossarium mediae et infimae latinitatis (1678), Niort, Favre, vols. I-X, 1883-1887.

EAST, Edward Hyde, Reports of Cases Argued and Determined in the Court of King's Bench, vols. I-XVI [1800-1812], London, Butterworth, 1801-1814.

ELLIS, Henry, A General Introduction to Domesday Book, vol. I, s.l., Public Records Commissioners, 1833.

EPSTEIN, Richard Allen, Past and Future - The Temporal Dimension in the Law of Property, in Washington University Law Review, 64 (1986), pp. 667-722.

EVERARDUS, Nicolaus, Loci argumentorum legales, Venetia, Nicolinum, 1567.

Finlason, William Francis, The Common Law Procedure Acts of 1852, 1854 and 1860, London, Stevens \& Sons, 1860.

FitZHERBERT, Anthony, The New Natura Brevium, $8^{\mathrm{a}}$ ed., London, Savoy, 1755.

FITZNigEL, Richard, De necessariis observantiis scaccarii dialogus, edit. por HuGHES, Arthur, CRumP, Charles George e Johnson, Charles, Oxford, Clarendon, 1902.

Fleta seu Commentarius Juris Anglicani (c. 1290), 2ª ed., London, 1685.

FORSYTH, William, History of Trial by Jury, London, Parker and Son, 1852.

ForTESCUE, John, De laudibus legum Angliae (1470), trad. ao ing. de Amos, Andrew, De laudibus legum Angliae - The Translation into English, Cambridge, Smith, 1825.

FRANCESCHELLI, Remo, Il trust nel diritto inglese, Padova, CEDAM, 1935.

FRANCIS, Richard, Maxims of Equity - Collected From and Proved by Cases Out of the Books of the Best Authority in the High Court of Chancery, to Which is Added the Case of the Earl of Coventry, in HENING, William Walter, Maxims in Law and Equity, Richmond, Shepherd and Pollard, 1823, pp. 2-87.

FRYDE, Edmund Boleslaw et al., Handbook of British Chronology, $3^{\mathrm{a}}$ ed., Cambridge, Cambridge University, 1986.

Gale, Thomas, Historiae Britannicae, Anglicanae, Saxonicae, Anglo-Danicae, Scriptores $X V$, vol. I, Oxford, 1691. 
García Del Corral, Ildefonso L., Cuerpo del Derecho Civil Romano, vols. I-VI, Barcelona, Jaime Molinas, 1889-1898.

GARNER, Bryan Andrew (coord.), Black’s Law Dictionary, 9ª ed., Saint Paul, West, 2010.

GIERKE, Otto Friedrich, vol. I, Deutsches Privatrecht, Leipzig, Duncker \& Humblot, 1895.

GILISSEN, John, Introduction historique au Droit, 1976, trad. port. de Espanha, Antônio Manuel e Malheiros, Manuel Macaísta, Introdução Histórica ao Direito, $4^{\mathrm{a}}$ ed., Lisboa, Fundação Calouste Gulbenkian, 2003.

GlanviLla, Ranulpho, Tractatus de legibus et consuetudinibus regni Angliae (c. 1187-1189), London, White \& Brooke, 1780.

GLARE, Peter Geoffrey William (coord.), Oxford Latin Dictionary, London, Oxford University, 1982 [reimp. 2007].

GordLey, James, Foundations of Private Law, Oxford, Oxford University, 2006.

GrAY, Kevin e GrAY, Susan Francis, Elements of Land Law, $5^{\mathrm{a}}$ ed., Oxford, Oxford University, 2009.

GROSsI, Paolo, s.v. Proprietà (dir. interm.), in ED 37 (1988), pp. 226-254.

Grotius, Hugo, De aequitate, indulgentia et facilitate, 1625, anot. por Barbeyrac, Jean, Amsterdam, 1720.

GuARINO, Antonio, Diritto privato romano, 12ª ed., Napoli, Jovene Napoli, 2001.

GÜTERBOCK, Karl Eduard, Henricus de Bracton und sein Verhältniss zum römischen Rechte: Ein beitrag zur geschichte des römischen rechts in mittelalter, Berlin, Springer, 1862, trad. ing. de Coxe, Brinton, Bracton and His Relation to Roman Law: A Contribution to the History of the Roman Law in the Middle Ages, Philadelphia, Lippincott, 1866.

GÜTERBOCK, Karl Eduard, Henricus de Bracton und sein Verhältniss zum römischen Rechte: Ein beitrag zur geschichte des römischen rechts in mittelalter, Berlin, Springer, 1862.

HANBURY, Harold Greville, The Legislation of Richard III, in AJLH 95 (1962), pp. 95-113.

HARE, Thomas, Reports of Cases Argued in the High Court of Chancery, vols. I-XI [18411853], London, Maxwell, 1843-1858; LEADAM, Isaac Saunders, Select Cases in the Court of Requests - 1497-1569, in The Publications of the Selden Society, vol. XII, London, Selden Society, 1898.

Helmholz, Richard, Trusts in the English Ecclesiastical Courts 1300-1640, in Helmholz, Richard e ZIMMERMANN, Reinhard (org.), Itinera Fiduciae: Trust and Treuhand in Historical Perspective, Berlin, Duncker \& Humblot, 1998, pp. 153-172. 
Hemmeon, Morley de Wolf, Burgage Tenure in Medieval England, Cambridge, Harvard University, 1914.

Herbert of Cherbury, Edward, The Life and Reigne of King Henry the Eighth, London, Thomas Whitaker, 1649.

Hermann, Shael, The Canonical Conception of the Trust, Helmholz, Richard e ZIMMERMANN, Reinhard (org.), Itinera Fiduciae: Trust and Treuhand in Historical Perspective, Berlin, Duncker \& Humblot, 1998, pp. 85-109.

Hespanha, Antônio Manuel, Cultura Jurídica Européia: Síntese de um Milênio, Florianópolis, Boiteux, 2005.

HoLDSwORTH, William Searle, A History of English Law, vols. I-III, $3^{\mathrm{a}}$ ed., London, Methuen \& Co., 1922-1923.

Holmes, Oliver Wendell, The Common Law, Boston, Little Brown, 1881, trad. port. de Melo, J. L., O Direito Comum - Origens do Direito Anglo-Americano, Rio de Janeiro, Cruzeiro, 1967.

HoRAK, Frans, Dogmática e Casuística no Direito Romano e nos Direitos Modernos (sem título em alemão), trad. port. de Silveira Marchi, Eduardo César, in Revista de Direito Civil, Imobiliário, Agrário e Empresarial, 28 (1984), pp. 82-90.

HUNTER, Joseph, Fines sive pedes finium sive finales concordiae in curia dominis regis, vol. I, s.l., Public Records Commission, 1835.

James, Henry, A Literal Extension of the Domesday Book in Relation to the County of Cornwall, London, Vacher \& Sons, 1861.

JAMES, Philip Shears, Introduction to English Law, $3^{\text {a }}$ ed., London, Butterworth, 1955.

JEnKs, Edward, A History of the Australasian Colonies, Cambridge, Cambridge University, 1912.

JOHnSTON, David, The Roman Law of Trusts, Oxford, Clarendon, 1988.

Johnston, David, Trusts and Trust-like Devices in Roman Law, in R. Helmholtz e R. ZIMMERMANN (coord.), Itinera Fiduciae: Trust and Treuhand in Historical Perspective, Berlin, Duncker \& Humblot, 1998, pp. 45-56.

KeEton, George Williams, The Law of Trusts, $4^{\mathrm{a}}$ ed., London, Sir Isaac Pitman \& Sons, 1947.

Kelley, Donald R. e Smith, Bonnie G., What Was Property? Legal Dimensions of the Social Question in France, in Proceedings of the American Philosophical Society 128 (1984), pp. 200-230. 
Kemble, John M., Codex Diplomaticus Aevi Saxonici, vol. V, London, Sumptibus Societatis, 1847.

KERLY, Duncan, An Historical Sketch of the Equitable Jurisdiction of the Court of Chancery, Cambridge, Cambridge University, 1890.

KoschaKeR, Paul, Europa und das römische Recht, $3^{\mathrm{a}}$ ed., München, Beck, 1958.

LELY, John Mounteney, e FoulKes, William Decimus Inglett, The Judicature Acts 1873 and 1875, $2^{a}$ ed., London, H. Sweet, 1877.

LePAUlle, Pierre, Civil Law Substitutes for Trusts, in Yale Law Journal, 36 (1926-1927), pp. 1126-1147.

LePAUlle, Pierre, Traite theorique et pratique des trusts en droit interne en droit international, Paris, Rousseau, 1932.

LieBMan, Enrico Tullio, Manuale di diritto processuale civile, $2^{\mathrm{a}}$ ed., vol. I, Milano, Giuffrè, 1968.

LitTleton, Thomas, Tenores Novelli, London, Lettou \& Machlinia, 1482, trad. ing. de Coke, Edward, London, reed. e rev. por ToMLINS, Thomas Edlyne, Lyttleton - His Treatise of Tenures - In French and English, London, Sweet, 1841.

LitTleton, Thomas, Tenores Novelli, London, Lettou \& Machlinia, 1482, trad. ing. de Coke, Edward, London, reed. e rev. por WAMBAUGH, Eugene, Littleton's Tenures - In English, Washington, John Byrne \& Co., 1903.

LONG, George (coord.), Penny Cyclopaedia 9 (1837)

LuPOI, Maurizio, s.v. Trusts - Convenzione della'Aja e diritto italiano, in Enciclopedia Giuridica Treccani 36 (1995), pp. 1-12.

LUPOI, s.v. Trusts - Convenzione della'Aja e diritto italiano (postilla di aggiornamento), in Enciclopedia Giuridica Treccani 36 (1995), pp. 1-7.

LUPOI, s.v. Trusts - Profili generali e diritto straniero, in Enciclopedia Giuridica Treccani 36 (1995), pp. 1-15.

LuPoI, Trusts, Milano, Giuffrè, 1997, trad. ing. de Dix, Simon, Trusts: A Comparative Study, Cambridge, Cambridge University, 2000.

MACNAIR, Mike, Equity and Conscience, in OJLS 27 (2007), pp. 659-681.

MAINE, Henry Sumner, Dissertations on Early Law and Custom, $8^{\mathrm{a}}$ ed., London, John Murray, 1891. 
Maitland, Frederic William e Montague, Francis Charles, A Sketch of English Legal History, New York, Putnam's Sons, 1915.

MaITLAND, Frederic William, Bracton's Note Book, vols. I-III, London, Clay \& Sons, 1887.

Maitland, Frederic William, Canon Law in England, in The English Historical Review, 43 (1896).

MaITLAND, Frederic William, Equity - Also the Forms of Action at Common Law, Cambridge, Cambridge University, 1910.

MaITLAND, Frederic William, The Mystery of Seisin, in FISHER, Herbert Albert Laurens, The Collected Papers of Frederic William Maitland, vol. I, Cambridge, Cambridge University, 1911, pp. 358-384.

MaITLAND, Frederic William, The Seisin of Chattels, in FISHER, Herbert Albert Laurens, The Collected Papers of Frederic William Maitland, vol. I, Cambridge, Cambridge University, 1911, pp. 329-357.

Malaguti, Maria Chiara, Il trust, in Galgano, Francesco (org.), Atlante di diritto privato comparato, $3^{\text {a }}$ ed., Bologna, Zanichelli, 1999, pp. 179-193.

Marrone, Matteo, Istituzioni di diritto romano, $3^{\text {a }}$ ed., Palermo, Palumbo.

MARTINs Rodrigues, Dárcio Roberto, Das Regulae Iuris aos Brocardos Jurídicos, in Revista da Faculdade de Direito de São Bernardo do Campo 13 (2007), pp. 77-94.

MAXWELL-LyTE, Henry Churchill (coord.), Liber Feodorum - The Book of Fees - Commonly Called Testa de Nevill, vol. I, London, His Majesty's Stationary Office, 1920.

MaXwell-Lyte, Henry Churchill, A Descriptive Catalogue of Ancient Deeds in the Public Record Office, vol. IV, London, Mackie \& Co., 1902.

MegarRy, Robert e WAdE, William, The Law of Real Property, $7^{\mathrm{a}}$ ed., London, Sweet \& Maxwell, 2008.

Meredith, Sandra e Nolan, Donal (ed.), Oxford Standard for the Citation of Legal Authorities, $4^{\mathrm{a}}$ ed., Oxford, Oxford University, 2010.

MiLsom, Stroud Francis Charles, Historical Foundations of the Common Law, $2^{\mathrm{a}}$ ed., Oxford, Oxford University, 1981.

Milward, Richard, Table-Talk: Being the Discourses of John Selden, London, Smith, 1689 [reimp. por ARBER, Edward, John Selden: Table-Talk, London, Murray \& Son, 1869], pp. 3120.

MoccIA, Luigi, Il modello inglese di “proprietà”, in ALPA, Guido et al., Diritto privato comparato - istituti e problemi, Roma, Laterza, 2004, pp. 35-145. 
MoffAt, Graham, Trusts Law, $5^{\mathrm{a}}$ ed., Cambridge, Cambridge University, 2009.

MoreteAu, Olivier e VANDERLINDEN, Jacques (org.), La structure des systèmes juridiques: collection des rapports - XVI congrès de l'Académie internationale de droit comparé, Bruxelles, Bruylant, 2003.

Pennington, Kenneth, The Prince and the Law - 1200-1600, California, University of California, 1993.

PetTit, Philip Henry, Equity and the Law of Trusts, 11 a ed., Oxford, Oxford University, 2009.

PICKERING, Danby, The Statutes at Large, vols. I-XLVI [1215-1806], Cambridge, Bentham, Archdeacon et al., 1762-1807.

Plowden, Edmund, Commentaries or Reports of Edmund Plowden, vol. único [1548-1579], London, Brooke, 1816.

PluCKNETT, Theodore Frank Thomas, A Concise History of the Common Law, $5^{\mathrm{a}}$ ed., London, Butterworth, 1956.

Pollard, Alfred F., The Growth of the Court of Requests, in The English Historical Review, 56 (1941), pp. 300-303.

Pollock, Frederick e MaITland, Frederic William, The History of English Law Before the Time of Edward I, vols. I-II, $2^{\mathrm{a}}$ ed., Cambridge, Cambridge University, 1898-1899.

Pollock, Frederick e Wright, Robert Samuel, An Essay on Possession in the Common Law, Oxford, Clarendon, 1888.

PothIER, Robert Joseph, Traité des obligations, 1761, in DuPIN, Ainé, Oeuvres de R. J. Pothier, vol. V, Bruxelles, Tarlier, 1831.

PRINGSHEIM, Fritz, The Inner Relationship Between English Law and Roman Law, in The Cambridge Law Journal, 5 (1933-1935), pp. 347-365.

PRINGSHEIM, Fritz, The Unique Character of Classical Roman Law, in The Journal of Roman Studies, 34 (1944), pp. 60-64.

PUGLIESE, Giovanni, Ius honorarium a Roma ed equity nei sistemi di common law, in Revista Trimestrale di Diritto e Procedura Civile 42 (1988), pp. 1105-1126.

R. DAVID, Les grands systèmes du droit contemporains, trad. port. de Carvalho, Hermínio A., Os Grandes Sistemas de Direito Contemporâneo, 4ª ed., São Paulo, Martins Fontes, 2002.

REEVES, John, History of the English Law, vols. I-V, Philadelphia, Murphy, 1880. 
ReID, Kenneth, Visser, Daniel e Zimmermann, Reinhard (org.), Mixed Legal Systems in Comparative Perspective - Property and Obligations in Scotland and South Africa, Oxford, Oxford University, 2004.

Rescigno, Pietro, s.v. Proprietà (dir. priv.), in ED 37 (1988), pp. 254-297.

RHEInSTEIN, Max, Some Fundamental Differences in Real Property Ideas of the "Civil Law" and the Common Law Systems, in University of Chicago Law Review, 3 (1935-1936), pp. 624635.

Riccobono, Salvatore et al., Fontes iuris romani anteiustiniani II - Auctores, Firenze, Barbera, 1941 [reimpr. 1968].

RuFFHEAD, Owen, The Statutes at Large, vols. I-XIV [1215-1800], London, Basket, Eyre \& Strahan, 1763-1800.

SaInt Germain, Christopher, Dialogues Between a Doctor of Divinity and a Student in the Laws of England, 1518, rev. e corr. por Muchall, William, The Doctor and Student, Cincinnati, Robert Clarke \& Co., 1874.

ScotT, Austin Wakeman, Select Cases and Other Authorities on the Law of Trusts, Langdell Hall, Cambridge, 1919.

ScOTT, Austin Wakman, The Nature of the Rights of the Cestui Que Trust, in Columbia Law Review, 17 (1917), pp. 269-290.

SCRUTTON, Thomas Edward, The Influence of the Roman Law on the Law of England, Cambridge, Cambridge University, 1885.

SCRUTTON, Thomas Edward, The Influence of the Roman Law on the Law of England, Cambridge, Cambridge University, 1885.

SHELford, Leonard (org.), The Real Property Statutes Passed in the Reigns of King William IV and Queen Victoria, London, Sweet et al., 1863.

Silveira Marchi, Eduardo César, A Propriedade Horizontal no Direito Romano, $2^{\mathrm{a}}$ ed., São Paulo, Quartier Latin, 2003.

SilveIRA MARChI, Eduardo César, Guia de Metodologia Jurídica (Teses, Monografias e Artigos), Lecce, Grifo, 2001.

SIMPSON, Alfred William Brian, An Introduction to the History of Land Law, Oxford, Oxford University, 1961.

SIMPSON, John Andrew e WeINER, Edmund S. C., Oxford English Dictionary, $2^{\text {a }}$ ed., vols. IXX, Oxford, Clarendon, 1989 [reimp. 2000]. 
SPELMANNUS, Henricus, Glossarium archiaologicum continens latino-barbara, peregrina, obsoleta \& novatae significationis vocabula, $3^{\mathrm{a}}$ ed., Thomas Braddyll, London, 1687.

SPENCE, George, The Equitable Jurisdiction of the Court of Chancery, vols. I-II, London, Stevens \& Norton, 1846-1849.

Statutes of the Realm, vols. I-IX, London, Record Commission, 1810-1822.

StEPHEN, James (org.), The Common Law Procedure Act 1860, London, Butterworths, 1860.

Stockwell, Nigel e Edwards, Richard, Trusts and Equity, $7^{\mathrm{a}}$ ed., Harlow, Pearson Longman, 2005.

STORY, Joseph, Commentaries on Equity Jurisprudence, $3^{\mathrm{a}}$ ed., London, Sweet \& Maxwell, 1920.

StubBs, William, Select Charters and Other Illustrations of English Constitutional History, $9^{\mathrm{a}}$ ed., Oxford, Clarendon, 1921.

Swanston, Clement Tudway, Reports of Cases Argued and Determined in the High Court of Chancery, vols. I-III [1818-1819], London, Butterworth, 1821-1827.

TAINE, Hippolyte Adolfe, Les origines de la France contemporaine, vols. I-II, Paris, Hachette, 1876-1878.

TALAMANCA, Mario, Istituzioni di diritto romano, Milano, Giuffrè, 1990.

TARELlo, Giovanni, s.v. Povertà, in NDI, vol. XIII, Torino, UTET, 1957, pp. 520-523.

TARELlo, Giovanni, Storia della cultura giuridica moderna, vol. I, Bologna, Mulino, 1976.

The Statutes of the United Kingdom of Great Britain and Ireland - 2 \& 3 William IV, London, His Majesty's Printers, 1832.

Thorne, Samuel Edmund, On the Laws and Customs of England, vols. I-IV, Cambridge, Harvard University, 1968-1977.

ThORPE, Benjamin e PrICE, Richard (org.), Ancient Laws and Institutes of England, s.1., Public Records Commissioners, 1840.

VACCA, Letizia, Contributo allo studio del metodo casistico nel diritto romano, Milano, Giuffrè, 1976.

VAn ERP, Sjef, Comparative Property Law, in REIMANn, Mathias e ZIMMERMAnN, Reinhard (coord.), The Oxford Handbook of Comparative Law, Oxford, Oxford University, 2006, pp. 1043-1070. 
VAn RheE, C. H., Trusts, Trust-like Concepts and Ius Commune, in European Review of Private Law, 3 (2000), pp. 453-462.

VATTEL, Emmerich, Le droit des gens ou Principes de la loi naturelle, I-II, Leiden, Compagnie, 1758 [reimp. vol. I, Washington, Carnegie, 1916].

VERnON, Thomas, Cases Argued and Adjudged in the High Court of Chancery, vols. I-II [1681-1720], London, Butterworth, 1828.

VESEY, Francis, Reports of Cases Argued and Determined in the High Court of Chancery, vols. I-XX [1789-1817], London, Brooke, 1827-1833.

VinOGRAdOFF, Paul, English Society in the Eleventh Century - Essays in English Medieval History, Oxford, Clarendon, 1908.

VINOGRADOFF, Paul, Villeinage in England, Oxford, Oxford University, 1892.

VisSer, Daniel e Zimmermann, Reinhard (org.), Southern Cross - Civil Law and Common Law in South África, Oxford, Clarendon, 1996.

WaAl, Marius J. de, Comparative Succession Law, in ReImAnn, Mathias e Zimmermann, Reinhard (coord.), The Oxford Handbook of Comparative Law, Oxford, Oxford University, 2006, pp. 1071-1098.

WALKer, David Maxwell, The Oxford Companion to Law, Oxford, Clarendon, 1980.

WATKIN, Thomas Glyn, Quia Emptores and the Entail, in TR 59 (1993), pp. 353-374.

WAtson, Alan, Roman Law \& Comparative Law, Athens, University of Georgia, 1991.

WHEELER, Edd, The Battle of Hastings: Math, Myth and Melee, in Military Affairs 52 (1998), pp. 128-134.

Williams, Joshua, Principles of the Law of Real Property, $23^{\mathrm{a}}$ ed., London, Sweet \& Maxwell, 1920.

WILLIAMS, Joshua, The Seisin of Freehold, London, Chancery Lane, 1878.

WoODBINE, George Edward, Bracton De legibus et consuetudinibus Angliae (c. 1268), vols. I-IV, New Haven, Yale, 1915-1942.

WYCLIF, John, The Grete Sentence of Curs Expounded, 1383 in ARNOLD, Thomas, Selected English Works of John Wyclif, vol. III, Oxford, Clarendon, 1871.

Wyndham, Henry Penruddocke, Wiltshire Extracted from Domesday Book, Salisbury, Easton, 1788. 
Zeumer, Karl, Formulae Merovingici et Karolini Aevi, in Monumenta Germaniae Historica, Hannover, 1886.

ZIMMERMANN, Reinhard, Roman Law, Contemporary Law, European Law - The Civilian Tradition Today, Oxford, Oxford University, 2004.

Zimmermann, Reinhard, The Law of Obligations - Roman Foundations of the Civilian Tradition (1990), Oxford, Clarendon, 1996.

ZwEIGERT, Konrad e KöTZ, Hein, Einführung in die Rechtsvergleichung auf dem Gebiete des Privatrechts, 1971, trad. ing. de Weir, Tony, Introduction to Comparative Law, $3^{\text {a }}$ ed., Oxford, Clarendon Press, 1998. 


\section{Resumo}

A real property law inglesa é um tema pouco estudado na tradição jurídica de base romanística, e menos ainda no Brasil. Mesmo a literatura comparatística tem minimizado, ou mesmo omitido, o estudo abrangente das fontes inglesas ao analisar o tema, resultando na ausência de trabalhos escritos desde uma perspectiva do direito privado continental que analisem com maior profundidade os principais elementos formativos dos direitos reais sobre bens imóveis de matriz inglesa. As referências e alusões ao sistema do common law, contudo, são hoje cada vez mais freqüentes nos ordenamentos de matriz civilística, principalmente em razão da maior interação entre ordenamentos pertencentes a sistemas jurídicos de tradição histórica diversa. Portanto, para estabelecer diálogos relevantes, deve-se dedicar atenção especial aos principais elementos de formação do sistema de direito inglês, de modo a desvendar sua particular estrutura e terminologia.

O primeiro passo para estabelecer esse diálogo é conhecer os elementos que deram origem ao sistema do common law. Dado o forte vínculo do direito inglês com a sua história, torna-se necessário o estudo da real property law por meio de uma análise das suas fontes históricas que revele tanto a estrutura conceitual quanto o sentido das expressões e dos institutos mais típicos do sistema do common law. É esse estudo que pretendemos realizar neste trabalho, mediante a análise da formação histórica das tenures, dos estates, da equity e dos trusts

Uma pesquisa baseada nas fontes relativas à formação da real property law traz a vantagem adicional de fornecer uma visão ampla acerca da natureza e o funcionamento do sistema do common law como um todo, na medida em que o desenvolvimento primário do direito inglês esteve associado à estrutura dos direitos reais sobre bens imóveis na Inglaterra. Desse contexto derivam, em larga medida, as particularidades e as características que tornam o sistema do common law, em muitos aspectos, diverso dos sistemas jurídicos de tradição romanística.

A busca por uma aproximação entre os sistemas pertencentes a essas duas tradições jurídicas exige uma compreensão dos elementos que deram origem à diversidade entre elas. Nossa proposta é, justamente, identificar esses elementos e torná-los compreensíveis desde uma perspectiva civilística, por meio de uma análise das fontes inglesas mais relevantes para o tema. 


\begin{abstract}
English real property law is not a subject very often studied in the legal tradition based on Roman law, and even less so in Brazil. Even comparative writers have tended to minimize, if not altogether omit, a comprehensive study of the English sources when discussing the subject, resulting in a lack of literature, written from the perspective of continental private law, that analyses in greater depth the main formative elements of the law of real property based on the English legal model. The references and allusions to the common law legal system, however, have become increasingly more frequent in civil law contexts, largely due to the greater degree of interaction between legal systems belonging to different historical traditions. Thus, in order to establish meaningful dialogues, special attention must be given to the main factors that shaped the English legal system, thereby unveiling its specific structure and terminology.
\end{abstract}

The firs step towards establishing such a dialogue is to understand the elements that gave birth to the common law legal system. Given the strong connection English law has with its history, it is necessary to study the real property law through an analysis of its historical sources, which will reveal the conceptual structure and the meaning of the most typical expressions and institutions of the English legal system. That is the task undertaken herein, to be accomplished through the study of the historical inception of the doctrine of tenures, the doctrine of estates, equity and trusts.

A study based on the sources regarding the formation of the real property law brings the additional advantage of providing a broad outlook on the nature and operation of the English legal system as a whole, as the primary development of English law was associated to the structure of rights over land in England. That context is the cause, to a large extent, of the peculiarities and characteristics that make the English legal system, in many ways, different from legal systems based on Roman law.

The pursuit for a closer interaction between the legal systems that belong to those two legal traditions requires an understanding of the elements that determined their differences. The object of this research is to identify those elements and make them comprehensible from a civilian perspective, by means of an analysis of the most relevant English sources on the subject. 